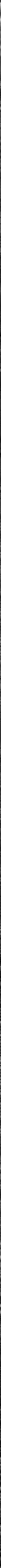




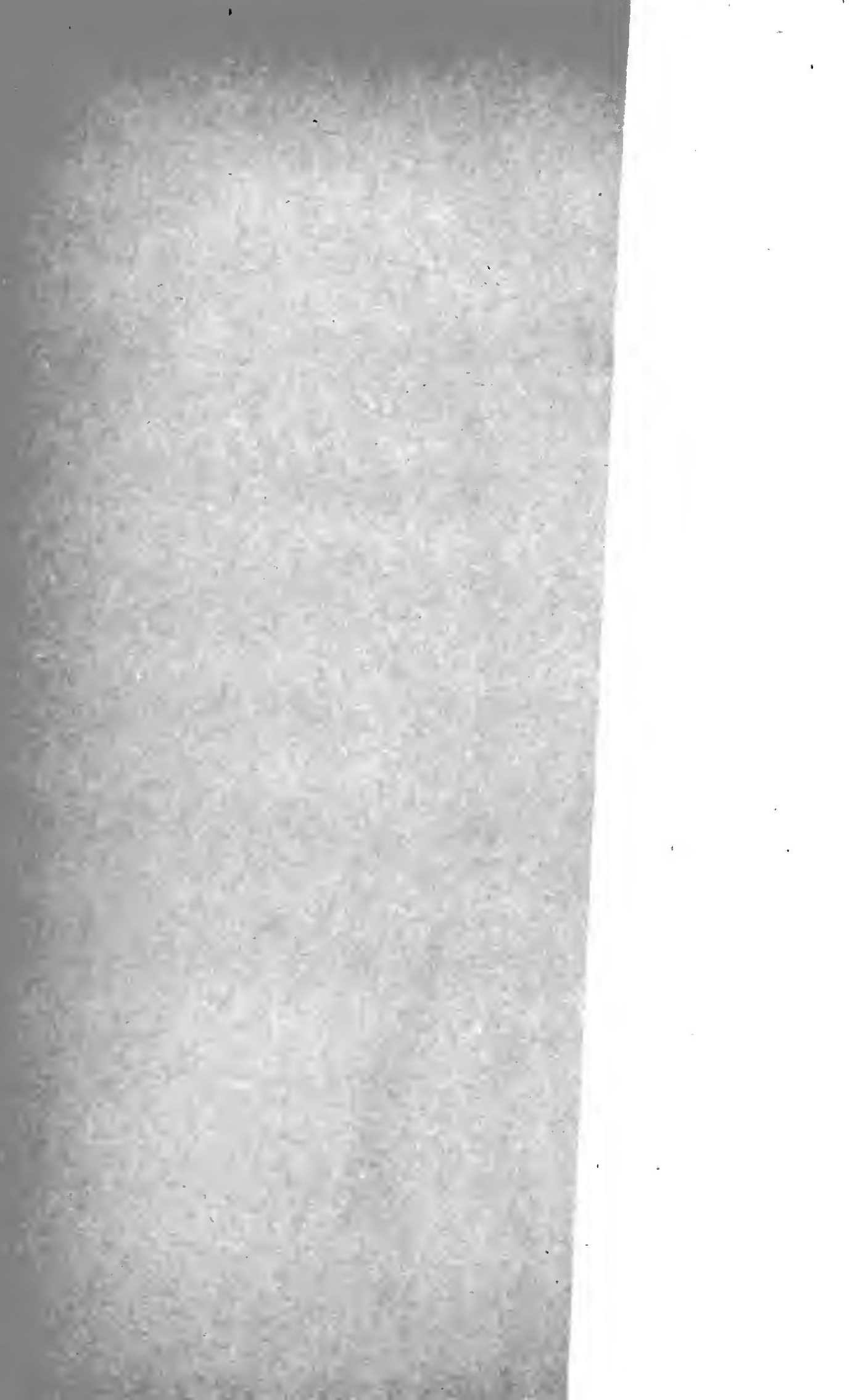


Digitized by the Internet Archive in 2007 with funding from Microsoft Corporation 



\title{
Guide to the Materials for American History in Swiss and Austrian Archives
}

\author{
BY \\ ALBERT B. FAUST \\ PROFESSOR OF GERMAN IN CORNELL UNIVERSITY
}

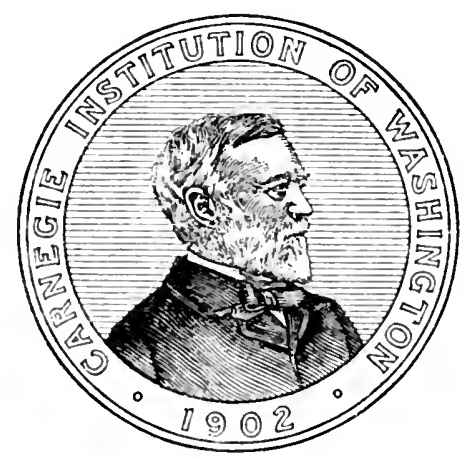

WASHINGTON, D. C.

Published by the Carnegie Institution of Wasinngton 


\section{CARNEGIE INSTITUTION OF WASHINGTON}

Publication No. 220

Papers of the Department of Historical Research

J. Franklin Jameson, Editor

Ebe Eord Baftimore prese EALTIMORE, MD., ס. S. $R$. 


\section{INTRODUCTORY NOTE.}

This descriptive inventory of the manuscript materials for the history of the United States contained in the various archives of Switzerland and Austria stands closely related, in the plans of this department, to a previous volume in the same series, Professor Marion D. Learned's Guide to the Manuscript Materials relating to American History in the German State Archives (Washington, 1912). Among the reasons for the preparation of the latter book, one, and on the whole the chief reason, is common to the two books, namely, the large part which emigration from German lands had in the populating of America. The records and other manuscript materials found in archives within the present German Empire are far from covering the whole history of that immigration, for a large part of it came from the Germanspeaking cantons of Switzerland, and a portion of it from the German parts of Austria. Therefore, after the preparation of Dr. Learned's book, it was natural to think of supplementing it by reasearches in the archives of these German lands outside of the German Empire, and for such a task it was natural to obtain the aid of Professor Albert B. Faust of Cornell University, author of a widely-known history of The German Element in the United States (Boston, 1909). But if a volume were to be published having as its main subject the materials in the archives of the German cantons, it should for the sake of completeness include also a treatment of the less important materials in the archives of the French cantons. These the undersigned examined in the summer of 1912; Professor Faust's researches, first in the Austrian archives and then in those of German Switzerland, occupied the spring and summer of the next year.

Besides those officials in Switzerland and Austria to whom Dr. Faust's thanks are expressed at the end of his preface, we are also very greatly indebted, for aid most kindly rendered in the general preparations for our expeditions, to their Excellencies, Dr. Paul Ritter, envoy of Switzerland to the United States, and Hon. Henry S. Boutell, envoy of the United States to Switzerland.

J. Frankin Jameson. 


\section{SUPPLEMENTARY NOTE.}

In the original manuscript corresponding to pp. I49-184 of this book expression was given, under each of the French-speaking cantons, to the compiler's gratitude for aid most kindly rendered by M. Tobie de Raemy, archivist of state at Fribourg; by M. Octave Oberson, sub-archivist of the same canton; by M. Alfred Millioud, sub-archivist at Lausanne; by the Reverend Abbé Léo Meyer, archivist of state at Sion; by M. Arthur Piaget, archivist of state at Neuchâtel; by M. Louis Thévenaz, sub-archivist of the same canton; by M. Paul Martin, archivist of state at Geneva, and M. Charles-Arnold Roch, sub-archivist there. To conform to the practice followed by Dr. Faust (pp. vi, vii, below) these acknowledgments were removed from the main text with the intention that they should be formed into a paragraph on page iii. By an unfortunate error, they were omitted there; the attempt is made, with many apologies, to remedy the error by means of this slip.

J. F. JAMESON. 


\section{PREFACE.}

The quest for materials relating to American history in the archives of German Switzerland and Austria extended through a period of about six months, from March to September, 1913. In Switzerland the search could not be confined to state ( $i$. e., cantonal) archives, since materials of equal importance were frequently hidden in municipal archives, or in city or private libraries. For this reason the number of repositories visited and examined became quite large.

In Austria the attempt was not made to visit all the archives, owing to specific directions that, within the limited period allotted, effort should be concentrated upon the archives of Vienna, Salzburg, and if possible Innsbruck. Six archives in Vienna were found to contain materials for American history. These showed that diplomatic and commercial affairs were in the foreground in the relations between the Hapsburg Empire and the United States before 1847 , the date beyond which the archives are closed to investigators. Emigration was effectively checked in Austria before this time, and was not a problem, as it became for certain provinces at a later day.

On the other hand, the question of emigration is at the very centre of interest in the materials found in the Swiss archives. Ever since the beginning of the eighteenth century, America periodically attracted large groups of Swiss emigrants. Carolina and Pennsylvania, supposed to be West India islands under the British Crown, were names that between I734 and I750 conjured panic fears in the bosoms of patriotic councillors in nearly every canton of Switzerland. The Ratsherren met and pondered, they gave paternal warnings, issued severe mandates, and punished offenders, nevertheless the " rabies Carolina " continued its ravages. Overpopulation and bad economic conditions sought relief beyond the seas. Switzerland is therefore linked with America not by governmental policy, but by the bonds of blood, that go back, just as in the case of Germany, and for the same reasons, to the earliest colonial periods.

In preparing this Guide, care was taken to indicate, by a few descriptive words, the nature or contents of every document examined, and wherever possible to preserve the title given by the archivist (in the latter case quotation marks have been used). hy this means investigators may be led directly to the material desired, or be spared vain incuiries. In many instances large abstracts of the contents of acta liave been made, where important policies were outlined, or sometimes documents have becn quoted in full, as in the case of some decrees against emigration. The purpose was to provide more than a mere calendar, to present some results to those who will not find the opportunity themselves to draw from the sources, and partially to reveal the valu- 
able and fascinating record of human experience which these archives contain. In all quotations the original dialect and spelling have been preserved, so as to reproduce the characteristic color, personality; or social condition. A brief survey of the materials found in the archives is given in an Introduction preceding the Guide.

The following are lists of the archives visited and examined in Switzerland and in Austria respectively, which contain materials for American history:

\begin{tabular}{|c|c|c|c|c|}
\hline Canton. & $\begin{array}{c}\text { State (or cantonal) } \\
\text { archive. }\end{array}$ & Municipal archive. & $\begin{array}{c}\text { City } \\
\text { library. }\end{array}$ & Other archives. \\
\hline Zürich............. & I & ${ }_{1}^{2}$. & I & 一 \\
\hline Bern............... & I & Zurich, Winterthur & I & $\begin{array}{l}\text { Bundesarchiv, Auswander- } \\
\text { ungsamt, American Lega. } \\
\text { tion }\end{array}$ \\
\hline Luzern........... & I & - & I & - \\
\hline Uri ................... & I & - & - & - \\
\hline $\begin{array}{l}\text { Schwyz.............. } \\
\text { Obwalden...... }\end{array}$ & I & $\overline{-}$ & $\bar{z}$ & $\begin{array}{ll}\text { I } & \text { Einsiedeln } \\
\text { I } & \text { Engelberg }\end{array}$ \\
\hline Nidwalden........... & $\begin{array}{l}1 \\
1\end{array}$ & - & - & I Engelberg \\
\hline Glarus............ & I & - & - & - \\
\hline $\mathrm{Z}_{\mathrm{ug}} . . . \ldots \ldots \ldots \ldots$ & I & - & - & - \\
\hline Solothurn......... & I & - & - & - \\
\hline Baselstadt.......... & I & - & - & - \\
\hline Baselland .......... & I & - & - & 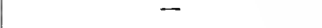 \\
\hline Schaff hausen ..... & I & - & z & $\overline{-}$ \\
\hline $\begin{array}{l}\text { Appenzell A. Rh... } \\
\text { Appenzell I. } R h . . .\end{array}$ & $\begin{array}{l}I \\
I\end{array}$ & $\bar{z}$ & $\overline{-}$ & $\overline{-}$ \\
\hline St. Gallen........... & I & 2 & - & $\begin{array}{l}\text { Stiftsarchiv, Kaufmän. } \\
\text { nisches Direktorium }\end{array}$ \\
\hline Graubünden....... & I & I & - & - \\
\hline Aargau............. & I & - & - & - \\
\hline Thurgau.......... & I & - & - & - \\
\hline Ticino............. & I & - & - & - \\
\hline Totals....... & 20 & 5 & 3 & 7 , together, 35 \\
\hline
\end{tabular}

The archives of the French cantons: Fribourg, Vaud, Valais, Neuchâtel, Geneva, were examined by Dr. Jameson. See pp. 149-184, post.

\begin{tabular}{|c|c|c|c|c|}
\hline Place. & State archive. & Municipal archive. & $\begin{array}{l}\text { City } \\
\text { library. }\end{array}$ & Other archives. \\
\hline $\begin{array}{l}\text { Vienna........... } \\
\text { Salzburg .......... } \\
\text { Innsbruck......... }\end{array}$ & $\begin{array}{l}I \\
I \\
I\end{array}$ & $\begin{array}{l}1 \\
- \\
-\end{array}$ & $\begin{array}{l}\text { I } \\
\text { I }\end{array}$ & $\begin{array}{c}\text { Kriegs-, Hofkammer- } \\
\text { Minist. d. Innern } \\
\text { I } \\
\text { Erzbischöf. }\end{array}$ \\
\hline Totals....... & 3 & I & 3 & 4 , together, II \\
\hline
\end{tabular}

Total of archives examined, 40; libraries, 6 .

An investigation of this kind could not be carried forward without constant help from those familiar with the contents of their archives and expert in bringing them into service. In gathering the material for this Guide the investigator was uniformly aided, in Austria and in.Switzerland, by the most cordial coöperation of the archivists in charge and their assistants. His grateful acknowledgments extend to Hofrat Árpad von Károlyi, director of the K. u. K. Haus-, Hof- und Staatsarchiv of Vienna, and to Dr. Hanns 
Schlitter, vice-director, whose valuable publications from the archives of Vienna and Washington are mentioned below; also in the same archive to Dr. Roderich Goos, Vizearchivar, and to Dr. Hans Prankl, who made the laborious search and prepared the outline in the section under the rubric "Länder". Similarly, to Oberstleutnant Ludwig Eberle, and Rittmeister von Lerchenau, of the K. u. K. Kriegsarchiv; to Professor Dr. Heinrich Kretschmayr, director, and Dr. Josef Kallbruner, secretary, of the Allgemeines Archiv d. K. K. Ministeriums d. Innern ; to Archivdirektor Dr. Hermann Hango of the Archiv der Stadt Wien, and to Dr. Gustav Bodenstein, archivist of the Hofkammerarchiv. Likewise to Dr. Andreas Mudrich, director of the Archiv d. K. K. Landesregierung at Salzburg, and his assistant, Dr. Franz Martin: to Professor Dr. Michael Mayr, director of the K. K. Staatsarchiv, Innsbruck, and Dr. Otto Stolz, assistant.

In the three Swiss archives where the fullest harvest of American materials was gathered, at Bern, Zürich, and Basel, it was my good fortune to meet archivists who became deeply interested in the subject, who spared no efforts to strike into obscure recesses, often to be rewarded with nuggets of unsuspected richness and quality. I refer to Professor Dr. Heinrich Türler, archivist, and Mr. G. Kurz (to whom I am indebted for some of the most interesting materials), assistant archivist of the Staatsarchiv of Bern; to Professor Dr. Hans Nabholz, state archivist of the canton of Zürich; to Dr. Rudolf Wackernagel, state archivist, and Dr. August Huber, assistant archivist of the Staatsarchiv d. Kantons Baselstadt. I wish to give expression to my indebtedness for facilities provided and courtesies extended, also to Professor Dr. W. F. von Mülinen, chief librarian of the Stadtbibliothek of Bern, who also permitted me to use the Graffenried manuscripts in his private library; to Dr. Jakob Kaiser, archivist of the Confederation ${ }^{1}$ in Bern; to Mr. J. Möhr, chicf of the federal Auswanderungsamt in Bern; to Mr. J. Weber, assistant secretary of the American Legation; to Dr. F. von Jecklin, town archivist in Chur; to Dr. Robert Durrer, archivist of Stans, Unterwalden; to Dr. P. Odilo Ringholz, Stiftsarchivar, Einsiedeln ; to Professor Dr. Johannes Dierauer, historian and librarian (Vadiana), Dr. Schiess, town archivist, and Dr. Hermann Wartmann, actuary of the Kaufmännisches Direktorium, in St. Gallen; to Dr. Hermann Escher, chief librarian of the Stadtbibliothek of Zürich; to Mr. Friedrich Frey, cantonal archivist at Glarus; Dr. H. Werner, archivist of the Staatsarchiv at Schaffhatusen; Dr. A. Lechner, Staatsschreiber at Solothurn; and Signor Bustelli, arehivist at Bellinzona. To all of these and many more it gives me pleasure to express sincere thanks for their valuable assistance in this work.

Cornell University,

Albert BFrnilardt Faust.

Ithaca, July I, 1914.

\footnotetext{
${ }^{1}$ Upon Dr. Kaiser's retirement in 1914 , Prof. Dr. Türler, Staatsarchivar, was appointed director of the Bundesarchiv, while Mr. G. Kurz was advanced to the position of archivist of the Staatsarchiv of Bern.
} 



\section{TABLE OF CONTENTS.}

INTRODUCTORY NOTE.

PAGE

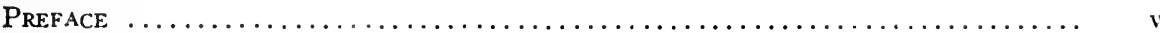

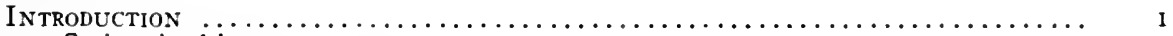

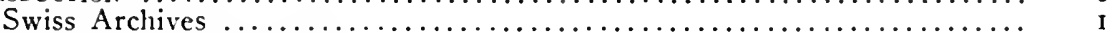

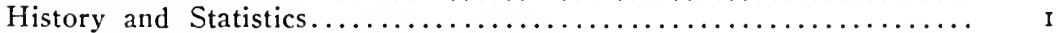

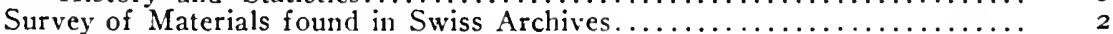

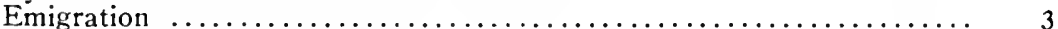

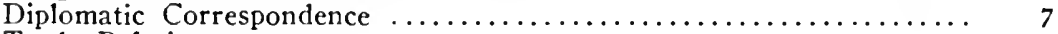

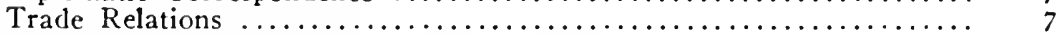

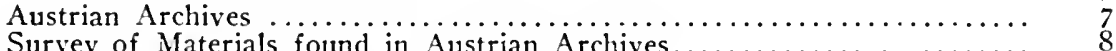

Survey of Materials found in Austrian Archives $\ldots \ldots \ldots \ldots \ldots \ldots \ldots \ldots \ldots \ldots \ldots$
Eighteenth Century $\ldots \ldots \ldots \ldots \ldots \ldots \ldots \ldots \ldots \ldots \ldots$

Trade Relations $\ldots \ldots \ldots \ldots \ldots \ldots \ldots \ldots \ldots \ldots \ldots \ldots \ldots \ldots \ldots \ldots \ldots, 8$

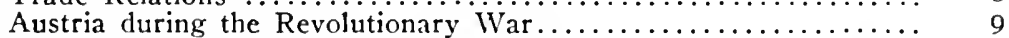

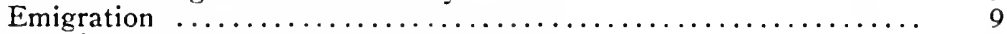

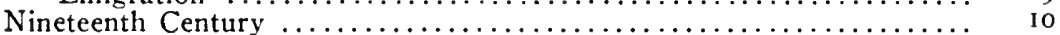

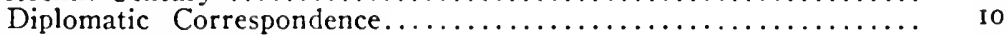

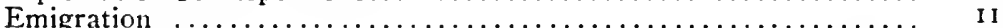

Police Records ................................ I

\section{SWISS ARCHIVES, GERMAN CANTONS.}

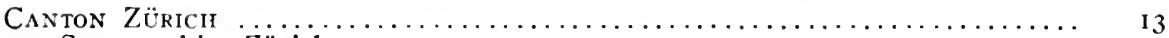

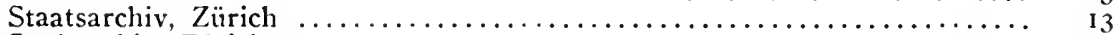

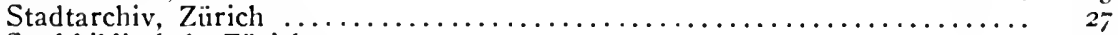

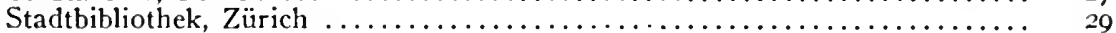

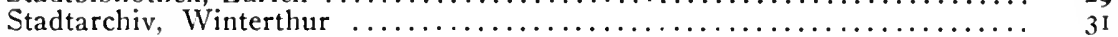

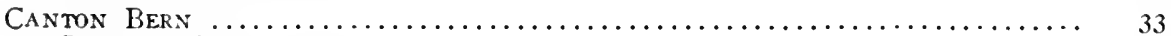

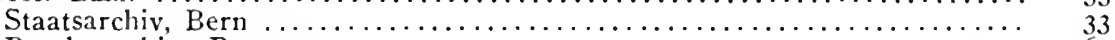

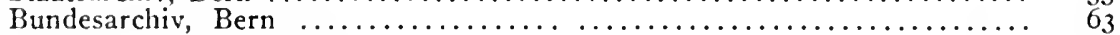

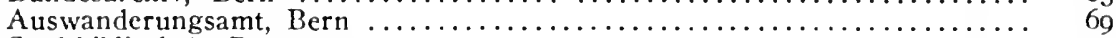

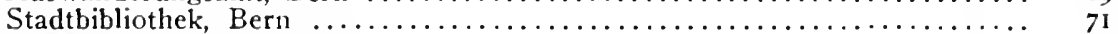

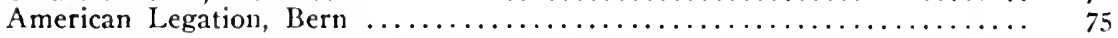

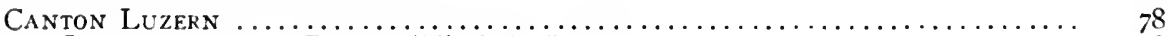

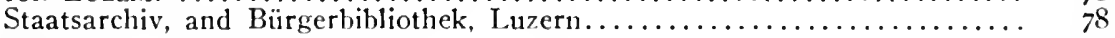

Canton URI $\ldots \ldots \ldots \ldots \ldots \ldots \ldots \ldots \ldots \ldots \ldots \ldots \ldots \ldots \ldots \ldots \ldots \ldots \ldots \ldots \ldots \ldots$

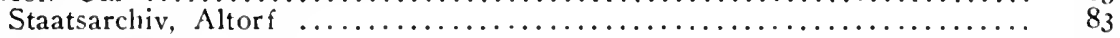

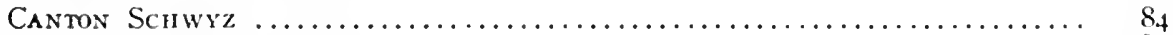

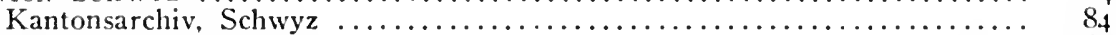

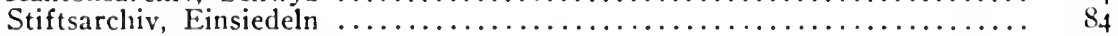

Canton Unterwalden $\ldots \ldots \ldots \ldots \ldots \ldots \ldots \ldots \ldots \ldots \ldots \ldots \ldots \ldots \ldots \ldots \ldots \ldots \ldots \ldots . \ldots \ldots$

Obwalden: Staatsarchiv, Sarnen $\ldots \ldots \ldots \ldots \ldots \ldots \ldots \ldots \ldots \ldots \ldots \ldots \ldots \ldots . \ldots \ldots$

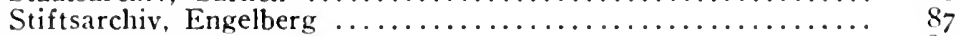

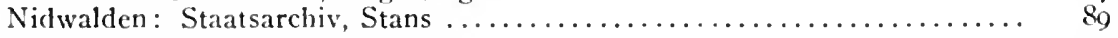

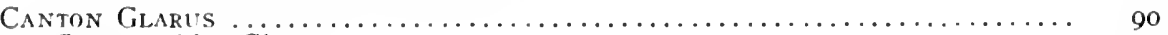

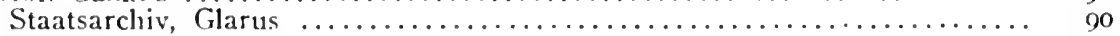

Canton Zuc $\ldots \ldots \ldots \ldots \ldots \ldots \ldots \ldots \ldots \ldots \ldots \ldots \ldots \ldots \ldots \ldots \ldots \ldots \ldots \ldots \ldots \ldots . \ldots \ldots$

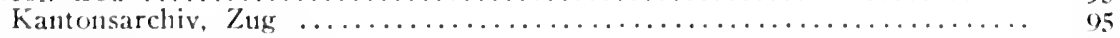

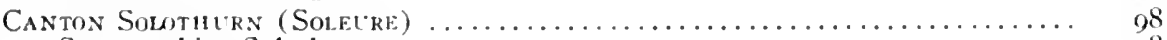

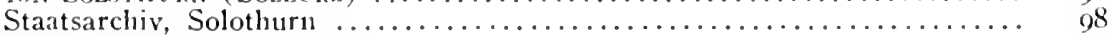

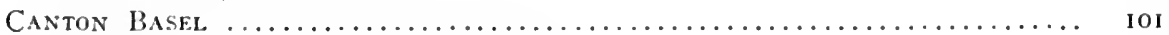

Basel-Stadt: Staatsarcliv, Basel ........................ IOI

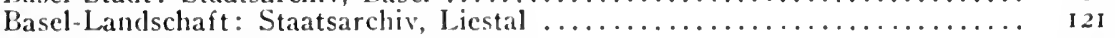

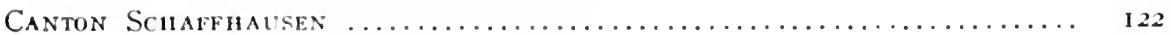

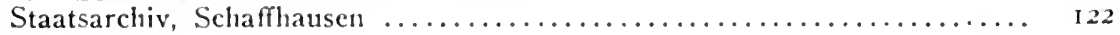


Appenzell I. Rh.: Staatsarchiv, Appenzell $\ldots \ldots \ldots \ldots \ldots \ldots \ldots \ldots \ldots \ldots \ldots \ldots \ldots \ldots$ 126

Appenzell A. Rh.: Staatsarchiv, Herisau .................... I27

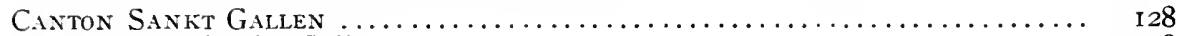

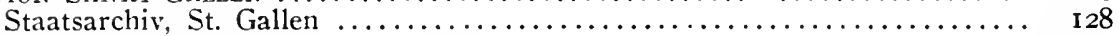

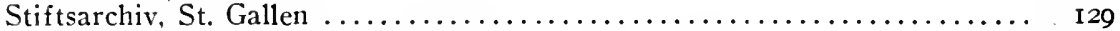

Archiv der Stadtgemeinde, St. Gallen........................ I 29

Stadtarchiv, St. Gallen............................... I30

Das Kaufmännische Direktorium, St. Gallen................... I30

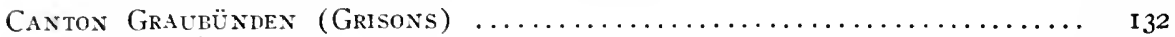

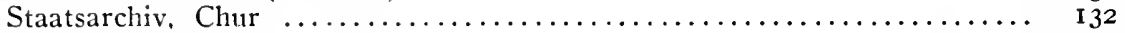

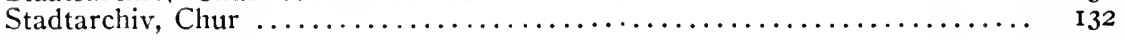

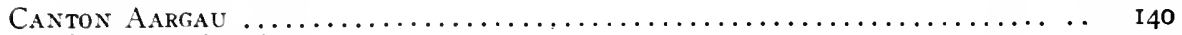

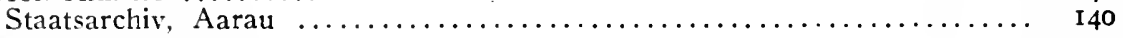

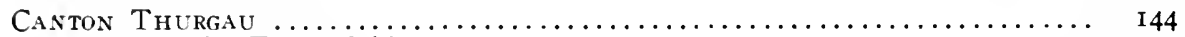

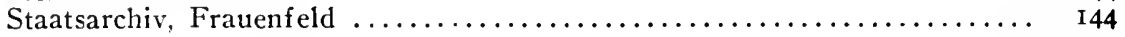

ITALIAN CANTON.

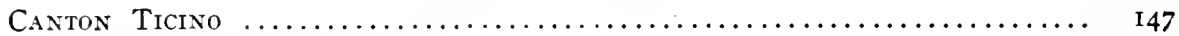

Archivio Cantonale, Bellinzona $\ldots \ldots \ldots \ldots \ldots \ldots \ldots \ldots \ldots \ldots \ldots \ldots \ldots \ldots \ldots \ldots \ldots$

FRENCH CANTONS.

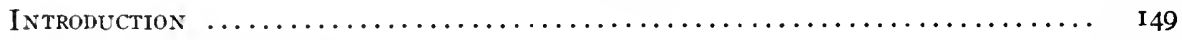

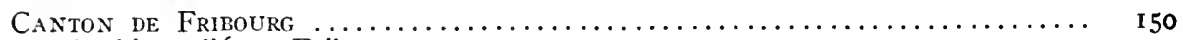

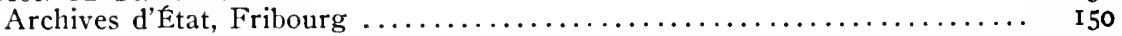

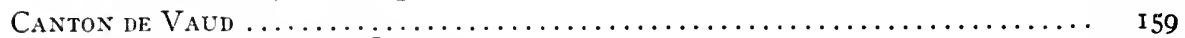

Archives Cantonales, Lausanne........................ I 59

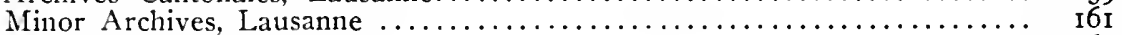

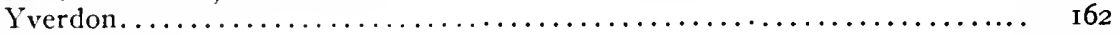

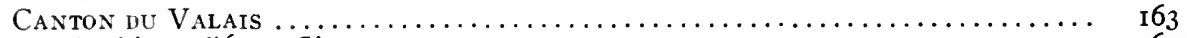

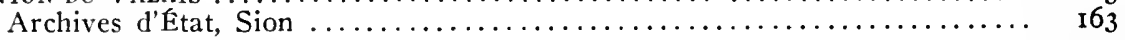

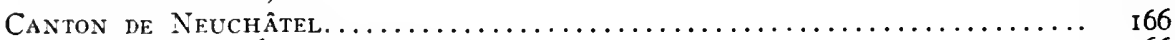

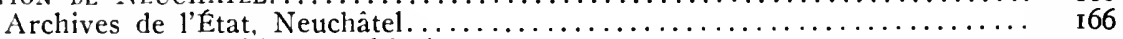

Archives de la Ville, Neuchâtel. ........................ I73

Bibliothèque de la Ville, Neuchâtel $\ldots \ldots \ldots \ldots \ldots \ldots \ldots \ldots \ldots \ldots \ldots \ldots \ldots \ldots \ldots$

Compagnie des Pasteurs, Neuchâtel...................... I73

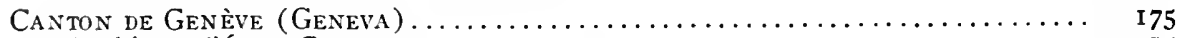

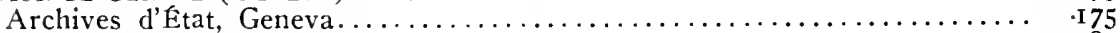

Ecclesiastical Archives, Geneva........................ I83

\section{AUSTRIAN ARCHIVES.}

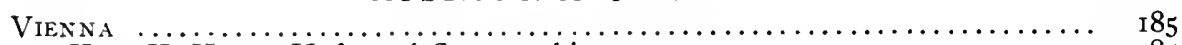

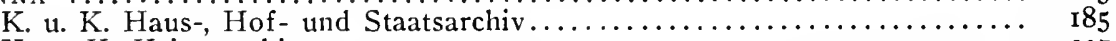

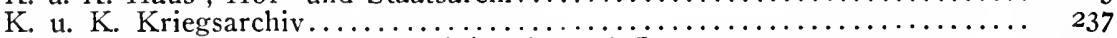

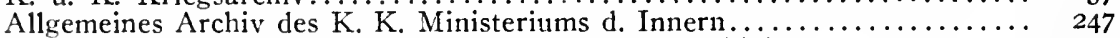

K. u. K. Gemeinsames Finanzarchiv (Hofkammerarchiv) ............ 252

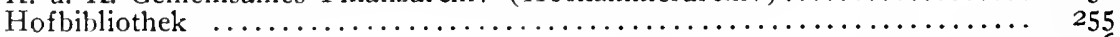

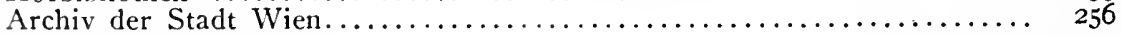

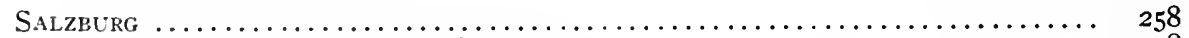

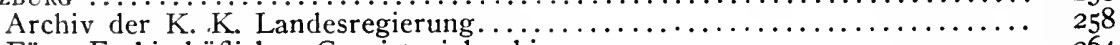

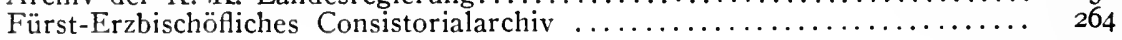

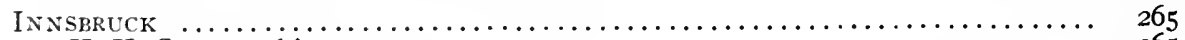

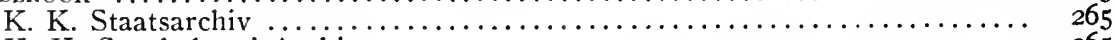

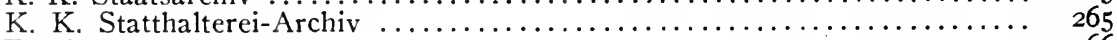

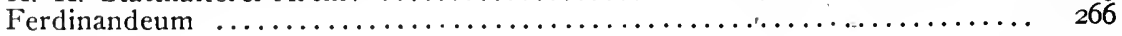




\section{INTRODUCTION.}

\section{A. SIVISS ARCHIVES.}

The cantons of Switzerland have had an independent development, though at various epochs some were bound together in confederacies without strongly centralized power. Naturally every canton is eager to preserve the records of its independent existence, and there has never been an attempt to gather in one place the large body of historical material deposited in the cantonal archives. The latter, called Staatsarchive, vary greatly in equipment and resources. Some are well supplied with a staff of archivists, copyists, cataloguers, etc., but in many cases the annual sum granted by the canton is not sufficient to pay the salary of one archivist, or to carry on the work of cataloguing and indexing the materials, or putting them in order, so that they may be used by investigators. Most of the archives of Switzerland are housed in old buildings, in some cases renovated so as to be serviceable, in others allowed to remain inadequate. These handicaps place a heavier burden upon the archivists, whose zeal, efficiency, and scholarship very generally make up for the lack of material equipment. In the systematic grouping of materials, in convenience of access, indexing, card-cataloguing, and various other helps, the Staatsarchiv of the city of Basel stands out pre-eminently. The Bundesarchiv of Bern is housed in the only really modern structure, built with attention to danger from fire. The Bundesarchiv was completed in 1899, built by the Federal State for the safe-keeping of materials that concern its own history, since its foundation in 1848 , and also the records of the confederacies of the nineteenth century, going back to the Helvetic Republic ( 1798$){ }^{1}$

\section{History and Statistics.}

The essential facts in the development of the Swiss confederation need to be borne in mind by the readers of this book, and help to explain its structure. At the end of the seventeenth century, when Swiss relations with America began, the league consisted of thirteen members: Zürich, Bern, Luzern, Uri, Schwyz, Unterwalden, Glarus, Zug, Fribourg, Solothurn, Basel, Schaffhausen, and Appenzell. This was its composition from I5 13 to 1798 . The members were united in a loose confederation lacking in executive power, and were represented in its Diet. The independence of Switzerland was proclaimed in the treaty of Westphalia in 1648 , but the Confederation leaned heavily on France, and the country was a great source of supply of troops to that kingdom. The govermments of the individual states had by the opening of the eighteenth century become highly oligarchical. In the course of that century movements of revolt against aristocratic rule occurred in many states. The agents and armies of revolutionary France broke up the old governments, and substituted for the Confederation in 1798 a Helvetic Republic, with a highly centralized government modelled on that of the

\footnotetext{
${ }^{2}$ On the Swiss archives in general, see Ch. V. Langlois and H. Stein, Archie'es de l'Histoire de France (Paris, 1891 ), pp. 823-840.
} 
French Directory. In ISoz Bonaparte, by the Act of Mediation, set up in place of this a federal constitution, partially modernized, with the addition of six new cantons. After his fall in 18 I4, there was a recurrence to a system resembling that which had prevailed before 1798 , but with the new cantons added, making twenty-two states instead of thirteen; and whereas before I 798 many portions of the Swiss territory were in somewhat abject subordination to the original states, now all cantons stood upon an equal basis in constitutional law. The Diet remained weak. The seat of government under it shifted every two years between Zürich, Bern, and Luzern (the three Vororte). The cantonal governments became once more reactionary, but by I 848 most of them had been liberalized. In that year, as the result of the brief war of secession with the Sonderbund (I847), a new federal constitution was adopted, instituting a strong central government, with its seat at Bern. The present, revised constitution, radically democratic, dates from I 874 .

Of the additional cantons established in 1803 , St. Gallen had before I798 been an ally of the Confederation (or rather two allies, abbot and town). Graubünden (or the Grisons) had been an allied federal republic. Aargau, Thurgau, and Ticino had been dependencies of groups of the old cantons. Vaud had before 1798 been subject to Bern. Of the three cantons added in I8I4, Valais had long been an independent republic, having relations more or less close with the Swiss Confederacy; Neuchâtel, an independent principality till I8I4, was from I7O7 to I857 under the sovereignty of the king of Prussia as prince; Geneva had been till I798 a separate republic with a famous history, then for fifteen years a part of France.

The order in which the cantons are treated in this volume is that followed in official publications of the Swiss federal government, except that the cantons of German, Italian, and French speech are treated in separate groups, the archives of the French cantons having been described by another hand than those of the German and the Italian. The official order gives precedence to Zürich, Bern, and Luzern, and presents the other cantons in their chronological order, Fribourg appearing next after Zug, and Ticino, Vaud, Valais, Neuchâtel, and Geneva after Thurgau.

The Federal State of Switzerland now consists of twenty-five cantons (including the three divided cantons Appenzell, Basel, Unterwalden, which are counted double), and has a population of 3,74I,97 I (Dec. I, I9IO). Classified according to speech, 69 per cent. of the population is German, 2 I.2 per cent. French, 8 per cent. Italian, I. I per cent. Romansch, o.7 per cent. other stock. Nineteen cantons are dominantly German, five French (Fribourg, Vaud, Valais, Neuchâtel, Geneva), one Italian (Ticino). Graubünden contains almost all of the Romansch population ( 46 per cent. German, 38 per cent. Romansch, I 4 per cent. Italian); Bern is 83 per cent. German, I 5 per cent. French; Fribourg 68 per cent. French, 3 I per cent. German; Vaud 8I per cent. French, I I per cent. German, 5 per cent. Italian.

\section{B. SURVEY OF THE MATERIALS FOR AMERICAN HISTORY IN SWISS ARCHIVES.}

The material relating to American history found in Swiss archives may be discussed under three heads: I. Emigration; II. Diplomatic correspondence; III. Trade relations. 


\section{EMigRation.}

The earliest plan of a Swiss colony in America was that of $\mathrm{H}$. Ritter, of Bern, concerning which there is a record as early as I705 (Rats-Manuale. Bern, 18). The governing Ratsherren of Bern were willing to coöperate with Ritter, seeing their advantage in a scheme which was to eliminate what they considered undesirable elements of the population, Wiedertäufer (Mennonites, Anabaptists), and Landsassen (pauper squatters). In I7Io Ritter received 45 thalers a head for the deportation of Swiss Mennonites (R. M. 41), an expedition which ended in failure because of the determined opposition of Dutch Mennonites against forceful deportation of brothers in their faith. Some of the group returned to Switzerland, others found refuge in the Netherlands or in Prussia. In succeeding years considerable numbers of Swiss Mennonites reached Pennsylvania and Carolina.

In I 7 Io Christoph von Graffenried founded the colony of New Bern, N. C., and on his return in $\mathrm{I} 7 \mathrm{I} 3$ he wrote a description of the colony together with a narrative of his adventures. Three manuscripts of this "Relation", two in French and one in German, were found, and two were subsequently published (see German American Annals, n. s., XI. 205-312, and XII. 63-I90, I9I3 and I9I4). Descriptions of the new country soon began to awaken general interest, as is shown by the purchase on March 2I, I7 I I, by the council of Bern, of 50 copies of the book of Ochs (Johann Rudolff Ochs, Amerikanischer Wegweiser, Bern, I7 I I, describing Carolina, based on Lawson's New Voyage to Carolina, London, I 7 IO).

The records show that attempts were made in 1720 by Merveilleux (captain in the regiment Karrer) to win recruits for the Mississippi service, and that J. P. Pury and Company of Neuchâtel began as early as I 725 to advertise their colonial scheme, which culminated in the founding of Purysburg, S. C., in I 732. Both of these plans were strenuously opposed by the Ratsherren of Bern, who began to fear an exodus of their people. The emigration fever (" rabies Carolina") reached its most critical stage in the years I734-I750, and affected most the populous Protestant cantons Bern, Zürich, and Basel. Decrees (Mandate) were issued against emigration in $1720,1735,1736,1738$, I 749, I 753, I 754, I 77 I, and I773, with ever increasing severity. Loss of landright and citizenship, not to be restored in case of return, restriction of sale of lands, severe punishment of those attempting to induce others to emigrate, were some of the terrorizing defensive meastures adopted to restrain the flow of emigration.

Lists ( $R \ddot{o d e l}$ ) of those leaving the country go back to the seventeenth century and are very frequently found in the archives. The more valuable are those giving exact dates, and the destination of the emigrants. There is one in the Staatsarchiv of Zürich which gives a complete catalogue of all those that migrated to America from every district of the canton between the years I734 and I744. The total number is 2310 . This document furnishes the only means of determining with some degree of accuracy what was the actual number of Swiss emigrants from Switzerland in the eighteenth century. It is also very valuable for genealogical purposes, and should be published entire. Decrees against migration to other comntries than America also appeared, to Russia in 1765 , to the Spanish colonies in 1767, to Prussian Pomerania in I77I. In the Ratsmanuale of Bern, which were searched very thoronghly and yielded rich returus, we find the statement in 1742 , "ist die Auswanderung wieder lebhaft im Gang”, and in 1750 that the emigration fever had again 
taken hold. The periodic tides of emigration could not be stopped; the compelling force of overpopulation with bad economic conditions was behind it.

The various cantonal governments made every effort to get at the causes of emigration. Their investigations appear in the form of examinations ( $V$ erhöre) of individuals and groups of people about to leave the country, reports (Berichte) of special committees, discussions, or statements of opinion (Gutachten), complaints and warnings (Bedenken, Gravamina, Beschwerden), all of them interesting and many of them valuable. A plan conceived in Bern to relieve the poor by providing opportunity for work at home on a large scale, and thus to remove one of the main causes of emigration (see Responsa Prudentum), was never carried into execution. Poverty, non-employment, small returns for labor, large families to provide for, no hope of improved conditions in the future, these were reasons commonly assigned by those wishing to leave. The unwary spoke of the expectation of improving their condition in the American colonies, and of favorable reports on this point. Such impressions were gained through letters from settlers in America, and through printed emigrant literature.

Favorable letters from emigrants settled in Carolina appeared in Bern as early as i 7 IO (see Graffenried Manuscripts, Bern), and undoubtedly such genuine records of actual experience were of determining influence. The archive of Basel contains the best collection of letters from Swiss settlers in Carolina, Pennsylvania, and other colonies. A large number of them were undoubtedly confiscated letters kept in the archive to remove the danger of their circulation. Records in the Ratsmanuale prove that letters were feared and hunted quite as much as emigrant agents. A consistent policy seems to have prevailed, that letters which reported unfavorable conditions should be published in the annual calendars and spread about in printed editions, while those containing favorable reports were captured and rendered harmless by safe-keeping in the archives. Not surprising therefore is the fact, which appears for the first time in these archives, that devices were used to conceal letters, such as that of Peter Huber, who brought letters from America in the false bottom of a wooden drinking-cup, which, he confessed when his captured baggage was examined, had been constructed by a German settler in Carolina. (See Thurn-Buch, Bern, I740-I742.)

A complete collection of the interesting enigrant literature, pro and contra, published in Switzerland in the eighteenth century, nowhere exists. The best collection is found in the Simmlersche Sammlung in the Stadtbibliothek of Zürich, which, though by no means complete, contains some of the classics of emigrant literature, as: Der nunmehro in der nenen Welt vergnïgt und ohne Heim-Wehe lebende Schweitzer; and the reply published in the same year, and given much encouragement by cantonal governments, Neue Nachricht alter und neuer Merkwïrdigkeiten, enthaltend ein vertrantes Gespräch und sichere Briefe von der Landschaft Carolina und übrigen englischen Pflanzstädten in Amerika, zufinden zu Zïrich, Bern, Basel, Schaffhansen und St. Gallen ( I734).

Especially severe measures were taken to arrest and punish persons suspected to be emigrant agents, or to be in any way stirring up (aufwiegeln) a desire in the rural population to emigrate. The Swiss archives throw much new light on the methods by which such men proceeded, the manner in which they evaded detection, and the skill with which they defended themselves when caught. The two most interesting cases are those of Peter Huber (I742), and Peter im Aebnit (I744). The verbatim reports of their trials 
in Bern (Thurn-Buch) and Basel (Huber only), are unique documents, of historical, literary, and human interest. Peter Huber escaped from the hands of his judges, while Peter im Aebnit was less fortunate. Though escaping from torture with which he was threatened, he made an unsuccessful attempt at flight from the prison tower at Bern, in which he lost his life. Conspicuous figures in emigration matters, though of a different type, were also Pfarrer Göttschi, and his son (see Zürich archives), and Michael Schlatter (see Bern, St. Gallen, etc.).

Though most emigrants were poor and not able to pay for their passage, a large number of others had possessions large or small in amount, which were taxed before leaving the country. The Staatsarchiv at Basel contains very many lists of property belonging to departing emigrants. Permission had to be obtained to sell their property (Vergantung), which was taxed ten per cent. (Abzug) for emigration; and if the emigrant was a serf who had property, about eight per cent. in addition was exacted for the purchase of freedom (Manumission). In this way the canton attempted to insure itself against too great a loss of property through emigration. Often, to evade the taxes, emigrants disposed of their property secretly, and left without permission or passes. They sometimes left pathetic letters behind, taking leave of their friends, whom they did not wish to implicate with a knowledge of their flight before it was accomplished. (See archive of Basel: "Heimliche Enigranten ".)

The larger number of emigrants came from the mountain districts, e. $g$., from the Berner Oberland, rather than from the city of Bern, or from the country districts of Zürich rather than from the cities of Zürich and Winterthur; this seems to indicate better conditions in the cities than in the country. The Protestant contributed more emigrants than the Catholic cantons. The Benedictine monasteries Einsiedeln and Engelberg established branches in the United States during the nineteenth century.

The embargo placed upon emigration was removed in the nineteenth century, when conditions of overpopulation, famine, failure of crops, hard times, etc., periodically recurred in many districts. Paternal authority began to see some advantages in emigration, provided the emigrants prospered in their new abode. The complaints from the governments of France, the Netherlands, and Prussia, in the second decade of the nineteenth century, concerning the congregating of large numbers of Swiss paupers at the seaports, hopelessly waiting for an opportunity to embark for America, brought about the beginnings of the regulation of emigration from Switzerland. The money for the trip had to be vouched for before an emigrant was furnished with a pass. The policy was adopted, neither to encourage nor to discourage emigration, but to let it take its course, and to protect the enigrant as far as possible against the selfishness of speculators. The business of transporting emigrants was leit in the hands of agencies, who were soon required to secure a license and obey the laws protecting the emigrant. In 1880 the Federal Emigration Bureau (Eidgenössisches Auswanderungsamt) was established at Bern, to watch the licensed emigration bureaus, to distribute literature furnishing all needed information, to advise ennigrants personally, and to keep statistics of emigration.

A phase of the emigration problem which hastened regulation was the tendency, which arose in Switzerland about 18,8 , to ship undesirables to the United States, i. e.. criminals, paupers, and defectives. For instance, when a criminal was about to complete lis term of sentence in the penitentiary, he 
would plead for a sum of money to pay his transportation to America. Town, parish, canton, and friends made contributions for the necessary sum to rid the community of the undesirable person. The United States complained through its first minister to Switzerland, Theodore S. Fay (see archives of American Legation, I855, etc.). The central government at Bern acted promptly in an effort to prevent the continuance of this abuse, but its power was not great enough to prohibit the deportations. Some cantons (see, e. g., archives of Frauenfeld, Canton Thurgau) continued the practice until the United States shipped back persons of the undesirable classes at the expense of those that sent them. The deportations then came to an end.

The Federal Emigration Bureau issues annual statistics of Swiss emigration, giving the home canton and the destination. In the section devoted to its archive will be found a list of places in the United States where larger numbers of Swiss settlers have gathered. As a rule the Swiss do not isolate themselves in colonies. Even at New Glarus, Wisconsin (see Neues Archiv d. Kantons Glarus), many Swiss settlers have left, being most content and successful when becoming assimilated.

The Swiss official statistics of the last fifty years show an average emigration of 8000 Swiss per annum, of whom on an average 4500 per annum are stated to have come to the United States. The United States statistics as to Swiss immigration run back to 1820 , and show a total of nearly 520,000 . The rate in recent years has exceeded 3000 per annum. The number of inhabitants in the United States who were born in Switzerland was reckoned at I 24,848 in the census of 1910 . Of these, I6,3I 5 were found in the state of New York, I4,52I in California, I0,988 in Ohio, 866 I in Illinois, and from eight to six thousand in Wisconsin, New Jersey, Pennsylvania and Missouri; no other state contained more than four thousand. Of the total number, I03,652 had German for their mother tongue, I I, I70 French, and 7835 Italian.

Bibliography: J. Dreifuss, Émigration. Élaboré par J. Dreifuss, Chef du Bureau Fédéral de l'Emigration. Fasc. Vgge of Bibliographie Nationale Suisse (Berne, I905, pp. viii, 68).

L. Karrer, Das Schweizerische Auswanderungswesen und die Revision und Vollziehung des Bundesgesetzes betreffend den Geschäftsbetricb von Auswanderungsagenturen. Bericht im Auftrage des schweiz. Handels- und Landwirthschaftsdepartements erstattet von L. Karrer, Nationalrath. (Bern, I886, pp. 318.)

Id. (French edition of the above.) L'Émigration Suisse et la Loi Fédérale sur les Opérations des Agences d'Émigration. Rapport, etc. (Berne, I887, pp. 286.)

Ratgeber fïr Schweizerische Auswanderer nach den Vereinigten Staaten von Amerika. Verfasst vom Schweizerischen Auswanderungsamt in Bern. (Bern, no date, but since 1906.)

Ernest Röthlisberger, "Die Internationale Bedeutung der Schweiz, III. Die Schweizer in der Fremde", in Paul Seippel's Die Schrveiz im Neunzehnten Jahrhundert, I. 577-596 (Bern, I899; French ed., La Suisse au Dix-neuvième Siècle).

N. Reichesberg, Handwörterbuch der Schzueizerischen Volkszeirtschaft, Socialpolitik, und Verwaltung (Bern, 1903), I. Band, pp. 380399: "Auswanderungswesen", I. Allgemeines; II. Geschichtliches; III. Auswanderungspolitik, I. Politik der Kantone, 2. Politik des Bundes; IV. Statistisches; V. Ursachen der Auswanderung; VI. Literatur. 
Dr. Adelrich Steinach, Geschichte und Leben der Schwoizer Kolonien in den Vereinigten Staaten von Nord-Amerika (New York, I889).

Many documents and reports respecting the matter may be found in the weekly Bundesblatt der Schweizerischen Eidgenossenschaft (Feuille Fédérale de la Confédération Suisse) from I848 down.

An account of the earlier history of the Swiss migration to America, by the writer of this book, appears as an article in the American Historical Review for (probably) July, I9I6 (vol. XXI).

\section{Diplomatic Correspondence.}

This material is of the nineteenth century and is found in the Bundesarchiv at Bern. The general letters, Kreisschreiben, of which the originals are at Bern, are found also in the cantonal archives. Subjects included are: the establishment of consulships in the United States, $e$. g., at New York, Alexandria, Philadelphia, New Orleans, Madison, Galveston, Louisville, etc.; the reports of consuls on American conditions, on property of individuals, answers to the questions of the Comités d'Émigrations des Sociétés d'Utilité Publique des Cantons de Vaud et de Genève; correspondence of the United States consul general in Switzerland; and acta concerning emigration and extradition treaties with the United States. The first treaty, concerning rights of domicile ("Freizügigkeitsvertrag") was rejected by the United States Senate June II, I836, taken up again and carried May I8, I847.

The diplomatic correspondence after 1848 is not accessible, but adequate reports upon the action taken by the Bundesrat can be found in the Bundesblatt, and the Amtliche Sammlung. Interesting legislation can be followed there on the establishment of emigrant agencies and the central emigration bureau (laws of I880 and I888). Other questions are matters concerning the postal union, the pensions of Swiss who served the Union in the Civil War as volunteers, etc.

The archive of the American Legation at Bern, very well kept, and accessible to students of history, fills the gap between I 848 and the present. Its most interesting material is that on forced emigration, $i . e$., deportation of criminals, defectives, etc., referred to above. In 1879 the activities of Mormon preachers who were endeavoring to induce Swiss peasants, especially women, to emigrate, becomes a subject for diplomatic correspondence.

\section{Trade Relations.}

Consular reports on trade are found most complete in the Bundesarchiv, yet are also scattered in many other places, notably Zürich, Bascl, Zug, and St. Gallen. The archive of the Kaufmännische Direktorium in Sankt Gallen is onc of the best sources for the study of Swiss-American trade relations. The retiring actuary, Dr. Hermann Wartmann, pioneer in the study of the history of Swiss trade, is inclined to see an American influence on Swiss trade, viz., in the matter of centralization, systematization, and largeness of view (Grossziigigkeit). This would apply, $e$. g., to the development of Swiss manufacture and trade in laces at St. Gallen, and the milk industry at Zug.

\section{AUSTRIAN ARCHIVES.}

The archive material of Austria-Hungary has not been centralized. The three crown lands have somewhat jealously guarded the records of their past, 
resulting in three principal stations for state archives, viz., Vienna, Budapest, and Prague. There are ten provincial archives, at Brünn (Moravia), Graz (Styria), Innsbruck (Tyrol), Klagenfurth (Carinthia), Cracow (Austrian Poland), Laibach (Carniola), Lemberg (Galicia), Prague (Bohemia), Salzburg (Salzburg), and Troppau (Silesia). Cf. Langlois and Stein, Les Archives de l'Histoire de France, pp. 645-655.

An attempt at centralization has been made in the K. u. K. Haus-, Hofund Staatsarchiv in Vienna, for which copies of the most important historical documents were made, the originals of which could not be obtained from the country or province of their origin. For students of history, therefore, this archive is the principal source, in which investigation should begin. It contains also the most abundant store of materials pertaining to American history. Other archives of Vienna examined and found to contain American materials, were: the K. u. K. Kriegsarchiv, Archiv der Stadt Wien, Allgemeines Archiv d. K. K. Ministeriums des Innern, K. u. K. Gemeinsames Finanz-Archiv (Hofkammerarchiv), K. K. Hofbibliothek. The archives of Salzburg and Innsbruck were found to contain interesting but not abundant American material.

The archives visited were provided with large and able staffs of archivists, many of whom were engaged upon historical investigations. The buildings, with the principal exception of the K. u. K. Haus-, Hof- und Staatsarchiv, were generally old and inconvenient, and the work of indexing, cataloguing, and arranging the material had not always been completely or adequately carried out. The date beyond which manuscript materials are not accessible is fixed at 1847 .

Diplomatic correspondence with a view to cultivating better understanding between the two nations, Austria-Hungary and the United States, and establishing trade relations favorable to both, forms the centre of interest in the Austrian archive material discovered. Emigration to the United States, while it occurred sporadically, seems never to have been frequent enough before 1847 to attract governmental attention. Indications of increased emigration in printed records begin after 1848 ; only within recent times and in certain provinces has it grown so as to become a problem.

\section{SURVEY OF THE MATERIALS FOR AMERICAN HISTORY IN AUSTRIAN ARCHIVES.}

The material relating to American history found in Austrian archives may be grouped as follows:

I. Eighteenth century: (a) Trade relations; (b) Austria's attitude during the American Revolutionary War; (c) Enigration.

II. Nineteenth century: (a) Diplomatic correspondence ; (b) Emigration ; (c) Police records.

\section{Eighteenth Century.}

(A) TRADE RELATIONS.

Voluminous reports were sent home to the Belgian government by the first agent (Handelsrat) to the United States, Baron Beelen-Bertholff, I784-I789. These interesting reports have been published in full by Dr. Hanns Schlitter: Die Beziehungen Österreichs zu den Vereinigten Staaten, I778-I787 (Innsbruck, I885); and Die Berichte des ersten Agenten Österreichs in den Vereinigten Staaten von Amerika, Baron de Beclen-Bertholf, an die Regie- 
rung der Österreichischen Niederlande in Brïssel, I784-I789 (Vienna, I89I), vol. XLV. in the second series of the Fontes Rerum Austriacarum. ${ }^{1}$ The material in this section includes the draft of a treaty of commerce between Austria and the United States, a letter of Benjamin Franklin (1784) regarding this treaty, and notes and criticisms of the articles of the treaty by Count Mercy.

In the Hofkammerarchiv the earliest reference to America is a fantastic scheme for a world-wide expansion of trade, by Filippo Fabrini; there is another plan of trade with America in 1776 by Christoph Beller; in 1783 the sending of Beelen-Bertholff is noted. The Kriegsarchiv shows a record of an offer of grain for sale from America in 1789 .

(B) AUSTRIA'S ATtitude DURing the Revolutionary War.

The earliest record in the Kriegsarchiv at Vienna shows that some few (20) men from Austrian domains in 1780 slipped away to join the troops of the Anspach contingent which was used by England against her revolting American colonies. In $1780-1781$, auxiliary troops to the number of 3300 passed through Höxter on the IVeser on their way to the British American service. They were not Austrian subjects, and were stopped at Höxter long enough for the arrest of deserters and Austrian subjects who might be found in the ranks. By Austria's action in preventing her own subjects from entering this service, the cause of the American colonists was greatly benefited. Had Prussia and Austria, the two most populous and powerful German states, allowed recruiting in their territories, the number of auxiliary troops that England could have put into the field against the American colonies would have been greatly increased, perhaps with crushing force.

The division "Länder" in the K. u. K. Haus-, Hof- und Staatsarchiv tells us that in $\mathrm{I} / 8 \mathrm{I}$ there was a secret attempt on the part of one Gerstenberg, secretary of legation to the English ambassador at Vienna, to secure recruits for England from among Austrian subjects, and in 1782 there is a record that there was some success. When this was reported, measures were taken to prevent its recurrence (see Kriegsarchiv, I78I-I 783 ).

The Staatsarchiv records the arrival of William Lee in Vienna, May, I778; he was not received and his mission was unsuccessful, because the court did not wish to antagonize England. Franklin's arrival in Paris is noted in 1776 and his appointment as minister to France in 1779 . Traces of a plan of mediation on the part of Prussia and Russia, between England and France and the American colonies, appear in 1779 . Between 1774 and 1784 frequent complaints are made on the part of England concerning shipments of arms and supplies to the American army by way of St. Eustatius (WVest Indies), principally by Dutch vessels.

\section{(c) EMIGRATION.}

Decrees were issued against enigration, not so much from any fear of losing population to America, or any other country, but as a protective measure against desertion from the army, or the loss of recruits for military service. The old tradition placed emigration on the same level as desertion; it was morally wrong. The prohibition of emigration brought a complaint (in 1794) from a district under Austrian rule wedged into Swabia, where it

${ }^{3}$ See also American Historical Revicw. XVI. 567-587. 
was difficult to obey the emigration law. A lenient policy prevailed, so long as the enigration did not exceed the immigration.

The Salzburg archives do not mention the name America, though this Austrian province furnished an influential group of sturdy pioneers in the earliest settlement of Georgia. Nevertheless in the Staatsarchiv of Salzburg can be found excellent material for the study of the steps that led up to the cruel expulsion of the Salzburg Protestants from the archbishopric of Salzburg in I73I. The inquisition of heretics for breaking fast, for reading a Lutheran tract, or owning a Lutheran Bible, the dangers of being under suspicion of concealing a Protestant book, can be authentically followed in these records. The adjustments of property claims, forced by the action of King Frederick William I. of Prussia (I734), continued until I 764, thirty-three years after the publication of the famous edict of expulsion, Emigrations Edikt vom $3 \mathrm{I}$. Oktober, I73I.

\section{Nineteenth Century.}

(A) Diplomatic CORREspondence.

The K. u. K. Haus-, Hof- und Staatsarchiv contains the complete reports of the diplomatic agents sent by the court of Vienna to the United States, beginning with Graf von Stürmer in I8I9, succeeded in the following year by Freiherr von Lederer, consul general, and in effect chargé d'affaires until the appointment in I 838 of Baron Mareschal as first minister plenipotentiary of Austria to the United States, the same year in which Henry Augustus Mühlenberg was sent as first United States minister to the Dual Empire. The reports of Baron Lederer to Prince Metternich were carefully prepared and gave detailed information on current events in the United States, they reviewed the action of Congress and the messages of presidents (with comments), and attempted also to give an impression in regard to the state of public opinion, illustrating with numerous clippings from newspaper editorials, and public addresses. The inquisitorial mind of Metternich was observing America through his agent's eyes. Baron Lederer's principal achievement was the successful negotiation of the commercial and navigation treaty between Austria and the United States, which failed to meet the approval of Henry Clay as Secretary of State, but was safely carried through under his successor in the same office, Martin Van Buren, in the following year, 1829. Interesting items in the correspondence are a statement on Austria's position in regard to slavery ( 1830 ), on the Austro-Italian political refugees, comments on the Mexican situation, and on the condition of Catholics in America. Occasional characterizations of public men appear, as of Randolph in I830, wher about to visit Vienna- " an extraordinary envoy, not an envoy extraordinary"; " die Menge seiner Ideen war er nie im Stande in Ordnung zu bringen".

The reports of the minister, Baron Mareschal (I838-I $84 \mathrm{I}$ ), are not as full as those of Lederer and contain more matters of routine. The best part are the enclosed reports of the secretary of the legation, von Hülsemann (Chevalier de Hülsemann), who was sent on numerous trips throughout the country, and required to submit his observations and results. This was accomplished by Hülsemann in a thorough and able manner, $e . g$. , in his paper on the written constitution and the rights of neutrals on the sea; report on a trip to the Southern States (products and commerce of Virginia; relation of white and black labor; leading cities. Norfolk, Charleston, Savannah, etc.) ; report on a trip to New England (factories at Lowell, railroads of Belgium com- 
pared with those of the United States, I839) ; pen-portraits of the principal members of Congress, Nov. 22, I839; report on the Whig convention of 1839 and the Democratic convention held at Baltimore, May 4-5, I840. Hïlsemann was rewarded for his zeal and industry with the position of chargé d'affaires at Washington after Baron Mareschal left the post for that of Lisbon in I841. The reports of Hülsemann to Metternich continue from I 84 I to $18_{47}$. He negotiated an extradition treaty in 1856 .

In the archives of the War Department some interesting American influences are noted. In I8I9, when new frigates are to be constructed for the Austrian navy, the newest type of frigate in the American navy is to be taken as a model. After 1820 a number of American marine inventions, and the use of cotton duck for sails (instead of flax or hemp), are earnestly inquired into. Travels in America, as the journey of Duke Bernhard of Saxe-lVeimar ( $1825-1826$ ), are watched with interest.

\section{(B) EMIGRATION.}

Edicts against emigration continued in force in the nineteenth century. They seem not to have been a cause of hardship, however, as in the case of Switzerland or Germany, hemmed in on all sides by vigorous peoples. The great incentive for the ambitious emigrant, free land, could be had at home for the Austrian. There were still unsettled areas in the plains of Hungary, the mountains of Transylvania, and the Galician territory on the other side of the Carpathian range. These favorable conditions prevailed for the greater part of the nineteenth century. The records at Innsbruck show that emigration for America was not of moment in Tyrol before the middle of the nineteenth century. Only one other province seems to show a greater proclivity toward emigration, viz., the crown land Bohemia. It is possible that the records of Bohemia if carefully searched might show an earlier migration to America. The country is populous, and the friction between Slav and German is not of recent date; it might have acted as an incentive to either race-stock to leave a district where it was outnumbered.

\section{(c) POLICE RECORDS.}

In the archive of the Department of the Interior (Allg. Archiv d. K. K. Ministeriums d. Innern) in Vienna are deposited the records of the police department under Metternich. They constitute a great mass of material poorly indexed, and consequently the progress of work in them is slow and difficult. Knowing the name of a particular refucee it is possible to fund the acta concerning him, but to collect the whole body of material relating to America would be a huge task. Several great bundles of acta are found on the Lombard-Venetian conspirators of 1835 , deported subsequently to America, and on another group of revolutionists from Galicia deported in 1836 ; acta are found (1823) on the refugee Carl Postl (the novelist Charles Seals-

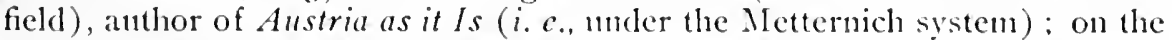
religionist Bernhard Müller, alias Proli, of Offenbach (I830); on P. Szirmay's plan of enigration in 1835 , concerning which he writes to Gottfried Duden, author of the book of travel in the Middle West, which brought great numbers of settlers to Missouri; on Friedrich Baraga (I8+I), the Indian missionary of Michigan and I ake Superior : on the merchant Leopold Först (Ferstl), 1846; on Friedrich Wilhelm Bornemann ( 1847 ), an emigrant agent for North America ; on Karl Heinzen, the revolutionist of is 8 , anthor 
of " der teutsche Tribun", who is reported as " aus der Schweiz gewiesen". It is very regrettable that the accessibility of the archives ceases with 1847 , for the period of ${ }_{1} 848$ and thereafter would unquestionably furnish the most interesting material from the American point of view. Acta on the career of Hans Kudlich, the liberator of the Austrian peasantry, leader of the revolutionists in Vienna in 1848 , sentenced to death, refugee in America (where he lived in retirement from politics), and of many other brilliant men of this epoch, would undoubtedly appear in this archive. 


\section{CANTON ZÜRICH. \\ ZÜRICH: STAATSARCHIV.}

Location: The "Staatsarchiv des Kantons Zürich" is located on the second floor of the Obmannant, which faces the Hirschengraben.

Hours: 8 a. m. to 12 m.; 2 to 6 p. m.

Bibliography: Paul Schweizer, "Geschichte des Staatsarchivs Zürich", in Neujahrsblatt des Waisenhauses Zürich (Zürich, I894).

Paul Schweizer, "Inventar des Staatsarchivs des Kantons Zürich”, in Inz'entare Schweizerischer Archive, Beilage to the Anzeiger für Schweizerische Geschichte, II. I-I IO (Bern, I899.)

A. 103. Auswanderungsverzeichnis. 1651, 1661, 1680. A large bundle of acta. Destinations of emigrants: the Palatinate, Netherlands, Swabia, French and Dutch service. Some of these probably migrated to America, though the American colonies are not named as a destination.

E. II. 269. "Rödel aus allen Capiteln, namentlich der nach der Pfalz, dem Elsass und Würtemberg Ausgewanderten, nebst Mandaten und Rathserkenntnissen seit I 65 I, mit Index." I 657.

E. II. 270. "Rödel (a) nach Gemeinden sämtlicher Capitel der nach der Pfalz, der Markgrafschaft Baden und Vürtemberg Ausgewanderten, mit Index." I657, I663.

(b) "Rödel der aus dem Capitel Regensberg in den Vilmerger Krieg zu Feld gezogenen." I656.

(c) "Gemeinderödel v. Dielstorf, Dietikon u. Regensberg." I649.

E. II. 270 a. "Rödel der I66I ausser Landes befindl. Züricher Landleute." I66I.

E. II. 268. "Gemeinderödel der Stadt Eglisau." I 767.

A. 8. "Visitation- und Undersuchung, wie selbige in Ao. I702 ist vorgenonmen worden, von derjehnigen Mannschafft ausz mr. Gin. Hrn. Bottmäszigkeit, welche sich theils in Frömbden Kriegsdiensten, theils sonsten auszert Lands befindet, wie solches von dem Hrn. Decanis einkommen." This is a list of names of persons who were not at home in the year i jo2. The place whence they were last heard from is given wherever possible. Many undoubtedly found their way from Alsace to the American colonies.

A. 90. 2. (XVII. 75. 2.) "Herr Jacob Christ. Zollikofer, Bürger von St. Gallen; dermahlen Einwohner und Handelsmann zu Virginien in America : alsz zu dieser Affaire bevollmächtigter, bittet um gnädige Beistener zum Kirchen und Schulban für die Deutschen in Virginien." Zürich, Aug. 28, I720. (3 Stück.)

"Virginia Gemeinde besteht aus I2 Familien Reformierter und 20 Familien Lutherische." This was the German colony founded by Governor Spotswood in Virginia, "Germanna ", and its off shoots, Germantown, Hebron Church (Madison County), etc. Letter dated June I8, 1720. 
A. 128. Io. "Akten betr. Auswanderung in Carolinam et Pensylvaniam." Vogtei Knonau. I729, I734-I735. (I2 Stück.)

Inquiry for advice concerning emigration. Mar. 29, I729.

Reply and plan suggested. Apr. 2, I729.

Description of Pennsylvania. "Verhör einiger Mannspersonen welche nacher Pensylvaniam reisen wollen." Reasons for emigration. Apr. 4, I729.

"Drei treue Hausväter" wollen reisen. Apr. II, I729.

Passes given. July 27, I734.

Attempt to dissuade emigrants from going to Carolina. Aug. 4, I 734.

Other acta dated Aug. 5, 20, Sept. I 5, 25, Oct. 5, I734; Apr. I3, I735.

A. 131. 25. Akten. Kieburg. (6 Stück.)

"Verhör." Aug. I8, I734.

List of emigrants. Apr. 3, 1737.

Request to emigrate. Oct. 8, I734.

Returning emigrant. Sept., I 738 .

A. 169.2. Akten. Verhör Götschi, etc. Briefe von Emigranten aus London. The letters are dated Oct. 4, 20, 25, I734. They describe the journey through France and the long delays before embarkation at London. They give a favorable picture in the main, describing hardships as possible to endure or overcome. (8 Stück.)

A. 44. I. Mandate auszuführen vs. Emigration. Dec. 7, I739. ( I Stück.)

A. 174. "Verzeichnisse der Ausgewanderten nach Carolina und Pensylvanien." I734-I744. Nos. I-98. This is a complete list of emigrants from every district of the canton of Zürich during the period of greatest migration to the American colonies. It is invaluable for genealogical purposes, and should be printed entire. It is the only source which gives complete statistics on which we can base an accurate estimate of the number of persons that came to America from Switzerland during the great exodus of I734I744. During this decade, in spite of repressive measures of all kinds, the number of emigrants that came from the "ZürichGebiet" and journeyed to the American colonies was 23Io. The record made by the district Eglisau was 680 . The country districts furnished more emigrants than the cities Zürich and Winterthur. Many names that have become familiar American family names are found in these lists, as Frik (Frick) from Knonau (also from Aargau), migrating to Carolina in 1739.

"Protokoll über ausgefertigte Mannrechts-Patente für hieszige Bürger und Angehörige so ihr Bürger- und Landrecht aufgeben ; angefangen von Hans Wilgert Zoller, Staatsschreiber, Ao. I720, revidiert und registriert von Johann Conrad Hirzel, Staatsschreiber, Ao. I785."

A. 26. I8. Zürich, Stadt und Landschaft. Criminalsachen, Diverse Personalien, I74I-I755.

X. I35. 6. "Acta u. Verhör der nach Pensylvania abreisenden Landleuthe." Apr.-May, I743. ( Io Stück.) Incl. letter of Johann. Mauritius Goetschius, Amsterdam, Aug. 8, I743.

B. VII. 13. Tom. XIII. 4. Auswanderungen, pp. 86-I05.

Printed pamphlet, Glückshafen, etc. Spanish emigration, i767. Acta concerning this, and also Pomerania (Preussisch Pommern). 
B II. Raths Manuale.

I734. Unterschreiber Manual (UM) II. “Caroliner Sachen." (2I references; see index at end of volume.)

Stadtschreiber Manual (SM) II. "Carolina, hinwegziehen dahin." (4 references.)

I735. UM I. "Ein Mann von Walliszellen kommt zurück", p. 45.

1736. UM I. "Caroliner Sachen”, p. 41.

1737. UM I. "Carolina", p. 187. A group of people from two districts planning to go to Carolina. They are to be reasoned with; dangers of the voyage to be urged; and loss of "Landrecht".

1738. UM I. "Das Reisen nach Carolina und Pensylvania verboten." (3 references.)

UM II. "Carolina, Reisen dahin." (8 references.)

"Carolina, Wiederheimkunft aus." (4 references.)

"Pensylvanien, Reisen dahin." (2 references.)

1739. UM I. "Carolina, Reisen dahin." (5 references.)

"Carolina, Mandat deswegen." (2 references.)

1740. UM II. "Carolina, Colonie in America." (2 references.)

1741. UM I. "Carolinam, Reisen in." (I4 references.)

I743. UM I. "Carolina, dahinziehendes Landvolk." (4 references.)

"Pensylvania, dahin ziehende Landleuth." (2 references.)

UM II. "Pensylvania, dahin zu verschicken parat gelegene Quart Biblen", p. 54 .

I744. UM I. "Carolina, dahin verlangende Landleuth", p. 66.

Mandate.

III. Landwirtschaftliche Sachen.

I. Emigration; Lands-Verlassung.

1652, Aug. 2. "Dass niemand mehr ohne Erlaubnis aus dem Land wegzeuche ; sonderlich nicht an papistische Ohrt ; noch zu den Widertäufferen." CXL.

1734, Nov. 3. "Verbot nach Carolinam zu reisen." DCVII.

"Wir Burgermeister und Rath der Stadt Zürich entbieten allen 11. jeden Unseren Angehörigen auf Unserer Landscha ft Unseren gnädigen Grusz, und darbey zuvernemmen: Demnach wir zu Unserem nicht geringen Bedattern und Miszfallen schen und erfahren mïssen, wie dasz einerseiths die Zeithero eint und andere. Uns zum Theil bekannte Persohnen sich understanden, hin und wider anf Unserer Landschafft viel von Unseren Angchörigen, unter allerhand, meistens gantz und gar unwahrhafft, nichtig- und boszhaftersomnenen Auszstreuw und Vorgebungen zu überreden, und zu vermögen, dasz sie würklich in die Vicl Hundert Meilen weit von hier in West-Indien gelegene, theils der Bottmässigkcit Ihro Königlichen Majestät von Grosz-Brittanien, theils aber dem unsicheren Gewalt allerhand wilder und unchristlicher Nationen unterworffene Landschafft Carolinam abgereiset; anderseiths aber, dasz vil-ermeldt-Unserer Angehöriger sich durch allerhand verführische Büchlein, und ihren Eigensinn so stark eimemen lassen, dasz selbige weder denen auf Unseren Befehl von Oberkeitlichen, noch denen von Privat-Persohnen gegen ihnen ausz aufrichtiger Wohmeynung geschehenen Abmahnungen Gehör 
geben wollen, dieselbe unwüssende und unbesinnter Weise verachten, und gäntzlich in den Wind schlagen, ja gar einiche, als wann man ihnen an ihrem Wohlstand verhinderlich seyn wollte, sich leichtsinniger Dingen einbilden dörffen; als haben Wir ausz Lands-Vätterlicher, für den. Wohlstand der lieben Unserigen, aufrichtig tragender Vorsorg und ausz habender Überzeugung, nicht allein was grosser Mühe, Kosten und Gefahr die Reise, sonderlich für kleine Kinder, in ein solch-entfehrntes Land unterworffen, sonder auch mit wie vielem Ungemach und allerdings unübersteiglichen Schwierigkeiten eine neue Einrichtung in diesem Land unausweichlich begleitet, und annoch, ob die würklich Abgereiseten in dieses Land übergeführt, oder zuruck gewisen werden, gantz ungewüsz seye, Unsere Oberkeitliche Pflicht und Schuldigkeit zu seyn ermessen, durch offentliche Verkündigung dieseres Unsers best-gemeynten Mandats, jedermänniglichen mit Vorstellung vor auszgeführtem, der Sachen wahrer Beschaffenheit von solch leichtsinnig, unbegründetem und sehr grossen Gefahren begleitetem Vornemmen treuhertzig abzumahnen und zu verwahrnen, und hingegen, wie hiermit geschihet, alles Ernsts für diszmal zugebiethen, dasz bisz auf Unsere weitere Verordnung niemand, weder Mann, Weib noch Kinder ausz dem Land gehen, sondern in demselben verbleiben, und mittlest des Allerhöchsten mitwürkenden und verheiszenen Segens durch fleiszig und ehrliche Arbeit, sich und die seinigen redlich zu ernehren trachten thue, und wollen dahero, dasz Unsere Oberund Land-Vogt, und dero nachgesezte Beamtete, dergleichen Leuthen ligend- und fahrend-Gut $z \mathfrak{u}$ verkauffen keineswegs mehr gestatten, die würklich beschehene Kauff und Verkauff auf Verlangen der Verkäufferen, wenn sie den Kauff-Schilling wider erstatten können, wider aufheben, auf die Auszstreuer dergleichen verführischer Büchlenen und die Aufwigler zü Statt und Land geflissene Achtung gegeben, selbige auf Betretten gefänglich anhero geschickt, und von der hierzu verordneten Commission exemplarisch abgestrafft ; und wann über all dise Unsere, so wohl- und Vätterlich-gemeynte Verwahrungen und Gebott, dannoch der eint oder andere sich erfrechen, und heimlich darvon ziehen thäte, dem ald [=oder] denenselben nicht allein das hiesige Land-Recht auszhingegeben, sondern auch, wann ein solcher ausz Armuth getrieben, darinnen er sich auf dise Weise muthwillig gestürtzet, wider in sein Heymath käme, von denen Beamteten Unseren Ober- und Land-Vögten angezeiget, mit Weib und Kinderen, von Stadt und Land verwisen, und zu keinen Zeiten mehr darinnen geduldet werden solle. Wornach sich jedermänniglich zurichten, und vor Straff und Ungnad zuverhüten wohl wüssen soll und wird.

"Geben, den dritten Tag Wintermonats, nach Christi unsers lieben Herrn und Heylands Geburth gezelet, Ein Tausend, Siben Hundert, Dreyszig und Vier Jahr. Kantzley der Stadt Zürich.”

I735, Jan. 29. “Dto. wie I734." DCX.

"Wir Burgermeister u. Rath d. Stadt Zürich entbieten allen und jeden Unseren Angehörigen zu Stadt und Land Unseren Gnädigen Grusz und darbey zuvernehmen:. Demnach Wir zu Unserem 
nicht geringen Bedaueren sehen und erfahren müssen dass ungeachtet all Lnserer vorgewandt-Lands-Vätterlicher Sorgfalt und des unterm 3 ten Winter-Monat letst-verwichenen Jahrs ab allen Cantzlen zu Stadt und Land verlesenen wollgemeinten Mandats, dennoch viel der Unsrigen auf eine muhtwillige Weisz ihr Vaterland verlassen mit ihren Weibern und vielen ohnschuldigen Kindern in der Meynung verreiset in dem so weit entlegenen Carolina ihr Leben besser durchzubringen, einestheils: Anderseits aber verlauten will, als wann durch Aufwiegelung ohntrener Leuthen annoch eint- und andere in gleiches Unglïck verleitet werden möchten: Als haben Wir Uns zu wahrem Nutzen samtlicher Unserer lieben Angehörigen veranlasset gesehen, obvermeldt-Unser-Hoch-Oberkeitliches Mandat zuwiederholen, und dahin zuvermehren, dasz hiermit männiglichen das Verreisen in Carolina gänzlichen und so verbotten seyn solle, dass derjenige, so sich hierauf erfrechen wurde, heimlich ald offentlich wegzuziehen, hardurch sein Burger- und Land-Recht solle verlohren haben, und weder er noch die Seinigen zu keiner Zeit mehr dazu gelangen mögen: Und damit dieserer Unbesonnenheit der Riegel noch mehrers gestossen werde, so sollen Unsere Ober- und LandVögte fleissigste Achtung geben, dasz dergleichen Leuthen keine Verkauff mehr, es seye von Ligend- oder Fahrendem zugelassen, sondern selbige behinderet, und je nach Beschaffenheit der Sach die Käuffere, als die neistentheils hardurch ein unbillichen Eigennutz suchen, mit ernsthafter Straff zur Verantwortung gezogen werden. Auch werden sie so wohl als ihre nachgesetzte Beamtete, wie dann in Unserer Stadt von den eigens hierzu verordnetgeliebten Mit-Rähten auch beschehen wird, auf obvermeldte Aufwieglere eine genaue Aufsicht haben, und selbige auf Petretten zu ernstlich und exemplarischer Abstraffung ohngesäumt allhero schicken. Alles um so mehr, weilen WVir sint der Zeit die betrübte Nachricht ganz Stand- und wahrhaft erhalten, dasz obgleich keiner von diesen elenden Leuthen in das sogenannte Carolina kommen wird, dennoch eine grosze Anzahl meist Unserer vormahligen Angehörigen zwar in Engelland angekommen, sich aber in dem gröszten Elend und Erbarmungswürdigsten Zustand befinden, so dasz zubesorgen, sie werden, als dic sich selbst in äusscrstes Elend gestïrzt in Ermangelung nöthiger Lebens-Mitten, so wohl als der Kleidern, ihre Ohnbesonnenheit und den ihrem Vaterland bewiesenen Ohndank, in ihrem Verderben bedauren müssen; Welches Wir hierdurch jeclermänniglichen zuwüssen thund, und also auch ein jeder sich vor Unglïck, Straff und Ungnad zuverhüten wohl wïssen wird.

"Geben Samstags den Neun und Zwanzigsten Jenner, Fintausendt Siebenhundert Dreyszigr und Fünf Jahr. Kantzlei der Stadt Zürich."

1736, Feb. 3. "Dto. wie 1736." DCXV.

1739, May 13. "Verbott in Süd-Carolinam, Pensilvaniam, Gcorgien u. andere Oerther zu ziehen, conf. 1736." DCXXXVII.

1741, Feb. 4. "Dto. wie 1739." DCLIII.

I744, Mar. I8. "Dto. wic 1741." DCLXXIII. 
I 67 , Dec. Io. “ Mandat wider die Emigration in die spanische Colonien, für das Thurgau. Idem für das Rheinthal; Sargans; O. fr. (frei) Ämter: Gr. Bad. u. fr. Ämter ; alle gleichlautend." DCCCLV. I770, Nov. 29. "Verbott in das preussisch Pommern zu ziehen. Conf. I767." DCCCCVII.

E. II. 43, 44. Protokollum Actorum Ecclesiasticorum ab Anno I731-I749, I $749-1757$.

E. II. 43. p. 27I. Zell: “Gravamen [i.e., Beschwerde] Begird in Carolinam zuziehen. Wird vielleicht im Prosynodo der HHrn. Decanorum vorkommen." Oct., I734.

p. 4 IO. "Hr. Decan berichtet am end, dass in dem den I4 Sept. gedruckten Nachrichtsblättlein enthalten, dass viel aus dem Canton Appenzell und Grafschaft 'Toggenburg nacher Carolina reisen. Dieses und dergleichen, um unser Volck nicht auf das neue gelüstig zumachen, sollte nicht gedruckt werden. Einer der Ihr. Censorum berichtete, dass ob er es gleich improvirt, der Drucker es dennoch auf seinen Kopf gedruckt: worüber er zu reden gestellt worden." Oct., I736.

p. 736. "Carolina. Schweizerische Colonisten, die sich dort niederlassen. Um dieser ..... als Prediger Indianer begehrte (I734) ein gr. [i.c., gewisser] Mawritz Göttschi von .... ein Attestat von hier. Acta 260, 263, welches ihm auch gegeben ward. Sein Sohn Heinrich schrieb aus Pensilvanien (p. 58I) begehrt ad S. Minist. ordinirt zu werden; was man zu thun bedenklich fand. Schreibt wieder aus Holländ. America (p. 736) u. verlangt, ein Membrum Synodi nostra zu seyn, und dass man auch seinen aus Carolina hergeliommenen Bruder zum Ministro mache, damit er hernach die Gemeinde der Schweizer-Colonisten in America bedienen könne. Auf das erste wurde geantwortet- Einen Abwesenden und bey uns nicht ordinirten in Synodum auf zunehmen, reime sich nicht mit unserer Verfassung. Seinen Bruder betreffend, wird selbiger aus S. Allmosenamt adsistirt, dass er Chirurgie erlehrnen kann. MGn. HHrn. haben seinethalben expresse erkannt, dass er bey uns ad S. Minist. nicht adspiriren solle, aus landesväterlicher Sorg, dass er nicht nach der Hand viele von unserm Volk zu emigriren lüstern mache',"

"Späterhin ( I747) liess ersterer, durch eben diesen seinen Bruder bitten, dass man ihm im Sackcalender unter unsern Ministris in der Fremde mit einrücken mögte. Erk[annt] Nein; er solle ein Patent einschicken, wann, wo und wie er ordiniert worden sey ", p. 828 .

p. 283. "Schulmeister Kuhn von Grafstal der Pfarr Lindau, so wegen Carolina sein Sächli verkauft, von der Gemeind seinen Dienst aufgegeben, und ein Abschiedszeugnisz bekommen, jezo aber den reuen spilt, bittet MHHrn mit einem für ihne mitgekommenen Kirchenpfleger demüthig, ihne wider in seinen Schuldienst einzusezen. Ward ihme in seiner angelegenlichen Bitt gnädig willfahret, und deszen zum Urkund ein Schrn. an seinen Hrn. Pfarrer, Hrn. Camerarium Wysz, mitgegeben."

pp. 286-287. "Hans Heinrich Maag, der in Carolinam ziehen wollen, und ein extra guter angenehmer Sänger ist, zu Schulmeistern gesezet und erwehlt worden." Nov., I734. Beylag 553. 
p. 287. "Schulmeister zu Ellikon hat in Carolinam ziehen wollen." (Received an inducement to stay.) Nov., I734.

p. 345. "Emigratio in Carolinam. Elsau: Bericht Hr. Decani von I6 Emigranten seiner Gemeinde. Ist gut wann die fata und elend dieser zurückgekommenen leuthen unserm Landvolk bekannt, und dadurch andere vom emigriren abgehalten werden." Oct., I735.

p. 385. "Elgäuer Capitel. 2. Bericht wegen Carolina (nicht vorhanden)." Apr., I737.

p. 518. "Emigrirte aus diesem Capitel [Eglisau] in Carolinam sind 29I Seelen; die mit weggenohmen 432I fl. [Gulden] nur was man weiszt; noch vieles unwiszend." Nov., I 738 .

p. 593. "Vorhabendes Emigriren in Carolinam. Weyach: Da und in der Nachbarschaft grosse Bewegung und Anstalten, könftige Frühling in Carolinam wegzuziehen. Hierüber kann man sich bey der Commission, die MGHHrn geordnet, anmelden. Diesmalige Kriegs-Conjuncturen in selbigem Lande sollten unseren Landen den appetit vergehen machen." Oct., I 740.

p. 638. "Weiach: Gravamen wegen des Leuthverführer Bersinger, nach Carolinam." Oct., I741.

p. 639. "Märsteten: grav. dasz 3 Haushaltungen in I9 Personen bestehend, nacher Carolinam emigrirt. Wollten sich nicht hinterhalten laszen." Oct., I74I.

p. 712. "Jägerlen (Steinercapitel) lamentirt, dasz nur aus seiner Pfarr. 53 Personen in Carolinam emigrirt." Nov., I 743.

pp. 276, 7I4. "Auswanderer nach Carolinam. Ein Gravamen Synodale."

pp. 6i8, 699. "Das Emigriren nach Pensylvanien. Ein Gravamen Synodale."

E. II. 434. Litterae et acta varia; ab anno 1737 et deinceps ecclesia; speciatim Anericanas, Palatinas, Polonicas, Lithuanicas, Rhaeticas, et Wetzsteinianas lites concernentia.

A large number of letters concerning contributions to churches in Pennsylvania and Carolina, $c$. g.., Schlatter's attempt to secure contributions (I75I); letter of Balthazar Pfister (1752) explaining why no contribution was possible from Schaffhausen; Götschi's letter in Dutch; a request for 50 copies of the Bible refused.

A copy of Schlatter's book: Wahrhafte Erzchlung von dem wahren Zustand der meist IIrtenlosen Gemeinden in Pensilaranicn und denen angrensenden Prowinzen, von Michacl Schlatter, Ea'angelisch Reformirten Prediger an Philadelphia, denen Hoch-Ehrwiirdigen Chrisllichen Symoden in den Nicderlanden, aie anch andern mildthätigen Christen in Hollündischer Sprache vorgestellt. Nummeliro aber a'on dem Verfasser selbst in die deutsche Sprache ïbersctact, unl aly leich an dic lobliche Reformirte laidsenoszschaften und Ministeria in der Schaveitz dediciret, nebst cinem Vorbericht der Verorducten won der Classe an Amsterdam (Frankfurt a. M., gedruckt bey Ph. W. Eichenbers, d. Jüngern, $1752)$.

E. II. 44. p. 65. "Obrigkeitliche Veranstaltungen die Auswanderung nach Carolina zu verhindern." Apr., 1750. 
E. II. 66. Beylagen zu dem Protokoll Actorum Ecclesiasticorum ab anno I73 I ad an11. 1749. (A large number of references.)

No. 516 ad p. 260. "Supplication Hrn. Moritz Götschis."

No. 524 ad p. 263. "Erlaubnis dass Götschi als Prediger der Schweizer Colonisten in Carolina diene." Aug. 29, I734.

Das Hochoberkeitliche Staats Archiv zum Frauen Münster von Alten her bis auf das Jahr I740. Register von Salomon Wolf I778. Entries under "America".

I726. "Reisen in Ost- und West Indien, in Carolinam, in Pensilvaniam."

I734. "Löblichen Stands Bern Anzug, wegen der in Carolinam häufig reisenden Leuthen." XXX. 552. 2.

"Junker Landvogt Zoller zu Kyburg berichtet, es wollind viele "Leuth in Carolinam reisen." IX. 663. 24 b.

"Item Hr. Pfr. zu Altorf, dass Jacob Schenkel mit Weib und Kinder dahin wolle." IX. 663. 24 b.

"Mandat wieder das Reisen in Carolinam." XXX. 553. I.

"Basel bittet, dass man die Caroliner mit Pässen versehe, damit sie ihnen mit Bettlen nicht beschwerlich fallen." V. 73I. I8.

1737. " Hr. Landvogt Leu zu Kyburg berichtet seine vergebens gehabte Bemühungen zwey von Billikon und Ernst von ihrer Reisz in Carolinam abzuhalten." IX. 668. 32.

1738. "Relation eines von hoher Verordnung verhörten und aus Carolina zurückgekehrten Elggauers." IX. 670. 9.

"Johannes Schweizers vorhabende Entführung seiner Ehebrecherin, in Carolinam." XXIII. 709. 5.

"Rahts Begehren Hrn. Landvogt Wolfen zu Greyffen See, wegen einicher aus seiner Herrschaft in Carolinam zu reysen entschlossener Haushaltungen." X. 563. 33.

"Item Jkr. Landvogt Grebel." X. 704. I6.

"Hrn. Landvogt Stockers Amts Bericht, auch deswegen." X. 878. 29.

"Idem begehrt Befehl, wie er sich der zurückgekommenen Carolinern halben zu verhalten habe." X. 878. 30 .

"Die Gemeind Boppelsen beschwährt sich über die thro zugemuthete Vieder Annahme eines nacher Carolinam verreisten Heinrich Mathisen, oder dessen Kinderen Versorgung." X. 704. 17 .

America. 1741-1756.

1741. "Hr. Landvogt Streif zu Frauenfeld berichtet das Vorhaben vieler seiner Angehörigen in Carolinam zu ziehen." V. 4. I8.

I752. "Abgeschlagene Steter für die Kirchen in Pensilvanien." I. 273. I4.

"Einfrag bei Mr. de Vermont ob man zu Hünigen in der Schweiz herumvagierende Bürsch annehmen [=verhaften], und in die americanischen Insuln schicken würdé." I. ‘27I. Beilage C, D.

"Französische Antworten betr. den Eidgenöss. Vorschlag wegen Verschickung der Vaganten in die französ. Colonie in America." I. 107. 9, I0.

1756. "Gottlieb Mittelberger übersendet aus Stuttgart einiche Exemplar seiner Beschreibung von Pensilvanien." I. 7II. IO. 


\section{Emigrationen.}

1729. "Resolution etwelcher junger Mannschaft aus der Herrschaft Knonat in das Neu Engellend in America zu ziehen, und Rathsbegehren, ob sie nicht von dem mitnehmenden Gelt den Abzug liefern sollen." XI. I64. Io.

"Verhör einicher Manns Personen, aus der Herrschaft Knonau, welche nacher Pensylvanien zıl reisen gesinnet." XI. I65. I I.

"Aus der Herrschaft Knonau in Neu England Abzug von dens." See A. 128. Io, above, p. I4.

1734. "Hr. Landvogt Schenchzers Bericht, dass einiche von denen in Carolina zu reisen gesinnten sich abhalten lassen, und die Päss zurückgeben." XI. I73. I7 a.

"Hr. Landvogt Schenchzer berichtet, dass Heinrich Näf von Hausen (ein ziemlich bemittleter Paur) verschiedene (Pietisten) zur Reisz in die Insul Carolinam animiert und entfülırt." XI. 173. I 7 b.

"Hr. Land Schreiber zu Knonau bcrichtet, dic Namen der i I Personen, so in Carolinam verreiszt, der Abzug werde genohmen von dem Gut, so aus dem Land gezogen werde, der Näfen Bruder wolle die 605 fl. nicht verabziigen." XI. I73. I7 c.

"Hr. Landvogt Scheuchzer bittet um befehl, wie er sich wegen der Näfen aus der Graben, der Pfarr:Hausen, verweigernden Abzug ihrer Brüdern in Carolina gezogener Mittlen zu verhalten." XI. 173. 18 .

"Verhör der nach Carolina ziehenden Alt Pfarrer Götschis und Meister Wüsten des Metzgers, samt einigen Berichten von abgereisten Carolinern aus der Herrschaft Knonaww, von London." XIX. I049. 26.

"Verdacht auf Ludwig Herder und Heinrich Kambli wegen des Caroliner Geschäfts." XXIII. 668. 8.

1735. "Des Metzger Wüsten schlecht Aufführung in dem Caroliner Geschäft." XXIII. 689. 4.

1738. "Johannes Schwcizcrs vorgehabte Entführung s. Ehebrecherin in Carolinam." XXIII. 709. 5.

1739. "Emigrationen. Gutachten deswegen." XIV. 280. 12.

Emigrationen, 1740-1790.

1740. "Gutachten betr. den Streit zwischen Hrn. Landvogt Öris sel[igen] Erben, und den Verwandten der in Pensilvanien sich befindenden Hagemanns von Herziken." VI. 513. + a.

1741. "Ulrich Hubers und Heinrich Weidmanns von Süniken beharrliches Vorhaben mit ihren Haushaltungen in Carolina zu ziehen." VI. 546.5 .

"Verhör mit 3I Emigranten in Carolina aus dem Zürichgebieth." VIII. 357.8 .

"Hr. Landvogt in Thurgan bittet unn einen Provisional Befehl d. L[öblichen] Stfatt] Zïrich, wegen vieler Thurgater Vorhabender Emigranten in Carolina." V. 4. IS.

I743. "Der nach ['nsilvanien ahzureisen vorhabender Landleuten Verhör." X. 135. 6. (With lists of names.)

"Bericht der Hrn. schirm Vögten betr. den von Zürich abreisenden Solomon Nïscheler." VIII. 338. I I b. 
“Bittschrift Moritz Götschis aus Pensilvanien.” XII. 40. 20.

"Basel berichtet betr. ein nach Carolina gereistes und zu Mumpf gestorbenes Töchterlein." III. 450. I2.

I743 u. I744. "Acta betr. emigrirte Landleute in Carolina." VII. 257. I a. I749. "Drei Männer von Ryken wollen in Pensilvanien ziehen." VI. I42. 4.

"Bern klagt über Jacob Walder von Knonau, wegen Verlockens in Pensilvanien." III. I2. IO.

1750. "Weisung betr. den aus Carolina zurückgekommenen, und während sr. Abwesenheit Verauffalten [i.e., in Concurs geratenen] Küfer Öri von Zürich." VIII. I IO. 7 .

I751. "Weisung betr. Seckelmeister Bären Sohn, ab den Hirzel, der aus Pensilvanien zurïckgekommen." VII. I65. IO.

"Bern berichtet dass sie Hrn. Pfarrer Schlatter wegen einer Steuer zur Reise in Pensilvanien abgewiesen haben." III. I8. I7.

I752. "Weisung betr. die Erbs-Extradition der in Pensilvanien sich aufhaltenden Elisabeth Bleuler von Zolliken." VII. 227. I7.

I759. "Verena Üelin von Andelfingen, kommt aus Carolina zurück." X. I 59. I3.

I 65 . " Bern berichtet, dass in der Eidgenossenschaft Verlocker in die Russischen Colonien herumschleichen." III. 37. I8-20.

I767. "Solothurn notificirt betr. Lockungen in Spanische Colonien." II. 262. 9 .

Wegen emigranten in Spanische Colonien. Mandate, etc. III. 42, I2-23.

"Bern consentirt zu den Anstalten in untern freien Aemtern wegen der zurückkehrenden Colonisten." III. 42. 25.

"Glarus consentirt auch deswegen." III. 42. 26.

"Gutachten betr. die emigrationen in Spanishe Colonien." VIII. 3 I9. I, 2, 6 .

I768. "Wegen Verlockung in Spanische Colonien." II. 262-3. IO-I 5. "Emigrationen dahin." VIII. 319. 7. "Anstalten dagegen.", VIII. 320. 4-6; VIII. 321. 6 , etc.

"Verhör mit dem nach Pensilvanien zu reisen vorhabenden Heinrich Huber von Metmenstätten." VI. 7I7. II.

I769. "Vollmacht auf Heinrich Grob Übernehmung der Mittlen, des in Pensilvanien sesshaften Heinrich Syzen von Knonau." VI. 7 I8. 2.

I770-I77I. "Acta betr. die Mittel Extradition Zwyer in Pensilvanien sesshaften Angehörigen von Wädenschweil und Knonau." VI. 767.7 .

I773. "Knonau berichtet betr. die Erbs Theilung des in Carolina verstorbenen Christian Groben von Maschwanden." VI. 726. I4.

"Mittel Extradition des in Pensilvanien sesshaften Heinrich Schweizers von Opfikon." VI. 209. 9.

I778. "Appellation zwischen Rudolf Rütschi von Dällikon einer-, dann Kirchenpfleger Bersinger, Müller zu Weyach und Mitintressierten Erben, der in Pensylvanien verstorbenen Margaretha Bersinger anderseits,--betr. eine Schuldforderung von Fl. 7I 5 Capital, nebst Zinsen, welche lestere an Erstern machen." VII. IO5. 3.

"Commisionalacta über obig bersingerische Schuld- und Erbstreitigkeit." VII. I05. 4-8.

\section{America. I790-I798; I803-I8I4.}

I79I. "Angesuchte Mittel und Landrechts Extradition der zu Albanien sich aufhaltenden Huberischen Famille von Unter-Mettmenstetten." IX. 34 I. 52 . 
1794. "Amts Bericht des Landvogtey Amts Knonau, wegen einem dem in America sich aufhaltenden Jacob Buchmann v. Dachelsen zufallenden Erb." IX. 346. 48, 50.

1803. "Anzeige und Bericht von vorhabender Auswanderung einiger Familien von Hesserschweil nach Nord America." IX. 426. 2, 4, 5.

"Raths Erlaubnis und Auftrag deswegen an die Commission des Innern." IX. 426. 3.

I804. "Antrag wegen Versendung des Staatsgefangenen Hauptmann Hanharts von Pfeffikon nach dem Spanischen America." XIII. 929. I33; XIII. 936. 79.

"Acta betr. Masznahmen in Absicht d. i. span. America ausgebrochenen gelben Fiebers." XI. 3 u. 4.

I805. "Gutachten betr. die Versorgung des inhaftirten Staatsverbrechers J. Jacob Hanhart von Pfäffikon nach Nord America." VI. 995. I.

"Antwort der Regierung des Cantons Basel auf die diesfällige Recharge." Ibid., 4.

"Ob die hinterlassene Tochter d. nach America emigrirten Hr. Ulr. Hinderling von Waltenstein daselbst als Gemeinde Bürgerin aufgenommen werden müsse." IX. 443. 83 .

1806. "Schuldstreitigkeit einiger von Alfoltern mit dem in America sich aufhaltenden Heinr. Schneebeli, und der Kinderen des dorten verstorbenen Schrepfers E. Schneebeli sämtl. von Alfoltern." XIV. 63. 24.

1807. "Einfrage: Ob Bürger, so aus einer Gemeinde wegziehen, eine Tröstung zurücklassen müssen, oder nicht." IX. 339. II2.

"Gutachten deswegen." IX. 445.69.

America. 1814-1827.

I8I5. "Die Berner Polizeidirektion meldet den Aufenthalt von Joseph Buonaparte in America." XVI. 511. 43.

I815-1816. " Acta betr. das Vermögens Extraditions Begehren der zu Harmonic in Nord Amerika befindl. Joh. Meyer von Winkel." VI. 76. I I-I 5 .

I816. "Die eidgenöss. Canzley übermacht verschiedene Berichte über die gute Behandlung der nach America attsgewanderten Schweizer." IX. 503. 28 .

I817. “ Anzeige dass G. Bader, Schuldner, nach Nord Amerika ausgewandert sey." I. 729. 7.

"Der eidgenössische Vorort communiciert eine k. niederländische Verordnung dass alle nach Holland kommende Auswanderer nach America Bürgschaft leisten sollen, dass sie dort bis zur Abreise ihren Unterhalt finden können." IX. 509. I 3; IX. 507. 25, 26.

I8I9. "K. span. Decret welches Todesstrafe und Ausschliessung von Amuestie gegren diejenigen ausspricht, welche den südamerikanischen Insurgenten durch Kriegsdienste oder Lieferung von Waffen, Munition und soweitere Hilfe leisten." I. 429. 36.

"Der eidgenöss. Vorort berichtet dass der k. preuss. Cesandte laut $k$. Verordnung nur denjenigen Auswanderern nach America die Pässe visiere, welche die Reisekosten vorweisen können." I. $55^{6 .} 4,5$. 
"Der eidgenöss. Vorort erinnert an die Verordnung der $\mathrm{k}$. holländ. Regierung, dass Auswanderer nach America für ihre Aufenthaltskosten in Holland Bürgschaft leisten müssen." XVII. 512. 43.

"Acten betr. Erbschaften." IV. 474. 3I, 32; VI. 82. 18, 20.

I820. "Rathsbeschluss betr. die zu beobachtenden Maasnahmen wegen Auswanderungen nach America und Brasilien." XVII. 690. 39.

"Deposition Hr. Schiffmeisters Reutlinger über den bey Goldbach verunglückten Hr. F. W. Goddard von Poston [Boston] in America, nebst Auskunft des Schiffknecht Rud. Gimpert von Küssnacht." XVI. 746, 96.

I821. Acten betr. Erbschaften. IX. 380. 3I, 32 ; XVII. 529. I; XVII. 530.8 .

1823. Acten betr. Vermögens Extradition. V. 833. 38; XVII. 588. r3.

"Der eidgenöss. Vorort berichtet die Anerkennung des schweiz. Handelsconsuln zu New York und Alexandria." VIII. 268. 44.

"Ansuchen des Herrn von Mater aus America um Ratification seines Kaufs des Gutes Goldenberg im Oberamt Andelfingen und um Gestattung seiner Niederlassung." VI. 735. 63; XVIII. 24. 32,33 .

1824. "Acten betr. d. Nachfrage wegen Johann Meyer in Harmonie in Nordamerika und Bericht über das Absterben dieses Meyer, von Heisch gebürtig, in Paris." I. 348. 27-32.

"Gutachten d. Commission des Innern betr. die Erblassung der in Virginien in Amerika verstorbenen Carl Frey von Weisslingen." V. 685.4 .

"Bitte des Jacob Meyer von Winkel, dass auf diplomatischem Wege in Erfahrung gebracht werde, ob seinem Bruder in Amerika die Ao. 1816 übersandten 10o Ldors zugekommen und ob er noch am Leben seye." VI. 88. 49, 50.

"Rathsbeschluss betr. die Mittheilung der Eröffnungen d. Hr. A. Sg. Cazenova, Consul in Alexandria, wegen Betreibung der.Verlassenschaftsangelegenheiten der in Amerika mit Tod abgehenden Schweizer." IX. $384 \cdot 3$ r.

"Die Berner Polizeidirection übermacht eine Publication rücksichtlich der nach Nordamerika auswandernden Schweizer." XVIII. 216.99.

I826. "Der Kirchenrath empfiehlt den Wunsch des amerikan. Geistlichen Hr. James R. Reily zu Errichtung eines theologischen Seminariums für die deutsch-reformierten Gemeinden in den Vereinigten Staaten milde Beiträge zu sammeln." XI. 356. 2.

1824, 1826. "Verschiedene Acten betr. Erbschaft von Barb. Frey verstorben in Little York in Amerika."

\section{America. 1827-1848.}

1827. " Bericht d. Eidgenöss. Vorort, dass die Nachforschungen über Leben u. Tod eines Ao. 1805 nach Amerika ausgewanderten Joh. Meyer von Winkel bisher fruchtlos geblieben; und Auszüge aus den Protokollen der Commission d. Innern betr. den diesem Meyer 'als Colonist in Harmonie in Nord Amerika' übersandten Vermögensbetrag von Fl. 1000." V.I. 93. 32, 33; VI. 95. I4. 
I828. "Ansuchen des Obrmt. Embrach betr. d. Verlassenschaft eines zu Philadelphia verstorbenen Georg Friedrich Haga." I. 652. 2.

"Wegen angeblicher Erbverlassenschaft Barba. Frey." V. 695. 6.

I828-I 829. Erbschaftsangelegenheiten. IV. 574. 47 ; XVII. 723. 12.

1830. "Verschiedene Akten betr. die Ankunft d. Hrn. J. G. Böcker als General Consul d. Nord Amerikanischen Freystaaten i. d. Schweiz." II. 631. 35, 36.

"Vorörtliches Kreisschreiben betr. die Form d. eidlichen Beglaubigung von Waarenfacturen die aus der Schweiz nach Nordamerika gehen." Ibid., 37.

"Ratherkanntnusz betr. die Einfragen des Nord Amerikanischen General Consuls auf welche Weise die Angaben des Werthes von Waaren Sendungen in die Schweiz erhärtet werden; diesf. Auskunft der 1. Staatskanzlei ", etc. Ibid., 38-4I.

Erbschaftsangelegenheiten. IV. 575. 12, 33-35.

"Antrag Hrı. F. L. Guyot in Paris die aus Frankreich zurückkehrenden Schweizertruppen zur Colonisation nach Columbia zu senden." XVII. 492. 7.

I83I. "Der Consul der Ver. Staaten i. Nord Amerika erkundigt sich nach dem Werte des spanischen Thalers auf hies. Platz." I. 439. 7I.

"Vorörtliches Kreisschreiben betr. d. Anweisungen, welche die durch Frankreich Auswandernden zu leisten haben." II. 308. 5.

Id. "betr. ein Ansuchen d. vereinigten Nord Amerikanisclien Staaten um Mitteilung d. schweizerischen Handelsgesetze." II. 639. I 52.

"Akten betr. das abgelehnte Ansuchen d. Hr. Pfarrer Schinz in Fischenthal seinem in Kulm Ct. Aarau sesshaften Jakob Furrer, Spengler, um eine Unterstützung an die Kosten semer beabsichtigten Reise nach Nord Amerika zu geben." II. 885. I I, I2.

"Das Nord Amerikan. Handelsconsulat bittet um Mitteilung d. hiesigen Handelsgesetze; Bericht d. kaufmännischen Directorii." XIII. 712. 16,17 .

"Bericht d. Regierungsrath löblichen Stands Lızerı wegen Gebrüder Yedy von Bern, dato in Amerika." XVIII. 495. 25.

"Auftrag d. Regierungsrath betr. das Auswandern scluweizerischer Angehörigen nach Amerika." XVIII. 496. 39.

I832. “Akten betr. eine Vorörtl. Zuschrift an die handeltreibenden Stände über das schweizer. Handelskonsulat und die Grundlagen der nit Mexiko und Nord Amerika anzubahnenden Unterliandlungen und Bekanntmachung einer Note des Consuls." XV. 75I. I-4.

"Akten betr. die Mitteilung einer französ. 11. holländ. Note ïber die Auswanderer nach Anlerika." XV. 75I. 5, 6.

"Der eidgenöss. Vorort theilt die holländ. Verordnung betr. die Answanderung durch die niederländ. Staaten nit." XIX. 266. 51.

"Die österr. Gesandtschaft ersucht um Bekanntmachung des von ihrem Hofe erlassenen Gesetzes ïber die Auswanderung aus dortigen Staaten." VIII. 9II. II.

I833. "Vorörtliches Kreisschreilen betr. dic Visirung der l'ässe zur Auswanderung." Seh. 591. M1. I. I I.

1836. “Akten betr. d. lireizügigkeitsvertrag mit d. Ver. Staten v. Nordamerika." [i. 1. A. 2. M. 1. I 5 .

1837-1839. "Nkten betr. d. Verhältnisse d. schweizer. Handelsconsulate dasellist." F. 1. A. 5. M. I. 1, 2. 
IS39. "Einsendung d. Berichtes d. Staatssecretairs d. Finanzen an d. amerikanischen Congress." F. 1. A. I. 32. M. I. I.

r $8_{45}$. "Vorörtliches Schreiben betr. d. Vertrag mit den Ver. Staaten über gegenseitige Auslieferung der Verbrecher." F. 1. A. 2. M. 2. 2O-2I.

"Aliten betr. die Handelsverhältnisse mit Obigen.” F. 1. B. 10. 2. M. I. 40.

"Schreiben d. Consuls in New York betr. d. Auswanderungen nach d. Ver. Staaten." F. 3. D. 3. M. 1. 8.

IS46. "Anerbieten d. Consuls über Einrückung von Inseraten in nordamerikanische Blätter.” F. 1. A. I. 32. M. I. I2.

IS47. "Vorörtliche Kreisschreiben betr. d. Handelsverkehr aus der Schweiz nach d. nordamerikan. Freistaaten." F. 1. B. ro. 2. M. 2. 2, 6.

"Bericht d. glarnerischen Vereins für Auswanderer über die Kolonie Neu Glarus." F. 3. D. 3. M. I. Io.

"Vorörtl. Kreisschreiben betr. d. Auswanderung nach d. Vereinsstaaten." F. 1. A. 2. M. 2. 27, 28.

Id. "Erhebung von auswandernden Schweizern dahin. F. 3. D. 3. M. I. I3.

Id. "Überfahrt dahin." F. 3. D. 3. M. I. I6, I7.

O.61. I. Handelsverhältnisse mit dem Ausland.

(13) Vereinigte Staaten von Nordamerika. I84I-1853. Contains:

Acta concerning commercial treaty with U. S. I 845 .

$I d$. concerning changes in tariff.

$I d$. concerning consular fees.

Id. concerning improvement of trade facilities between Switzerland and the United States.

$I d$. betr. Eidesleistung für Verification von Facturen.

$I d$. betr. Gesuch, Zürich: Seidefabrikanten um diplomat. Verwendung.

$I d$. betr. Generalkonsulat in Washington: Beschlagnalıme von Seidenwaaren in New York. I867.

Id. betr. Sequestration Schweiz. Seidenwaaren. I867.

O. 60. I. Ausstellungen im Ausland.

No. 2. Acta über Ausstellung in New York. 1854.

No. I2. Id. Philadelphia. 1876.

No. 22. Id. Chicago. I 892.

L. 2. I. Schweizerische und ausländische Angelegenheiten.

Ausland. Allgemeines II. Geschäftsträger und Consulate, I804-I873. Vereinigte Staaten von Nordamerika I823 f.

Consulate in den Ver. Staaten: Cincinnati, Chicago, New York, New Orleans, Philadelphia, Washington, St. Louis, Louisville, Charleston, Milwaukee, Highland, San Francisco.

Consulate in Centralamerika, Mexico, Panama, Brasilien, Peru, Chili.

L. 2. 2. Geschäftsträger und Consulate im In- und Ausland. I874-

L. 33. Schweizerische und ausländische Angelegenheiten. Ausland. Amerika. Vereinigte Staaten. I832-1854. (Mostly federal circulars relating to arrival and recognition of American consuls general in Switzerland.)

L. 33 a. Dasselbe. Brasilien, Mexico, Argentinien, Chile, etc. 
L. 104. I. Auswanderungswesen. Allgemeines. I843-190I. Gesetze, Verordnungen, Kreisschreiben, Gutachten, Massregeln, Mitteilungen, etc.

Allgemeines. I880-I890. Agenturen.

Allgemeines. I89I-1901. Agenturen.

L. 104. 2. Allgemeines. 1902. Agenturen.

L. 104 a. Spezielles. I837-1848. Auswanderung nach New Orleans. Kreisschreiben des Bundes.

1837-1846. Id. Algier. The same.

1856-1858. Id. Brasilien. The same.

1889-1901. Verschiedene Akten, darunter Fall einer Verletzung der Vorschriften seitens der Auswanderungsagentur Zwilchenbart, mit Bundesbeschluss, Jan. I3, i893.

\section{Bevölkerung.}

N. 35. I. Auswanderung. Allgemeines, I847- . Cf. L. 104.

Gesetze, Verordnungen, Kreisschreiben, Gutachten, Verzeichnisse von Agenturen, etc.

N. 35 a. I. Auswanderung. Spezielles. Cf. L. 104.

Anfragen, Auskünfte, über einzelne Agenturen, etc. $1838-\quad$ : $888_{1-}$. Berichte, Correspondenz, Regierungsbeschlüsse, Briefe, etc., betr. die Auswanderung nach Brasilien.

\section{Innere Angelegenheiten.}

N. 74. I. Armen- und Unterstützungswesen. I854-I877.

Verpflegung Angehöriger des Auslands. Amerika, I86r. (2 cases of support of children.)

N. 76. I and 2. Armen- und Unterstïtzungswesen. Schweizerische Hilfsgesellschaften in Ausland.

Allgemeines, u. a. Quittungen über die Beiträge an die schweizerischen Hilfsgesellschaften im Auslande: Boston, I868-1888; Cincinnati, 1880- ; New Orleans, 1837-1862; New York, 1851-1873; Philadelphia, I864-1880; San Francisco, 1886- ; Washington, I867-1879; Chicago, I873- ; St. Louis, I874-

P. 214. I. Zustellung von Akten aus dem Ausland. I836-I 858 .

Matters concerning the affairs of several immigrants to the U.S.

\section{Kirchenwesen.}

T. 59. Verschiedene freie Gemeinschaften resp. Sekten. $18 \mathrm{I} 7-$

No. 5. Methodisten. (A large number of acta.) i858-1874.

No. 6. Mormonen. (A large number of acta.) I854-1863.

No.8. Separatisten ohne besonderen Charakter. I8,30-18sig.

T. 59. 2. Wiedertäufer (Baptisten) und Neutäufer (Fröhlianer). 1829-ISg6.

\section{ZÜRICH: STADTARCHIV.}

Location: The city archive of \%ürich is located in the Stadthans, opposite the post-office.

Hours: By arrangement with the city archivist.

Bibliography: Theodor Usteri, "Inventar des Archivs der Stadt Zïrich", in Inentare Schacizerischer Archin'e, Beilage to the Anzeiger fïr Schacizerische Geschichte, II. I11-117 (Bern, 1899). 
G. Meyer von Knonau, Der Kanton Zürich (St. Gallen and Bern, I844), I. 222.

Das Archiv der Stadt Zürich (Zürich, I900, pp. I9).

\section{STADTRATSPROTOKOLLE.}

Acta Nr. 350. "Verabfolgung einer Reiseunterstützung an Joh. Schweizer, Kammacher, zur Übersiedelung nach Amerika." S. had been sentenced to imprisonment for two years, had served two-thirds of the time, and now petitioned for permission to emigrate and for partial payment of his transportation. Decision: "Es seie die Polizeicommission eingeladen, den Petenten für den Fall seiner Abreise nach Amerika ein Reisegeld v. Fr. IOo zu verabfolgen und dasselbe auf den Titel der ausserordentlichen Polizeiausgabe zu nehmen. Diese Schlussnahme wird der Direktion d. Strafanstalt zu Handen des Schweizer mitgeteilt.” May 6, I848.

No. 6o9. "Abweisung des Gesuches d. Hrn. Zimmermann, um Reisemittel zur Übersiedelung dahin.” (Südamerika.) July ı 8, I848.

Nos. 672-674. "Verhandlungen betr. Unterstützung an nach Amerika auswandernde Stadtbürger u. diesfällige Bestellung einer Spezialcommission." Aug. I5, I848.

No. 742. "Bestimmung der zu befolgenden Grundsätze bei der Behandlung der Unterstützungsbegehren von verbürgerten Auswanderern nach Amerika." Sept. 5, I848. Decision of the special commission: "Stelle sich die Auswanderung als ein durch die Verhältnisse begründetes Gemeindebedürfnisz dar, so seie die Gemeindebehörde nach $\S$ I des Gesetzes über die Verwaltung der Gemeindegüter befugt, unter Umständen sogar verpflichtet, das Gemeindegut zur Unterstützung dieses Bedürfniszes in Anspruch zu nehmen. Im entgegengesetzten Falle aber, wo die Auswanderung nicht als Gemeindebedürfnisz, sondern als individuelles Bedürfnisz erscheine, seie die Befugnisz, das Gemeindegut hiefür in Anspruch zu nehmen, nur in den seltensten Fällen vorhanden, wo gleichzeitig neben dem individuellen Grunde zur Auswanderung noch ein öffentliches Bedürfnisz, die betreffenden Personen aus hiesiger Gegend zu entfernen, damit verbunden seie. In allen andern Fällen erscheine die Unterstützung der Auswanderung als Gegenstand persönlicher Vorsorge, für welche der hiesigen Gemeindeverwaltung keine bestimmten Güter oder Stiftungen zugewiesen seien. Es müszte sich somit in allen diesen Fällen einfach fragen, ob die städtische Armenverwaltung Interesse oder Veranlassung habe, seie es vorsorgend oder unterstützend sich bei einem Auswanderungsprojecte zu betheiligen; und somit alle Gesuche in dieser Richtung, bei welchen nicht ein öffentliches Interesse die betreffende Person aus hiesiger Gegend $z u$ entfernen vorliege, ausschliessend in die Behandlung der Armenbehörden zu weisen. Nach Anhörung und Prüfung dieses Gutachtens werden die in demselben aufgestellten Grundsätze von dem Stadtrathe für alle in nächster Zukunft erscheinenden Auswanderungsbegehren einstimmig als maszgebend erkannt." Sept. 5 , I 848 .

Nos. $673,674,743$. " Demgemäsz werden : die Gesuche von J. Körner, Commis, vom 25. Juli, Johannes Brunner, Mahler (v. 7. Aug.), und 
ein ähnliches neu eingegangenes Gesuch gleicher Art von J. Jakob Maurer, Schneider, abgewiesen, mit dem Bemerken, dass sjch die Petenten hierüber an die städtische Armenpflege zu wenden haben." Sept. 5, I 848 .

Nos. 761, 798, 799. A number of similar cases. Sept.-Oct., I848.

I 854, p. I 38. "Das Statthalteramt erlässt unterm 26. Merz ein Kreisschreiben an die Gemeinderäthe, in welchem diese erinnert werden, dazu keinerley Hand zu bieten, dasz ganz mittellose Leute, oder gar Verbrecher zur Auswanderung nach Amerika veranlaszt oder unterstützt werden, in dem die Kosten für deren Rücktransport auf die Gemeinden fallen müssten. Nach Einsicht dieses Kreisschreibens wird beschlossen: es seye die Kanzley beauftragt, in dem Falle, wo eine Paszempfehlung zur Reise nach Amerika für eine mittellose hiesige Bürgerperson verlangt würde, vor deren Ausstellung dem Stadtrathe hievon Kenntnisz zu geben." Apr. 3 , I 855 .

I857, no. 6I9. “Bericht an's Statthalterant über die Zahl der von I854 bis incl. I 856 nach Nordamerika Ausgewanderten." Aug. 25, I857.

\section{ZÜRICH: STADT-BIBLIOTHEK.}

Location: Adjacent to the Münster-Brücke, in the same ancient building (Wasserkirche) with the Zwingli Museum and Gottfried Keller rooms.

Hours: Io a. m. to I 2 m. ; 2 to 6 p. m., except Saturdays.

This libiary contains one valuable collection of manuscripts and early prints of the eighteenth century, relating to early Swiss settlers in Pennsylvania and Carolina. It is found in the extensive series of Igo manuscript volumes called the Simmlerische Sammlung.

"Extract aus einem Brief, der den 9/20 Febr. in Charleston, dem ersten Orth u. Anlandungs-Hafen in Georgien [sic] geschrieben, und den 20/3 I May in Sankt Gallen angelanget." References to Purysburg and Sebastian Zuberbühler (who is expected to arrive in Charleston with 50 or 60 families to settle in Carolina). Year not given. [I73I-I 740.]

"Verbote gegen Auswanderung." I734, I735, I736, I739, I741, I744.

"Abschiedsgebet bey Einschiffung der Züricherischen Colonie nacher Carolina, I734." (Three manuscript pages.)

Neu-Gefundenes Eden, oder aussführlicher Bericht von Süd und Nord Carolina, Pensilzania, Mary Land und Virginia. In Truck verfertiget durch Befelch der Heluetischen Socictït (1737).

Hans W. Trachsler, Kurtz verfasste Reisz-Beschreibung eines neulich aus Carolina in scin Vaterland zurückgckommenen Lands-Angehörigen. (Zürich, Bürkli, 1738, pp. 13; unfavorable.)

Nöthigste Nachricht, betreffend Carolina, aus den Weitlüufligern kurtz gefasset, für den gencinen Mann. (1734, pp. 2; warning.)

Johann Tobler von Appenzell, Eine ausfiihrlichc Relation aus Carolina, Gedicht. (Bern, I742.)

“Merkwürdige Beschreibung von Süd-Carolina." In J. Tobler's Alter u. verbesserter Schrcib-Kalender. (St. Gallen, I754, P1. I I ; favorable.) 
Copia eines von cinem Sohne N. N. an seine Eltern ausz America abgelassenen Briefes, sub dato Philadelphia, d. 7. Martii, I684. Next page: Sichere Nachricht ausz America, wegen der Landschafft Pennsylvania, von einem dorthin gereiszten Teutschen, de dato Philadelphia, d. 7. Martii 1684.

(The author of this printed document of 8 pages was undoubtedly Pastorius, the founder of Germantown, Pa. See M. D. Learned, Life of Francis Daniel Pastorius, Philadelphia, I908, in which will be found photographic facsimiles of the Copia and of the Sichere Nachricht, facing respectively P. I 24 and p. I28. A translation of the latter will be found in A. C. Myers, Narratives of Early Pennsylvania, in the "Original Narratives" series, at pp. 392-4I I.)

Königlich Englisch in Teutschland verschickte Erklährung oder Abmahnungs-Schreiben (Dec. 31, I709).

Eine leyder wahrhaffte Traurige Geschicht $u$. Beschreibung, wie im nächst abgewichenen Monat Julii, I754, ein grosses Schiff nach West Indien mit 468 Personen, ein lamentables Ende genommen (1754). Poem at the end.

Christholds Gedanken, bey Anlasz der Bewegung, welche die bekannte Beschreibung von Carolina, in America, in unserm Land verursacht, und der vor etlichen Tagen dahin geschehenen Abreisz verschiedener von unserm Volck (pp. I2). Argument: The Kingdom of Heaven is superior to the New Eden; a beautiful voyage thither without sea-sickness; eternal peace instead of wars; no savages, no wild beasts, and a great and just king, better than the king of England, however good.

(The book in question, the "bekannte Beschreiben", is perhaps that named above: Neu-Gefundenes Eden oder ausfïhrlicher Bericht von Siid und Nord Carolina, etc. I737.)

Warhaftige und gantz zuverlässige Gute Zeitung von der Königlich-Englischen Provintz Carolina, hergebracht von glaubwiirdigen Männern die vor 4 Jahren hineingereiset, anjetzo glücklich wiederum zurück gekommen u. aufs neue dahin sich zuverfügen entschlossen. (St. Gallen, 1740, pp. I5.) Signed by 3 I heads of families living in Saxe-Gotha, S. C., in I740.

Der Hinckende Bott von Carolina, oder Ludwig Webers von Wallissellen Beschreibung seiner Reise von Zürich gen Rotterdam, mit derjenigen Gesellschaft, welche neulich aus dem Schweizerland in Carolinam zu ziehen gedacht (Zürich, I735, pp. 32).

(The author went with the group, I94 persons, under the leadership of Pfarrer Götschi of Zürich; he went as far as Rotterdam, and then turned back. On his return, he explains his reasons for returning home, to a schoolmaster-the form of the "Gespräch", question and answer, was popular in books of this kind, and very effective. The story told of the difficulties encountered by Götschi is probably authentic. Götschi was obliged to take a ship for Philadelphia instead of Carolina. Many returned, fearing the redemptionist system. The leader Götschi died soon after landing in America. His son, whose name appears in records quoted on previous pages, subsequently became a minister in the Dutch Reformed Church of America. Cf. James I. Good, History of the Reformed Church 
in the United States, $1725-1792$; based on researches in archives made by W. J. Hinke.)

Der nunmehro in der Neuen Welt vergnügt und ohne Heim-Wehe lebende Schweitzer. Oder: Kurtze und eigentliche Beschreibung des gegenwärtigen Zustandes der königlichen englischen Provinz Carolina, aus den neulich angekommenen Briefen der Alldorten sich befindenden Schweitzeren zusammengetragen von J. K. L. (Bern, getruckt bey Joh. Bondeli, I734, pp. 46).

Neue Nachricht alter und neuer Merkwiirdigkeiten, enthaltend ein vertrautes Gespräch und sichere Briefe von der Landschafft Carolina und iibrigen Englischen Pflantz-Städten in Amerika. Zufinden zu Zïrich, Bern, Basel. Schaffhausen u. St. Gallen in den BerichtHäusern gegen Ende des Jahres I734 (pp. 8o).

(The latter work was published and freely distributed to counteract the effects of the former. Cf. L. Hirzel, "Nach Amerika aus dem Anfang des i8. Jahrhunderts", Sonntagsblatt des Bunds, Bern, Nov. 8, I 5, 22, 29, and Dec. 6, i 3, 20, 1896.)

Another booklet published to counteract the influence of immigration literature, in an earlier period, was the one entitled: Das verlangte, nicht erlangte Canaan bei den Lust-Gräbern; Oder. Ausfïhrliche Beschreibung von der unglücklichen Reise derer jïngsthin aus Teutschland nach dem Engelländischen in Anerica gelegenen Carolina und Pensylvanien wallenden Pilgrim, absonderlich dem ... Kocherthalerischen Bericht wohlbedächtig entgegen gesetzt (Frankfurt and Leipzig, I 7 I I, pp. xvi, I27).

(It is found in the Stadtbibliothek-not in the Simmlerische Sammlung-which contains a good collection of printed books on America. The Ausfiiluliche Beschreibung also opposed the following very widely distributed and influential book of J. R. Ochs on Carolina.)

Amerikanischer Weguciscr oder kurtze und eigentliche Beschreibung der englischen Provintzen in Nord-America, Sonderlich aber der Landschafft Carolina, mit Grossem Fleiss zusammen getragen und an Tag gegebcn durch Joh. Rudolff Ochs neben einer neuen u. correcten Land-Karten von Nord-und Sïd-Carolina (Bern, I 7 I I ).

(50 thalers were voted to the author, by the Berner Rath, for this work. See Ratsmanuale of Bern. A copy of this work is to be found in the Stadtbibliothek of Bern; one is in private hands in Bern. There seem to be no other copies.)

Among books of curious interest in the Stadtbibliothek of Zürich referring to American conditions, are the works of the local celebrity Karl Bürkli, socialist and idealist, $\varepsilon$. g.. Das Evangelium der Armen, Chiridonius Bitter Süss (1861), etc.

\section{WINTERTHUR: STADTARCHIV.}

On application, the materials in this archive may be sent to the Staatsarchiv in Zürich, and used there.

Akten. Kasten I., No. I5.

1734, Sept. 4. "Begehren des Rathes v. Zürich um Einvernalme des Goldschmid Sulzer, von hier, wegen Verleitung zürcherscher Angehöriger zur Auswanderung nach Carolina." 
Nov. 5. "Begleitschreiben des Rathes von Zürich zu seinem Mandat wider die Auswanderung nach Carolina." (Beigelegt sind das gedruckte Mandat vom 3. Nov. und die behufs Verlesung in der Kirche zu Winterthur verfasste schriftliche Ausfertigung.)

I735, Jan. 29. "Züricherisches Mandat gegen die Auswanderung nach Carolina, verlesen in der Kirche zu Winterthur am i 3. Februar."

1736, Feb. 15. "Begleitschreiben des Rathes von Zürich zu seinem Mandat gegen die Auswanderung nach Carolina." (Beigelegt sind das gedruckte Mandat vom 3. Februar und die schriftliche Ausfertigung, welche am 26. Feb. in der Kirche zu Winterthur verlesen wurde.)

I739, May I3. "Begleitschreiben des Rathes von Zürich zu seinem Mandat wider die Auswanderung nach Amerika." (2 Beilagen.)

I768, Apr. I. "Begehren des Rathes von Zürich, dass den schwäbischen Auswanderern nach den spanischen Colonien kein Durchzug gestattet werde."

1848, Aug. 2. "Gewahrungen von. Unterstützung behufs Auswanderung I850, July 24. $\}$ nach Amerika. Übernahme der gesamten Kosten."

I850, Jan. 7. "Gesuch um Erhöhung des Beitrages der Stadt Winterthur von 80 Fk auf I 50 Fk für den Sträfling Stoll zur Auswanderung nach Amerika." Vormund der Bruder: C. Stoll, Eichmeister.

I862, Dec. 9. "T. Barbe, Auswanderungsagent in Basel, wiederholt gegenüber der Waisenkommission Winterthur die Forderung von $\mathrm{fr}$. 265 für Verpflegung der nach Amerika ausgewanderten und nun im Spital zu New-York weilenden Marie Hardmeyer von Winterthur."

I869, Jan. I8. "Kreisschreiben der Direktion des Innern in Zürich betr. die Einführung einer Auswanderungsstatistik." 


\section{CANTON BERN.}

\section{BERN.}

The "Staatsarchiv" of Bern is the repository of the historical materials of the canton of Bern, the most populous and at many periods the strongest of the Swiss cantons. The "Bundesarchiv" contains only materials of the nineteenth century, concerning the Helvetic Government (1798-I803), the Federation ( $1803-1814,1814-1848$ ), and the Federal State since 1848 . Materials relating to American history were also found in the Eidgenössisches Auswanderungsamt, the Stadtbibliothek, and the archive of the American Legation.

\section{BERN: STAATSARCHIV.}

Location: In an old building, Postgasse 72, adjoining the picturesque old Rathaus. New quarters are soon to be prepared.

Hours: 8 a. m. to I 2 m.; 2 to 6 p. m., except Saturdays and holidays; on Saturdays, closed at 5 p. m.

Bibliography: Heinrich Türler, Uebersicht ïber den Inhalt des Staatsarchiz's des Kantons Bern (Bern, I889, pp. 36).

Id., "Inventar des Staatsarchivs des Kantons Bern", in Inventare Schweizerischer Archive, Beilage to the Anweiger für Schweizerische Geschichte, I. 37-64 (Bern, 1895).

Dr. E. Lerch, Die Bermische Auswanderung nach Amerika im I8. Jahrhundert. Separate print from the Blätter für Bernische Geschichte, Kunst, und Altertumskunde, Jahrgang V., Heft 4, December, 1909. $32 \mathrm{pp}$. (Based on archive study.)

E. Rodt, Bern im XVIII. Jahrlundert (Bern, I90I). Pp. 86-88 contain a brief account of Bernese emigration in that century.

\section{MANDATEN-BUCH.}

I64I, Mar. I2. "Emigranten um sich anders wo zu sezen, werden nicht nur nicht bey ihrer Rückkunft wieder als Unterthanen annehmen, sondern habend auch ihr Hab und Guth verwürkt." 6, 270, 332 ; 7, 660 .

1643, Feb. 28. "Emigranten, an den Pässen anzuhalten." 6, 332 b; 7, 660.

I660, Jan. I3. "Denen aus dem Land reisenden noch darein zurückkonmenden, keine Scheinen, noch Extracten, ohne oberkeitl. Einwilligung zu ertheilen." 8, 77.

i 7 I0, Jan. I8. "Emigrationen nach Danzig und Pennsylvanien. Abmahnung. Einerseits Pest, anderscits Desert." 11, 338, 339.

I7 I7, July 8. "Verbot der Emigration, und wie zu hintertreihen." (Opposition to emigration based on religious grounds, loss of sonls for church.) 12, 203-205, 585.

1720, Apr. IO. Merveilleux, oder Wunderlich, has sent out printed circulars, recruiting soldiers for service across seas, in .Mississippi or Louisiana. Platcards (affiches) to be set up against him. (Opposition also on religious grounds; service under Catholic régine.) 
May 28. Mandate against Merveilleux of Neuchâtel not being observed, and the recruiting continuing, a reward of 30 thaler is offered for catching him. (Merveilleux was probably securing recruits for the regiment Karrer-Hallwyl.) 12, 572-574.

1735, Jan. 12. "Die dahin abreysenden, sollen abgemahnet werden." 15, 37-40.

"An etwelche Oberländische Ambtleuth, als Thun, Oberhofen, Wimmis, Underseen, Interlaken und Oberhassli. Ihnen befehlen, diejenigen so auss Ihren Aembteren annoch entschlossen, in Carolina Ihr Glük zu suchen, von dieser Reyss nochmahlen kräfftigster massen abmahnen, und selbigen mit allem nachtruk die vorschwebende gefahr und andere zu befahren habende ohngemach vorstellen.

Schultheiss und Rath der Statt Bern.

"Nachdemme Wir durch einen Auszschuss aus Unsern Ehrenmittlen dein Schreiben samt Verzeichnuss und Bericht, ansehend diejenigen, so sich entschlossen, die Reyss in Carolinam anzutretten, und alldorten Ihre Fortun zu suchen, reyfflichen erdauren und das befinden Unss referieren lassen; so habend wir gut funden, dir in antworth zu befehlen, denen, so noch auff dieser vorhabenden Reyss in Carolinam verharren, nochmahlen die beweggründt hierwider mit allem ernst und nachtruk dahin vorzustellen:

" (I) dass die in offentlichen Truk aussgangene und andere berichten von Carolina nicht allerdings richtig; hingegen

“"(2) viel gewüsser, dass sothane Reyss über Meer von hier sehr weith entfehrnt seye, und die meiste, sonderheitlichen die Schweitzer, die grosse veränderung der lufft, die auf der See gewohnliche, aber sonst ohngewohnte nahrung, der mangel süessen wassers, und andere dergleichen zustossende noht und ohngemach nicht vertragen können, sonder darvon erkranken, ja gar sterben müssind;

“(3) Ferners seye diese Reyss in ansehen der See-Räuberen gefährlich, da nun Sie in dero handen gerahten thäten, wurde mann Sie in die Sclaverey verkauffen, annebens obschon selbige Reyss wohl von statten gehet, sehr kostbahr, und fallen ohngewitter ein; oder tragen sich andere dergleichen ohnversehene zufähl zu, so wirdt die überfahrt entweders umb viel verlängert, oder gehet gar alles zu grund. Und

"(4) Wurden sie nun in Carolina oder der Enden also anlangen, dass Sie erkranket und presthafft worden und Ihre bahrschafft oder andere effecten verbraucht, müssten Sie dem Allmoossen nachziehen, oder wurden villicht gar um Ihre freyheit kommen, dass sie als Sclaven dienen müessten, etc.

" Solten aber diese so Landsvätterliche und treüwe Vermahnungen nicht erheblich, sondern ohnverfänglich seyn, die vest entschlossenen nach Carolina, von dieser Ihrer vorhabenden Reyss abwendig zu machen, So wollen wir selbige jehdenoch durch gewalt nicht hinderen, wohl aber Ihres vermeinendes glük suchen lassen, ohne sie mit einicher ungnad anzusehen, aussert denen jenigen, so sich hier Landts wohl erhalten können, und über fünffhundert 
Pfund mittel besizen, dass dieselben, fahls Sie so viel vermögen, auss dem Landt zu ziehen gesinnet wären, selbige auch zugleich gehalten seyn sollen, Ihres Landt- und Mannreeht auffzugeben, oder sonsten dasselbe verwürkt haben wurden. Welch-Unsseren bestgemeinten willen du denen Interessierten zu eröffnen wohl wüssen wirst. Datum I2. Jan. I735."

Jan. I2. "Ihnen anch keine Päss gegeben werden." 15, 63-67.

Feb. 24. "Den Schiffleuthen verbothen dieselbigen abzuführen." 15,65 . Mar. 2. "Etlichen die Abreisz (nach Carolina) gestattet." 16, 66.

Mar. 17. "Desshalb getruktes Gespräich den Ambtläıthen zur Publication zugetheilt." 15,73 .

Mar. I7. "Dass die Aufwükler, so die Leuth zu dieser Reysz bereden, soll geachtet [beobachtet] werden." Sollen als falsche Werber bestraft werden. $15,74-78$.

July I3. "Denen, so sich von diser Reyss haben lassen abmahnen, wird zur Erhaltung ihrer Kinder gesteuert." 15, I00.

Sept. 26. "Anstalten zu nochmaliger Verhinderung der Abreysz." 15, IIO-I II.

Apr. 1o. "Wer solche dahin Abreyssende und die ihre Mittel heimlich wegziehen wollen entdeckt, soll belohnt werden." 15, 292-293.

\section{Mandaten-Buch.}

I739-I744.

"Carolina, reysen dahin verboten. Auf die Locker zu achten." 16, 230, $332,349,359,363,365,367,390,399$.

Mandate: "Wiederholte Verbote nach Carolina zu reysen."

I2. Januar I 735 .

Io. April 1738 .

I9. Januar 1742 .

26. April 1742 .

"Auf den Missionarium Riemensperger soll geachtet werden." 16, 229. 23 I, 233, 234 .

"Von Geburt ein Toggenburger, der sich verpflichtet hat einhundert Familles aus unseren Landen, sowohl als aus dem Zürich-Gebieth und Toggenburg den einten halben Theil nach Carolinann, den anderen halben Theil aber nacher Georgien zu transportieren. Falls er das Land betreten, solle selber und sein Knecht in Giefangenschaft gesetzt werden. Wir für jeden dieser Beyden eine Recompens von 50 Thatern entrichten lassen werden für solche die indicieren wollen, dass selbe in Gefangenschaft gebracht werden."

"Carolina. Peter IIuber mit Weib und Kindern dorthin zu ziehen erlanbt." 16, 325-330, 363, 365. See pp. 55, i I 1, post.

"Peter und Jakob Nägely, so dorthin zu zichen in Verdacht, ihre Mittel und Land Recht wegzuzichen, abgeschiagen." 16, 327, 352.

"Ihre Mittel sequestrirt." 16, 355-357.

"Dem Peter Stoker sollen seine aus Carolina gekommenen Briefe "alggefordert werden." $16,35^{8}$.

"Den Hans Brumer, so hier zu bleiben sich entschlossen, sollen seines Kindes Mittel zugestellt werden." 16, 388. 
"Anna Brunner, Peter Wysen sel. Wittib soll ihr Gelt restituirt werden." 16, 388 .

"Die dahin reysende banisirt." ("Eine Zeit von drei Monaten angesetzt, in welcher diejenigen so verreyset, ohngehindert sich wieder im Land setzsen mögen. Nach Verfliessung dieser Zeit aber soll die Bannisation ihre völlige Würkung erreichet haben." Mar. I7, I742.) 16, 390.

"Wie ratione ihres Erbrechtes zu halten." 16, 399-403.

"Auf die wiederkommende soll geachtet werden." 16, 724 . Verhaft zu setzen bis zu fernerer Verordnung.)

I749, May 6. "Carolina, Pennsylvania und Neu Schottland. Dahin zı reysen verboten." 18 , IO-I4.

I75I, May I3. “Emigration nach Neu-Schottland verboten." (Recompens von IOO Thalern Verführer und Anlocker einzufangen.) 18, I 44 - I 46 .

I753, May 21. "Neues Auswanderungsverbot." 18, 434.

I754, May I8. "Nachricht, dass eine grosse Anzahl unserer Unterthanen nach Pennsylvanien gezogen, Entvölkerung unserer Landen zu besorgen. Kein Wegzug ohne Erlaubnis. Verbot auch denen Unterthanen so im Erguel auf Lehen sitzen." 18, 515.

"Emigration. Auf die Emboucheurs eine Summe von Ioo Thalern gebothen." 18, I4.

I756, Jan. 2. "Carolina. Wie die Emigrationen zu hinterhalten." 19.

"Carolina. Einen Emboucheur proscribirt." 19.

Jan. 7. "Carolina. Wie wegen denen wiederkommenden zu procediren." 19.

I765. "Emigrationen, Verbot, besonders nach Russland." 21, 534, 538, $54 \mathrm{I}, 569$.

I767, Nov. 23. "Emigration, Verbot in die spanischen Colonien." 22, 308-310.

I768, Mar. 31. "Emigration, Verbot in die spanischen Colonien." 23, 419, $42 \mathrm{I}$.

Dec. 21. "Vorsorge wider die Verlockung hiesiger Angehörigen nach Spanien. Das ganze Land wird verwahrnet, dass sich nicht jemand nach Sierra Morena verlocken lasse." 23, 5 o.

I770, Feb. I 3. "Das Welschland besonders, wegen denen Einladungen nach dem Captalat de Buch und der Teich en Guiêne." 23, 322.

I77I, Nov. 29. " Das ganze Land wird verwahrnet wegen Preussisch Pommern.” 24, 7 I, I60.

\section{Teutsche Missiven Buch der Stadt Bern.}

\section{Wiedertäufer.}

I 599-I600. "Confiscationen gehören den Twingherren nicht, und die zu Sumiswald gehören nach Trachselwald." 22, I68, 381.

" $\mathrm{Zu}$ Sumiswald mag der Landvogt zu Trachselwald fangen lassen." 22, 378,380 .

I602. "Die ungehorsamen [Wiedertäufer] hieher zu liefern." 22, 898.

1616. "Ein ihnen günstiges Tractätlein von Poll--zu unterdrücken. Poll selbst in Zürich verhaftet." 1, 26I, 314.

I644. "Derselben-sowohl eingebornen, als fremden-will man sich hier (und in Zürich) entladen." 12, 655 . 
1648. "Ernstliche Nachstellung gegen solche irrige Leute, die dann 'aufs Meer nach Venedig' zu Kriegs- oder Soldatendienst verschicket werden sollen." 14, 512.

I660. "Ihrer hierseitigen Behandlung und Landesverweisung halb-Erklärung an die für sie intercedirenden Staaten, von Holland, auch Städte Amsterdam und Rotterdam." 20, 307.

I668. "Intervension der Stadt Amsterdam für dieselben abgelehnt." 23, 56. 1671. "Werden ' in Eisen gefesselt' unter bewaffnetem Geleit über Lauls an Venedig abgeliefert zu zweijähriger Ruder-Arbeit-ungesöndert auf einer Galeere." 24.

ı676. "Hier fortgewiesen [Wiedertäufer] solle auch Solothurn ausmustern helfen." 25, 295.

I683. "An einige [W.] in der pfalz Vermögens-Ablieferung halb." 27, 20,154 .

I699. "Ihr Lehrer, Isaac Kaufmann, der ostindischen Compagnie in Amsterdam überliefert zur Versendung: Für Mehre bestellen MeGnHn. [Meine Gnädige Herren] Platz." 34, 822.

I705. “ N. Testament, Basel, bey Genath, I702, soll Basel wegen 'wiedertäuferischen Version' unterdrücken helfen.” $38,277$.

"An Hn. Angliombi [Aglionby], Englischen Envoyé. (Hr. Ritter und seine in Americam zu führen vorhabende Colonie recommendieren.)

"Hochwohlgebohrener, etc.-Unser liebe und getreuwe Burger Georg Ritter hat uns in mehrerem zu vernemen gegeben, welcher massen er und mit Interessierte auf unsere Bewilligung bedacht wären, eine Colonie in diesen schweizerischen Landen von vier-bis in fünfhundert Persohnen stark aufzubringen und under Ihro Königl. Mayst. in Engelland Gebiete in West Indien etwan in Pensylvania, oder der Gegend Virginien zuführen und zusetzen, zu welchem Ende cr beykommendes Placet an hochbesagte Ihro Königl. Mayst. gestellet, und uns in Demulht ersuchet, dass Wir dasselbe dem Herren zulangen lassen und mit unser Vorschrift begleiten wolten, damit durch dessen Mittel dieses Placet Ihro Nayst. behändiget, und darüber dero gnädigster Entschluss vernommen werden möchte; womit Wir Ihme unserem Burger Ritter in willfahr geantwortet, den Herren also durch disz wenige fründtdienstlichen ersuchende, demselben mit seinen vielgültigen Officien und Favorn zunderstïtzen, damit dafern Ihro Königl. Mayst. diese Colonic ebenmässig belieben thäte, dieselbe deszfalls Ihro Mayst. Gnade und allen müglichsten Vorschiebs sich zugewarten und zubefreüwen hätte; zugleich auch erforschen, ob im Fahl allhiesiger Stand mit der Zeit under einigen gedingen auch eine Colonie dahin verschaffen wolte, allda zu einem gewüssen Bezirk landts hoffnung gemacht werden könnte: Für die Mühwalt und Officien, die der IJerr ühernemen wirdt, ermanglen wir mit neben gezimenden Dank denselben in allerley begegnussen mit unsern Fründdienstgefälligkeiten, z.ı reciprocieren, und erlassen danit den Herren der starken Obhut des Allerhöchsten. Dato 19. Martii, 1705. Schultz und Raht der St. Bern."

I707. "Vermehrung derselben [Wiedertäufer] im Bucheckberge." 39, 5I3. 
I710. "Abführung einiger [W.] in America, den Rhein hinunter, mit I20 freywillig in West Indien Reysenden."' 41, 397, 4I3, 4I4, 430, $468,607$.

"Aufnahme von 400 an der Zahl in die Preussischen Staaten wird negotiiert." 41, 594, 666, 702 .

I7II. " Und ferner $55^{\circ}$ Männer, Weiber, Kinder-unter Führung Georg Riedens, Negt." 41, 949, 985, 990, 994.

I712. "Von hier in Holland Vermögens-Verabfolgung an dieselben." 42, $26 \mathrm{I}$.

I7 I5. "In Holland verwiesen, schleichen sich wieder ein; zur Galeere verurtheilt ; Hollands Fürsprache." 45, 226, 237, 660, 664.

I717. "Wiedertäufer und Pietisten: Unterdrückung der ihnen dienlichen Bücher, wie des Froschauer N. Testament." 47, 206.

I725. "Lehrer-Grimm und Brechbühl—zu behändigen; Lucern verfolgt sie auch." 52, 433, 445, 463, 531, 564 .

I726. "Vermögens- und Erbschaften halb." 52, 941.

I728-I73I. “[Wiedertäufer] auch Wiedertäuferinnen werden verfolgtdurch 'Täufer-Jäger'-bis ins Lucern Gebiet." 54, I39, I73, $329,429,529 ; 55$, 19 .

[W.] "daheriger Grenzmarch- und Jurisdictions Zwist" (see Luzern). $56,83,91,486,616$.

I729. "Versammlung im Schlössli zu Mett." 55, 213.

I732. "Erbschafts Angelegenheiten zwischen Holland und Bern." 57, 5 Io. I734-I735. "Wegen Fortschaffung derselben hinter Valengin, Unterhandlung mit Preussen und Neuenburg." 60, 73, 76, I00, I12, 189, 3I I, 319, 338, 346, 356, 397, 404, 423.

I739. "Ihrethalben Beschwerden von Valenzin." 62, 707, 708, 730, 731.

"Ihrethalben Königl. Preuss. Rescript." 63, 8, 93.

I756-I 757. "Abwesende [W.], als Ansprecher in einem Bucheckbergischen Geldstage für hierseitige Angehörige erklärt." 75, 500, 519.

I760-1761. "Hans Farnis, von Steffisburg, Nachlass, von abwesenden Enkeln reclamirt, nicht verabfolgt, sondern der Kirche daselbst zugesprochen." 77, 500, 702, 853 .

I762, I766, I772. " Ihnen wird kein Vermögen aus dem Kantone verabfolgt." 78,$359 ; 80,653 ; 85,3$ I 3 .

\section{Teutsches Missiven-Buch der Stadt Bern.}

Carolina.

I735. "Auswanderung dahin wird zu verhindern gesucht" (Pury). 60, 279, 29I, 478, 5 IO.

"Auswanderer dahin wird Neuenburg zurückzuweisen ersucht (keine Pässe zu erteilen ", etc.). 61, 3 .

I740. "Gegen Anwerbung und Auswanderung dahin strenge Maassregeln." $63,308$.

I741-1742. "Dahin und nach Georgien wirbt Hans Riemensperger und Peter Huber: sollen verhaftet werden." (Peter-Huber wird von Basel ausgeliefert.) 64, I 10, 566, 574, 577.

I742. "Basel. Wegen behändigung eines gewüssen Hubers, der die Leüth in Carolinam verlocket.

"Tit. Schon sinth geraumer Zeith dahar ist Peter Huber, einer unser Unterthanen von Oberhasli in starkem Verdacht gewesen, ob 
habe derselbe im Oberland und der Enden viele Unserer Angehörigen angetrieben, sich in das entfernteste Land nacher Carolina zu begeben, da num erst under gestrigem Dato Wir die zuverlässige Nachricht erhalten, was gestalten etwelche Haushaltungen von Oberhaszli and Interlaken, bestehend in 20 bis mehr Persohnen theils zu Wasser, theils über Land aus Basel zu nacher Carolina verreyset, welche alle von erwehntem Peter Huber hierzu verleitet und aufgewiklet worden sein sollen, und nun uns daran gelegen sein will, dass sothaner Peter Huber zu gebührender Verantwortung auf allfählig in die behörige Straf gezogen werde, als haben auch vernomen, dass derselbe ïber den Brünig nacher Basel verreyst seyn und dorten diesen Lenthen warten solle,-Wir nicht unhin mögen, Euch dessen allesen hiemit zu benachrichtigen, mit dem beyläufigen freundteydtgenössischen Ersuchen, Ihr beliebt sein wollet, die fürdersame ohnbeschwehrte Anstalt, in Euwerer Hauptstadt und Pottmässigkeit dahin ergehen zu lassen, dass dieser Huber, als welcher unsre Underthanen, auf eine so gefährliche Weiss entführt, auf betretten angehalten, und in gefängkliche Verhaft gebracht, Wir aber dessen nachrichtlich verständiget werden; Wir wollen an geneigter Willfahr keines Wegs und umb so da minder zweifeln als einerseiths uns höchstens daran gelegen, dass dergleichen landschädliche Leuth und Entführer der verdienten Bestrafung nicht entgehen; anderseits dann wir ein solches in gleichen und andern Begebenheiten zu erwiedern nicht ermangeln werden, in dessen Erwartung Wir in, [etc., etc.]. Dato I Martii, I7+2. Schultheisz und Raht der Stadt Bern."

I7+I-I742. "Carolina-die dahin reysen soll Basel abmahnen." 64, 586.

1744. "Verführer dahin Peter in Aebnit [Amt lnterlaken] ausgeschrieben, von Basel ausgeliefert." 66, 183, 202, 209, 21 1, 233, 57 7 , 57\%.

1749. "Verführer dahin und nach Pemnsylvanien zu bestrafen" (Walter). 70, I05, I39.

1750. "Auswanderung nach Carolina und Pennsylvanien eidgenössisch zu verhindern, Verführer zu bestrafen." 71, 20.

"Vermögens-Abzug dahin à 5 per cent. bezogen." ${ }^{2}$ 71, $37 \mathrm{I}$.

"Dentsche Prediger dahin nicht zu bewilligen" (Schlatter). 72.97.

"Fryburg. Wegen Abzug des Christen Gilgiano Mitlen."

"Unser freundlich willig Dienst, sant was wir ehren liebs und guts vermögen zuvor, Fromb, Fürsichtig, Ehrsamb, Weiss, sonders gut Freund, getreuw lieb Eydgenossen Mitburger und Brüder.

"Euer Schreiben vom 4. abgewichenen Monats Junii, über die Bittschrift der Anverwanten des in Carolina verstorbenen Christen Gilgiano, dass nämlich denenselben, von denen $572 \mathrm{Kr}$. so sie in Carolinam zusenden gemüssiget, der Abzug nachgelassen werden möge, ete. ; haben wir in Ueberlegung nemen lassen, und anf mess erstattete Relation hingleich Ench, etc., billich befunden, dass von diesen $572 \mathrm{Kr}$. lhnen der Abzug, aus milten Considerationen jehdoch höher nicht als auf 5 per cent. gefordert werden solle, in massen

\footnotetext{
"Kaspar Hauser, "Ueloer den Alzzug in der Schweiz", in Jahrbuch für Schaidizerische Geschichte, heransgegeben auf Veranstaltung der Alleemeinen Geschichtsforschenden Gesellschaft der Schweiz, Bd. XXXIV. (Zurich, 10(x).)
} 
desshalb Wir an Unseren gemeinen Amtsmann zu Schwarzenburg befelchlich-abgeben, was aus Copeyl. Anschluss [copy enclosed] zu ersehen; welches Euch hie anmit, freund eidgenössisch participiercn, etc. Dato den 26. Dec., I750. Schultheisz und Raht." 71.

I751. "Wegen Michael Schlatter, Prediger der teutschen Gemeind zu Philadelphia in Pennsilvanien." 72, 96-97.

"Bei einem Ehrwürdigen Convent allhier hat sich angemeldet Michael Schlatter, Prediger der teutschen Gemeind zu Philadelphia in Pennsilvanien, und den Zustand der daselbstigen Teutsch Reformierten zum Theil aus Schweizern bestehenden Colonie vorgestelt, auch mit Attestates versehen, dargethan, dass Ihme aufgetragen seye, 5 oder 6 tüchtige teutsche Prediger für Pennsilvanien aufzusuchen, und eine milte beysteuer zu diesem Vornehmen zu begehren und dahero sich bey den evangelischen Kantonen der Eydgenossschaft und zugewanten Orten anzumelden; Wann aber Wir betrachtet, was für Bedenklichkeiten hier unterlaufen, da oft unter dergleichen Vorwand unsere Angehörigen und Unterthanen in diese entfernte Land verlocket, und in Unglïck gestürzt werden; haben Wir in dieses Pfarrers Begehren auch im Wenigsten nit eintreten wollen, sondern hierbey sorgfältigst ausgemitten [gemieden], was etwan unseren Unterthanen Anlas geben möchte, wider Unsere Verbot in diese Land zu gehen, und haben von dieser Unser Gesinnung und Entschluss Euch die Vertraute Nachricht hiemit geben, und inmitlest, in, etc. Dato den 25. Nov., I75I. Schultheisz und Raht."

\section{Raths-Manuale der Stadt Bern.}

I7OI.

“Auswanderer bezahlen Io per cent. Vermögenabzug.” R. M. 1, 359.

“Auswanderer Errichtung einer Kontrolle." R. M. 2, 229.

(See Rödel Weggezogener Mannrechten, I694-I754, Alphabetisches Verzeichnis der Namen.)

I702.

“ Nach Brandenburg Untersuchung.” R. M. 8, I 35, I 39.

“Vertheilung geistlicher Bücher an die Auswanderer." R. M. 9, 86.

“Abzugsbefreiung für Auswanderer.” R. M. 9, IOO.

1703 .

“Mit Wegzug des Vermögens geht auch das Landrecht verloren." $\quad$ R. M. 11, $2 \mathrm{O} 3$.

1705.

"Colonien Gründung aus hiesigen Landsassen in Pennsylvanien." 18, 196, $475 ; 19,12 ; 24,461,496$.

Herr Georg Ritter, Specierer (Kleinhändler), plans to found a colony in Pennsylvania. A commission appointed and the English envoy in Switzerland consulted. This is an actual attempt on the part of the government of Bern to found a colony in America. The desire was to send off "Landsassen", an undesirable element from the government's point of view. 
I709.

“Beabsichtigte Ansiedlungen in Amerika." R. MI. 40, 238; 46, 346.

I7IO.

“Nach Danzig und Pennsylvania, Warnung davor.” R. M. 40, 392. (See Mandaten-Buch, Jan. I8, I 7 Io.)

"Abschiebung der Täıfer nach Amerika durch H. Ritter, welchem für die Person 45 Thl. von der Regierung bezahlt wird." R. M. 41, 229, 28I, 285, 301, 306, 307, 323, 437, 488 .

"Landankauf in Amerika behufs Abschiebung der lästigen Unterthanen." R. M. 41, 408.

$$
\text { I7 I I. }
$$

"Von Zweysimmen (arme Leute dort, im Oberland), Warnung vor Auswanderung unter Hülfsversicherung durch die Regierung." R. M. 46,345 .

Mar. 2I. "Die dem Rathe dedicierte gedruckte Beschreibung 'der amerikanischen Inseln', speciell Carolina, dafür 5o Thaler verordnet Recompens." (The author of this was Rudolff Ochs.)

"Zedel, was massen Hr. Rudolff Ochs gesimnet wäre etwelche MIGH. Unterthanen mit sich in Americam zu nemen; Vorschläge anhören."

I 712.

“Auswanderung nach Preussen, Abmahnung davor." R. M. 50, 32 I 51, $86, \mathrm{I} 62$.

I 76 .

"Auswanderung soll nur solchen gestattet werden, die bescheinigen kömnen, dass sie in der Religion wohl unterrichtet, und arm seyen." R. M. 68,36 .

1720.

"Anwerbungen nach Mississippi durch $\mathrm{H}$. Wunderlich (Merveilleux) von Neuenburg." R. M. 84, 94.

“Dahin die Recroutirung verboten." R. M. 61, 94. 3I I.

“Merveilleux.” R. M. 61, 3I I, 378.

"Vermahnung sich nit in die Companey des Mississippi zu lassen." R. M. 84, 6r. (See also Mandaten-Buch.)

“Erlach. Wunderlich-Merveilleux." R. M. 84, 94.

"Klage des Merveilleux wider das Verpot seiner Mississipianischen Werbungen, zu erdatuern und referieren." R. MI, 84, 3I I.

May 28. "Iverten. Ueber Begehrte Wegweisung, wie er sich, wegen von N: Merveilleux Hatubtmam ïber 200 nach Mississippi angeworbener Mämner empfangene Verweis Schreibens-darin For sich desz sub ro. Aprilis lesthin wider Ihne auskündeten Mandats beschwährt etc. zan verhalten habe: wollendt thro Gin. Thme hiemit befohlen haben, dasz Merveillenx Schreiben für unempfangen zu achten, mithin dann Ihne Nerveilleux durch Affiches an die Gränzen zu proclamieren; ïbrigens aber $4 m$ b) so da geflissener, ob thr Gn. jetzgemeltem Mandat so eyfferen, weilen gefallenen Bericht nach eint und anders thr Gn. Unterthan under 
allerhandt Vorwand auf die Grenzen angelocket, nachwertz mit Gewalt weggenommen und bis auf allgemeinen Abmarsch eingespehrt werdindt." R. M. 84, 378. See also M. B. 12, pp. 572-574 (April Io, I720), 585-586 (May 28, I720).

Apr. I5. "Erlach: Aus seinem Schreiben habend Ihr Gnaden verstanden, dass durch ein gewissen $\mathrm{Hr}$. Wunderlich von Neuwenburg verschiedene arme gantze Familles es seye durch gute Wort oder Gelt verlocket und angedinget worden, etc. Nun stehend Ihr Gn. in denen Gedanken, dass er dergleich Sachen wegen Ihr Gn. Befelch and Willen werde vernommen haben, welchem nach Er sich zurichten müssen werden. Indessen solle $\mathrm{Er} \mathrm{Ihr} \mathrm{Gn}$. berichten, wasz für Leüth sich nach Mississippi zugehen gegen Hrn. Wunderlich verbunden, wer sie verlocket, und was Qualitet und von wannen sothane Unterthane seyen." Erlach Buch D., p. 66r.

I723.

"Auswanderung ins Niderlandt, wie zu hinterhalten soll untersucht werden." R. M. 93, гт8.

1725 .

"Errichtung einer Colonie in Amerika durch H. Pury et Cie. in Neuenburg." July 30, I725. R. M. 102, 295.

"Erlach: Aus seinem Schreiben und beygefügt gewesenes gedrucktes advertissement habend $\mathrm{Ihr} \mathrm{GnH}$. ersehen wie die $\mathrm{H}$. Pury et Cie. von Neuwenburg von $\mathrm{Ihr} \mathrm{GnH}$. Unterthanen suchend in die Americanische Insul Carolinam zu verlocken; wie nun Ihr $\mathrm{GnH}$ solches als ein ohngewüsses und den Ihrigen nachtheiliges Etablissement ansehend, als wollend sie Ihme gleich gegen verschiedenen Anderen Ambtleüthen auch beschicht hierdurch befohlen haben, seine Ambtsangehörige zu verwahren, dass sie sich ohne Ihr GnH. Vorwüszen and Bewilligung nicht dahin begeben thüyend; fürs Einte [illegible] fürs Andere dann wollend Ihr $\mathrm{GnH}$ Ihme hiemit aufgetragen haben, Nachforschung zehalten, durch wen die H. Pury et Cie. solche Advertissement ausstreuwen lassind? Und von weme er der Herr Ambtsmann das allhar communicirte Exemplar bekommen haben und dessen $\mathrm{Ihr} \mathrm{GnH}$. zuberichten, wie zethun er wissen werde."

I729.

Mar. 24. "Zwei Brüder Schwarz, der eine mit 4 Söhnen, erhalten die Erlaubnis, gegen die Erlegung des Abzuges von Io Prozent nach Pennsylvanien auszuwandern. Die Leute stammen von Langnau im Emmental." R. M. 121, 29I.

\section{I73I.}

Nov. 5. "Im Rat taucht die Frage auf, ob nicht das bäuerliche Erbrecht zu ändern sei. In gewissen Gegenden waren dadurch die jüngern Kinder benachteiligt, weswegen viele auswanderten. Ziel der Auswanderung war um diese Zeit auch Nassau-Saarbrücken, wie 20 Jahre früher Ostpreussen."' R. M. 133, 35 . 
1732.

Dec. 17. "Der Grosse Rat verwirft den Antrag, es seien mit der Krone England oder 'Indianischen Compagnien' Verhandlungen anzuknüpfen, un Verbrecher nach Kolonien zu verschichen." R. M. 137,482 .

\section{733 .}

Mar. I9. "Die Regierung gestattet dem aus Münchenbuchsee stammenden, in Philadelphia angesiedelten Johannes Bartlone, sein Muttergut unter Erlegung des Abzuges aus dem Lande zu ziehen. Sie lehnt eine Beitragsleistung für Kirchen und Schulen in Pennsylvanien ab." R. M. 138, 591-592.

\section{4 .}

Jan. 2r. "Die Geneinde Thierachern wird von der Regierung angewiesen, dem Christian Küntzi soviel von seinem Vermögen anszuhändigen, als zur Reise nach Pennsylyanien enforderlich sei." R. M. 142,95 .

June 22. "Alle Amtleute erhalten Weisung, von der Auswanderung nach Carolina abzumahnen. Der Schultheiss wird angewiesen, nur noch Heimatlosen und Proselyten Reisegeld zur Auswanderung zu bewilligen.” R. M. 144, 8.

June 28. "Die Regierung verlangt von der Vennerkammer ein Gutachten über die Anwerbungen durch Herrn Pury und andere." R. M. 144,43 .

June 29. "Der am 22. Juni beschlossene Befehl an die Amtleute wird rorläufig noch nicht ausgegeben." R. M. 144, 47 .

July 6. "Dieser Befehl wird num doch erlassen." R. M. 144, 106.

"Der Amtmann von Unterseen wird angewiesen, den Auswanderungslustigen zu erklären, das 'gedruckte Büchlein' enthalte mwahre Angaben. Unbelehrbare können abreisen, mïssen aber 5 Prozent Abzug zahlen.” R. M. 144, I I I.

July i2. "Ein neues Mandat zur Warnung vor Auswandermng wird vorläufig noch aufgeschoben." R. M. 144, 162.

Aug. I6. "Bern setzt Zürich auseinander, warmm man bezïglich der Auswanderung nach Carolina eine abwartende llaltung eimnehme. Bericht über den bisherigen Verlanf der Dinge." R. N. 144, 259.

Oct. 4. "Ein Auswandermasagent Stryger zu Steffishura soll verhört werden." R. M. 144, 508.

Oct. If. "Der Agent Striker I= Strygerl, der aus Graubünden stammt u. in Steffisburer als Büchsenschmied wohnt, soll zur dushändigung der Verzeichnisse der Auswanderumgshotigen veranlasst werclen." R. N1. 145, ı.

Nov. Io. "Die Nuswandermusangelegenheit soll an der Tassatmung hehandelt werden. S. Instruktionenbuch. Der Iscent Striker soll

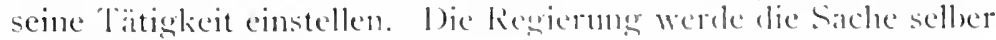
an die Hand nehmen." K. M. 145, 85.

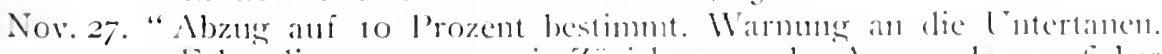

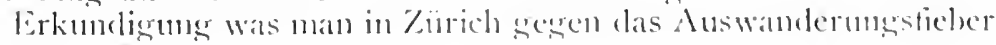
tue." R. M. 145, 172. 
Dec. 7. "Eine Untersuchung über die Verhältnisse und Beweggründe der Auswanderungslustigen wird angeordnet." R. M. 145, 256.

Dec. I I. "Der Agent Striker wird ausgewiesen." R. M. 145, 284.

\section{I735.}

Jan. 3. "Eine Kommission wird beauftragt, ein Gutachten über die Auswanderungssache auszuarbeiten." R. M. 145, 4I 5 .

Jan. I2. "Warnung ins Oberland vor der Auswanderung." R. M. 145, 475. Jan. I8. “Die Kommission erhält zwei Briefe aus Landau mit Berichten über Carolina, ferner das zürcherische gedruckte Mandat gegen die Auswanderung.” R. M. 145, 507.

Feb. I4. "Die Auswanderung ist zwar nicht zu verbieten, aber tunlich zu verhindern und zu erschweren. Die Kommission erhält Auftrag, ihr Gutachten zu entwerfen. Die Gemeinde hofft man gegen die Auswanderung zu stimmen, indem man Zwangseinbürgerung von Heimatlosen an Stelle der Ausgewanderten in Aussicht nimmt." R. M. 146, I38.

Feb. 23. "Zürich wird um Auskunft ersucht, ob man dort Nachrichten über Carolina habe.” R. M. 146, 212.

"Es sollen an Auswanderer keine Pässe mehr verabfolgt werden." R. M. 146, 2 I 5 .

Mar. 2. "Wiedererwägungsgesuch der Auswanderungslustigen gegen das Passverbot." R. M. 146, 262.

"Die Abreise wird 322 Personen gestattet. Beschluss des Gr. Rates." R. M. 146, 266.

Mar. 3. "Weitere Auswanderer aus dem Oberhasle dürfen ebenfalls abreisen. Jeder soll aber $500 \mathrm{lb}$. Mittel besitzen. Zurückbleibende Kinder müssen sichergestellt werden.” R. M. 146, 270.

Mar. 8. "Das Zürcher Mandat gegen die Auswanderung soll in das 'Ordinari Sambstagsblätlin' eingerückt werden.” R. M. 146, 298.

Mar. I3. "Für die Abfahrt des Hauptschwarms der Auswanderer sind 3 Schiffe bestimmt." R. M. 146, 337.

Mar. I6. "Die Kommission hat ihr Gutachten eingereicht." R. M. 146, 35I.

Mar. I7. "Mandat an die Untertanen gegen die Carolina-Reise." R. M. 146,366 .

"Beschluss, den in Bern versammelten Auswanderern den bezahlten Abzug zu schenken, d. h. wieder zu geben. Wer jetzt noch heimzieht, darf s. verkauften Güter wieder lösen. Wenn Kinder nicht mit den Eltern ziehen wollen, müssen letztere ihnen einen Teil des Vermögens hinterlassen.” R. M. 146, 368/7o.

Mar. I8. "Ein Gespräch gegen die Auswanderung soll nachgedruckt, ins Französische übersetzt und verbreitet werden.” R. M. 146, $37 \mathrm{I}$.

“Der Grosse Rat genehmigt die gestrigen Beschlüsse der Regierung. Der Agent Striker sei der Anführer der Gesellschaft. Allfällig von Auswanderern ihm anvertrautes Geld soll er hergeben." R. M. 146, 375/377.

Mar. 19. “Die Kommission soli über die Regelung der Verhältnisse der Umkehrenden Bericht geben, letztere erhalten Reisegeld.” R. M. 146, 379 . 
Mar. 21. "Mandat zur Abmahnung vor Auswanderung nach Carolina und andere entfernte Gebiete." R. M. 146, 385 .

Mar. 23. "Von dem bernischen Kommissär May in England (Er verwaltete dort die in England angelegten Schatzgelder Berns) sind betrübliche Berichte über den Zustand der nach London gelangten Auswanderer angekommen. Es sind solche aus Bern, Zürich, und Graubünden. Diese Nachrichten sollen deutsch und französisch gedruckt werden. Die Kommission soll Vorschläge machen betr. Rückschaffung der in London liegenden Leute.” R. M. 146, 395.

Mar. 29. "Die Kommission erhält Vollmacht, die in London zurückgebliebenen Auswanderer mit Reisegeld zur Rückkehr zu versehen. Einer Witwe Christen aus Aarburg u. ihren Kindern-die man nicht zurückwünscht-soll per Kopf I Guinée bezahlt werden zur Fortsetzung der Reise." R. M. 146, 433.

Mar. 3I. "Massregeln zur Unterztïtzung der umgekehrten Auswanderer." R. M. 146, 444.

"Gesuch an den kaiserlichen Botschafter in Basel um Ausstellung eines Passes an die Fortziehenden." R. M. 146, 447.

Apr. 25. "Auswanderer aus der Gegend von Oberhasle und Interlaken, 'so sich vorgenommen, ihr vermeint besser Glük in der entfernten Insul Carolina zu suchen', konnten z. T. wieder abwendig gemacht werden. Die Amtleute erhalten nun Auftrag zu berichten, wie diesen armen Leuten geholfen werden könne und ob ihre Klagen begründet seien.” R. M. 147, I2.

Sept. 26. "Nassregeln gegen einen gewissen Quinche von Neuenburg, der neuerdings Leute zur Auswanderung nach Carolina veranlassen will." R. M. 148, 387 .

Nov. 21. "Der bernische Kommissär in London meldet, dass dort verschiedene Berner angekommen seien, die nach Georgien auswandern wollen." R. M. 148, 547 .

The following note in the D. Sekelmeister-Rechnung, refers to the above action of the Berner Rat:

"Auf Befehl des Rates wurde mehreren Carolina-Emigranten der an die Amtleute bezahlte Abzug mit zusammen 237 Kronen i6 Batzen 2 Kreuzer rïckvergütet. Die Auswanderer stammten von Schwarzenburg (Bücher, Gilgen, Wäber, Stäbli, Mischler. Zwahlen), Güggisberg (Wänger), Interlaken (im Äbnit), Oberhasle (Rüdler, Meiden, Egger, Rübi, Zäuger, Horger).

"An Auswanderer, die von ihrem Vorhaben abwendig gemacht werden konnten, wurden als Reisegeld nach Hause 226 Pfund i3 Schilling 4 F'fennigr ausbezahlt." " D. Sekelmeister-Rechnung, I735, p. 76 .

$$
1736 .
$$

Oct. 8. "Da das Avis-Blättlin neulich einen Artikel über Carolina gebracht hat, wird der Herausgeber angewiesen, zukünftig keine Nachrichten über Carolina und den Zustand der dorthin Ausgewanderten zu veröffentlichen. Jedenfalls soll nichts Vorteilhaftes über Carolina gedruckt werden." R. M. 152, 224.

\footnotetext{
${ }^{2}$ A pound at that time was equivalent to about $4-5$ francs, a crown to about $13-15$ francs.
} 
1737 .

Feb. 27, Mar. 5. "Hans Georg Striker hat von Carolina aus an Leutnant Rubi in Thun einen Bericht über dieses Land geschickt. Der Brief wird beim Empfänger konfisziert und der Regierung vorgelegt." R. M. 153, 403-443.

\section{I738.}

Feb. 6. "Da neuerdings von Neuenburg aus für Carolina und Pennsylvanien Stimmung gemacht wird, erhalten die Avisblätter in Lausanne und Bern Befehl, über diese beiden Länder keine Nachrichten ins Publikum zu tragen.” R. M. 157, I22.

Mar. I2. "Neuerdings Auswanderungslust in der Gegend von Bern." R. M. 157, 370 .

Apr. Iо. "Mandat betr. Auswanderung beschlossen." R. M. 157, 531.

May 20. "Der Antrag, es sei der Abzug für Auswanderer nach Carolina zu erhöhen, wird fallen gelassen." R. M. 158, 307.

$$
\text { I74I. }
$$

Mar. 30. "Befehl, den Agenten Hans Riemensperger aus dem Toggenburg, der Leute nach Carolina und Georgien anlocken will, zu verhaften. Neuenburg wird vor dem Manne gewarnt. An Zürich werden Nachrichten über Carolina geschickt, die Bern aus London erhalten hat." R. M. 169, 383 .

Apr. 5. "Neue Vorkehren gegen Riemensperger." R. M. 169, 408.

$$
\text { I742. }
$$

Jan. I9. "Ein Mann aus Oberhasle Peter Huber, der nach Carolina ausgewandert war, holt Weib and Kinder. Andere Oberländer wollen auswandern."

"Die Regierung verlangt ein Gutachten, wie armen Leuten, die sonst auswandern, Arbeit verschafft werden könnte." R. M. 173, 275.

Feb. Io. "Vorkehren gegen die sich wieder regende Auswanderungslust." R. M. 173, 403.

Feb. I3. "Peter Huber soll sich 'ohne Verzug mit Weib und Kind fortpaken'. Man sucht zu verhindern, dass er nicht Leute zur Auswanderung verleite." R. M. 173, 432.

Feb. 22. "Weitere Verfolgung Hubers. Er hat zahlreiche Leute auswanderungslustig gemacht, sogar einen 75 jährigen Mann." R. M. $173,498$.

Mar. I. "Die Auswanderung wieder lebhaft im Gang. Leute aus Oberhasle und Interlaken ziehen über den Brünigpass. Man sucht Huber zu erwischen." R. M. 173, 552-554.

Mar. 3. "Polizei soll auf Auswanderer fahnden." R. M. 174, 8-9.

"Man soll ihnen keine Pässe mehr geben." R. M. 174, I 2-13.

Mar. 6. "Huber ist in Basel erwischt worden." R. M. 174, 29.

Mar. 7. "Meldung aus Basel, man habe Huber verhaftet und halte die Auswanderer an." R. M. 174, 34 .

Mar.8. "Ein aus Carolina kommender, an Daniel Kissling in Wattenwil adressierter Brief soll ausgehändigt werden." R. M. 174, 54.

Mar. 9. "Massnahmen gegen die Auswanderung." R. M. 174, 63. 
Mar. Io. "Massnahmen gegen die Auswanderung. Man teilt den Leuten mit, Huber sei verhaftet worden." R. M. 174, 68-69.

Mar. I2. "Man bringt verschiedene Auswanderer dazu, statt nach Carolina in den franz. Kantonsteil zu ziehen, um dort Arbeit zu suchen. Diese Leute werden unterstützt und sollen den Abzug wieder erhalten." R. M. 174, 78-80.

Mar. 13. "Man verschafft ihnen das beschlagnahmte Gepäck wieder." R. M. 174,88 .

"Vorbereitung einer Druckschrift zur Warnung vor Carolina." R. M. 174,89 .

Mar. I4. "Man will die Auswanderung radikal verbieten, dagegen für Arbeit im Lande sorgen." R. M. 174, I00-102.

Mar. 17. "Mandat betr. Auswanderer." R. M. 174, I 29.

Apr. 2. "Die Basler Polizei stellt Rechnung für ihre Bemuihunngen zur Anhaltung der Auswanderer." R. N. 174, I84.

“Der Grosse Rat beschliesst: 'Die Auswanderung bernischer Untertanen nicht nur nach Carolina, sondern nach Amerika überhaupt ist verboten!"," R. M. 174, i 87.

Apr. 26. "Dieser Beschluss wird als Mandat veröffentlicht." R. M. 174, 383 .

\section{4 .}

Jan. I8. "Peter Inäbnit ist aus Carolina nach seiner alten Heimat Grindelwald heimgekehrt und wirbt Auswanderer an. Er soll verhaftet "und nach Carolina abgeschoben werden." R. M. 181, I03-104.

Jan. 22. "Inäbnit ist verhaftet. Grosse Untersuchung. Er hat an den englischen Residenten geschrieben. Brief beschlagnahmt." R. MI. 181, I $27-128$.

Feb. 4. "Der gefangene Inäbnit soll schärfer ausgeforscht und mit der Folterung bedroht werden, wenn er nicht Auskunft geben will." R. M. 181, 2 I 2.

Feb. 17. "Er gesteht nichts, kommt für zwei Stunden an den Pranger und wird an die Grenze geführt." R. M. 181, 305.

Feb. 20. "Ein Brief von Philipp Friectrich Wild aus Rotterdam an Inäbnit wird beschlagnahnt. Es stellt sich heraus, dass Inäbnit etwa 7o Familien auswanderungslustig gemacht hat. Die Post wird angewiesen, verdächtige Briefe auszuliefern. Inäbnit soll wieder verhaftet werden." R. M. 181, 322-325.

Feb. 27. "Trotz aller Anstrengungen der Regierungen 'ziehen oberländische Lindleute haufenweise nach Carolina'. Man lässt sie ziehen. Befehl, aus Carolina zurückkehrende Leute in Gefangenschaft zu nehmen. Auftrag an (len Kommerzienrat, für Alhilfe zu sorgen.” R. M. 181, 357-35\%.

Mar. 4. "Polizeinassualmen, un die Anwerbung von Answanderern durch Briefe zu verhindern." R. 11. 181, 397.

"Basel wird ersucht Inäbnit zu verhaften und auszuliefern." R. M. 181,399 .

Mar. 9. "Die Regiertung sucht die jungen Lente zurüickzuhalten, damit sie nicht mit den Eltern abreisen. Man sucht die Auswanderer damit zu schrecken, ilı Fühner Inäbnit sei verhaftet." R. M. 181, $42 \mathrm{I}-425$.

Mar. I6. "Die Auswanderer erhalten Fïsse, verlieren aber das Landrecht." R. M. $181,+66$. 
Mar. I7. "Heute passieren 80 Auswanderer, die den Abzug bezahlt haben, die Stadt per Schiff." R. M. 181, 475.

"Inäbnit ist nun wieder in der Gewalt der Berner Regierung, Verhör." R. M. 181, 478 .

Apr. 2. "Bei einem Befreiungsversuch stürzt Inäbnit vom Turm herab zu Tode. Leichnam wird unter dem Hochgericht verscharrt." R. M. 181,537 .

$$
\text { I } 749 \text {. }
$$

Apr. 21. "Hans Curt aus dem Amt Wangen will nach Pensylvanien ziehen. Man geht damit um den Abzug von Io auf 20 per cent. zu erhöhen.” R. M. 201, 312.

Apr. 24. "Befehl an die Amtleute, auf die Amerika-Werber zu achten. Die Kanzlei soll einen Bericht erstatten, was bisher in der Auswanderungssache vorgekehrt worden sei." R. M. 201, 35I, 358.

"Befehl an alle Amtleute des ganzen Kantons, insgeheim auf die Verführer zu achten, welche bernische Untertanen verlocken, "ihr vermeint besseres Glück in America und Pensilvanien zu suchen'. Die Agenten sind $z u$ verhaften, sobald sie sich verdächtig machen." Geheimes Missivenbuch C, 532.

Apr. 28. "Auswanderungsfieber im Aargau. Agent Jakob Walder aus dem Kanton Zürich." R. M. 201, 386.

May 3. "Abzug wird vorläufig nicht erhöht." R. M. 201, 444.

May 6. "Massregeln gegen die Auswanderung aus dem Aargau." R. M. 201, $480-483$.

May I2. "Zwei Basler werben in der Gegend von Büren für Carolina und "Pennsylvanien." R. M. 201, 535-536.

May I3. "Erwägung der Frage, ob den zahlreichen Heimatlosen die Auswanderung zu gestatten sei." R. M. 201, 55I.

May 19. "Die beiden Basler, die aus Pennsylvanien zurückgekehrt sind und nun Leute anwerben, heissen Jakob Joner von Prattelen, M. Spänhauwer von Muttenz. Befehl sie zu verhaften." 'R. M. 202, I I-I 2 .

June 26. "In Zeitungen erscheinen Berichte, dass in Basel viele Tausende sich sammeln, um nach 'Amerika und Neu Schottland' auszuwandern. Bern sucht in Basel, Zürich, etc., zu bewirken, dass solche Zeitungsmeldungen unterdrückt würden.” R. M. 202, $377-378$.

1750.

Feb. 24. "Auswanderungsfieber in der Gegend von Interlaken. Die Vorbereitungen zur Abreise werden heimlich getroffen." R. M. 205, 88-90.

Feb. 26. "Der Redakteur der in Bern erscheinenden französischen Zeitung de Morancour erhält einen Verweis, weil die gestrige Nummer einen Artikel über Carolina und Pennsylvaníen brachte, wo 'die Leute ihr Glück finden '.” R. M. 205, I05.

Mar.6. "Empfang eines Schreibens von Basel betr. Zeitungsmeldungen." R. M. 205, I64.

Mar. 9. "Konfiszierte Briefe aus Amerika für bernische Untertane." R. M. 205,185 . 
Apr. Io. "Auswanderer aus dem Oberland sind von Yverdon (am Neuenburgersee) aus zu Schiff abgereist. Den Schiffern von Yverdon wird verboten, Leute, die nach Carolina, Pennsylvanien und NeuSchottland reisen wollen, mitzunehmen." R. MI. 205, 4I2-4I3.

\section{I75I.}

Mar. 27. "Jakob Joner aus Pennsylvanien versucht das Vermögen Ausgewanderter herauszubekommen. Seine Vollmachten werden aber nicht für genügend erachtet. Er wird ausgewiesen." R. MI. $209,440$.

Apr. I6. "Man ratschlagt wieder einmal, wie die Auswanderung in ' americanische Colloneyen' verhindert werden könne." R. II. 209, 545.

Apr. 21. "Auswanderer nach Pennsylvanien werden verhört." R. M. 210, 5.

May 5. "Dupaquier von Neuenburg Agent für Neu-Schottland." R. MI. $210, \mathrm{I} 43$.

May 24. "Eine arme Familie namens Bernhart aus dem Städtchen Wiedlisbach wird ziehen gelassen. Nachforschung, wer sie "franko bis ans Meer' liefern wolle." R. M. 210, 28I.

June 26. " Drei Agenten: Joner, Tschudi, und Bratteler, werden proskribiert. Sie kommen gewöhnlich im Monat März ins Land, um Auswanderer zu holen." R. M. 210, 540-541.

\section{(I75I.)}

"Zedel an Hr. Groszweibel: indeme Hr. Michael Schlatter Prediger der Teutschen Gemeind zu Philadelphia in Pennsilvanicn sich bey allhiesigem E. Convent angemeldet, und den Zustand der alldort etablirten zum Theil schweizerischen Religionsgenossen vorgestellet, mit dem Beyfügen, dass die holländischen Sinodi Ihne Pfarrer mit Beglaubigungsbricfen an die Reformirte Ministeria vorgehen, und Ihme aufgetragen, etwelehe Prediger für Pennsilvanien auszusuchen, und auch milte Bëysteuer zu suchen, haben $\mathrm{MeG}_{\mathrm{H}} \mathrm{n}$ in Bedenken der bösen Folgerungen so aus dergleichen Sachen entstehen, in dieses Pfarrers Begehren gar nit eintretten können, sonderen befehlens thme $\mathrm{H}_{n}$. Groszweibel demselben zu bescheiden, lhme das Consilium Abeundi von hier zu ertheillen. mit der Vermahnung hierlands von seinem Vorhaben mit niemand zu reden, sonsten er sich in schwäre Verantwortung setzen würde. Ubrigens haben MeGnHn Ihm bisz zu heutigem dato (inclusive) Ine für seinen Aufenthalt althier kostfrey halten und vom Wirthen lösen wollen, massen Hr. Ammann den Conto unterschreiben solle." R. M. 212, 78-79.

1752.

Apr. 29. "Briefe* aus Pennsylvanien werden von der Polizei geöffinet und abgeschrieben. Die darin enthaltenen ungünstigen Nachrichten sollen inn nächstjährigen Kalender † erscheinen." R. M. 214. 9.

* Nacher werden sie den Ariressaten zugestellt.

$\doteqdot$ S. Hinkender Bote, I749-1756. Confiszierte Briefe, I752.

Auszugr aus einen brief von Johannes Storker aus Pennsylvanien.

Ein anders Schreiben eines Land-Manns aus dem Oberland.

Brief aus Pennsylvanien an Weib und Kinder.

Brief eines bekannten Schweizers ans Philadelphia. 
June 4. “Der Kirchenkonvent beschliesst, das Gesuch zu unterstützen, 'zu Errichtung fernerer Kirchen und Schulen und Salarierung Prediger und Schulmeister in Pensilvanien' sei von Staatswegen eine Beistener zu geben. Das Gesuch von den holländischen Synoden an die evangelischen Orte der Eidgenossenschaft." Akten des Kirchenkonvents, IV. I2.

\section{3.}

Feb. 19. "Briefe zur Verlockung nach Carolina und Pennsylvanien in der "Gegend von Interlaken." R. M. 217, 185.

Feb. 20. "Ihre Überbringer Hans Zurflüh von Oberried und Hans Wyss von Isenfluh werden auf 24 Stunden eingesperrt und sollen in 8 Tagen das Land räımen. In der Regierung wird der Antrag gestellt, es sei den Auswanderern das Erbrecht auf Vermögen in der Heimat zu nehmen.” R. M. 217, 202.

Feb. 24. "Überweisung des Antrages an eine Kommission." R. M. 217, 233. May 2I. "Das Mandat vom 26. Apr., I 742, wird bestätigt. Von einer Verschärfung wird Umgang genommen." R. M. 218, 345.

1754 .

May I8. “Die Regierung nimmt hinterlassenes Gut von Auswanderern in Verwaltung. Aus der Landschaft Erguel, die dem Bischof von Basel untertan war, wo aber viele Berner als Pächter wohnten, sind solche nach Pennsylvanien abgereist. (Es waren meist Wiedertäufer.) Sie durften nach Befehl des Bischofs nur abreisen, wemn sie andere vermögliche Leute als Pächter stellten. Die bern. Regierung sucht eine Abwanderung nach dem Erguel zı1 hindern." R. M. 223, 45.

\section{I755.}

Sept. 25. "Herr Gasser, Prediger bei der reform. Gemeinde Sandyvarck ${ }^{1}$ in Süd-Carolina bewirbt sich $11 \mathrm{~m}$ cine Beisteuer in Geld, Bibeln oder Psalmenbüchern. Der bern. Kirchenkonvent empfiehlt das Gesuch. Die Regierung weist Gasser $a b$, gibt ihm ein Viaticum von 6 Dukaten und zugleich das Consilium Abeundi." R. M. 228, 4I I.

$$
\text { I } 756 .
$$

Jan. 2. "In der Gegend von Interlaken Auswanderungslust. Befehl, den Prediger Gasser, der Leute anwerbe, zu verhaften. Er stammte von Steckborn im Thurgau." R. M. 229, 339-34I.

Jan. I5. "Einer Familie von Interlaken ( г Köpfe) wird das Vermögen gesperrt, damit sie nicht auswandern könne." R. M. 229, 425 .

Jan. 24. "Zwei aus der Gegend stammende Männer Hans Moser und Heinrich Ritschard, die von Carolina zurückgekommen und als Agenten verdächtig sind, kommen unter Polizeiaufsicht." R. M. $229,48 \mathrm{I}$.

${ }^{1}$ This is undoubtedly Santee Forks. Cf. Wm. J."Hinke, "The Origin of the Reformed Church in South Carolina", Journal of the Presbyterian Historical Socicty, III. 387 (Dec., I906). 
Apr. 24. "Ein gewisser Gottl. Mittelberger, gegenwärtig zu Stuttgart, sendet an die Regierung einige Exemplare seiner gedruckten Reisebeschreibung von Pennsylvanien." ${ }^{2}$ R. M. 230, 504.

$$
\text { I } 763 \text {. }
$$

Apr. 28. "Johannes Christen, aus dem Kit. Basel, sucht das Vermögen des in Pennsylvanien befindlichen Hildebrand Inäbnit herauszubekommen." R. MI. 265, I99.

May 17. "Nach dem Mandat vom I6. Apr., I742, verfügt die Regierung, dieses 1200 Kronen ausmachende Vermögen sei nicht auszuhändigen, sondern unter vormundschaftliche Verwaltungr der Gemeinde Grindelwald zu stellen. Inäbnit war ein Leineweber." R. M. 265, 355 .

Dec. 28. "Auch 400 Kronen Schulden des Inäbnit werden aus dessen Vermögen nicht bezahlt. Mittel, die Auswanderung im Volk verhasst zu machen." R. M. 268, zi.

$$
\text { I } 764 \text {. }
$$

Jan. 23. "Um diese Zeit werden vielfache Klagen über die Entvölkerung des Kantons laut. Zahlreiche Gegemmassnahmen werden vorgeschlagen, und es wurde auch die erste Volkszählung nach neuzeitlichen Grtndsätzen vorgenommen.

“Als Grund der Entvölkerung wird auch die Anwerbung von Männern und Franen nach England und Amerika, "in die neuw angelegten Plantationen' angegeben.” R. M. 268, 260.

Mar. 27. "Eine abschreckende 'Relation von Philadelphia' von einem gewissen Pfarrer Rottenbühler (vermeintlich in Amerika) verfasst, soll durch den Druck verbreitet werden." R. MI. 269, ${ }_{5}$ S.

$$
1765 .
$$

Dec. 4. "Massnahmen gegen die Entvölkerung des Landes sollen von einer besondern Konmission vorgeschlagen werden." R. M. 277, 460.

$$
\text { I } 766 .
$$

Jan. 23. "Bern erkundigt sich bei mehreren anderen Kantonen, was man dort gegen die Auswanderung vorkehre." R. M. 278, 367.

$$
\text { 1 } 767 .
$$

Nov. I. "In Bern ist ein nach der Meinung des Kirchenkonvents irreligiöses Buch: Sur la population de l'Amérique erschienen. Theologieprofessor Stapfer soll es mäher prïfen." Akten des Kirchenkonvents, IV. 328 .

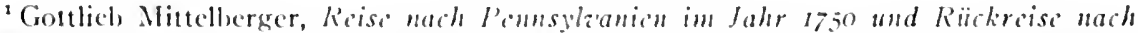
Teutschland im Jahr 175. (Stuttgart, 1750). This hook, appearing in 1750, was welcomed by those that opposed emigration. The full tille literally translited is as follows: Gotslieb Wittelberger's Journey to P'ansylatania in the lear 1750 and Return to Germany in the Year $175 \%$ contuining not only a lescription of the conntry according to its Present Condition. but also a Detailid fecoumt of the Sisd and llifortwnate Circomstances of most of the Germans that hase cmigrated, or are cmigrating to that country. It has been transiated from the (ierman hy C. T. Eilen (1hilidtelphia, 1898, pp. 129).
} 


$$
1768 .
$$

Jan. Io. "Das Buch bestreitet die Inspiration der Bibel. Das Gutachten Stapfers geht dahin, wenn man das Buch verbiete, werde es begierig gelesen. Es soll also mit Schweigen übergangen werden." Akten des Kirchenkonvents, IV. 334.

$$
\text { I } 769 .
$$

May 24. "Die Synode von New York (Novum Eboracum) und Philadelphia schreibt an die schweiz. ref. Kirche in lateinischer Sprache und gibt Auskunft über ihre Verhältnisse seit I729." Akten des Kirchenkonvents, IV. 418.

\section{I $77 \mathrm{I}$.}

Mar. Io. "Der bernische Konvent lässt ebenfalls lateinisch durch Prof. Joh. Stapfer antworten. Hoffnung auf Bekehrung der heidnischen Eingeborenen." Akten des Kirchenkonvents, IV. 420.

I779.

Nov. 24. "Jakob Philadelphia aus Amerika erhält die Erlaubnis während der Messe seine 'mathematisch-physikalischen Künste' dem Publikum vorzuführen." R. M. 350, г61.

$$
\text { I } 780 \text {. }
$$

June 2. "Die Regierung lässt die Einführung von Blitzableitern prüfen." R. M. 353, 296.

Aug. 25. "Man will nächstes Jahr damit einen Versuch machen.” R. M. 354,377 .

$$
\text { I 78I. }
$$

"Es sind Werbungen für die ostindische Kompanie im Gange. Bern hält seine Angehörigen zurück und verfolgt die Werber. (S. auch R. M. 360.)"

(Summer.) "Der franz. Gesandte reklamiert wegen Werbungen für den Königl. Grossbrit. Dienst in Amerika." R. M. 359, 395, 408, 433.

Aug. I3. "Nach dem Ergebnis einer grossen Untersuchung über unerlaubte Werbungen wurden diese vorgenommen:

I. für die englische-ostindische Kompanie.

2. für die holländische-ostindische Kompanie.

Dagegen wurde festgestellt, dass es sich nicht um Werbungen für den K. Grossbrit. Dienst in Amerika handle." Manual der RekrutenKammer, 35, I 57.

$$
1796 .
$$

Nar. I4. "Der bernische Kaufmann Rudolph Tillier ersuchte die Regierung um die Erlaubnis, 24-30 freiwillige Arbeitsleute nach Amerika anwerben zu dürfen. Er wurde mit seinem Begehren an den Grossen Rat gewiesen (scheint aber von der Sache abgestanden zu sein). Tillier hatte den Auftrag aus Amerika bekommen. Rud. Tillier geb. 1754, war mit einer Engländerin verheiratet." R. M. 445,70 . 
July 7. "Die Regierung erwägt den Verkauf englischer Fonds und die Erwerbung amerikanischer Fonds." N. B. Der bernische Staatsschatz besass I790: 440,960. I6. Io Pfund in englischen Fonds. Durch Spekulation in Mississippiaktien gewann s. Z. das bernische Bankhaus Malacrida und Co. I50,000 Kronen; aber durch den Mississippi- und Südsee-Krach um I 720 verloren der Staat Bern und bernische Privatleute: 5I3,6II. 20. 3. Taler +85 , 445. I2. 5 Pfund. Bankiers: Malacrida und Co. (Bern), Müller und Co. (London)." R. M. 447, 194. ${ }^{1}$

I 820 .

Apr. 4. "I. Bericht des Hauptmanns Rudolph May über die Anwerbung von Züchtlingen für die Kolonie des Lord Selkirk am Roten Fluss (Hudson Bay Distrikt)." R. M. 52, 56, 57 .

1821 .

Jan. 26. "Mehrere (etwa 30) sich bereit erklärt nach der Colonie am Rothen Fluss in Nord Amerika für welche Hr. Hauptmann May (von Utzendorf) Colonisten sucht; mehrere ihre Reisekosten ganz zu bezahlen vermögen; Strafumwandlung, Deportation. Verneint: (I) weil Colonie von Selkirk noch keineswegs so weit gediehen ist; (2) weil keine Sicherheit gegen das Entlaufen und Rückkehr. Beschluss: Werden Sträflinge nicht freigegeben." R. M. 54.

\section{TÄUFER.}

Manual der Täufer-Kammer (special court established). 4 vols. I72I-1743.

\section{RODEL.}

Rodel Weggezogener Mannrechten. I694-I754. Alphabetical list of persons who withdrew their home-rights. The destination of the emigrants is unfortunately never mentioned.

\section{Recrouten Kammer.}

Manual MHHRN der Recrouten Kammer der Statt Bern. Nr. 8. I720-I724. p. 7: "Entführung dahin Daniel Müllers" (case of a father and 2 sons kidnapped for service in Mississippi). Evidences of the successful recruiting of Mervcilleux.

pp. 25-26: "Friedrich Vannaz, wegen seiner Entfülırung nach Mississippi." The following droll entry appears: "Bomont. Praef.: Ihme befehlen, den Frielrich Vannaz von Gingins, so wider Verbott, für das Mississippi Dienst genommen, hernach sich wieder los gemacht und ins Land kommen, vor sich zu beschicken, und ihme verdeuten, dass er das Schallenwerk [Schellentragen, i. e., Zuchthaus, penitentiary] verdient hätte; weihlen er aber sehr einfältig, und wenig Verstand habe, so seye er pardoniert, und wollind MHWWH die Sach dahin gestellt seyn lassen." Jan. 9, 1722.

${ }^{1} C f$. Landmann: "Die auswärtigen Kapitalanlagen aus dem Berner Staatsschatz im 18. Jahrhundert", in Jahrbuch für Schaceiz. (ieschichte, XXVIII. 
Erlach D., p. 66I. “Demnach ich vernommen, wie dass sich einige arme gantze Famillen etc. sich in die neuerfundene Insull Mississippi zubegeben und von einem gewüssen $\mathrm{Hr}$. Wunderlich von Neüwenburg auf gute vorgebente Wort und Gelt dorthin engagirt worden. Als habe ich dise.Leuth, umb selbige von ihrem Vorhaben abwendig zu machen vor mich beschieden, allein nichts bey ihnen ausrichten können, allemaszen sie, wie mir der Bericht abgestattet worden kurtz darauf verreiset. Wann ich dises nun von groszer Consequentz erachte in Betrachtung man nicht weiss, wo dise Leuth hinkommen und wie es ihnen in Ansehen der Religion oder sonsten ergehen möchte, Als habe Ew. Gn. dessen in aller Gebühr verständigen, dero Hochweyssen Guthfinden hierüber erwarten mithin dieselben göttlichem Machtschirm wohl erlassen wollen, verbleibe, Ener Gnaden, etc. Hier[onymus] Huser, Ambtsmann zu Erlach." Apr. 13, I720. See action of Berner Rat. Rats Manuale, Apr. I 5, I720.

Erlach D. Printed advertisement of "Messieurs Purry et Compagnie", "ayant besoin de trois ou quatre cents hommes ouvriers de differentes professions, pour aller faire bon Etablissement en Amérique dans la Caroline Mćridionale etc." Neufchâtel, June 28, I725.

Neuenburg Bücher. I735, pp. 599-6Io. Capitaine Quinche accused of luring Bernese to Carolina. His denial and defense. As Maitre des Clefs in Neufchâtel, which gave Capt. Quinche military power, he probably succeeded in getting people off. See also Missiven Buch, Sept. I6, and Nov. 22, I735: the Bernese Council insists on the correctness of its information, which Quinche denies.

Frütigen D., pp. I06I-I072. Concerning the legacy of Hans Schrantz, who in I749 emigrated to Carolina, and subsequently became a well-to-do man in Canastoga (probably Conestoga, Pa.). .

Hasle-Buch D. Typical case: "Barbara Horger, so in Carolinam ziehen will, haltet um Verabfolgung ihrer Mittel an." (Vermögen $90 \mathrm{~K}$. Io per cent. Abzug.)

\section{Säckelschreiber Protocolle.}

W. Protocollum vom I. Februar, I735, bis I. August, I 736.

pp. 57-6r. "Vortrag MrHwH der Commitirten wegen Versorgung deren, so nacher Carolinam emigrirt waren." All those stranded at forcign ports to be brought back, transportation paid, "damit sie desto sicherer ankämen, und durch Erzählung ihres überstandenen Elends die anderen desto mehr von der Nachfolg abschrecken thäten, dann es ist zu besorg, dass diese Sucht der Emigration je mehr und mehr überhand nehmen werde, also allerhand gelind Mittel dar wieder vorzukehren nit undienlich." Mar. 28,1735 .

Y. Protocollum, Aller von mir Beath Ludwig May diszmahligem Teutschen Sekelschreiber, expedierten und signierten Instrumenten, Bedäncken, Vorträgen, etc., angefangen d. I3. Januarii I738 und endet d. I3. Marty I739.

"Gutachten: Ob der Abzug von denen so nacher Carolinam emigriren zu erhöhen seye. Acte 5 May, I738." Conclusion: that the tax on emigrants should not be increased, first, because of attention 
and dissatisfaction aroused, and secondly, emigration was now less frequent. Characteristic passage: "Anderseits dann ist nummehr die RABIES CAROLINAE [sic] zu gutem Glück allerdings verschwunden, und haben sich die Unterthanen durch das Traurige Fatum der angesehensten von den Emigranten ein mehrers belehren lassen, als durch alle MeGH Ihnen gethane so väterliche Vermahnung ....”

\section{Responsa Prudentum.}

VI., pp. I 55-I87. "Ohmmaszgebliche und Wohlmeinentliche Gedanken Wie die von der Carolinischen Reyse abgehaltene Oberländische Hauszhaltungen, samt übrigen dortigen Armen in einen besseren Nelırstand gesetzet werden könntenl." (Addressed to Commercien Räthen.)

pp. I89-I9I. "Wegen der Armen im Oberland." Advice to establish manufactures. Mar. 3,1744.

pp. I93-210. "Wie der Armut im Oberlande abgeholfen werden könnte." Mar. 5, I 744 .

pp. 2I 5-235. Abstract of all suggested plans, Memoriale, on the subject. Proposal of "Arbeitshaus". None of the plans were carried out. For a brief account, $c f$. E. Lerch, Die Bernische Ausi'anderung nach Amerika im I8. Jahrhundert (1909).

VII., pp. 823-833. "Gutachten zu Behinderung der amerikanischen Emigrationen." May 6, I 749 .

\section{Tilurn-Buch der Statt Bern.}

$$
\text { I } 740-1742 .
$$

The Thurn was the tower, used as a prison, and the Thurn-Buch the record kept of the examinations of prisoners confined in the tower (now an archive) in Bern. The questions and answers of these searching court-examinations are carefully recorded in the Thurn-Buch, and afford a most realistic picture of social and moral conditions of the period. Two of these "Verhöre" concern American history, inasmuch as the prisoners examined are suspected of being emigrant agents, who have been inciting Swiss people to immigrate to Carolina. Their names are Peter Huber and Peter Im Aebnit, both born in the Berner Oberland. These "Verhöre" will be published in full in the American Historical Revica, abstracts only follow here:

$1740-1742$, p. 479 f. (4I pp.). "Peter Huber, 36 Jahre alt, gebürtig von Ober-Hasli, Schuhmacher, Weib und 3 Kinder, davon eines in Carolina.

"Der zu Basel arrestirte Peter Huber wegen Verdachts ob hätte er Leuthe in hiesigen Landen angeworben, nach Carolina in America zu führen, auf Ihr. Gn. Befehl anhero gebracht worclen-habend dato 21. Mär\%, 17+2, folgendes lixamen mit demselben gehalten": (Huber denies having indued anyone to go; claims to have represented facts as they were, calling attention to dangers and difficulties; has appointed no meeting-place at Basel or elsewhere: has bad nothing to do with crowds of emigrants gathering at Basel.-See notes on Basel archive below, p. 111.)

F. "Ob er nicht ein hölzernes Geschirr habe, da man obenher Getränk, unden her aber Briefen darim thun kömme?" 
A. "Ja ein solches habe Ihme ein gewisser Hans Rodt in Carolina gemacht und werde man solches under seinem Plunder wohl finden."

F. "Er habe nun alle an Ihne gethane quaestiones ziemlich hartnäckig geläugnet und darbey versichert, dass er gern alles bekennen wollte was wahr seye, nun wolle man anoch eine frische ganz wahrhafte frag an Ihne truken und darbey sehen, wie sehr er die Wahrheit liebe? Ob er nicht vorgestern ein Papeyr aus Gefangenschafft einem Weibe von seinen Lands Leuthen zu geworfen darauf geschrieben gestanden, das diejenige so auch Lust haben möchten mit Ihme $z \mathfrak{u}$ reisen, trachten sollind, in das Neuenburgische zu gehen und sich dorten eine Weil aufhalten, Er hoffe seine Sachen seyen noch nicht so schlimm beschaffen, dass er nicht Hoffnung haben sollte bald loos zu werden, wenn er dann loos seye, wolle er hinkommen und im Vorbey gehen Sie mit Ihme nemen, sie seyind als dan grad in Burgund, und könnind Ihren Weg ohngehindert vortsezen?"

A. "Über diese quaestion schienen Er ganz erschrocken zu seyn, schauete hin $u$. her, wusste ein Weile nicht was er sagen sollte, und schosse Ihme das Wasser in die Augen. Endlich sagte er. Ja! Er könne dieses nicht läugnen, Er habe vermeinet, wan er einmal ledig werden könte und diese Leuthe auszert Er. Gndl. Bottmässigkeit antreffen wurde, er selbige, ohne dann Übels zu thun, mit sich nemen könte, er gestähe aber auch, hierinnen gröblich gefählet zu haben, seye Ihme wohl herzlich leid, er bitte Bott. und Er. Hoh. Gn. in dehemuth um Verzeihung u. Gnad."

"Worauf er wieder in seinen Orth geführt worden." Mar. 21, I742.

Examination of numerous persons who were to go with Huber (same method pursued at Basel). Attempt made by the court to get witnesses to declare that they were encouraged by Huber to emigrate. Peter Scherz is determined to emigrate, he sought Huber, not Huber him; poverty was the cause. Ulrich Müller induced by encouraging letters from America. Jacob Ritschard, with family of seven, long determined to go. Hans Poster induced by poverty, Christ. Oehrli by relations in Carolina. Hans Egger declared Huber had said he would get 50 acres of land and cash money on arrival in Carolina (large inducements were made at that time for colonists).

\section{Klein Thurn-Buch der Statt Bern.}

\section{I743-1744.}

I743-1744, pp. I32-I 49. “Peter Im Aebnit aus Grindelwald, bey 25 Jahren alters, vor neun Jahren mit Vater, Mutter, Geschwistern und vier Landsleuthen nach Carolina ausgewandert." When asked to explain his reappearance in Switzerland, he declares that he was sick all but two years in Carolina, and therefore wished never to return thither. Questioned about his visit to the English minister at Reichenberg; about the crowds gathering about him at Grindelwald; the letters he had carried with him ( 8 in number), etc. List of 20 adults and 44 children who are resolved to go to Carolina. pp. I 53-I60. "Da er nun ohngeachtet alles ernstlichen Zusprechens, Antrohung der Marter, und da der Scharfe Richter Ihme vorge- 
stellet worden, ein mehreres nicht bekennen noch eingestehen wollen, ward derselbe hinauf und zı der Folter-Bank geführet, Ihme nochmalen äussersten Ernsts zugesprochen und die Marter anzuwenden angetrohet, dessen ohngeacht verbliebe derselbe durchaus bey seiner hiervorigen Aussaag, und dass er gar nicht gekommen, jemand nach Carolina zu verleiten, noch dass er gewusst was in denen mitgebrachten Briefen enthalten gewesen, er seye selbsten nicht gesinnet wieder hinein zu gehen, und werde niemand zeugen können, dass er jemanden dahin verlocket, in dem Gegentheil habe er mehr abgewerth als angerathen; im übrigen seye er in seiner Hohen Oberkeit Banden, man könne mit Ihme nachen was man wolle; er bäte aber um Gnädige Looslassung." Actum, Io. Feb., I744.

"Wird an den Pranger gestellt, und ewig banisirt."

In answer to the question, how many went with Peter Huber, he said, nine to ten persons arrived with him in Carolina. Huber derived no profits from them, he declared.

pp. 206-215. After this punishment with the stocks and subsequent banishment, Peter Im Aebnit was implicated again and imprisoned in the Kefi-Thurn (Käfig-Turm, still standing) in Bern. From this tower Peter Im Acbnit tried to escape by means of a rope which his friends had brought him. The rope broke and Peter lost his life. His body was picked up in the morning, and the following record appears in the book: "Wegen der am Tag liegenden, und $z$. Theil gestandenen Verbrechen" wurde "der tote Körper unter dem Hoch-Gericht verscharrt."

\section{Die Eidgenössischen Abschiede aus dem Zeitraum von I712-I743.}

Printed volume (Zürich, I860, VII. I of the series), prepared by D. A. Fechter, containing the minutes of congresses of the thirteen cantons.

p. 506 b. "Bern ersucht die Gesandten Zürichs, mitzutheilen, was für Maszregeln ihre Gn. Herren und Obern gegen die in so groszer Zahl nach Carolina 'in Westindien' reisende Leute getroffen hätten. Diese antworten, dass dieselben in Folge der zu Bern 11. Neuenburg eingezogenen Berichte den Verkauf des Büchleins von Herrn Pury von Neuenburg im Lande verboten hätten. Wie nun aber gegen den Herbst trotz aller Abmahnungen dennoch ïber 200 Personen dahin verreist seien, so habe man durcl ein Mandat die fernere Auswanderung verboten. Da jedoch 'diese Krankheit' dergestalt überhand genommen habe, dass seither noch mehr verreist seien, und im Frühlinge noch mehr wegzichen wollen, so hätten sie die Untersuchung dieser Sache einer Conmission übergeben. Es wird eimmütig befunden, dass man auf die Rädelsführer Acht haben und sie zur Strafe ziehen solle; ferner, dasz man niemanden mit Pässen oder Geld für die Abreise Vorschub thun, im Gegentheil dieselbe auf alle Weise hindern solle." Dec., 1734 .

p. 696. Auswanderung. Mandat: "Die Gemeinden sollen dem Landvogt anzeigen, wenn jemand ausziehen will." Oct. 16, 1728. 
Acta Conventus Ecclesiastici Bernensis, MS.

III. 67 I f. Praeside Hr. Decan Kilchberger.

Acta: "Erschinne Hr. Michael Schlatter prediger göttlichen worts zu Philadelphia in Pensilvania vorweisende ein recommendatorium von dem allgemeinen Synodo der Hollendischen Kirchen an die Reformirten Kirchen in der Eydgenossschafft, in welchem gezeiget wird, mit wass mühe und vielem seegen dieser $\mathrm{Hr}$. Schlatter, sonst gebürtig von St. Gallen, dortige Colonien der Reformirten, deren Anzahl sich auff 30,000 belaufft, under welchen die Helffte Emigranten aus der Reformirten Eydgenossschaft, in eine kirchliche Verfassung gebracht, in verschiedenen Kirchspielen eingetheilt, und alles also angeordnet, dass wofern ihme mit kreftiger Hülffe under die armen griffen werde, zu hoffen, dass under Gottlichem Beystand das Evangelium mit grossem seegen alldorten werde fortgepflanzet werden. destwegen schon albereit ihr Hochmögenden für 5 Jahr jedes Jahr zu steuern erkent 2000 Gulden, sonder ess haben die Synodi erklärt, hierzu ansehenliche Collecten zu samlen, wie dan ihr Vorwort an alle Reformirten stenden der eidgnossschaft dahin gehet, dass auff eine gleiche weise der aufnahm der Reform: Kirchen in america durch thätliche liebe beherziget werde. die gantze nachricht von dieser Reform: Colonie ist getruckt in Hollendischer Sprach, wie zu sehen in den authenticis zu disem Manual."

"Erkent: (I) wurden Hr. Prof. Altmann und Hr. Theologus Wytenbach verordnet, Hrn. Schlatter für die audientz zu Ihren Gnaden zu begleiten, sein begehren im Namen eines E. E. [ehrwürdigen] Convents kreftig zu understützen. (Zusatz: ware aber vollkommen abgewiesen.)

" (2) war Hr. Theologo Wytenbach aufgetragen, entweders an die H. Representanten des General Synodi im Haag oder an den Synodum in Amsterdam zu schreiben, mit verdeuten einerseits, wie dass wir diss christl. werck nach unsserem vermögen werden zu understützen und befördern trachten, anderseits anzurühmen den lobl. Eifer Hrn. Schlatters, nach welchem er ihme die beförderung der Ehre Gottes in fortpflanzung seines evangelii höchst angelegen sein lasset." Nov. 2I, I75I.

\section{Evangelische und Drey-Oerthische Abscheiden. I746-I 752.}

AA, p. 883 f. " Der Synodus der Reformierten Kirche in der Republik Holland hat die Löbl. Eidgenossenschaft um ihre Milte Concurrenz zu gemeinsamem Handeln zu gunsten des wahren Gottesdienstes in Pennsylvanien, Besoldung der nötigen Lehrer und Schulmeister" gebeten. (Bitte des Hrn. Michael Schlatter, gebürtig in St. Gallen.) "Verneint." Denied to discourage emigration. "Diese Leuthe sind wider sorgfältige Einrathung und Vermahnung weggezogen", " jetzt auch darauf angewiesen sein sollen".

Emigration. Sammlung verschiedener Verordnungen und Mandaten, die Grafschaft Baden, das Thurgau und die Freyen- ̈̈mter betreffend. I 770 .

Emigrationen nach Spanien und spanischen Colonien. 1767 . 
Allgemein Eidgenössische Bücher. Special Heft: Verordnungen gegen die Auswanderungen, 1765-1770. Especially concerned with Spanish American colonies. Most interesting collection of letters, pamphlets, circulars, printed advertisements, $c$. g., Gliicks-Hafcn, oder Reicher Schatz-Kasten, welehen der Spanische Monarch als einer der reichsten Königen zum Trost und Nutzen aller Teutschen und Niederländischen Bauersleuten, Taglöhnern, Handa'erkMännern, Burschen oder Gesellen, Jungen und Alten, Ledig-und Verheuratheten Manns-und Weibs-Personen und kleinen Kindern aufgeschlossen hat; aus aichem sie allezeit Treffer, als Geld, Rindziehe, Schafe, Geisscn, oder Ziegen, Schieine, Flïgchierk, Waizen, Korn, Gersten, und anderc erdenkliche nothiendige Lebensmittel; ingleichem Häuser, Aecker, Wiesen, Waldungen, wie auch allerley nöthigen Handwerkzeug und sonst Instrumenten, heraus ziehen können; wenn sie nachstehende Nachricht und Vortheile sich zu Gemiith führen, und der angehängten Vorschrift folgen wollen ( $1 ; 67)$.

Engelland-Buch. D.

1772. Gebr. Fiess in Nordamerika, Vermögenssache. p. 493.

1772. Franz Spring, Verlassenschaft, Überlassung an Dan. Kahn, Lancaster, Pa. pp. 499-5I4.

1773. Vermögenswegzug, Erbschaft von Anna Barbara Schmidt, geborene Küntzlin. pp. 55 I-566.

A document conveying power of attorney, printed in German. Michael Schmidt of Boxborough (Philadelphia County), conveys power to Joh. Jakob Pfister of Reading (Berks County).

A document, signed by Rev. A. Helffenstein, testifying that Anna Barbara Schnidtin and her husband Michael Schmidt are members of the Reformed Church. Inheritance divided into shares, one-fifth to Anna Barbara Schmidt; ro per cent. Abzug.

1775. Jakob Plüss. Verlassenschaft in Amerika. p. 587.

I776. Künzli. Schwestern in Amerika. Vermögenssache. pp. 59I-6ro.

Frankreich-Buch. NNN. 231.

I78I, July I 3. "Der französische Gesandte de Polignac antwortet nach W'eisung von Paris der bernischen Regierung ablehnend auf ihre Beschwerde, weil Waren, die bernischen Kaufläuten gehörten, auf englischen Schiffen weggenommen worden waren. Es handelte sich um folgende Fälle.

“ (a) Mr. de La Mothe Piquet (franz. Anführer) hatte englische Schiffe weggenommen, die anch schweizerische Waren fülırten. Der König erklärte diese Waren nicht freigeben zu können, weil keine Ausnahme möglich sei.

“(b) Ein englisches Schiff La Lady war von einem anerikanischen Korsaren genommen und nach linankreich geführt worden. Der König wies daranf hin, in diesen Falle könne er erst recht nichts z.11 Gunsten der bernischen Kanfleute tun."

Frankreich-Buch. NNN. $441-4+8$.

I784. "Der bernische Angehörige Moise Roch von Chatean d'Oex war als Kaufmann in Dienste eines Hambnrger llauses nach San Domingo gekonmen und dort gestorben. Der franz. Fiskus wollte die Erbschaft an sich zichen, weil die Abzugsfreiheit 
zwischen Frankreich und der Schweiz sich nicht auf die Kolonien erstrecke. Auf Beschwerde Berns gab der König aus besonderer Gunst das Erbe aber doch frei."

Procedur zivischen dem Edelgebohrnen Mmzughrn. Fürsprech Wysz, als Vogt des in Virginien verstorbenen Christoph von Grafenrieds hinterlassenen Mannesstammes, gegen den wohledelgebohrnen MnHhrn. Ohmgeldner Ryhiner, als rechtsgeordneten Vogt der Hochgeehrten Frau Landvögtin von Grafenried von Boaden, und allfällige Erben des sel. verstorbenen Hrn. Alt Landvogt von Grafenried von Nydau, gewesenen Herrschafts Herrn auf Worb.

Rechtsfrage: "Ob die Herrschaft Worb, in Kraft des i. J. I683 aufgerichteten Kaufbriefs einer ewigen Substitution unterworfen seye?- - und daher dem Herrn Kläger zu Handen des von Herrn Christoph von Grafenried so in Virginien verstorben, hinterlassenem Mannsstamm, um die in dem Kaufbrief bestimmte Summe der 42,000 Pf. abgetreten werden müsse?" (Printed pamphlet, Bern, I 78 I.)

Note: The Graffenried family, the most numerous among the members of the old Bernese aristocracy, dates back to the thirteenth century. The estate Worb, a few miles distant from the city of Bern, was by will, in 1683 , not permitted to depart from the male heirs of the Graffenried family. In 1780 the widow of Karl Emanuel Graffenried received permission from the government to sell the property, against the claim of the male descendants of Baron Christoph v. Graffenried in America. The lawsuit that arose is described in the records cited above.

The son of the founder of New Bern, also named Christoph Graffenried (b. 1691), remained in America after the departure of his father. The son seems not to have remained long in Newbern, N. C., but he and his descendants lived in other states. Hon. Reese Calhoun de Graffenried (b. 1853, d. 1902) was a member of Congress, I897-1902, from Texas. For the Graffenried manuscripts, descriptive of the New Bern settlement in North Carolina, see below.

Auswanderung. Schriften betreffend die Auswanderung nach Brasilien und Nord Amerika in den Jahren 1810 bis und mit 1821 .

A large volume of letters, reports, and memoranda, mostly on Brazil. No index in back of volume. Several letters complain of large number of paupers at French and American ports, and urge government action to prevent the evil.

AKTEN DES DIPLOMATISCHEN DEPARTEMENTS DES CANTONS BERN. 1831-1846. Ausland. Amerika.

I833. "Landschafts Commission von Ober-Simmenthal bittet Beitrag an die Kosten, welche Reise eines oder mehrerer Männer zur Folge hätten, Colonie zu gründen, Ländereien in Nordamerika auszusuchen. Überhandnehmende Verarmung, Arbeit suchende und keine $z u$ finden." p. 19 f.

Apr. I5. "Ablehnung des Gesuches" . . . Manual des Diplomat. Departements, Nr. 3, Pp. I2I-I 23. 
Aug. 21. "Le département diplomatique" announces that whereas the sum. of $850 \mathrm{fr}$. was necessary heretofore to pass through France to Havre for emigration, now only $300 \mathrm{fr}$., in U. S. paper money or equivalent, are required. Manual, Nr. 4, pp. $283-284$.

I836. "Anf rage wegen Texas, über Auswanderung dahin. Man soll warten, weil Mexico und Texas Krieg führen." Mantual, Nr. 9, p. 65 f.

I846, Jan. 26. Plan of colonies in America. No results.

\section{DIREKTION DES INNERN.}

Auswanderungswesen: Akten der Direktion des Innern in den 4oer und 5oer Jahren. Contain many petitions from criminals for financial assistance to pay expenses of emigration; destination mostly North and South America.

Auswanderungswesen: Ao. 1855-1861. A large volume containing correspondence, agreements, reports, etc. Wholesale deportation of paupers and criminals. In 1855 the sum of 30,000 francs was distributed among the "Gemeinden" for deportation (mostly to America) of paupers and criminals.

Auswanderungs-Steuer-Begehren. 1855 .

Correspondenzen. Vorträge. Thorberg-Sträflinge. Large number of pleas for assistance to emigrate, before or at time of completion of sentence.

Id. Zuchthaus-Sträflinge.

Id. Abgrewiesene Auswanderungs-Stenerbegehren pro I 855 .

\section{JUSTIZ RATH.}

I820. Private advertisement of May's colony on Red River, Hudson's Bay district. Pp. 226-227.

1803-1846. Akten des Justiz Rathes. 119.

I817. Ueber Auswanderungen aus dem Kanton vorzüglich nach Amerika. Great increase of emigration reported. Policy to let the poor go without any restrictions (no loss of home right). Reference to Polizei Verordnung, June II, I804, \$5. Also to Mannrechtsordnung vom Jahre 1765 (restriction on fathers of families, etc.).

Causes of increase of emigration: Overpopulation, and "Verstückelung des Grundeigenthums". Emigration "in einigen Theilen so eingerissen, dass es eine eigentliche Angelegenheit der Regierungen wird, sich damit zu befassen ". Policy to favor enigration in order to relieve poverty and consequent burdens on the community. Passes to be provided without trouble.

Dangers of redemptioner system described. Care of enigrants. means of getting across; fathers of children, how latter are to be provided for.

Zürich also adopts liberal policy toward emigrants. In response to inquiry: " Eine Caution von 15-18 Lalrs. soll hinterlegt werden, welche alsdann dem schweizerischen consul in Ansterlam übersandt wird." Policy of Aargau also liberal. A large number go by way of Havre de Grace, France. Swiss consul there directed to take care of them. 
A reported communication of Gallatin from U. S. Gallatin suggests that consuls look into the matter of the terms on which the ship-owners transport the immigrants. Reported answers of Gallatin, as: "Il n'y a en général point de taxe fixe pour le passage-mais Mr. Gallatin suppose l'on doit demander à peu près 300 francs par tête (alors on a le pain, l'eau et la viande salée) et environ 1200 francs par famille."

Remarks on redemptioners, passports of various tradesmen, etc. Most arrivals are Germans. Government has established a magistracy for protection of arrivals, called: Register of German passengers. For a husband and wife and two children it takes four years to get clear of expenses of passage. A four-page wellwritten letter by Tschann, Paris, July i 5, I 8 I 7 .

I831. Several letters concerning passports, dated I83I and I832. This is a period of increased immigration by way of France and Holland.

Neue Offizielle Gesetzessammlung des Kantons Bern.

I7 5 -I 86 I. Ten printed volumes.

On the subject of emigration there is the following:

Auswanderung: Reisesteuern der Gemeinden an arme Angehörige.

Vorschriften, II. 49; VIII. I45.

Beschlusz über das Auswanderungswesen, Staatsschutz. V. 22.

Dekret (mit Citation darauf bezüglicher Erlasse). VII. 265.

Förmlichkeiten, die vorher zu erfüllen sind. VII. 519.

Amerikanische Inlandfahrbillets, Verbot des Verkaufs. IX. 337.

Pässe, Requisite zur Ausstellung. IV. I 20, I 2 I.

Pässe, Unentgeltliches Visa der französischen Gesandtschaft. VIII. 335 .

Auswanderungs-Agenten. Pflichten, Bürgschaft. VII. 307.

-Commissair. Ermächtigung der Regierung zu Ernennung eines solchen. Dekret VII. 265.

-Steuern. Gegen einseitigen Bürgerrechtsverzicht ist unzulässig. II. 49.

Repertorium der Abschiede der Eidgenössischen Tagsatwungen aus den Jahren $18 I 4-I 848$, bearbeitet von Wilhelm Fetscherin (Bern, I874-I876).

Auswanderungswesen, als Sache der Kantonsregierungen, nicht des Bundes. II. 582,583 .

Auswanderungswesen.

I8I7. "In Folge der furchtbaren Nothstände des Jahres i8I7, Auswanderung bedeutend zugenommen, ohne Erleichterung zu schaffen."

July I7. "Gesandte von Appenzell a. Rh. legte Frage vor, ob das Auswandern in fremde Welttheile zu, begünstigen oder einzuschränken sei. Kanton Glarus mehr als ein "Viertel der ganzen Bevölkerung ohne eigene Nahrungsmittel."

I8I8. "An 29. Juli Gesandte von Luzern zum Schutz der Auswanderer Errichtung schweizerischer Konsulate. 20 Stände beschliessen, Vorort möge nähere Berichte einziehen, über günstige Länder, passende Art der Reise, etc." 
I819, Aug. 9. “Auswanderung Sache der Kantonsregierungen, nicht des Bundes. Nur in seltenen Fällen Bundesunterstützung."

I848, Sept. 19. “ I30 im Grossherzogt. Baden wohnende Schweizer Bittschrift: dass die Tagsatzung die Auswanderungsfrage näher reguliere; zur Berücksichtigung dem Vorort überwiesen."

\section{EHEMALIGES FÜRSTBISCH.-BASELSCHES ARCHIV}

\section{im Staatsarchiv Bern.}

Location: Käfigturm, Bärenplatz. For admission apply at Statsarchiv, Postgasse 72 .

One fascicle on emigration. "Ab- und Freyzug der Obern Aemter des Fürstenthums Basel, auswärts." II. Theil, I730-I79I. Concerning a large number of inhabitants of Erguel, mostly Anabaptists, who propose to depart for America. Bern complains and wishes to prevent it. Discussion as to amount of tax, Io per cent. Abzug. Settlement in Lancaster Co., Pa. Mar. I I, I754. Also correspondence of $1786-1787$.

Landesfürstliche Verordnung, oder Emigranten betreffend. (Auswanderungsverbot.) "Simon Nicolaus, Bischof zu Basel, des Heil. Röm. Reichs Fürst.” May 4, гтフ .

\section{BERN: BUNDESARCHIV.}

Location: Kirchenfeld, Archivstrasse. A new building, completed in I899; modern fire-proof construction. This archive contains only materials beginning with the nineteenth century. It is the archive of the Federal State, founded in 1848 .

Hours: 8 a. m. to 12 m., 2 to 6 p. m. Closed Sundays and holidays.

Bibliography:: Reglement und Plan für das eidgenössische Archiv', nebst dazu gehörender Instruction vom I4. September, I864 (Bern, I 864 ).

Das eidgenössische Archiv, or Bundesarchiv, embraces :

A. Das Helvetische Archiv, including the period 1798-1803.

B. Das Tagsazungsarchiv, for the period $1803-1848$. This section is divided into: Die Mediationsperiode, I803-I8I3; Dic Restaurations- und Regenerationsperiode, 18 I 3-1848.

C. Das nene Bundesarcliv, for the period since Nov. 6, 1848 .

EIDGENÖSSISCHES ARCIIIV, PERIODE $1813-1848$.

AUswärtiges: Nordamerikanische freistaAten.

Ig78. HANIELSKONSULATE.

Schweizerisches Handelskonsulat in New York.

I 823-1832.

Reports of H. C. de Rhan, Swiss consul in New York (whose territory included New England, New York. New Jersey. Pennsylvania, Delaware, all the states to the north of the Ohio River, and Missouri).

$$
1833-18.42 \text {. }
$$

Reports and routine matters, settling of estates, etc. 
I $842-1848$.

L. Ph. de Luze, consul at New York from 1842 .

Reports, routine matters, legacies, passports, immigration statistics at the port of New York, Swiss commerce with the U. S. during the year I 843 .

I843. Answers to questions of the Comités d'Emigrations: For a number of years there has been a decline in the number of Swiss immigrants. In the years 1816-1819 there was a larger number. Most Swiss immigrants come from the canton of Bern, some from the canton of Aargau, also from the cantons Schwyz, Uri, and Unterwalden. They are mostly farmers, some merchants, and watchmakers from Geneva and the mountains of Neuchâtel.

"Je crois que petit à petit ils perdent leur nationalité, et se font dans la nation américaine et leurs descendants finissent souvent par oublier même la langue de leurs parents."

The laws of the U. S. neither favor nor discourage immigrants. Existence of a society in New York for the benefit of Swiss immigrants. Immigrants more easily take fevers and diseases than those acclimated. Those well established in the country exert a strong influence on the coming of friends and relatives from the old country.

"La grande Bretagne, l'Allemagne, principalement l'Allemagne méridionale et les provinces Rhénanes, Prussiennes et Bavaroises et l'Alsace, fournissent les plus grands nombres d'émigrants aux Etats-Unis. Je crois que ce sont les émigrants allemands et suisses qui réussissent généralement le mieux dans ce pays. La France, outre l'Alsace, fournit peu d'émigrants aux Etats-Unis et des pays du nord et du sud de l'Europe nous en voyons arriver fort peu."

Trade reports, passports of 1845 , etc.

Great increase of Swiss immigrants announced in a letter of Sept. 8, I848, from consul de Luze, who suggests the appointment of an able lawyer as general agent at Bern to guard their interests. Many difficulties arising daily from the great increase in the number of immigrants, many of whom are destitute, uninformed, or badly advised.

\section{Handelskonsulat in Alexandria bei Washington.}

I 823-I 848 .

Very elaborate reports by consul Anthony Charles Cazenove.

I843. Very complete answers to questions of the Comités d'Emigrations.

"Les Suisses sont probablement de tous les émigrés, eux qui reste[nt] le plus attachés à leur nationalité, puis les Ecossais, et généralement, les habitants de pays montagneux, mais les pères émigrés ne peuvent pas se cacher que leurs enfants, des deux sexes, n'importe de quel pays ils sont sortis eux-mêmes, montrent une impatience d'être fondus dans la masse du pays; en sorte qu'il est difficile de leur faire bien apprendre et encore plus parler la langue de leurs pères, si elle est autre que la langue anglaise."

Routine matters reported in great detail. 
1979. HANDELSKONSULATE, CONTINUED.

"Handelskonsulat. Korrespondenz der schweizerischen Konsulate in New Orleans, Philadelphia, Madison, Galveston, und Louisville." I829-1 848 .

\section{Handelskonsulat in New Orleans.}

In 1829 a group of about 30 Swiss residing in New Orleans request the Swiss diet to appoint a consul at New Orleans. Theodore Nicolet was appointed first consul in the same year. Henri Chatelanat, secretary, in charge of consulship for 3 years. John A. Merle, second consul, I839-1844.

Papers mostly concerning routine matters of business, reports on inquiries about prisons and conditions, deaths, legacies, etc.

Printed pamphlet: Compte Rendu de l'Assemblée Générale de la Société de Bienfaisance de la Nouvelle-Orléans tenue le I2 mars I838 (I année).

Passports delivered at the Swiss Consulate, 1842. (34 names, about one-half German, the other half French and Italian.)

1843. Answers to questions by the committee on emigrations of the Society of Public Utility of the cantons of Vaud and Geneva.

"Les émigrants suisses qui arrivent ici [New Orleans] ne restent que le temps de sortir du navire qui les amène d'Europe pour se mettre à bord des bateaux à vapeur qui les conduisent dans l'Ouest. Ils ne se présentent ni au consulat, ni à la mairie, n'ayant aucune formalité à remplir, pas plus à leur arrivé qu'à leur départ. Ils viennent et vont sans que personne s'enquière ou connaisse leur nationalité ou leur nombre, et comme la plupart sont des cantons. allemands et italiens, ils passent généralement pour Allemands ou Italiens, de mème que le peu de Suisses qui sont des cantons français sont généralement pris pour Français.

"Ils s'adonnent surtout à l'agriculture, et presque toujours se fondent dans la nation." (The latter in answer to the question: "Tendent ils à conserver leur nationalité ou à se fondre dans la nation?")

"Les émigrés prospèrent très généralement.

"Les lois des Etats-Unis protègent l'émigrant autant qu'un national, et comme dans ce pays on a toujours besoin de bras, les émigrants sont bien acceuillis quand ils sont industrieux.

"Question: Quelle condition ou garantie le gouvernement exige-t-il des émigrants à leur arrivée? Réponse: Aucunes.

"Cenx qui ont des métiers les suivent, ceux qui n'en ont pas travaillent la terre ou se font manœuvres. Avec de faibles resources ils penvent acheter un morceau de terre, des outils, et accumuler par la suite des capitaux considérables. Ils trouvent dans presques toutes les industries un bon intérêt. Ceux sans moyens se mettent charreticrs, laboureurs, manouvres, etc.

"Question: Comment la propriété foncière est-elle acquise? Réponse: Par achat.

"Les émigrants peuvent acheter comme tont citoyen de qui bon leur semble.

"Le prix des terres du gouvernement qui sont naturellement vierges est de \$1.25 l'acre. Les cultivées ou défrichées varient de \$2.50 à $\$ 7.00$, selon le phuts ou moins déloignement des points cent raux. 
"Les cultures les plus productives sont celles du coton, sucre, tabac, blé, mais, chanvre, et gros légumes.-Quelques Suisses avaient entrepris la vigne à Vevay [Indiana], mais le climat s'y est montré peu propice, et ils en ont presque entièrement abandonné la culture.

"Toutes les religions sans exception aucune sont tolérées aux EtatsUnis et jamais pays n'a offert une aussi grande variété de sectes. La seule qui n'y existe pas, est celle fondée sur l'Alcoran.

“Le climat à la Nouvelle-Orléans n'est pas sain, mais dans l'intérieur du pays où se rendent les émigrants, latitude de 35 à 46 , il y a parfaite salubrité.

“Toutes les professions sont bien rétribuées pour le travailleur consciencieux.

"Question: Comment les Suisses établis dans le pays ont-ils été poussés par cette émigration? (Par publications, emboucheurs, etc.?)

"Réponse: Rien à dire à ce sujet.

"Pour tout individu qui se trouve trop serré dans la vieille Europe, qui ne peut y gagner que difficilement sa vie, ce pays-ci offre d'immenses régions où certe il se trouvera au large et son travail sera bien rémunéré.

"La meilleure époque de l'année pour arriver ici et repartir pour l'intérieur, est le printemps. Plus tard que juin il y a danger de fièvres malignes, fièvre jaune et al. De décembre à juin il n'y rien à craindre.

"Question: Si vous désapprouvez l'émigration, quels moyens croyezvous les plus propres pour éclairer les émigrants et y mettre un terme?

"Réponse: Rien à répondre, si ce n'est que tout homme qui est heureux dans son pays a toujours tort de le quitter.

"Toutes les nations d'Europe-les Allemands, Irlandais, Fránçais, Suisses forment le plus grand nombre [des émigrants à New Orleans], et tous réussissent au moins à se procurer le nécessaire et quelquefois arriver à la fortune quand ils ont santé, industrie, économie et capacité."

List of passports, I843-I848.

Explanation of purpose of "Die Deutsche Gesellschaft und deren Agentur" (foundation for the benefit and assistance of emigrants). Letter signed by William Vogel, president.

\section{Handelskonsulat in Philadelphia.}

$$
\text { I842-I } 847 \text {. }
$$

Exequatur of consul Johann Georg Syz, who was followed by Jean Syz, I $845-1847$.

I 844. Answers to questions of the Comités d'Émigrations des Sociétés d'Utilité Publique des Cantons de Vaud et de Genève.

"D'après tous les renseignements que j'ai pu obtenir sur ce sujet, je suis d'opinion qu'elles [nombre des familles] ont été plutôt réduites qu'augmentées et que le nombre sorti de la Suisse française compare avantageusenent avec celui de la Suisse allemande, c'est-àdire que comme la population de cette dernière est plus nombreuse en Suisse, il en résulte que le nombre des émigrants de la Suisse 
allemande arrivé aux Etats-Unis, est dans la mème proportion plus numérique."

Swiss emigrants are declared to be for the most part agricultural, preferring the country and village to the city; their success depends upon themselves. "Se fondre dans la nation."

Treatise on the potato disease. Two printed pamphlets by Thomas Croft, Wilkesbarre, $\mathrm{Pa}$.

\section{Handelskonsulat in Madison, Indiana.}

1843 .

Consul A. Ott. Territory: Ohio, Indiana, Kentucky, Illinois, Michigan, and territories of Wisconsin and Iowa.

Answers to questions of the Comités d'Emigrations: Swiss immigrations not large in this territory. Oldest settlement at Vevay. In general most Swiss emigrants from canton of Bern. "Généralement ils tendent à maintenir leur nationalité ; même leurs descendants qui sont nés dans ce pays-retiennent leur caractère national et rarement un descendant Suisse se fondra aisement dans la nation." ${ }^{1}$

Comments on laws favoring immigrants, rapid naturalization, etc.

Letters written home by successful immigrants have had a stimulating effect upon immigration.

“Les Royaumes de Prusse, Bavière, Würtemberg, Hanover, Angleterre, Ecosse, Irlande, IVales, les Duchés de Hesse-Darmstadt, HesseKassel et Baden "-ont le plus grand nombre d'émigrants. "Un nombre très limité d'Hollande, Belgique, Italie, France, et l'Espagne se trouve dans nos états." "Parmi la masse des émigrants les plus destitués sont les Irlandois, les Badlois, et les Espagnols, moins les autres plus actifs et moins indolents."

\section{Schweizerisches Handelskonsulat in Galveston.}

$$
\text { I } 846 .
$$

T. C. Kuhn appointed consul of the Swiss Confederation for the state of Texas.

Application of 15 Swiss citizens for consul in Galveston, Mar. 3, I845.

Schweizerisches Handelskonsulat in Louisville.

$$
1845-1848 \text {. }
$$

N. J. Basler succeeds consul Ott (after the latter's death), who was located at Madison, Ind.

Clippings from Cincinnati Volksblatt, i 846.

Routine matters.

2123. verHANDLUNGeN AUSẄ̈rtiger STAATEN MIT DEN BUNDESHEHÖRDEN.

Nordamerika. Korrespondenz des Generalkonsuls der Vereinigten Staaten von Nordamerika in der Schweiz, $1830-1848$.

Exequatur of John G. Boker, consul general.

Appointments of consuls in various places in Switzerland.

${ }^{2}$ This statement is contradictory to the reports from other localities. 
Gerard Koster's defalcations ( 1844 ) instrumental in advancing negotiation in matter of extradition treaty.

Printed pamphlet on Oregon question; routine matters.

\section{4.}

Akten betreffend die Unterhandlung eines Freizügigkeitsvertrags und eines Vertrags über Auslieferung der Verbrecher zwischen der Schweiz und den nordamerikanischen Freistaaten. I834-1848.

2125. FREIZÜGIGKEITSVERTRAG.

Treaty rejected by Senate June I I, 1836. Taken up again, and carried May I8, I847.

Vertrag über Auslieferung der Verbrecher (correspondence). I844-1847.

The diplomatic correspondence after 1848 is not accessible.

\section{EIDGENÖSSISCHES ARCHIV, I848-}

Akten des Bundesrats Über Auswanderung.

III. ABTEILUNG : AUSWANDERUNGSWESEN.

Fasz. 1. Verhandlungen der Bundesbehörden über das Auswanderungswesen. (I. Bd.)

Fasz. 2. Auswanderungswesen im Allgemeinen. I848-1853.

Fasz. 3. Auswanderungswesen im Allgemeinen. I854-1870.

Fasz. 4. Gesetzliche Bestimmungen des Auslandes über das Auswanderungswesen.

Gesetzliche Bestimmungen der Kantone über das Auswanderungswesen. Gesetzliche und reglementarische Bestimmungen der Kantone über die Auswanderungsagenturen und daherige Konzessionen.

Auskunft über das schweizerische Auswanderungswesen an das Ausland. Massnahmen zum Schutze von solchen, welche ohne bestimmtes Ziel auswandern.

Kolonieprojekt Joos [Costa Rica, I859-1863].

Petition des schweizerischen Auswanderungsvereins. I867.

Auswanderungsstatistik.

Unterstützung der Auswanderungs Zeitung von Jäggi-Gyger in Bern. Verschiedenes.

Ordnung der Kautionen.

Fasz. 5. Bundesgesetze betr. den Betrieb von Auswanderungsagenturen vom 23. Dezember 1880 und 22. März I888. Schweizerisches Auswanderungs Bureau. Vollziehung und Interpretation. Patentierung von Auswanderungsagenturen.

Fasz. 6. Organisation und Personal. Enquête über das schweizerische Auswanderungswesen. 1886 .

Fasz. 7. Klagen und Beschwerden gegen und von Auswanderungs Agenturen.

Auswanderung nach den Vereinigten Staaten von Nordamerika.

Fasz. 1. Allgemeines, 1852 bis 18 -

Fasz. 2. Californien.

Untergang des Schiffes Royal Charter, 1 859 , und des William Nelson, 1865 .

Verkauf von Inlandfahrbillets. 
Beschwerde der Regierung des Kantons Aargau gegen den nordamerikanischen Konsul Wolff in Basel wegen Erschwerung der Auswanderung.

Landschenkungen in Florida und Texas.

Kolonisationsprojekt Plümacher in Tennessee.

Beschwerde der Auswanderungs Agentur Stössel und Cie. in Basel, gegen den schweizerischen Konsul Wanner in Havre.

Kolonieunternehmung in West Virginien.

Kolonie Bernstadt in Kentucky.

Fasz. 10. Auswanderung nach den Vereinigten Staaten von Nordamerika.

Abschiebungen von Mittellosen, Krüppeln, und Verbrechern.

Fasz. 11. Auswanderung nach Zentral- und Südamerika, Magellenstrasse, und Fetuerlandsinseln, und projektierte Gründung einer Kolonic daselbst, Mexiko, Neu Britannien (Port Bretton) in Stillen Ozean, Uruguay, Venezuela, etc.

Fasz. 12. Auswanderung nach Argentinien.

Fasz. 13, 14, 15. Auswanderung nach Brasilien. I850-1860. Mission Tschudi. Prozess Vergueiro.

Fasz. 16. Auswanderung nach Brasilien. I870.

Fasz. 17. Auswanderung nach andern Ländern.

Frankreich und französische Kolonien.

Russland, Ungarn, Alexandrien in Aegypten.

Kleinasien, Ostindien, Australien.

The Eidgenössisches Archiv contains sets of three printed series which, though also to be found elsewhere, and, for instance, in some American libraries, may well be mentioned here, because they contain much material relating to Swiss relations to America. These are:

I. The Amtliche Sammlung der Bundesgesetze und Verordnungen der Schweizerischen Eidgcnosscnschaft (1848-) ), containing treaties and federal laws and decrees, and of course all those respecting America and emigration.

2. The weekly Bundesblatt dor Schwicizerischen Eidgenossenschaft (the French edition is entitled Feuille Fédérale de la Confédération Suisse, see above, p. 7), which, from 1848 down, has contained many reports and other documents on these subjects, such as diplonlatic papers, reports of Swiss consuls in America, and reports on Swiss emigration, monthly from I887 on, less frequent before that date. For references in detail, to both collections. for 1874-1893, see F. Wilmer, Alphabetisches Sachregister zum Bundesblatt und zur Amtlichen Sammlung der Bundesgesetze und Verordnungen der Schweizerischen Eidgenossenschaft, Jahrg. I874-1893, pp. 37-39.

3. Berichte des Schweizcrischen Bundesrates an dic Bundesiersammlung iiber seine Geschäftsfïhrung vom Jahre -(I848- ). Reports of the executive to the legislature, continuing to the present time. Each volume is furnished with an adequate index.

\section{BERN: EIDGENÖSSISCHES AUSWANDERUNGSAMT.}

\section{Location: Bollwerk 27, Bern.}

This federal emigration bureau was founded in 1880 , by a law of the Bundesrat passed Dec. 24, 1880. The chief business of the federal bureau is the regulation and watching of the activities of the various enigration bureaus, required in every case to procure a license; in addition to this to keep accurate statistics of emigration, and to render service to prospective 
emigrants by furnishing accurate and useful information concerning conditions and prospects in foreign countries.

The Auswanderungsant contains an extensive archive, including reports from the numerous Swiss emigration bureaus, statistics in detail, acta concerning various Swiss colonies in foreign countries, etc. Since I88I annual reports have been published on the emigration from each canton, Die überseeische Auscuanderung aus der Schzveiz, the destination also being tabulated in these thoroughgoing reports. For a bibliography of Swiss emigration, see above, pp. 6-7.

The following are Swiss settlements, at least in origin, upon which there are (incomplete) acta in the archives of the Auswanderungsamt. The bureau acknowledges a debt to the New-Yorker Staatszeitung in compiling this list:

Alabama:

Arkansas:

Dakota:

Florida:

Georgia:

Illinois:

Indiana:

Iowa:

Kansas:

Kentucky:

Michigan:

Minnesota:

Missouri:

Nebraska:
I. Cullman, Cullman Co.

2. Newbern, Hale Co.

3. Pocahontas, Randolph Co.

4. Seelisberg, Spink Co.

5. Monticello, Jefferson Co.

6. New Switzerland, Habersham Co.

7. Stuckey, Montgomery Co.

8. Eberle, Effingham Co.

9. Highland, Madison Co.

Io. Newberne, Jersey Co.

I I. Vevay, Switzerland Co.

I2. Tell City, Perry Co.

13. St. Meinrad (Einsiedeln), Spencer Co.

I4. Switz City, Greene Co.

I5. Bremen, Marshall Co.

I6. Berne, Adams Co.

I7. Newbern, Bartholomew Co.

I8. Luzerne, Benton Co.

19. Newbern, Marion Co.

20. Zwingle, Dubuque Co.

21. New Basel, Dickinson Co.

22. Enterprise, Dickinson Co.

23. Newbern, Dickinson Co.

24. Zürich, Rooks Co.

25. Bernstadt, Laurel Co.

26. White Lily, Laurel Co.

27. Pine Hill-Salzburg, Rockcastle Co.

28. Grünheim, Lincoln Co.

29. Highland, Lincoln Co.

3o. Berne, Huron Co.

31. Luzerne, Oscoda Co.

32. Newbern, Dodge Co.

33. Helvetia, Carver Co.

34. New Engelberg, Nodaway Co. .

35. Coppeln, St. Charles Co.

36. Swiss, Gasconade Co.

-. (Swiss Colony Ozark)

37. Zürich, Hall Co.

38. Grütli, Platte Co.

-. (Steinauer, Pawnee Co.) 
North Carolina: 39. Ridgeway, Warren Co.

40. Asheville, Buncombe Co.

4r. Newbern, Craven Co.

New York: $\quad 42$. Berne, Albany Co.

43. Zürich, Wayne Co.

Ohio: $\quad 45$. Switzer, Monroe Co.

46. Basil, Fairfield Co.

47. Tell Cottage, Hamilton Co.

48. Berne, Noble Co.

49. Geneva, Ashtabula Co.

Oregon: 50. Cedar Mill, Washington Co.

Pennsylvania: 52. Biehl, Union Co.

53. Brunnerville, Lancaster Co.

54. Benzinger, Elk Co.

55. Berne, Berks Co.

56. Geneva, Crawford Co.

57. Baumgardner, Lancaster Co.

58. Luzerne, Luzerne Co.

59. Tell, Huntingdon Co.

6o. Stauffer, Westmoreland Co.

61. Brodbecks, York Co.

62. Eberly's Mill, Cumberland Co.

63. Swissvale, Allegheny Co.

Tennessee: $\quad 64$. Warburg, Morgan Co.

65. Winchester, Franklin Co.

66. Grütli, Grundy Co.

67. South Pittsburg, Marion Co.

68. Newbern, Dyer Co.

Texas: $\quad 69$. New Baden, Robertson Co.

7o. Seguin, Guadalupe Co.

7I. Swiss Alp, Fayette Co.

72. Cheesland, Angelina Co.

Virginia: $\quad$ 73. Newbern, Pulaski Co.

West Virginia: 74. Helvetia, Randolph Co.

75. Alpena, Randolphi Co.

76 . Kendalia, Kanawha Co.

77. New St. Gallen, Webster Co.

78. Cotton Hill, Fayette Co.

Wisconsin: 79. New Glarus, Green Co.

8o. New liln, Winnebago Co.

8r. Interlaken, Price Co.

82. Burklardt, Saint Croix Co.

83. llelvetia, Waupaca Co.

BERN: STADTBIBLIOTHEK.

Location: Old, spacious building, entrance on the Kesslergasse, not far from the cathedral.

Hours: 9 a. m. to 12111 ; 2 to 7 p. m.

Catalogue: Katalog der Handschriften zur Schreizergeschichte der Stadtbibliothek Born (Bern, i895). 


\section{Manuscripts relating to American History.}

MSS. Hist. Helv., III. 81 (4) : "Momente aus der Geschichte von Amerika. Auszüge aus Bancroft." (A chronological table derived from Bancroft's History of the United States.)

MSS. Hist. Helv., III. 245 (92) : "Aus Bancrofts Geschichte von Nordamerika. Auszug aus dem 24. Kapitel."

MSS. Hist. Helv., VII. 113 (52): "Wunderbare Nachricht aus Amerika. Stück einer geographischen Beschreibung.” Pp. 393-399. (Descriptions of some fabulous beasts in America.) Aus Hallers Sammlung (son of the great anatomist of Bern).

MSS. Hist. Helv., X. 152 : Franz Ludwig Michels Reisebeschreibung, I7OII702. A quarto volume, bound in half-vellum, with 73 numbered leaves, some armorial drawings, and several illustrations of remarkable interest. The manuscript contains: ff. I-6I, narrative of voyage to America, then of travels, chiefly in Virginia; f. 63 recto, pen-and-ink drawing, "Collegium zu Willemsburg stehend, worin der Gouverneur seine Wohnung hat ", i. $є$., the first building of the College of William and Mary, planned by Wren, begun in 1694 , burned in 1705 , of which, as of the two other buildings mentioned below, no other picture is known; also, a typical "Kaufmanshausz", "Ein Baurnhausz", "Das Fundament des Rathauses", "Das neuwe Rathausz so man dis Jahr 1702 angefangen zu bauen ", $i$. e., the half-finished Capitol of Virginia, erected at this time and standing till $\mathrm{I} 746$, and "Die Kirche so $z \mathrm{u}$ Willemsburg stehet", i. e., Bruton Parish Church, finished in I683, and replaced by the present structure in $1715 ;^{1}$ f. 64 recto, a waterspout, three Indians and their house; f. 64 verso, a rude map of Chesapeake Bay; ff. 65-70, two or three letters from America, preserved by Michel's brother, from whom the book comes down ; ff. 72, 73, George Ritter to Queen Anne. The following note shows that Michel made a second trip to Carolina before Graffenried: "Mein elterer Bruder Frantz Ludwig ist den I4. Februar I703 wieder von Bern nach Amerika verreiset, und den I6. Jan. I704 glücklich aldort wieder angelanget. Wie aus seinem Schreiben zuersehen." Much of the text of this manuscript, though with paraphrasing in parts, and with explanations instead of text in parts, is given in an article by J. H. Graf, entitled "Franz Ludwig Michel von Bern und seine ersten Reisen nach Amerika I70r-I704; ein Beitrag zur Vorgeschichte der Gründung von New-Berne ", in the Neues Berner Taschenbuch for I898, pp. 59-I44. This printed narrative is of about twothirds the length of the original journal.

MSS. Hist. Helv., XI. 8. Folio volume. Among the contents are, (IO) "Auswanderungen":

(a.) “Colonie Brandenburg (Preussen),' I704:1707; Hrn. A. M. d'Arnay's nach St. Domingo; von bernischen Täuffern nach Amerika, I7IO-I7II." $7 \mathrm{ff}$.

\footnotetext{
${ }^{1}$ Photographs of these drawings, of unique interest, are in the possession of Dr. J. F. Jameson. A translation of Michel's journal into English by Professor William J. Hinke appears in the Virginia Magazine of History, beginning in January, I9I6.
} 
(c.) “Relation de l'Établissement d'une Colonie française réfugiée en Pensilvanie." [This is a letter of I700, written not from Pennsylvania but from New Oxford, Mass., by a minister established there (Rev. Jacques Laborie) to the widow of a French minister in London, Madame Favin. J. F. J.]

Lettre de Mr. Michel de Carolina, I\%O3 (French), und vom nemlichen an Herrn Ochs ans Maryland, von I7O4 (German). The latter also found in the manuscript Hist. Helv., X. I 52.

Auswanderung des Herrn G. Ritter, Spezierer von Bern, 1705-1 jo8, various writings. $\mathrm{I} 2 \mathrm{ff}$.

Ibid., (15). Auswanderungen, aus dem Kanton Bern. A general account, the beginning of which is printed in the Berner Monatschrift, p. $77 \mathrm{ff}$. (fragment), and which is here continued, I6921805. I2 ff. This is for the most part an abstract based on the materials found in the "Mandatenbïcher" of Bern. (See record of this material under "Staatsarchiv" of Bern.)

MSS. Hist. Helv., XIV. 116. A quarto volnme, rot pp., half-vellum binding, nineteenth century.

(ıо.) Schweizerische Hülfsgesellschaften im Ausland, Nordamerika und Auswanderung, pp. 7o-88. (One interesting point brought out: Proletariat of Europe now entering America, too great leniency; no restriction. "Trop de bonté est bêtise!")

The Stadtbibliothek of Bern (located on the Kesslergasse), and the Schweizerische Landesbibliothek (located in the same building with the Bundesarchiv, i.e., Archivstrasse, Kirchenfeld), eacl contains a collection of printed books descriptive of American colonies, and of travels in America, some offering advice and information to immigrants. The rarest prints, those of the eighteenth century, are nowhere grouped together, and are mostly scattered in private libraries.

\section{The Graffenried Manuschipts.}

A series of manuscripts of which Christoph von Graffenried, the founder of the colony of New Bern, N. C., was the author. Four of them (A, B, C, D) describe his successes and mishaps in America, two (E, F) are autobiographical, relating to other periods of their author's life."

A.

This manuscript was written in the French language, between 1710 and 1714. It consists of 105 folio pages, and is preserved in the library of the city of Yverdun (No. 31 IO). It contains a series of detached chapters or adventures, written by various hands, but corrected in the handwriting of Graffenried. A good description of the manuscript is to be found in the Revue Historique Vaudoisc, reprinted under the title New Bcrne, by John Landry (Lausanne, 1907). A translation of this mannscript appeatred in the Colonial Records of North Carolina (1886), I. 905-y85.

\footnotetext{
${ }^{1}$ For a fuller account of these manuscripts, including my comparison of their merits, sec German American Amals, n. s., XI. 205-210 (1913). Of the manuscripts named above, $\mathrm{B}$ and $\mathrm{C}$ are printed for the first time, in the original languages, in German Anerican Anuals, n. s., XI. 210-302; and XII. 63-190.
} 
B.

Written in the German language, about the same time as manuscript A, though probably begun later; preserved in the private library of W. F. von Miilinen, ${ }^{1}$ in the city of Bern. This manuscript consists of 154 pages, as follows :

(a) A large map of the colony of New Bern, N. C.

(b) Letter descriptive of Carolina, dated: Carolina, Neu Bern d. 6 May I7II. Also bills of expenditures. pp. I-20.

(c) Handlungs Contract zw. Michel, Graffenried, und Georg Ritter und Co. May I8, I7Io. pp. 2I-27.

(d) Memorial über Eint und andere Puncten Carolina betreffend, aus dem Englischen übersetzt. pp. 28-47.

(e) Copia unterschiedlicher Briefen ausz Nord Carolina. pp. 47-67.

(f) Vorbericht und Relation meines amerikanischen Unterfangens. Description of Graffenried's adventures in America, settlement of New Bern, capture by the Indians, etc., as in manuscript A. pp. 68-I 54 .

C.

Written in the French language, about I7I6; a revision of manuscript A, surpassing it in style and in the order of arrangement of events, and containing a large number of additions in material. This manuscript is preserved in the private library of W. F. von Mülinen, in Bern. It was written in Graffenried's own hand." Title: "Relation du Voyage d'Amérique que le B. de Graffenried a fait, en y amenant une Colonie Palatine et Suisse; et son Retour en Europe".

\section{D.}

A small manuscript written in French, Io folio pages; preserved in the state archive of the city of Bern. The titles describe the contents: (a) "Copie d'une Lettre écrite sous date New-Berne en North Caroline le 4ème Janvier I7I2 par le Baron de Graffenried, Gouverneur des Palatins en North Caroline, à Msr. Ed. Hyde, Gouverneur des Colonies et Provinces de la North Caroline"; (b) "Copie d'un Traité conclu sous date du mois d'Octobre I7II entre le Baron de Graffenried et les Indiens de Tuscaroro", etc., etc.; (c) "Copie d'une Lettre écrite sous date 8ème Octobre I 7I I par Alexandre Spotwood, Lieutenant Gouverneur et Commandant en Chef des Colonies et Provinces de Virginie, à la Nation des Indiens qui tiennent le Baron de Graffenried prisonnier".

${ }^{1}$ W. F. von Mülinen, librarian of the city library of Bern, has written the authoritative account of the life and career of Christoph von Graffenried, based throughout on the original manuscript material given him by the Graffenried family. Cf.: Christoph von Graffenricd, Landgraf von Carolina, Grïnder von New-Bern, zumeist nach Familienpapieren und Copien seiner amtlichen Berichte, von Wolfgang Friedrich von Mülinen, Neujahrsblatt hrg. v. Historischen Verein des Kantons Bern für I897 (Bern, I896). A trustworthy and very readable account in English of Graffenried's settlement of New Bern has appeared in the Jahrbuch der Deutsch-Amerikanischen Historischen Gesellschaft von lllinois, Jahrgang I9I2, by Vincent H. Todd: "Christoph von Graffenried and the Founding of New Bern, N. C."

${ }^{2}$ For the proof of this statement, see German American Annals, XI. 205 f. The C manuscript is printed in full in the same journal, XII. 63-190. 
E.

Written in German; prescrved in the private library of W. F. von Mïlinen, Bern. Title: "Fataliteten Hrn. v. Graffenriedt Alt Landvogt v. Yverdun und Herrschaft Herrn zu Worb, in seinen jüngeren Jahren ". I. Teil, I 49 pp.; II. Teil, r23 pp. This is the story told by Graffenried, after 1716, of his early experiences and escapades in England, France, and at Yverdun.

\section{F.}

A series of family letters, written partly in French, partly in German, many of them addressed to the writer's father. Anton Graffenried. These letters also belong to the private library of W. F. von Miilinen, Bern.

\section{BERN: ARCHIVE OF THE UNITED STATES LEGATION.}

Location: Hirschengraben 6.

Hours: By appointment, archive open to scientific investigation only.

The most interesting portion of the diplomatic correspondence is that concerning forced emigration, $i$. e., the deportation of patpers and criminals, and that concerning the Mormon missionaries seeking Swiss colonists. This material may also be found in Washington, D. C., in the archives of the Department of State.

Under the former head, the following dispatches are noted:

No. 108. Theodore S. Fay (first minister to Switzerland, appointed 1853 ). Protest against shipment of four Unterwalders to America : shown not to be deported criminals, and protest withdrawn. Suggestion of agreement between U. S. and European countrics on matter of deportation. Feb. 22, 1855 .

III. Protest against shipment of paupers and criminals produced considerable attention on the part of the public press of Switzerland.

120. Abuses in emigration looked into by cantons.

226. Circular No. 17 on emigration. Mar. 3, 1857.

243. Emigration abuses. Junc I I, I857.

247. June 23,1857 .

248. July 7,1857 .

25I. July I7, I 857 .

258. Correspondence on emigration. Concerning Castle Garden. Oct. IO, 1857 .

269. Since 1834 the annual emigration from Switzerland has averaged 6000-7000. Total to U.S. since I834, 168,000. During last three years greatest number from Solothurn, Aargau, Glarus, and Schafflausen. Thirteen licensed emigration bureaus, of which two occupy themselves with South Anerica. Havre is the port usually proposed. Attempt to prevent inland booking. Dec. 15, 1857 .

341. Mar. 14, 1859 .

25. Oct. 25,1862 .

7. Feb. 17,1866 .

36. Shipment of criminals. Aug. 13, 1867.

63. Aug. 1, 1868.

71. Oct. 7, 1868 .

83. Ja11. 22, 1872 . 
78. June 3,1878 .

8I. June IO, I878.

82. June 16, I 878 .

83. June I6, I878.

84. June I8, I878.

IоI. Sept. 20, I878.

I08. Sept. 23 , I878.

I6o. Mar. ıо, I879.

I8o. May 26, I879.

I8I. May 26, I879.

20I. July 24, I 879 .

202. July 30, I 879 .

204. Aug. I6, I879.

226. Nov. I5, 1879.

246. Feb. I0, I880.

26I. Apr. I6, I880.

265. Apr. 30, i880.

266. May 5, I88o.

269. May I I, I 880.

297. Proposed Swiss federal law concerning emigration agencies. Discussion in the National Council; its adoption and modification by that body. Strong opposition. The clause forbidding the deportation of pardoned criminals struck out in opposition to the Federal Council. Postponement of its consideration by the Council of States. Necessity of our legislation (Nicholas Fish, minister). Sept. I8, I880.

298. Colonization scheme of the Grütli Verein. Their petition is referred without comment to the Federal Council. Sept. I8, I880.

300. Swiss law respecting emigration agencies. Sept. 24, 1880.

319. Dec. 9 , I 880 .

32I. Dec. I5, I880.

326. Jan. IO, I88I.

328. Jan. IO, I88I.

330. Jan. I $5, \mathrm{I} 88 \mathrm{I}$.

33I. Jan. 20, I88I.

332, 333. Jan. 24, I88I.

334, 335. Jan. 26, I88I.

338. Feb. I0, I88I.

343. Feb. I6, I88I.

37I. Mar. 20, I88I.

372, 373. Mar. 23, I881.

375. Mar. 25, I88I.

376. Mar. 26, I88I.

377. Mar. 27, I88I.

383. Mar. 31, I88I.

384. Apr. 4, I88I.

385. Apr. 5, I881.

386. The return of several of criminal class by the U. S. announced to the federal government. Comments of the Swiss press thereon. Apr. 8, I88I. 
387. Quotation from an article in the Journal de Genive, defending the position, that "the U. S. is the reformatory (Botany Bay) of Europe, and comparable to the British penal colonies". "It will be news to some portions of our press, that their Genevan colleague considers that Switzerland has a vested interest in the U.S. as a reformatory for Swiss delinquents" (Nicholas Fish) Apr. 9, I88I.

391. Apr. I6, I88I.

392, 394. Apr. I8, I88 I.

398. Apr. 28, I88I.

400. Apr. 29, I88I.

403. May 8, I88I.

409. May I3, I88I.

496. July I 2, I 881 .

68. July 5, I883.

183. Nov. 26,1884 .

188. Dec. I8, I884.

254. Jan. 24, I889.

Ior. Feb. 3, I895.

Io. Mar. 6, I896.

After this date there appear no more cases of assisted or forced emigration. Secondly, as to Mormon emigration. Mormon preachers visited Swiss cantons with the purpose of soliciting emigrants, mainly women. Instruction No. 107 received from U. S., Wm. M. Evarts to Nicholas Fish, Washington, Aug. 9 (received Aug. 28), I879: wishes that the government of Switzerland shall take measures such as to prevent Mormon emigration; encouragement of bigamy thereby, against laws of U.S. Dispatches:

No. 213. Aug. 29, I879.

220. Oct. 21,1879 .

229. Nov. 27, 1879.

262. Apr. I6, I880.

319. Dec. 9 , I880.

I3. May I3, I 882 .

225. May 8, 1885 .

6I. May 25, I 886 .

66. June 23, I 886 .

I68. Oct. $24,1887$. 


\section{CANTON LUZERN.}

\section{LUZERN：STAATSARCHIV.}

Location: In the Jesuitenkollegium (1894), Bahnhofstrasse I8.

Hours: 8 a. m. to $12 \mathrm{~m}$; 2 to $6 \mathrm{p} . \mathrm{m}$. In winter the archive closes earlier. Permission to use the archive is given on application to the Regierungsrat.

\section{Acta.}

1793, Nov. 17. " Dekret des Nationalkonvents, die Neutralität zusichernd der Eidgenossenschaft und Amerika."

Fach II. Kreisschreiben des schweizerischen Bundesrats an sämtliche eidgenöss. Stände. (1848-1902.) Ausland. III. Amerika. A. I848-.

I859. "Über den zum Vice-Consul vorgeschlagenen John [Joseph] Suppiger von Sursee in Highland [Illinois]. Schultheiss u. Regierungs Rath des Kantons Luzern an das Titl. Schweiz. Handels u. Zolldepart. in Bern, und das Stadthalteramt Sursee an d. Eidgenöss. Depart. d. Äussern d. Kantons Luzern.”

Contains two interesting letters of recommendation respecting Joseph Suppiger, telling of his affairs, $e . g$.,

$\S 4$. “Im Jahre 1830 wanderte er mit seinem Vater, der ein Vermögen von 30,000 Gl. mitnahm, aus, baute in Highland eine Dampfmühle, welche er mit seinen Geschwisterkindern betreibt. Aus einem [mir] vorgewiesenen Briefe ergiebt sich, dass er erst das verflossene Jahr an derselben Verbesserungen im Bauwerte von 20,000 Dollars vornahm."

$\S 5$. "Er wurde daselbst zum Friedensrichter erwählt, und soll diese Stelle freiwillig abgegeben haben."

§6. "Gegen die Familie Köpfli, mit denen er verwandt ist, und welche ihr Vermögen durch Landankauf und Wiederverkauf bedeutend vergrössert, wurden vor mehreren Jahren Klagen laut, die sich darauf mögen bezogen haben, dass sie vielleicht die Einwanderung zu hoch anpriesen, um Land verkaufen zu können, und dieses theurer verkauften, als sie den Wert in einem gedruckten Buche angaben." (See titles of works below, in Bürgerbibliothek.)

§8. "Ich kenne in Highland noch mehrere Luzerner, worunter viele Sursee'r, aber keinen dem Herrn Suppiger für die Stelle vorzuziehen; er gilt für den geachtetsten Mann in Highland."

I86I, May 20. "Todesanzeige des Joseph Suppiger, Vize-Konsul in Highland."

I865, May 4. "Schreiben an den Schweiz. Bundesrat mit Beileidsbezeugung in Betreff der Ermordung des Präsidenten Abraham Lincoln."

I882, May 2 and 6. "Oberst Emil Frei in Arlesheim, Kanton Baselland, Ernennung zum ausserordentlichen Gesandten und Bevollmächtigten Minister der Schweiz. Eidgenossenschaft bei der Regierung der Vereinigten Staaten in Washington." 
Fach II., Fascikel 1. Amerika. I830-. Gesandte auswärtiger Mächte und Staaten.

Nordamerika: Freistaaten, Mexico. Kolumbia.

Freistaaten: Consulate in der Schweiz. I830-I846.

Schweiz. Consulate in d. Ver. Staaten. I823.

Auslieferungsvertrag. 1845 .

Freizïgigkeitsvertrag. $\quad$ I 836

Erbwesen. 1824.
Andere Kreisschreiben. $\quad{ }_{1} 86$.

Mexico. Kreisschreiben.

Kolumbia. Anerkennung der Republik. 1822.

Südamerika: Brasilien.

Rio de Janeiro.

Pernambuk.

Fach III. Ausland III. Amerika. A.

"Geschenk von Militärpapieren (Bürgerkrieg, I86I-I865) durch Casimir Muri ", (Gotthardbahn Beamter). Nov. 6, ig07.

"Kreisschreiben betr. Ausbezahlung von Nachtragsvergütungen an gewesene Soldaten der Union oder deren Erben."

"Kreisschreiben betr. Kriegsdienstvergütungen (bounties)."

"Reklamation des Johann Baptist Minder von Flühli (Luzern), gewesenen Soldaten in den Ver. Staaten für Ausrichtung von Nachtragsbounty." I867-1869.

"Verwendung für Entlasstmg des Joseph Mahler von Kriens aus dem Heere der Ver. Staaten." June 3, i8jo. Vide Personalia.

"Pensionsangelegenheit betr. Kasimir Muri von Schlötz." i872. Vide Personalia.

"Vinzenz Schärli, Soldatenangelegenlıeit." 1880.

"Kreisschreiben."

Fach IV., Fascikel 48. Auswanderung. I798-1848.

"Dekret gegen die Auswanderung, 1799." (Printed decree, prohibiting emigration under heavy penalties; men needed as defenders of the country against foreign invaders.) Feb. 22, I 799.

"Warnung vor der Auswanderung vorzüglich aber nach Dänemark." June, I SoI.

"Koncessionen der Kais. russischen Regierung für die Kolonisten in ihren Staten (nach der Krim)." Sept., 1806.

"Bericht der Regierung von Basel über die Auswanderung nach Amerika." Apr., 1816 .

"Massregeln in Amsterdan gegen Auswanderer." Apr.-June, I8I7.

"Auswanderung einer Anzahl L.uzerner nach den Nordamerikanischen Staaten." 1817. (Eleven cases, certificates, letters, etc.)

"Verfügungen der Königl. preuss. Regierung wegen der schweizer. Auswanderer nach Amerika oder Polen." (Gegen .Mittellose, etc.) May, I8Ig.

"Verordnung der Königl. niederländ. Regrierung betreffend die truppenweise Durchreise der Auswanderer durch dieses Königreich." Feb. 28,1828 .

"Schiffbruch einer Abteilung nach Chili Auswandernder. Unterstützung der Fanilic Glanzmann von Marbach behufs Rückkehr." 1828 . 
"Beschluss über Verabfolgung der Mittel der Auswanderer." Mar. I6, I 83 I.

"Anfrage des Gemeinderats Escholzmatt, ob man die Auswanderung nach Nordamerika verhindern solle oder könne?" Apr., I832.

(Two families, including about twenty individuals, made preparations to emigrate, selling their property, and procuring passes without stating definitely that they intended going to America. It was known that a member of the family had been in America, visiting an uncle, and returned with very favorable reports. Reply: that nothing could be done to stop them, and since their property was exclusively theirs- "Verfügungsrecht ausschliesslich"- - they could dispose of it as they saw fit.)

"Ansuchen die Auswanderung nach Nordamerika zu verschieben, bis die in Havre angehäuften Auswanderer weitergeschifft wären." May, 1832 .

"Weisung jenen Auswanderungslustigen, die wenigstens 25 Louis d'or auf den Kopf vorweisen können, die nötigen Reiseschriften zu verabfolgen." Feb. 25, I833.

"Anzeige, dass künftighin alle schweizerischen Auswanderer nach den Vereinigten Staaten Nordamerikas ihre Reisepässe bei dem nordamerikanischen Vizekonsul in Basel zu visieren haben." Feb. 28, I833.

" Bericht des schweizerischen Handelskonsuls in New Orleans, in betreff der kommerziellen Beziehungen und über die Verhältnisse der Einwanderer in die südlichen Staaten der Union." Mar. 30, I835. Antrag zur Aufnahme schweizerischer Colonisten in der zum Staate Mexico gehörigen Provinz Texas im westlichen Nordamerika. (Printed circular.) I835.

"Berichte über Auswanderung nach Nordamerika, und Kreisschreiben." I 844 -I 847 .

Das Fïr und Wider der Auswanderung nach Amerika (pamphlet, Sursee, I835). Contains a discourse against emigration addressed by Sonnenwirth Johann Lanz of Huttwyl to Schlosser Bandtli of Willisau. Part I., sheets I.-V. (IV. is lacking). Part II., Blatt VI., contains the answer of Bandtli. Motto of Blatt I.: " Einst hörte ein Savoyarde von einer Meerreise erzählen; am Ende sprach er: "Ig willen lieber marschier, wo Kuh spazier, als Fisch spazier.'" Motto of Blatt VI.: "Ich liebe mein Vaterland vor jedem andern Land auf Erden, so lange ich darin frei und unabhängig sein kann. Ich liebe und ehre die Priester, wenn sie das Volk lieben wie sich selbst. Ich hasse aber und verachte die Pfaffen, die unser Vaterland bald zum Narrenhaus gemacht, und dasselbe als solches gerne an das Ausland überliefern möchten. Bei diesen beichte ich nicht, denn sie sollten bei mir beichten." $C f$. also Dr. Theodor Liebenau, Geschichte der Stadt Willisau, p. 9I, etc.

Fach IV., Fascikel 49. Auswanderung. 2( I 798-I847).

I8I9. Auswanderung nach Brasilien. (Large bundle of papers.)

Fach IV., Fascikel 66. Auswanderung im Allgemeinen. Verträge. 3( I848).

"Versuch einer Gesellschaft aus Genf die schweizerische Auswanderung nach Amerika zu organisieren und zentralisieren." I 848 . 
"Gesuch einer Anzahl Bürger des Kantons Luzern das Auswanderungswesen durch die Regierung zu organisieren." 1848 .

"Einstweiliges Verbot des Durchpasses aller und jeder Auswanderer durch Frankreich." (Anhäufung in Havre der Auswanderer.) Mar. 24, 1849.

"Warnung vor den Auswanderungsagenten der kalifornischen Gesellschaft." Dec., i 850.

"Statistische Erhebungen über die Auswanderung aus dem Kanton Luzern in den Jahren I854, I855, 1856." I8 57 .

"Verunglückung des Auswandererschiffes William Nelson auf der Reise Antwerpen nach New York. Daherige Entschädigungsklagen und Untersuchungen." I865-1866.

Two printed pamphlets: Ratgeber fïr die schweizerischen Ausz'anderer in den Vereinigten Staaten von Nordamerika (Bern, I893). Official publication. Die materiellen Verhältnisse und Vortheile für Einzeanderer in Staate Kentucky (Frankfort, Ky., I880). A publication of the "Kentucky Bureau für Geologie und Immigration ", John R. Proctor, Director.

"Erkundigungen betreffend die Heimat verschiedener auf der Bourgogne angeblich ums Leben gekommene Schweizer." Nov. 2, I 898 .

“Auswanderungsverträge 1862-1889." (Large bundle.)

Fach IV., Fascikel 67. Statistik der überseeischen Auswanderung. 18731899 .

Fach IV., Fascikel 68. Auswanderungsagenturen. I 888-1896.

Fach IV. Kreisschreiben. I860-187I. Verträge, Auswanderung, Gesetze, etc.

Fach VII. und VIII. Consulatsberichte und Schreiben, betr. Handel, Zolltarif, etc.

\section{LUZERN: BÜRGERBIBLIOTHEK.}

Location: In the same building with the Stadtarchiv, Münzgasse.

This library is the government repository of books on Swiss history before 1848 (Eidgenössische Sammelstelle für Helvetica vor 1848), the Landesbibliothek in Bern containing the works on the period after that date. The Bürgerbibliothek contains a very good collection of books, pamphlets, and articles written on America in the first half of the nineteenth century, mainly by Swiss settlers or travellers, and bearing on the questions of emigration, $e . g$.:

Der Waldstätter-Bote (Luzern, I828-1844), contains a number of articles on America, as nos. 13, 14, 15, in the year 1828. (Story of shipwreck.)

Reisebericht der Familie Köpfli und Suppiger nach St. Louis am Mississippi und Grïndung von New-Szeitzcrland im Staate Illinois (Sursee. 1833).

Kaspar Köpfli, Vater, Arzt, Licht und Schattenseite von New-Sacitzerland in Nordamerika, 2te Aunf. (Sursee, 1833).

Franz G. Rüegger. Kurzer Reisebericht zon Haze bis Highland (New-Savitzerland in Nordamerika) (Luzern, I846).

Salomon Köphi, Geschichte der Ansiedlung z'on Highland, Illinois (Highland, I859).

Id., Neut-Scha'cizerland in den Jahren I8 1 I und IS.1I (Luzern, 1842). 
Id., Spiegel von Amerika: Praktische Grundsätze, Belehrungen und Warnungen für Auswanderer nach Amerika (Luzern, I849).

Theil von einem Schreiben eines Landmanns aus Pennsylvanien, an den Lands-Venner Martin von Sarnen, welches von des Hrn. Pfarrherrn Rothenbïhler cigner Hand geschrieben, und von dem in Bern befindlichen Hrn. Pfarrherrn Rothenbiihler, als die Hand seines Bruders erkannt worden (no date, 4 pp.).

The following manuscripts were found in the Bürgerbibliothek:

"Beschreibung der Meerfahrt, und der übrigen Schicksale der SchweizerKolonisten, die nach Brasilien wanderten samt einer kurzen Darstellung der Beschaffenheit des Königreichs Brasilien, der Sitten und Gebräuche der Einwohner, der Behandlungsart der Neger und anderen Merkwürdigkeiten, verfasst durch einen Privatmann im Jahre I822 heimgekehrten Schweizerkolonisten." (Joseph Hecht, Canton Luzern.) Im Jahre 1823. (A manuscript of 216 pp.)

Manuscript No. XXIII. "Traitement que les Bataillons Suisses auront en Amérique." (I. e., in South America. Manuscript of 4 pp., probably of eighteenth century.) 


\section{CANTON URI.}

\section{ALTORF: STAATSARCHIV.}

The Staatsarchiv (Cantonal Archive) is located in the town of Altorf, and kept in the Rathaus. During the French invasion, Apr. 5, I 799, fire destroyed all records of the earlier periods. The archive therefore contains only materials of the nineteenth century. One of the earliest notices respecting emigration from Uri may be found in the Anzeiger fïr Schweizcrische Geschichte, n. F., Bd. XI. (I9II), no. 4, p. Igo, from the autobiography of the Uri historian Franz Vincenz Schmid: " 1776 im Frühahr kehrte ich zum Regimente auf Verdun zurück. Mich wandelte die Lust [an], in königlich englische Dienste zu treten und den Feldzug in Amerika mitzumachen [Nordamerika, Unabhängigkeitskrieg], allein meines dringlichsten Bittens ungeachtet, mochte ich die Bewilligung hierzu von meinem Herrn Vater nicht auswirken."

\section{Faszikel I. C. 5-9.}

Verhältnisse zur auswärtigen Gesandtschaft. Kreisschreiben. I848.

Tarif-Verhältnisse u. Handelsverhältnisse zu den verschiedenen Staaten Amerikas. I847-I85I.

Auslieferungsvertrag mit der Republik Salvador, Amerika. Kreisschreiben, I 884 .

Faszikel: Auswanderung, überseeische. Meist nach Nordamerika. Kreisschreiben. $\quad$ I875-ISS3.

A number of petitions of individuals desiring passes for emigration.

Faszikel: Pässe, Heimatscheine, und Wanderbücher.

Several volumes. I 807 to present time. In the years i $867-18 ; 2$ a large number of emigrants came out of the district Wassen, in the Meienthal, canton Uri, reduced to poverty on account of bankruptcies, inebricty (Schnapspest), and intemperance (coffee and liquor habit).

From a manuscript chronicle, in the manuscript collections of Dr. Karl Franz Lusser, landammann and physician, which are now a part of the archives: Aug. 29, 1806, "Wandert Vinz. Good heimlich nach Amerika, von wo er nicht wieder kam, aus, und entzog so dem Lande und den Armen sein bed[eutendes] Vermögen." 


\section{CANTON SCHWYZ.}

\section{SCHWYZ: KANTONSARCHIV.}

Location: Cantonal archive in the town of Schwyz, located in an old towerlike building very near the Rathaus.

Hours: 9 a. m. to I 2 m., or by appointment.

Bibliography: J. C. Benziger, "Das Schwyz. Archiv", in Mitteilungen des Historischen Vereins des Kantons Schwyz, Heft i6.

The material of the eighteenth century is not in condition for investigation; that of the nineteenth century is being put into order. That relating to American history of the nineteenth century seems confined to the circular letters (Kreisschreiben der Vororte), which are preserved, more or less completely, in most of the cantonal archives. The following will serve for illustration: Faszikel "Amerika", containing acta on North America, Mexico, South America.

I8I7. " Schreiben des Königs der Niederlande, Klage über unbemittelte Schweizer in den Häfen der Niederlande, die nach Nordamerika abreisen wollen."

I8I9. Inquiry as to estimated cost of immigration to Brazil, etc.

I830. Consul Boker, and other consulships.

1838. "Der Schweizer Verein zum Wohithun in New Orleans an d. Herren Glieder der Regierung d. löblichen Staats zu Schwyz." Jan. 22, 1838 .

I 838-r847. Kreisschreiben an sämtliche eidgenössische Stände.

Faszikel "Auswanderung". I846-1847.

\section{EINSIEDELN: STIFTSARCHIV.}

The archive of the Benedictine Abbey of Einsiedeln contains records of the founding of branch institutions in the United States, e. g., St. Meinrad Abbey, St. Meinrad, Spencer Co., Ind. ; New-Subiaco Abbey, Spielerville, Logan Co., Ark. ; St. Mary's Abbey, Richardton, Stark Co., N. D. Cf. the following:

P. Franz Züricher, "Die Benediktiner in Amerika ", in Katholische Studien, Heft II., 37 pp. (Würzburg, I875) ; this article gives an account of the settlements of the Benedictine order in the United States, beginning with St. Vincenz, in Westmoreland Co., Pa.

Annalen der Verbreitung des Glaubens, arts.:

"Missionen in Amerika; Überblick der acht ersten Jahre der Benediktinermissionen in Indiana; aus einem Schreiben des Pater Martin an seine Oberen und Mitbrüder in Einsiedeln in der Schweiz. Sankt. Meinrad (Indiana) d. I. Januar, r86r.." No. 199, p. 428 f.

"Schreiben Sr. Gnaden d. hochwürdigsten Herrn Baraga, Bischofs von Sancta Maria v. Obernsee (Lake Superior)." No. I99, pp. 75 f., $462 \mathrm{f}$.

"Bericht des P. Beda Conner. Indianastaat im September i853." No. I 25 , p. $225 \mathrm{f}$. 
Dr. P. Odilo Ringholz, Geschichte des Fürstlichen Benediktinerstiftes U. L. Frau von Einsiedeln.

Die Kulturarbeit des Stiftes Einsiedeln, p. II. ("1852, 21. Dezember, verreisen $P$. Ulrich Christen, und $\mathrm{P}$. Beda O'Connor nach Amerika zur Gründung des neuen Klosters St. Meinrad in Indiana." Ringholz.)

The Catholic Church in the United States of America (New York, 1912), I. 58 .

Die katholischen Missionen im nordöstlichen Arkansas und das BencdiktinerFrauenkloster Maria Stein, bci Pocahontas, Randolph Co., Ark. Eine Festschrift zum goldenen Jubiläum der Dï̈zese Little Rock und zum Silbcrjubiläum der Mission Nordost-Arkansas (Little Rock, I893, pp. I Io). An historical account of the Catholic missions in the northeastern part of Arkansas, since their foundation by Bishop Fitzgerald in 1868 .

\section{EINSIEDELN: BEZIRISSARCHIV.}

This archive contains records of emigration ; $c f$. :

Meinrad Kälin, "Einsiedler in der Fremde", in Einsiedler Anzeiger, I909, 6tes Blatt. This is based upon the records, and adds some information drawn from the immigrants settled in the U. S.

Id., "Vom Geisbuben zum Städtegründer", in Alte und Neue Welt, 42. Jahrgang, 1907-1908, 9. Heft, pp. 336-338. (Steinauer, Neb., founded by the Swiss settler J. A. Steinauer.)

Kälin estimates that over two thousand settlers from Einsiedeln are living in the United States. 


\section{CANTON UNTERWALDEN.}

Divided politically into two half-cantons, Obwalden and Nidwalden.

\section{OBWALDEN.}

\section{SARNEN: STAATSARCHIV.}

The cantonal archive is located in the town of Sarnen, and in the Rathaus.

\section{Akten über Auswanderung.}

Kreisschreiben von 1850 bis 1909 .

Verzeichnis der anno I852 ausgewanderten Alpnachter Familien, und was sie bei ihrer Abreise schuldig geblieben (about 5200 francs). Their destination was Brazil. Six cases. Similar record of 7 cases in I 854, indebtedness I I, $000 \mathrm{fr}$.

Protokoll der Konferenz der eidgenössischen Stände Zürich, Unterwalden, Glarus, Schaffhausen, Graubünden, und Aargau, betreffend die Lage der schweiz. Kolonisten in Brazilien.

Brief eines Ausgewanderten in Brasilien, d. 5. Nov., I854, an den Herrn Anton Britschgi in Alpnach, Canton Obdenwald.

Query about Alois Britschgi, who left with indebtedness of $900 \mathrm{fr}$.

Letters of immigrants to Brazil, mostly lamenting their departure.

Printed report of Dr. Heusser (a trusted teacher, sent to investigate), "an die Direktion der Polizei des Kantons Zürich" (Zürich, I857): Die Schweizer in St. Paolo in Brasilien (printed I860, Tschudi).

Zuschrift an den Bundesrat über die Auswanderung nach Brasilien. (Stirring complaint.) Dec. I, I857.

Brief von i I Familien um Contract bittend, aus Sarnen, Sachseln, und Alpnach.

Bericht des Dr. Heusser v. 28. März, u. 6. April I857, betr. die Colonie in Brasilien.

Answer to inquiry, how many went to Brazil from Obwalden, I852-I854, viz.: 33 persons over 8 years, 9 under 8 years; five families were given help to emigrate.

Letter of complaint from Brazil to the President of the Swiss Confederation. Rio de Janeiro, Mar. 8, 1858.

Protokoll der Konferenz der eidgenöss. Stände Zürich, Bern, Ob dem Wald, Glarus, Schaffhausen, Graubünden, und Aargau, betr. die Lage d. schweiz. Kolonisten in Brasilien. (22 pp.) I., 2., 3. Sitzung, etc.

I866. Complaint of Schweiz. Wohltätigkeitsgesellschaft concerning immigrant paupers.

1868. Vermögensangelegenheiten der Theresia von 'Deschwanden in St. Louis, Amerika.

I 876. Warnung vor Auswanderung nach Bolivar, S. A. Kreisschreiben von Bern.

I88I-I900. Auswanderung X. I2. Statistiken über Auswanderung, und Kreisschreiben. 
I900-I9I2. Auswanderung X. 12. Kreisschreiben über Auswanderungsagenturen. Statistiken der Auswanderung.

The names of all emigrants between I854 and I 894 from the half-canton Obwalden are printed in the Amts-Blatt des Kantons Unteralden ob dem $W$ ald. The custom of printing their names originated in the desire to enable creditors to collect debts before the emigrants' departure. 'Typical entry: "Nach Amerika wollen auswandern:

" I. Joseph Andermatt und dessen Frau und drei Kinder, von Alpnacht.

“2. Franz Wallimamn, mit Familie, von Alpnacht.

"Etc., etc.

"Allfällige Einsprache gegen Aushingabe von deren Reiseschriften sind sogleich bci der unterzeichneten zu machen.

"Sarnen den I4. März, I 855. Die Standeskanzlei."

Many interesting items under the rubric "Auswanderung" can be found in the pages of the Amts-Blatt. Since Igoo a larger number of emigrants left Obwalden than Nidwalden. The larger part settled in California: many in Washington (Tacoma).

\section{SARNEN: FRAUENKLOSTER ST. ANDREAS.}

Archives not accessible. Two printed pamphlets on branches founded in the United States:

Nach dem fernen Westen. Reise-Notizen der Klostcrfrauen von St. Andreas in Sarnen, O. S. B. Sechste Auflage nit 27 Abbildungen. (Printed in Einsiedeln; Verlag des Frauenklosters St. Andreas in Sarnen, 1886, pp. 94.)

Verzeichnis der Benediktinerimnen zur Hl. Gertrud. der Grossen, O. S. B. (Cottonwood, Idalı, U. S. A., 19I I, pp. 20.)

\section{ENGELBERG: ABTEI.}

The archive of the monastery of Engelberg contains the following material relating to America:

I. P. Adalbert Vogel, Die Benediktinerkolonic in Nenengelberg bei Conception. Separatabdruck aus der Zeitschrift Studien und Mittheilungen aus den Benediktiner- und Cistercienserorden, Bd. LV.. pt. III. (I882), erschienen bei L. Wörl in Würzburg. ("Es ist eine Schilderung der Klostergründung von Conception im Staate Missouri. Das dortige Kloster wurde in Jahre 1873 von Engelberg aus durch P. Frowin Conrad gegrïndet und im Jahre I 880 zur Abtei erhoben." P. B. E., Stiftsarchivar.)

2. Ein Gesuch an den Papst un Erhebung Nenengelbergs zur Abtei, mit einigen historischen Notizen.

3. Personallisten dieses Klosters aus verschiedenen Jahren mit Heimatsangabe.

4. Zeitungsberichte ïber die Niederlassung. Welche P. Adelhelm Odermatt von Engellserg aus in State Oregron gründete und Mount Angel nannte. ("Diese Gründung fand inn Jahre 1882 statt. Für sie mag einc Bemerkung in Bote der l'rschacia, no. 100 (1882), von Belang sein; es heisst nämlich da, diss nit den l'atres fünfzig Urschweizer ausgezogen seien." I'. B. R... Stiftsarchivar.) 
5. Prospekte und Tahresberichte des im Tahre ISS- eröffineten Mount Angel College.

6. Bulletin mit kurzer Schilderung des Brandunglückes. durch welches am 3. Mai. ISgz, das ganze Kloster Mount Angel in Asche gelegt wurde.

-. Baupläne von Mount Angel.

Nore material relating to these monasteries founded in Anerica may be obtained by addressing the Rer. Abbot of the abber of Conception. Missouri, and of Mount Angel. Oregon. The archives of these American monasteries may also throw light on the question. whether Swiss immigrants settled aromd the monasteries to any considerable extent. 


\section{CANTON UNTERWALDEN. NIDWALDEN.}

\section{STANS: STAATSARCHIV.}

The Staatsarchiv (Cantonal Archive) is located in the town of Stans, and in the Rathaus.

Bibliography: Adalbert Vokinger, "Inventar des Staatsarchives des Kantons Unterwalden nid dem Wald in Stans ", in Inventare Schaveizerischer Archive, Beilage to the Anzeiger fïr Schaceizerische Geschichte, I. I 53-168 (Bern, I895).

Registration of emigration since $\mathrm{I} 848$, in the Ratsprotokolle.

Names of emigrants printed, for the benefit of creditors, in the Amts-Blatt des Kantons Unterwalden Nid dem Wald. This begins with the first recorded case in 1854 and ends in I895. The following is a typical case :

“(1) Geschwister Franz und Anna Ackermann, Kinder des Goldschmid Felix und der A. M. Ackermann sel., von Buochs, ledig, ersterer 26 und letztere 3 I Jahre alt;

"(2) Alois Hug, Sohn des Alois und der A. M. Christen, von Buochs, ledig, 2 I Jahr alt" ; etc., etc.

"Dieses wird in der Absicht zur öffentlichen Kenntnis gebracht, damit allfällige Einsprachen gegen die Aushingabe der Reiseschriften binnen nächsten 3 Wochen beim Titl. Polizeiamt erhoben werden können. Stans, den 20. Hornung [Feb. 20], I860. Dic Standeskanzlei."

The Stammbuchant is also in the Rathaus at Stans, and contains "Obrigkeitliche Stammbücher" (official genealogies), back into the fourteenth century. This official bureau of genealogies was established in the eighteenth century. 


\section{CANTON GLARUS.}

\section{GLARUS: STAATSARCHIV.}

Location: "Neues Archiv des Cantons Glarus”, in the Gerichtsgebäude, Hauptstrasse.

Hours: 8 a. m. to 12 m.; 2 to 6 p. m.

No material was found belonging to the eighteenth century, and none relating to the nineteenth, before 1837 .

Acta. T. 22.

Rubrik 73. Auswanderung. Vermögenszug.

Fascikel 1: Vermögenszug: Jahre I837-1867. (A considerable number of cases of transfer of property to persons in America.)

Fascikel 2: Auswanderung: Jahre 1837-1852.

No. I. “ Der Interims-Präsident des Auswanderungs-Vereins macht Mitteilung vom Auswanderungs-Plan, von den sich beteiligenden Gemeinden und ersucht um Unterstützung durch die Regierung." May 28, I844.

No. 2. "Der Vorstand des Auswanderungs-Vereins ersucht um Beförderung der Vorlage des Schreibens vom Interimspräsidenten vor Rath." May 31, I844.

No. 3. "Gemeindebeschlüsse über den Beitritt zum AuswanderungsVerein und über die zu gewährende Unterstützung." June 3-I2, I844.

No. 4. "Landammann u. Rath: Circular an sämtl. Gemeinedräthe über Unterstützung u. Betheiligung des Landes am Auswanderungsverein." June I2, I844.

No. 5. "Standeskommission: Circular an die eidgenöss. Consulate in Nord-Amerika über die Auswanderungsfrage." June I4, I844.

No. 6. "Der Präsident des Auswanderungs-Vereins setzt die Wichtigkeit der Auswanderungsfrage und die Dringlichkeit der Beförderung derselben auseinander." July 23, I844.

No. Io. "Abschrift eines Briefes von W. Blumer von Allentown in Pennsylvanien, Auswanderungs-, Untersuchs- und LandankaufsReise betreffend." Nov. 8, 1844 .

No. I I. "Der Vorstand des Auswand.-Vereins macht Mitteilung einer stattfindenden Versammlung, und ladet die Regierung zur Teilnahme durch Abgeordnete ein." Nov. 29, I844.

No. I2. "Der Vorstand teilt die Beschlüsse der Versammlung des Auswand.-Vereins vom 30. November mit."' Dec. I3, I844.

No. I3. "Hr. Peter Jenny v. Schwanden macht Mitteilung eines Plans zur Bildung einer schweiz. Unterstützungs- u. SchutzGesellschaft für Auswanderer." Jan. I7, I845.

No. I4. "Nachträgliche Erklärungen des Gemeinderaths betr. die Auswanderer auf die Anfrage vom 22. Januar, I845." Jan., I845. 
No. I5. "Der Vorstand des Auswand.-Vereins: Einladung an die Regierung, sich gutächtlich ïber die, von den resp. Tagwen (Bürger der Gemeinde, die besitzen) zu leistenden Beiträge auszusprechen." Jan. 22, 1845 .

No. I6. "Einladung des Auswand.-Vereins Vorsțands zur Beschickung der Versammlung der Abgeordneten der betreffenden Gemeinden durch Mitglieder der Regierung." Jan. 31, i 845 .

No. 17. "Landammann u. Rath: Circular. Mitteilung der gefassten Beschlüsse über die Unterstützung der Auswanderer von Seite des Landes, der Gemeinden und durch Liebesstenern." Feb. 5, I845. ( $100 \mathrm{fr}$. for each Bürger, $25 \mathrm{fr}$. for each minor.)

No. I8. "Protestation einer Minderheit des Tagwens Reuty gegen einen Tagwens-Beschluss, die Unterstïtzung d. Auswanderer betref." Feb. 5, I $8+5$.

No. 19. "Protokoll über die Versammlungen u. Comite-Sitzungen des Auswand.-Vereins." Feb. 5, 1845: May I9, I847.

No. 20. "Einladung an die Regierung zur Teilnahme an der Versammlung d. Auswand.-Vereins. Bezeichnung der 2 Experten zur Genehmigung." Feb. 18, 1845 .

No. 21. "Übersendung eines königl. Dekrets, betr. schützende Bestimmungen für durch die Niederlande reisende und dort einschiffende Auswanderer." Feb. 21, I 845.

No. 22. "Übersendung der Statuten, Anzeige und Ursache des Wechsels des 2ten Experten." Mar. I8, 1845.

No. 23. "Standeskommission: Einladung an die Polizeikommission, betr. Verhinderung der Kollektionen unter dem Titel der Auswanderung." Mar. 19, I 845.

No. 26. "Eidgenöss. Vorort Zürich: Mitteilung einer Warnung d. schweiz. Consuls in New York vor dem Auswandern armer Personen." Oct. 24, 1845 .

No. 27. "General-Consul d. Ver. Staaten für d. Schweiz: Mitteilung eines Gesetzes des States New York, die Auswanderer betreffend." Mar. I3, 1846.

Nos. 28, 29. " Eidgenöss. Kanzlei in Zürich: Kreisschreiben über die Auswanderung nach Amerika." I846.

No. 3o. "Der Vorstand d. Auswand.-Verein: Übersendung eines Berichts von Neu-Glarus; Comité-Beschluss über denselben; Wunsch d. Erwähnung d. Verteilung der Vorschuss-Summe vor d. Rathe." Janl. I2, I 847.

No. 31. "Der Glarnische Auswand.-Verein und die Colonie NenGlarus in Wisconsin. Hauptbericht d. Auswanderungs-Conités." 6. Hormung (Feb. 6), 1847 .

No. 32. "Stadtrat Winterthur: Anfrage ïber den Schutz d. Auswanderer durch die Regrerming u. die Gemeinden und über Anschluss an den Auswand.-Verein und die Colonie Neu-Glarus." Mar. 3,1847

Nos. 33. 34. "Kreisschreiben (Vorort Bern) über die Auswaunderumir." 1847 .

No. 35. "Ubersendung von Unterrichtsmittehn u. Selulnaterialien an die Colonie Nett-Glarus." May 19, 1847.

No. 36. "Landammann 11. Rath: Kreditbewilligung von $100 \mathrm{fr}$. zu Schulzwecken für Neu-Glarus." June 15, I847. 
No. 37. "Gemeinde-Berichte über den Stand der Auswanderung und tabellarische Zusammenstellung derselben." Aug. I3, I847.

Nos. 38, 39, 40. Emigration of a number of individuals.

No. 4I. "Hr. Adv. Rud. Gallati ersucht im Namen mehrerer um Obrigkeitl. Aufhebung der Gemeindebeschlüsse von Mollis über die Unterstützung der Auswanderer." Feb. I, I 848 .

No. 42. "Antwort von Glarus, Kerenzen, und Filzbach auf ein Circular, betreffend die Beitragsleistungen der Gemeinden." Mar. $23, \mathrm{I} 848$.

No. 43. "Gemeinde Mollis: Nachsendung des Reisegeldes,für die in Mainz zurückgehaltenen Auswanderer." Apr. I4, i848.

No.44. "Akten iiber die Allgemeine Gesellschaft gegenseitiger Unterstützung für Auswanderer in Genf.” Apr. I4, I848; Jan. I 2, I 849 .

No. 45. "Preislisten verschiedener Agenten zur Spedition von Auswanderern und vergleichende Zusammenstellung derselben." I 848-I 849 .

No. 46. "Eidgenöss. Consulat in Brüssel u. Antwerpen: Empfehlung d. Auswanderung über Antwerpen." Feb. 9, I849.

No. 47. "Die Agentur für glarner Auswanderer in Basel betr." Feb. I 5, I 849 .

No. 47 a. "Tabellarische Darstellung d. Auswanderung im Kanton Glarus I845-I848 und Beleuchtung derselben.” Feb. 21, I 849 .

Nos. 48, 49, 5I. Auswanderungsagenturen betr. I849.

No. 50. "Gesetz über den Durchzug d. Auswanderer durch Belgien." June 28, I849.

No. 52. "Bericht über die Zustände der Kolonie Neu-Glarus." May $7, \mathrm{I} 850$.

No. 53. "Königl. belgischer General Konsul i. d. Schweiz: Mitteilung eines kön. Dekrets die Sicherheit d. Auswanderer auf ihrer Reise betr." June 5, I850.

No. 54 " Bericht über die Verwendung d. Kirchensteuer für NeuGlarus.” Sept. I8, I850.

No. 56. "Anzeige über die Errichtung eines Post-Bureaus in NeuGlarus." Dec. 27, 1850.

( 185 I. Collekte für Neu-Glarus, s. in Rubr. I6o.)

Nos. 57,57 a, 58, 58 a. Details. I851.

No. 59. "Einsendung eines eingegangenen Berichts über NeuGlarus (Copie). Vorschlag zu weiterer Unterstützung des Kirchengutes u. s. w. dieser Gemeinde." Jan. 2 I, I852.

Nos. 59 a, b, c, d, 60, 6r. Details. I852.

Fascikel 3. Auswanderung. Jahre I853-1866.

Nos. I-I2, I4-I7. Details.

No. I3. "Gemeinderat Glarus: Tagwensbeschluss betr. Unterstützung d. Auswanderer in Nord-Amerika." Sept. 30, I853.

No. I8. "Gemeinderath Elm: Beschluss betr. Unterstützung d. Auswanderung nach Amerika." Jan. 27, I854.

Nos. 19-28. Details. I 854 .

No. 29. "Gemeinderath Netzthal: Bericht über die 1854 nach Amerika ausgewanderten Personen.” Jan. Io, I855. 
No. 30. "Bundesrath: Warnung vor Absendung nittelloser Auswanderer oder Verbrecher nach Amerika." Mar. 2, 30, I855.

Nos. 31, 32. Details. I 855 .

No. 33 a. "Glarnischer Auswanderungs-Verein. Schlussbericht, Schlussrechnung, Liquidation des Vereins." Nov. 25, I855.

No. 35. "Bericht der Gemeinden über die Auswanderung I854-I 856 . Schreiben."

Nos. 36-62. Details on emigration, I857-1866, including consular reports, statistics on emigration from canton Glarus, prevention of transportation of paupers and criminals. (No more forced emigration.)

Fascikel 4. Auswanderung. I867-1875.

Nos. I-26. Annual statistics, property settlements, immigration agencies, etc. Immigration to South American states (Nen Helvetia, Uruguay: La Plata states).

Fascikel 5. Auswanderung. I 868-1883.

Nos. I-39. Vermögenszug, Erbschaftsangelegenheiten.

Fascikel 6. Auswanderung. I876-1890.

Nos. I-46. Emigration statistics, licensed emigrant agencies, increase of emigration. Not all to United States. Chili, etc.

No. 20. "Auswanderung aus der Schweiz im Jahre I884 und 1885 resp. seit 1879 , und speziell im Jahre $1885 . "$

Fascikel 7. Auswanderung. Vermögenszug. Akten aus den Jahren I $884^{-}$.

Nos. I-32. Individual cases.

Fascikel 8. Auswanderung. Akten aus den Jahren I89I-.

Úberseeische Auswanderungen aus der Schweiz. Statistik.

Amerika.

Rubrik 1. A1. Fascikel 1. I $837-1856$.

Acta $\mathrm{I}-44$. Consular reports, conmunications, and abstracts of messages delivered to all the cantons by the "Vorort", and after I 848 by the "Bundesrat", concerning the United States, Mexico, and the South American states.

Fascikel 2. 1857-1895. Material as above.

Registratur. Vereinigte Staaten von Nord Amerika. Igor-rgog.

(Kreisschreiben von Bern.)

Landammannamt No. 926. "Auszug aus dem Protokoll des Regierungsrates des Kantons Glarus v. 27. Juli, I905. \$ 826: Feier des 60-jälırigen Bestandes der Kolonie Neu-Glarus in Nordamerika." Congratulatory message to New Glarus, Wis., and correspondence.

Memorial für dic ordentl. Landsgemeinde des Jahres 1874 (printed), pp. I3-I8: §8: "Erwerbung eines Landkomplexes in Amerika." The "Kantonale Arbeiterbund" in 1873 addressed to the "Dreifaclie Rath" a plea for the purchase of a large tract of land as a permanent place of refuge for the unemployed (encouraged by the success of New Glarus colony in Wisconsin). Long argunent presented, and conclusion as follows: "dlass der Staat dic Auswanderung weder hemmen noch fördern, sondern dass er sie frei gewähren lassen soll". 
Bibliography of printed material: Katalog der Landesbibliothek in Glarus (Näfels, 1903).

Berichte der Schweizerischen Consular Agenten, mit Anmerkungen der Auswanderungs-Commission der Gemeinnuitzigen Gesellschaft (Glarus, I845).

Der Glarnische Auswanderungs-Verein und die Colonie Neu-Glarus: Hauptbericht des Auswanderungs-Comité, mit a Karten (Glarus, I 847 ).

Zweiter Bericht ïber die Colonie Neu-Glarus (Glarus, I85I).

The Planting of the Szviss Colony at New Glarus, Wisconsin, by John Luchsinger. Reprinted from Wisconsin Historical Collections, vol. XII. (Madison, Wis., I892).

The Sziss Colony of New Glarus, by John Luchsinger, with additional notes by J. J. Tschudy. From vol. VIII. of Wisconsin Historical Collections ( I879).

D. Dürst, Die Griindung und Entwickelung der Kolonie Neu-Glarus (Wiskonsin, N. A.) umfassend den Zeitraum von I844-1892, nebst einer Reisebeschreibung, mit 3 Plänen (Zürich, I894).

Andreas Baumgartner, Ein Besuch in Neu-Glarus. Separate reprint from the Glarner Nachrichten (Glarus, 1906).

Id., Erinnerungen aus Amerika (Zürich, 1906), pp. 86-ı25. "Besuch in Neu-Glarus." 


\section{CANTON ZUG.}

\section{ZUG: RANTONSARCHIV.}

Location: In the Regierungsgebäude, on the Postplatz.

Hours: 8 a. m. to $\mathrm{I} 2 \mathrm{~m}$.; 2 to 6 p. m.

The materials of the eighteenth century are not put in order; a governmental appropriation is expected for this purpose. The nineteenth century material is well grouped, arranged, and indexed.

\section{Ausland. Amerika. Theke i.}

\section{A. Schweizerische Konsulate in Amerika. 1823-1847.}

I824." Bericht über Erhebung von Verlassenschaften verstorbener Schweizer."

\section{B. Amerikanische Konsulate in der Schweiz. 1830-1845.}

1831. "Bericht über Handelsverhältnisse mit Mexiko."

1832. "Handels- und Freundschaftsvertrag mit Mexiko."

I833. "Französische Verfügung zur Durchreise von Auswanderern nach Amerika."

"Freundschaft- u. Handelsvertrag mit den mexikanischen Staaten."

I834. "Ubereinkunft zum freien Vermögensbezug zwischen der Schweiz $u$. Amerika."

I836. "Ermordung des schweizerischen Handelskonsuls (Marret) in Mexiko." Nov. 8,1835 .

I843. "Bericht über die Handels- u. Douanen-Verhältnisse in Mexiko."

" Verbot des Detailhandels für die Ausländer in Mexiko."

"Weisung über Beibringung von Todesscheinen u. Nachlass-Liquidationen in übersceischen Ländern."

I846. "Vertrag über Auslieferung der Verbrecher mit Nordamerika."

"Verhaltungsmassregeln für Auswanderer."

"Auskündigungen in amerikanischen Zeitungen" (Erbschaften, ete.).

"Verhaltungsmassregeln für Auswanderer nach Amerika vom amerikanischen Consul Goundie in Basel."

Inneres. Auswanderung. $1803-1847$.

I817. "Warnung vor der Auswanderung nach Amerika."

$$
\text { Ausland. Archiv Akten 1848-1873. Thlike i. }
$$

Amerikanische Freistanten, Verträgre mit der Schweiz, über:

I 848. "Aufhebung des Heimfallrechts und der Auswanderertaxen."

"Urlaub des Konsuls der Vereinigten Staaten (Goundie)."

I 855. "Freundschafts-, Niederlassungs-, Handels-, u. Auslieferungs-Vertrag."

1858. "Verhältnisse der amerikanischen Israeliten in der Schweiz."

I 859. "Legalisation von gerichtlichen Akten." 
I860. "Bürgerrecht für Schweizerinnen, die sich mit Amerikanern verheiraten."

I861. " Reisevorschriften."

1865. "Sympathie- u. Beileids-Adresse an die amerikanische Union." (Lincoln's death.)

I 866. "Nachtragsvergütungen an Soldaten der Vereinigten Staaten."

"Vorschriften über Sendung von Waaren und Briefen, I85I-1863."

I868. "Beschwerde über Spedition von Vagabunden und Verbrechern nach den Vereinigten Staaten."

"Austausch der amtlichen Publikationen." "Mittel gegen die TraubenKrankheit."

"Statistik der Vereinigten Staaten."

I869. "Geld-Auswechselungsvertrag."

1872. "Nachtrags-Artikel zum Postvertrag über Postanweisungen."

INNEREs. I848-I873. TheKe 8I.

K. I. AUSWANDERUNG.

Gesetze und Verordnungen über das Auswanderungswesen.

Auswanderung in Unteregeri: Vertrag mit der Korporation.

Statistik von Zug, I867-1873.

Statistik: Überseeische Auswanderung aus der Schweiz im Jahre I87I.

Auswanderungs-Literatur. Schweiz. Auswanderungs-Zeitung, etc. Unterstützung für Auswanderer und Kolonisation, etc.

Bureau für Auswanderung in New York.

Eidgenössische Organisation der Auswanderung. Konferenz hierüber. Protokoll.

Nachweisungsbureau in Bremen.

Anweisung für Auswanderer.

Konferenz-Protokolle.

Auswanderung nach Algerien, Brasilien, Polen.

Auswanderungs-Agenturen. Anzeigen.

Untergang des Auswanderer-Schiffs William Nelson (1865).

Bedingungen zur Auswanderung nach Algerien.

Mitteilungen bezüglich der Auswanderung nach Amerika; Brasilien.

Auswanderer aus dem Kanton Zug. (25 individual cases.)

Auswärtige Angelegenheiten. i874-1893. A. Theke i.

I. VERTRÄGE UND ABKOMMEN.

a. Mit Amerika.

I. "Nachtragsartikel zum Postvertrag zwischen der Schweiz und den Ver. Staaten v. Amerika, betr. den gegenseitigen Austausch von Korrespondenzkarten." Mar. 3I, Apr. 2I, I874.

2. "Bundesbeschluss betr. Vertretung der Schweiz in Washington." Jan. 28 , 1882 .

3. "Freundschafts-, Niederlassungs-, u. Handelsvertrag mit der Republik Salvador." Oct. 30, 1883.

6. Ditto, mit Ecuador. June 22, I888.

7. "Gegenseitige Auslieferung von Verbrechern und Vollzug von Requisitorien. Übereinkunft v. 22. Juni, samt Begleitschreiben." July I8, I889. 
8. “Auswechselung von Geldanweisungen-Vertrag mit den Vereinigten Staaten." Oct. I8, I88 I.

6. Auswanderung. Theke 77 II. Q. 6.

a. Auswanderungskommissariat.

I. Aufgabe des Kommissariats. Kreisschreiben des eidg. Departments für Auswanderung. Sept. 26, I888.

II. Geschäftsbericht. Kreisschreiben des eidg. Depts.

b. Agenturen. (Complete material accessible in Bundesarchiv, and Eidg. Auswanderungsamt, Bern.)

c. Statistik. (As above.)

d. Verschiedenes.

I. Iten Bländus, Oberägeri, Auswanderung nach Canada. Reklamation des schweiz. Konsulats in Philadelphia betr. zu geringer Subsistenzmittel. Nos. I-IO, I87 I, I874.

II. Röllin Johannes. Auswanderungsgesuch. (I) Schreiben des Gemeinderats Menzingen; (2) Agentur Baumgarten, Basel, an Nenzingen, Feb. I2, I879.

III. Auswanderung nach Uruguay, Südamerika. 1879.

Schweiz. Auswanderungszeitung. Jäggi an Reg. Rat. June 24, I88o.

VI. Auswanderung nach Chile. Schreiben d. eidg. Depts. Dec. II, I883.

Úbermachung des Auswanderungswesens. Auszug aus dem Protokoll der Commission des Innern. Mar. 27, 1884. 


\section{CANTON SOLOTHURN (SOLEURE).}

\section{SOLOTHURN: STAATSARCHIV.}

Location: In the Rathaus, a good building with annex.

Hours: 8 a. m. to $12 \mathrm{~m}$.; 2 to 6 p. m.

MANDATEN.

Auswanderung. "Ausser Land ziehen, den Unterthanen verboten." Year I 49I, p. 3 .

Auswanderung. "Ausser Land ziehen, unter fremde Fürsten." I 537, p. 284 ; I 577 , p. 436 ; I 585 , p. 445 .

Auswanderung. "Ausser Land ziehen, ohne Billigung der Obrigkeit bei Verlust von Bürgerrecht und Hab und Gut" [verboten]. I647, p. 825 .

Auswanderung. "Mittel (Vermögen) soll keiner ausser Land ziehen ohne Vorwissen und Billigung der Obrigkeit." I706, p. I64.

RATSPROTOKOLLE.

I767. Auswanderung. Spanische Kolonien. ( I8 documents.)

I768. Auswanderung. Spanische Kolonien. (27 documents.)

I769. Auswanderung. Spanische Kolonien. (I I documents.)

Ratsmanuale. IV. Staatssachen. Inneres.

I837. "Für den nach Amerika reisenden Benedikt Schwaller von Oberdorf darf ein Pass ausgestellet werden."

“Dem Benedikt Bättiger von Schnottwil wird die Auswanderung nach Amerika auf verpflogenen Rechnungstag bewilligt."

I838. "Weisung wegen Abzugsgebühr von Io per cent."

1839. Three requests for passes for emigrants granted, two refused, one inquired into.

I840. One family refused permission to emigrate; a number of other individuals allowed to go.

I84 I-I 845. Emigration, also to Algiers and Russia.

1846. "Die Mitteilung der eidgenöss. Kanzlei betreffend die Auswanderung nach Amerika wird überwiesen."

I850. "In das Gesuch der Gemeinde Sumiswald den Johann Tschan, Schuster von hier, welcher mit Frau und Kindern nach Amerika auszuwandern wünscht, zu verhindern, wird nicht eingetreten." No. 28 , a. b.

"In das Gesuch des R ... von A . . . um eine Staatsunterstützung nach Amerika, wird nicht eingegangen."

I 852. "Den Gemeinden Breitenbach, Büsserach, Erschwil, Himmelrid, und Kleinlützel wird die Verwilligung zu Geldaufbrüchen für Unterstützung auswandernder Familien nicht ertheilt." 
"Von H. Turnlehrer Hängi werden I 5o Copien seiner Denkschrift über die nordamerikanischen Verhältnisse@ I fr. angekauft und jeder Gemeinde eine Kopie zugeschickt." (Copy found in Staatsarchiv.)

I852. "Walterswil Gemeinde. In das Ansuchen, zur Unterstïtzung der Auswanderer Fr. IOoo aus dem Armenfond zu entheben, und um einen Beitrag von Seite des Staats, wird nicht eingetreten."

I853-1857. Detailed information about individual cases of emigrants; taxation of emigrants; some few cases of contributions to aid emigrants.

I855. "Auswanderung mittelloser Personen." Applications for assistance.

"Von einer Mitteilung des Bundesrats vom ig. dies bezïglich Auswanderung gänzlich mittelloser Personen und selbst Sträflingen nach Amerika wird vom Departement des Innern in Abschrift Mitteilung gegeben." No. 325 .

\section{Registratur zu den Ratsprotokollen.}

I847. Ausland B. 355. "Der vom Vorort übermachte Auszug einer Depesche des schweizer. Konsuls zu Amsterdam betreffend ein in Amerika wild wachsendes Knollengewächs, welches geeignet wäre die Kartoffeln zu ersetzen, wird überwiesen."

A number of property claims; inquiries as to persons : consular reports, etc.

\section{Auswanderungswesen. i8 37 -I857. Acta.}

Rub. 229. No. I24. Bound volume of papers, mostly manuscripts; some few printed pamphlets; all pertaining to emigration, not all, however, concerned with the United States.

\section{FRANKREICH.}

During the period before the French Revolution the ambassadors of the King of France to the Swiss Confederation customarily resided at Solothurn. Therefore the archives of this canton contain, in a section entitled Frankreich. a collection especially devoted to Franco-Swiss relations, and containing correspondence with the ambassadors, correspondence of Swiss officers in the French service under the many contracts successively made by France for auxiliary Swiss troops, correspondence respecting the regiments, rolls of regiments, etc.

Of correspondence of Swiss soldiers in the Swiss archives there are some ten manuscript volumes, belonging to the eightcenth century. These volumes are not paged or indexed. Some of then have been gnawed by rats, others damaged by moisture. It was not possible in a rapid search to discover in them any reference to Swiss soldiers employed in the French service in America.

Bibliography: Emanuel May, Histoire Militaire de la Suisse, et celle des Suisses dans les différens Services de l'Europe (Lausanne, I 788. 8 vols.).

Baron Zur-Lauben, Histoire Militaire des Suisses au Service de la France (Paris, 1751, 8 vols.). 
Abbé François Girard, Histoire Abrégée des Officiers Suisses qui se sont distingués aux Services Etrangers aux Grades Supérieurs (Fribourg, I78I, 2 vols.).

R. von Steiger, "Coup d'Oeil sur l'Histoire Militaire des Suisses aux Services Etrangers", in Archiv fïr Schweizerische Geschichte, XVII. (187I).

I. E. Kilchenmann, "Schweizersöldner im Dienste der Englisch-Ostindischen Kompanie um die Mitte des 18. Jahrhunderts", in Neues Solothurner Wochenblatt, I. Jahrgang, no. 34 (Solothurn, May I9, I9I I). 


\section{CANTON BASEL-STADT.}

BASEL: STAATSARCHIV.

Location: The cantonal archive of Basel is well housed in a special building on the site of the old Rathausgarten. The building is described in Archivalische Zeitschrift, n. s., XI. 237-252 (1904). The entrance is at Martinsgasse 2 ; the initiated may also enter from the Marktplatz by way of the stairways and galleries of the picturesque old Rathaus, with which the Archivgebäude is connected.

Hours: 8 a. m. to 12 m.; 2 to 6 p. m.

For conveniences for work and for accessibility of material, the Staatsarchiv of Basel is a model of its kind. The card index and the exhaustive catalogue, Repertorium des Staatsarchivs zu Basel (Basel, 1904, pp. 1xviii, $834)$, are of very great service. The Repertoriuin contains a history of the archive, the regulations, a description of the building, etc.

The Schweizerisches Wirtschaftsarchiv is connected with the Staatsarchiv, and is under the same head, the state archivist.

The materials in the Staatsarchiv relating to America are chiefly to be found in the journals (Protokolle) of the Kleiner Rat and of its committee the Dreizehnerrat, in the section Nordamerika, and in the section Auswanderung. The latter consists of two divisions: Auswanderung A, Allgemeines und Einzelnes, 1732-1885, and Auswanderung B, Auswanderungsstatistik, I 8 I $7-1885$.

\section{Protokolle des Kleinen Raths.}

No references to Carolina, Pennsylvania, or other American colonies until 1734 .

\section{Vol. 106. I734-I 735 .}

p. 144. "Hans Heinrich Breitenstein um Reisegelt in Carolinam." Oct. 23, 1734. (4 Gulden were voted to be given him when aboard ship.)

Jacob Miiller (informator, Lehrer) begs to go to Carolina with wife and 3 children, and asks for help (Reisegelt). Nov. 17, i734. K1. R. Beschluss: "Ist abgewiesen, und solle weder er, noch andere, die in Carolinam reisen wollen, oder reisen zu wollen vorgeben, nicht weiter angehört werden."

p. I46. "In Carolinam reisende arme lent atss d. Zürich Gebiet" (ungefähr Ioo Personen). Oct. 27, 1734.

"Solle diesen Lenten, ihre Reisz, wie sie es gnt befinden fortzusetzen überlassen, doch das Bettehn in der Stadt verbotten, und wan ihnen wegen Almosen etwas angelegen, sie an die arme Herberg verwiesen, übrigens nacher Zürich, dass man dergleichen lent mit erforderlichen Pässen versehe, geschrieben werde."

p. 154. Zürich writes, that these people left without permission, "gegen ihren willen, werden aber solehe Anstalten vorkehren, dass diese reisende hiesiger Stadt nicht mehr beschwerlich fallen." Nov. 6, I 734 .

K1. Rath.: "bleibt dabei und wollen MGGHerrn den Erfolg erwarten." 
p. I87. "Hans Giegelmann von Bubendorf mit Frau und 6 Kindern willens in Carolinam zu reisen, bittet sie der Leibeigenschaft gegen Gebühr zu entlassen und die Gebühr in etwas miltern." Dec. I, I734.

K1. R.: "Sollen MGnHn die XIII wie dergleichen Reisen in Carolinam $z \mathfrak{u}$ verhindern Rathschlag abfassen und eingeben."

p. 208. Mention of a book that instigates to immigration for Carolina. Several cases mentioned. Dec. I 5, I734.

p. 228. Zürich sends request to check fever of immigration to Carolina. Jan. $3, \mathrm{I} 735$.

p. 229. MGnHn XIII.: “In Betrachtung, dass die dahin sich begebenden Personen ihrem Verderben, grossem Elend und Sklaverey entgegen laufen, vorgeschlagen, dass zu Stadt und Land zu Verhinderung einer solchen reisz eine ernstliche Warnung gethan, die Auf wickler oder Anwerber angehalten, den Underthanen aus dieser Absicht keine Ganten [i.e., Versteigerungen, freiwillig oder unfreiwillig] bewilliget, auch sonsten sie von dergleichen Undernehmung mit nachtruck abgehalten werden sollten." Jan. 5, I735. See below: XIIIer Raths-Protokoll.

p. 345. "Gebrüder Giegelmann und noch einige andere Underthanen, welche umb in Carolinam zu reisen, ihre Güter und Mittel vergantet, sich immer anmelden, dass die Reiss und Päss bewilligt ", etc. Mar. I 2, 1735 .

K1. R.: "Weil vor dem Verbott ihre Güter vergantet, soll Pass ertheilt werden."

p. 346. "Gant umb in Carolinam zu reisen, abgeschlagen. Ferner nicht erlaubt." Mar. I6, I735.

p. 380. "Mandat soll getruckt, zu Stadt und Land publiciert, und auf der Landschaft drey Sonntag nach einander ob den Kantzlen abgelesen werden." Apr. I6, I735.

p. 389 . Seven families, 42 persons, given passes for journey down the Rhine, on way to Carolina. Apr. 23, 1735.

"Solle die Manumissions und Abzugsgebühr von sämtlichen bezogen, deswegen auf ihre in dem Land besitzende oder noch zu erben habende Güter Achtung gegeben werden."

\section{Vol. 107. I $735^{-1} 73^{6}$}

p. 324. About 80 persons, desirous of emigrating (destination Pennsylvania or Carolina), on examination declare, that poverty is the cause of their desire to emigrate, that the country is overpopulated, and that the soil cannot support them. When the hardships and dangers of the journey were described to them, they still insisted on going, and desired passes. Feb. 15, 1736.

K1. R. addresses "Oberbeamten und Geistliche" to do all in their power to exert a restraining influence.

p. 334. A few of the above group persuaded to remain, but others take their places, making more than before asking to leave, for Carolina and Pennsylvania. Feb. 22, 1736.

K1. R.: "Ein Bedenken abfassen."

p. 349. Compelled to let immigrants for Pennsylvania go. Provision made for children who were left behind. "Vergantung" permitted. “Abzug und Manumission" both deducted. Mar. 3, I736. 
p. 355. Another group, for Pennsylvania. Emigration and "Vergantung" permitted. Wonen and children asked whether they wanted to go; if not, provision for them taken out of the goods and property of the immigrant male relatives. Manumission und Abzug. Mar. I0, 1736 .

pp. 368, 372, 373, 383. "Abreisz gnädig bewilligt." Mar., I736.

Four weeks period for "Vergantung". Some leave without giving notice.

p. 387. One case of refusal, another of granting permission to emigrate. Apr. 4, I736.

p. 409. A large number of cases of emigration. Sales of property, deductions, accounts. Apr. 18,1736 .

p. 4I4. "Schreibern von Liechstal berichtet, dass dem Hans Joggi Bohni von Franckendorf, welcher mit Weib und 8 Kindern in Carolinam zu ziehen willens, nach beschehenen Gant 7oI Pf. im Vermögen bleibe: indessen wolle seine zweite 23 jährige Tochter Eva Bohni nicht mit ihm wegziehen." Apr. 2 I, 1736.

Kl. R. Beschluss: "Kann die Tochter hierbleiben und solle bevögtiget, auch ihro so viel als wann die Eltern todt wären, von den Mitlen hinderlassen, und von dem Überrest der Abzug, samt denen Manumissionsgebühren von den Alten bezogen, die Kinder aber deswegen frey gelassen: übrigens von den Herren Deputierten veranstaltet werden, dass diesen wegziehenden Leuten über die Gebühren nichts abgenommen werde."

p. 421. A list of ten heads of families. Apr. 25, I736.

K1. R.: "Solle der Abzug schon erkanntermaszen von den wegziehenden Geldern und die Manumissionsgebühren von denen Häubtern der Hauszhaltungen, Vatter und Mutter abgestattet, doch denen welche weniger als roo Pfund besitzen mit beiden Forderungen verschont werden."

p. 425. "Die Herren Deputierten haben wegen denen Unterthanen, welche in Carolinam zichen wollen, ihre ferneren Berahtschlagungen gehalten, verschiedene angehöret und von denselben keine andere Ursach ihres Vorhabens um wegzuziehen vernommen, als dass sie in hiesigem land ihr nahrung nicht finden können." Apr. 25, I736.

Vol. 109. $1737^{-1} 73^{8}$.

p. 355. "Schreiben von Zürich: Brief v. 24. November, I736 aus Philadelphia, aus welchem zu ersehen, in was elenden Stand sich die dahin reisenden personen stïrtzen."

Beschluss: "Solle diese Abschrift getrucket, auf die Landschaft in alle änter übersannt, denen Herrn Predigern in allen Gemeinden zugestellet, und absonderlich denen Unterthanen, welche aus dem Land zn zichen und in Pennsylvaniam zu reisen lust bezengen, nitgetheilet und kund gemacht werden." Apr. 2, I738.

$$
\text { Vol. 111. I739-1740. }
$$

p. 329. "Hans Jogrgi und zwei andere bis nach London gekommen und zurückgekehrt zu ihren Weibern in Läuf elfingen." Nov. 28, 1739.

Beschluss: "Die Vögte der Weiber cntlassen, das nöthige zugesprochen. (In Gnaden anfgenommen.)" 
p. 453. New cases of emigrants; a considerable number.

A letter of $H$. Riggenbacher, who writes from Carolina, to be confiscated. Feb. I3, I740.

p. 457. "Lockbrief soll verlesen werden." Feb. I7, I740.

p. 464. "Brief von H. Riggenbacher aus Carolina an seinen Bruder verlesen." Attempt to get information concerning damage the letter has done. Feb. 20, I740.

p. 473. The letter taken up again. Feb. 27, I740.

\section{Vol. 112. I740-I74I.}

p. 21. Of a group of persons desirous of emigrating, some are persuaded to change their minds, and remain. Mar. I9, I740.

pp. 27, 35, 4I. Emigrants. Mar., I740.

p. 65. A group of emigrants permitted to go. Some of them well-to-do. Apr. 20,1740 .

p. 76. More permitted to go, to Pennsylvania and Carolina. Apr. 27, I740.

p. 8I. Three heads of families destined for Pennsylvania. Property $47 \mathrm{I} 2$ Pfund. ${ }^{1}$ Apr. 30, I740.

p. 84. Twelve persons, permitted to go to Pennsylvania or Carolina, property aggregating I 2,370 Pf. 9 Sch. 2 R. Apr. 30, I740.

Beschluss: "Neben Abzug, die Manumissions-Gebühren also bezogen werden, dass ein Vatter, Mutter oder die eigene Mittel haben, die Gebühr gantz, die Kinder jedes ein halbe Gebühr und jenige so nicht einmal hundert Pfund wegziehen, nichts abrechnen sollen."

Vol. 121. 1747-I 748.

p. 51. "Colonie Holländisch Surinam" (Guiana).

p. 284. "Emigranten, wie selbige verhindern."

\section{Vol. 122. I748-I749.}

pp. I 5I-I68. “Emigrierende Unterthanen."

Ten cases or more requesting permission to emigrate with families (destination Pennsylvania), and to sell their property. Reason urged: "Weilen ihr Handwerk gering sei." Referred to Herren Dep. in Landsachen. Feb. 20, I749.

A number of additional cases. Mar. I, I749.

A large number of additional cases. Mar. 5, I749.

Four more cases. Mar. 7, I749.

p. I69. "Bedenken." 5 pp.

Decree: Everything to be done to dissuade emigrants, by persons in authority, and sermons to be preached in all churches on the evils and dangers. Of those that persist, the following class permitted

${ }^{2}$ The following table, from Hannauer, Études Économiques, I. 501, will give a clue to the value of the Basel (and Swiss) coinage. The basis here is the franc.

\begin{tabular}{|c|c|c|c|c|c|c|c|}
\hline $\begin{array}{l}\text { Année. } \\
\text { I } 728 . .\end{array}$ & $\begin{array}{c}\text { Rappen } \\
\text { (pence). } \\
\text { o.018 }\end{array}$ & $\begin{array}{c}\text { Schilling. } \\
\text { O.II }\end{array}$ & $\begin{array}{l}\text { Pfund. } \\
2.12\end{array}$ & $\begin{array}{c}\text { Gulden. } \\
2.65\end{array}$ & $\begin{array}{c}\text { Batzen. } \\
\text { o.I } 8\end{array}$ & $\begin{array}{c}\text { Kreutzer } \\
0.045\end{array}$ & francs \\
\hline 174 & 0.017 & 0.10 & 2.04 & 2.55 & 0.17 & 0.042 & $G$ \\
\hline$\ldots \ldots$ & 0.016 & 0.10 & 1.96 & 2.45 & 0.16 & 0.04 & \\
\hline 然 & 0.015 & 0.075 & 1.50 & 2.25 & 0.15 & 0.038 & \\
\hline 18 & 0.0143 & 0.071 & 1.43 & 2.14 & 0.143 & 0.036 & " \\
\hline
\end{tabular}


to emigrate: those that have no children and the unmarried persons ; permitted also to sell their lands (at auction, Ganten), and leave after paying all taxes (Gebühren), Abzug (io per cent.), and Manumission (Io Pfund a head); their landright (Landrecht) forfeited, and not allowed to return and resettle except by special permission. Mar. 8, I749.

pp. 172-380 (26 references). "Emigrierende Unterthanen."

A large number of additional applications. Mar. I2, I749.

Ruling of March 8 upheld. Persons with children not permitted to leave. Government feels responsible for safety of children; fear expressed, that if children were left behind by their parents, they would go to the bad, and become objects of charity. (Mortality of children on sea-voyage also probable consideration.) Reward set for discovery of emigrant agents at work among the people, "Werber".

A large number of additional cases. Mar. 15, 1749.

Niarch 8, 12, I5, I749, total number applying for permission to emigrate: 85 men, 73 women, 224 children ( 382 persons).

Joner, suspected of being a "Werber", notified to leave the country within twice 24 hours. All "Werber" to be taken into custody.

More petitions for permission to emigrate. Mar. I9, I749.

Permission granted to several couples without children. Mar. 22, I 749.

More petitions granted to couples without children. Mar. 26, I749.

Permission granted to several couples with children. Mar. 29, I749. Announcement made that no more would be granted.

A few more petitions granted. Apr. 2, I749.

“Emigranten in dem Land zufallende Erbschaften." Bedenken, 4 pp. Apr. 12, 1749.

“Manumissions-Gebühren betr." Not taxed, if not possessed of property.

"Landesflüchtige Emigranten." Three cases of emigration without permission, two men with wives and children, one without wife. May I4, I 749 .

Beschluss: "Sollen die Hrn. Ober Beamte genan vigiliren, dass dergleichen clandestine Emigrationen künftigs nicht mehr beschehen, die also weggezogene Emigranten aber wenn sie wieder ins Land kommen beygefängt werden."

“Bernische Angehörige nach Pensylvanien zu reisen verführet." May I 4, I 749 .

“Leonlhard Bientzen Sohn soll verleitet worden sein, zu enigriren. Soll in Basel verbört werden." May I.4. I749.

"Verhör des Rudolf Bientz." (Father caught him at Strassburg and brought him back.) May $21,17+9$.

"Verhör giebt nicht viel an Tag." Beschluss: "Bleibt dabei." May 24,1749 .

“Projekt des Mandats." August i 3, I 749.

pp. 308, 331 , 332, 333. "Erbschaften dic Emigranten betreffend."

"Alle welche vor dem 22. Mertz 1849 [see Mlandat below] aus dem Land in Americam gezogen anf keine Weiss etwas erblich bezichen dürfen, sondern als tod angesehen werden." Aug. 13, I749. (Their inheritance to go to nearest relatives, or if none, then into "Armen-Seckel".) 
Vol. 123. I749-I 750.

p. I85. Jacob Joner Verhör (suspected of being a "Werber"). Feb. 25, I750.

pp. 190-36r. (I 5 references.) "Emigrationes."

"Emigration in Neu Schottland, Carolinam u. Pensylvaniam." Mar. 4,1750 .

"Jacob Joner betr." Mar. 7, I4, I750.

After his business completed (collecting inherited money for a friend), banished from land ("zum Land hinaus geführt").

"Jacob Joner Vollmacht in Erbschaft." Mar. 2I, I750.

Case of proteciion of children of emigrant. May 6, I750.

"Emigranten ohne obrigkeitliche Erlaubnusz." May 9, I750.

Petitions for emigration. June 30, I750.

\section{Vol. 124. I750-I75I.}

p. I74. Johannes Tschudi, returned from America, suspected of "werben". To be taken into custody, if possible to catch him. Mar. 6, I75I. p. I8r. Reward of 4 Neue Thaler offered to anyone who captures Joner ("Werber"). Mar. Io, I75I.

p. 2r4. "Heimlicher Emigrant, Konrad Weyser, mit Weib und Kind, und Iooo $£$ bar Geld" (Gut vergantet). Apr. 7, I75I.

p. 216. Applications for permission to emigrate. Apr. 7, I75I.

Policy of "Mandat" ( I749) to be adhered to.

p. 227. Increased emigration. Large number of applications. Complaint made against "Frondienst". Examination of emigrants recommended, and strict carrying out of the policy of the "Mandat" of I749. Apr. 2I, I75I.

p. 246. Inquiry about Weysz. Friends and neighbors assert they did not know that he was going to emigrate. May I, I75I.

"Jacob Schaub, ein liederlicher Mensch, erlaubt nach Pennsylvanien zu ziehen." May 22, I75I.

p. 363. "Emigrirensverdächtige." July 28, I75I.

\section{Vol. 125. I75I-I752.}

p. 65. "Pensylvanische Reformirte Gemeinde: Memoriale d. Süd Holländischen Synodi an sämtl. evangel. Cantonen gerichtet, Beistand für reform. Gemeinde in Pensilvanien; Pfarrer Schlatter von St. Gallen berichtet 40 Gemeinden Pfarrer und Lehrer nötig."

Vol. 140. I767.

pp. I 39-382. “Emigrationsgeschäfte.” I8 references.

pp. I39, I45, I64. "Martin Schäublins Wegziehen." Verhöre, etc. Apr. 8, 1767.

pp. 21 I, 213. Petitions for emigration. May 27, 1767.

pp. 232, 233. Some petitions granted. June Io, i 767.

"Zwei heimliche Emigranten." June II, I767.

pp. 280, 283. "Heimliche Emigranten." Additional cases. July I 5, I767. 
Vol. 142. I769.

pp. I4I, 200. "Emigrationes nacher Spanien."

Vol. 143. I770.

pp. I54, I59. "Heimliche Emigrationes.” “Fabrique-arbeiter debauchieren." June 2, 17\%o.

Vol. 144. I771.

pp. 3I-4I4. "Emigrationes." 38 references.

pp. I 59, 4I 4. "Enigranten, wegen Veräusserung ihrer Güter."

pp. I9I, I93. "Ganten und Käufe."

pp. I95, 218, 224. "Wegen heimlichen Wegziehens."

p. 202. "Minder jährige Emigranten."

p. 220. "Armer Emigranten Manumissions-Gebühren."

p. 31. "Bedenken der Landcommission über die Auswanderungen." Jan. 26, I 771 .

p. 104. "Mandat." Mar. 25, I77I.

p. II8. Petitions of emigrants, destination Virginia (Junt, Rieger), with wives and children. Permitted. Apr. IO, I77I.

A large number of additional petitions, destinations mostly Pennsylvania.

$$
\text { Vol. 145. I } 772 .
$$

pp. 2-I24. "Emigrationes." (22 references.)

pp. 73, I 45. "Emigranten, ob nicht Einhalt zu thun."

p. I47. "Emigranten, so wieder zurück kommen."

p. 282. "Emigrant, um Begnadigung."

Vol. 146. I 773 .

pp. 82, 86, 94, I02, I 21. Petitions of emigrants.

Vol. 159. I 786.

p. 7o. "Emigranten und Emisarii. Mandate sollen wieder verlesen werden." Mar. I, i 786.

p. 373. "Heimlicher Emigranten Erbrecht." Sept. 2, i 786.

Vol. 160. 1787 .

p. 206. "Verdächtige Emigranten.,

Vol. 161. I 788 .

p. 246. "Emigrant zurückgekommen" (nur bis Holland gekommen). Begnadigt.

Vol. 162. $178 y$.

p. 88. Petitions for emigration. Mar. 24, 1789.

Vol. 165. I 792.

A few cases of emigrants. 
Vol. 185. I8I6.

pp. 7-372. 16 references to immigration to United States. This was a period of famine (Das Hungerjahr, as Wackernagel calls it). A very large number of people from the canton Basel immigrated to the United States.

Letters: "Briefe von Verwandten in Amerika". Jan. 3I, I8I6. Letters of Dürring, Vogt, Hofmann, Breitenstein, etc.

Vol. 186. I8I7.

pp. 72-286. Some 30 references to emigration. Large emigration to the United States. Measures taken to prevent paupers from gathering at shipping ports.

Vol. 187. 1818.

A few cases of emigration.

Vol. 199. I83o.

Two cases of emigration.

Vol. 200. I83I.

Nineteen cases of emigration.

Vol. 201. 1832.

Thirty-five cases of emigration. Names recorded.

Vol. 202. 1833 .

Three cases of emigration.

Vol. 214. 1845 .

Two cases of emigration.

Vol. 215. 1846.

Proposals of Graubünden concerning emigration.

Vol. 216. I 847.

"Auswanderung aus Glarus nach Amerika."

Vol. 217. 1848 .

Pp. I73, I94, 217, 339, 403., "Auswanderer nach Amerika. Warnung und Anweisungen."

p. 405. "Andr. Suter in der Strafanstalt. Er habe in Californien einen Oheim, der ihm wohl behülflich sein werde."

Stadtrath gives him $80 \mathrm{fr}$., making $800 \mathrm{fr}$. in his possession. Permission to emigrate granted.

Vol. 218. I 849.

A number of " Unterstützungsgesuche um nach Amerika auszuwandern." 
Dreizehner Raths Protokoll (Ausschuss des Kl. Raths). C I.

\section{Vol. 3. $1735^{-1} 75^{8}$.}

"Weilen so viel Landsleut in Carolinam gereiset, auch dem Verlaut nach cinige MGnHrn Underthanen die Begierd hegen, solche reisz vorzunemen, als ward, wie solche liederliche Sehnsucht zu hemmen die Berahtschlagung vorgenommen, darbey reflectieret, dasz diese leut sich in das gröste Elend werfen:"

Beschluss: "Sollte zu Stadt und Land zu hinderung dieser Reisen die erforderliche befehl publicieret und morgen meinen Gn. Hrn. vorgelegt werden." Jan. 4, I735.

"Soll ein Mandat, diese leut abzuhalten, concipieret und nächsten Rahtstag MnGnHrn vorgelegt werden." Apr. 14, I735.

"Weilen sich noch immer vicle underthanen anmelden, die aus dem Land ziehen und in Carolinam reisen wollen, die Herren Deputierte zu denen Landsachen auch denenselben, um sie abzuhalten, all mögliches vorgestellet, und dennoch nichts ausrichten können, indessen jenige, welche diesen Entschluss gefasset, und sich solches in den Kopf gesetzet, nichts mehr arbeiten, sondern nur herumziehen, darbey verlautet, dass sie ob verschiedenen Beschwärden, Frohnen, Zinsen, Strafen etc. klagen, als ward, was vorzunemmen, deliberieret:"

Beschluss: "Sollte MGnHrn angerahten werden, dass man jenige, die sich diesmalen angemeldet und auf 120 Seelen belaufen, gegen Abstattung der Gebühr, könne laufen, doch keine weitere, bis man von diesen werde bericht haben, gehen lassen." Mar. 3, I740.

\section{Mandate.}

EMIGRATIONEN, AUSWANDERUNGEN DER UNTERTIIANEN.

I649, June 2. "Emigriren verboten." (After Thirty Years' War.) V. 11. 39. 1735, Jan. 29. "Züricherisches Auswanderungsverbot."

1735, Apr. 20. "Emigrations Mandat" (vs. Carolina). IV. 11. I 29.

I738, Apr. 2. "Enigrations Verbott, sant Brief aus Carolina." I, VII, $\S 2 \mathrm{n} .4$.

1749, Aug. I 3. "Erbschaften der Wegziehenden" (since Mar. 22, I749, no inheritance could be collected by enligrant). V.n. 67 .

I77I, Mar. 25. "Emigrations Mandat” (repetition of above). V. n. I38.

I773, Jan. 30. "Anhang zum Emigrations Mandat." V. n. I 59.

(Particularly severe against agents, "Werber", here also called " Neuländer", who pretended to collect inleritance for friends in Anerica.)

\section{Nord-A MERIKa. \\ ALLGeMEINES UND EINZELNES. 1844-1885.}

A I. Meist Kreisschreiben von den Vororten, dann von Bern. Auslieferungen, 3B. Millionen-Dieb: Gerh. Koster. I8 44 .

Acta über die Auslieferung des Anerikaners J. M. Shrok und für dessen Anlıaltung ausgesetzte Prämic. I $855^{-1} 85^{6}$.

Kreisschreiben meistens Auslief erungen von Bet rügern betr. I $855-1885$.

A 2. Auslieferungsvertrag der Sclweiz mit Nordamerika. I845-1846.

Kreisschreiben von Bern. 
A 3. Freizügigkeitsvertrag der Schweiz mit Nordamerika. 1834-1848. Kreisschreiben.

A 4. Freundschafts-, Niederlassungs-, Handels-, und Auslieferungsvertrag der Schweiz mit Nordamerika. I855.

B I. Schweizer in Nordamerika. I753-1886.

I753, I772. Vermögenssachen betr.

1774. Hinterlassenschaft von Adam Fluebacher in Pennsylvanien.

I797, Feb. 2I. Brief (Copia) des Hrn. Pfarrer Hantz über Vermögen ( 700 Pf.) des verstorbenen Meyer.

I807. Die verneintliche Erbschaft eines gewissen Hrn. Peter aus Amerika.

1816. Erbschaft Häfelfinger mit Einlage eines Briefes von Verena Plattner aus Baltimore, geschrieben d. I6. Juni, I815.

I824, I838, I839, I841, I846-I 886. Acta betr. Hinterlassenschaften, Auskünfte, Berichte, Nachforschungen, Todesscheine etc.

B 2. Schweizer in Nordamerikanischen Diensten. 1865-1878. Erkundigungen, Nachforschungen wegen Schweizer im Bürgerkrieg.

C I. Nordamerikanische Konsulate in der Schweiz. 1830-1855.

C 2. Nordamerikan. Konsulat in Basel. I830-1883.

C 3. Id. Zürich. I $843^{-1} 844$.

C 4. Schweizerische Konsulate in Nordamerika. I823-184I.

C 5. Schweiz. Konsulat in Charleston. 1854.

C 6. Id. Chicago. $1859-1880$.

C 7. Id. Cincinnati. I $864-1866$.

C 8. Id. San Francisco. 1858-1867.

C 9. Id. Highland. 1856-1859.

C io. Id. St. Louis. 1867.

C I I. Id. Madison. I845-1853.

C 12. Id. New York. I842-1867.

C I3. Id. New Orleans. I837-1870.

C I4. Id. Philadelphia. I84I-I857.

C 15. Id. Texas. 1846 .

C I6. Id. Washington. 1864 .

C 17. Schweiz. Gesandtschaft in Nordamerika. 1882.

Auswanderung A. Allgemeines und Einzelnes. I732-1738.

"Acta wegen Emigration einiger Baslerischer Underthanen in Americam so die Memorialen, Bedenken, Verordnungen, Schreiben und Specificationen der Weggereisten enthalten. Vom I6. April 1732, bisz 29. Mertz I738."

Large bound volume of manuscript acta, including answers to request sent to various parts of the canton for information concerning the reasons for emigration to Carolina and Pennsylvania. One examination, dated Mar. 6,1738 , proved, that of 17 persons questioned, 6 emigrated because of poverty, 6 of inability to find work, 3 in hope of finding good land, 2 without assigned reasons. Several discussions of question of emigration. Many lists of persons desiring to emigrate to Carolina. Accounts of property. Deductions: for manumission 5-8 per cent.; tax for emigration Io per cent. Certificates of character by preachers. 
I738. “Waldenburg sagt, die Unterthanen arbeithen nicht gern, seyen zu viel dem Wein ergeben, und funden Arbeit genug wenn sie wollten, könten nunmehro zum Weg bey Höllstein gebracht werden."

1738. "Homburg vermeint die Bauern ziehen meistentheils aus Bosheit aus dem Land und vermeint wenn sie arbeiten wollten, so könnten sie sich durchbringen."

1738, Mar. 25. "Bedenken des Herrn Deputirten wegen denen Emigranten." (Io pp.)

Advice: The very poor have reason to go, the well-to-do should not go, in consideration of the danger.

Two other "Bedenken." (7 pp.)

$$
\text { I } 740-1748 .
$$

I740, Feb. 27. "Information wegen einem aus Carolina geschriebenen und in dem Land ausgebreiteten Brief."

Feb. 20. "Relation der Herren Deputaten wegen vorhabender Emigration (nach Carolina) einiger Unterthanen von Muttents." Long lists of enigrants' names.

Mar. I9. "Einige von Muttents, so ihre Resolution (nach Carolina) zu emigriren geenderet."

Apr. 20. "Status über die Habschaft einiger Enigranten."

May II. "Relation der Herren Deputaten in Landts Sachen, wegen Daniel Meyer, welcher aus Amerika alhero gekommen, und denen von Ihme und Springen mit sich alhero gebrachten Brief."

Enclosure: letter, Dec. 3, I737.

Apr. 23. "Bericht über den Zustand der Länder Carolina, Pennsylvanien, und dgl.

Apr. 4. "Hans Spring[en] von Reutingen, Berner-Gebieths, wegen Werbung in Carolina."

Apr. 2. Id.

Apr. 30. "Letztes Verhör von Spring[en]." Skilful answers by Spring. May 14. "Verrichtung der Herren Sieben (HHR VII) bey Mattis Singeisen von Liechstal, welcher ausz seinem Accord [contract of service] und in Pennsylvanian ziehen wollen." The HHR. is a "Gerichtsbehörde", a police-court.

I74I, Apr. 8. "Bedenken der Deputaten in Landts Sachen, wegen Barbara Boerlis Mittel, so nummehr in Pensylvania."

May-June. "Bedenken d. D. in L. S. wegen einiger nach Pensylvania zielien wollenden Untertlianen."

1742. "Acta betr. Peter Huber yon Oberhaszli, Bern, so die Leuth in Carolinam zu reisen verleitet."

Gefangennahme. Verhör Hubers und der Berner Emigranten. (This is a most fascinating series of documents.)

1746. "Bericht der Herren Deput. zu den Fabriques wegen Jacob Dürrenberger von Lupsingen." Acta, 7 Stücke; including Verhör, and a French passport.

I747, Dec. 20. "Schreiben von Amsterdam wegen Kolonisten zu Surinam" (Dutch Guiana, South America).

I748, Jan. 28. $A$ list of alout 100 persons willing to go.

A large number of acta on Surinam emigration, written in Dutch, French, and German. 
I749.

A large fascicle, containing important and very interesting materials, which may be grouped under the following heads:

(I) Petitions of large numbers of subjects (of Basel) for permission to emigrate. Reasons stated for their desire to leave. (Poverty, lack of work, letters from relatives and friends, hope of bettering their condition.)

(2) Certificates of character, and written testimonials by ministers of the respective parishes, on the religious and moral standing of petitioners.

(3) Lists of names of petitioners, and number in family of each, with age of each member.

(4) Statements of the means of those permitted to emigrate, with deductions made by government. For "manumission", $i$. e., release from serfdom (when still in bondage), eight per cent. of total amount of property. For "Abzugsgebühren", deduction for privilege of leaving the country with property, ten per cent. of total valuation. Thus, many emigrants were taxed i 8 per cent. of their property, before receiving permission to leave.

(5) “Verhöre der Behörden, der Deputaten, der VII", etc. Examinations of emigrants before various courts. Reports of questions and answers.

(6) "Bedenken der Behörden." Reports on conditions. Pros and contras concerning emigration. Before 1749 the destination was mostly Carolina, especially in the thirties; in I 749 Pennsylvania received the larger number of emigrants from this section of Switzerland.

(7) Emigrants returning and claiming property. Arrested and examined before court. Emigrants not returning, but claiming property, usually by proxy.

(8) "Emigranten-Manumissions-Gebühren betreffend."

$$
\text { I750-1770. }
$$

I750, Feb. 25. "Jacob Joner aus Pensylvanien, und dessen Stifbruder Johannes Schwab betr." (Very interesting "Verhör" before the HHR. VII.) Vollmacht zur Einziehung einer Erbschaft.

Feb. 28. "Riggenbagherische Geschwisterte in Pensylvanien, um Beziehung eines Erbs."

Acta. Emigranten aus Surinam, etc.

Dec. 19. "Bedenken lobl. Waisenamts wegen Heini Wagners Verlassenschaft, dessen Tochter in Americam gezogen."

I751, May 1o. "Besprechung MGH. VII wegen aus Pensylvanien zurückgekom. Johannes Tschudi und übrigen Personen" (Verwandten). "Tschudi nicht mehr vorhanden." Is quoted as having said: "Wer aber nicht wolle arbeiten, der solle nur zu Hause bleiben, und wer gern Wein trinken wolle, solle auch nicht hierin gehen, denn sie haben nichts anders als Klein-Bier und Aepfelwein."

May 26. Briefe aus Pensylvanien.

I750-I770. Verhöre von Wegziehenden, Erbschaften, zurückgelassene Briefe von Emigranten an Freunde Abschied nehmend, Meldungen über Ausgewanderte ohne Abschied, Gesuche zur Auswanderung, Abhorung von Eingefangenen oder abgehaltenen Emigranten. Heimliches Wegziehen. 
I765. Werbungen in russische Colonien Gedruckte Formulare der Engagements.

1767, Apr.6. Johamnes Tschudi. He emigrated with his wife in I749, reappeared in $175 \mathrm{I}$ in company with "dem berüchtigten James Joner von Brattelen "; has after many years' absence appeared again, and is reported to be spending many English guineas luring people for the purpose of enigration.

"Verhör von J. J. Tschudi." A large number of acta on Tschudi ("er ist von der väterlichen Erbschaft ausgeschlossen"). Several others of the same family name: Nicolaus und Martin Tschudi. Johannes Tschudi is called a "Neuländer"; attempts to catch him. Jacob Würths Verhör.

Apr. I4. "Gutachten des Hochw. Kirchenrathes wegen Wegziehung nach Neu-IVied (Herrnhuter, Niederrhein) und Versendung der jungen Leute dahin zur Erziehung."

1767-1 769. Acta betr. spanische Colonien. (In Spanien.)

I768. "Der Emigration verdächtige Personen" (large number of acta), " nit einem Brief aus Amerika".

I769. Verhöre, etc.

1770. Züricher Verbot gegen Emigration nach Preussisch Pommern. (Printed.)

$$
\text { I } 77 \text { I-I } 798 \text {. }
$$

1771. "Bedenken und Verbot wegen Auswanderungen." Also one in 1772. Emigration und Werber. Mit Brief aus Lebanon, I769. Viele Acten.

Bittschriften um Entlassung von Leibeigenschaft, und zur Auswanderung.

"Memoriale der Canzley wegen unvermöglichen Unterthanen."

"Heimliche Emigranten." Large number of acta, proving that emigration without permission or passes was very frequent.

"Einige Emigranten." Numerous acta.

I77I-I 772. Auswanderungsgesuche. Very many cases, mostly of very poor people. Accompanying certificates of character by minister. A large number ask for release from Leibeigenschaft. ${ }^{2}$

1772. "Bewilligungen für Auswanderer." About 60 heads of families, 285 persons.

"Freylassung und Abzug der ausgewanderten Unterthanen im Jahr I772." Total taken from them 2595 Pf. 3 Sch. 4 R. ${ }^{2}$

I $784-1787$. Renewed petitions for permission to immigrate to America.

I 786, Nov. 22. "Emigranten um Auslieferung von Mitteln, nach Amerika." I79I, Feb. 26. Id.

I794, June I8. Id.

1798. “Gesetz die Auswanderung verbietend.” “Im Namen der helvetischen einen und untheilbaren Republik." This decree was made largely to prevent emigration of able-bodied men, who were needed in defense of the comntry. Penalty: "1o Jahre in Ketten, Verlust der Bürgerrechte."

${ }^{1}$ Leibeigensehaft continued untiI 1790. Cf. P. Ochs, Geschichte der Stadt und Landschaft Basel (Basel, 1832), VIII. 110, note: "Dic I'reylassungs- oder MamumissionsGebühren waren von 10 Pfund, ausser den Kanzlei-Sporteln für den Manumissionsbrief selloer."

'See p. ro, note 1 , ante. 


\section{I $80 \mathrm{O}-\mathrm{I} 808$.}

I803, Jan. I5. "Wegen d. Abzug v. Erbschaften an nach Amerika ausgewanderte hiesige Landbürger."

"Verzeichnis derjenigen Personen, grössentheils aus d. Canton Basel, welchen im Januar u. Hornung d. Jahres I 803 auf dem Bureau d. Unter-Statthalters d. Cantons Basel Pässe nach Amerika ertheilt worden sind." Total 278 persons; 84 heads of families.

"Verzeichnis über diejenigen Personen welche aus d. Gemeinden des Distrikts Gelterkinden (Baselland) unterm 3 ten März I803 nach Nordamerika ausgewandert sind." Personen ausgewandert, 84 ; Personen die sich noch dazu vorbereiten, 77 ; total (Pässe erhalten), i6r.

Causes assigned for emigration, on being questioned:

(I) Verdienstlosigkeit.

(2) Unerträgliche Abgaben, und andere Lasten.

(3) Hoffnung Glück zu finden, wo Bekannte sich niedergelassen haben. Günstige Berichte von solchen.

(4) Aussichtslosigkeit im Vaterland.

(5) Stehen dem Bettel bevor.

Mar. 4. District Waldenburg, in answer to inquiry, reports that 26 persons emigrated for North America, and 9 more are desirous of going. Reasons for emigration stated to be impoverishment, the result of the foraging of French troops since the Revolution. The latter left in their hands "nur lehre [leere] Bongs" (a Bon is a receipt for goods or supplies furnished to the soldiers and a promise to repay), which were never redeemed by the French government. As a result the people got deeper and deeper into debt.

Mar. 5. Eight more persons destined for North America.

Auswanderer aus dem Distrikt Liestal...44 Personen.

Auswanderer willens im Monat Mai zu ziehen....27 Personen.

I804. Acta betr. Auswanderer nach Nordamerika. Schuldverzeichnisse; Zeugnisse; Bescheinigung des Verzichts auf das Bürgerrecht; Auskündigung der Auswanderer (dass Gläubiger sich melden) auf vier Wochen; gewöhnlich freiwillige Auskündigung.

Auskündigungs-Protokolle. Extractus. Nos. 437-459, etc.

$$
\text { I8I6-I8I7. }
$$

I8I6, Jan. Inquiry of Bürgermeister u. Rath d. Cantons Basel an Statthalter d. Untern Raths, as to causes of renewed emigration to the United States.

Jan. 24. "Schreiben von Sissach wegen Emigration."

"Ankunft eines Haufens Briefe aus Nordamerika, günstig lautend", etc.

Feb. 7. "Gutachten 1öbl. Justiz und Polizey Colleg. "über Auswanderung nach Amerika."

"Zwei Briefe aus Amerika”, eingefangen d. 29. Januar, I8I6. Beide: Jakob Schweitzer aus Frankendorf. Philadelphia d. 29. Juni, I809; und I6. Mai, I8I5.

Mar. and Apr. Acta wegen Auswanderung. 
Apr. I8. Luzern speaks of "Aufmunterung zur Auswanderung nach Nordamerika und Werbungen zu dem Ende vom Canton Basel". (Stadtrath der Stadt u. Republik Luzern an Bürgermeister u. Rath d. Standes Basel.)

"Verzeichnis derjenigen Angehörigen des Bezirks Waldenburg welche nach Amerika ausgewandert. I816." I9 Personen.

"Schriften von H. Halter und General Consul de Planta, etc., wegen Verdächtigungen hinsichtlich d. Transports der Auswanderer nach Amerika."

Überfahrtskosten Verzeichnis. (Printed.)

I8I , Jan. I9. Permission to emigrate given to a family, "denn sie sind in keinem guten Ruf”. (Shipment of paupers and undesirables brings about a complaint from the ports.)

"Auswanderung von Bevogteten." (Minors, boys and unmarried girls, and widows. A "Vogt" appointed as protector.)

Jan. 21. Complaint from Amsterdan, including letter of Consul General de Planta, Jan. II, I8I 7 , on the condition of large numbers of indigent Swiss emigrants in Amsterdam who expect to be transported to America.

Jan. 29. "Wegen Auswanderung nach Russland."

"Gutachten löbl. Justiz w. Polizey College über Auswanderung von Minderjährigen."

Feb. I 5. "Verordnung in Betreff der Auswanderung." (No passes to paupers.)

Feb. I8. "Verlockungen von Werbern zum Auswandern."

Large number of acta, granting permission to individuals to emigrate; their names and conditions, with "Gutachten".

"Verordnungen über das Auswandern nach Amerika. Vom. I4. Sept., I8ı6; I5. Feb., I. Mai, I6. Mai, 7. Juni, I8ı7."

Feb. 28. Ship contract, including rate and daily menu.

Cases of emigrants returned from Holland, who had not the means for passage across.

Lists of emigrants. "Verzeichnis der Angehörigen des untern Bezirks, welche Anno I8I7 ausgewandert sind." 3I cases.

$$
\text { I8I9-1847. }
$$

I8r9. Kreisschreiben, Luzern. "Vorschriften für Auswanderer durch die preussischen Rheinprovinzen, d. 22. Mai, I8ı." (Against paupers.)

Kreisschreiben, Luzern. Id. durch Holland.

Acta concerning individuals or groups of individuals emigrating to United States, 1819, I822, I825, 1832, I833, I834, I837, I838, I 845 , I 846.

1820. "Acta und Druckschriften dic Kolonie des Rothen Flusses in Nordamerika betreffend." Pamphlet: Capt. Ruclolf von May, Kur $\approx e^{\prime}$ und zuahe Uebersicht (Bern, 1820). Verhör eines Werbers in Basel (claimed that he received 6 francs a head). Letter from London in answer to inquiry concerning the Hudson Bay Colony.

1828. "Holländische Verordnung wegen Auswanderung."

1829. "Auswanderung nach Buenos Ayres."

I83 I. "Vorschriften der Auswanderung durch Frankreich." 
I832, May 24. Report that many Swiss, Baden, and Württemberg emigrants are lying at port of Havre, and that cholera morbus has broken out among them.

May 27. Kreisschreiben from Luzern, concerning emigrants in France. I833. Kreisschreiben von Zürich. "Visirung der Pässe."

"Vermögensauslieferung. Verfügen für Auswanderer nach Amerika." I837, Nov. I I. "Abmahnung vor Auswanderung nach Neu-Orleans." I843. Kreisschreiben von Luzern. Auswanderung nach Algier. I844, Feb. I7. "Erleichterung für Auswanderer nach Amerika."

I 8 45, Aug. Io. "Christ. Schauenburg, Schuhmacher von Wolfenbüttel, bittet um Unterstützung zur Auswanderung nach Amerika, verlobt mit Wittwe Mohl, Basel."

Aug. 22. "Christoph Lehmann, Zimmergeselle, bittet um Mittel z. Auswanderung."

I846. "Vorschriften für Auswanderer nach Amerika." Kreisschreiben Zürich.

Apr. 8. "Unterstützungsgesuch zur Auswanderung."

May 2. "Unterstützungsgesuch zur Auswanderung nach Texas." Another, May 27.

May 6. "Vorschläge des Consuls in Havre zum Schutz d. Auswanderer." Kreisschreiben Zürich. Also May 28.

"Gesammelte Notitzen in betreff d. Auswanderungen."

"Protokoll einer am 8ten Herbstmonate I846 zwischen den Abgeordneten der Kantone Zürich, Bern, Glarus, Basel Stadttheil, Schaffhausen, Appenzell AR., Graubünden, Aargau, Thurgau, Tessin, Waadt, und Neuenburg abgehaltenen Konferenz, betreffend die Auswanderung aus der Schweiz." (Policy: Neither to encourage nor to discourage emigration; no subsidies to be granted by state for paying expenses of emigrants; limited support might be extended by "Gemeinden"; concentration in colonies not good for Swiss.)

Nov. 9. Kreisschreiben Zürich. Meeting on question of emigration.

I 847, Jan. I6. "Unterstützungsgesuch zur Auswanderung nach Nordamerika." Joh. Schultz. Thirteen other similar cases, extending to December.

Apr. 21. Kreisschreiben Bern. Report on recommendation of Graubünden. "Wertvolle Aufschlüsse von Consulaten."

May 8. Über Auswanderung.

Sept. 24. "Gesuch des Speditors K. Fischer in Basel v. I8 d. M. um Erlaubnis zur Vermittlung des Transports von Auswanderern betreffend."

\section{I $848-1853$.}

I848. "Bittschriften um Unterstützung zur Auswanderung nach Amerika." I 5 cases. Letter from St. Louis, Mar. I 5, 1848.

Jan. 28. "Beiträge zur Auswanderung in der Stadt Aarau." Answer to inquiry was, that they handled cases as individuals (not by any law or rule). Similar answer from Glarus. Conditions in Basel.

"Kreisschreiben von Bern über Auswanderungsverhältnisse." Schafflausen recommends united action, a uniform policy. 
Oct. I8. "Übersiedlung des wegen Diebstahls in der Strafanstalt befindlichen Martin Schaffner." Basel gives 60 fr., i. e., half of sum requested.

Dec. 27. Another case. (Suter.) Out of Strafanstalt.

4 Kreisschreiben.

I849-I 852. Unterstïtzungsgesuche. 38 cases of persons of good character.

1849. Mar. 21. Case of woman of criminal class, plea for support for transportation to America, on ground of being undesirable and little hope of improvement.

Similar plea for a family of undesirables.

1850, Feb. 20. “An Bürgermeister und Rath d. Kantons Basel-Stadt vom Departement des Innern wegen Unterstützung von Auswanderern." 5000 francs voted by the Swiss "Bund"; of this $2720 \mathrm{fr}$. paid in support of agency in Havre, I000 fr. to the "Schweizerische Hilfsgesellschaft in New York", I 280 for Basel and New Orleans.

Numerous papers relating to the beginnings of the emigration agencies.

Apr. 5. "Brief an Gebrüder Iselin, Basel, Beschreibung der 'Accomodations 'auf den transatlantischen Schiffen von Havre aus."

1852, Feb. I3. "Schreiben des Agenten V. Klenk wegen Fortschaffung von Flüchtlingen."

Acta concerning individual cases of emigrants (4).

"Die Auswanderer Fanilic Friedrich Vogt von Riehen." Subscriptionsliste [ $545 \mathrm{fr} ., 37$ names of contributors] zu ihrem Transport. Auswanderungsbureau Beck u. Herzog, Basel.”

"Acta betr. Auswanderungsagenturen. Gutachten. Beschwerden, etc. Gesetze."

"Acta betr. Besprechung der Vorschläge des Kantons Aargau wegen Auswanderungsbehörde. Entwurf eines Gesetzes."

1853, Mar. 30. "Missbrauch beim Abschluss von Auswanderungsaccorden." Apr. 20. "Gegen das Auswanderungsbureau Beck u. Ilerzog in Basel."

$$
\text { I 854-1863. }
$$

1854. "Gesuche zur Unterstützung zur Auswanderung nach Amerika." 32 calses.

I 854-I855, I857-I859. Kreisschreiben betr. Auswanderung. Anfragen, Gutachten, Agenturen betr., Aargau betr., etc.

1855. Acta über Auswanderung, Agenturen, Gesetze, etc.

Missbräuche: Anhäufung der Auswanderer in den Hafenstïlten Amerikas. Beschwerde der Vereinigten Staten über Strällinge to mittellose Personen. Kreisschreiben d. 19. Februar. Ermahnumgen.

1855-1863. A uswanderungs-Agenturen.

1856. Auswandermugsunterstiitzungsgestuche; 7 cases. In 1858,3 cascs.

1857. "Zweite Warnung der amerikanischen Gesandtschaft an Auswanderer."

1857-1858. "Das Justizkollegrium des Kantons Basel-Stadt in Sachen der Agenturen."

I858, June I I. "Joh. Dettwyler aus der Sträflingsanstalt, Gestattung zur Auswanderung nach Anerika, anstatt Versorgung nach Kalchrain ('Thurgau)." 
I860. "Beschwerden von Auswanderern nach Buenos Ayres gegen das Haus Beck u. Herzog und Barbe."

I86I. "Beschwerden gegen Auswanderungsagenturen."

I862. "Fahrten Billets nach dem Innern von Amerika."

$$
\text { I 864-I869. }
$$

I864. Acta. "Unterstützungsgesuche zur Auswanderung nach Amerika." I864-I869. Auswanderungsagenturen: Zwilchenbart, Rommel, etc.

I864-I 865. Polizeidirektion. Auswanderungswesen. Agenturen, etc.

I865. "Auswanderungsschiff William Nelson verbrannt." Liste der umgekommenen Schweizer.

I866. "Auswanderer-Reisekosten nach Buenos Ayres."

"Cholera auf den Dampfern England, Virginia, und Helvetia."

I 867. "Kreisschreiben über Auswanderungswesen", e. g., Sträflinge nach Amerika.

June I2. Rathsschreiben No. 20 I (I867).

I869. "Deutsche Gesellschaft von New York bietet ihre Dienste auch Schweizern an." Verlesen d. 20. Januar, I869.

$$
\text { I 870-1 } 880 \text {. }
$$

I870-1880. Auswanderungsagenturen. Anzeige der Namen; der Zeit d. Abreise. Printed material used by agencies: Zwilchenbart, Rommel, Baumgartner, Schmid, Werdenberg, Schneebeli, Brown and Co., etc. Klagen über Auswanderungsagenturen. Auskunft für beabsichtigende Auswanderer; auf Befehl d. Canadischen Regierung herausgegeben (printed pamphlet, without date). Bericht und Anleitung betr. die verschiedenen Reiserouten der Auswanderer nach allen Landungsplätzen (pamphlet, Basel, Zwilchenbart, i864).

I870-I880. Polizei-Direktion. Auswanderungsacten. Agenturen, Anzeigen. I873. Kreisschreiben, etc. Warnung gegen Auswanderung nach Bahià.

I870-I880. Kreisschreiben über Auswanderungswesen. Agenturen, Gesetze. Entwurf eines Bundesgesetzes betr. Auswanderungsagenturen ( 1875 ). Auswanderung von Krüppeln und Arbeitsunfähiger.

I879. "Auswanderung nach Uruguay."

$$
\text { I 88I-I } 884 \text {. }
$$

I88I-I884. Polizeidepartement des Kantons Basel-Stadt. Acten : Auswanderungswesen, Anzeigen, Agenturen, Übertretungen der Gesetze, Klagen, etc.

I88I, Apr. 5. "Amerikanisches Konsulat contra Verbringung von Dirnen nach Amerika." (Gemeinde Böttstein, Kanton Aargau, auf ihre Kosten 2 Dirnen nach Amerika spedirt.)

I88I-I884. Kreisschreiben. Agenturen. Gesetze. Übertretungen d. Gesetze. Klagen des Bundesrates gegen Agenturen, I882.

I882. Polizeidepartement Basel-Stadt. Objection to K. K. Kennan's methods of advertising emigration to Wisconsin. Acta: Question whether a violation of law against advertising emigration schemes. The following clipping illustrating $\dot{K}$.'s method is taken from Der Volksfreund aus Schwaben (Tübingen, Feb. I3, I883) : 
“Auswanderer! Die fünfte gemeinschaftliche Reise nach dem Staate Wiskonsin (Nordamerika), findet von Bremen aus, am 4. April, mit dem neuen Expressdampfer Elbe statt. Überfahrt von Bremen nach New York nur neun Tage. Auskunft betreffs Reisekosten ertheilt die Direktion des Norddeutschen Lloyd in Bremen. Werthvolle Karten und Broschüren über Wiskonsin sendet auf Verlangen gratis und portofrei der Commissär der Einwanderungsbehörde genannten Staates: K. K. Kennan in Basel, Schweiz."

188I-I884. Handels- und Landwirthschaftsdepartement. Verzeichnis der Agenten und Unteragenten, vom Bundesrat genehmigte Agenturen. Auswanderungsursachen.

$$
\text { I } 885-1896 \text {. }
$$

Kreisschreiben vom Bundesrat über Auswanderungssachen. Agenturen, Gesetze, Übertretungen der Gesetze, Strafen. II. Abth. Auswanderer. Auswanderungswesen.

Handels- und Landwirtschaftsdepartement, ïber Agenturen, Beschwerden, etc.

Polizeidepartement d. Kantons Basel-Stadt. Berichte, Agenturen, Ubertretungen der Gesetze. Report of Mar. 22, I889.

Schweizerisches Departement des Auswärtigen. Abtheilung: Auswanderungswesen. Übertretungen der Gesetze. Verzeichnis der Agenten. Large number of acta. Last accessible ones, of 1896.

Auswanderung B. AUSWANDERUNGSSTATISTIK, I8I7-I885.

"Nach Amerika ausgewandert": Lists of emigrants; names and birthplaces of men, women, and children; ages of each; date of permission to emigrate; anlunt of money in hand after deduction of debts; destination; date of leaving. Totals. Emigrants enumerated from each district of canton Basel.

"Sumnation der im Jahre I8I6 nach Amerika Ausgewanderten."

"Anregung vom Bundesrath, 2I August, I867, zu Tabellen der Auswanderungen."

\section{Handel und Gewerbe.}

V ı. Handel mit Nordamerika. ı828-ı 880. Handelsverhältnisse, Zölle. Verträge, Berichte, Gebühren, Waarenausfulır, etc.

I843, Sept. 15. "Visirming d. Fakturen aller nach Nordamerika versandten schweizerischen Waren durch die amerikanischen Konsuln in der Schweiz."

\section{KirCIIEN.}

K 25. Deutsch-Reformierte Kirche in Amerika. I826.

ı 826, Jan. 2r. "Collecte für die Nord-Anmerikanische Reformierte Kirche." 5 documents.

K 26. Reformierte Gemeinte in Carolina. I755.

"Memoriale E. E. Ninisterii wegen Anschaffung einiger Christl. Bücher für eine Reformierte cemeinde in Carolina." One document ; read Oct. 22. 
MILITÄr.

G 82. Militärpflichtersatz. I870- I880.

\section{Niederlassung.}

L Io. Nordamerika.

"Angehörige von Nordamerika und deren Heimatschriften überhaupt." I 869- I 882.

I 880, Feb. 20. "Militärpflicht der niedergelassenen Amerikaner."

R 2. Pässe nach Amerika. I854-I86I. Passrevision der amerikanischen Consuln.

\section{Post.}

S6. Postverhältnisse mit Amerika. Amerikanische Correspondenz. I803I874.

\section{ABTEILUNG EHE- ODER WAISENGERICHT. ${ }^{1}$ Waisengericht Akten.}

1818. "Erbschaften betr., mit vielen Schriften von und über schweizerische Ansiedler in America." From Philadelphia, I817; Lancaster, Ohio, 1818; Charleston, S. C., I819.

Letters: I8I8, May I I, from Swiss settler about 50 miles from Baltimore. I8I9, Mar. 20, from Swiss settler near Hanover, Pa. I826, Oct. I2, from Swiss settler 4 miles from Hanover. I826, June I2, from Swiss settler near Cincinnati, O. I827, Mar. I, from Swiss settler in Pennsylvania, 7 pages. I829, Feb. 26, from Swiss settler in Schöneck, near Nazareth, Pa. I829, Feb. 26, from Swiss settler, Lancaster, O.

All these letters speak very favorably concerning conditions in America.

Documents relating to inheritances ; certificates of death ; accounts of property; relationships established; power of attorney given.

The emigration bureaus of Basel, such as the long established houses Zwilchenbart, and Rommel and Co., have not preserved their archive materials. The Iselin family of Basel (originally from Rosenfeld, Württemberg) has several important branches, among them the American, of which Adrian Georg Iselin (1818-1905) was the founder. Cf. Heinrich Iselin von Rosenfeld, und sein Geschlecht, zusammengestellt und bearbeitet von Fried. WeissFrey (Basel, I909).

\footnotetext{
${ }^{2}$ Not yet arranged.
} 


\section{CANTON BASEL-LANDSCHAFT.}

\section{LIESTAL：STAATSARCHIV.}

Location: The "Staatsarchiv des Kantons Basel-Landschaft" is located in the "Regierungsgebäude" of the city of Liestal, the capital of the half-canton.

After the separation in 1832 of the country from the city, the records and documents which concerned Basel-Landschaft alone were brought to Liestal, constituting the "Altes Archiv"; the materials collected since then make up the "Neues Archiv". A good summary of the contents of both has been published: Das Staatsarchiv des Kantons Basel-Landschaft, Archivplan (Liestal, 1907, pp. 34). The materials relating to American history are scant and unimportant. In the Neues Archiv, B 4: Justiz und Polizei, see under " (d) Auswanderungen: Werbungen". 


\section{CANTON SCHAFFHAUSEN.}

\section{SCHAFFHAUSEN：STAATSARCHIV.}

Location: Staatsarchiv (cantonal archive) in the Rathaus of Schaffhausen. Hours: 8 a. m. to 12 m.; 2 to 6 p. m.

Bibliography: Register zu den Akten der Gesetzgebungs- und Verwaltungsbehörden [to I890] (Schaffhausen, 3 vols., I882-I892).

\section{Raths Protokolle.}

I734, Oct. 8. Henrich Vogel, Küster, Weib und 2 Kinder. Auswanderungsgesuch (Arbeit und Nahrungsorge) erlaubt, und Beysteuer von 20 fl. aus Säckelamt erlaubt, "solche ihne aber erst in einer Statt in Holland zugestellt werden solle".

I735, Jan. 3. Carolina Engl. Provintz. "Von diesem Orth nichts zu drucken oder zu verkaufen."

"Dass nichts in die Zeitungen komme, welches die Leuth dahin zu gehen gelüstig machen möchte."

I735, Mar. I4. "Dahin begehrende Landleuth abzumahnen."

I735, June 20. "Jacob Pfeiffer von Neunkirch, welcher vor etwas Zeit den Forstknechtdienst aus unbegründeter Hoffnung in Carolina sich glücklich zu machen, aufgegeben, nun aber ihme solchen wider in Gnaden anzuvertrauen gebetten, ist hierin zwar in Gnaden entsprochen, er aber auf ein halbes Jahr der Besoldung verlustig erkannt."

I737, Jan. 2. "Hans Conrad Speiszegger, Orgelmacher, von seiner vorhabenden Reise nach Carolina zu dehortieren."

Oct. 3. "Nachdem H. Göpfert und Thebis Rüger von Meriszhausen, wie auch Jakob und Andreas Steinimann von Opfershofen, um permission in die Provinz Carolinam ziehen zu dürfen, bittlich angehalten; ist ihnen in bescheyd ertheilt, dass ausz vielen bedenklichen $\mathfrak{u}$. mehrentheils ihnen selbst eröffneten Ursachen die permission nicht gegeben werden könne, sollten sie aber dessen ohngeachtet fortgehen, so seyen sie eo ipso ihres Landrechts verlustig, auch vorhin der Abzug zu bezahlen, und ihre Creditores zu befridigen, gehalten."

Oct. 29. "Derjenige Kauf, welcher dato zwischen Hans Göpfert von Meriszhausen und Hans Weber daselbst vorkommen, ist zwarn Rechtl. gefertiget: weilen aber Verkäufer nach Carolina zu ziehen, ohnerachtet allen abmahnens, resolviert bleibet, dem Käufer den Kaufschilling an Hrn. Ober 'Vogt Hardern zu bezahlen, anbefohlen, ermeldtem Hrn. Ober Vogt aber aufgetragen worden, die Veranstaltung zı machen, dass vor allen Dingen des Göpferten Creditoren befriediget, die auf dem. Lehen stehende Restanz entrichtet, und von seinem übrig habenden Mittlen, welche er ausz dem Land ziehet, der Abzug erstattet werde." 
I738, Nov. 7. " Nachdem Hr. Ober Vogt Harder berichtet, wie denen nach Carolina reisen wollenden Meriszhausern u. zwar dem

Thebis Rüger, Wagner, etwa zu........... $300 \mathrm{fl}$. dessen Sohn ........................ 50 "

Hans Dunklen ...................... I05 “

Peter Straaszer ...................... 234 “ und Hans Göpferten, dessen Kauf, weil Käufer, nicht bezahlen können, aufgehoben und das Lehen einem andern überlassen werden müssen, wan er von einem andern gleichviel löste.......... 275“

nach bezahlung ihrer passivorum (Schulden) übrig bleibe, welche aber sammtl. um. Gnl. Nachlasz des Abzugs bitten, ist diszfalls sie ohne Erkanntnusz conivendo zu entlassen resolviret worden."

174I, Mar. I5. "Weillen Hans Jakob Pfeiffer von Neunkirch, in Pennsylvanien zu ziehen nicht nur resolviert, sondern auch auf Vorbieten anstatt künftigen Kreuztag zu erscheinen, sich heut morgen mit Weib und Kindern würklich auf und davon gemacht, alsz solle er für sich und die seinigen desz gehabten Landrechts verlustig sein, sein Name in der Bürger Rodel zu Neunkirch ausgestrichen, und wann noch etwas von seinem Vermögen daselbst zu finden, solches von Hrn. Landvogt zu weiterer Versorgung in Verwahr genohmen werden."

\section{Mandatenibuch.}

1738, Sept. 8. Actum vor gesessenem Rath.

Mandat betreffend die nach Carolina ziehen wollende Unterthanen. (Loss of Landrechts, refusal of readmission in case of return.)

1748, July 12. Actum.

Mandat wegen der vilen Emigranten. (Threat of refusal of permission to dispose of property before emigration, loss of Landrecht, refusal of readmission on return.)

175I, Jan. 25. Actun.

Mandat auf die Landschaft. "Keinen ausz Carolina oder Pennsylvania kommenden hiesig gewesenen Underthanen noch freunden underschlauf (Herberge) zu geben."

\section{Gutachten u. Berichite von Anno i8i5 bis isiz.}

No. 79. "Die Behandlung der Auswanderer nach Amerika betreffend." June 5, I8I7. If emigrants insist on going, they must show that they are in possession of the means to make the journey, $i . \mathcal{c}$., for a person between 4 and $\mathrm{I}_{4}$ years, 85 fl., and for adults $\mathrm{I}_{5} \mathrm{fl}$. This to prevent paupers gathering at the seaports.

Protokolle des Kleinen und Grossen katils, i8i6-i8i7. Acceptance of "Gutachten" above. Ju1ne 6, 1817. I'. 341 .

III. Auswanilikung uni Nimbrtassunti. i870-1874.

1870. No. 2. Auswanderung der Elisabeth Waldvogel.

No. 5. Entziehung d. Patente von Auswanderungsagenturen.

No. 6. Agenturen in Basel. Brown und (o. 
I87 I. No. 2. Auswanderungsagenturen. Rommel und Co., Basel.

No. 6. "Controle" über die Auswanderung.

I872. No. 4. Gegenstand: Brasilien. Warnung vor der Auswanderung.

No. I2. Auswanderungsagentur des Hauses Andr. Zwilchenbart in Basel.

No. I6. Controle über die Auswanderung.

Nos. 6, 8, 9, I2. Auswanderungsagenturen.

I874. No. 5. Controle über die Auswanderung.

III. Auswanderung und Niederlassung.

$$
\text { I875-I878, I879-I880, I88I-I883. }
$$

Auswanderungsbewilligungen, Agenturen, Controle über die Auswanderung, Ausweisungen ausser Landes.

1876. No. 2. Auswanderung nach Brasilien. Warnung vor Auswanderung nach Venezuela.

1877. No. 2. Reisebeitrag nach Amerika für Schreiner Lang.

I878. No. 5. Protest gegen die Spedition des Jakob Zimmermann nach Amerika. (Large number of acta.)

I879. No. I. Auswanderung der Familie des (Sträflings) Martin Bächthold.

Unterstützung und Rückkehr. Ausweisungen ausser Landes.

No. 6. Controle der Auswanderung.

I880. No. 8. Tabellen für I880.

I88I-I883. Ausweisungen, Controle der Auswanderungen.

AMERIKA. I880-I889.

No. I. I880-r883. Gegenstand: Amerikanische Pensionen. (8 cases.)

No. 2. r $88 \mathrm{r}$. Erbschaftssachen und Informationen betreffend.

No. 3. 1882. Id.

No. 4. I883. $I d$.

No. 5. I884. Erbschaften und Unterstützungssachen betreffend.

No.6. r884-r889. "Pensionsbezüger." (7 cases.)

Among items derived from printed materials may be mentioned:

Offizielle Sammlung der Gesetze und Obrigkeitliche Verordnungen des Kantons Schaffhausen, VII. Heft (I824), pp. I I-I2.

IV. Verbott gegen das leichtsinnige Auswandern (ohne Hülfsmittel). Gegeben d. I3. Juni, I817. Canzley des Kleinen Raths.

Offizielle Sammlung der fïr $d$. cidgenöss. Stand Schaffhausen bestehenden Gesetze, Verordnungen, und Verträge, N. F., I. 441-442. "Verordnung, die Agenturen betreffend." Schaffhausen, Aug. 23,1854 .

N. F., IV. x7-18: "Regierungsbeschluss, betreffend die staatliche Controle der Auswanderung." Schaffhausen, Sept. 25, I867.

Chronik der Stadt Schaffhausen, called Harder Chronik (Schaffhausen, I844). See V. I20, I26, 127, 139.

I738, Sept. 8. " Im Juni wanderten viele arme Leute aus den umliegenden Orten, namentlich von Merishausen und vom Reiat nach Carolina in Nord Amerika aus. Als sodann auch 'einige Unterthanen zu Rüdlingen und Buchberg den unzeitigen Schluss gefasset, aus ihrem Vaterlande. hinweg und in weit entlegene Länder zu ziehen und sich also vielem Ungemach, ja dem äussersten Elend auf eine unbesonnene Weise und zu ihrer allzuspäten 
Reue zu exponiren', schritt die Regierung ein, und verbot das Auswandern bei Verlust des Landrechts."

I748, July I2. " Gegen das Auswandern ' in weit entlegene Länder' erliess die Regierung wieder ein Mandat, und zwar insbesondere zu Handen der Gemeinde Unterhallau."

I75I, Jan. 25. "Die auf die Auswanderung gesetzte Strafe des Landrechts-Verlustes wird über mehrere aus Karolina und Pennsilvanien zurückkehrende frühere 'Landeskinder' verhängt."

I75I, Mar. 5. "Am 5. März wurde verboten, den Auswanderungslustigen ihre Liegenschaften abzukaufen."

1770. "Der grossen Noth wegen waren einige Familien von der Landschaft nach den preussischen Ländern ausgewandert und eine grosse Anzahl schickte sich an, ihnen zu folgen, wurde aber durch obrigkeitliche Maszregeln gezwungen zu bleiben." 


\section{CANTON APPENZELL INNER-RHODEN.}

\section{APPENZELL: STAATSARCHIV.}

Location: The cantonal archive is located in the church.

In the cantonal archive of Appenzell Inner-Rhoden, the manuscript material is indexed from the fourteenth to the sixteenth centuries, but not beyond. By a decree of I 597 Appenzell I. Rh. was to accept as citizens all the Catholics of the other half-canton, Appenzell A. Rh., while the latter agreed to take all the Protestants of Appenzell I. Rh. The emigration from Appenzell has not been large. Some few families are known to have come to the United States, $e$. $g$., families of the names Linherr, Signer (I850-I85I), Kolbener, and Hershey. The ancestor of the Hershey family (who settled in Lancaster Co., Pa., in the eighteenth century), was Hans Hersche, a Mennonite, of Appenzell. Cf. History of the Hershey Family from the Year I60o, by Scott Funk Hershey (New Castle, Pa.). Representatives of the family in Appenzell preserve the original spelling of the name.

Several volumes of lists of "Heimatscheine" exist, but give no clue as to possible emigration to America. A curious circumstance is the recarding not only of the family and surname, but also of the familiar name (Spitzname), as: Unterhuslebube, Zünglershanesli, etc. 


\section{CANTON APPENZELL AUSSER-RHODEN. (TROGEN.) HERISAU: STAATSARCHIV.}

The cantonal archive is divided between the two towns Trogen and Herisau. The materials pertaining to the courts (Gerichtssachen) are deposited in Trogen, as also the old historical materials, which, however, are not indexed, and are not in condition to be examined. The materials pertaining to the administration of cantonal affairs (Verwaltungssachen) are deposited in the capital city, Herisau. They are located in the city church. The archive is the proud possessor of one of the two extant copies of the Sachscnspiegel. The material pertaining to American history is all recent, $i$. e., since $\mathrm{I} 850$, and consists for the most part of circular letters sent from the Bundesrat at Bern.

\section{Fascikel I. Ausländscie Stahten.}

A. Amerika. I86I-1893. Kreisschreiben von Bern, Bundesrat u. Departement des Auswärtigen.

\section{Fascikel XXYVit. Auswanderungswesen. No. il 4.}

Walzenhausen. "Pfarrer Keller empfiehlt die Einführung von Auswanderungsbïchern." June 27, 1850 .

Bemerkingen darüber. Aug., I850.

Auswanderungsagenturen. June $1,1852$.

Aarau. Gutachten über Auswanderung. June 2, I 854.

Bundesrat. Warnung über Auswanderung. Mar. 2, 1857.

Memmingen. "Der Stadtmagistrat ersucht das Polizeiamt Herisau, einer dortigen Betrügerin für Weisung und Beistand bei ihrer Auswanderung nach Amerika zu sorgen." Apr. 6, I857.

Bundesrat, Bern. Mitteilungen über das Auswanderungswesen. June, July, I 857 .

"Erhebungen in den Gemeinden betr. Auswanderung in den letzten 3 Jahren." Aug., Sept., 1857.

Gais. "Synode des Kantons Appenzell A. Rh. über die Führung des Auswanderungsbuches." (Controlle.) Nov. 22, 1858.

Kreisschreiben des Bundesrats in Bern über Answanderungssachen. I865I 885 .

Herisau. Bericht v. Etzweiler-Merz, über Auswanderungsagentur. JulyAug.. I 881 .

Herisau. Ratsschreiber Engwiller. Bericht und Antrag über Aufsicht über die Auswanderumgsagenturen. Aug. 2, I 888.

Kreisschreiben des Bundesrats in Bern über Auswanderungssachen. 1889I 898.

Printed Matter: Amtsbläter des Kantons Appenzell A. Rh., since I834. (With inclex.)

Rechenschaftsberichte des Regierungsrats an den Kantonsrat von Appenzcll A. Kh. (Fifty-third report in $191 \mathrm{I}-1912$; see index.) 


\section{CANTON SANKT GALLEN.}

\section{SANKT GALLEN: STAATSARCHIV.}

Location: The cantonal archive is located in the Regierungsgebäude (bei der Stiftskapelle), in the same quarters as the Staatsbibliothek des Kantons Sankt Gallen.

Hours: 9 a. m. to $12 \mathrm{~m} . ; 3$ to 6 p. m. Permission for use is obtainable from the state archivist.

The archive contains material since 1803 , the date of the founding of Sankt Gallen as a canton.

\section{Rubrik 45. Fascikel: Amerikanische Staaten.}

Árgentinien (La Plata Staaten mit Paraguay u. Uruguay). I858-rgo8.

Brasilien. I825-I833; I840-I844; 1905 .

Chile und über Spanisch Amerika. I867-I88I.

Hayti. 1857 .

Mexiko und Central Amerika. I825-1884.

Vereinigte Staaten von Nordamerika. I824-I908. Kreisschreiben der Vororte und später vom Bundesrat, Bern. Consularberichte, Erbschaften, Handelsverkehr mit Nordamerika, Handels- und Auslieferungsvertrag, etc.

Rubrik ioo. Fascikel i. Zeitraum i803- .

I. Auswanderungswesen im Allgemeinen.

2. Auswanderung nach Algerien.

$3^{a}$. Auswanderung nach Nordamerika.

I8I 7. Warnung gegen Auswanderung nach Nordamerika.

I817, Feb. 28. Typical contract for transportation, of 587 emigrants, on 3 ships, Amsterdam to Philadelphia. Rates:

\begin{tabular}{|c|c|c|c|}
\hline & $\begin{array}{l}\text { Those who } \\
\text { pay in full at } \\
\text { Amsterdam. }\end{array}$ & $\begin{array}{l}\text { Those who } \\
\text { pay } \frac{1}{1} \text { at Phila- } \\
\text { delphia, at at } \\
\text { Amsterdam. }\end{array}$ & $\begin{array}{l}\text { Those who } \\
\text { pay in full at } \\
\text { Philadelphia. }\end{array}$ \\
\hline Adults, men or women: & I 70 francs & I 85 francs & I9o francs \\
\hline $\begin{array}{cl}\text { Children } & \text { under } 4: \\
" & \text { from } 4 \text { to I } 4: \\
\text { " } & \text { I4 and over: }\end{array}$ & 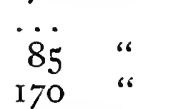 & $\begin{array}{l}\cdots \\
92.10 “ \\
185\end{array}$ & $\begin{array}{r}\cdots \\
95 \\
190\end{array}$ \\
\hline
\end{tabular}

Daily bill of fare given in detail in the contract.

I820, Oct. 9. "Regierung über die Colonie in Amerika so Hauptmann May zu errichten sucht. Über Colonisten Werbung an dem Rothen Fluss, in Nordamerika durch Hrn. Hauptmann May von Bern. Antrag d. Hauptmanns abgelehnt, Werbungen in diesem Kanton auszuüben. (Ungewissheit der Erfüllung der Versprechen; zu weit nördlich, d. i. Hudson Bay; wenn indessen Kantonsbürger aus eigenem freien Willen Lust und Neigung haben, dahin zu ziehen, so soll denselben keine Hindernisse gemacht werden.)" See under Neuchâtel. 
I832. Sämtliche Kreisschreiben von den Vororten Luzern, Zürich, Bern.

I869, Mar. I2. "Auswanderung nach Chicago, trügerische Verlockung durch Inserat im Tageblatt St. Gallen v. Casper Pfeiffer." (A copy of his article, which contains statement concerning high wages paid in Chicago.)

I880, Dec. I 5. Neues Auswanderungsprojekt. Harlan u. Bell counties. Kentucky.

3b. Auswanderung nach Brasilien u. Süd Amerika. I8I8-I888.

\section{Fascikel 2. Auswanderungsagenten.}

No. I. Allgemeines. Zeitraum 1849- .

No. 2. Individuelles. Zeitraum I849- . Kreisschreiben. Processacten.

I 854. "Processacten gegen Josepl Rufli von Siszeln, Kanton Aargau. (Rufli, Spediteur, der 24 Auswanderer nach Amerika befördern sollte, in folge dessen Insolvenz ein Theil der Überfahrtskosten vom Staat bestritten worden.)"

Auswanderer aus den Kanton Sankt Gallen.

Auswanderer aus dem Bezirk Werdenberg-in Havre, Unterstützung.

Auswanderer aus dem Bezirk Werdenberg-in Havre, Unterstützung zur Überfahrt.

Auswanderer aus dem Bezirk Grabs, Rückvergütıng für Reiseunterstützung.

\section{SANKT GALLEN: STIFTSARCHIV.}

Location: In the same building as the famous library of the abbey (Stiftsbibliothek), $i$. e., in a wing of what is now the cantonal Regierungsgebäude. The privilege of using the materials is granted on application to the archivist. The materials desired may be sent to the Staatsarchiv, where it is more convenient to work.

Rubrik X. Gemein-eidgenössische Bundesangelegenheiten.

Polizeiliches. Zeitraum 1 $767-1-69$, I 770 .

Fascikel 15. "In Schwabenland angeworbene Emigranten für die neuen spanischen Kolonien." Swabian emigrants seeking passage through Zürich are refused permission to pass through that territory. Bürgermeister and Rath of the town of Zürich address Abbot Beda of St. Gallen, asking whether it be not desirable to give them no advantage and to send them back. $\lambda_{\mathrm{pr}}$. I, I 768 .

Printed circular from Bern repeating order of Feb. 24, I 769 , forbidding passage of recruits through country. Mar. 6, I770.

Printed circular from Luzerm. Passage allowed only under restrictions; danger of citizens being carried along. Mar. 26, I770.

\section{ST. GALLEN: ARCHIV DER STADTGEMEINDE.}

Location: In the Rathaus (St. Lconhardstrasse).

"Notizen oder Verzeichnis hiesiger bürgerlicher Personen, die grössentheils unter meiner (i.c., J. M. Scheitlin, Präsident d. Verwaltungsrates) Mitwirkung mach Amerikis ausgewandert sind." I $846-$ 1853. 
"Verzeichnis der im Jahre 1854 aus der Stadt Sankt Gallen ausgewanderten Personen." ( 28 persons, all to America.)

Id. I855. (I 5 persons.)

Id. 1856. ( 8 persons.)

Id. 1857 . (I4 persons.)

Id. 1858. ( 6 persons.)

Id. I859. ( 4 persons.)

Id. I860. ( 9 persons.)

Id. 1862. ( 9 persons.)

Another rise in the number of emigrants from St. Gallen occurred after I880.

\section{SANKT GALLEN: STADTARCHIV.}

Location: In the new building of the Stadtbibliothek (Vadiana), on the Notkerstrasse.

Hours: 8 a. m. to 12 m.; 2 to 4 p. m.

The older section of the "Archiv des Kaufmännischen Direktoriums Sankt Gallen " (beginning with 1830 ) is deposited here.

Handlungs-Sachen überhaupt. I830.

Handlungs-Sachen überhaupt, Amerika betreffend. I831-I 835, I836-1838.

See also “Archiv des Kaufnännischen Direktoriums", below.

"Verzeichnis der hiesigen Ministerii, d. i. aller Herren Prediger der Stadt Sankt Gallen von Zeit der Reformation bis zum Jahre I 799, nebst alphabetischem Register."

This valuable collection of records and biographical material on the Protestant ministers of Sankt Gallen, containing also a large quantity of letters of the Swiss reformers, including Zwingli, was removed from the church to the safe-keeping of the Stadtarchiv. No. I8o, etc., contain records concerning Michael Schlatter, in detail: birth (1716), education, graduation (1739), vicarship in Thurgau, flight to America (1746); visit to Sankt Gallen (I750) ; attempt to procure ministers of the Reformed Church for Pennsylvania; return to America ( $175 \mathrm{I}$ ).

The Stadtbibliothek contains a collection of books (mostly not rare) on America, among them a copy of Michael Schlatter's Wahrhafte Erzehlung (Frankfurt a. M., I752), for full title of which see p. I9, above.

\section{SANKT GALLEN: ARCHIV DES RAUFMÄNNISCHEN DIREKTORIUMS.}

Location: Near the Stiftskirche. Permission to use the materials of the archive can be obtained on application. The publications of the Direktorium are thoroughgoing, the principal ones being the following:

(a) Dr. Hermann Wartmann (Aktuar des Kaufmännischen Direktoriums, 1863-1913), Industrie und Handel des'Kantons Sankt Gallen auf Ende I866 in geschichtlicher Darstellung (St. Gailen, 1875).

This is the pioneer work, which stimulated similar efforts in other cantons, e. g., Jenny-Trümpy, Handel und Industrie des Kantons Glarus (Glarus, I898); Berichte des Schweizerischen Handelsund Industrie-Vereins (Zürich, new series from I874); T. Geer- 
ing, Handel und Industrie der Stadt Basel: Zunftwesen und Wirtschaftsgeschichte bis zu Ende d. I7. Jahrhunderts, aus den Archiven dargestellt (Basel, 1886).

(b) Berichte des Kaufmännischen Direktoriums über Handel, Industrie und Geldverhältnisse des Kantons St. Gallen.

These reports are annual, and go back to 1844 . The exports of embroideries, laces, and cotton and silk weavings are largest to the United States, though there has been a falling off in the last years. ${ }^{1}$ Even so, the U. S. is St. Gall's best customer. In 1910 the exports to the U. S. amounted to over $83,000,000$ francs, in 19II, over $79,000,000$ francs.

(c) Die Kaufmännische Corporation und das Kaufmännische Directorium in St. Gallen in den Jahren I9oI-19Io (St. Gallen, I913).

(d) Verwaltungsberichte des Kaufmännischen Direktoriums an die Kanfmännische Corporation in St. Gallen, 1891-1900, pp. 22-27; $1897-$ I898, pp. I-8; "Zollkrieg mit New York" (Dingley Bill). 'These reports are published annually.

${ }^{1}$ Cf. Schweizerische Blätter für Handel u. Industrie, XX. Jahrgang, pp. 278-280; Dr. H. Beerli, "Der Stickerei-Export im ersten Quartal I9I3." 


\section{CANTON GRAUBÜNDEN (GRISONS).}

\section{CHUR: STAATSARCHIV.}

Location: The "Staatsarchiv des Kantons Graubünden" is located in the Regierungsgebäude (Regierungsplatz) of the capital city, Chur. The archive is not in good condition, but the work of rearranging the large stores of manuscripts, indexing them, and making them accessible, has been begun. Judging from the large amount of material on emigration found in the Stadtarchiv in Chur, it would seem likely that more material relating to American history is contained in this cantonal archive than is accessible at present.

Hours: 9 a. m. to $12 \mathrm{~m}$.; 3 to 6 p. $\mathrm{m}$.

\section{ACTA.}

Freizügigkeitstraktate mit dem Nordamerikanischen Freistaate. Kreisschreiben an sämtliche eidgenössische Stände. I833-1834.

Italienische Flüchtlinge von 1848 , I849, I850.

Politische Flüchtlinge und Conscribierte aus Italien. I870-1873.

Auswanderung nach überseeischen Ländereien und den erlebten Erfahrungen mehrerer Bündnerfamilien. (Bundle of papers.)

Nach Brasilien, I857-1859. Die Schweizer auf der Kolonie in St. Paolo in Brasilien. Auswanderung nach Brasilien betr. Überfahrtsverträge. Vorschüsse an die Halbpachtkolonisten des Hauses Vergueiro et Cie. in Brasilien betr. Anzeige und Weisung betr. Oct., 1860 .

\section{CHUR: STADTARCHIV.}

Location: The Stadtarchiv is located in the Rathaus (Obere Reichsgasse), an old building in the oldest section of the city.

Hours: 8 a. m. to $\mathrm{I} 2 \mathrm{~m} . ; 2$ to $6 \mathrm{p} . \mathrm{m}$.

\section{B. 3. Auswanderung: i844-I852; i853-1867.}

Two bundles of acta, mostly petitions for financial aid in defraying transportation expenses incident to emigration. A number of typical examples are given below, the minutes pertaining to them being quoted in full :

RATSPROTOKOLLE. “GESUCHE UM UNTERSTÜTZUNG ZUR AUSWANDERUNG NACH NORDAMERIKA."

I845, July 3 (pp. 400-40I) : “Es wird eine Einlage von Andr. Kron, Sohn, hiesigem Angehörigen, verlesen, womit derselbe die Absicht ankündigt, samt Kindern, Vater, Schwester, und Stiefmutter (I I Personen) nach Amerika auszuwandern u. damit das Gesuch um ein angemessenes Reisegeld verbindet. Der Herr Amtsbürgermeister fügt bei: er habe vernommen, dass je nach dem Schick- 
sal, welches diese Bittschrift haben werde, noch eine Anzahl anderer Angehörigen dem Beispiel des Petenten folgen würde.

"Die Versammlung, zumal im Hinblick auf die Eröffnung des Präsidiums, die Wichtigkeit der Angelegenheit erkennend, beschlossen : dieselbe, und zwar insbesondere in dem Sinne vor die Behörde von Rath und Gericht zu bringen, dass darüber die Berathung gepflogen werde, wie namentlich anch die katholischen Angehörigen zum Fortreisen bewogen werden könnten? Zugleich wurde, um den diesfälligen Berathungen besagter Behörde eine Grundlage zu geben, die Vorberatungs-Kommission beauftragt, vorerst nachzuforschen, welche Angehörige sonst noch nachzureisen Willens wären."

July 25. Wurde erkannt: "Eine besondere Commission von 3 Mitgliedern auszuschiessen und zu beauftragen, die Verhältnisse der betreffenden Auswanderungslustigen näher zu untersuchen und sowohl mit den Übernehmern als mit andern zuverlässigen Personen, die mit der Lage und andern Umständen in Nordamerika bekannt sind, Rücksprache und Correspondenz zu pflegen und sich über alles darauf bezügliche hinlängliche Auskunft zu verschaffen, -sodann einen umfassenden Bericht nebst Gutachten einzureichen." Zur Commission wurden ernannt: (I) Herr Bürgermeister, (2) Stadtrichter, (3) Altstadtvogt.

\section{RATHSPROTOKOLLS-SBOZZO ${ }^{1}$ VON I844-I 845 .}

729. "Aufstellung einer Commission für die Auswanderung nach Nordamerika."

752. Bericht: "Zur Auswanderung hätten sich 5I Individuen gemeldet, wovon 30 ausgewachsene, 2 I unausgewachsene, I I bürgerliche $u$. 40 angehörige, unter welchen letzteren 2 katholische Fanilien seien. Die Vermögensverhältnisse aller seien derart, dass sie nach Abzutg der Schulden, sämtlich nichts behielten, ausser das Guthaben, das mehrere Angehörige an ihrer Versorgungskasse haben. Unter solchen Umständen, da die Auswanderungslustigen nicht nur für die Reise, sondern auch für die Ansiedelung und das weitere Fortkommen in der neuen Welt, wofür man dann doch auch zum Voraus besorgt sein sollte, so zu sagen, nichts beitragen könnten, sei die Commission eben im Begriff gewesen, einen abmahnenden Antrag an die Behörde zu bringen, als dieser Tage eine Abordnung der Tennessee Colonisationsgesellschaft, welche mit Gründung einer Colonie im nordamerikanischen Staate Tennessee umgehn, erschienen sei und, unter Vorweisung eines diesfälligen Prospelits und sehr vorteilhafter Zeugnisse, äusserst günstige Ant räge, sowohl bezüglich des Transports als der Ansiedlung selbst gemacht hätte, wonach die Transportkosten für eine erwachsene Person bis auf Ort und Stelle circa fl. Io8 R. W., für Kinder noch billiger, zu stehen kämen, und jede Familie unbebautes Land bis zum Belauf von 200 Acker zu $37 \frac{1}{2}$ Kreuzer per Acker erhalten könnte. Nach den Eröffnungen jener Abgeordneten wïre die Kolonisationsgesellschaft zudem erbötig, den Auswandernden den Kaufpreis fürs Land bis zu dem $5^{\text {ten Jahre }}$

${ }^{1}$ Sbozzo, from Ital. sbozzare, to outline; Protokolls-Entwurf. 
zu kreditiren, sowie den Auswandernden, sei es zur Überfahrt, sei es zum Bodenankauf von der Stadt gemachte Vorschüsse durch ihre Agenten später wieder einzuziehen, sodass es dannzumal der Stadt frei bliebe, das zurïckbezahlte, wenigstens teilweise, zu beliebigen Auswanderungszwecken zu bestimmen.-Was die Auswanderungslustigen selbst betreffe, so seien die meisten von ihnen in Falle, durch ihre Arbeit, sei es als Handwerker, sei es als Landbatter, fortzukommen. Da num die von dieser Tennessee Kolonisationsgesellschaft gestellten Bedingungen billiger seien, als sie sonst anderswie erhältlich wären und überdies den Vorteil gewährten, dass damit für das weitere Fortkommen des auswandernden Individuum gesorgt würde, auch nach dem persönlichen Eindrucke der hier anwesenden Herren Abgeordneten sowohl, als nach ihren Ausweisschriften, durchaus Grund sei, an die Solidität der Gesellschaft zu glauben, habe die Conminssion geglaubt, darauf antragen zu sollen, dass vorerst beschlossen würde, auf die Anträge der besagten Gesellschaft einzugehen, und die Auswanderung in diesem Sinne möglich zu machen und sodann eine Commission daniit zu beauftragen, unter Ratifikationsvorbehalt, das genatuere sowohl mit der Gesellschaft als mit den auswanderungslustigen Individuen festzusetzen. Beschlossen :

"Den Antrag der Commission zu genehmigen und zwar so, dass schon diesen Herbst einige wenige gleichsam versuchsweise nach Tennessee abreisen sollen, um bis nächsten Frühling das genauere darüber berichten zu können, auch solle, was die Angehörigen in der Versorgungskasse besitzen, nicht zu Bestreitung ihrer Reisekosten, sondern zum Ankauf von Land verwendet werden. Mit der zweiten Ausführung dieser Sache nach dem Antrage der Commission immer aber unter Vorbehalt der Ratification wurde sodann die bestehende Commission beauftragt," etc. Aug. I5, I 845 .

763. "Dem ihr gewordenen Auftrage nachkommend, habe die Commission vorerst die Auswanderungslustigen gefragt, wer von ihnen zur Abreise mit dem ersten Transport (v. I-IO. Sept., I845) bereit wäre? Und als sich hierzu beinahe alle bereit erklärt, habe die Commission unter ihnen eine Auswahl treffen müssen, welche sie denn teils auf diejenigen Individuen zu lenken gesucht, welche den Bodenankauf möglichst aus eigenen Mitteln, nämlich aus ihrem Guthaben an der Versorgungskasse zu bestreiten vermöchten, teils auf diejenigen, welche während des Winters, besonders wegen zahlreicher Kinder, hier am schwersten fortkommen könnten. Hiernach habe sich dann für die sofortige Auswanderung eine Anzahl von 5 Familien bestehend aus 24 Individuen gefunden, nänlich, die Familie von Andreas Kron, Sohn, bestehend aus 9 Köpfen, diejenige von Joseph Vollmer best. aus $6 \mathrm{Köpfen,} \mathrm{kathol.} \mathrm{Confession,} \mathrm{diejenige} \mathrm{von} \mathrm{Christ.} \mathrm{Brei,}$ best. aus 3 Köpfen, diejenige von Simon Schmid, best. auts 3 Köpfen, und endlich diejenige von Ciprian Fischer (Färber), ebenfalls 3 Köpfe zählend. Dem letzteren aber, der nur auf sehr dringendes Verlangen mitgelassen worden, habe man, in betracht der höchst geringen persönlichen Gewehr, welche er zu bieten im Fall ist, erklärt, es geschehe dieses nur unter der Bedingung, dass 
er eine genügende Bürgschaft stelle, welche im Fall, dass er zurückkehren sollte, den ihm gemachten Vorschuss wieder erstatte. Überdies mache die Commission den Antrag, dass insofern ein diesfälliger Grundsatz von der Bürgerversammlung beliebt würde, dass durch die Abreise des Simon Schmid ledig werdende Gemeingut von der Stadt etwa 5 Jahre lang beibehalten werde. um mit dessen Erlös sowohl die dem Schmid als dem Fischer gemachten Vorschüsse zı Ankauf des Bodens zı decken. Was die mit diesem Transport abreisenden betreffe, so besässen sie sämtlich in der Versorgungskasse so viel als zum Ankauf des Bodens erforderlich seie, nämlich

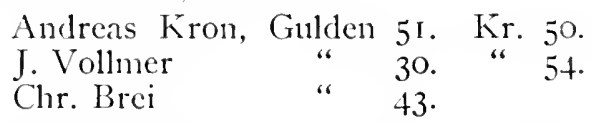

"Auf solche Weise belaufe sich die gesante der Stadtkasse zur Last fallende Ausgabe zu gewusten obigen 24 auswandernden Indiviluen, sowohl für die Reise als für den Bodenverkauf, auf Gulden 2304, Kr. 15, R. W. Den Transport derselben übernehme die Kolonisationsgesellschaft von Wallenstadt weg bis an Ort und Stelle, worüber die lier anwesenden Agenten bereits einen Schiffsakkord entworfen hätten. In Gemässheit des ihr gewordenden Auftrages habe dann die Commission auch den zwischen löblicher Stadt und der Colonisationsgesellschaft abzuschliessenden Vertrag entworfen, worin als Hauptgrundsätze aufgenommen worden: es sollen die Überfahrtskosten zur Hälfte gegen Ausweis der Einschiffung der Auswandernden in Antwerpen, und zur Hälfte gegen Ausweis ihrer Ankunft in Charleston oder New Orleans, und der Kaufpreis des von ihnen zu olkupierenden Borlens bei Übergabe des förmlichen Verkaufsaktes in beglaubigter Abschrift an die hiesige Obrigkeit, ausbezahlt werden. Es solle das diesen Colonisten angewiesene Land insofern sie es verlassen würden in das Eigentum der Stadt übergehen. Es soll ferner der Agent der Gesellschaft in Tennessee die von der Stadt für clie Colonisten ausgelegte Summe von den letztern vom 5ten Besitzesjahre an, während der nächst folgenden 5 Jahre ratenweise zu Handen der Stadt einziehen und endlich sei die Colonisationsgesellschaft verpflichtet in Laufe des Jahres I 846 noch weitere 250 Acker gleichen Bodens zu gleichem Preise behufs fernerer Ansiedlung abzutreten, welch letzterer Punkt deshalb aufgenommen worden sei, weil die Bodenpreise vom nächsten Jahr an um die Hälfte steigen. Ausserdem bliebe dann noch der Vertrag mit den Auswanderen selbst abzuschliessen. Schliesslich bemerkte der Referent, es hätten die letzteren den Wunsch geäussert, man möchte ihnen, da sie sich laut Schiffsalkkord bis Mannhein selbst verköstigen müssten, etwas weniges anf die Hand zul geben. Nach Verlesung des Entwurfs zu dem Schiffsakkord sowohl als zu einem Vertrag mit der Gesellschaft und hierüber gewalteten Diskussion, während welcher sich die Versammlung von der Zuverlässigkeit obiger Bestimmungen überzengte, wurile beschlossen:

"Die Vorschläge der Commission unter Verdankung ihrer Bemühungen zu genehmigen, anch den Auswanderern eine auf die Köpfe zu 
verteilende Summe von Gulden 50 als Viaticum mitzugeben." Aug. I9, I 845 .

Vouchers for these transactions are to be found in the Kassenbuch, under date of Oct. I6, I845, and May 2, I846.

The "Register zu den Ratsprotokollen" show a large number of applications for aid in defraying the expenses of emigration. In the years 1846I847 at least 9 are noted; 14 in 1848,6 in 1849,14 in 1852,6 in 1853 , 10 in 1854 , fewer after that. A great many of these applications were favorably received; for a time there were many " undesirables" among them, including criminals and paupers, some of whom were transported to America. Some typical cases are the following:

PROTOKOLLE. RATH UND GERICHT.

I845, July 25. "Sodann trug das Präsidium vor: Es sei nun schon zu wiederholten Malen der junge Christian Heinz, Sohn des Chirurgen Johann Martin Heinz, auf den Schub hierher geführt und an das Kantonsverhöramt abgeliefert worden. Da nun dieser junge Mensch sich ungeachtet aller Ermahnungen und Drohungen nicht bessern zu wollen scheine, sondern sich immer noch dem Müssiggange und einem liederlichen herumvagierenden Leben hingebe, und seinen Eltern schon so viel Kosten, Kummer und Verdruss verursacht habe, so sei bei seinem Vater der Wunsch rege geworden, diesen seinen Sohn entweder nach Fürstenau (Correctionsanstalt) oder nach Amerika zu schicken, doch trage er einiges Bedenken denselben nach Amerika geben zu lassen aus Besorgnis, dass sein Sohn bald wieder von dort zurrückkehren, grosse Kosten verursachen, und neue arge Streiche machen könnte. Es frage sich nun, was die Behörde hinsichtlich dieses Subjekts, welches seit einigen Tagen hier auf dem Rathause verhaftet sei, beschliessen wolle. Nach Vorbescheiden und Einvernehmung des jungen Heinz wurde erkennt: denselben auf unbestimmte Zeit nach der Zwangsanstalt in Fürstenau zu versetzen und die löbliche Kantonalarmenkommission um dessen Aufnahme daselbst ersuchen."

Aug. I 5. "In einem v. 20. Juli dat. Schreiben stellt Herr Chirurgus J. M. Heinz das Gesuch, man möchte seinen entarteten Sohn Christian statt ihn nach Fürstenau in die Zwangsarbeitsanstalt zu thun, nach Amerika auswandern lassen. Er der Vater wolle zu diesem Behufe die Hälfte der Reisekosten übernehmen, wenn die Stadtkasse in Berücksichtigung seiner bedrängten ökonomischen Verhältnisse die andere Hälfte bestreiten wolle. Mit dem Aktuar der Kantonalarmencommission wurde (auf Beschluss v. 25. Juli) Rücksprache genommen und von demselben erfahren, dass die Versetzung schwerlich sogleich bewerkstelligt werden könne, indem in jener Anstalt bereits sozusagen alle Plätze besetzt seien. -In Berücksichtigung sowohl der letzterwähnten Umstände, als des von dem Vater ausgesprochenen Wunsches, beschloss die Versammlung:

"Dem jungen Heinz aus der Pflegschaft einen unverzinslichen Vorschuss von f. 50 als beiläufig der Hälfte der erforderlichen Reisekosten zum Behufe seiner Übersiedelung nach Nordamerika zukommen 
zu lassen, jedoch unter der Bedingung, dass der Vater Herr Chirurgus Heinz auf den Fall dass sein Sohn zurückkehren sollte, sich zur Erstattung des obigen Vorschusses verpflichte."

1846, Mar. 30. "Gesuch der Frau Verena Camenisch um Unterstützung ihrem Manne nach Amerika zu folgen, der sich früher dort angesiedelt hatte. Ihm war eine Unterstützung von f. I 50 gegeben, Entschädigung für seinen Anteil am Gemeingut. Der Frau wird f. Ioo gegeben als Entschädigung für ihr. Anteil, und dass die Vereinigung der beiden Ehelette, die ja sonst getrennt blieben, erzweckt werden sollte."

Mar. 30. "Mit Einlage v. I9. d. M. bittet Andreas Büchele, hiesiger Angehöriger, theils auf seine schwächliche Gesundheit, theils auf seinen dürftigen, ausschliesslich auf Handlangerdienst beschränkten Erwerb hinweisend, um eine Unterstützung zur Auswanderung nach Nordamerika:-welchem Gesuche, in Betracht dass der Petent ein junger Mann ist, der sein Brod erwerben kann, nicht zu entsprechen beschlossen wurde."

1847, Mar. 18. "Schwestern Maria und Susanna Fehre hiesige Angehörige unter Hinweisung auf ihre z. Theil durch verschiedene Unglücksfälle herbeigeführte Mittellosigkeit, Schwächlichkeit und Kränklichkeit, das Gesuch ihnen zum Behuf der Auswanderung nach Nordamerika, welche sie in Gemeinschaft mit ihrem wackern Schwager dem Schuhmachermeister Heinr. Schuler von Zürich zu unternehmen gedachten, Unterstützung angedeihen zu lassen. Beschluss: Angelegenheit an die Auswanderungscommission zu weisen und sie zu ermächtigen, die von der Stadt aus zu leistende Unterstïtzung bis auf $f$. Ioo für jede von beiden Schwestern festzusetzen."

Mar. I8. "Mit Einlage v. 23. Feb. abhin, bittet der hiesige Angehörige Mathis Plöckli zum Behufe der Auswanderung nach Nordamerika, wohin er auch seinen blödsinnigen Bruder Peter mitzunehmen gcdächte, sowohl um Nachlass seiner rückständigen Besitzstener in Betrag v. f. 50 als um Leistung einer anderweitigen Unterstützung. Da die Behörde es für den Peter Plöckli sehr bedenklich fand mit seinem Bruder auszuwandern, da derselbe einerseits den Mathis in seiner Ansiedlung nur hinderlich sein könnte, und anderseits wenn ihm einst aus welchen Gründen immer der Bejstand des letzteren abgehen sollte, hülflos allem Elend preisgegeben werde, wurde beschlossen: dem Mathis Plöckli zwar behufs Unterstïtzung seiner Auswanderung sowohl die rückständige Beisäszsteuer nachzulassen, als darüberhin ihm aus der Stadtkasse einen Beitrag v. f. 50 zukommen zu lassen, jedoch ihun zugleich die Bedenken der Behörde bezüglich semes Vorhabens seinen Bruder Peter mitzunchmen zu cröffuen, und ihn wonı̈glich von diesem Gedanken abzubringen snchen.",

1848, June 14. "In einer andern Einlage wird Vorstellung gemacht namens der hiesigen Lucia Meyer, dass derselben in ihrer bedrängten Lage zur Sicherung ihrer eigenen Existenz und jenes ihrer 2 ausserehelichen Kinder kein anderer Ausweg übrig bleibe als die Auswanderung nach Amerika. Wo dam ilır Verlobter, der Vater des jüngeren Kindes, ein Bürger des Kgr. Würtemberg für ihr und ihrer Kinder Fortkommen sorgen würde, während 
hingegen ihrer Verehelichung mit demselben hierzulande die Schwierigkeit sich entgegen stelle, dass sie das dazu erforderliche Vermögen nicht aufweisen und auch den Einkauf in die Heimatgemeinde ihres Verlobten nicht zu bestreiten vermöge. Da jedoch die Bittstellerin dermalen nicht im Stande sei, die zu ihrer Auswanderung nach Amerika benötigte Summe näher zu bezeichnen, so gehe ihre geziemende Bitte einstweilen nur dahin, es möchte aus der Mitte dieser titul. Behörde eine Commission mit Untersuchung und Begutachtung dieser Angelegenheit beauftragt werden. Hierüber wurde in Betrachtung dass es nicht nur nicht in der Pflicht der hiesigen Behörden liegen könne, sondern vielmehr in moralischer Hinsicht und des Beispiels wegen von den schlimmsten Folgen für das Gemeinwesen sein würde, wenn hiesigen Bürgerinnen oder Angehörigen, welche sich in Umständen wie die der Petentin befinden, etwelchen Vorschub behufs Auswanderung geleistet werden wollte, erkennt das vorliegende wie auch künftige ähnliche Gesuche abzuweisen."

July I 4. "Frau D. Ursula Gubler (geb. Braun) mit 3 Kindern, Bitte ihr in Betracht angeführter Umstände (Rechte auf Anteil an unverteiltem Zunftvermögen) die Summe von f. 500 aus der Stadtkasse zukommen zu lassen, um Reisekosten zur Auswanderung nach Amerika zu bestreiten. Genehmigt."

I849, Aug. I 5. "Antrag v. Hr. A. Passett auf sein hiesiges Bürgerrecht zu verzichten zu wollen, unter der Bedingung einer Unterstïtzung von f. 700 behufs seiner Auswanderung nach Amerika und zwar nach dem Goldlande Californien nachgesucht, worüber beschlossen: da dem Petenten seither diejenige Unterstützungssumme, welche ihm teils von dieser Behörde aus zuerkannt, teils von seinen Anverwandten zu gedachtem Zwecke zusammengeschossen, verabreicht worden sei, so könne sich die Behörde zu keinem weiteren Opfer zu Lasten der Stadt verstehen, und werde daher das gestellte Begehren abgewiesen."

Aug. I 5. "Zwei andern schriftlichen Gesuchen der hiesigen Bürger F. Moritzi, Schreiner, and Jeremias Hatz, Schmied, um Unterstützung zur Auswanderung nach Amerika, wurde ebenfalls nicht entsprochen, weil die Petenten, zumal bei ihrer Arbeits- und Berufsfähigkeit sich hier eine eben so sichere Existenz als anderswo verschaffen können, wenn sie nur arbeiten wollen."

\section{Auswanderung. Acta.}

\section{B. 3. I853-1867. (Complete fascicle.)}

Bittschriften an den Amtsbürgermeister der Stadt Chur im Kanton Graubünden um Unterstützung der Auswanderung (I) nach Nordamerika, (2) nach Brasilien.

I854, June I. "In sehr bescheidenem Ton anher gerichtete Gesuch des in der Zwangsarbeitanstalt von Fürstenau befindlichen Bürger Joh. Rohner Sohn um seine sofortige Freilassung aus der genannten Anstalt sowie um Zuerkennung resp. Rückerstattung der Hälfte des von ihm i 849 ohne etwelche seitherige Genutzniessung bezahlten Bürgereinkaufs behufs seiner nochmaligen Auswanderung nach Nordamerika, wurde erkennt: dem Petenten die nachge- 
suchte Freisprechung innert Jahresfrist in Aussicht zu stellen, sofern es sich fortan durch folgsames und ordentliches Betragen die Zufriedenheit der Anstaltsdirektion sich zu erwerben beflissen sein wird, mit dem Bemerken jedoch, dass auf sein weiteres Ansuchen um materielle Unterstützung zu dem angegebenen Zweck hierorts nicht eingetreten werden könne, sondern man vielmehr darauf halten müsse, dass er sich alsdann über die ihm zu Gebote stehenden Mittel zu beabsichtigter Auswanderung des näheren ausweise, welcher Beschluss dem Herrn Direktor der mehrgenannten Anstalt zur Kenntnis gebracht werden soll."

The Stadtarchiv contains files of the following newspapers, which contain frequent references to emigration: Churer Wochenblatt, I839-1850; Churer Zeitung, I8I4-I856; Bïndner Zeitung, I830-I 856; Morgenstern, I842-1843; Der liberale Alpenbote, I848-1860; Der Freie Rätier, I843-1848, I868Bïndner Tageblatt, I852- ; Rheinquellen, 1856-1860. 


\section{CANTON AARGAU.}

\section{AARAU: STAATSARCHIV.}

Location: The old "Staatsarchiv des Kantons Aargau" is located in the same building as the Cantonal Library (Kantonsbibliothek), i.e., behind the Regierungsgebäude. Nothing relating to American history was accessible in the old Cantonal Archive. The Cantonal Library (about 100,000 volumes) contains about 500 manuscripts. There is an index for the latter, but this does not describe the manuscripts, some of which, such as the large group of the Hallwyl manuscripts, may in their great bulk contain some reference to America. The material for the nineteenth century is contained in the Registratur, located in the neighboring Regierungsgebäude. There is interesting evidence here of a large emigration from Aargau in the nineteenth century.

Hours: The state archivist, who is also cantonal librarian, must be consulted for permission and hours for work.

\section{AARAU: REGISTRATUR.}

\section{Protokolle des Regierungsrates. ${ }^{\prime}$}

$$
\text { I } 803-1809 .
$$

"Valentin Jäggy von Siszlen nach Amerika." Protok. No. 2, pp. 87, I8I. (Auswanderung gestattet, ro per cent. Abzug, I803.)

"Joh. Jakob Urech von Othmarsingen nach Amerika." Prot. No. 7, p. 317. (Erlaubt. Io per cent. Abzug. Verlust des Bürger- und Landrechts. I806.)

\section{I8IO-I819.}

"Amerika, Auswanderung." Nos. I0, I I, I6, I7, I8, I9."

"Grundsätze und Regeln darüber." No. 16.

“Anordnungen und Berichte." No. I7.

"Abzugsgebühren von Auswanderern." No. I7.

"Anwerbungen durch Hüber, Märk und Wasmer." No. I7.

"Auswanderungswerber." No. I6.

"Aus den Bezirken Baden und Brugg." No. 16.

"Bürgschaft und Geldhinterlagen der Auswanderer." No. I 7 .

"Bürgschaft der Gemeinde Wallbach für ihre Ausgewanderten." No. I7.

"Bürgerrechtsverzichtleistungen." No. I7.

"Heimatlose, Beförderung ihrer Auswanderung." No. I7.

“Masznahmen von Preussen, Holland und Baden gegen die lästigen Auswanderungstransporte." No. I9.

" Rückkehr von Ausgewanderten in traurigem Zustande." No. I7.

"Called "Kleiner Rat" until 1840 , and elected by the "Grosser Rat".

${ }^{2}$ 'The numbers here correspond to the years, e.g., I9 means I8I9. 
"Planta, Handelskonsul in Amsterdan, Geldvorschïsse-Rechnung." Nos. I7, I8, 19 .

"Siggenthaler, auswandernde, Unterstützungsgesuch.” No. I6.

"Totenscheine der Ausgewanderten." No. I7.

"Auf der Reise verstorbener." No. I9.

"Weibergutsversicherung auswandernder Bürger." No. I6. (Emigrant compelled to insure property of wife.)

SPEZIALIA.

Thirty-seven cases, between I8I6-I8I9, of individuals on record, some with families, emigrating to Anerica.

I820-1829.

Amerika. "Aufstellung zweier schweiz. Gesandten in d. Ver. Staaten.” I823.

"Auskundschaftung der Ausgewanderten: Johann Jakob Märlis Familie. von Rufenach." Nos. 24, 27, 28.

"Auswanderung nach Amerika." 9 cases, some with families. Nos. 20, 2I, $24,27,28,29$.

"Bürgschaftsleistung bei Auslieferung von Erbschaften." No. 24.

"Geldvorschüsse an die Auswanderer nach Nordamerika aus der Staatskasse. Rechnung darüber." Nos. 20, 21. (48 persons, total of over $2600 \mathrm{fr}$.)

“Holland: Klage wegen der Zudringlichkeit der Auswanderer." No. 20.

"Holland: Formalitäten für die einzuschiffenden Auswanderer." No. 28.

"Rechnung des schweiz. Consuls über die Auswanderer." Nos. 20, 2I, 22.

"Verrechnung der Depositengelder von den im Jahre I8I7 Ausgewanderten." No. 29 .

$$
\text { I } 829-1840 .
$$

“Auskunft über bestehende Handelsgesetze." No. 3I.

"Formalitäten für die Reisenden über Holland." No. 32.

"Requisiten der Auswanderer durch Frankreich." No. 33.

"Unglückliche Lage der Auswanderer in New Orleans." No. 37.

"Unterstiitzung der schweiz. Hülfsgesellschaft in New Orleans." No. 38. "Visirung der Pässe der Auswanderer." No. 33.

Kreisschreiben. Matters pertaining to consular business. See Bern archives. Auswanderung: Besonderes. About 50 individual cases of emigrants.

$$
\text { I840- I } 849 \text {. }
$$

Amerika. "Auslieferung des Gerhard Koster." No. 44.

"Auslieferungsvertrag mit den Vereinigten Staaten." No. 45.

"Auswanderung dahin, diessfällige Gefahren für Unvorsichtige." No. 45.

"Andreas Dietsch in Aarau, Kapitalfond d. Nuswanderungsgesellschaft betr." No. 44.

"Eingangszoll für Seidenstoffe." No. H. Other consular business.

"Rathanerbieten für die Auswanderer." No. 46.

"Consule und Vice-consule." Nos. $43,44,45,46$.

"Handelsvertrag mit der Schweiz." Nos. $44,45,46$.

"Privilegiengesuch eines Bürgers der Ver. Staaten für die. Erfindung einer Doppelzunge auf Feuerspritzen." No. 4o. 
"Unterstützungsgesuch des J. P. Meier von Wohlen zur Auswanderung." No. 45 .

"Zuschrift von Ellion Cresson in London über den Vorzug der Auswanderung nach den Ver. Staaten, statt nach Afrika." No. 4I.

"Auswanderung-Unterstützungen (Beisteuern) und Gesuche." 38 cases, I848-I849.

Kreisschreiben. See Bern archives.

"Versammlung von Auswanderern zu Degerfelden." No. 48. "Zu Windisch." No. 48.

$$
\text { I } 850-1859 .
$$

"Steckbriefe gegen Verbrecher. Versendungsart." No. 50.

"Requisite der Bürgerbriefe." No. 53.

"Wechselsendungen, erforderliche Verfallzeit bei Sicht." No. 59.

"Auswanderung-Staatsbeisteuern."

Several hundred cases, men and women, mostly from 185 I to I854, fewer I 855 to I857. A typical case is the following:

1854. "Oberlehrer Kaspar Bächli : Gesuch mit Frau und 6 Kindern um Staatsbeisteuer." Protokoll: "Der Hr. Direktor des Innern referirt mündlich über das von Oberlehrer Kasp. Bächli in Würenlingen an die Erziehungsdirektion gerichtete und von dieser der Direktion des Innern zur Entsprechung empfohlene Gesuch um Verabfolgung einer Unterstützung, um ihm, seiner Ehefrau, und seinen 6 Kindern die Auswanderung nach Nordamerika möglich zu machen, da nur dieses Mittel ihm übrig bleibe, dem drohenden Geldstag und dem drückendsten Elend zu entgehen." Nach Antrag wird beschlossen: "In Anbetracht des zojährigen Lehrerdienstes des Benannten, die Direktion des Innern zu ermächtigen, demselben einen ausserordentlichen Beitrag von Fr. 50. verabfolgen zu lassen."

$$
\text { I860-I 869. }
$$

" Beschwerde über die Abschiebung von Vagabunden, Angeklagten, und Verbrechern nach Nordamerika." No. 68.

"Bürgerrechts-Erwerbung durch Schweizerinnen infolge Heirat mit einem nordamerikanischen Bürger." No. 60.

"Enigrations-Bureau-Errichtung zu Schutzen der Auswanderer." No. 64 .

"Schenkung eines Lincoln-Albums." No. 68.

"Staatliche Verhältnisse-betreffende Broschüre von Stiger." H. No. 64.

"New York. Schweiz. Wohlthätigkeits Verein, Beschwerde über Spedition hülfloser Auswanderer durch viele Gemeinden." No. 66.

$$
\text { I870-I } 879 \text {. }
$$

"Statistik der überseeischen Auswanderung vom Jahr I873 bis I879."

"Angebliche Nötigung zur Auswanderung der Anna Büchi von Unterehrendingen nach Nordamerika." No. 77. (Beschwerde des Consuls in Philadelphia.)

"Angebliche Abschiebung der Marie Wehrli, von Küttigen, nach Nordamerika." No. 77. (Pflichtwidriges Verfahren gewisser Agenturen in Basel.)

"Beschwerde in Einwanderungssache."

"Militärpensionen aus Nordamerika." Nos. 70-79. Very many cases.

“Philadelphia Weltausstellung." Nos. 75, 76. 
I880- I 889.

“Mormonenstaat Utah. Warnung." Kreisschreiben. No. 86.

"Statistik." Nos. 80-89.

Spezielles unter den Namen der Auswanderer.

Auswanderungen, i8 $80-185$ I.

“ Bezirksweise Übersicht der Auswanderungen während der letzten i I Jahre (I840-1851)." A most interesting table of statistics showing the number of emigrants from every district of the canton of Aargau, men, women, and children, also the amount of their property (both that which was carried away and that which was left behind), and also the amount paid in support of those needing financial aid for emigration. During this period there were 3343 emigrants. of whom 2II2 were adults, I23I children; I990 were males, I353 females. The value of the property taken away amounted to over 588,530 francs, that left behind 196,220 francs; the home districts (Gemeinden) furnished 198,998 francs in support of these emigrants, the state gave 25,940 francs. The state (i.e., the canton) made a practice of giving 30 francs per head to those emigrating poor persons to whom their own districts also gave aid (for the defraying of the expense of transportation to the foreign land). "Eine hergebrachte Unterstiitzung von Fr. 30 per Kopf für Arme von ihrer Gemeinde gleich falls unterstïtzte Auswanderer."

Printed Reports: Rechenschafts-Berichte des Kleinen Raths (Regicrungsrates) an den Grossen Rat des Kantons Aargan, I $837-19 I 3$.

Berichtliche und Statistische Notizen über Ausa'anderung v'om Kanton Aargatt. 


\section{CANTON THURGAU.}

\section{FRAUENFELD: RANTONSARCHIV.}

Location: The "Thurgauisches Kantonsarchiv" is located in the Regierungsgebäude of the capital city, Frauenfeld.

Hours: 9 a. m. to 12 m.; 3 to 6 p. m.

Serfdom (Leibeigenschaft) existed in the canton of Thurgau until 1760 , rendering emigration practically impossible before that time. As a result of the hard times of 1798 , when the Thurgau became the scene of war between the French, Austrians, and Russians, there arose a desire to emigrate, but the difficulties existing or imposed prevented emigration. No records on America appear before the nineteenth century.

The "Thurgauisches Kantonsarchiv, Alteidgenössische Abteilung" contains the "Archiv des Schlosses Arenenberg."

Rubrik IX. 221. Polizeiwesen. Sicherheitspolizei.

Auswanderung, I803-1804. Nach der Krim.

Auswanderung, 1817. Nach Russland.

Beschwerde des Königs d. Niederlande gegen (mittellose) Auswanderer nach Nordamerika. Kreisschreiben. I8I7.

Gesuche um Bewilligung zum Auswandern nach Amerika. I828-I830.

Gesuche um Unterstützung zum Auswandern. I848, I85I, I852.

Rubrik IX. 222. Auswanderungsangelegenheiten. Polizeiwesen, Flïchtlinge, Auswanderung.

I860-I 863. Verhältnisse der schweizerischen Auswanderer in Brasilien.

I860, Nov. 3. "Auf die Mitteilung des Polizeidepartements, dass der Schutzverein für entlassene Sträflinge in Verbindung mit der Gemeinde Landschlacht beschlossen haben, dem Reinhard Schilling, Schlosser von Landschlacht, gegenwärtig 30 Jahre alt, die Reisekosten nach Amerika zu bestreiten, falls auch vom Staate hierfür ein Beitrag geliefert werde, in Betracht:

“ (a) dass Schilling seit dem 24. Juni I848, wo von begangener Betrügereien zum ersten Mal mit 6 Wochen geschätztem Arrest belegt wurde, 6 weitere Verurteilungen wegen Diebstählen und Betrügereien erlitt und in Folge dessen während diesem Zeitraum $7 \frac{1}{2}$ Jahre theils im Arbeitshause, theils im Zuchthause zubringen musste-

" (b) dass Schilling laut den aufgenommenen Verhörakten bereits Bekanntschaft mit den gefährlichsten Verbrechern in mehreren Strafanstalten gemacht und selbst in ihrer Gesellschaft Verbrechen verübt hat-

“ (c) dass unter diesen Umständen kaum gehofft werden darf, dass der gesunde, kräftige und auch geistig begabte junge Mann genug Kraft in sich fühle, von dem bisherigen verbrecherischen Lebenswandel abzugehen, so lange er mehr oder weniger in Verbindung mit den Genossen seiner Verbrechen steht-

“(d) dass Schilling als geschickter Arbeiter, sowohl als Schlosser als auch als Rothfärber mit Leichtigkeit überall sein redliches 
Auskommen finden kann,- - und dies natürlich da um so mehr, wo seine früheren Lebensverhältnisse gänzlich unbekannt sind

" (e) dass nach den Akten dem Schilling bei seiner Verhaftung in Gossen eine ihm eigentünlich zugehörende Uhr abgenommen und an das Verhörant dahier eingesandt wurde, die laut Bericht dieser Behörde nicht mehr aufgefunden werden könne, daher der Staat demselben hiefür einen Ersatz zu leisten hat-

" (f) dass in Besichtigung aller dieser Thatsachen es vollkommen sich rechtfertigt, wemn auch der Staat das Bestreben des Schutzvereins für entlassene Sträflinge und der Gemeinde Landschacht in concreto durch einen Beitrag unterstützt-anf den Antrag des Polizeidepartements : beschlossen :

“( (1) Sie dem Schutzaufsichtsverein ein Beitrag an die Auswanderungskosten des Reinhart Schilling nach Amerika von f. 80 zu verabreichen, in der Meinung, dass damit auch die Angelegenheit wegen der obberührten Taschenuhr ihre Erledigung gefunden habe und dass der Schutzverein dafür besorgt sei, dass Schilling. wirklich nach Amerika auswandere.

"(2) Mitteilung dieser Schlussnahme an die Finanzverwaltung behufs Ausbezahlung des fraglichen Beitrags."

I86I, Mar. I3. 50 f. granted to Schutzaufsichtsverein in connection with another thief named Huber.

Aug. I3. Ioo f. granted to Ulrich Früh, thicf, similarly for emigration.

I864, July I. 430 f. granted to J. Ruckstuhl, thief, similarly for emigration.

July 23. I25 f. granted to Lisette Klein, mother of 2 illegitinate children, for expenses of emigration.

I865. List of I 76 Swiss who went down on the William Nelson, which was burned at sea June 26, I865.

1867. Kreisschreiben. Untersuchung über Auswanderung.

Gesuche um Unterstützung zur Auswanderung.

I868, Apr. I I. Basel, Consulat der Vercinigten Staaten v. Nordamerika. lit. "Auf ihr verehrliches Schreiben v. I6 d. M. mittelst welchem Sic uns mitteilen, dass die Regierung d. Vereinigten Staaten Ursache habe, zu glauben, dass cine Combination in fremden Ländern bestehe, die den Zweck habe, Vagabunden, Angeklagte, und Verbrecher von Verhaftung und Einkerkerung zu befreien, un sie nach den Vereinigten Staaten zu senden, beehren wir uns Ihnen zu erwidern, dass es im herwärtigen Canton laut diesfalls eingezogenen Berichten hic und da vorkonment, dass einzelne arbeitsschene, jedoch arbeitsfähige Individuen, welche sich aus íreien Stücken zur Auswanderung nach Amerika verstehen, hiefür aus Gemeindemitteln Reiseunterstïtzungen erhalten, dass uns dagegen durchaus keine Fälle bekannt sind wo Angeklagte oder Verbrecher, um sie vor Verhaftung und Einkerkerung zul befreien, nach Amerika geschickt worden wären." (Large number of papers on this matter, including replies from various districts of the canton.)

June ro. "Gesuch der Schwestern Maria Müller und Enilie Vollenweider, um Unterstütung zur Auswanderung nach Amerika. Ahgeschlagen." 
Statistik der Auswanderung aus dem Thurgau im Jahre i8\%o. Aus verschiedenen Bezirken.

I873. Warnung vor der Auswanderung nach brasilianischen Kolonien. Kreisschreiben.

I874, Apr. I7. "Auf das Gesuch der katholischen Kirchenvorsteherschaft Leutmerk[en] v. 9. April, dass dem verwahrlosten und wegen Diebstahls schon wiederholt bestraften Adolf Schönauer v. Leutmerk (geb. Io. Mai I856) die Auswanderung nach Amerika durch Zuwendung eines Staatsbeitrags ermöglicht werde, sowie in Hinblick auf das unterstützende Begleitschreiben des Bezirksamts Weinfeld v. 3I. Mai, und die vorausgegangenen Präcedenzfälle (Konrad Huber, I86I, und Reinhart Schilling, I860 ${ }^{1}$ ) wird zufolge des Antrags des Armendepartements, beschlossen:

“ ( I) Sei der kathol. Kirchgemeinde Leutmerken an die Kosten der Auswanderung des Adolf Schönauer aus dem Hülfs- und Armenfonds ein Beitrag v. fr. Ioo bewilliget.

" (2) Sei dieser Beitrag an die kathol. Armenpflege L. aushinzubezahlen, sobald sie den Nachweis der erfolgten Einschiffung des Adolf Schönauer geleistet haben wird.

"(3) Mitteilung an die kathol. Armenkasse Leutmerken."

I875, Nov. 5. Refusal of an application for support of emigration.

Statistics on emigration.

I88I, Sept. 5. A case of support for an emigrating family. (Not of undesirable class.)

I883. "Auswanderung nach Chili betreffend." Kreisschreiben.

Printed Material: Amtsblatt des Kantons Thurgau. Rubrik Auswanderungswesen, especially I888, I889, I892-I898, I904.

Sonntagsblatt der Thurgauer Zeitung, Mar. 9, I9I3: "Eine Schweizerkolonie im Ausland." Neu-Helvetia in Uruguay (Jakob Nater).

${ }^{1}$ Statement is made that these, on hearsay, are doing well in America. 


\section{CANTON TICINO.}

\section{BELLINZONA: ARCHIVIO CANTONALE.}

Location: The "Archivio Cantonale in Bellinzona" is located in the government building, "Guberno ", Piazzo Giardino.

Hours: 8 a. m. to 12 m.; 2 to 6 p. m.

The mantuscript material relating to America is very scant and umimportant. The archivist reports that under his predecessors the custom prevailed of lending manuscripts to private persons without proper security for their return. As a result of this custom the archive has been deprived of some of its most valuable materials.

\section{Manuscripts: "Emigrazione".}

Bern, June 2, I8I7. N. Direttorio Federale: "Communica nota importante, concernente quegli individui, che intendono emigrar per 1' America, e sono privi di sustenenza per la loro dimora nei Paesi Bassi, e per far fronte alle spese per imbarcassi sul mare."

Bellinzona, Apr. I7, 1819. Communication in regard to the establishment of a colony of Swiss in Brazil, under the name of Nouvelle-Fribourg; also terms offered officers and underofficers in this service.

London, Oct. I2, i821. "Il sg. Pietro Schmidtmeyer trasmette un rapporto in francese ed altro in inglese sull' infelice stato delle Colonia Svizzera a Conta-Gallo nel Brasile, e fa conoscere i soccorsi destinati a quella populazione."

Zürich, Nov. 9, ı846. " Trasmette il prodocollo d' una conferenza tenuta nell' 8. sett. I $8+6$ concernente l'emigrazione dalla Svizzera."

\section{Printed Material.}

Emilio Bontà, "L' Ėmigrazione nel Cantone Ticino ", in Almanaco del Popolo Ticinese (Locarno, Sctola Normale, edito per cura della Società degli Anici (lell' Educazione e di Utilità Pubblica), No. 68, I9I2, 1P. IO4-I 23 .

Bollettino Storico della Svizzera Italiana (ed. Enilitio Motta ${ }^{1}$ ), I888, pp. 276 . 277; I891, p. I20; 1906, p. I6.

Conto Reso del Consiglio di Stato della Repubblica e Cantone del Ticino per l' Amministrazione dello Stato dal $r$. Gennaio al $3 I$. Dicembri I855 (Bellinzona, I856). These publications (accounts rendered) continue to the present time.

1 Dovere: Giornule dei Liberali Ticinesi. No. 34 (Locarno, Mar. I, I884). Fetilleton: "I Fratelli Delmonico: La storia dei piì famosi Trattori d"America." (The story of the founding of the Delmonico restaurant of New York (ity; the Delmonico brothers eame originally from Ticino.) This article is taken from a San Francisco paper, l'oce del Popolo di S. Francisco.

\footnotetext{
${ }^{1}$ Signor E. Motta, archivist in Milan, is regarded as the leader in collecting the materials for the history of Italian-Swiss emigration. The bibliography here given was compiled with the aid of his suggestions.
} 
Patria e Progresso: Organo dell' Emigrazione Ticinese, No. I6 (Bellinzona, I888). La Festa annuale della Società Demopedenta e la Storia dell' Emigrazione Ticinese. (Enilio Motta proposes a plan of gathering all available extant material for a history of emigration from the Canton Ticino.)

Patria e Progresso, I 885-I886, various numbers.

L'Agricoltore Ticinese: Organo della Società Cantonale di Agricoltura $e$ Selvicoltura (Lugano, I897). L'Emigrazione in rapporto alla Prosperità del Cantone. Signed, Gallachi.

Brenno Bertoni, "Plan d'une Statistique de l'Émigration Tessinoise”, in Zeitschrift für Schweizerische Statistik (Bern, I892), pp. 284297.

Le Colonie Svizzere di California alla fine del Secolo Decimonono, I9oo-I9or (San Francisco, Geo. F. Cavolli, I90I), pp. I0-40. Reprinted in the Nuovo Secolo dell' Elvezia, Nos. 3-4 (1905).

Schueizerisches Bundesblatt, I 849 , II. 348 ; I 853 , II. 447,654 ; I854, I. 6046I 5 ; I868, II. 57 I ; I869, II. Io8, etc.

T. Hardmeyer, “Ticinesi in California”. Dal Dovere di Locarno, I 885. In N. Züricher Zeitung, Nos. I72-I74 ( 1885 ).

G. Preziosi, Gl' Italiani negli Stati Uniti del Nord (Milano, Libreria editrice Milanese, I908).

In the absence of adequate manuscript and printed materials, the student of Italian-Swiss ( $i$. e., from the canton Ticino) emigration would do well to consult native or resident observers of emigration. The compiler received, e. g., from Professor Eligio Pometta (author of the history of Ticino in its relations with Switzerland and Italy, in 3 vols.), the following interesting information: Some sections of Ticino are almost depopulated by emigration, as the Val Maggia and the Val Verzasca, similarly Broglio and sections near Locarno. The destination is mostly California; a few go to Argentina. The emigrants from Ticino are mostly successful in California and remain there. They are liberal in supporting needs at home with money. There is a newbuilt church in the village of Brontallo which bears the inscription: ".cum auro Californiae". Some of the few that return bring 10,000 to 20,000 francs with them, and build villas. The returning emigrants are called Californians (Californese), not Americans. Most of those that revisit their homes in Ticino (and the most desirable class) return to California. The climate of California and the means of livelihood correspond most closely to conditions at home. Two of the Italian newspapers, one in New York and one in San Francisco (Novella Helvetia) are published by Ticino-Americans. 


\section{THE FRENCH CANTONS.'}

The French cantons of Switzerland, named in the order fixed by Swiss law, are Fribourg, Vaud, Valais, Neuchatel, and Geneva. Of these Fribourg, the least completely French and the only one predominantly Catholic, is the only one which belonged to the old Swiss Confederation. In the official order of cantons it stands between Zug and Solothurn, while Vaud, Valais, Neuchâtel, and Geneva, added as cantons in I8O3 (Vaud) and in I8I 5, stand, in the order named, as the last four of the twenty-two cantons. The archives of the five are treated below in the order indicated.

The French cantons of Switzerland hold a much less important relation to American history than the German. The emigration from them to America has been much less. Since 1878, when full Swiss statistics begin, the number annually migrating from the French cantons to America (to North America as a whole down to $\mathrm{I} 886$, to the United States, separately entmerated, since then) has averaged only about 30 from Fribourg, I 20 from Vaud, Ioo from Valais, 200 from Neuchâtel, and 80 from Geneva. Though America has owed to French Switzerland some very eminent persons-Bouquet and Haldimand, Gallatin and Agassiz and Guyot-the total emigration has not been of such dimensions that we could expect to find in the archives of these cantons much material bearing on American history.

The amount of such material has been lessened by the fact that the emigration from these regions has in very few instances been organized emigration, almost always individual. Moreover, the governments of these cantons have not usually prescribed for their subjects a formal govermmental permission to emigrate, as the governments of the states of Germany have usually done (see Mr. Learned's Guide to the German State Archives, passim); and when the emigration was the result of revolution or of political disturbance, as it often was, it naturally took place without passports, and left little or no trace in the governmental records.

Each of the cantonal archives of French-speaking Switzerland has a library. sometimes of moderate extent (best in the cases of Neuchatel and Geneva). containing the local and other publications most needed for consultation by persons working in the archives.

\footnotetext{
${ }^{1}$ The archives of these cantons were examined, and the following accounts of them written, by J. F. Jameson; sce the preface.
} 


\section{CANTON DE FRIBOURG.}

\section{FRIBOURG: ARCHIVES D'ÉTAT.}

Location: Chiefly in the Chancellerie, but see below.

Hours: 9 a. m. to $12 \mathrm{~m}$. : 2 to 5 p. m. (in winter, 2 to 4 ).

Down to 1902 the bureau of the archives was a portion of the Chancery, or office of the secretary of the Council of State. By arrêté of January 27, 1902, the archives of the canton are made a subdivision (département) of the Ministry (Direction) of Public Instruction and Archives. The Department of Archives was by this law given charge of the administration of the archives of the state, and of the control and supervision of the archives of the various executive ministries and offices, and also of the archives of the communes, parishes, and state institutions.

A riglement of September 20, I867, respecting the organization and employees of the Chancery of State, still holds good in respect to details in spite of this transfer.

Reports on the archives, fuller than is usual in other cantons, are to be found in the annual Rapports du Conseil d'État sur sa Gestion. Before I9O2 these are to be found in the section "Chancellerie" ; after that date in the section devoted to the Ministry of Public Instruction and Archives.

The offices of the archivist, and the archives with the large exceptions noted below, are in the building called the Chancellerie, the main seat of the cantonal government. They have indeed always been kept there since that edifice was built, in the seventeenth century. For some time, however, it has been necessary, besides the two basement rooms in the Chancellerie now devoted to the archives, to make use of two others in a building called the Grenette, close by the Church of Notre Dame. A fifth large room at the Convent of the Cordeliers was also used until 1903 ; but in that year the manuscripts contained in it were removed to rooms in the basement or ground floor of the Hotel de Ville (Hotel Cantonal, Rathaus).

The archives of Fribourg are extensive, amounting to some 15 ,000 volumes and nearly 20,000 parchments, the oldest being the will of Queen Bertha of Burgundy, A. D. 961. There are many special inventories or indexes, and a general manuscript Inventaire des Archives, made carefully in 184I. The last is long since out of date, and the present archivist has begun a new general and complete inventory. The following are the most important of the series in the archives: the Manuaux du Conseil or journals of the Council of State, the chief executive body of the canton, extending from I 438 and now (I9I2) amounting to 465 volumes; the Mandaten-Bücher or books of their ordinances, extending, in $\mathrm{Ir}$ volumes, from $\mathrm{I} 498$ to the beginning of the nineteenth century; the Missiven-Bücher or letter-books of the council, which for the period from I 449 to $\mathrm{I}_{814} 4$ extend to IO4 volumes; the Correspondance Extérieure, beginning in 1800 ( 37 volumes); the correspondence with the other cantons; various record books of the administrative boards, and papers turned over from time to time by the executive ministries (no regular periods for this); the Abschied-Bücher or copies of the proceedings of the federal diets, filling about 250 volumes, from 1498 to I848; the Livres de la Bourgeoisie of the town of Fribourg, for various periods from the fourteenth to 
the eighteenth century, I 3 volumes (the registers of bourgeoisie since 1798 are in the archives of the town of Fribourg, those of other towns are preserved locally); a certain number of judicial and family records; and a great variety of financial accounts. Chief among the latter are the accounts of the treasurers, extending from 1376 to the present time, in nearly 700 volumes. It is in the Manuaux and in the Correspondance Exterieure that materials having any bearing upon the history of America might be found (see the list which follows). Each of the volumes in these series has its own index, but there is no general repertory of these series. Since I902 the protocols (journals) of the Conseil d'Etat have been printed (printed as manuscript, in three copies only), and are fully indexed.

The deposit at the Hotel de Ville or Hôtel Cantonal consists of the conventual, feudal, and other medieval documents which have fallen into the possession of the cantonal government. That at the Grenette consists chiefly of the registers and papers of notaries, and of land papers. M. Joseph Schneuwly, for a long time (I867-I908) state archivist of Fribourg in the last generation, ${ }^{1}$ displayed especial activity in the gathering and preservation of notarial papers, and the collection now numbers some six thousand volumes, rumning from the fourteenth century down. A guide to it may be found in a printed list prepared by him, Tableau Alphabétique des Notaires qui ont stipulé dans le Canton de Fribourg antéricurement à I 868 (Fribourg, Inprimerie de Ch. Marchand, I868, pp. I03), which gives each notary's name, domicile, date of patent and of death, the dates and number of volumes of his registers and where they are preserved-but all in this list are now in the archives of state.

The registers of itat cizil are kept in the communes solely. Births, marriages, and deaths have been registered by the communes since IS 76 : baptisms, marriages, and deaths have long been registered by the ecclesiastical anthorities of the parishes, in accordance with the decrees of the Council of Trent. There is no sending of duplicates of registers of état civil to a central or cantonal deposit, as in certain other cantons.

Each commune has its archives. There is no fixed relation between the cantonal archives and those of the communes, no service d'inspection, for example; but Mr. Schneuwly in his time classified all the communal archives on a uniform system.

After the death in 1897 of Abbe Grenaud, professor in the University of Fribourg, his manuseripts were bought by the cantonal govermment and these now form a special collection in the cantonal archives. Of this section there is a catalogue prepared by .I. Patul E. Martin, formerly subarchivist of Fribourg, now archivist of Geneva, Catalogue des Manuscrits de la Collection Grenulud aux Archives d'Etat de Fribourg (Fribourg, 191 I, pp. 68). For the most part these papers relate to the earlier periods of Fribourg history. One notes, however (p. 45 of the Cataloguc) : "Projet d'un mémoire sur l'Atlantide, on la connaissance qu'avaient les anciens d'Amérique, de la forme et du mouvement de la terre."

Regrulations of the canton concerning enigration, I8.48, 1852, 1854 , and especially Nov. 25, 1862, may be found in their proper chronological places in the Bulletin Officiel des Lois, Décrets, etc.

'See the article, "Joseph Schueuwly, Archiviste d'Etat", in Rerth llistorique laudoise, XVI. 34-349, copied from articles in the local newspaper, la liberté, issues of Oct. 5 and 57,1908 , by his successor, Mr. Tobie de Raemy. Substantially the same article appears, in German, in Friburser Geschichtsblitter. IV. 140-1.H. 
There are also at Fribourg the following archives: archives of the commune, naturally less important than those of the canton, at the Maison de Ville, next door to the (now cantonal) Hotel de Ville ; archives of the bishopric, relating to the period since the bishop removed his residence from Lausanne to Fribourg-that is to say, mostly modern-kept at the Evêché, and very well arranged; also archives of the convents (6), and of private families.

The following list of data as to relations between the canton of Fribourg and America, more especially the United States, was prepared by Mr. Georges Corpataux, under the direction of Mr. Tobie de Raemy, state archivist of the canton.

\section{Manuaux du Conseil d’État.}

\section{Manual for I8I7.}

ff. I05, I 54, 257. Concernant l'émigration pour l'Amérique.

f. 358 . On ne prendra point de mesure pour empêcher l'émigration.

I819.

f. 66. Emigration d'une colonie Suisse au Brésil.

ff. 265, 28I. Mesures prises par la cour de Baden au sujet des émigrants.

I820.

f. 240. Concernant l'émigration des Suisses pour l'Amérique.

$$
\text { I } 83 \text { I. }
$$

f. I32. Mesures au sujet des émigrants pour l'Amérique.

$$
1832 \text {. }
$$

ff. I $71,596,673,862,863,884$. Émigration pour l'Amérique.

f. 777. Etats-Unis: Droits d'aubaine et de traite foraine.

ff. 862, 863. Émigrants pour l'Amérique: Émoluments pour expédition de passeports.

$$
1833 \text {. }
$$

ff. I47, 626. Emigrations pour les Etats-Unis.

f. 273. Emigration pour le Brésil. Manière d'obtenir l'indigénat.

$$
1834 \text {. }
$$

f. 219. Mr. Charles Ryhiner renonce à sa place de vice-consul des Etats du Nord de l'Amérique; et son remplacement.

$$
1835 \text {. }
$$

f. 545. Mémoire de Mr. Bühler sur les émigrations au Brésil.

$$
\text { I836. }
$$

f. I 5. Négociations avec le gouvernement du. Brésil pour une émigration. 
I 839 .

f. I96. Nomination du consul aux États-Unis.

Nomination de Powers comme consul.

1842.

f. 242. Petition adressée par un certain nombre d'émigrés.

I 843 .

f. 255. Emigrés: Mémoires des Argoviens.

I 844 .

f. 86. Emigrants: Transport gratuit jusqu'à Anvers de leurs effets.

f. 148. Etats-Unis d'Amérique: Nomination du consul.

f. 559. Démission du consul des Etats-Unis d'Amérique en Suisse.

1845 .

f. 2Io. Etats-Unis: Remplacement du consul général.

f. 314. Présentation pour le sixième consulat.

f. 366. Projet de traité entre la Suisse et les Etats-Unis concernant l'extradition des criminels.

f. 522. Nomination du consul de commerce des États-Unis à Bâle.

f. 504. Dangers auxquels s'exposent les émigrants en Amérique.

$$
\text { I } 846 \text {. }
$$

f. 54. Déclaration pour les marchandises à destination de l'Anérique.

f. II3. Annonce du consul des tats-Unis de l'Amérique de faire les publications des émigrés en Amérique.

f. 288. Circulaire sur les a vis dans les contrats des émigrants en Amérique.

$$
\text { I } 847 \text {. }
$$

f. Ir3. Annonce du consul des tetats-Unis de faire les publications pour les émigrés.

f. 268. Les Grisons demandent que la question des émigrations soit traitie ì la diète.

ff. 527,572 . Rapport de la conférence sur les émigrations.

f. 56I. Enquête au sujet des émigrations de Gruyères.

$$
\text { I } 848 \text {. }
$$

f. I 7 . Emigrations en Amérique, projet.

ff. 209, 226, 440, 593. Emigrations en Amérique, renseignements.

f. 3r3. Emigrants sins ressources: plainte du consul suisse an Havre.

f. 419. Emigration: Circulaire de l'tetat de Schaffouse.

f. 45I. Avis à la Feuille Officiclle concernant l'émigration.

f. 792. Instructions anx émigrants en Amérique.

$$
1849 .
$$

f. 212 . Enigrants. 


$$
1850 \text {. }
$$

f. 382. Mesures prises par la Belgique concernant le passage des émigrants.

f. 788. Les mandats d'arrêts à envoyer en Amérique du Nord, doivent être expédiés par Liverpool.

f. 864. Publications signalant les menées de quelques agents pour recruter des émigrants en Californie.

$$
\text { I } 851 \text {. }
$$

f. 40I. Émigration: Bureau de renseignements à Brême.

f. 5I2. Émigrations: Propositions pour projet de loi.

$$
1852 \text {. }
$$

f. 2IO. Emigrants: Mesures prises concernant les subsides communaux.

ff. 301, 387. Agence fédérale d'émigrations.

f. 395. Conférence.

f. 47 O. Renseignements sur les mesures de précautions à prendre par les émigrants en Amérique.

f. 47o. Émigrants: Précaution à prendre pour se rendre en Amérique.

$$
\text { I853. }
$$

f. Ior. Emigrants en Amérique, précautions.

$$
1854 \text {. }
$$

f. I3I. Circulaire aux communes concernant les formes à stivre en cas de demande de subside pour émigrations.

f. I40. Émigrations: Renseignements sur demandes.

f. I45. Emigrations: Défense de viser des passeports sans déclaration du préfet.

f. I77. Emigrations: Avis au public concernant les subsides des communes.

f. 217. Plainte du consul Suisse au Havre sur les nombreuses missions et demandes en matière concernant émigrations.

f. 330. Rapport d'Argovie sur la question d'émigrations.

f. 365. Emigrations: Circulaire d'Argovie concernant un concordat à établir.

f. 48I. Mesures à prendre concernant les émigrants pauvres à New-York.

$$
1855 \text {. }
$$

f. IOf. Emigrations: Le ministre des États-Unis fait des observations.

f. I8I. Emigrations: Surveillance.

$$
1856 .
$$

f. 8. Traité de commerce et d'extradition en Amérique.

f. 199. Emigrants: La légation de France de visa gratis sur attestation de pauvreté.

$$
\text { I } 857 \text {. }
$$

fí. 9o, 455. Journal général sur l'émigration.

f. I33. Nouvel avis du Conseil Fédéral concernant les mesures à prendre pour l'émigration.

f. 357. Trafic dans les billets de voyage des émigrants.

f. 444. Amérique: Emigrants, billets de voyage. 
f. 455. Amérique: Emigrants, statistiques.

f. 559. Etats-Unis demandent par l'entremise du Conseil Fédéral la loi sur les incendies.

f. 6ro. Statistiques des émigrés en Amérique.

$$
1858 \text {. }
$$

f. 246. Emigrés au Brésil: Projet de réponse sur la part du remboursement des avances faites.

f. 906. Mesures contre les abus qui se pratiquent à l'occasion de la vente de billets de transport pour les émigrations dans l'intérieur des Etats-Unis.

$$
1859 .
$$

ff. 125,595. Enigrants: Billets de transport.

f. I 25. Renseignements sur la position des émigrés au Brésil.

t. 493. Billets de transport pour les émigrants aux Etats-Unis; renseignements.

I 860 .

f. 22I. Visa gratuit de la légation française en faveur des émigrants traversant la France.

f. 242. Circulaire fédéral concernant la législation de l'Amérique du Nord.

f. 539. Renseignements demandés sur la convention de 1818 sur l'émigration au Brésil.

$$
\text { I86I. }
$$

f. 4o. Précautions à prendre pour empècher l'enrôlement pour l'Amérique.

f. 356. Etats-Unis: Réclamations au sujet de Pierre Hermann.

f. 459. Amérique du Nord: Correspondance.

I 862.

ff. $807,842,942,986$. Entreprise d'émigration: Maison Barbe, plainte de Chaney.

ff. 942, 986. Emigration: Zwilchenbart à Bâle, cautionnement.

ff. 986, 1018, 1036, 1053. Compagnies d'émigration; projet de sécret sur garantie.

$$
\text { I863. }
$$

f. 725. Dr. Joos, projet d'énigration dans l'état de Costa Ricea.

$$
1864 \text {. }
$$

f. 206. Amérique du Nord. Brochures de Mr. Stiger.

$$
\text { I } 866 .
$$

f. 657. Emigration: Plaintes du Conseil Fécléral, avis an public.

$$
1867 .
$$

ff. 13, 34. Amérique, Yitats-Luis: Règlement concernant allocation de bonifications supplémentaires atux ex-soldats de l'Union.

f. 384. Amérique: Envois de malfaiteurs, réponse au Conseil Fédéral.

f. 772. Etats-Unis: Demande d'échange des publications officielles. 
I 868 .

f. 25. Emigrations: Tableau à fournir au Conseil Fédéral.

f. I93. Amérique: Réclamation concernant envoie de criminels.

f. 273. Amérique: Liste des réclamations liquidées, pour solde, pensions, etc., des ressortissants Fribourgeois.

f. 366. Lois concernant l'émigration, envoi au gouvernement d'Italie.

I869.

f.6. Réponse à la circulaire du Conseil Fédéral au sujet du nombre des émigrants.

$$
\text { I870. }
$$

f. 75. Amérique du Nord, statistique des terres de l'état.

$$
\text { I87. }
$$

f. 82. Emigration dans la République Argentine, brochure.

f. 286. Amérique: Brochure concernant l'instruction publique.

$$
1872 .
$$

f. I93. Envoi de la Gazette d'Émigration, par Allemann.

ff. $273,347,473$. Emigration de Fribourgeois, renseignements.

f. 7 +2. Etats-Unis, paiement de pension.

$$
\text { I873. }
$$

Jan. 24. Brochure sur l'émigration.

Jan. 3I. Emigration: Renseignements sur le Brésil.

Nov.8. Emigration pour la colonie de Monitz au Brésil, circulaire fédéral.

$$
1874 \text {. }
$$

June 20. Émigration: Lettre au Conseil Fédéral.

$$
\text { I } 875 \text {. }
$$

Apr. 2. Emigration de mineurs, convention internationale.

Apr. I6. Id., conférence.

Apr. I9. Id., projet de concordat.

Apr. 26. Concordat projeté.

May 10, 28, Aug. 27 (bis), Sept. 3. Concordat.

Dec. I8. Concordat approuvé.

Dec. 3I. Emigration de mineurs, conférence.

$$
\text { I876. }
$$

Jan. 5, 7. Emigration de mineurs, conférence.

Mar. I 5. Opération des agences d'émigration.

July i 5. Agences d'émigration: Observations.

Sept. 22. Avis concernant Société d'Émigration.

Nov. I 5. Emigrants: Projets de loi (premiers débats).

$$
1877 .
$$

Mar. 2. Etats-Unis: Envoie de rapports de question.

Dec. I I. Émigrants à Punta Arena, demandes de rapatriement. 
I878.

Jan. 23. Enigrants à Punta Arena, demandes de rapatriement.

I 879 .

Feb. 7. Rapport sur l'émigration.

Apr. 7. Enigration: Envoi de tableau au Conseil Fédéral.

I 880.

Jan. 12. Emigration, statistique.

Apr. 26. Emigration: Envoi de formulaire an Conseil Fédéral.

June 29. Amigration: Envoi de journal.

I88I.

Jan. 17. Statistique des émigrations.

Apr. I 5. Émigration: Entrée en vigueur de la loi fédérale.

May II. Emigration: Promulgation de la loi fédérale.

June 3. Emigration: Tableau des agents patentés.

Sept. 3o. Emigration: Modifications à la loi sur agences.

1883.

Dec. 15. Emigration: Suspension pour le Chili.

Correspondance Extérieure.

Volume for 1818 -1820. ${ }^{1}$

f. I 46. Amérique, insurrection.

ff. I O66, I I I, I I 2, I 43, I 47, I 50, I 54, I62, I65, I68, I69, I 70, I79, I86, I87, I88, 189, 190, 193, 195, 197 (bis), 199 (bis), 229, 233, 234, 237, 242 (bis), 321, 324, 361, 393. Emigration de Fribourgeois au Brésil.

fi. 224, 234, 324. Planta, consul d'Amsterdam.

f. 229. Amsterdam, émigration suisse ponr le Brésil.

f. 357. Réponse à une plainte du consul suisse à Amsterdam.

$$
\text { I 824-i 826, June } 30 \text {. }
$$

f. 9. Ytats-Unis d'Amérique. Succession des Suisses y décédés.

f. 56. Manière d'obtenir un acte authentique du Brésil.

ff. 316, 35 I. Brésil: Déclaration d'indépendance; a vènement de Dom Pedro: tritité de paix et alliance avec le Portugal.

$$
\text { I 826, July I-I 829, June } 30 \text {. }
$$

f. 249. Emigration en Amérique par les Pays-Bas: condition.

$$
\text { 1829, July 1-183, Nar. } 7 \text {. }
$$

ff. I98, 209. Etats-Unis: Lettres de créance de Böcker comme consul général de commerce en Suisse.

f. 215. Lettres de créance de Charles Ryhinner comme vice-consul des Etats-Unis.

\footnotetext{
'These dates in the titles of the volumes are inclusive.
} 


$$
1831-1832 \text {. }
$$

ff. 40, 454. Passage par la France d'émigrants en Amérique.

ff. $45+, 462$. Passage par les Pays-Bas d'émigrants en Amérique.

$$
\text { I833-1 } 835 \text {. }
$$

f. 26. Amérique: Visa des passeports pour les Etats-Unis.

f. I 53. États-Unis: Agents de voyage des émigrants suisses.

f. 268. Amérique du Nord: Nomination d'un vice-consul.

f. 467 . Relations commerciales avec les Etats-Unis; situation des émigrés.

$$
1836-1838 .
$$

f. 4. Emigration au Brésil: Négociations.

$$
\text { I839-1 } 840 \text {. }
$$

f. 53. Exequatur donné à Mr. de Powers, consul général suisse aux EtatsUnis.

$$
1847-1850 \text {. }
$$

f. I68. On remercie le consul belge en Suisse des renseignements donnés sur les mesures prises en Belgique pour le transport des émigrants pourr l'Amérique.

$$
\text { I } 857 \text { - I } 860 .
$$

f. 98. Tableau des émigrés en Amérique.

f. I95. Réclamation au sujet des juifs des États-Unis.

$$
\text { I } 864 \text { - } 1865 \text {. }
$$

f. 289. Procès des communes suisses avec la maison Vergueiro d'Amérique.

$$
\text { I } 866-\text { I } 867 .
$$

f. 258. Émigration au Brésil: Difficulté entre les communes suisses et les

f. 277. Amérique: Pensions militaires. agents d'émigration Vergueiro et Cie.

f. 294. Amérique: Pension réclamée par la veuve Ruffener.

f. 428. Amérique: Pension d'Elise veuve Ruffener née Stettler. 


\section{CANTON DE VAUD.}

\section{LAUSANNE: ARCHIVES CANTONALES.}

Location: In the tower of the Cathedral.

Hours: 8 a. m. $1012 \mathrm{ml}$; 2 to 6 p. m.

Bibliography: Maxime Reymond, article "Archives" in the Dictionnaire Historique, Géographique et Statistique du Canton de Vaud, ed. E. Mottiz (Lausanne, I9I I), pp. 79-8I.

Antoine Baron, "Notices sur les Archives du Canton de Vand", in the Journal de la Socićté Vaudoise d'Utilité Publique. XIII. 3II$318(18.45)$.

The region now embraced in the canton of Vaud consisted in the Middle Ages of at variety of jurisdictions, subject to the Bishop of Lausanne, to other feudal lords, and to municipalities. From I 536 to 1798 this region of "Suisse Romande "was subject to the authorities of the canton of Bern. From I 798 to 1803 it was a part of the Canton du Léman, in the Helvetic Confederation; from I 803 to I 8 I 4 , of the French Empire and of the Département du Léman. It is only since 1815 that it has been a canton of the Swiss Republic.

In the Middle Agres the Bishop of Lansanne, the fendal lords, and the municipalities each kept their own archives. The Bernese on taking possession of the land transferred to Bern a vast number of parchments, chiefly ecclesiastical, as being useful for the administration of the land, and at Bern they were classified, in some cases copied into record books, and listed in inventories of various sorts-Inventaires Blanc, Rouge, and Vert, large parts of which have recently been consolidated into the Inventaire Blen. In 1798 the short-lived République Lémanique claimed from Bern the archives relating to the Pays de Vatud. At various times from that date to $18+3$ the Bernese government sent to Latusanne some 50,000 parchments relating to Vaud, and also several thousand volumes covering the Bernese administration of Vaud in the period from 1536 to 1798 . These the govermment of the canton of Vand installed in the belfry of the cathedral at Latusamne. In 1829 it appointed a cantonal archivist, Antoine Baron, who served from I829 to I86I; his successor, Aymon (rousa\%, from ing r to Igor).

Besides the docmments thus transferred from Bern, the cantonal archives embrace the minutes of the notaries of the Pays de Vaud from the fourteenth to the eighteenth eentury, the cadastres and accompanying banks from the seventeenth century down, the registers of atat ciall from about I 5 (ro to IS2I, and the govermmental palpers of the perion since $17 y 8$, in so far as these have been turned over by the executive departments to the cantonal archives. Such deposits have been made at various times by the seven executive ministers, but it may in general be said that the latter retain the papers which have arisen in their lusiness since albout 1870 .

At first the cantonal arehives were subject to the Commissaire (ieneral, after 18.37 to the (1hancery of State; now they are subordinate to the I)epartment of Public Instruction. Their administration is governed by a law of November 24, 1905. in accordance with which the Council of State appoints the archivist and subatrchivist for terms of four vears. 
Further particulars respecting the history of the cantonal archives may be found in the articles mentioned in the bibliography above.

The office of the archives is in an ancient building opposite the northwest cormer of the cathedral. The archives themselves are kept in the cathedral tower, in which they fill three large, high rooms, one situated over the other, and each having one or more galleries.

The highest apartment, in the third story, is, with its galleries, mainly occupied with the records of the Bernese and earlier periods. Its main room contains many volumes of mandates and ordinances ("Obrigkeitliche Mandaten und Verordnungen") of the Bernese government for the various bailliages of which the Pays de Vaud consisted under the Bernese administration; the onglets or letter-books of the bailliages, some 200 volumes, and many portfolios of unbound correspondence; several hundred, perhaps a thousand, volumes of their financial accounts; and several hundred volumes of the decrees and other documents of the Cour d'Appellation Romande, of the Chambre des Bannerets, of the Chambre Économique, of the Commissariat. and of the criminal courts-the general administrative bodies maintained at Bern for the government of the Pays de Vaud. One likewise finds here registers of the church and of the Academy, and a certain number of books of the consistory, and other ecclesiastical records. This chamber also contains the registers of état civil (births, marriages, and deaths) down to I82r.

The records of births, marriages, and deaths in the Pays de Vaud begin practically with the Reformation. From that time the pastors kept registers of baptisms and marriages, though with some irregularity. The Bernese government in I707 required the recording of births and baptisms, and in I708 registration of deaths. Under the Helvetic Confederation, from I799 to the beginning of $\mathrm{I} 8 \mathrm{OI}$, the registers of état civil were kept by the municipal authorities, but the function then returned to the hands of the pastors. The Dictionnaire Historique, Géographique et Statistique du Canton de Vand gives (pp. 272-274 of the supplement of the old edition) a conspectus for each of the IO7 arrondissements d'ctat civil showing from what dates registers of births, marriages, and deaths have been preserved. These are the primary materials for genealogical researches anterior to I82I. Since that date a system of registration on official blanks has been followed, in accordance with which one set of registers of état civil is preserved in the local arrondissements, while a duplicate set is to be found at the Department of Justice and Police.

The first gallery of this highest apartment contains the 50,000 medieval parchments already alluded to, the copies made from them, and their inventories. The second or highest gallery contains the cadastres of the period before 1798.

The apartment on the second or middle floor contains the cadastres territoriaux for the various districts and communes of Vaud in the nineteenth century, with many maps and plans. In the gallery are a part of the notarial documents mentioned above. These notarial documents, some 6000 volumes in number, were for a time kept in the castle of Chillon, but a few years ago were incorporated with the cantonal archives at Lausanne.

The lowest of the three apartments consists of a main floor and a gallery floor. The former is devoted chiefly to documents concerning births, marriages, and deaths, down to the latest times, but contains also the journals and letter-books of the administrative bodies and tribunals of the Canton du Léman under the Helvetic Confederation, I798-I803. The gallery floor contains the archives of the departments of the canton from I $_{5} \mathrm{I}_{5}$, and indeed 
from 1803 (Canton du Léman). In this section, in one of the cartons of the Conseil d'Etat, lettered "L, Agriculture, Industrie, Commerce, etc.", is found a dossier of papers of dates from 1822 to 1856 , relating to enigration, and containing administrative circulars, reports, petitions, and correspondence with other cantons, with emigration societies, and with foreign officials respecting migration to the United States and other countries. Upon this gallery floor are also volumes of registers of the diet of the Confederation and papers arising from the relations of the government of Vaud with the federal government; a part of the collection of notarial registers; and a part of the journals, letter-books, and account books of the bailliages under the Bernese. For one important section of this material, the plumitifs (journals) of the Council of State in the nineteenth century, there is a general index: the original of the plumitifs is at the chateau or government building of the canton, but a duplicate set is in the archives. It should be mentioned also that there is a general inventory for the Décrets Romands, an important series of the Bernese period; that many other of the Bernese volumes, especially of the eighteenth century, have individual indexes; and that a repertory of the onglets has been begun. There is no general inventory of the whole archive.

The oldest document in the archives is a grant to the abbey of Payerne from Queen Bertha of Burgundy, A. D. 962.

The canton of Vand contains 388 communes. The communal archives are from time to time inspected by the cantonal archive officials, and at the request of the local authorities are classified.

It could not be expected that much material bearing on American history should be found in the archives of Vaud. Such emigration as has taken place has mostly been individual. A few instances of organized emigration can, however, be cited. ${ }^{1}$ In 1796 Jean-Jacques Dufour, of Montrenx, migrated to America, where he took up land on the Kentucky River, and in ISOI was joined by seventeen other emigrants from Montreux and Blonay, who founded the colony of Firstvineyard. Others, joining them in I803, went forth to found Switzerland, Dearborn County, Ohio, and Vevay, Switzerland County. Ind., just across the Ohio. About the same date others went with Genevese to Geneva, N. Y., while in the middle portions of the century others went to Highland, Ill., Alpina, Pa., Lcopoldina in Brazil, and Esperanza in Argentina. Some data respecting these may be found in the carton "Emigration" mentioned above, in the onglets for the bailliage of Vevey, and elsewhere. The papers relating to the colony of Vaud on the Pecos River in New Mexico. being of late date (1892), will be found rather in the offices of the departments than in the cantonal archives.

\section{LAUSANNE: MINOR ARCHIVES.}

Besides the cantonal archives and those of the departments, Grand Council. and courts, there are also at Lausanne the archives of the synod of the National (Protestant) Church, kept in a builcling close by the office of the cantonal archives, and those of the city of Lausanne, kept in the Hotel de Ville.

\footnotetext{
"See the article " Timigration", in the supplement to Martignier and Crousaz, Dictionnaire Historique du (anton de l'and (Lausanne, 1887), 1. 265; the article by Dean Bridel, "Colonies Suisses sur lOhio", in Le Conseratiour Suisse, VIl. 237-254 (Lausanne, 1856 ), based on manuscripts of Dufour; and that of Miss Julia L. Knox, "Vevay and Switzeriand County", in lndimo Magazine of Ilistory, XI. 216-2.30 (Sept., 1915).
} 


\section{YVERDON.}

The library of Yverdon possesses one of the manuscripts of Christoph von Graffenried's memoirs of his American experiences, the one of which an English translation is printed in the North Carolina Colonial Records. ${ }^{1}$

General Frederick Haldimand came from Yverdon, ${ }^{2}$ but it is reported that no manuscript materials relating to him are to be found there.

${ }^{1}$ I. 905-985. See Faust in German American Annals, n. s., XI. 206, and John Landry, "New Berne" in Revue Historique Vaudoise, XV. 83-94 (1907); and above, pp. 3, 73. Graffenried was at one time bailiff of Yverdon.

"Born in 1718 . In the list of notaries given in Revue Historique Vaudoise. XII. 299301, from a manuscript "Livre des Notaires du Bailliage d'Yverdon", one finds an F. Haldimand signing in 1698 , and an F. L. Haldimand in 1732 . Bouquet was also a native of the Pays de Vaud (b. Rolle, I7I9), but I was not so fortunate as to find anything about him in the cantonal archives. See A. Burnand, "Le Colonel Henry Bouquet, Vainqueur des Peaux-Rouges", in Revue Historique Vaudoise, XIV., five articles (I906). 


\section{CANTON DE VALAIS.}

\section{SION: ARCHIVES D'ÉTAT.}

Location: In the Lycée-Collège.

Hours: 8 a. ill. to $12 \mathrm{~m}$.; 2 to 5 p. m.

The archives of the canton of Valais are in the care of the Archiviste d'Etat, whose office since I9 Io has been attached to the Ministry of Public Instruction of the canton, having before that time been attached to the Ministry of the Interior. The archives are administered under a réglement of the Council of State of September 12, I873, for which, however, a more modern regulation may soon be substituted. The present archivist is also librarian of the cantonal library (and of the society of natural history and Alpine Club), and the archives are kept in the building called the Lycée-Collège, of which the wings are occupied respectively by the cantonal college and the normal school, while the central portion of the building contains the library. Five rooms, situated in the basenent, but dry and light, are devoted to the cantonal archives, together with a large closet containing the very curious archives of the family of Torrenté. Of these rooms, one is the study room and the archivist's office, containing also the documents which are in process of classification and the local registers of état civil, which not long ago were transferred to the cantonal archives from their local repositories. Another room contains, first, a special collection made up of the individual volumes and documents, medieval and modern, which have the greatest interest for historical purposes. This section is of great interest and value but contains nothing for the purposes of the present volume. In the same room are preserved the registers of the Council of State and Grand Council, papers relating to them, and copies of the proceedings of the diet of the Confederation. A third large room is mainly devoted to volumes and portfolios of documents originating in the excutive departments of the government of Valais and those resulting from judicial proceedings in earlier and later times. I small room is occupied with printed books, while a fifth contains the archives of the family de Rivaz, valuable for many periods of the history of Valais but apparently having no relation to American history. except for the possibility that the two volumes of the journal of Charles Emmanuel de Rivaz as prefect under the Helvetic and eight volumes of his letter-books for the same period may contain material on Turreau, commander of the troops stationed in Valais from July, I 798, to September, i So2, and afterward ( $803-18$ IO) minister of France in the United States. There is also a special volume of documents relating to Turreau ("Recueil de diverses Picees", etc.), but its table of contents shows nothing concerning" America. The chief authority for his regime in Valais is the Mémoires of Rivaz (Sion, I890). Mangourit, consul at Charleston 1792-1794, also played an important part in Valais as resident of France, 1797-1798.

The cantonal archives of Valais comprise those still remaining from the period of the sovereignty of the bishops, those of the period of the republic, from 1628 to 1798 , those of the period of grovermment under the Itelvetic Confederation. I798-1802, those of the second period of independence of 
Valais (République Rhodanique), from 1802 to $18 \mathrm{Io}$, those of the period of the French government, I8IO-I8I5, including the period of the mediation of ISI 4 , and, finally, those which are of date subsequent to the incorporation of Valais into the Siviss Confederation in I I $_{5} 5$.

For the period since I8I5 the documents are or are to be arranged in accordance with the following categories: I. Diet and Great Council; II. Council of State; III. Departments. The first embraces the journals, laws, bills, and miscellaneous documents of the legislature. Those of the second division include the proceedings and decrees of the council, the domestic and foreign correspondence of the canton and documents relating to its courts, its relations with other countries and cantons, the Sonderbund, ecclesiastical affairs, etc. The papers belonging to the third class are, naturally, classified under the respective departments : finance, interior, public instruction, justice, militia, and public works.

Besides papers emanating from governmental sources, the archivist is authorized to acquire archives of individual families and has gathered several extremely interesting collections of this sort.

The canton of Valais has developed much more completely than most governments its system of dealing with local records, and this, especially for the value of its example to American states, perhaps deserves special mention. The canton maintains two inspectors who upon a uniform system of printed instructions have examined the local archives in most of the I7I communes into which the canton is divided. Their reports, which in the case of separate documents and especially the earlier papers, amount to a full calendar, are made out upon uniform blanks and preserved in a series of thirteen portfolios corresponding to the districts of the canton. For each commune there are or may be reports upon the respective archives of the municipalite, of the bourgeoisie (the distinction is like that between town records and proprietors' records in early New England), and of the ecclesiastical parish, though reports of the latter, in view of the separation between Church and State, cannot be insisted upon by the cantonal government. These reports by the inspectors are made out in duplicate, one copy being preserved in the cantonal archives and the other in the local archives, which retain possession of the original documents.

As to registers of births, marriages, and deaths, and the genealogical information which can be obtained from them, they must, for the period before 1853 , be sought in the ecclesiastical archives of the parishes, though information respecting such volumes of parochial registers may frequently be found in the reports mentioned in the preceding paragraph. From 1853 to 1874 the curés of the parishes had a quasi-public function in respect to the matter, and records of état civil sent in by them are preserved in the cantonal archives. Since 1874 the records of état civil have been a federal affair, and complete sets of them, sent in on blanks from the communes, are preserved in bound volumes in the cantonal archives.

It should be mentioned that the cantonal library contains a large collection of files of newspapers published in Sion and other places, and these newspapers, which of course have nearly the rarity of manuscripts, sometimes in the earlier periods contain letters from emigrants to America. The first newspaper of Sion was the Echo des Alpes, which began publication in 1839 . There is a Bulletin Officiel, published by the cantonal government from 1803 to the present time, giving official acts, and there is a section on emigration and on the cantonal archives in each Rappart du Conscil d'Etat, a printed series beginning in $185 \mathrm{I}$. 
The executive departments of the canton retain possession of their recent papers, turning over to the cantonal archives those which are no longer in current use. In many cases this happens after three or four years, in other cases papers for as many as thirty years back are retained.

Of other archives in Sion, the archives of the bishopric were almost entirely destroyed in the great fire of 1788 . There are interesting municipal archives in a building near the old college, with a good manuscript inventory made in I750; and there are archives of the chapter, kept in a building adjoining the old cathedral (de Valère), but they are reported to contain nothing whatever for American history. 


\section{CANTON DE NEUCHÂTEL.}

\section{NEUCHÂTEL: ARCHIVES DE L'ÉTAT.}

Location: In the Château.

Hours: 8.30 a. m. to 12 111.; 2 to 4 p. 11 .

It is necessary to remind the reader of the peculiar history of Neuchattel. Throughout the Middle Ages it was governed by its counts, usually allies of the Swiss Confederation. From $\mathrm{I}_{503}$ to $\mathrm{I} 707$ was the period of the (usually non-resident) counts or countesses of the French house of Longueville, who habitually maintained the same alliance. Under the counts, though they were Catholics, Neuchâtel became Protestant, the government of the church passing into the hands of the Company of Pastors, or Venerable Classis (for which in 1848 was substituted a synod, two-thirds laymen). In I707 the King of Prussia became Prince of Neuchâtel, and he and his successors remained its sovereigns until I857, except that from I806 to I8I3 it was placed by Napoleon in the hands of Marshal Berthier, as prince of Neuchâtel. In I814 it became a canton of the Swiss Confederation, the King of Prussia still remaining its sovereign. This anomalous position caused two insurrections in September and December, I83I, and a revolt in 1848 ; and the Prussian rule was ended in 1857 .

Under the counts the Audience du Comte was the highest administrative and judicial court and also had legislative attributes. Toward the end of the Middle Ages its judicial functions passed into the hands of the Tribunal des Trois États, while the Audiences Générales (three estates) became the legislative body, but were not convoked from I6I8 to I8I4. After existing actively from I8I 5 to I83I, this body was superseded by a more popular Corps Législatif, and this in 1848 by the present Grand Council. Under the Prussian rule, or at any rate from I 707 to 1848 , Neuchâtel, still in alliance with the Swiss Confederation, and from I 8 i 5 a member of it, was ruled chiefly by its (native) Council of State, though with a Prussian governor.

The archives of Neuchatel existed from medieval times, in the charge of the Chancellerie or of the Secretary of State. In the course of the eighteenth century a Commissaire Général was appointed, whose functions included those of an archivist. A cantonal archivist was substituted in 1848 and he continued until I898. In that year the archives were reorganized. Down to that time there had been two deposits. The Commissaire Général and Archiviste Cantonale just referred to had had charge of all of the earlier papers, of date previous to I707, while the papers of date subsequent to I707 had been in charge of the Chancery of State. In I898 an Archiviste d'Etat was appointed to take charge of the later series, as well as of the judicial documents brought together from the whole canton, and for four years (I898-I902) there were thus two archivists. In I9O3 the two offices were combined by an arrêté of the Council of State. Except for the changes made in that year, the archives are governed by a règlement of the Council of State of February 7 , 1899 .

The archives of the canton of Neuchatel have for centuries been housed in the ancient chateau of the counts. The general office and consultation room is in the southwestern tower, which forms the most ancient portion now 
existing of the castle, dating from about i I9o. Several rooms along the south curtain of the fortification and near its southeast corner have for many years been occupied with the archive materials. In 1902 a plan was formed for a new building. In Igo8, however, the Council of State resolved instead to make larger provision for the archives within the walls of the castle. Accordingly a large four-story stack has been built in an old court-yard at the north of the present quarters. This, with the space afforded by the present storage rooms (also converted into stacks) makes an ample provision of a most modern character for the installation of the archives. The additions are estimated to amount to 8000 metres of shelving. A well-catalogued library of 7000 or 8000 titles, made up partly of the books most appropriate for a cantonal archive, and partly by a recent concentration of the small and miscellaneous libraries of executive departments, and a good photographic apparatus, complete the equipment.

The archives are at present classified into three major sections, corresponding respectively to the periods of Neuchatel history previous to I $70 \%$, from 1707 to 1848 , and from 1848 to the present time. There are two classifications of the archives, one for the period previous to 1707 , the other for the period from $I 707$ to $I 848$. The papers since 1848 are of course classified according to executive departments, which turn them over to the archives from time to time, retaining in general those of the last twenty-five years. For the papers of the first period there is an inventory, practically complete; for the latter the inventory is only partially completed. For this latter period, the only one which in any way concerns America, the most important section of the archives consists of the papers of the Council of State, which from the sixteenth century to the institution of a legislative body of modern form was by far the most important institution of the land, having both administrative and judicial functions and taking cognizance of all sorts of events and details of business. The most important portion of its archives consists of the Manuaux, i.e., its journals, extending from 1514 to the present time298 great volumes.

Closely related to this are the Pièces Ammexes, arranged in two sections, one anterior to 1707 , the other posterior, and containing the papers on which the action of the Council was based, such as reports, petitions, letters from subjects, addressed to the Council of State, etc. The former series lias an inventory in four large volumes; for the latter, there is a less perfect inventory in some ten volumes, amounting to little more than a chronological list of these papers. The Pièces Annexes for the period from I 707 to 1848 are classified in bundles, according to the subject-matter, such as, to name the dossiers most likely to contain American materials: Archives, Bourgeoisie, Chancellerie, Cultes-Général, Cultes-Pastcurs, Emigration (also the separate groups of documents made for each period of political revolution may contain papers respecting persons expatriated by reason of them), Etat Civil (several), Marchandises Anglaises ( I806), Militaire (Service à l'Étranger), Naturalisation, Passeports, Relations Extérieures, and Successions. These dossiers or cartons are numbered; in each there is a chronological arrangement. Each document possesses its own number, by which it may be found through the general inventory of the Pieces Annexes.

There are tables of contents, for each ten years, of the Manuaux, also indexes of names for the Manuaux for the period from 1820 to 1850 . For the volumes of correspondence there are nierely tables of contents in each volume. 
Other series are: "Missives" (general correspondence, from I 560 to the present time), Letters to and Rescripts from the King of Prussia (I707I 8.8), Lettres à la Suisse, and Lettres de la Suisse (to and from the other cantons and the federal authorities, since I $815_{5}$ ); also laws, decrees; and the record books of administrative and financial boards and of tribunals. Among the boards, special mention may be made of the Chambre Economique, which administered ecclesiastical property.

For the journals of the nineteenth-century Audiences Générales, see the recent official publication, Procìs-Verbaux des Audiences Générales de Neuchâtel, I8I6-I830 (Neuchâtel, I904), edited by the present archivist, M. Arthur Piaget. The only American item in them appears to be that on June 25, I8I9, Count Portalès-Gorgier made a proposal, which was merelv referred to the Council of State, that the deputation of Neuchâtel should be charged to submit to the diet the propriety of negotiating with some American state to assure better protection to Swiss emigrants in respect to property and other rights (Procès-Verbaux, I. 344-345). The archives of the Corps Législatif, and of its successor (since I848), the present Grand Council, consist of but little save the journals and the petitions and other papers upon which legislative action was founded.

The present archivist has obtained from Berlin a considerable mass of copies of documents of the Prussian administration of Neuchâtel, and a selection of these will be printed.

There is also a series of large volumes containing the Reconnaissances des Biens de Rentiers, drawn up from time to time and corresponding to cadastres. The archives have also a collection of newspapers of the canton, extending from 1830 .

There are ten or twelve thousand volumes of registers and minutaires of notaries of the period before 1873 . and others for the period since that date, at which time some modifications of the law respecting notaries were decreed. There are notarial documents from the fourteenth century. In I905 the Conseil d'Etat decreed that the notarial registers of earlier date than 1848 , preserved by the communes in their archives and clerks' offices, should be turned in to the archives at the Chateau. A detailed repertory of the notarial archives is in progress, and there is a card catalogue of the notaries. Of I 200 known to have exercised their functions in Neuchâtel, there are some 800 whose registers and mimutaires are in the archives-indeed practically all those of the eighteenth and nineteenth centuries.

The earliest registers of état civil date from about I 560, and were kept by the pastors. The registers of ctat civil have continuously remained in the hands of the local authorities; but, beginning in the eighteenth century in some cases, in the nineteenth in others, there are duplicates made by the local and transmitted to the cantonal authorities, and these are now in the cantonal archives. The local subdivision for such purposes is not precisely the commune; the canton is divided into 47 arrondisscments d'état civil, whereas there are 63 communes.

The law requires communes to keep their archives carefully and to have a place for them that is secure, dry, and safe from fire. By an arrêté of June IO, I905, the Conseil d'Etat decreed that, except in case of communal archives already systematically arranged and classified, communal authorities should proceed upon the plan of classification annexed to the arrêtć. A detailed classification under fifteen general headings is provicled. The archivists of 
communes are permitted for special reasons to make different subdivisions in their particular cases.

In rgr the archivist on request of the Council of State made a general inspection of all the communal archives. It appeared that of the $63 \mathrm{com}$ munes of the canton six had their archives completely classified, I 3 partially, while six are classifying them in accordance with the plan of 1905 , and 38 have neither classification nor inventory. Several communes have insufficient or dangerous places. The Council of State urged them to take proper measures. Some conmunes, however, have preferred to deposit their pieces of the old régime in the archives of state.

By search of indexes for most of the period from i 700 to 1848 the following itenis relative to American history were obtained:

\section{From the Manuaux du Conseil d’état.}

Oct. 7, I 720 . The chancellor is to write a circular letter to all the châtelains and maires, to be read in open court, forbilding any person to solicit subjects and inhabitants of this city to go to Mississippi.

Feb. II, I732. The Council being informed that M. Pury, formerly maire of Lignières, is engaging people in this country to go to Carolina and that a certain number of families subject to this state have already engaged with him, voted that orders be sent to the châtelain of the barony of Vautravers (Val-de-Travers), where the said Pury is, to collect and transmit information as to the truth of this affair, and what sort of engagements Pury is making. This is the only item found, relating to Jean Pierre Purry or his settlement in South Carolina. Prolonged search might have developed more. Judge H. A. M. Snith, in his article "Purrysburgh", in the South Carolina Historical Magazine, X. I87-219 (I909), the authoritative account of the colony, gives lists of two or three hundred names, many of which are of Neuchatel families.

From the Rescrits de sa Majestí.

July 8, I 754. The King has been informed that many subjects of his principality of Neuchatel and Valangin are allowing thenselves to be engaged by all sorts of promises to quit their comntry to nigrate to the English colonies of America. "Though we remember well that the third of the Articles Généraux provided that all subjects of the state may freely leave the country for travel or other purposes, we do not think that such a liberty ought to extend to wholesale enticing away of our subjects; also consider it our paternal duty to warn our subjects not to be deceived. Even the King of Great Britain has given his German subjects a warning of this sort, and we have refused such poor people permission to pass through our duchy of Cleves. Therefore you are to issue warnings and orders respecting such enticements." In the same volume is the rescript of Aug. 24, approving the action of the Conncil.

July 29, I 754. A rescript from the king having been received, ordering that everything possible be done to prevent the enticing away of his subjects in this state to go to the Finglish colonies in Anerica, it is ordered that a decree be drawn up) forbidding such enticement and such emigration muder the severest penalties. 


\section{Manuaux.}

Mar. 2I, I797. Col. Chambrier de Travanet recommended to the authorities of Philadelphia in a matter of collecting monies due him from Jean Antoine Guyenet of Couvet, who has died there.

June $7,{ }_{18} I_{7}$. Measures taken by the King of the Netherlands, because of the extraordinary number of Swiss emigrants crossing his country to go to America. See note from dossier "Émigration" in Pièces Annexes.

June I9, I 8 I7. No. 45. Resolved, to see if emigration should be regulated and direction given to it.

June 7 , I819. Notification from the Federal Directory, dated May 27, reminding the cantons that emigrants cannot go through the Netherlands without passports.

June 29, I819. Instructions to the deputies to collect information as to what other cantons have done to direct and protect emigrants to America, and to see if concerted action is possible or advisable.

Feb. 20, 182I. The mayor of Valangin having reported on the efforts to obtain recruits for the colony on the Red River, and suggesting measures to prevent the communes from ruining themselves by advancing money to such emigrants, the Council votes not to adopt the measures he proposes. See pp. I7 I, I72, post, and note.

May I I, I83I. The Council in pursuance of a circular from the Directory, dated Apr. 29, ordains the publication of a warning to persons intending to go to America, that the prefects of the French frontier departments will not hereafter grant passage through France to any who are not provided with the necessary papers and sufficient pecuniary means for the voyage.

June I I, I 832. Circular of the Federal Directory of May 27, transmitting the request of the ambassador of France that no emigrants for America be allowed to go out until those now in French territory, especially at Havre, have sailed. The Federal Directory has been notified that similar conditions also existed in the Netherlands.

Mar. 3I, I 828. Circular of Mar. 20, from the Federal Directory, transmitting an ordinance of the King of the Netherlands as to the formalities to be followed by emigrants going through his dominions to America.

Nov. 20, I837. Circular of the Federal Directory of Nov. II, informing that the consul at New Orleans represents the situation of Swiss emigrants there as so unfortunate that advice is given to stay away intil the financial crisis in America is over. The Council orders the communication to be sent to each local jurisdiction, to be read in open court.

Oct. 20, I845. Federal circular of Oct. I6, transmitting report from the Swiss consul at New York on the dangers surrounding emigrants arriving there. The Council sends it to the Chancery for publicity.

Mar. I6, i846. Similar warning from New York.

May II, I846. Circular from the Federal Chancery of May 6, on the difficulties surrounding intending emigrants at Havre. Publicity decreed.

Sept. 9, 1846. Warnings from America. 
Some items may also be found in the indexes under "Commerce". There are lists of passports since 1796 .

\section{Pièces Annexes.}

"Emigration": This dossier contains some 38 documents. Among them are the following relating to America:

Certificate of Jean Jaques le Roy, commissary on behalf of the King of Great Britain for colonists emigrating to Pennsylvania. In relation to a family whose transportation he had undertaken, the Sieur Friederich Guie, Marguerite Pewelef, his wife, Samuel Péter and Jean Friederich Péter, her children by a former marriage, and Jean Friederich Guie and Jeanne Marie Guie, children of this second marriage, all of Verrières in the county of Neuchâtel. Le Roy makes himself responsible for transfer to the stepchildren of any property belonging to them. Dampierre, outre les Bois, Feb. 2, 1754 .

Letter of Licut.-Col. Montjou to some one whom he endeavors to engage to collect colonists in Savoy and France and bring them to Basel to be taken down the Rhine to Amsterdam. Frankfort a. M., Nov. 20,1765 .

Letter of Savary, duc de Rovigo, Minister of Police, to Berthier, prince of Neuchatel, informing him that Huguenin, the civil lieutenant at Locle, had written to a London house for information as to the protection of Swiss who wish to emigrate to America. Paris, Mar. I3, I8I2.

Letter of Alexandre (Berthier), prince of Neuchatel, to the president of the Council, ordering that Huguenin be questioned. Paris, Mar. I4, I8I 2.

Printet arrêt communicating a recent decree of the King of the Netherlands, who in view of the increasing number of Swiss and Germans passing through the Netherlands to go to America forbids any bodies of such emigrants to pass through the Netherlands unless citizens of the latter will be responsible for them. Neuchatel, Jume 7, I 8 I 7 .

Printed circular in German, three pages, put forth by Captain Rudolf de Maly. [May 24, I820?]

Letter of $A$. de Chambrier, mayor of Valangin, calling attention to Captain May's circular of May 24, I820, making brilliant promises to colonists on Lord Selkirk's land, and suggesting that while Article III. of the Charte may make it impossible to forbid single men to emigrate, the communes might be forbidden to give assistance to enigrants, especially to the heads of families. Valangin, Feb. 12, 1821. Sec aljove, pp. 128, 170.

Letter of Major E. May, brother of Captain Rudolf A. de May (of the Régiment de Meuron), to a correspondent in Neuchâtel, recontmending Lord Selkirk's Red River proposals and referring to Mr. Hauser, who took out the expeclition of the preceding spring from Rotterdam to Fort York, to Mr. Colville, and to Ciptain Mathey as probably now at Nenchitel. Also to the recent union of the Hudlson's Bay (ompany and the Northwest Company. Bern, Feb. 28 [1822?]. 
[These items require further explanation. Lord Selkirk's first experiment in colonization of the Red River of the North (I8II-I8I6) not having succeeded, he or his agents distributed proposals in Neuchâtel, Vaud, Geneva, and Bern, and some 200 colonists, mostly French-speaking, agreed to set out in the spring of I82I. They went via Basel and Rotterdam, by sea to Fort York on Hudson Bay, and to Fort Douglas and to Pembina. Meanwhile Lord Selkirk had already, in 1816 , secured 80 colonists from the Régiment de Meuron and 20 from the Régiment de Watteville. Charles Daniel de Meuron (1738-1806), after French service in the Régiment de Hallwyl and in the guards, agreed in $178 \mathrm{I}$ to raise for the Dutch East India Company a regiment two-thirds Swiss. In I795, at Ceylon, he and his proprietary regiment passed into the English service. After various service in the Napoleonic wars (during most of which it was about one-third Swiss), and under various Colonels de Meuron, the regiment went to Canada in I8I4. Major Emmanuel May and Captain Rudolph May were of this regiment. After much suffering, many of the Swiss colonists withdrew in 1823 to St. Louis, in I 826 and after to Galena. See Th. de Meuron, Essai Historique sur le Régiment Suisse de Meuron (Neuchâtel, 1885); the same writer's articles on "Charles Daniel de Meuron et son Régiment", in the Musée Neuchâtelois, XVII.-XXI.; Gen. A. L. Chetlain of Chicago, "Une Colonie Suisse dans l'Amérique du Nord ", French translation from an article in the Chicago Tribune, in Musée Neuchâtelois, XVI. 36-43 ( I879) ; General Chetlain's The Red River Colony (Chicago, I893, pp. 60), an expansion of his article. "The Settlement on the Red River", in Harper's Monthly Magazine, LVIII. 47 (December, I878) ; and Dr. Châtelain, "Les Neuchâtelois à la Rivière Rouge, 1821-1826", in Musíe Neucliâtelois, XXXIII. 7-12, 38-44 (1896).]

To the avoyer d'état of the canton of Neuchâtel: letter of Joseph Paquier of Bulle in the canton of Fribourg. Hearing that this spring a colony is to go out to the United States, and that one should address one's self to the advocate of Neuchâtel, he and others request full information. Bulle, Feb. 4, 1828 .

Arrêt of the Council transmitting warning from the Federal Directory as to unfortunate situation of emigrants as represented by the Swiss consul at New Orleans. Neuchâtel, Nov. 20, I837.

Letter of Jacques Vuagneux, notary, concerning his son Charles, sworn notary in Porto Rico, asking letter of recommendation to the captain-general of the island. Neuchâtel, May 22, I84I.

Report of deputation to the diet. By vote of June I, I846, the Council had charged the deputation to take part in a discussion invited by Graubünden as to the safeguarding of, emigrants. This conference took place Sept. 8, 1846, twelve cantons or half cantons participating. The propositions of Graubünden are quoted. The deputies at the conference being without instructions, the conference voted that its minutes should. be sent to all the cantons with a request for consideration and instruction before the next diet. Zürich, Sept. 9, I846. 
There are other documents in the dossier relating to emigration to Russia under Catherine II.

The documents of the Council of State seem to contain nothing respecting Alpina, or the projects of Suchard and Favarger there. See below, Bibliothèque de la Ville.

\section{NEUCHÂTEL: ARCHIVES DE LA VILLE.}

The archives of the city of Neuchatel are kept at the Hôtel de Ville, in the charge of the secretary-archivist. They consist of the journals (procèsverbaut $x$ ) of the city council (Quatre Ministraux) from the sixteenth century ; of the journals of the Great Council; of the correspondence of the Quatre Ministraux with Bern and the other confederated states, with the Confederation itself, with Prussia, with France, etc.; and of voluminous financial accounts. The journals of the Quatre Ministraux for I73I seem to contain nothing respecting J. P. Purry's colonial enterprise.

\section{NEUChATEL: BIBLIOTHEQUE DE LA VILLE.}

A lithographed manuscript: Ph. Suchard and Ch.-L. Favarger, "Société en Commandite par Actions pour Achat de Terrain dans l'Etat de New York (Colonie d'Alpina) ", made at Neuchâtel in 1845 , apparently.

Philippe Suchard (1797-I884), the eminent manufacturer of chocolate and of confections, had visited America in 1824; Heinrich Zschokke made from his notes a little book entitled Ph. Suchard, Mein Besuch Amerikas im Sommer 1824 (Aarau, I827). In I834 Suchard established the first successful steamboats on Lake Neuchatel. Coming over to America again in I845, he took up lands apparently rich in iron in Lewis County, New York, and established there a colony, Alpina, with a stock company to exploit the iron mines. Charles Louis Favarger (I800-1882), afterward prominent in Neuchâtel politics, went ont as manager of the company. The colony prospered for five years, then was given up. See Ph. Suchard, Un Voyage aux Etats-Unis d'Amérique il y a quarante ans (Nenchâtel, I868, a revised version, in French, of Mein Besuch, above); Notice sur Alpina, Terres situées dans les Comtés de Jefferson et de Lezuis, Etat de New York (Neuchâtel, I847, pp. 64. three maps); Le V'́ritable Messager Boiteu.. de Neuchâtel, 1883, p. 4I, I885, p. 47 ; F. B. Hough, History of Lex'is County, I. 73, 99.

\section{NEUCiIÂTEL: COMPAGNIE DES PASTEURS.}

The archives of the Classis or Company of Pastors are in a building in the Rue Collégiale, now occupied by the independent faculty of theology. They date from the Reformation.

These archives contain, first, the registers of deliberations (minutes of meetings) of the Company of Pastors from I 560 to I 848 , the chicf records of the administration of the Chureh. There are eighteen volumes of these registers, quarto and folio. With 1848 begin the registers of the synod, whose records are kept in the Archives of State.

Secondly, the archives of the Company of Pastors contain the correspondence of the Classis, as follows:

(I) For the period of the Reformation and of the sixteenth century in general, ten portfolios of letters classified by anthors, and two large cahiers 
of letters stitched together without strict classification. One of the latter contains some letters of the seventeenth century.

(2) Two large registers of copies of letters written by the Company of Pastors, from about I 700 to 1848 . These represent only a part of the correspondence; the registers described above mention many letters not thus preserved.

(3) Letters received by the Company of Pastors since the seventeenth century. These have been brought together in portfolios, but with only a rough classification.

(4) Miscellaneous papers.

Rev. Joseph Bugnon, minister of Purrysburgh, S. C., was not consecrated at Neuchatel, and there seems to be in these archives no information respecting him.

There are also archives of the independent Protestant church of Neuchâtel, established in 1873 . These are at the Bâtiment des Conférences. 


\section{CANTON OF GENEVA.}

\section{GENEVA: ARCHIVES DE L'ÉTAT.}

Location: In the Hôtel de Ville, but see below.

Hours: 8 a. 11 . to $12 \mathrm{~m}$.; $\mathrm{I} .30$ to $3.30 \mathrm{p} . \mathrm{m}$. Thursday is reserved, but usually the archive is open on that day also.

Bibliography: Louis Dufour-Vernes, "Les Archives de l'Etat de Genève", in Bulletin de la Société d'Histoire et d'Archéologie de Genève, II. I9-4I (I 898 ).

F. Turrettini, Les Archiz'es de Genève: Inventaire des Documents contenus dans les Portefenilles Historiques et les Registres des Conseils, I528-154I (Geneva, I877, pp. iv, viii, 332, I9). Pp. i-viii form a "Notice sur les Archives de Genève", by Théophile Heyer, at that time director of the archives.

Alfred L. Covelle, Le Liure des Bourgeois de l'Ancienne République de Genève, publié d'après les Registres Officiels, I339-1792 (Geneva, I897, pp. xvi, 562).

Grenus-Saladin, Fragmens Biographiques et Historiques extraits des Registres du Conseil d'Etat de la République de Genìue de I535 à $I 792$ (Geneva, I I $_{5}$ ).

Herbert D. Foster, notes in article "Geneva before Calvin", American Historical Review', VIII. 2I8-2I9.

Geneva, which in the Middle Ages had been an imperial city, under a bishop who was a prince of the Empire, was from 1530 to 1798 an independent republic, allied with the Swiss cantons. In 1798 it was annexed to France. and became a part of the Département du Léman (to be distinguished from the contemporary Canton du Léman=Vaud, in the Helvetic Confederation); in the last days of $\mathrm{I} 8 \mathrm{I} 3$ it resumed its independence, in I8I 5 it became a member of the Swiss Confederation.

The state archives of the canton of Geneva, which for centuries have been kept in the Hotel de Ville, consist in the main of the archives of the old republic and of the period of French domination. They extend only to 1814 , except that they contain the registers of the Conseil d'ftat down to is,30. Documents subsequent to $\mathrm{I}_{\mathrm{I}} 4$ are in the Chancellerie, if they are documents of the Conseil d'etat, but in the offices of the executive departments if they originated in the latter. The whole collection in the archives amounts at present to at least 14,000 or I 5,000 volumes and 400,000 detached pieces. The oldest dlocument is of $A$. D. 912 .

Provision for historical use of the archives by the public began in ${ } \Omega_{4} 4$. M. Lotis Sordet, archivist from I830 to 1851 , began a classification of which the leading feature was the making of a series of "T'ortefenilles des Pièces Historiques". Some 40,000 documents were brought together into this collection of pieces classed as "historical" par e.rcellence, by a process of segregation which would not now be approved. M. Louis Dufour-Vernes, state archivist from 1885 to $190 \%$, introduced a more scientific classification, whose categrories rested on the ontlines of the old Genevese constitution, and made many new inventories, indexes, and calendars. 
The state archives of Geneva are installed in eight rooms in the Hôtel de Ville, in one large room at no. I I rue Calvin, and in seven rooms at no. I rue du Puits St. Pierre. In the Hôtel de Ville itself we have first the Salle des Fiefs, in the west corner of the building, on the ground floor. This room, which is used as the office of the archivist and as the search room for investigators, contains also the various inventories and indexes, the library of printed books, the collection called "Portefeuilles des Pièces Historiques", and a "Collection des Manuscrits Historiques", a certain number of maps and plans, the registers of baptisms, births, marriages, and deaths for the city and for the country districts of the canton (brought in by edict of 1902), and the registers of the Council of State from I8I 5 to 1830 , with a collection of accompanying documents.

Half-way down a staircase that leads from this room is found the Salle des Annexes, which contains a large mass of papers auxiliary to the proceedings of the Council, such as financial accounts, reports of committees, and miscellaneous documents; and a collection of maps and plans connected with the system of administration and taxation of real estate. At the foot of the staircase is the Grande Grotte, which is the lowest story of the ancient square tower of the Hotel, called the Tour Baudet, looking out upon the Treille. ${ }^{1}$ This room contains the registers of the Council, 322 volumes, I409-1798, with some gaps in the fifteenth century (this may perhaps be regarded as the most important series in the archives), petitions to the Council, publications of the Council relating to the affairs of individuals, called Livres des Particuliers, the accounts of the treasurer, and other financial documents of the Council, the letter-books of its correspondence, and the volumes, nearly 3500 in number, of the minutes and protocols of notaries.

The remaining rooms upon the lowest floor are still called the Salles Papon, from the name of a restaurateur who in 1822 was dislodged from the Hotel de Ville to make additional space. They lie along the northwest side of the basement and are designated as the Grande Salle Papon (directly under the Salle des Fiefs), and the First, Second, Third, and Fourth Petites Salles Papon. In general it may be said that the large room contains the record books and portfolios of documents of administrative boards of the Genevese government and a considerable part of the judicial papers, especially those relating to criminal trials; the first small room mostly those of civil courts, the second those of the outlying jurisdictions in the environs of Geneva, and the third and fourth, mostly record books and rolls containing the titres et droits de la seigneurie, evidences of property chiefly ecclesiastical, given to the bishop, the chapter, or the churches, and turned over to the state at the time of the Reformation. The collection embraces a wide variety of auxiliary materials, such as those relating to tithes and episcopal visitations. In the third small room are also the registers of the Communauté, I364-I386, which disclose the municipal business in the period before the registers of the Council begin.

At a short distance from the Hotel de Ville, at no. I I rue Calvin, in the building called Maison de Calvin, because it stands on the site of Calvin's dwelling, one very large room in the basement is filled with the documents

${ }^{1}$ The Tour Baudet dates from the fifteenth century, and its lowest story has remained unchanged since then. The Grande Grotte has been devoted to archives since $156 r$. See C. Martin, "La Maison de Ville de Genève", in Mémoires et Documents de la Société d'Histoire de Genève, third series, III. ( 1906, pp. xvi, I39). 
for the French period, I798-I8I4, chiefly the administrative documents of the department and prefecture of the Léman. These were installed in their present location in 1893 , are partially reduced to systematic arrangement, and are listed in a separate manuscript inventory called "Inventaire des Titres, Pièces et Registres mixtes de l'ancienne Préfecture ou ci-devant Département du Léman, de l'Arrondissement de Genève, et autres administrations, dressé par Monsieur Constantin de Magny, dépositaire royal nommé par Sa Majesté le Roi de Sardaigne, et Monsieur Martin Servand, dépositaire pour le Canton de Genève, en exécution de l'article 20 du Traité de Turin du I6 Mars i8 86. ."

Still another portion of the archives is kept at no. I rue du Puits St. Pierre, some two hundred yards from the Hotel de Ville, in a suite of seven rooms which formerly constituted the Salle des Hypothèques, but which since I9I I has been under the jurisdiction of the archivist. Here are kept the archives of the Bourse Française, I 550-I849, an institution administering funds and charities of Huguenot refugees; those of the Hôpital Général, I 535-1868, archives turned over to the state in I9I I ; and those of the courts of justice of the nineteenth century.

To all this mass of archive material there is a general guide, in the form of a manuscript inventory prepared by the present archivist, M. Paul Martin, a large volume of 2I 3 pages, bearing the title "État Général et Sommaire des Fonds, I9I I". It does not include in its scope the archives of the Department of the Léman, for which there is the special inventory mentioned above. Its plan is, while listing all subdivisions, to enlarge upon those only which are not covered by any existing inventory; where a serics has already been described in one of the ten partial inventories noted below, it refers to that book. Thus it supplements, and places in their general setting, in a classification corresponding to that of the old Genevese administration, the following bound volumes, all in manuscript:

Inventairc No. 1. Archives de Genève: Répertoire de la Partic Politique, par M. Ad. C. Grivel (a former archivist). Quarto, $85 \mathrm{pp}$. This presents an inventory of the documents of the chapter of St. Peter, of the registers and papers of the Council, of the Portefeuilles des Pièces Historiques, and of the registers of the treasurer.

Inventaire No. 2. Inventaire des plans et registres y relatifs déposés aux Archives de Genève, par M. Ad. C. Grivel. Small quarto, with parchment back, 93 written pages. This lists the various maps and plans of the earlier and later periods and the books of surveys and other books which accompany them, including the French land surveys.

Inventaire No. 3. Index des Chambres, par M. Dufour-Vernes. Quarto, 72 written pages. An inventory of the record books of various administrative chambers, such as the Chambre des Blés, Chambre des Comptes, Chambre du Vin, Département des Arts, de l'Industrie, du Commerce, et des Monnaies, Consistoire de Genève et des environs, Chambre de la Réformation (du Luxe), and some societies like the Société des Catéchumènes.

Inventaire No. 4. Militaire, Justice, et Police, par MI. Dufour-Vernes. Small quarto, witl cloth back, 72 written pages. This is a guide to the records of the various military boards and councils, and to those of various civil and criminal courts.

\footnotetext{
'See Dufour-l'ernes in Bulletin de la Société de l'Histoire. III. 23.
} 
Inventaire No. 5. Catalogue des Minutes des Notaires déposées dans la Grotte des Archives, par M. Dufour-Vernes. Small quarto, parchment back, 35, 45 written pages. Part I. of this is a list of notaries-some 220 , in chronological order, from I373 to 1857 , followed by an alphabetical list of the same, showing the number of volumes, from I to 90, coming down from each. Part II. is a list of former notaries of Geneva and its environs who are known to have existed but whose minutes are not in the archives.

Inventaire No. 6. Inventaire des Sceaux, Timbres, et Cachets, par MII. Grivel et Dufour-Vernes. Large quarto, II I written pages. This includes both Geneva and its environs.

Inventaire No. 7. Inventaire des Titres et Droits de la Seigneurie de Genève, rédigé de I888 à I89I, par M. Dufour-Vernes. Large quarto, in two parts, bound in cloth, with parchment back, 656 written pages. This inventory, carefully made, describes each roll, volume, or separate document contained in the series relating to the property rights of the bishopric, of the community, of the chapter and prévoté of St. Peter, of the priory of St. Victor, and of various minor and civil jurisdictions; secondly, those of the churches, chapels, convents, and hospitals of the city and bishopric ; and thirdly, of particular fiefs belonging at one period or another to Geneva.

Inventaire No. 8. Inventaire des titres, registres, papiers, et plans de la Société Économique. Large quarto, with parchment back, 60 written pages. The archives of the Société Économique were turned over to the archives of the state in I868 and 1869.

Inventaire No. 9. Catalogue des Archives de l'Hôpital Général de Genève. Small quarto, about 50 written pages. These archives were turned over to the archives of state in I9I I.

Inventaire No. 10. Inventaire Général et Topographique des Archives de l'État, par M. Dufour-Vernes. Small quarto, bound in cloth, 28 written pages. This is an inventory by the late archivist, not quite finished, which proceeds in a methodical order around the various rooms devoted to the archives, both at the Hotel de Ville and in the rue Calvin, and sets forth the order of arrangement, case by case and shelf by shelf. The order is not signally different from that maintained at present.

There are various other inventories; the above are the most general. The data which follow are arranged in the order pursued in M. Martin's "Etat Général et Sommaire des Fonds". Its first section relates to inventories, its second to the :

Portefeuilles des Pièces Historiques. A factitious collection, as mentioned above, filling some 6000 cartons. For the modern period it is derived mostly from the general correspondence received by the Council of State. There is a chronological inventory in two large folio volumes, and an alphabetical index of names and subjects. The only American pieces found by means of these were the following :

P. H. no. 3687. Long letter, of about a thousand words, of Jean Noblet, citizen of Geneva, dwelling at Amsterdam, to his cousin F. Duhamel, setting forth his design of colonizing three islands in the seas of America, to be a refuge for the Reformed and for those wishing to escape the wars of Europe. Others will help him, but 
he would like further subscriptions from the Genevese. Also, to insure neutrality, he wishes the Republic of Geneva to assume the sovereignty of these islands and grant them to him as a fief. It is not expedient to name the isles yet, lest he be anticipated; but they are fertile, of warm climate, not near the dominions of France or of Great Britain, uninhabited, and as good as the Antilles or Carib Islands. He wishes to know if preachers and rulers can be had from Geneva; states the terms for settlers; declares that the islands can be cultivated by indentured servants. and that negro slaves can be brought thither more cheaply than to the Antilles or Carib Islands. Amsterdam, May 2, I680.

Petition of Jean Noblet to the Council, in which he says that during his years of absence he has sailed the seas of America. May 2, I680.

Draft of a patent to him: the islands "several hundred leagues from the French and English colonies"; the patentee to have powers of sovereignty " like those of the Dutch West India Company". Its full text is quoted in the Histoire de Genève des Origines à l'Année I69o, par Jean-Antoine Gautier, Secrétaire d'Etat, VIII. 2I I-2I 2 (Geneva, I9I I).

P. H. no. 5416. In this carton, which consists of extracts from the registers of the central committee of the "Clubs Insurgés", containing votes of that body on various subjects, was found the following. It should be premised that on Aug. 23, 1794, soon after its dramatic reception of Monroe, the French Convention, after an oration by Reybaz as minister of Geneva, had decreed that the Genevese flag should be hung up in their hall alongside those of the French and the American republies. See also, below, p. ISo. the Council entries of Aug. 30, Sept. 5, I , 1794, and Writings of James Monroe, II. 34, 54 .

"Extrait des Régitres du Conité Central du ze 7’bre I794 l'an 3 de l'égalité Genevoise.-Les Clubs Révolutionnaires s'étant occupés d'une proposition tendante à ce que l'Administration soit chargée d'écrire au Congrès des Etats Unis d'Amérique pour l'informer de l'évènement qui a donné lieu à l'arboré du Drapeau Américain en leur demandant alliance et fraternité, Cette proposition a été acceptée par I73I suffrages contre 65I. En conséquence le Comité Central arrêté d'expédier le présent extrait de Régitres atux Syndics et Conseil; pour (ju'ils fassent droit au vou des Révolutionnaires.-Ant[oin]e Biveleux, Président du Conité Central. François 'Ture, Secrétaire."

Manuscrits Historiques. Another factitious collection. Manuscript inventory in order of subjects, one volume; alphabetical index, one volune. Apparently nothing American.

Archives d'Etat proprement dite.

Conseils. This large series, which precedes the subdivisions alphabetically arranged, enbraces the Registers of the Council, I 409-1798. in 322 volumes, ${ }^{1}$ and the Registres des Particuliers, I643-1798, containing votes respecting individuals. The volumes of the

\footnotetext{
'The Societe d'Histoire has published five volumes of the earlier registers, I $409-149$ ? (Geneva, I900-1914).
} 
former have individual tables of contents, but there is no general inventory or index (therefore no general search was made), though there are chronological and alphabetical répertoires of the pièces annexes. The Registres des Particuliers present many volumes of letters, acts, and proclamations of the Council and of the bodies which successively took its place during the revolutionary period.

Registers of the Council, vol. 180, f. 67. May 4, 5, r68o. The Council confers citizenship on Lord Cornbury, son of the Earl of Clarendon, who had been in Geneva for some time and had so distinguished himself in archery as to be crowned King of the Archers. The Council also ordered extraordinary honors to his kingship. See Récit de ce qui s'est passé à Genève, le zme de May M.DC.LXXXI, à la feste des Nobles Chevaliers Archers, en reconnaissance de l'honneur extraordinaire qu'ils ont receu, d'avoir pour leur Roy, Très Illustre et Très Généreux Seigneur, Messire Hyde, comte de Cornbury (Geneva, " par le Chappuzeau, chez Jean Herman Widerhold ", I68I, pp. I 5, quarto).

Registers of the Council, vol. 305, p. 603. "Le Cit. Syndic [Esaie] Gasc a rapporté que conformément à la commission qui lui en avoit été donné ce matin il s'etoit rendu au près de la commission révolutionnaire pour lui soumettre le préavis du conseil relativement à la solemnité à donner à la publication des nouvelles officielles attendues de notre envoyé à Paris; que la commission avoit écarté du plan proposé la jonction des Drapeaux des deux cantons non alliés à ceux des Républiques Française et Genevoise et leur avoit substitué celui des I 3 États-unis d'Amérique, motivant cet arrangement sur la fraternité des principes qui doit unir les trois nations, et exclure toute adjonction qui ne seroit fondée que sur des rapports purement diplomatiques." Aug. 30, r794. (Illumination ordered, etc. See above, p. I79, and Monroe to Reybaz, Sept. I5, 1794, in Writings, II. 64. Geneva and the United States were at this time the only states having diplomatic representatives in Paris.)

Registers of the Council, vol. 305, p. 624. The Council voted that such a letter as the revolutionary clubs had demanded (see above, p. I79) should be sent to the United States Congress, and charged Citizen [Jean-Lazare] De la Planche to prepare it. Sept. 5, I794.

Registers of the Council, vol. 305, p. I007. Under date of Dec. I I, I794, the Council records with expressions of vivid regret the announcement of $\mathrm{P}$. A. Adet that he is recalled as resident of France with only twenty-four hours' notice to go as minister to the United States.

Registres des Particuliers: Pièces Annexes. In an unnumbered carton, along with a document on the nobility of the house of Gallatin, are found several letters of I786, relating to a rumor of Albert Gallatin's death. They are inostly copies of letters addressed to Secretary Jay, in response to an advertisement inserted by him in the Philadelphia newspapers, early in May, I786, at the request of Galiatin's friends, made through Jefferson, ${ }^{1}$ who it

${ }^{3}$ Adams, Life of Gallatin, p. 64; Jefferson to Jay, Jan. 27,1786 , in the former's Writings, ed. Washington, I. 525. 
seems is quoted in the advertisement. The letter of Jefferson to Tronchin, Aug. I, I 786, is, however, an original. The others are from Terrasson, French consul, Robert Morris, H. S. Charton, Peter S. du Ponceau, Andrew Dunscomb, Henry Banks (register of the Court of Appeals in Cases of Capture), and Savary de Valcoulon. It will suffice to give extracts from those of Charton and di Poncean.

(H. S. Charton.) "I am perfectly acquainted with Mr. Albert Galatin who was reported some time ago to have met with so terrible a Fate, and I have the satisfaction to assure that he is still living; what gave rise to such a Report I don't know, but I was lately at Richmond with Mr. Savary de Valcoulon who was all the Time with Mr. Galatin in the back parts of Virginia, and who has told me, that none of their Party had received or likely to receive the least Alarm from the Indians.

"Mr. Galatin only went back to George Creek, the Place of his Settlement, in MIarch last, and I have no Doubt has written to his Family, to contradict the News that had given them so much Pain."

(P. S. du Ponceau.) "Having seen the Advertisement you have caused to be put in the public Papers respecting Mr. Gallatin, I think it my Duty to inform you that on the 2oth February last, the same Person was at my Office, and executed a Letter of Attorney to Messieurs Colladon and Hentsch of Geneva to transact his business for him in that commonwealth. He called himself Abraham Alphonse Albert Gallatin, Citizen of Geneva, and told me he was the same Man who had been killed by the Savages in the Fredericksburg Gazette. I believe he is now returned to the back Counties of Virginia, tho' I cannot well assert it. I shall be happy if this information proves any ways satisfactory to the Family of that young Gentleman, tho' I believe it probable that they have by this Time received more direct Intelligence respecting him."

Archives: Old inventorics and the like.

Assistance.

Assurance.

Bourgeoisie: Lists of citizens, embracing especially the "Livres des Bourgeois", rolls extending from I 442 to the end of the republic. See the book by M. Covelle, mentioned in the bibliography above. Cadastre. p. 175 .

Commerce.

Constitutions.

Douane.

Elections: This section includes the printed registers of electors from i 820 to I9I I.

Etat Civil: This includes, first, the "Livres des Morts", 1548-1798, consisting of 60 registers, with an index in ten volumes. The records of baptisms and marriages before 7798 , approximately complete from I 550, were formerly kept in the churches of the city, including, besides the parish clutrches of the established faith, the 
Italian, English, German Reformed, and German Lutheran churches, and in the latter part of the period the Catholic chapels. They are now in the state archives. The same is true of the country parishes, though in general their registers begin at later periods. The civil registers, kept by the municipalities, begin in the Pays de Gex in I792, in the Savoyard communes after the French occupation in I793, in the city of Geneva in 1798 . These civil registers, to $I 8 I 5$, are preserved in the archives of state. For the period since I8I5, the records of the births, marriages, and deaths are kept at the Bureau de l'Etat Civil Cantonal, 2 rue Etienne Dumont, with some additional local registers in the Catholic and other parishes. But the "répertoires" of the registers of état civil are at the Chancellerie d'État in the Hôtel de Ville. Neither this nor the Bureau d'Etat Civil Cantonal has any salle de consultation open to the public. But the archives of state has a duplicate of the "répertoires" for the period from I8I4 to I870. It now also has the registers for the earlier periods (I 550-I 798 and I 798-I8I 5, as above). It also has guides, generally speaking some 220 volumes of alphabetical indexes of various sorts, to this whole great mass of records of births or baptisms, marriages, and deaths from I 550 to 1870 . It also has by exception some Catholic parish registers.

Etrangers: Mostly registers of permis de séjour.

Feu.

Fiefs.

Finances.

Habitants: Most of these documents, relating to the refugees at Geneva, have been copied and indexed by M. Alfred L. Covelle.

Hygiène, and so on in alphabetical order, of series not likely to interest the American student.

Archives de la Société Économique. This was a group of fifteen Genevese citizens established in I 798 to administer the communal property for the benefit of educational establishments, of the Reformed worship, and of the maintenance of industries.

Archives Judiciaires. Records and papers of a great variety of judicial courts, of various periods.

Archives Notariales. There are 3474 volumes of minutes and protocols of the notaries from I 373 to I 878 . For a list of these notaries, see Inventaire no. 5. The series embraces a great number of deeds, marriage contracts, and wills. Besides analyses of the Latin documents in this series, extending to about I 535, and preserved at the archives, there are analyses of the French documents of the sixteenth, seventeenth, and eighteenth centuries in the possession of the Société d'Histoire et d'Archéologie de Genève.

Archives de Familles. This section seems not to include any names which have been of note in American history.

Archive de l'Église. Mostly elsewhere; see next section, pp. I83-I84.

Archives des Sociétés. This embraces books of the Noble Exercice du Canon, of the Exercices de l'Arcquebuse, of the Société des Catechumènes, etc. 


\section{GENEALOGICAL.}

For the benefit of those who may have occasion to make genealogical researches, the following account of the resources of Geneva in this respect has been drawn off from notes made by Mr. C. Roch, attache of the archives of state.

For the period before I 550 , one has the minutaires of notaries (see above), the registers of the councils, the grosses de reconnaissance, etc. By the study of the sections entitled "Titres et Droits de la Seigneurie" one may even go back to the tenth century. See the Regeste Gencoois, published by the Société d'Histoire.

For the period from 1550 to 1798 , one has, primarily, the parish registers of état civil, Genevese, French, Savoyard, and the indexes to them, as described above. One has also, at the Archives d'Etat, the Registres des Habitants, the Registres des Bourgeois (see Covelle's Livre des Bourgeois, mentioned in the bibliography), the minutes of notaries (of which there are analytical indexes at the rooms of the Société d'Histoire), the wills and inventories, the grosses de reconnaissances, the judicial papers, the Registers of the Council, the Registres des Particuliers, the documents of the Bourse Française, etc., and at the Chancellerie the "Registre Unique de Citoyens, I794" (index at the Archives). These for the Protestants of Geneva; for the Catholies, the communes added from Savoy and the Pays de Gex, there are the grosses, the minutes of notaries, and the documents of the tabellion of Carouge and St. Julien.

For the period from I 798 to I8I4, one has the Registres d'Etat Civil, at the Archives, with indexes in duplicate, at the Archives and at the Chancellerie; some parish registers, in the parishes, at the Archives, or at the Bureau Cantonal de l'Etat Civil; the papers of the Département du Léman; and some minutes of notaries.

For the period since 1814 , one has the Registres, with indexes at the Chancellerie and (to I870) at the Archives; and various parish registers, kept in the parishes, with indexes at the Archives and at the Bureau Cantonal.

The fees for copies of entries vary from two to three francs. Full name, and age at a given date, are generally prerequisite to successful search.

The genealogies of some seven hundred Genevese families have been published in the Notices Génćalogiques sur les Familles Generoises (Geneva, Jullien, 7 vols.), and in vols. I. and II. of the Recueil Génćalogique Suisse. The Archives d'Etat possess a set of the former collection annotated in manuscript by the former archivist, M. Louis Dufour-Vernes.

\section{GENEVA: ECCLESIASTICAL ARCHIVES.}

From Calvin's tine the Church of Geneva has been governed by two bodies. the Consistoire and the Compannic des Pasteurs et Professenrs. See Eugène Ritter, Les Archizes de l'Eglise de Genize (Geneva, I886, pp. I5). The archives of the Consistoire are kept at the Auditoire, a building opposite the cathedral. This is not a public archive, but it is accessible to scholars. The secretary of the Comsistoire, who has charge of it, is present during most of the day. It consists of from eighty to a hundred large volumes of registers, in which are recorded the proceedings and judgments of the consistory, matter abounding in lata for the history of manners and morals in Geneva. There are some gaps, but none after 1605 . The syndic August Cramer, who was apparently the only man who had ever reat them through, fur- 
nished a large specimen of what they contain, in a volume produced by lithographic (?) process (and difficult to read) entitled Notes extraites des Registres du Consistoire de Genève (Geneva, I853, pp. xvii, 459). The present secretary believes that the registers contain nothing for American history, and an examination of Mr. Cramer's book revealed nothing. The archive contains no correspondence. Since I8I4 both Consistoire and Compagnie have kept their papers with great care.

The archives of the Compagnie des Pasteurs et Professeurs are also kept at the Auditoire, so far as their registers are concerned. These records of their meetings, extending to fifty or sixty volumes, were not kept with great carefulness. Something of their history may be read in an article by $\mathrm{H}$. V. Aubert, "Nicolas Colladon et les Registres de la Compagnie des Pasteurs et Professeurs de Genève" in the Bullétin de la Société d'Histoire et d'Archéologie de Genève, II. I38-163 (I905). They abound in necrological notices, of which three specimens are printed as an appendix to M. Ritter's pamphlet noted above, pp. IO-I 5 .

The earlier part of the correspondence of the Compagnie des Pasteurs et Professeurs has been deposited at the Bibliothèque Publique et Universitaire, where it can be consulted in the same manner as the manuscripts possessed by the University. It begins with the correspondence of the Company with foreign churches in the times of Calvin and Beza, and extends from I 550 to I760. Calvin left his papers to Beza. What remains of them, and of the letters from his death on, is in the public library, as are also the papers of Antoine Court. Several families, descendants of the old pastors, have turned over their papers to the archives of the Venerable Company.

The correspondence of the Company is bound in 43 volumes. There is an old-fashioned manuscript "Inventaire de la Correspondance", and a carefully made card-catalogue, arranged alphabetically by authors and taking note of each letter. Nothing American was found, despite the hopes raised by the entry in Cotton Mather's Diary, under date of Apr. 6, I721, "Enter into a Correspondence with Geneva, whereto I am invited."

The papers of Genevese eminent in church or university affairs have of course often been preserved even till now by their families. Thus; it is in the correspondence of Professor Marc Antoine Pictet, privately preserved, that Professor Charles Borgeaud found some of the significant papers relating to the proposals discussed in 1794 by Jefferson, Adams, and Washington for the bodily transfer of the University of Geneva to America-one of the origins of the University of Virginia. See Professor Borgeaud's admirable Histoire de l'Université de Genève, 1. 6I2-6I3 (I900) ; and Edwin D. Mead, "The Proposed Removal of the Academy of Geneva to America in I794", in the Educational Review, April, I9Io. 


\section{AUSTRIAN ARCHIVES.}

The archives of Austria (see Introduction) searched for materials relating to American history were those of Vienna, Salzburg, and Innsbruck. In Vienna the following were found to contain materials bearing on the subject: the Kaiserliches und Königliches Haus-, Hof-, und Staatsarchiv; the K. u. K. Kriegsarchiv (archive of the Ministry of War); the Allgemeines Archiv des K. u. K. Ministeriums des Innern (archive of the Ministry of the Interior); the K. u. K. Gemeinsames Finanz-Archiv (Hofkammer-Archiv); the Archiv der Stadt Wien (archive of the city of Vienna); and the K. u. K. Hofbibliothek (Imperial and Royal Library).

\section{VIENNA.}

\section{K. . K. HAUS-, HOF- UND STAATSARCHIV.}

Location: Wien I., Minoritenplatz I. Very near the Hofburg; a modern building, constructed I899-1902, for the archive solely.

The idea of gathering all the archive material of the House of Hapsburg under one head and at a single station was probably conceived by the Emperor Maximilian I., but the plan was not carried into execution until the age of Maria Theresia, and under her special patronage. In 1749 she appointed Theodor A. T. von Rosenthal, who became the scientific founder of the archive. He attempted to centralize the material and enlarge the scope of the archive by copying on a large scale all documents of importance the originals of which could not be removed to Vienna. The leading position of the House of Hapsburg in Central Europc, continuous through centuries, the service of Austria as the bulwark against the invasion of the Turks, the resistance of Austria during the Napoleonic wars, have contributed to make this archive one of the most valuable in existence. Many losses also have been sustained, as when with the forfciture of her Italian provinces Austria had to give up also from her archive the documents relating to the history of Lombardy and Venetia.

The K. u. K. Hans-, Hof-, und Staatsarchiv is divided into the following large groups :
I. Das Haus- und Familienarchiv;
2. Das Staatsarchiv;
3. Das Archiv der Kais. Reichshofkanzlei und des Kais. Reichshofrats;
4. Das Italienische;
5. Das Niederländische oder Belgische;
6. Das Herzoglich-Lothringische:
7. Das Salzburgisch-Erzbischöfliche und Domkapitelarchiv;
8. Das Mainzer (Reichskanzlerische) ;
9. Das Archiv des ehemaligen Staatsrats:
Io. Urkinden.

There is also a special collection of about 2000 manuscripts (for guide see bibliography), and a library of about 20,000 volumes. There is at present no complete guide to the materials in the K. u. K. Haus-, Hof-, und Staatsarchiv, though the arduous labor of preparing such a gruide has been begun. 
Hours: On week-days, 9.30 a. m. to 7 p. m. Sundays and holidays, io a. m. to I p. m. Closed on Saturdays after 4 p. m., and for several days at Christmas, New Year, and Easter. Application for use of documents should be made before in a. m. for use on the same afternoon, or in the afternoon for use the next morning. If the investigator is pressed for time, he will often find however that the courtesy of the officials extends beyond their rules. An exhibition of historical manuscripts, seals, etc., takes place every Wednesday, io a. m. to I p. m.

Bibliography: Gerson Wolf, Geschichte der K. K. Archive in Wien (Vienna, I871 ). Treats the history of the three following archives, as well. Gustav Winter, Die Grïndung des Kaiserlichen und Königlichen Haus-, Hof-und Staatsarchivs, 1749-1762 (Vienna, 1902).

Id., Das neue Gebäude des K. u. K. Haus-, Hof-und Staatsarchivs zu Wien (Vienna, I903).

Langlois und Stein, Les Archives de l'Histoire de France (Paris, I891), pp. $645-655$.

Constantin Edler von Böhm, Die Handschriften des Kaiserlichen und Königlichen Haus-, Hof- und Staatsarchivs (Vienna, I873). Supplement (Vienna, I874).

Gustav Winter and Árpád von Károlyi, Katalog der Archivalien-Ausstellung des K. und K. Haus-, Hof-und Staatsarchivs (Vienna, I905).

Joseph Cuvelier, "Les Archives Autrichiennes", in Revue des Bibliothìques et des Archives de Belgique, V. I78-200 ( I906).

G. Des Marez, "Les Archives Royales et Impériales de Vienne", in Revue de l'Université de Bruxelles, April, I905.

See also the publications of Dr. Hanns Schlitter mentioned below.

\section{STAATSKANZLEI.}

Fasc. 62. Noten von der Hofkanzlei.

"Die Errichtung eines Handlungs-Vertrags mit den Vereinigten Amerikanischen Staaten." Nota der Vereinigten Hofkanzlei." Mar. 31,1785 .

"Die sich zu Triest formierende Oesterreichisch-Amerikanische Handlungsgesellschaft betr." Nota der Vereinigten Hofkanzlei. Sept. 5. 1785 .

\section{DAS BELGISCHE ARCHIV.}

The materials relating to American history contained in this section have been published by the archivist, Dr. Hanns Schlitter, in his two works: (I) Die Beziehungen Oesterreichs $\approx u$ Amerika, I. Teil, . . . zu den Vereinigten Staaten, $1778-1787$ (Innsbruck, 1885) (for the preparation of this work Dr. Schlitter also searched American archives); and (2) Die Berichte des ersten Agenten Oesterreichs in den Vereinigten Staaten won Amerika Baron de Beelen-Bertholff an die Regicrung der Oesterreichischen Niederlande in Briissel, I784-I789, herausgegeben von Dr. Hanns Schlitter (Vienna, I89r), published in Fontes Rerum Austriacarum: Oesterreichische Geschichtsquellen, herausgegeben von der Historischen Commission der Kaiserlichen Akademie der Wissenschaften in Wien, Zweite Abteilung, Diplomataria et Acta, XLV. Band, Zweite Hälfte, pp. 225-892. See also Hubert Van Houtte and Edmund C. Burnett, "American Commercial Conditions, and Negotiations with Austria, I783-1786", in American Historical Review, XVI. 567-587. 


\section{B. Vereinigte Staaten von Nordamerika.}

Aus Verträge betr. Acten, Fasc. 9. Report zu Abth. IV. I784. “Den beabsichtigten Abschluss eines Freundschafts- und Handelsvertrags zwischen dem Kaiser and den Vereinigten Staaten von Nordamerika betref. Actenstiicke." I784. Namely :

I. “Orig. Sehreiben des bevollmächtigten Ministers der Vereinigten Staaten in Paris Benjamin Franklin an den kaiserl. Botschafter Graf Mercy über die Bereitwilligkeit der Freistaaten einen Freundschafts- und Handelsvertrag abzuschliessen." Passy, July 30,1784 .

2. "Antwortsconcepte des Grafen Mercy." Paris, July 30, and Sept. 28, I784. "Bemerkungen über den Vertragsentwurf zwischen dem Kaiser und den Vereinigten Staaten von Nordamerika."

3. "Vertragsentwürfe und Bemerkungen über den Vertragsentwurf zwischen dem Kaiser und Nordamerika."

A large fascicle containing documents relating to the trade of Belgium with America and the negotiation of a commercial treaty, viz.:

I. "Berichte des Handelsrathes Baron Beelen Bertholff aus Amerika an das Belgische Gouvermement", etc. Aug., I784-Apr. 30, I789.

2. "Berichte eines Committees über diese." Aug., I $784-M a y 6$, I 786.

3. "Original Noten des Gr. Belgiojoso an Gr. Mercy." Oct. 28, I $784-$ June ro, I 8 , I 785 .

4. "Copie eines Schreibens des Gr. Trantmannsdorf an Gr. Proli." July 14 , I789. (An appendix to the following.)

5. "Original Schreiben des Grafen Proli an Brüssel (den Gouverneur), I4. Sept. I792, wurde als zu Belgien gehörig in das Filiale B. abgegeben."

Belgien DDB I82 a. "Berichte Beelen-Bertholfls an Belgiojoso, ministre plénip. à Bruxelles." I784, I785. III.

Belgien DDB I 82 b. "Berichte Beelen-Bertholff." I 785. IV-XII.

Belgien DDB i 82 c. "Berichte Beelen-Bertholff." I 786.

Belgien DDB I82 d. "Berichte Beelen-Bertholff." I 787.

Belgien DDB i 82 e. " Berichte Beelen-Bertholff." I $788-$ I 789.

Belgien DD 6, I, I82 e. "Berichte des Comité de Commerce." I $783-1785$. $6 / 5$. Relate to the reports of Beelen-Bertholff. Accompanying them are original letters of Starhemberg to Delplaneq, drafts of instructions to Beelen, memorials respecting commerce, etc.

Belgien Rep. DD. Abth. B. Fasc. I82 e. "Proli an Cobenzl." I792, i9/9. Among the accompanying documents, one, designated as B, “ Observations concernant la correspondance du gonvernement des Pays-Bas Autrichiens avec le conseiller de commerce Baron de Beelen depuis l'arrivée de celui-ci en Amérique en 1783 juspu'à la fin de $1787 \%$, gives a general conspectus of the matters treited by Bcelen in his reports.

Nr. 20. Vorträge an den Königr. Kannitz an Joseph. Département des PaïsBas. "Trés humble Raport du Chancelier de Cour et d'etat, parr lequel en présentant à la Rile Signature de Votre Majesté un Acte de I'lein Ponvoir qui antorise le Cte. de Merey a negocier et à conclure un Traité de Commerce avec les Etats-Unis d'Anérique." Mar. 8, i $86 .{ }^{1}$

\footnotetext{
${ }^{3}$ No. 13, Kaunitz to Joseph, Jeb. $2 \%, 1786$, is printed in the American Ilistorical Revicw, XVI. $576-578$.
} 


\section{STAATS-RATH.}

The Staats-Rath Indices begin with the year $176 \mathrm{I}$ and continue into the nineteenth century. The material bearing on America and emigration is not abundant ; the acta preserved, relating to America, are as follows:

I771. Nr. I864. "Auswandern, ist den gemeinen Handwerkern einzuschränken.”

I773. Nr. 340. "Auswandern, oder Reisen ausser Landes, das desfalls bestehende Gesetz ist auch in den Militär-Gränzen einzuführen."

I774. Nr. 2927. "Auswanderungen an den Gränzen sind nicht allgemein, sondern nur in gewissen Fällen zu gestatten."

1777. Nr. I955. "America wird in einem Buch beschrieben, so zwahr von der Censur in Anstand gezogen, dannoch aber passiret wird." Title of the book: Erdbeschreibung von ganz Amerika, I 11. 2 Theil.

I782. No. 4095. "Amerikanische Colonien. Dahin wird eine Schiffahrt von dem Consul zu Cadix eingeleitet." (Spanish-American colonies.)

I783. Nr. I467. "Amerikanischer Handel: In Absicht auf denselben wird eine Consignation der Hung. und Siebenbürgischen Naturprodukten und Manufakturen, und deren Preys überreicht." (North America.)

I784. Nr. 375. "Womit der Entwurf der aus 96 einzeln zerstreuten Verordnungen in ein Auswanderungspatent zusammengefasst wird." Vortrag, Jan. 28, I784.

Nr. 2304. "Im allgemeinen ist niemanden erlaubt weder selbst auszuwandern, noch jemand von seinen Kindern, oder von denen, welche unter seiner Gewalt und Aufsicht stehen, in fremde Landen zu senden." (Punishment, confiscation of property, or, if caught, hard labor; children of an emigrating father not deprived of property.) "Obrigkeitlicher Beamter oder Vorsteher der überführt wird, einem Auswanderer Hilfe zu leisten, Geldstrafe oder 6 Monate öffentliche Arbeit." Vortrag, June 4, I784. (This law applied to emigration to any foreign country.)

I785. Nr. 3489. "Amerikanische, und in Triest sich formierende Handlungs Societät."

Nr. I864. "Auswanderungs-Verordnung. Strafe eines Buchhändlers."

Nr. 4733. "Auswanderungspatent." Erbschaft.

I792. Nr. 2184. "America, dahinsiger Leinwandhandel." (Bohemia and South America.)

I794. Nr. 1872. " Die ständigen Deputirten stellten vor: dasz das bestehende Auswanderungsverboth den Unterthanen in Schwäbisch-Oesterreich bei der in fremden Territorien vermischten Lage des Landes sehr beschwerlich falle, und baten daher um Aufhebung dieses Verboths sowohl als der gewöhnlichen Auswanderungs-Bewilligungstaxen."

Regierung vermeint: "Es könnte diese zweyfache Bitte zur Probe bewilliget werden, wo sodann, wenn áus den jährlichen Berichten und Tabellen die Zahl der Auswandernden wider Vermuthen jene der Hereinziehenden übersteigen sollte, diesfalls immer Schranken gesetzet, und die Auswanderung wieder verbothen werden könnte." Vortrag gehàlten, Apr. I6, I794. 


\section{DIPLOMATIC CORRESPONDENCE.}

Nordamerika.

Under this rubric is found the entire correspondence between the Austrian agents in the United States and the home government under Metternich from I819 to 1847. The material is divided into the groups: (1) Berichte (Despatches), Faszikel I-6; (2) Weisungen (Instructions), Noten, Varia.

\section{BERICHTE.}

\section{Faszikel I.}

\section{Stürmer to Metternich.}

1819.

Four communications of: Barthol. Freyherr von Stürmer, k. k. GeneralConsul in den Vereinigten Staaten von Nord-Amerika. ${ }^{1}$

Mar. 5. Vienna. Claim of 300 pounds sterling for expenses of return trip from island of St. Helena, advanced by English governor.

Mar. 7. Vienna. Concerning two carriages left at Calais, belonging to the royal stables.

Apr. 8. Vienna. Offer of a substitute for a lost chart.

July I r. Vienna. Expenses of a trip from London to Milan, Dec. 25. I815, to Feb. 20, 1816 .

\section{Lederer to Metternich.}

$$
\text { I } 820-\text { I } 823 \text {. }
$$

Portrait of Lederer, with following note:

"Alois, Freiherr von Lederer, K. k. Oest. Generalconsul in NordAmerica, wurde im Jahre 18r9 mit der Anknüpfung des diplomatischen Verkehrs mit der Republik der Vereinigten Staaten betraut. Er fand New York als den passendsten Centralpunkt zur Erfüllung seiner Aufgabe und versah da sein Ant daselbst bis 1838 , wo dann seitens beider Staaten die Gesandschaftsposten crcirt wurden. Am 27. August 1829 unterzeichnete er den ersten Handels- und Schiffahrtsvertrag mit den Vereinigten Staaten von America."

(Most of the commumications of Baron Lederer were written in German, a few in French.)

\footnotetext{
${ }^{2}$ Bartholomäus Graf von Stïrmer (1). 1787) was sent to the island of St. Helena in $18 \mathrm{I} 6$ on special mission, as one of the commissioners kept there by the Allied I'owers, to keep watch over Napoleon as a prisoner on the island. Unsatisfactory in this eapacity, he was recalled after two years' residence on St. Helena, and appointed Austrian consulgeneral in the United States. IIe left St. Helena in July, $18 \mathrm{~S}$, eight months after the date of his new appointment. His reports, from Philadelphia, were directed to the Commerz-Hofkommission, not to I'rince Metternich. After two years of service, which did not satisfy the home government. he was sent to Rio de Janeiro, in 1820 , but his mission in Brazil terminated after five months, with the outbreak of the revolution. After these failures he seems to have lost favor, and did not receive a diplomatic post again until 1832, when le distinguished himself at Constantinople (1832-1850), being very successful in establishing an Austrian steamship service with the Orient.
} 
No. I. Report (in French). Exequatur; audiences with President Monroe and Secretary J. Q. Adams. Treatment of Austrian merchantmen in accordance with principle of reciprocity. Political conditions in U. S. Struggle between East and West. General ignorance of American newspaper editors concerning German and Austrian affairs. Làrge number of German immigrants contribute more to winning the soil for civilization than producing a favorable impression of the civilization of their native country. "In the National Library at Washington, containing 20-30,000 vols. in living and dead languages, I had difficulty in finding a single German book." New York, Dec. 9, I820.

2. Report (in French) on political affairs. Outline of the constitution of Missouri. The exiled French. Joseph Bonaparte. Difficulty in choice of duty among so many duties devolving upon the first and sole representative of his country (Austria) in America. New York, Dec. 30, I820.

3. Report. (a) Political news concerning the insurgents in the Spanish colonies; reported truce between Generals Morillo and Bolivar. (b) Expedition of Vice-Admiral Cochrane against Peru. New York, Jan. 6, I821.

4. Report on current events. England's attitude toward U. S. Missouri and slave-trade. Newspaper clippings. New York, Feb. 24-25, I $82 \mathrm{I}$.

5. Remarks on the attitude of American papers (National Gazette and National Intelligencer) in reference to political events in Europe. Acquirement of Florida. May I3 and I5, I821.

6. "Nachrichten über die revolutionären Umtriebe im südlichen Amerika." June I0, I821.

7. The Floridas not yet given over by Spain. Current events. July IO, I 82 I.

8. Cession of the two Floridas. J. Q. Adams probably the next president. Sept. Io, I82i.

9. Lederer applies for Tuscan consul-generalship in addition to present position. Same date.

IO. Report on various political events. Oct. 9, I82I.

I I. Report on current events. Governor Jackson and the Spanish Colonel Callava, at Pensacola. Boundary questions with England and Spain. Oct. I9, I82r.

I2. General Jackson and the Spanish Colonel Coppinger, governor of East Florida. (Baggage forced open to get documents that ought to have been given to U. S. government.) Nov. I2, I82I.

I3. Current events. President's message. Dec. IO, I82I.

I4. "Die nordamerikanische Regierung bedarf dieses Jahr keines Anlehens." Ukase of Russian Emperor claiming Northwest Coast, Behring Strait south to $51^{\circ}$. Impression in U. S. Jan. 9, I822.

I5. Report on census. Feb. IO, I822.

I6. Action of Congress. Mar. I 5, I822.

I8. Northwest boundary question. Apr. 30, I822.

I9. Recognition of independence of South American states. May 5, I822.

20. Current events. May 3I, I822.

21. Diplomatic relations between U. S. and South American states. June 28,1822 . 
22. Commercial treaty with France. July 5, i 822 .

23. Yellow fever in New York. Aug. 8, 1822.

25. Comprehensive report descriptive of conditions in U. S., relations to other countries, and suggestion of improvement of commercial relations between Austria and U. S. Sept. 9, I822.

26. Current events. Oct. I 5, I 822 .

27. Newspaper clippings (National Gazctte, Phila.). Nov. 6, 1822.

28. President's message. Dec. 5, I822.

29. Cuba. Clipping from National Intelligencer, Washington. Dec. 9, I 822 .

30. Appropriation to stop piracy in West Indies. Dec. 23, 1822.

31. Cuba ; current events. Jan. I 5, I823.

32. Treaty between U. S. and Great Britain. Jan. 31, I823.

33. Current events. Feb. I5, 1823.

34. No reliable information obtained on Bernhard Rauch, merchant. Feb. I 5, I 823 .

35. Current events. Mar. 7,1823 .

36. Current events. Mar. 3I, I823.

37. Current events; references to South America. Apr. 29, I823.

38. Current events. Same date.

39. Jackson proposed for next President. May I8, I823.

40. Current events. June 28, I 823 .

41. Diplomatic and consular service. Aug. 23, I823.

42. Current events. Slave-trade. Sept. 27, I823.

43. "Ackerbaugesellschaft in New York." Sept. 27, I823.

44. Remarks on President's message. Dec. 6, I823.

I 824 .

45. Import duties. Jan. 6, I824.

46. Current events. Jan. 7, I 824.

47. Translation of law governing duties and tonnage taxes of foreign vessels in American ports. Jan. 26, I824.

48. Current events. Feb. 24, I824.

49. Change of tariff on tomnage of vessels proposed in Congress. Apr. 27,1824 .

50. New tariff deciderl on. $£ 6600$ as present to Greeks. May 25. I824.

5I. Current events. June 2I, I 824.

52. Copy of treaty between U. S. and England. June 27, 1824.

53. Current events. July 28, I 824.

54. Treaty between Ritssia and U. S. Aug. 23, I824.

55. "Bitte um Urlaub: Der Wunsch meiner zwei Söhne in ihren gegenwärtigen zarten und kritischen Altern von 8 und ro Jahren von den hier herrschenden Grundsätzen zt1 bewahren, sie in einer Erzichungsanstalt unterzubringen, in welcher sie eine dem allerhöchsten Dienste unseres gnädigsten Monarchens angemessene Erzichung geniessen könnten, sind die Beweggründe, welche mich bestimmten, diese Bitte zu tragen." Aug. 30, 1824.

56. Appointments in diplomatic service. Sept. 26, i 824.

57. Prognostications concerıing the next president. Nov. I6, I824.

58. President's message. Dec. IO, I824.

59. Case of Joseph Hisky and his mother. Same date.

6o. No information on P'eter Cristofori. Dec. 20, I824. 
I 825 .

61. " Der Consul berichtet die Zunahme des Verkehrs mit Triest, welche ihm eine günstige Gelegenheit zur Ausführung solcher Massregeln anzubieten scheint, die die Gleichstellung der beiden Flaggen in diesen Staaten beabsichtigen." Jan. 3, I825.

62. Concerning the business of Count Barzizza. Feb. I4, I825.

63. The election of J. Q. Adams and J. C. Calhoun. Feb. I5, I825.

64. Current events. Nar. 9, I825.

65. The consul shows that in case of war between Spain and U. S., Austria would have advantages if her ships were treated on any equality with those of some other nations in American ports. Apr. Io, 1825 .

66. Letter of Von Kapff and Brune in Baltimore showing expensive process of following up land claim of Count Barzizza in Williamsburg, Va. Apr. 24, I825.

67. Probability of war with Spain. Additional reasons (see no. 66 above). Apr. 25, I825.

68. Austrian signal for pilots decided on. May 20, I825.

69. Current events. Indians. June I 5, I825.

70. Copy of treaty between U. S. and republic of Colombia. July 5, I825.

$7 \mathrm{I}$. Report of a committee of the house of representatives of the legislature of Georgia threatening secession. Lederer thinks the matter harmless for the present. July 6,1825 .

72. News of death of Peter Cristofori. July I5, I825.

73. Current events. Aug. I2, I825.

74. Visit of French fleet. Aug. I9, I825.

75. Remarks on difficulties between federal government and state government of Georgia. Sept. 20, 1825 .

76. Current events. Nov. I5, 1825 .

77. Message of President Adams. Dec. 12, I825.

78. Copy of letter of Henry Clay (Dec. 20, I825) to Baron Lederer in reference to some arrangement to facilitate negotiation of a treaty between Austria and U.S. Table of exports and imports between U. S. and Triest for the year I825. Dec. 27, I825.

I 826.

80. Leave of absence to begin in May. Jan. 20, I826.

81. Reciprocity navigation bill passed in Congress. Mar. 28, I826.

Sept. 23, 1826. Letter written from Vienna. "Bittet die Ernennung zum korrespondierenden Mitglied zweier wissenschaftlichen Gesellschaften annehmen zu dürfen." (Linnæan Society in New York, and Society of Natural History, Amherst, Mass.)

Oct. 19, I826. Letter written from Vienna. "Hinsichtlich des Landeigentums des David Parish." C. C. Peterson, consular agent, left in charge in New York.

Dec. I I, I826. (Report sent from Vienna.) "Denkschrift, einige Ansichten von den politischen Verhältnissen der' Nordåmerikanischen Vereinigten Staaten enthaltend." I7 pages. "Ich bin weit entfernt, ihre Staatsverfassung als dauerhaft anzusehen, sie scheint aber ihren gegenwärtigen Bedürfnissen, ihren Lokalumständen und anderen Verhältnissen angemessen zu sein, und so lange diese bestehen, wird sie wahrscheinlich keine Aenderung leiden." 
Dec. I I, I826. (Written during his brief stay in Vienna.) “Denkschrift über die Wichtigkeit eines Handelsverkehrs mit den Nordamerikanischen Vereinigten Staaten, und die Möglichkeit den mit der Oesterreichischen Monarchie schon bestehenden Verkehr mittelst eines Handlungs-Traktates auszudehnen." zo pages. Mit 5 Beilagen (A. and D. lacking).

B. Tabelle der Ausfuhr eigener Produkte aus den Nordamerikanischen Staaten im Jahr I 825 .

C. Tabelle der Einfuhr der vorzïglicheren Fremdenprodukte in die Nordamerikanischen Vereinigten Staaten im Jahre I825.

E. Abschriften der Handlungs-Konvenzionen der Nordamerikanischen Vereinigten Staaten mit Frankreich, Dänemark und der Republik Colombia.

$$
\text { I } 827-1828 .
$$

Mar. 22, I827. Keine Nachricht über Dr. Nikolaus von Niederberg aus New York erhalten. (Letter written from Vienna.)

Apr. 30, I827. Keine Nachricht über Philippo Ignazio Barzizza. (Letter written from Vienna.)

I. General report. (This and the succeeding numbers written from New York.) Dec. Io, I827.

2. "Erbschaft des Anton Marschner von Lebanon, Dauphin County, Penna." Dec. I7, I827.

3. Commercial and navigation treaty between U. S. and Sweden. Jan. 26, I 828 .

4. Georgia preparing for sccession. Article on Austria and the Porte. Mar. 3, I828.

5. Current events. Apr. 30, 1828.

6. Property of David Parish. May 22, 1828.

8. Treaty between Great Britain and U. S. May 26,1828 .

9. Prussia and reciprocity. May 28, i 828.

ro. Close of Congress. May 30, I 828 .

I I. Concerning Franz Anton Terzi of New Orleans. June 3, I828.

12. Navigation treaty between U. S. and Hansa cities. June 5, I828.

13. Navigation treaty between U.S. and Prussia. June IO, I828.

I4. Certain privileges to kingdom of Hannover. July 5,1828 .

15. Newspaper clippings (National Intelligencer). July 6, I828.

17. Receives commission to negotiate commercial and navigation treaty with U. S. July 24,1828 .

I8. The President appoints Henry Clay to confer with Baron Lederer. Aug. 8,1828 .

19. Legacy of Anton Marschner. Aug. 9, I 828 .

20. Affairs of F. A. Terzi. Sept. 4, 1828 .

21. Personal matters. Same date.

22. Navigation treaty between U. S. and Mexico. Same date.

25. "Two interviews with Clay about treaty. First draft and memoranda. Beilage A, B, C. Washington, Oct. 30, I 828 .

26. Newspaper clippings. Washington, Oct. 30, 1828 .

27. "Lederer berichtet, dass Herr Clay die Ünterhandlungen abgebrochen habe." Lederer's remarks on probable reasons. Washington, Nov. I 8, I 828 . 
28. Declarations of Austria's willingness to abolish discriminating duties. Clay's explanation of the limitations of his power. Washington, Nov. $28,1828$.

29. Prospective treaty with Austria mentioned in President's message to Congress. Washington, Dec. 3, 1828 .

30. No information concerning Johann' M. Weisz (oder Deisz). New York, Dec. 22, 1828 .

$$
1829 .
$$

31. Concerning Georgio Jovovich in Porto Rico. Jan. I2, I829.

32. Report on international relations of U. S. Jan. I 5, I829.

33. Copy of treaty of U. S. and Hansa cities. Jan. 20, 1829 .

34. General Jackson's probable appointments. Feb. 28, I829.

35. His inaugural address. Mar. 6, I829.

36. Lederer goes to Washington. Mar. 28, 1829.

37. Report on results of trip. Apr. 12, 1829.

38. Commercial treaties. Apr. 13, I829.

39. Routine matters. Same date.

40. Concerning Count Barzizza. Same date.

41. Concerning Jacob Werdtman. Apr. 15, 1829.

42. Routine matters. Same date.

44. Routine matters. May I2, 1829.

45. Concerning Michael Holzhofer. Same date.

46. Proposed visit to Washington on account of treaty. May 18, I829.

47. Proclamation of President of U. S. abolishing discrimination against Austrian vessels. May 20, I829.

48. News of six or eight weeks' delay in matter of treaty. June 9, 1829.

49. Routine matters. Same date.

50. Routine matters. June I5, 1829 .

51. Routine matters. June 21, 1829.

52. Routine matters. July 9, I 829 .

53. Copy of letter of Van Buren, stating that he is not quite ready to take up matter of treaty (Lederer: In spite of the fact, that Austria has long ago abolished discriminating duty). July $16,1829$.

55. Concerning Terzi, and Simon Cuculli. July 3I, I829.

56. Not yet invited by Van Buren, though envoys of England and France already received. Same date.

57. Van Buren invites Lederer to Washington. Aug. II, I829.

58. Lederer reports agreement with Van Buren. Aug. 22, 1829.

59. Treaty between Austria and U. S. signed Aug. 29, 1829. Sept. 2, I829.

60. Routine matters. Sept. 29, 1829.

61. Legacy, Terzi-Cuculli. Sept. 30, I829.

62. Routine matters. Oct. 7,1829 .

63. Cotton duck instead of hemp used in American sails. Oct. 7, 1829.

65. Routine matters. Nov. 9, I829.

66. Routine matters. Same date.

67. Routine matters. Nov. 19, 1829.

68. On some Catholic institutions in U. S. Nov. 30, I829.

69. President's message. Dec. 9, 1829.

70. Remarks on the message. Same date. 
Faszikel 2. A. I830-I83I.

7I. Conditions in Mexico. Jan. $15,1830$.

72. Report of U. S. Secretary of War. Jan. I8, I830.

73. Report of U. S. Secretary of Navy. Same date.

74. Legacy of Terzi, New Orleans. Ja11. 3I, I830.

75. Concerning Anton Marschner. Same date.

76. Duty on Austrian wines. Feb. I4, I830.

79. Concerning Terzi. Feb. 28, 1830.

80. American learned societies. Mar. 3, I830.

8I. On percussion-locks. Mar. 23, I83o.

82. Diplomatic agents of Portugal. Mar. 26, I830.

83. Concerning Terzi-Cuculli. Apr. 8, 1830.

84. Controversy between diplomatic agents of Portugal. Apr. 4, I830.

85. Concerning Terzi-Cuculli. Apr. 19, I830.

86. Concerning Portugal. Apr. 30 , I83o.

88. Movement against Masonic orders in U. S. May I, I8zo.

89. On change of tariff. May 3, I8zo.

90. Plan of lowering import duties. May 9, 1830.

9I. Report of Secretaries of War and Navy. May I2, I8zo.

92. On abolition of negro slavery. Same date.

93. Routine business. May 3I, I830.

95. Portuguese diplomats, Barrozo vs. Torlade. June i7, I830.

97. Report of Secretary of Navy. June 2I, I830.

98. Treaty between U.S. and Denmark. June 23, I830.

99. Routine matters. June 30,1830 .

IOI. Routine nuatters. July 8, I83o.

105. American Philosophical Society of Philadelphia. Ju1y 30, I8zo.

I06. Concerning Randolph, who is to visit Vienna. Characterization: "Die Menge seiner ldeen war er nie in Stande in Ordnung zu bringen." "An extraordinary envoy, not an envoy extraordinary." July 3I, I830.

I07. Routine matters. Sanne date.

- (no number). Routine matters. Aug. 9, I8zo.

II3. Routine matters. Sept. i3, I830.

I I4. Routine matters. Sept. I4, I830.

I 5. Routine matters. Sept. 30, I830.

I I6. Newspaper clipping, article written by Joseph Bonaparte, Point Breeze. Oct. I4, I83o.

I 17. U. S. and British colonies. Oct. I 5, I830.

I 8. Exequatur (President Jackson). Sane date.

I19. Anstria's position on slavery, published in Daily Advertiser of New York, and National Gazette of Philadelphia, regulating ships visiting the port of Triest. Oct. $3 \mathrm{I}, 183 \mathrm{O}$.

I20. Austria las recognized new government of France, announcencnt in New York. Nov. $15,1830$.

I22. President Jackson's message. Dee. 8, I8zo.

I23. Remarks on at message. Dec. 15, 18,30 .

I24. Routine matters. Dec. 31,1830 .

125. Routine matters. Jan, 10, I831.

I27. Treaty between U. S. and Turkey. Feb. Io, I831.

I30. Rontine matters. liel, 28, I 83 I. 
I32. Terzi-Cuculli. Mar. 5, I831.

I33. Marschner. Same date.

I35. Copy of convention between U. S. and Emperor of Austria concluded Mar. 28, i83o. Mar. 7, I83i.

136. Concerning increase of salary. Mar. 9, I831.

137. Routine matters. Same date.

I38. Marschner. Mar. 23, I831.

I39. Naine objects to boundary decision. Apr. 7, I831.

I40. Report on internal affairs in U.S. 35 pages. Apr. IO, I83I.

I4I. Resignation of members of the Cabinet. Apr. 22, 1831.

I 42. Northeastern Boundary question. Apr. 23, I83I.

I43, I44. Routine matters. May 3, I831.

I48, I49. Routine matters. May 9, I831.

I5I. Routine matters. May 23, I831.

I52. Prinz Paul von Württemberg in Mexico. May 31, I83I.

I53. Routine matters. June Io, I83I.

I54. Van Buren's proposed trip to England, and Portugal. June I9, I83x.

I55. Frigate Potowmac. June 28, I83I.

I56. Routine matters. July 5, I83I.

I 57. Routine matters. July I 3 , I 83 I.

I58. Attitude of government toward Austria. July 30, I831.

I59, I60, 162, I63. Routine matters. July 30, Aug. 12, 27, 29, 1831.

I64. Legacy of Anton Marschner (\$1360). Aug. 29, I831.

I67. Arrival of Prince or Count Leon, who contemplates founding a colony of Germans and Netherlanders, with over 50 followers. Sept. 30,1831 .

Note by Lederer: "Vor einigen Tagen ist hier ein Individuum von Bremen angelangt, das die Aufmerksamkeit des Publikums auf sich gezogen hat, und sich nach einigen Fürst, nach anderen Graf Leon titulirt. Er bringt ein Personale von mehr als 5o Individuen mit sich, die er theils wie Bediente, theils wie Kolonisten behandelt. Man ist nicht über sein Vaterland einig, das nach einigen Belgium nach anderen Deutschland sein soll. Er scheint mit sehr beträchtlichen Summen versehen zu sein. Er hat sich nur wenige Tage hier aufgehalten und sich dann über Albany nach dem Innern begeben, wo er eine Colonie zu stiften die Absicht haben soll, in welchem Falle er, seiner Aussage zu Folge, eine grosse Anzahl seiner Landsleute zı sich zu berufen gedenkt. Die Verschiedenheit dieser Gerïchte scheint sich auf die Verschiedenheit seiner eigenen Erklärungen zu gründen." ${ }^{1}$.

I69. Return of Randolph. Oct. 30, I83I.

I70, I7I. Routine matters. Oct. 3I, Nov. 29, I831.

I73. Report on internal conditions and foreign relations of U.S. Nov. 30 , I 83 .

174. President's message. Dec. 7, 1831.

I75. Remarks on the message. Dec. 29 , I831.

176. Last report of directors of National Bank, with some remarks. Dec. 3I, I83I.

${ }^{1}$ Cf. J. Hanno Deiler, Eine Vergessene Deutsche Colonie eine Stimme zur Verteidigung des Grafen de Leon, alias Proli, alias Bernhard Mïller (New Orleans, I90o). 
Faszikel 2.A. 1832.

I78. Routine matters. Jan. I7, I832.

179. Jewels of Princess of Orange found and claimed. Certain international questions arising from the incident. Jan. 30, 1832 .

I80. Anton Marschner. Same date.

I81. Routine matters. Jan. 3I, I832.

I82. U. S. and the Porte. Feb. I3, I832.

I84. Prevention of appointment of Van Buren as minister to England. Feb. 20,1832 .

I87. Routine matters. Mar. I5, 1832.

I88. Current events. Mar. 3I, I832.

I91. Concerning Terzi. Mar. 28, I832.

I92. Current events. Mar. 31, I832.

I93. Current events. June I 5, 1832 .

I95. U. S. and the Porte. Written from Newburgh, July I 5, I832.

197. Legislation of Congress. I8 pages. Newburgh, July 26, I832.

198. Current events. Newburgh, July 27, 1832.

203. Routine matters. Newburgh, Sept. 5, I832.

20.4. Routine matters. New York, Sept. 28, I832.

205. Anton Marschner. Newburgh, Oct. I6, I832.

206. Cholera in New York. Newburgh, same date.

207. Routine matters. New York, Oct. 20, I832.

208, 209, 210, 21 I. Routine matters. New York, Oct. 20, 30, 31, Nov. 6, 1832 .

212. Review of political situation in U. S. New York, Nov. 29, I832.

214. Duty on French wines. Nov. 30, I832.

215. South Carolina Convention. Same date.

216. President's message with comments. Newburgh, Dec. 7, 1832.

217. Duplicate of note on French wine. Dec. I4, I832.

218. Proclamation of President on nullification. Same date.

219. Current events. Dec. 3I, I832.

I 833 .

221, 222. Current events. Newburgh, Jan. 7, I0, I833.

223. Report of Secretary of State. New York, Jan. I0, I833.

224. Reciprocity. Jan. I7, I 833 .

225. Routine matters. Same date.

227. Jackson and Van Buren in office. Feb. I7, I833.

228, 229, 230. Current events. Mar. 7, 12, I8, I833.

23I. South Carolina and U. S. govermment. Mar. I9, I833.

232. Duty on wines. Mar. 24, I833.

234. Legacy of Dr. Spurzhein of Boston. Apr. 12, 1833.

$235,236,237,238,240,242,243$. Routine matters. Apr. 12-June I, 1833.

246. Reciprocity. June 29, 1833 .

248. Reciprocity. Aug. I 5,1833 .

250. Current events. Aug. 20, I833.

251. Reciprocity. Aug. 30, 1833 .

252. Kingdom of the Two Sicilies and U. S. Sept. 5, 1833 .

253. Routine matters. Oct. 1, 1833 .

254. Nattional Bank. Oct. 14, 1833 .

256. Anerican Zwieback. Nov. I, 1833 .

$257,258,259$. Routine matters. Same date. 
262. Report on condition of U. S. before opening of Congress. Nov. 23, 1833 .

263. Message of President. Comments. Matter of import duties with Austria regarded as settled. Dec. 6,1833 .

$$
1834 .
$$

265. 266. Routine matters. New York, Jan. I0, I834.

27I. National Bank question. Feb. 27, 1834.

274. Current events. Mar. 23, 1834 .

279. Current events. Apr. 21, I834.

280. American Government vs. National Bank. Apr. 22, I834.

281. Salute in harbor by mistake. Apr. 24, I834.

285. Treaty with Russia. June 20 , I 834 .

286. Treaty with Naples. Same date.

287. Treaty with Chile. Same date.

288. Current events. July 3, 1834 .

289. Adjournment of Congress. Comments. 27 pages. July 4, I834.

290. Evil influence of contest between government and National Bank. July I 5,1834 .

291. Riots (Volksaufläufe) in New York. Slight causes. July I 5, I834. 299. Report on general condition, preceding convening of Congress. Nov. 23 , I834.

300. Message of President and comments. Dec. 7, 1834 .

30I. Learned society of Philadelphia. Dec. I2, I834.

302. Concerning Maria Rosalia Gruner. Same date.

304. Concerning Pietro Maroncelli. Dec. I 5, I834.

-. Appointment of consular agent by Baron Lederer, letters dated Dec. IO and 26,1834 .

I835.

3I I. Attempted assassination of Jackson. J. Q. Adams's eulogy of Lafayette. Feb. 7, 1835 .

312. Current events. Feb. I5, 1835 .

314. France and U. S. Indemnity treaty. Feb. 23, I835.

316. Action of Congress. Mar. I5, I835.

318. Routine matters. Mar. 23, 1835 .

319. Plan of treaty. K. K. Porzellanfabrik. Apr. 23, I835.

320. Concerning Richard Harland. Same date.

322. Copy of monograph Foreign Conspiracy. May 9, 1835 .

-. Bill for mahogany for Metternich. May 30, 1835 .

327. More concerning the pamphlet, Foreign Conspiracy. May 30, I835.

329 , 330. Routine matters. June 7,1835 .

33 I. Riots and comments. June 30, 1835 .

333. Routine matters. July 3 I, I 835 .

-. Letter asking permission to introduce to Metternich Madame [Robert Goodloe] Harper, daughter of Mr. Charles Carroll of Carrollton, last surviving signer of the Declaration of Independence. Fact mentioned that they are a Catholic family. (French, signed by J. G. Schwarz). Nov. 4, 1835 .

338. Observations on existing political conditions. I9 pages. Nov. I6, I835.

34I. Comments on President's message. Dec. 4, I835. 


$$
\text { I } 836-1837 .
$$

344. Statistics of commerce. New York, Jan. 9, 1836.

345, 346, 347. Current events. Jan. I6, I9, 23, I836.

349. U.S. and France. Jan. 25, I 836.

35I. President's message. Feb. 15, 1836.

352. Current events. Feb. 29, I836.

353. Question of leave of absence. Mar. 18, 1836.

355 , 356. Routine matters. Mar. 23, 31, I836.

357. Hermann Czech, professor in the Royal Academy for the Deaf and Dumb in Vienna, offers his method to U. S. (John Forsyth, Secretary of State, letter to Lederer). Apr. 7, I836.

$358,359,360$. Current events and routine matters. Apr. 20, May I, I836.

36r. Florida. Texas. May I 5,1836 .

362. Texas. Indians in the South. May 30, 1836 .

363. Texas. Florida. June 10,1836 .

365. Suggestion to institute diplomatic post in U.S. July 9, I 836 .

$366,368,369,370,372,377$. Routine matters. July 30, Aug. 7, i 5, 31, Oct. I 5, I 836 .

379. Texas. Van Buren probably unsuccessful for presidency. Oct. 23, 1836.

381. Pietro Maroncelli. Oct. 31, 1836.

382. Report on political situation before opening of Congress. II pages. Nov. I 5 . I 836.

385. Texas. Dec. 6 , 1836 .

389. Routine matters. Jan. I, I837.

391. Santa Anna. Jan. 23, I837.

395. Van Buren elected. Feb. II, I837.

396. Called to Washington. Same date.

399. Congress decides to send U. S. minister to Vienna. Mar. 3, I837.

400, 402. Routine matters. Mar. 7, 10, I837.

406. Forsyth and Van Buren. Question about minister to Austria. Mar. $3 \mathrm{I}, 1837$.

408. "Bedrängte Zustände in hiesigen Handelsstande." Same date.

4ro. "Bedrängte Zustände im hiesigen Handelsstande." May 23, I837.

4II. Anthracite coal. May 30, 1837 .

4I5. Delay in appointment of minister to Austria. June I8, I837.

4I6. Mr. [Nathaniel] Niles sent on diplomatic mission to Austria, not as minister. June 19,1837 .

4I8. Purpose of the agent to pave way for a minister. June $30,1837$.

420. Mr. Niles has sailed. July I 5, i 837 .

423. Report on political situation before convening of Congress (extra session). I I pages. Aug. 23, I837.

一. Routine matters. Aug. 3I, I837.

425. President's message to Congress. Sept. $7,1837$.

428. Note of Secretary of State: No minister to be appointed in extra session; minister to procect on his mission in spring. Sept. 30, 1837 .

-. Original letter of Nathaniel Niles to his Highness Prince Metternich informing him of his appointment and his desire to present credentials. Oct. 20,1837 .

429, 430. Routine watters. Oct. $3,19,1837$. 
431. Asks permission to accept membership in Brooklyn Naval Lyceum. Oct. I9, 1837 .

432. John J. Boyd made consular agent during Lederer's absence. Oct. 23, I 837 .

433. Carl Christ. Holnenberger made temporary consul in New Orleans. Nov. 6,1837 .

434. Report on political situation before convening of Congress. Nov. 23, I 837 .

435. Message of President. Dec. 7, 1837.

436. Clippings with reports of Secretary of State. Dec. I5, I837.

437. Disturbances in Canada. Dec. 23, 1837.

-. Beilage B I-5 Amerika [found in fascicle I838] zu einem Berichte des K. K. General-Consuls in New-York Freih. Al. Lederer. (Newspaper clippings, Dec., I837.)

\section{Mareschal to Metternich. \\ Faszikel I. I 838 .}

Wenzel Philipp Freiherr von Mareschal, Gesandter in Washington, an Seine des k. k. Staats- und der auswärtigen Geschäfte Ministers Herrn Clemens Wentzel Lothar Fürsten von Metternich Winneburg, etc., etc., Durchlaucht. (À son altesse le Prince Clément Wenceslaus de Metternich Winneburg ... Minister Directeur des Affaires Etrangères de S. M. l'Empereur et Roi à Vienne.)

The correspondence of Baron Mareschal is written in the French language, with very few exceptions.

June 4, I838. Paris. Appreciation of the honor of the appointment.

July -, I838. Paris. Acknowledgment of receipt of letter brought by Mr. de Friedrichsthal.

Aug. 23, I838. Vienna. Claim of Franz Maurer vs. Ed. Lammer.

Aug. 3I, I838. New York. Announces arrival in New York, and makes some observations on the country.

Sept. I4, I838. Letter from Washington. Marginal note of Metternich: "N. B. Voici le second rapport, qui arrive sans signature. M."

Sept. 26, 1838. New York. "Le G'1 Baron de M. rend compte de l'impression produite à Washington, par le désaveu des mesures prises par L. Durham pour la pacification du Canada."

Sept. 28, 1838. New York. "Considérations sur l'établissement et les résultats des chemins de fer aux États-unis."

Oct. 2, 1838. Philadelphia. "Résignation de L. Durham."

Oct. 9, I838. Philadelphia. "M. transmit un mémoire rédigé par M. de Hülsemann, avec quelques observations." Hülsemann's report (on written constitution, and rights of neutrals on the sea) in German, I2 pp.

Oct. I8, I838. Washington. "Affaires du Canada. Blocus des côtes du Mexique. Elections."

Washington. "M. rend compte de la difficulté élevée par le gouvernement des États-Unis de recevoir la lettre de créance sans la remise préalable d'une copie d'office et de la manière dont cette difficulté a été tranchée." (With one postscript and two enclosures.)

Washington. "M. rend compte de la remise de sa lettre de créance à Mr. Martin van Buren Président des Etats-Unis." (Two enclosures.) 
Oct. 23, I838. Washington. "M. transmet deux brochures, le rapport du comité des ouvrages hydroliques au conseil municipal de la ville de Philadelphia, et celui des commissaires pour les eaux de celle de New York."

Washington. "M. transmet un article du Globe, organe du Gouvernement, annonçant que le Ministre du Texas a retiré la demande de ce pays d'être reçu dans l'Union fédérative des Etats-Unis; cause de cette démarche."

Washington. "Sur Lord Durham, ses projets et la situation du Canada, nouvelles courantes."

“ML. bestätigt den Empfang der Depesche v. 17. Juli d. J. die Aufstellung von provisorischen Consuln in den Hafenplätzen der nordamerikanischen Freistaaten betreffend."

"M. gibt die verlangten Auskünfte über Herrn Alexander Dallas [Bache] vom Girard College in Philadelphia."

“M. bestätigt den Empfang der Depesche vom 3o. Juli d. J. den Herm Ritter von Friedriclisthal betreffend."

Oct. 28, I838. Washington. "Le général Bon. de Mareschal accuse la réception de la dépêche du 6 sept. amonçant le couronnement de sa Majesté l'Empereur à Milan.",

Washington. "Le général Bon. de Mareschal accuse la réception des deux circulaires datées de Milan le 6 sept. concernant l'amnestie et transmet une lettre que lui a adressée Felice Argenti ainsi que sa réponse. Entretien avec Luigi Tinelli à New-York." (Two enclosures.)

Nov. 13, 1838. Washington. “Départ de L. Durham pour l'Europe. Nouveaux troubles éclatés au Canada." (Postscript and two enclosures.)

Nov. 23, 1838. Washington. "Freiherr von Mareschal berichtet ïber den Zustand der K. K. Gesandtschaft in Washington, die Theurung des Landes und die Unzulänglichkeit des ausgeworfenen Gehaltes [von 30,000 Gulden], um mit dem Anstande welchen der Rang des allerhöchsten Hofes erheischt, hier zu leben und den Zweck der Errichtung dieser Gesandtschaft zu erreichen."

Washington. "Ml. transmet une proclannation du Président des EtatsUnis à l'occasion des nouveatux troubles éclatés dans le Canada." (One enclosure.)

Dec. 2, 1838. Washington. "Afïaires du Camada; blocus des cotes du Mexique par l'escadre française; nombreuses et fortes défalcations des agents de l'administration aux Ktats-Unis." (One enclosure.)

Dec. 7, I 838. Washington. "Message du Président an Congrès avec quelques observations."

"Nouvelles courantes."

Dec. I I, I838. Washington. "M. transmet une copie de ha Convention conclue en date du 25 Avril 1838 entre les T́tats-Unis et la République du Texas pour fixer les limites des deux Ytats."

"Copie de la convention générale de paix, d'amitié, de commerce et de navigation conche ( Nov. 30, 1836) entre les fitats-Unis et la Conféderation I'ern-Bolivienne, et y ajonte l'observation, que les art. 1 I-22 se rapportent an principe, que le pavillon courre la cargaison." (One enclosure.) 
Washington. "Copie du traité de commerce et de navigation conclu (Dec. 22, I837) entre les Ê.-U. et la Grèce, et fait observer, que l'article 16 contient une stipulation sur le blocus des ports respectifs." (One enclosure.)

Dec. 29, I838. Washington. "Prise du château de S. Jean d'Ulloa par l'escadre française; capitulation de la Vera Cruz; position du gouvernement mexicain."

"Sur les affaires du Canada."

"Commotions civiles et désordres à Harrisburg en Penna. à l'occasion de l'ouverture de la législature de cet Etat." (One enclosure.)

"Nouvelles courantes."

Faszikel I. I839, January to April.

Jan. I3, I839. Washington. "Observations sur la partie du message du Président, faisant le panégyrique des institutions de l'Union américaine."

Washington. "Le Général Baron de Mareschal transmet des résolutions proposées dans la chambre des représentants par Mr. Cushing, apparemment dirigées contre l'Angleterre et la France, en y joignant l'observation, qu'elles n'ont aucune valeur pratique." (One enclosure.)

Washington. "Le Général Bon. de Mareschal transmet un pamphlet et deux projets de lois ayant rapport à la situation financière des Etats-Unis." (Three enclosures, including reprint from daily newspaper, "The Causes of the Present Crisis", shown by an examiner.)

"Transmet le rapport annuel du Sécrétaire d'État du trésor au Congrès." (One enclosure.)

"Transmet un acte de la législature de l'État de New York en date du 18 avril 1838 sous le titre de 'Act to authorize the Business of Banking "." (One enclosure.)

Washington. "Affaires du Canada; nouvelles du Mexique; péu d'intérêt, que présentent les débats du congrès fédéral." (One enclosure.)

Jan. 29, I839. Washington. "Affaires du Canada."

"Le Général B'on de Mareschal rend compte de l'échec éprouvé par l'administration dans la chambre des Représentants."

"Affaires du Mexico."

"Reprise des hostilités contre les Mexicains et les Français le 5 Dec. à la Vera Cruz; proclamation de l'admiral Baudin du 22 du même mois, déclarant le port de la Vera Cruz ouvert pour l'entrée des bâtiments, mais non pour le débarquement des marchandises, et celui de Tampico et du reste de la côte en état de blocus." (Postscript and one enclosure.)

“Rend compte de l'arrivée de Mademoiselle Ma. Ea. Ameriga dei Vespucci florentine, et de ses prétensions'à un bienfait du Gouvernement des États-Unis à titre de descendante directe de celui, qui a donné son nom à ce Continent."

Feb. 4, I839. Washington. "Nouvelles courantes."

Feb. I5, I 839. Washington. "Freiherr von Märeschal berichtet hinsichtlich des Rescripts der K. K. Geh. Haus-, Hof-, und Staatskanzlei vom 
I4ten Mai I838, den Taufschein der Aloysia Dür von Halifax in Neu Schottland betreffend, dass er denselben zu verschaffen von hier aus nicht in Stande war, und dennoch [demnach] die betreffenden Papiere an die K. K. Botschaft in London ïbermacht hat."

Feb. 19, I839. Washington. "Etat des affaires sur les côtes du Mexique; négociation entre l'admiral Baudin et le Gouvernement du Mexique par l'intermédiaire de Mr. Packenham, Ministre d'Angleterre." (With postscript.)

“Correspondance du Ministre des ftats-Unis, Mr. Stevenson, avec Lord Palmerston au sujet de la destruction du batea à vapeur la Caroline." (One enclosure.)

"Transmet une lettre d'un nommé Smolinkary avec un paquet pour Sa Majesté l'Empereur." ('Two enclosures.)

"Rapport du comité des affaires étrangères à la Clambre des Représentants sur le territoire de l'Oregon et proposition d'autoriser le Président à pourvoir à la protection des citoyens des Etats-Unis dans ce territoire ou trafiquant sur la rivière Colombia et ses affluens." (Two enclosures.)

"Etats des finances du gouvernement fédéral; augmentation rapide et disproportionée du nombre des banques sous le système de free banking, et resultat probable de l'expansion commercielle, qui doit en resulter." (One enclosure.)

"Nouvelles courantes."

Feb. 24, I839. Washington. "Difficultés graves sur la frontière de l'État du Maine et de la province anglaise de New Brunswick; violation du territoire; abduction de l'agent territorial américain par des sujets anglais; mesures hostiles et proclamations des detr gouverneurs." (One enclosure.)

Feb. 25, I839. Washington. "Frontières de l'Etat du Maine; communication du gouverneur de New Brunswick à celui du Maine; second messagre de cehui-ci à la législature de l'État; arrestation de l'agent territorial anglais Mr. McLaughlin par les américains; armement de l'Etat du Maine: appel au Gouvernement fédéral de soutenir les droits de l'Etat du Maine." (One enclosure.)

Feb. 26, I839. Washington. "Mesures prises à Washington pour mettre un terme aux actes hostiles, sur le territoire en litige entre l'état du Maine et la Province de New Brunswick."

Feb. 27, I839. Washington. "Etats des choses an Mexique. Le Général St. Anna Président."

Mar. 4, I839. Washington. "Issue des prétentions de Mlle. Ameriga dei Vespucci à la générosité du Congrès des Etats-Unis." (Three enclosures.)

"Freiherr von Mareschal berichtet, in Erledigung des hohen Rescriptes vom 6. Dez. 1838, das Gesuch des Joseph Svilovich w11n Beschaffung des angeblich von dessen verstorbenen Bruder Teter Svilovich in Savannah in Georgia hinterlassenen Testamentes betreffend, dass derselbe intestat und ohne Vermögren gestorben: und remittiert die betreffenden Dokumente." (Five enclosures.)

"Berichtet den Empfang des hohen Rescripts vonn Io. Nov. 1838, wodurch ihm die Eröffnung eines Credites von $4200 \mathrm{Pf}$. Sterl. für das Verwaltungsjahr 1839 bei dem Hatuse Rothschild in London angezeigt wurle." 
Mar. 6, I839. Washington. "Affaires de la frontière du Maine. La correspondance du Secretaire d'État avec Mr. Fox sur l'affaire du Maine ainsi que la communication du premier au gouverneur de l'État du Maine." (One enclosure.)

"Clôture de la 3 me et dernière session du 25me Congrès des Etats-Unis; ses travaux."

Mar. 7. I839. Washington. "Affaires de la frontière du Maine; considérations ultérieures."

Mar. I3, I839. Washington. "Cirkular des Finanz-Departementes, so wie die Abschrift einer darüber, sowie über die Suspension einiger Banken an den Gouverneur von Triest gerichteten Mitteilung."

"Affaires du Mexique; suspension de payements de deux banques."

"Affaires de la frontière du Maine."

Mar. I6, I839. Washington. “Divers documents sur l'état des relations territoriales entre l'Angleterre et les États-Unis, le blocus des côtes du Mexique et du Rio de la Plata, ainsi que sur la navigation, et les machines à vapeur et les causes de leurs fréquentes explosions."

Mar. I7, I839. Washington. "Affaire du Maine."

Mar. 20, I839. Washington. " Berichtet den Legations-Secretair, Herrn v. Hülsemamn nach Norfolk, Charleston und Savannah im Dienste abgeschickt zu haben."

Mar. 21, I839. Washington. "Affaires du Maine."

"Nouvelles courantes."

Mar. 28, 1839. Washington. "Handels- und Schiffsvertrag zwischen Sardinien und den Ver. Staaten."

"Exequatur des Herrn Hohenberger." (Consul at New Orleans; three enclosures.)

Nar. 30, I839. Washington. "La signature d'un traité entre la France et le Mexique, ajournement de la législature du Maine, ses derniers actes, embarras financiers aux Etats-Unis." (One enclosure.)

Apr. 8, I839. Washington. "Nouvelles courantes." (Three enclosures.)

Apr. I9, I839. Washington. "L'Autriche et la Belgique."

"Arrivé du Great Western; aspect pacifique des relations entre l'Angleterre et les États-Unis; effet produit sur le commerce et les fonds publics, situation présente de la question de juridiction dans le territoire en litige, esprit public sur la frontière du Canada."

Apr. 28, I839. Washington. "Legations Secretair Hülsemann berichtet über die Produkte und den Handel in Virginien; Verhältnis der Arbeit der Weissen und der Negersklaven; die Städte Richmond und Norfolk; Nord Carolina; Süd Carolina und die Stadt Charleston; Commercial Convention; Georgien und die Städte Savannah und Augusta; Oesterreichische Produkte, für die sich dort ein Absatz erwarten liesse." (One enclosure.)

Faszikel II. 1839, May to December.

May I6, I839. Washington. "Le Général B'on de Mareschal transmet 5 rapports, que Mr. de Hülsemann lui a adressés en suite de son voyage dans la Virginie, les deux Carolines et la Géorgie." (The five enclosed reports are written in German.) 
May 3I, I839. Washington. "Freiherr von Marcschal übermacht eine Liste der unter gleichem Datum durch das Schiff Gustav über Bremen eingesandten Dokumente." (One enclosure.)

"Ueber den Handel und die Schiffahrt der Vereinigten Staaten im Allgemeinen, und besonders über jene zwischen den Vereinigten Staaten und Triest."

"Ueber dic Mittel einen Absatz für unsere Weine in den Vereinigten Staaten zu finden."

June 8, 1839. Washington. "Vorschreiben für Herrn G. Plitt" (Europareise zum Studium des Postwesens).

June I0, I839. Washington. Letters of introduction for Mr. George Plitt.

"Traité de commerce conclu entre S. M. Néerlandaise et les États Unis."

"Le Général B'on de Mareschal rend compte des formes observées par les Cours de Russie, de France, d'Espagne et d'Angleterre dans leurs communications avec le Président des États-Unis, et rappelle la difficulté qui s'est elevée à la remise de sa lettre de créance, laquelle n'a point encore été levée."

"Nouvelles politiques."

"Den genannten Braditsch, alias Cliovitsch, alias Baron Fridolin, aus Triest gebürtig, betreffend."

Sept. I3, I839. Vienna. "A1. Baron v. Lederer (Generalconsul in New York) bittet, falls die Sendung eines Agenten nach Mexico beschlossen werden sollte, auf ihn gnädige Rücksicht nehmen zu wollen."

Sept. 25, 1839. Washington. "Legations Sekretair Hülsemann berichtet über die von ihm nach den Staaten von Neu England unternommene Reise im Allgemeinen, sich die Entwerfung detaillierter Berichte vorbehaltend."

Sept. 28, I839. Washington. "Le Général B'on de Mareschal : État du crédit public et de la circulation, currency, embarras du commerce."

"Nouvelles politiques."

"Freiherr von Mareschal berichtet, in Folge des ihm durch Rescript v. 2I. Mai gewordenen Auftrages, die Mitteilung der von den Gebrïdern Grant et Comp. gegen Cornelius Specht zu St. Jago de Cuba erhobenen Klage an letztere, vermittelst des nordamerikanischen Consuls alldort, betreffend, dessen Auftrag vollzogen zu haben, und sendet den Empfangsschein des Cornelius Specht ein."

"Le G'l B'on de M. rend compte du voyage qu'il vient de faire dans l'Ouest et le Nord de l'Union. Ainsi que de celui de Mr. de Hülsemann dans l'Est."

"Accuse réception des hautes dépéches."

"Gesıch des Ferdinando Antonio Anelli aus Dessenzano in der Provinz Brescia, gegenwärtig in New York, um Erteilung eines Passes zur Rückkehr ins Vaterland."

Oct. 3, 1839. Washington. " Le G'1 B'on de M. transmet trois rapports [written in German] de Mr. de Hülsennann, l'un sur la législation sur les chemins de fer dans l'état de Massachusetts, les denx autres contenant des notions statistiques sur les fabriques de Lowell et l’État de Massachusetts en général. Observations sur la législation des railroads aux Etats Unis, et sur les lacunes, qui s'y tronvent." 
Oct. 8, ı 839. Washington. "M. transmet les réglemens de l'académie militaire de West Point." (One enclosure.)

"M. berichtet den Tod und etwaigen Nachlass des Johann Mölzel, Verfertigers des bekannten schachspielenden Automaten, betreffend, dass derselbe am igten Juli I838, auf der Ueberfahrt von Havanna nach Philadelphia gestorbèn ist, $\mathbf{u}$. kein Vermögen hinterlassen hat."

"Ueberschickt den Report des Secretary of the Treasury über Handel und Schiffahrt, v. 30. Sept. I837-30. Sept. I838."

"Canal de Pennsylvania."

"Unsern Handelsvertrag mit d. Ver. St. betreffend."

Oct. 8, 1839. Washington. "Général B’on de Mareschal sur la crise financière et commercielle."

Oct. $17, x 839$. Washington. "M. transmet une publication de Mr. le Chevalier de Gerstner" (Railroads in the Kingdom of Belgium compared with those in the U.S.) "avec quelques observations". (One enclosure.)

“Indian Rubber oder gomme élastique Pontons.” ('Two" enclosures.)

"Suspension des payemens en espèces par la Banque des Etats Unis et les autres banques de Philadelphie, suivie de celle de la plupart des banques du Sud." (Two enclosures.)

“M. meldet, dass der von ihm unter d. I6. Mai I 839 zum Vice Consul in Savannah vorgeschlagene Louis Ganalh, infolge eines Fallimentes nach Europa abgegangen sein soll."

Routine matters.

Oct. 22, I839. Washington. “M. transmet la copie d'une lettre datée de Llanos de Santa Rosa in Guatemala 29 Juillet I839, communiquée confidentiellement par le Secrétaire d'Etat." (Two enclosures; the confidential letter, copy, is written in English, on conditions in Central America.)

" Suspension des Banques-crise du commerce."

“M. rend compte de la manière dont le gouvernement fédéral a répondu à la protestation du gouvernement de Lisbonne contre le dernier Bill du Parlement anglais relatif à la traite des nègres. Envoi d'une croisière américaine sur la côte d'Afrique." (One enclosure.)

Nov. 5, I839. Washington. " Nouvelles courantes."

Nov. 22, I839. Washington. "M. berichtet, den Freiherrn Carl von Luzenberg betreffend, dass derselbe am Leben und einer der ersten ausübenden Aerzte in New Orleans ist."

"Fabriques de Pittsburg."

Washington. "M. transmet un travail de Mr. de Hülsemann sur les principaux membres du Congrès." 4I MS. pages in French; pen portraits of Col. R. M. Johnson, Silas Wright, Buchanan, Benton, Clay, Calhoun, Jackson, Van Buren, Preston, Crittenden, Webster, Rives, Tallmadge, Polk, Howa'rd, Leegaré, Cushing, J. Q. Adams, etc.

Pension of Frau Antonia von Höffern.

“Navigation des rivières aux Etats-Ụnis; celles de l'Est et celles de l'Ouest." 
Nov. 27, 1839. Washington. "M. rend compte de la difficulté, où se trouve la Légation résidente à Washington de suppléer à l'absence prolongée du Consul Général à New York."

"Rend compte de la prétention élevée par les consuls brésiliens, de numir les bâtimens, qui se rendent dans les ports du Brésil, de documens consulaires brésiliens."

"Exposé de la situation des États-Unis dans le rapport des finances et de la politique intérieure au moment de l'ouverture de la première session du 26ème Congrès."

Dec. I I, I 839. Washington. "Nouvelles courantes."

Dec. 21, 1839. Washington. "Nouvelles courantes."

Dec. 28, I839. Washington. “M. transmet le message du Président au Congrès, avec quelques observations."

"Rapport annuel du Sécrétaire du Trésor au Congrès."

\section{Faszikel 4. I839-I840.}

This bundle of manuscripts contains letters and reports of Baron Mareschal to Prince Metternich from Feb. 4 to Oct. 8, I839, and from Jan. 28 to Dec. 28 , 1840 . They are concerned with routine matters of business, current events, deportation of political refugees from Lombardy, and a few reports of Mr. Hülsemann.

Feb. 4, I 839. Washington. "Supplique de Felix Argenti, l'un des déportés." May I6, I839. Three reports, one containing: Prayer of Alessandro Bargnani, political refugee, asking permission to return home to Lombardy, and then to live in some country in Europe. ("Avocat de profession, il a moins qu'un autre trouvé le moyen de s'occuper et de gagner sa vie, et se tronve donc dans un plus grand dénuement, et plus malheureux que ses compagnons.")

May 22, I839. Washington. Two reports, one containing: "Une supplique de Felix Foresti, déporté, demandant la permission de rentrer au sein de sa fanille."

May 3I, I839. Washington. " Supplique de Luigi Tinelli, déporté, a fin d'ètre gracié, rétabli dans les droits civils et placé dans la position, dans laquelle se trouvent les émigrants, ayant formé ici un établissement commercial." (Tinelli's plea is to be found among the "Polizeiakten".)

"Le déporté Felix Argenti."

June ${ }_{13} 3,1839$. Washington. "Achille Murat. Situation et intentions."

Oct. 8, 1839. Washington. "La conmission verbale envers le sicur Bargnani."

Oct. I7, I839. Washington. "Nareschal rend compte de la manière dont il s'est acquitté des ordres contenuts dans les trois hautes dépéches. datées Vienne le 31 juillet, concernant les déportés Luigi Tinelli, Felix lioresti, et Alessandro Bargnani."

Jan. 28, 1840. Washington. "Mareschal transmet une lettre d'Alessandro Bargnani, déporté, demandant l'appui et l'intervention du gonvernement afun d'anener à un terme la liquidation de ses intérêts en Lombardie."

Mar. 16, 1840. Washington. “M. transmet une supplique de Luigi Tinelli, demandant copie officielle de sa sentence à la peine capitale prononcée contre lui par le tribunal de Milan, ainsi que celle de la 
Révolution Impériale de l'an I835 et du procès verbal, par lequel il a accepté la déportation en Amérique, enfin copie de la déclaration de dame Anne Tinelli, née Baronne Zanini, de ne vouloir point le suivre dans l'exil."

“M. transmet une lettre de Msgr. Rosati, Evêque de St. Louis, à Msgr. l'Archevêque de Vienne, demandant des secours de l'Institution Léopoldine pour son diocèse." 1

Apr. I0, 1840. Washington. Current events.

“Mr. Hülsemann: rapports peu satisfaisants d'une partie des Indiens émigrées à l'Ouest du Mississippi avec le Gouvernement des États Unis."

Apr. 28, 1840. Washington. Luigi Tinelli. Divorce case before Senate. (Contains interesting American newspaper clipping.)

May 29, I840. Washington. Luigi Tinelli. Bittschrift in den Polizeiakten (Ministerium des Innern).

June 6, I840. Washington. Bittschrift des Deportierten Giovanni Albinola (Polizeiakten).

"M. rend compte d'une conversation avec Mr. Forsyth, que Mr. Mühlenberg [U. S. minister to Austria] venait d'obtenir le congé qu'il souhaitait depuis longtemps."

“M. transmet un rapport de Mr. de Hülsemann sur le comité provincial catholique tenu à Baltimore le 7 mai, avec quelques observations sur l'Église Catholique aux États Unis."

“M. annonce le départ de Mr. de Hülsemann pour visiter l'Ouest et le Nord des Etats Unis, avec une copie de ses instructions."

June 22, I840. Washington. Concerning Alessandro Bargnani.

Washington. Concerning Felice Argenti.

July 28 , 1840. Washington. Current events. Seven communications, the last one on Giuseppe Vannoni, and the political refugees.

Aug. 4, I840. Washington. Alessandro Bargnani.

Sept. 2, 1840. Washington. Felice Argenti.

Oct. I3, I840. Washington. “M. transmet quatre reports de Mr. de Hülsemann, ensuite de son voyage dans l'Ouest, le Canada et le Nord de 1'Union." (Four enclosures.)

Oct. 29, I840. Washington. Current events.

Washington. "M. rend compte d'une visite de Mr. Achille Murat et de son intention d'aller en France et d'attaquer son oncle foseph Bonaparte pour obtenir sa part de l'héritage de l'Empereur Napoléon."

Giovanni Albinola; Luigi Tinelli.

Nov. 6, I840. Washington. "Mareschals Bericht über die nach den Staaten von Neu England und Boston im Laufe der Monate August und September letzten Jahres gemachte Reise."

Nov. 27, I840. Washington. Current events, three communications, last one on Alessandro Bargnani.

Dec. I 5, 1840. Washington. Routine matters.

Dec. I6, I840. Washington. Alessandro Bargnani.

Current events.

Dec. 28,1840 . Washington. Convention of tobacco planters, Dec. I5, I840 (with clipping from National Intelligencer).

${ }^{1}$ See Catholic Historical Review, I. 51-63, I75-I9!. 
Faszikel 2. 1840.

Jan. 2I, I840. (All the following reports come from Washington.) Routine matters.

Jan. 28, I840. Eight communications. Rontine matters and current events. Jan. 29, 30, I840. Two communications. Id.

Feb. 7, 1840. Two communications. $t_{4} 200$ sterling received for expenses of the year 1840 .

Feb. 26, I840. Three communications. "Le général Baron de Mareschal remarque que le Io Février I 840 , terme auquel d'après l'article i2 de notre traité de commerce avec les États Unis les deux parties sont autorisées à le dénoncer, est passé sans notification quelconque à cet effet."

Mar. 5, i8 40 . One communication. Nouvelles courantes.

Mar. I6, I840. Four communications. Id.

Mar. 28, i840. Four communications. Id.

Mar. 30, i8 4 o. Two communications. Id.

Apr. I4, i840. Two communications. Id.

Apr. 28, i 840. Seven communicatious. Id.

May 6, 1840. Death of Professor François Antoine de Gerstner.

May 9, 1840. Report of Hülsentann on the two conventions (Whig and Democratic) held in Baltimore May 4 and 5. (I 2 pages in French.)

May 22, I840. Comments on the political conventions.

May 29, I840. "Nouvelles courantes."

June 22, 1840. Two communications. Id.

June 28, I840. Three conmunications. Id.

July 28 , I 840 . Two communications. Id.

Ang. 30, I8fo. One communication. Id.

Sept. I, I840. One communication. Id.

Sept. 24, I840. Five communications. Id.

Oct. 28, i840. Rontine matters.

Nov. 4,184 o. Id.

Nov. 25, I840. Id.

Nov. 26, 1840. Id.

Dec. I 5, 1840. Id. Alessandro Bargnani.

Dec. I6, I 840. Three communications, one concerning replacement of Henry Augustus Mühlenberg in Vienna.

Dec. 28, i840. "Nouvelles courantes."

Faszikel 2. I $84 \mathrm{I}$.

Jan. 5, 1841. Two communications. The MeIeod alfair and relation between England (Canada) and U. S. are the subject of a great many reports in this year.

Jan. 27, i $8+1$. Three communications. "Nouvelles courantes."

Feb. ro, 184 . Three communications. Id.

Feb. I8, i 84 . Rontine matters.

".I. transmet wn travail din Baron de Rocnne, ministre de Prusse, sur une loi uniforme de bancueroute aux Ytats Unis, qui se trotve devant le Congrès." (German manuseript of 32 pages.) 
Mar. 7, I I, I 84 I. Eight communications. "Nouvelles courantes."

Mar. 27, I841. Six communications. Id.

Apr. 5, 8, 13, I841. Six communications. Id.

May 3, I841. Seven communications. Id.

Nay I9, I84I. One communication. I $d$.

May 27, I84I. Three communications. Id.

June I2, I84I. Eight communications. Id.

July i I, I84I. One communication. Id.

July I 3 , I84I. Three communications. Id.

July I 4, I84I. One communication. Id.

July 24, 184I. New York. "Baron von Lederer, Generalkonsul in New York, bittet um die Geschäftsträgerstelle im nordamerikanischen Freistaate."

July 26, I84I. Four communications. " Nouvelles courantes." The last one instructions for trip of the secretary of legation, Hülsemann.

Mareschal receives post to Lisbon, and writes letter of thanks to Prince Metternich.

Aug. 5, I 841. Three communications. "Nouvelles courantes."

Aug. I2, I84I. Two communications. Id.

Aug. 27, I84I. Three communications. Id.

Sept. I I, I84I. Daniel Jenifer of Maryland, envoy extraordinary and minister plenipotentiary to Austria (successor to H. A. Mühlenberg).

Sept. 22, I84I. Three communications. "Nouvelles courantes."

Sept. 27, I84I. Two communications. Id.

Sept. 28, 1841. "Tournée de S. A. R'le le Prince de Joinville aux Etats Unis." Sept. 29, 184I. (Written from New York.) Lederer to Metternich (concerning Joseph A. Menzel).

Oct. 7, I841. One communication. Routine matters.

Oct. I2, I84I. Two communications. "Nouvelles courantes."

Oct. I5, I 84I. "Hülsemann berichtet, dass Baron Mareschal am I4. Oktober dem Präsidenten sein Zurückberufungsschreiben übergeben hat; und er als Geschäftsträger präsentirt worden ist."

"Hülsemann annonce le départ de Baron de Mareschal de New York le I9 octobre, et transmet le discours adressé par le Baron au Président, aussi bien que la réponse de Mr. Tyler."

Oct. 24, I84I. Two communications: (I) Le procès de McLeod terminé ; (2) Pétition de Mr. Bernardino Castelli.

Oct. 25, I84I. Routine matters.

Nov. I2, I84I. Id.

Nov. I8, I84I. "Hülsemann transmet une pétition d'Alessandro Gambato de Rovigo de rentrer en Autriche."

Nov. 2I, I84I. "Nouvelles courantes."

Dec. 2, I84I. Bernardino Castelli.

Dec. I I, I84I. Three communications. "Nouvelles courantes."

Dec. 20, I84I. One communication. Id.

Dec. 26, r841. "Hülsemann berichtet den Empfáng des hohen Rescripts vom II. November d. J. und des Credits für die K. K. Mission von I $200 £$ Sterling für das Verwaltungsjahr I842."

Dec. 27, I84I. Three communications. "Nouvelles courantes." The last, "affaire de la Créole". 


\section{Hülsemann ${ }^{1}$ to Metternich.}

Faszikel 5. Convolut 1. I842.

Jan. 23, I842. "Bemerkungen über das Bankwesen in den Vereinigten Staaten.” (Most of Hülsemann's communications were written in the German, the others in the French language.)

Three communications. Current events. Jan. 27, I842. Six communications. Current events.

Feb. 6. 1842. Four communications. Current events, inchuding a petition of Alessandro Luigi Bargnani (sce Polizeiakten).

Mar. I2, I842. One commumication. Current events.

Mar. I5, 1842. Routine matters. "H. berichtet, in Erwiderung des hohen Rescripts vom I2. September vorig. J., Karl Bozzachi betreffend, dass es ihm nicht möglich gewesen, etwas über dessen Leben oder Tod zu erfahren."

Mar. 27, 1842. Six communications. Rontine and current events.

Apr. 4, I842. One communication. Routine matters.

Apr. 5, 1842. One communication. Current events.

Apr. I4, I842. "Lederer berichtet dem Hauptmann Moering Verlängerungsurlaub übermacht zu haben."

Apr. I5, I842. Two communications.

Apr. I8, I842. Ankunft des Ingenieur Ghega.

Apr. 26, r842. Two communications. Current events.

May 7, 1842 . Two communications. Routine matters.

May 8, i 842. Two communications. Id.

May 9, I842. One communication. Id.

May IO, I842. One communication. Cur rent events.

May 22, 1842. One communication. Id.

May 27, 1842. Two communications. Id.

June 13,1842 . Three communications. Id.

June $28,18+2$. Two communications ; the last contains a letter of the deported Felix Argenti.

Two communications. Routine matters.

June 29, I842. One communication. Current events.

July I 2 , I $8+2$. Three communications. Id.

July I 3,1842 . One communication. Id.

July 28,29 , I 842 . Three communications. Id.

Aug. I3, I842. Three commumications. Id.

Aug. 18, I842. Petition of Alessandro Bargnani.

Aug. 29, 30, 31, 1842. Four communications. Current events.

Oct. I3, I $8+2$. Three communications, including a request of Baron Lederer, consul-greneral of New York, for leave of absence for six months.

Oct. I4, I 842. One communication. Routine matters.

Oct. 22, I8+2. (From Philadelphia.) Id.

Nov. 2, I8 8 . Report that Pietro Pelizcaro lives in Havana.

Nov. I 1, 1842. Two commmications. "Hïlsemann übermacht ein Schreiben des Herrn K. K. Ingenieurs Hauptmann Carl Moering und 2 Ilefte von dessen Werk über die Eisenbahnen, sowie 2 Berichte an Se. Kais. Hoheit dem Erzherzog Johann."

\footnotetext{
'The Chevalier Hülsemann was Austrian chargé d'affaires in Washington from 184! to 1855 , minister resident from 1855 to 1863 .
} 
Nov. I 5, 27, I842. Two communications. Current events.

Dec. I 2, I842. One communication. Id.

Dec. 27, I 842. Two communications. Routine and current events.

Faszikel 5. Convolut. 2. 1843.

Jan. 4, 5, 27, 29, I 843. Seven communications. Current events.

Feb. 24, 26. I 843 . Five communications. Id.

Mar. I5, I8, 20, I843. Three communications. Routine and current events.

Apr. 7, 27, 28, I843. Six communications. Id.

May 7, 9, I I, 26, I843. Six communications. Id.

May i6, i843. Ingenieur Carl Moering in U. S.

June 15, I843. "Das K. K. General Consulat in New York betreffend." (Lederer died at the end of December, I842.)

June I5, 29, i843. Three communications. Routine matters and current events.

July I2, I843. Two communications. Id.

Sept. I2, I843. One communication. Id.

Oct. I3, i843. Two communications. "Bruits sur les relations entre les révolutionnaires italiens et des inhabitants des États Unis."

Oct. 23, I843. 'Three communications. Routine matters.

Oct. 28, I843. Two communications. " $\mathrm{H}$. rend compte d'une conversation de Mr. Upshur, dans laquelle Mr. le Secrétaire d'État exprima le désir du gouvernement des Etats Unis, de faciliter les relations commerciales entre l'Autriche et ce pays-ci."

Nov. 4, I843. "Das Vermögen von Emigranten betreffend."

Nov. I3, I843. Routine matters.

Nov. 30, I 843. "Etwaige Beiträge zu den Wiener Jahrbüchern betreffend."

Dec. 6, I3, 26, I843. Eight communications. Routine matters and current events.

Dec. I7, I843. “ H. transmet la constitution d'une société anti-catholique "Christian Alliance'." (Printed constitution enclosed.)

I 844 .

Jan. 28, 29, I844. Three communications. Routine and current events.

Feb. 22, I844. Four communications, including: "Convention entre les États Unis et la Mexique sur des indemnités. L'Empereur d'Autriche désigné éventuellement comme arbitre. Le Mexique envoit un agent diplomatique à Vienne."

Feb. 27, 29, I844. Two communications. Routine matters.

Mar. 4, I844. “H. transmet une lettre du déporté G. Albinola."

Mar. 6, 1844. Four communications. Current events. (The first contains a number dated Mar. 2, I844, of the Deutsche Schnellpost, a German semi-weekly published by Baron Eichthal and Bernhard.)

Mar. 28, 30, I844. Three conmunications. Current events.

Apr. I4, I8, 28, I844. Four communications. Id.

May 4, I 3, 29, 30, I844. Five communications. Id.

June 8, i 844. Three communications. "Concernant Texas; les inconvénients d'une organisation séparée des Irlandais, Allemands, etc.; Mr. Morse's télégraphe."

June I3, r844. " Bruit de la prochaine nomination de Mr. Charles J. Ingersoll pour Vienne." 
June 25, I844. “La nomination de Mr. Charles J. Ingersoll n'a pas encore eu lieu."

June 26, I844. Two communications. Current events.

July 24, i 844 . Routine matters.

Aug. I3, I844. Two communications. Routine and current events.

Sept. 24, 29, I 844. Two communications. Id.

Oct. 27, I844. One communication. Current events.

Nov. 3, 9, 27, 1844. Three communications. Id.

Dec. 4, I3, I7, 23, 26, 1844. Six communications. Routine and current events.

Faszikel 5. $\quad 1845$.

Jan. I3, I845. "H. transmet une pétition de Giovanni Albinola."

Jan. 2I, I845. "H. transmet des extraits du Democratic Reviezw concernant $\mathrm{H}-\mathrm{O} \mathrm{H}-\mathrm{g}$ " (Harro Harring; see the biographical articles by Alexander H. Everett in the Democratic Review, Oct., Nov., Dec., 1844, XV. 337-347, 462-475, 561-579).

Jan. 22, 28, 30, I845. Five communications. Routine and current events.

Feb. 4, 25, 28, 1845 . Seven communications. Id.

Mar. 5, IO, I5, 16, 31, I845. Eight communications. Id.

Apr. I4, 22, 28, 29, I 845 . Five communications. Id.

May 9, 28, 1845. Three communications. Id.

June I I , I6, 28, I845. Three communications. Id.

July 5, I 845. " $\mathrm{H}$. übermacht eine Convention zwischen den Vereinigten Staaten und Hessen-Darmstadt zur Aufhebung des Abzugsrechts." (Droit d'aubaine, and taxes on emigration.)

July 6, I5, i 845 . Current events.

July 30 , I 845 . Id. Texas.

Aug. I 5, 1845. Two communications. Texas and Mexico.

Aug. 30, I845. Two communications. Current events.

Sept. I4, 30, I 845. Two communications, including: "Expulsion de Mr. Albinola de la Toscane."

Oct. I, I845. Three communications, including: " $\mathrm{H}$. transmet un rapport du sénateur Berrien sur des abus commis dans la naturalisation d'étrangers. Plusieurs gouverneurs allemands sont accusés par des dépositions jointes à ce rapport, d'encourager l'émigration des criminels aux Etats Unis."

Oct. 24, 29, 1845. Two communications, including: Question of war and peace.

Nov. 3, 25, i 845. Seven communications, including: " H. transmet la réponse faite par Mr. Buchanan à une réclamation de certains éditeurs de journaux allemands aux Etats Unis contre la défense de ces journaux par la Diète Germanique." (Referring to the prohibition by the German Diet of Frankfurt of all newspapers or periodicals in the German language.)

Dec. 4, I2, 24, 28, I845. Four communications, including: Oregon question. Texas admitted.

$$
1846 .
$$

Jan. I5, 1846. Current events.

Jan. 28,1846 . Id. "Quelle sera la position des Grandes Puissances continentales de l'Europe dans une guerre entre les Etats Unis et l'Angleterre?" H.'s solution, strict neutrality. 
Feb. 8, 25, 26, I846. Three communications. Routine matters and current events.

Mar. 29, i 846 . Two communications. Id.

Apr. 6, 25, 1846. Two communications. Id.

May 4, I846. Correspondence with Secretary Buchanan on a point in the President's message.

May I3, I9, 21, 22, 26, I846. Five communications. Routine matters and current events, including War with Mexico.

June 16,24 , I 846. Three communications, including: Oregon treaty.

July I6, 30, I 8 \&6. Two communications, including: Mexico.

Aug. I4, 29, I846. Five communications. Current events.

Aug. 3I, I846. " H. berichtet in Erledigung des hohen Rescriptes vom 3. Juli

d. J., dass die nordamerikanische Regierung bereit ist, mit Sr.

Kais. Majestät ein Uebereinkommen wegen wechselseitiger Aus-

lieferung der Verbrecher abzuschliessen; sowie auch zur Regulirung sonstiger Schwierigkeiten durch additionelle Artikel."

Sept. I4, I846. "Wegen Aufhebung von droit d'aubaine und Emigrantensteuern."

Sept. I 5, 30, I846. Two communications. Routine and current events.

Oct. 8, I4, 28, 1846. Two communications. Current events.

Nov. 24, I846. One communication. Id.

Dec. 3, 12, I 846 . Five communications. Id.

\section{847 .}

Jan. 27, I847. One communication. Current events.

Feb. I, 25, I847. Two communications. Routine and current events.

Mar. I I, 29, 1847. Four communications. Id.

Apr. 2, I I, 28, I847. Four communications. Id.

May I3, I847. One communication. Id.

June I, I847. Observations on consequences of Mexican War. Sympathy for

Mexico. European intervention? H. favors strict neutrality.

June I4, i 847 . Current events.

June 25, I847. "Observations sur 1'Académie militaire de West Point."

May 8, i 847 . Routine matters.

June 29, I847. Two communications. Rumor of peace.

July I 3, 26, 30, 3I, I 847 . Five communications. Routine and current events.

Aug. I4, 31, I 847. Two communications. Id.

Sept. 14, 23, 1847. Three communications. Id.

Sept. 24, I847. "Observation de la question d'Italie. Entretien avec Mr.

Buchanan sur les affaires d'Italie. Influence dangereuse de M.

Hughes, Evêque de New-York, pour exciter la population irlandaise", etc.

Sept. 30, I847. Current events.

Oct. 6, i847. "Occupation de la ville de Mexico."

Oct. I 5, 28, I 847. "Nouvelles du Mexique."

Nov. I3, I 847 . "Nouvelles du Mexique."

Nov. I6, I847. “Projet d'une grande démonstration populaire à New York en faveur de la révolution italienne."

Dec. 13, 30, 1847. Four communications. Current events.

The diplomatic correspondence is not accessible after 1847 . During the Hungarian revolution President Taylor sent an agent to Hungary (in I849), 
for the purpose of obtaining information. ${ }^{1} \quad$ When the agent arrived, Russian intervention had already put down the Hungarian revolution. Hülsemann complained of the action of the United States government in sending a representative to investigate conditions in Hungary. Daniel Webster, secretary of state, replied in the "Hülsemann Letter", that the United States had the right to recognize any de facto revolutionary government, and to seek information in all proper ways in order to guide their action. The letter was meant as a sharp rebuke to the Austrian chargé, and was a very poptular stroke, rousing national pride. Kossuth, who had sought refuge in Turkey, was brought from the Mediterranean to New York in a United States frigate in $185 \mathrm{I}$. The general enthusiasm with which Kossuth was received everywhere was such a blow to Hiilsemann that he left the country with indignation. Cf. Schurz, Henry Clay, II. 392; and Lodge, Danicl W' $334-335$.

\section{WEISUNGEN.}

F. 1. Convolut 1. Metternich an Bartholomäts Freiherrn von Stürmer. I8I7-I8I9.

“Baron de Stürmer, commissaire de S. M. l'Empereur d'Aıtriche à Ste. Hélène nommés au poste de Consul Général aux Etats-Unis d'Amérique." Vienna, Nov. 26, I8I7.

"Schreiben an den Staats Sekretär der Vereinigten Staaten von Amerika. Kreditiv für Freih. v. Stürmer als General Consull." Vienna, Nov. $26, \mathrm{I} 8 \mathrm{I} 7$.

"Derselbe (Stürmer) wird von seiner Anstellung als K. K. Kommissär auf Helena enthoben, und erhält einstweilen $2000 \mathrm{Fl}$. Staatgeld jährlich, welches vom I6. Juli I8I8, als dem Tage seiner Abreise von St. Helena flüssig genacht worden ist." 2 documents, dated Vienna, Jan. 22, and Mlar. I3, I8Ig.

F. 1. Convolut 2. Metternich an Alois Freiherrn von Lederer. I82I-I830.

Orders, rescripts, etc., largely concerning individuals to be traced, or whose property is to be looked after.

Note: "Weisungen in deutscher Sprache; antlicher Briefwechsel in dentscher Sprache; die französische Sprache bleibt einzig für rein politische Berichte vorbehalten."

F. 1. Convolut 3. "Rescripte der Staats-Kanzley an den General Consul B. Lederer." I830-1837.

F. 1. Convolut 4. Metternich an Mareschal. I838-I84I. "Historische Auseinandersetzung der von der kaiserlichen Regierung in Ausführung gebrachten Deportations-Massregel.-Grundsatz, der von der K. K. Gesandtschaft bei der Berührung mit den Deportirten fest im Auge zu halten ist."

"Liste der an Bord der Brigg Ussaro nach Nord Amerika deportirten, October I 836 zu New York gelandeten Verbrechern ": I. Luigi Tinelli ; 2. Giovanni Albinda ; 3. Pietro Borsieri ; 4. Cesare Benzoni; 5. Felice Argenti; 6. Nlessandro Bargnani; 7. Felice Forresti; 8. Gactano Castiglia. Federigo Confaloniere arrived at New York Feb. 22, I837; he soon returned to Provence.

\footnotetext{
"The agent was $A$. Dudley Mann. His report, not published at the time, was printed in 1911 as 61 Cong., 1 and 2 sess., Sin. Doc. No. 279.

"See Moore, Digest of Intcrnational Laae', I. 223-234.
} 
F. 1. Convolut 5. I 838 . Weisungen, Staatskanzlei an General Consul und Minister.

F. 1. Convolut 6. I839. Weisungen, an Baron v. Mareschal.

F. 1. Convolut 7. 1840. Weisungen, an Baron v. Mareschal.

F. 1. Convolut 8. I84I-IS43. Weisungen, an den Gesandten Mareschal, den General Consul Lederer, den Geschäftsträger Hülsemann.

F. 1. Convolut 9. I84I-I847. Weisungen. Metternich an Hülsemann.

\section{NOTEN.}

F. 1. A. I $838-1844$.

Letters to Metternich. Credentials of Flenry Augustus Mühlenberg, U. S. minister. Letters concerning: Regulation of "MauthTarif "; Jerome Bonaparte (Oct. 30, I839) ; passport of Mühlenberg; estate of Mellen Chamberlain; notes on Daniel Jenifer, successor to Mühlenberg; etc.

Convolut 2. I $839-1846$.

Routine matters. Mühlenberg and Jenifer. Notes of chargés d'affaires des Etats Unis: J. Randolph Clay and Wm. H. Stiles. Case of Bargnani ( 1846 ), etc.

\section{VARIA.}

F. 1. Pamphlets, containing printed reports of American state departments, associations, railroads, conventions, etc.

Newspaper clippings: American newspapers on contemporary events.

Letters, mostly translations into German of American originals, I808, I8I6, I818. Copies of letters of Metternich, I821.

V. Micarelli, Mémoire on advantages of commerce with United States. Trieste, May I, I827.

Letter concerning the estate of Mr. Shindle, of Lebanon, Pa.

Handelsvertrag zwischen Oesterreich $u . d$. Ver. Staaten, abgeschlossen d. 27. August, I829. (Printed.)

Manuscripts and printed pamphlets on the "Leopoldinen Stiftung in Wien zur Unterstützung der katholischen Missionen in Nordamerika." I829-1830.

Copy of letter of Buchanan to Stiles. (Mexican blockade.) May I4, I 846 .

Letter of August Belmont to Freih. v. Kribeck, in Vienna, on Oregon question, Mexico, and financial situation. July Io, I846.

Letter of August Belmont to Count Stadion, governor of Illyria and Trieste.

\section{MANUSCRIPTS}

in the K. K. Haus-, Hof- und Staatsarchiv relating to American history. A catalogue, descriptive of the entire manuscript collection, was published in I873-1874: Die Handschriften des kaiserlichen und königlichen Haus-, Hofund Staatsarchivs, beschrieben von Constantin Edlen von Böhm (Vienna, I873; Supplement, Vienna, I874).

33, 2. (B. I6.) Ansprïche Spaniens auf Ameriká.

"Discorso delle Ragioni cha il Rè Catolico sopra il novo Hemispero et altri Regni d' Infideli secondo la scrittura con li Theologi, che di cio hanno scritto."

682. (B. I92.) "Relacion de las Indias de 'Fray Marcos de Nica. I 538." 
683. (9r.) Spanien Nr. 37. "Ueber die von der spanischen Regierung angewandten Mittel die Schätze Indiens nicht fremden Staaten zufliessen zu machen."

Fourteen manuscript pages in Spanish, in a collection of manuscripts entitled: "Promemoria eines Spaniers über die Nothwendigkeit den Krieg in Flandern auf irgend eine Weise zu beenden. I623."

114. (62.) P. XVII Convohute Fol. und $4^{\circ}$. Collectanea historica. Franciscus Guillemann: "Diese durchgehends in lateinischer Sprache abgefasste Sammlung enthält Auszüge aus verschiedenen Schriftstellern und Chroniken, Notizen, etc., insbesondere zur Geschichte Oesterreichs und der deutschen Kaiser aus der Zeit vom 6. bis zum 17. Jahrhundert ; auch enthält sie Miscellanca de novo orbe."

\section{ABTEILUNG: LÄNDER.}

This section consists of a miscellaneous mass of material on foreign countries, material not otherwise classified. It has at present no adequate index, but it is proposed to provide an exhaustive guide to it at some time in the future. Meanwhile the following items from it have been listed for the present book by Dr. Hans Prankl, an assistant of the staff. A considerable number of the documents in this division, even among those described here by title, are understood to have been destroyed. On the other hand, the quantity of documents remaining is very large, since often ten pieces go with a single title such as is here given. Papers which are here listed, and which are still extant, can, it is understood, be found if needed, in spite of the absence of numbers, provided the rubric "Länder" and the year are given.

$$
1768 \text {. }
$$

Holland. Der vielfältige Durchzug deutscher Enigranten nach Amerika durch Holland.

\section{I774.}

Spanien. Tätigkeiten zwischen Spaniern und Portugiesen am Fluss Rio Grande.

Irrungen zwischen Spanien und Portugal an Fluss Rio Grande bei Buenos Ayres, etc.

Prüfung verschiedener neuer Kanonen von Eisen aus Amerika.

Entdeckung der Stadt De los Cesares in Sïdamerika.

Holland. Irrungen mit dem dänischen Gouverneur der Insehn in Amerika wegen Sequestrierung der dem Amsterdamer Handels Haus Borck verhypothezierten Aktien.

Vorstellungen des dortigen englischen Botschafters gegen Zufuhr der Kriegsmunition nach den amerikanischen Kolonien auf holländischen Kauffahrteischiffen.

England. Die Händel mit den annerikanischen Kolonien und die diesfälligen Parlamentsverhandlungen.

Einführung einiger nenen Steuern in (anada und Quebec.

Reisen der Kapitäne Fourneau und Cook num die Welt mit den liregatten Azenture und Resolution. 
I775.

England. Die Zwistigkeiten zwischen England und den englischen Kolonien in Amerika.

Anmerkungen über die anwachsende Bevölkerung in den amerikanischen Kolonien.

Errichtung eines neuen Etablissement Cap Charles auf der Küste von Labrador.

Gerücht der Behandlung eines Subsidientraktates zwischen England, Preussen, etc., und Russland gegen Abschickung von 20,000 Russen nach Amerika.

Betrachtung über die kritische Lage der Irrungen mit den Amerikanern.

Die bourbonischen Höfe in Ansehung der engländischen Irrungen mit den Amerikanern.

Spanien. Die angebliche Entdeckung einer neuen Stadt in Südamerika.

Neue Entdeckungen in Nordamerika.

Ausrüstung einer kleinen Escadre nach Vera Cruz unter Commando des Dr. Ulloa.

Holland. Vorstellung des dortigen englischen Botschafters gegen die Zufuhr von Waffen und Munition auf holländischen Kauffahrteischiffen nach den amerikanischen englischen Kolonien.

Vorstellung der Generalstaaten gegen das Verbot der Aus- und Einfuhr der Esswaren in die englischen Kolonien von Nordamerika.

Anstände mit dem spanischen Hof wegen Debauchierung der Sklaven aus den holländischen Kolonien in Amerika.

Ansuchen des englischen Hofes bei den Generalstaaten um einstwillige Überlassung der in Diensten der Republik stehenden drei schottländischen Regimenter an England gegen die Kolonien in Amerika.

$$
\text { I776. }
$$

England. Nachricht des Erscheinens französischer Emissäre in den englischamerikanischen Kolonien.

Die Irrungen mit den amerikanischen Kolonien.

Kriegerische Vorfälle in Amerika: Verlust von Boston.

Eroberung von Neuyork. Diesfällige Karte.

Vermutung feindlicher Absichten von Seiten Englands auf die spanischen Besitzungen in Amerika.

Vergleichsunterhandlungen mit den englischen Kolonien in Amerika.

Frankreich. Beladung einiger amerikanischer Fahrzeuge mit Kriegsrïstungen im dortigen Hafen.

Dortige Massnahmen betreffend die Streitigkeiten zwischen England und den amerikanischen Kolonien gemeinschaftlich mit Spanien.

Dortige geheime Komerzialunterhandlungen mit den englischen Insurgenten in Amerika.

Holland. Drohungen und Memoires des dortigen englischen Botschafters wegen des holländischen Kriegsmunitionshandels nach Amerika mit Visitierung der Schiffe und Contrebanden.

Anstände mit Dänemark wegen Anhaltung zweier holländischer Schiffe auf dem Walfischfang an der grönländischen Küste.

Lissabon. Die Ausgleichung der Irrungen zwischen Portugal und Spanien bei Rio Janeiro. 
Verordnung gegen das Erscheinen der Schiffe der englisch-amerikanischen Kolonien in den portugiesischen Häfen.

Neuerliche Feindseligkeiten der Portugiesen am Rio Grande gegen Spanien.

Neuyork. Karte von New-York.

Spanien. System des dortigen Hofes betreffs der Irrungen zwischen England und ihren amerikanischen Kolonien.

Projekt einer amerikanischen Leibgarde.

Neue Entdeckungen in Kalifornien.

Errichtung eines neuen Gouvernements in Amerika.

Ausrüstung einer Flotte zu Cadiz nach Neuspanien mit dem General Cevallos.

Freilassung eines amerikanischen Kapers aus dem Hafen zu Bilbao.

Abfahrt der Flotte von Vera-Cruz.

\section{7 .}

Amerika. Ansuchen des spanischen Hofes um Abschriften der in der k. $k$. Bibliothek oder in den k. k. österreich. Archiven etwa vorfindigen Briefschaften betreffend die Entdeckung von Amerika.

England. Verdankung der von dem französischen Grafen Bulkeley angebotenen Dienste gegen die Amerikaner.

Prisen der amerikanischen Kaper über die Engländer.

Gefechte mit den Kolonien in Amerika. Kriegsrüstungen gegen sie.

Die englischen Irrungen mit den amerikanischen Kolonien überhaupt.

Parlamentsverordnung wegen Verführung des Nutzholzes nach den westindischen Inseln.

Fliegrende Schriften über die engländischen Streitigkeiten mit den Amerikanern.

Niederlagen der Rebellen in Amerika. Niederlagen der Engländer.

Die in dortiger Gefangenschaft befindlichen französischen Offiziere von der Partei der amerikanischen Insurgenten.

Bewegungen im Parlament wegen der Niederlagen der Engländer in Amerika. Massuahmen ungemeiner Kriegsrüstungen.

Gestattung der freien Getreidecinfuhr in England wegen des Krieges mit den Amerikanern.

Ansuchen des englischen Hofes bei dem k. k. österreichischen Hofe um die Befreiung der in den diesseitigen Häfen cinlanfenden englischen Kriegsschiffe von der Visitation and um die Abweisung der etwa hier eintreffenden Emissäre der amerikanischen Kolonisten mit ihren Antrïgen.

Verbot des IJofes des Verkanfes der von den Anerikanem den Enerlïndern abgejagten I'risen.

Dortige Massnahmen in Ansehung der englischen Irrungen mit den anerikanischen Kolonien. Heinliche Begünstigung der letzteren.

Vorstellungen der allda befindlichen amerikanischen lusuryenten an den dortigen k. k. üsterreichischen Botschafter.

Frankreich. Ileimliche Entweichung des Marquis de la latyette zu den Insurgenten in Amerika.

Irrungen mit lingland wegen des freigelassenen amerikanischen Kapers Cumningham |Conỵnhaml. Französische Nachgiebigkeit. 
Eintreffen französischer Schiffe mit Kriegsgerätschaften bei den Amerikanern in Boston.

Der Aufenthalt und die Bewegungen des bekannten Dr. Franklin aus Amerika und Insurgenten gegen England in Frankreich.

Holland. Dortiger Schleichhandel mit Waffen nach den englischen Kolonien in Amerika.

Englische Beschwerden über den Schleichhandel der Holländer zu S. Eustache mit den amerikanischen Rebellen.

Englisches Ansuchen um den freien Durchzug der nach Amerika bestimmten in Deutschland aufgebrachten Rekruten.

Verordnung der Generalstaaten wegen Aretierung der englisch-amerikanischen Kaper mit den gemachten Prisen.

Hinwegnahme eines amerikanischen Schiffes mit Reis durch ein englisches Kriegsschiff.

Vorstellungen der Handelsleute nach Westindien wegen der Notwendigkeit der Bedeckung ihrer Schiffe durch Kriegsschiffe.

Antrag der Errichtung einer Konvention mit Spanien wegen Zurückstellung der aus der holländischen Kolonie nach den spanischen Besitzungen in Amerika flüchtenden Sklaven.

Englische Insurgenten in Amerika. Antrag derselben einen Minister an den k. k. österreichischen Hof abzusenden, um das Commercium mit den österreichischen Untertanen zu pflegen.

Vorstellungsschreiben der englischen Insurgenten in Amerika an den k. k. österr. Botschafter zu Paris durch ihre dortigen Kommissäre.

Lissabon. Neuerliche Feindseligkeiten der Portugiesen am Rio Janeiro.

Vorteile der Spanier über die Portugiesen unter Commando des D. Cevallos in Südamerika. Eroberung der Insel St. Catharina.

Beschwerden des dortigen Hofes über den englischen Schiffskapitän wegen eigenmächtiger Anhaltung eines amerikanischen Schiffes im dortigen Hafen.

Die Entbindung der Prinzessin von Brasilien.

Tod der neugeborenen Infantin der Prinzessin von Brasilien.

Prisen der amerikanischen Kaper über die Portugiesen.

Verminderung der Abgaben auf das Gold aus Amerika.

Spanien. Nachrichten von der grossen spanischen Escadre unter Cevallos und Casatilly.

Abweisung eines Agenten der amerikanischen Insurgenten.

Verzeichnis der zu Mexiko ausgeprägten Gold- und Silbermünzen.

Entdeckung eines englischen Schleichhandels in Mexiko.

Anfrage des englischen Hofes beim spanischen Hofe wegen der Behandlung der Insurgenten in Amerika von Seite des Madrider Hofes. Antwort des letzeren Hofes.

Verlust des nach Acapulco bestimmten reich beladenen Schiffes durch einen Wetterstrahl zu Manilla.

$$
\text { I } 778 \text {. }
$$

Amerika. Die englischen Kolonien in Amerika. Französische Unterhandlungen mit denselben.

Die blühende Handlung der bourbonischen Häuser mit den amerikanisch-englischen Kolonien. 
Anbringen der Deputierten der Kolonien zu Paris beim dortigen k. k. österr. Botschafter. Ankunft des William Lee ${ }^{1}$ in Wien. Abfertigung desselben.

Schluss eines Freundschafts- und Kommerzientraktates zwischen Frankreich und den verbündeten Kolonien.

Gerücht von einer Alliance der Kolonien mit Preussen.

Aufnahme eines Darlehens in Amerika zur Bestreitung der Kriegskosten.

Französische und spanische Subsidien an die Kolonien.

Die Kommunizierung der in den $k$. $k$. österr. Erblanden vorfindigen Urkunden betreffend die Entdeckung von Amerika an den spanischen Hof.

Ankunft des Comte d'Estaing mit der französischen Flotte in Amerika.

Die Einleitung des Handels nach den amerikanisch-englischen Kolonien.

England. Erklärung des französischen Hofes an den englischen Hof von dem Abschluss eines Konmerzientraktates mit den amerikanischenglischen Kolonien.

Eroberung der zwei Forts auf dem Delaware durch die Engländer.

Friedenspläne mit den Kolonien. Unterhandlungen.

Mündliche Versicherung des spanischen Hofes, den französischen Traktat mit den amerikanischen Kolonien nicht beitreten zu wollen.

Der Krieg mit den Kolonien überhaupt.

Ernennen des Clinton zum Commando in Amerika an Stelle des Howe.

Rückkunft des Generals Howe aus Amerika.

Einfall der amerikanischen Kolonisten in West Florida.

Rückkunft der ost- und westindischen Flotte.

Spanien. Antrag auf Errichtung eines allgemeinen Schiffsbauwerfts in Amerika.

Verfall des Commercii in Amerika, Verwüstung der Städte Acapulco und Sonsonate durch ein Erdbeben.

Sanmlung der Verordnungen, das amerikanische Commercium betreffend.

K. Verordnung, das freic Commercium in Amerika betreffend.

Erwartung der Silberfotte aus Vera Cruz. Ankunft.

Eroberung einer portugiesischen Festung, genamnt Gatainai, in Paraguay durch die Spanicr.

Plünderung einer spanischen Karawane unweit Buenos Ayres, durch die sogenannten Indios bravos.

Frankreich. Die französischen Unterhandlungen mit den amerikanischen Kolonien.

Absendung des Gerard zu den Amerikanern und Interimsanstellung des Hennin z.11n I. Statats-Kommissär an die Stelle des ersteren.

Hollanıl. Auslanfen des Convoi nach Holländisch-Westindien.

Die von' den Spaniern angesprochene Insel Urica in Amerika betreffend.

Anhaltung eines amerikanischen Lagerschiffes zu S. Eustache.

Frbeutung eines holländischen nach Virginien bestimnten Schiffes durch cinen englischen Kaper.

Ansuchen der holländischen Kolonie Deneray un einige Kriegsschiffe zur Bedeckung gegen die Engländer.

${ }^{1} C f$. Schlitter, Bezichungen Oesterrcichs zu Amorika, pp. 5-6. 
Antrag der englisch-amerikanischen Kolonien auf Errichtung eines Handlungs- und Freundschaftstraktates mit Holland.

I779.

Amerika. Der französische Traktat mit den dortigen engländischen Kolonien.

Ernennung des Franklin zum bevollmächtigten Minister des dortigen Kongresses in Paris. Dortiger Aufenthalt des Gerard von Seiten Frankreichs.

England. Der Krieg mit den englisch-amerikanischen Kolonien überhaupt. Spuren von einer russisch und preussischen Mediation zwischen England und Frankreich und den amerikanischen Kolonien.

Untersuchung des Betragens der englischen Generale in Amerika, desgleichen des Lord Sandwich.

Manifest, die Schiffahrt neutraler Mächte nach den Kolonien in Amerika betreffend.

Korrespondenz des General Howe aus Amerika mit dem amerikanischen Staats-Sekretär über den dortigen Krieg.

Gerücht von neuerlichen Friedensverhandlungen der Kolonien mit England.

Holland. Spanische Beschwerden über die Feindseligkeiten der Einwohner von Curaçao.

Frankreich. Audienzen verschiedener neuer Minister, darunter des Franklin von den vereinigten englischen Staaten in Amerika.

Antrag des k. k. österr. Konsuls zu Nantes auf Ausrüstung eines Schiffes mit k. k. Flaggen und Pässen zur Ueberbringung der Lebensmittel nach der französischen Insel St. Domingo.

Franklin. Ernennung des Franklin zum bevollmächtigten Minister des amerikanischen Kongresses in Paris.

Spanien. Neue Einrichtung des amerikanischen Commercii.

$$
\text { I } 780 \text {. }
$$

Amerika. Die englischen Friedensunterhandlungen mit den dortigen englischen Kolonien.

Druckschriften, die dortigen unierten englischen Kolonien betreffend.

Ankunft und Aufträge einiger amerikanischer Abgeordneten in Spanien.

Den erbländischen Handel nach den französischen und englischen Pflanzstädten in Amerika betreffend.

Der Handel mit den französischen Pflanzstädten.

England. Der Handel der k. k. österreichischen Untertanen nach den englischen Kolonien in Amerika.

Entdeckung einer dortigen geheimen Korrespondenz nach den amerikanischen Kolonien.

Zurückkunft der auf Entdeckungen im nördlichen Teile des Stillen Meeres zwischen Asien und Amerika ausgeschickten zwei Schiffe.

Aufgabe der Hoffnung, die Amerikaner unterwürfig zu machen.

Holland. Die Kommerzialunterhandlungen des Ratspensionaire von Am. sterdam mit den englisch-amerikanischen Kolonien.

Die Viollierung des holländischen Territoriums zu St. Martin in Amerika durch die gewaltsame Kaperung der englisch-amerikanischen Schiffe von Seite der Engländer. 
Frankreich. Der Antrag auf Verproviantierung der französischen Pflanzstädte im mexikanischen Meerbusen durch niederländische Schiffe.

Gedanken über die Einleitung des Commerciums aus den Niederlanden und den Häfen zu Triest und Fiume nach den französischen Kolonien.

Mexiko. Antrag des französischen Hofes auf Verproviantierung seiner Kolonien im mexikanischen Meerbusen durch k. k. österr. Untertanen.

$$
\text { I78I. }
$$

Amerika. Erscheinen und Akzeptierung amerikanischer Wechsel in Spanien und Frankreich.

Absendung eines amerikanischen Emissärs nach Berlin und Kopenhagen zum Einkauf von Tuch und Gewehr.

Frankreich. Präsentierung des jungen Laurens als Deputierten der englisch-amerikanischen Stände beim französischen Hofe.

Gelddarlehen für die amerikanisch-englischen Kolonien.

Holland. Druckschriften der Unterhandlungen der Stadt Amsterdam mit den englischen Kolonien in Amerika; diesfälliger Untersuchungsprozess.

Bewegungen des Adams zur Erwirkung seiner Anerkennung als bevollmäclitigten Minister des englisch-amerikanischen Kongresses allda.

Dänische und schwedische Geldnegotiationen allda, ebenso des englischamerikanischen Kongresses.

Geldnegotiationen für die englisch-amerikanischen Kolonien allda.

Die Angelegenheiten dortiger westindischer Kompanien.

Krieg. Eroberung der holländischen Inseln St. Eustache und St. Martin durch die Engländer, sowie mehrerer anderer solcher Besitzungen, sowie einiger Faktoreien.

Wiedereroberung der von den Engländern bei St. Eustache weggenommenen holländischen Kauffahrteiflotte durch die Franzosen.

Fehlgeschlagene englische Unternehmung auf St. Vincent, Neu-Orleans, La Mobile.

Spanische Wiedereroberung der Kolonie von St. Juan de Nicaraguas.

Fehlgeschlagene französische Unternehmung in der Bay von Chesapeake.

Krieg zwischen England und seinen Kolonien in Amerika, Vorteile der Engländer über die Kolonisten.

Abfall cines Teiles der Armee der Kolonisten an die Engländer.

Vorteile der Kolonisten über die Engländer.

Gefangennane des Lord Cormwallis nit seiner Armee in Chesapeake.

Spanien. Der Aufruhr in Amerika.

Der allen Spaniern freigelassene Handel nach dem spanischen Westinclien und die für die erbländischen Produkte hiebei zu erzielenclen Vorteile.

Verfall des dortigen llandels.

Werbung. Die englischen Werbungen in den Reichslanden nach Anerikal.

llemliche Werbung der k. k. österr. Untertanen mach Amerika durch den L.egationssekretär des hiesigen englischen Ministers Gerstenberg. 
I 782 .

England. Debauchierung von k. k. österr. Untertanen nach Amerika durch den englischen Legationssekretär in Wien.

Resignierung des amerikanischen Staatssekretärs Lord Germaine, dessen Nachfolger und übrige Vèränderungen im Ministerium; gänzliche Abänderung desselben.

Uebertragung des Generalkommandos in Amerika an General Carlton. Bewegungen im Parlament zur Beendigung des Krieges in Amerika mit den Kolonien.

Frieden. Abschluss der Friedenspräliminarien zwischen England und den amerikanischen Kolonien.

Die englischen Friedensunterhandlungen mit den amerikanischen Kolonien.

Holland. Die Verrichtungen der Deputierten der englisch-amerikanischen Kolonien allda. Anerkennung ihres bevollmächtigten Ministers Mr. Adams.

Projekt des holländischen Kommerzientraktates mit den nordamerikanischen Staaten, den englischen Kolonien.

Dortige Behandlung eines Darlehens für die englisch-amerikanischen Kolonien.

Krieg. Eroberung der Insel St. Eustache durch die Franzosen.

Nachrichten von einem förmlichen Angriff von Jamaica durch die Spanier und die Franzosen.

Gefecht des englischen Admirals Hood über den französischen General De Grasse bei der Insel St. Christophe. Eroberung derselben durch die Franzosen.

Verheerung der Hudsonsbay-Compagnie durch Paul Jones.

Eroberung der Insel Roatan in der Bay von Honduras durch die Spanier.

Eroberung der Insel Providence durch die Spanier.

Eroberung von Essequibo und Demeray durch die Franzosen.

Ankunft der Admirals Pigot in New-York mit 23 Linienschiffen. Erbeutung verschiedener spanischer und amerikanischer Kaper.

Eroberung einiger englischer Besitzungen in der Hudsonsbay durch die Franzosen.

Spanien. Uebermachung der spanischen Schätze aus Amerika auf portugiesischen Schiffen.

Werbung. Heimliche Anwerbung von k. k. österr. Untertanen nach Amerika durch den Legationssekretär des hiesigen englischen Ministers.

Die Werbungen des Fürsten von Anhalt-Zerbst für England nach Amerika.

$$
1783 .
$$

Amerika. Die dortigen unabhängigen Staaten und vormaligen englischen Kolonien. Anfrage wegen Anerkennung ihrer auswärtigen Minister von Seite der k. k. Minister.

Vorschlag eines Anonymi auf Einleitung eines erbländischen Handels mit den amerikanischen Kolonien.

Die spanischen Kommerzial- und Grenzscheidungstraktate mit den amerikanischen Staaten.

Der Antrag Englands zur Abschliessung einer geheimen Offensif- und Defensif-Alliance mit dasigen Staaten und Einladung des russischen Hofes zum Beitritte. 
Die Errichtung eines diesseitigen Handels- und Freundschaftstraktates mit den amerikanischen Staaten und Dahinsendung eines diesseitigen Bevollmächtigten.

Vorhabende Handelsexpeditionen aus Triest nach den dortigen Staaten.

Die engländischen Kommerzialunterhandlungen mit den dortigen Staaten.

Der Handel nach Amerika überhaupt.

Die Geldnegotiationen für die dortigen vereinigten Staaten in Holland.

Antrag auf Behandlung eines Kommerzien-Traktates mit Portugal.

Das Misstrauen der dortigen Staaten gegen Frankreich und England.

Versuch des Dean [Francis Dana] in Petersburg um seine Anerkenmung als Gesandter der neten Staaten von Amerika.

Ernennung des Grafen Gansa zum dortigen spanischen Minister.

England. Ankunft eines amerikanischen Fahrzenges.

Die englischen Handelstraktate mit den amerikanischen Staaten.

Eroberung der Bahamischen Inseln durch die Engländer.

Emigranten. Antrag auf Ansiedhung der aus Amerika zurückgekehrten deutschen Reichsuntertanen in den österr. Erblanden.

Frankreich. Errichtung eines monatlichen Paketbootes von Portlouis nach Amerika.

Holland. Ernennung des von Berkhel zum holländischen Gesandten bei den amerikanischen Staaten.

Auswechselung der Ratifikationen des holländischen Freundschafts- und Kommerzientraktates mit den vereinigten amerikanischen Staaten.

Spanien. Amnestie für die Rebellen in Mexiko und Behebung ihrer Beschwerden.

Empörungen im spanischen Amerika.

Ernennung des Carnichael zumı amerikanischen Geschäftsträger alldort.

$$
\text { I } 78+
$$

Amerika. Die Eröff̈nung des Commerciums mit der Reichsstadt Hamburg.

Die vereinigten amerikan. Staaten. Englische Verordnungen den Handel mit denselben betreffend.

Der Minister der dortigen Staten in dem Haag verlangt die Gegenvisite vom dortigen $k$. $k$. österr. Minister.

Die Anlaltung eines Expressen des amerikanischen Ministers Adams in Brüssel.

Antrag der amerikanischen Staaten anf Abschluss eines Freundschaftsund Kommerzientraktates mit dem k. k. österr. Hofe.

Der Zustand der Handlung der Stadt Hamburg nit den dortigen Staaten.

Der toskanische IIandel nach Amerika.

Kaperung eines amerikanischen Schiffes durch einen Marokkaner Korsar.

England. Enisrierung dortiger Fabrikanten, und aus Irland nach Amerika und linalukeich; diesfällige Verbote.

Häufige Emigrationen aus England nach Amerika.

Holland. Der amerikanische Minister allda verlangt Gegenvisite des k. k. österreichischen.

Spanien. Aufstand in Mexiko.

Irrungen mit lingland wegen der Girenzen von Florida. 


\section{5 .}

Amerika. Die Errichtung eines diesseitigen Handelsvertrages mit den dortigen vereinigten Staaten.

Ernennumg des John Temple zum dortigen englischen Generalkonsul und Verlängerung der Interimalhandlungsverordnung zwischen England und den vereinigten Staaten.

Die Beschwerden dortiger vereinigter Staaten über die Engländer wegen verzögerter Räumung der in dem Frieden abgetretenen Forts.

Plan einer Triester Handelskompagnie nach den dortigen vereinigten Staaten, bezw. die in Triest sich bildende österreichisch-amerikanische Handelsgesellschaft.

England. Die Kommerzialınterhandlungen mit den amerikanischen Staaten.

Parlamentsbewilligungen zur Entschädigung der amerikanischen Loyalisten.

Audienz des amerikanischen Ministers Adams.

Vorhabende Errichtung einer Handelskompagnie nach den Kuritischen [Kurilischen] Inseln.

Frankreich. Ankunft des nenen Ministers der amerikanischen Staaten Jefferson.

Spanien. Irrungen des dortigen Hofes mit England wegen der Grenzberichtigung von Florida und Fällung des Färbholzes.

Probe mit einen auf neue Art gebauten Linienschiff $S$. Ildefons.

Verzeichnis der I 784 aus Amerika nach Spanien und vice versa überbrachten Schätze und Waren.

Neuer Aufstand in Mexiko.

Königliche Gnade für den Vizekönig in Peru.

Abschaffung der Grabstätten auf St. Ildefons.

$$
\text { I } 786 \text {. }
$$

Amerika. Spanische Grenzirrungen mit den dortigen vereinigten Staaten und den Wilden.

Antrag auf Abschluss eines diesseitigen Handelsvertrages mit den vereinigten amerikanischen Staaten.

Handelspläne aus Nordamerika.

Gerücht von den englischen Unterhandlungen mit den unzufriedenen Provinzen wegen ihrer Wiedervereinigung mit England.

Irrungen des Kongresses mit den Staaten; diesfällige französische Intriguen.

Verfall des Handels aus Hamburg nach Amerika.

Pretıssischer Handelsvertrag mit den amerikanischen Staaten.

England. Die Forderungen der k. k. österr. Untertanen wegen ihrer in St. Eustache durch den Admiral Rodney eingezogenen Schiffe.

Konvention mit Spanien wegen Uebersetzung der im spanischen Amerika angesessenen Engländer.

Konvention mit Spanien wegen Beilegung der Irrungen betreffend Musquitos in Amerika.

Holland. Beschwerden der dortigen westindischen Kompagnie über die Engländer und Dänen auf der Küste von Guinea.

Beschwerden bei Frankreich wegen Debauchierung der Neger von Amerika und Essequibo. 
Portugal. Begünstigung der Einfuhr der portngiesischen Weine nach den amerikanischen Staaten.

Ankunft der Silberflotte aus Brasilien.

Spanien. Tätigkeiten zwischen den Spaniern und Engländern in Amerika.

Verzeichnis der vorjährigen Warenladungen aus Spanien nacil Amerika et vice versa.

Beilegung der Irrungen mit England wegen der Küste von MIusquitos.

Gerücht von der Absendung eines spanischen Emissärs nach Ungarn zur Debauchierung dortiger Berglente nach Amerika.

$$
1787 \text {. }
$$

Amerika. Anfrage wegen Einsendung (Geschenk an den Kaiser) eines Gedichtes des Mr. Barlow auf die Freiheit der nordamerikanischen Staaten.

England. Debatten in Parlament gegen den mit Spanien geschlossenen Vertrag wegen Abtretung der Küste von Musquitos an Spanien.

Portugal. Vermutung eines französischen Anwurfs wegen Vermählung des Prinzen von Brasilien nach vorgängiger Scheidung mit der französischen Prinzessin Elisabeth.

Spanien. Spanische Irrungen mit England wegen Räımung der Tï̈ste von Musquitos.

Tod des Vizekönigs von Mexiko, Dn. Bern. de Galver; dessen Nachfolger, lilore.

Werbung. Heimliche Werbungen im Reiche nach Amerika.

$$
1 ; 88 .
$$

Louisiana. Der Einfall der Amerikaner in Louisiana.

England. Absendung von Truppen und Munition nach Ost- und Westindien.

Abberufung des dortigen Ministers der amerikanischen Staaten. Adams.

Seereise des Prinzen Wilhelm nach Amerika.

Holland. Abberufung des holländischen Ministers van Berckel von den nordamerikanischen Staaten.

Ernennung des van Berckel zum holländischen Residenten bei den amerikanischen Staaten.

Kriminalprozess gregen den van Berckel.

Absendung einiger Kommissäre nach Westindien zur Untersuchums. dortiger Kolonien; Verordnungen, diesen Handel betreffend.

Portugal. Kommerzialunterlandlungen des dortigen Hofes nit den amerikanischen Staaten.

Blattern des Prinzen von Brasilien. Tod desselben. Eloge. Hoftratter. Gährungen im Ninisterimm nach dem Tode des Prinzen von Brasilien.

Dortige allgemeine Bestürzung über den Tod des Prinzen von Brasilien. Beisorge wegen lirlöschen des Mannesstammes und der spanischen Sukzession in Portugal.

Chatrakter des nummehrigen P'rinzen von Brasilien und seiner Gemahlin. Verwendung des P'rinzen.

Wittum für die verwitwete Prinzessin von Brasilien.

Spanien. Entdeckung eines neuen Silberbergwerkes in Peru.

Verbot der Ausfuhr fremder Tücher aus Cadiz nach Amerika.

Schweiz. Auswanderungen aus der Schweiz nach Amerika. 
I 789.

Amerika. Behandlung eines Anlehens in Holland für die nordamerikanischen Staaten.

Ernennung des Carol zum dortigen katholischen Bischof.

England. Fortgang der Ansiedlungen der Delinquenten in Amerika.

Joseph II. Antrag der auf Vermählung Kaiser Josefs II. mit der verwitweten Prinzessin von Brasilien.

Portugal. Beträchtliche Einkünfte und Schmuck der verwitweten Prinzessin von Brasilien.

Antrag auf Vermählung der verwitweten Prinzessin von Brasilien mit dem spanischen Infanten Dn. Antonio.

Ausrüstung einer Escadre gegen die Algierer und nach Brasilien.

Aufstand in Pernambucos in Brasilien. Beilegung der Sache.

Krankheit des Prinzen von Brasilien. Genesung.

Fehlgeschlagener Versuch des Beichtvaters des Prinzen von Brasilien auf die Wiedereinräumung des Klosters zu Mafra an die Franziskaner.

Sonora. Eine angebliche goldreiche Provinz in Amerika.

I790.

Amerika. Die neuen russischen Kolonien in Nordamerika; diesfällige Unterhandlungen mit Spanien.

Der englische Pelzhandel in Nordamerika; diesfällige spanische Gegenvorkehrungen. Wegnahme einiger englischen Schiffe; englische Beschwerden hierüber.

Spanische Verordnung, die Freiheit der Negerslilaven in Amerika betreffend.

Aufstand in französisch-amerikanischen Kolonien.

Frankreich. Gährungen in den französisch-amerikanischen Inseln.

Denunziation der Inwohner von St. Domingue gegen den Seeminister. Abdankung desselben.

Ernennung des Chr. Ternan zum französischen Minister bei den amerikanischen Staaten und des Grafen Du Moustier beim Berliner Hofe.

Spanien. Dortige Furcht vor Anzettelung eines Aufstandes in den spanischamerikanischen Besitzungen. Verteidigungsanstalten.

Gerücht von einer englischen Landung auf Pensacola in Florida.

Dortiger Aufenthalt und Unterhandlungen eines nordamerikanischen Emissärs.

$$
1791 .
$$

Amerika. Die Reichsemigranten nach Amerika.

Angeblicher Antrag der dortigen vereinigten Staaten, das Pouvoir executiv einem englischen Prinzen zu überlassen.

England. Die Vorteile des vorigen Jahres zwischen England und Spanien geschlossenen Vergleichs für dortigen Hof in Bezug auf die Erweiterung des englischen Handels in Amerika.

Ernennung des Hammond zum englischen Minister bei den amerikanischen Staaten. 
Frankreich. Bedenkliche Gährungen in St. Domingue und den übrigen französischen Inseln.

Untersuchung der französischen Nationalversammlung wegen der französischen Kolonien und des Negeraufstandes in St. Domingue.

Portugal. Portugiesische Beschwerden über die holländisch-westindische Kompagnie.

Akreditierung des Humphrey als dortigen Residenten der nordamerikanischen Staaten. Portugiesische Kommerzialunterhandlungen mit denselben.

Spanien. Die bedenklichen Folgen des vorjährigen Vergleichs zwischen Spanien und England in Bezug auf die spanisch-amerikanischen Besitzungen.

Dortige Massnahmen gegen die Verbreitung des Aufruhrs in St. Domingue.

Ankunft der Silberflotte aus Amerika.

Dortige Besorgnis wegen feindlicher englischer Absichten auf Louisiana und die Antillen.

Spuren neuer Feindseligkeiten zwischen Spanien und England in Amerika.

Spanische Irrungen mit den amerikanischen Staaten wegen der freien Schiffahrt auf dem Ohio und Mississippi im mexikanischen Meerbusen. Englische Intriguen.

Gibraltar. Antrag auf Ueberlassung dieser Festung an Spanien gegen Abtretung der spanisch-amerikanischen Besitzungen an England.

I792.

Amerika. Krieg der Indianer des Ohioflusses mit den vereinigten nordamerikanischen Staten.

Uebermachung verschiedener Pflanzen aus Amerikis für den botanischen Garten in Wien.

England. Gährungen in Jamaica.

Debatte wegen Aufhebung des Negerhandels.

St. Domingue. Französische Insel in Amerika. Aufruhr und Ravagen dortiger Sklaven.

Holland. Absendung einer kleinen holländischen Escadre nach Westindien gegen die Negersklaven.

Bewilligung einer Million zur Tilgung der Schulden der aufgehobenen westindischen Kompagnie.

Ankunft des Ministers der vereinigten amerikanischen Staaten, Short.

Portugal. Ansuchen des Prinzen von Brasilien unn die päpstliche Dispens zur Beibehaltumg des Malteser Grosspriorates.

Spanien. Spanien lässt eine Seckarte vom mitternächttichen Amerika aufnehmen.

Vergleich mit England wegen der dammifizierten englischen Schiffe in dem Nootkasund.

Berlenkliche Forderungen der nordamerikanischen Staten an Spanien wegen der freien Schiffahrt am Mississippi.

Anmerkinngen iber den spanischen Reichttun ans Anerika und den llandel.

Dortige Hoffnumgen auf den Fall der Thronbesteigung des Prinzen von Brasilien in Portugal. 
I793.

Amerika. Antrag dortiger französischer Inseln, sich unter englischen Schutz zu begeben.

Die Gesinnungen der vereinigten nordamerikanischen Staaten gegen Frankreich.

Häufige Getreide- und Munitionsausfuhr aus den nordamerikanischen Staaten nach Frankreich und feindliche Absichten derselben auf dortige holländische Kolonien.

England. Ausgleichung der Zwistigkeiten mit Spanien wegen der in dem Nootkasund angehaltenen englischen Schiffe.

Englische Eroberung der Insel Tabago.

Die fehlgeschlagene englische Landung auf Martinique.

Holland. Holländische Eroberung der Insel St. Martin.

Portugal. Schwangerschaft der Prinzessin von Brasilien. Entbindung von einer Prinzessin.

Wegnahme einer französischen Fregatte in Brasilien.

Nachrichten von einer Descente der Franzosen aus Cayenne in Brasilien.

Portugiesische Grenzirrungen mit Spanien in Amerika.

Neuerliche Schwangerschaft der Prinzessin von Brasilien.

Abreise des Beichtvaters der Prinzessin von Brasilien nach Spanien. Eloge desselben.

Promotionen und Gnadenverleihungen anlässlich der Entbindung der Prinzessin von Brasilien.

Spanien. Ankunft des nordamerikanischen Negotiateurs Short zur Ausgleichung der spanischen Irrungen mit dortigen Staaten wegen der Schiffahrt auf dem Ohio und Mississippi.

Unterhandlungen mit dem dortigen englischen Minister L. [Lord] St. Helens über die gemeinschaftlichen Kriegsoperationen gegen Frankreich; England dringt auf einen Landkrieg mit spanischen und portugiesischen Truppen gegen Garantierung der spanischen Besitzungen in Amerika.

Ankunft einer französischen Escadre mit französischen Emigrahten aus Martinique in der spanischen Insel Trinidad.

Spanische Besorgnis wegen der zu befürchtenden Alleinherrschaft der Engländer zur See und der reichen spanisch-amerikanischen Besitzungen.

Ausrüstung einer Flotte nach Westindien.

Ankunft einer Silberflotte aus Amerika.

Errichtung eines Volontaires-Corps von Contrebandiers und Vermehrung der Gardes du Corps mit 200 Amerikanern.

Ernennung zweier Vicekönige nach Amerika.

Errichtung eines Paketbootes zwischen Corugna und Falmouth.

Quarantaine auf die nordamerikanischen Schiffe wegen des epidemischen Gelbfiebers in Amerika.

r794.

Amerika. Angebliche kriegerische Absichten Englands gegen die nordamerikanischen vereinigten Staaten.

England. Wiedereroberung der von den Franzosen gekaperten Kauffahrteischiffe aus Terre Neuve. 
Holland. Dortige Besorgnis wegen eines Krieges zwischen England und den amerikanischen vereinigten Staaten.

Portugiesische Reklamierung eines nach St. Eustache entwichenen portugiesischen Korsaren.

Portugal. Ausrïstung einer Escadre gegen die Algierer Korsaren und nach Brasilien.

Abreise des dortigen Ministers der nordamerikanischen Staaten, Obristen Humphreys.

Spanien. Ankunft des nordamerikanischen Ministers Short.

Ankunft der Schätze aus Amerika.

I795.

Portugal. Schwangerschaft der Prinzessin von Brasilien. Taufpaten der Papst und die Königin von Spanien; Entbindung von einem Prinzen.

Erwartung der Schätze aus Brasilien. Ausrïstung einer Escadre zur Ueberbringung derselben; Auslaufen.

Spanien. Verzeichnis der im vorigen Jahr aus Amerika eingekommenen Schätze: Ankunft neuer Schätze.

Spuren der Behandlung eines Handelsvertrages zwischen Spanien und den nordamerikanischen Staaten. Schluss.

Ankunft der Schätze aus Amerika.

Einschiffung des im spanischen Sold stehenden Korps der französischen Emigrés in Cadiz nach St. Domingo.

Abschluss des spanischen Kommerzientraktates mit den nordamerikanischen Staaten.

Englische Vorstellung gegen die spanische Abtretung von St. Domingo an Frankreich.

$$
1796 .
$$

Spanien. Unterhandlungen des dortigen englischen Botschafters wegen der Insel St. Domingo.

Abschlägige französische Antwort wegen Wiederabtretung von Domingo gegen ein Aequivalent. Diesfällige Unterhandlungen.

Verzeichnis der im vorigen Jahr aus Amerika überbrachten Geldschätze. Ankunft neuer Schätze.

Negeraufstand im spanischen Domingo auf französisches Anstiften. Schwäche der spanischen Truppen allda und im ganzen spanischen Amerika.

Absendung des französischen Kommissärs Rome auf einer spanischen Fregatte nach St. Domingo zur Uebernahme dieser Inscl. Nachrichten aus St. Domingo.

Der zwischen dem dortigen Hof und den nordamerikanischen Staten geschlossene Traktat.

Französische Forderung, dass der dortige Hof die Inscl St. Domingo gegen einen feindlichen englischen Angriff verteidigen solle.

Gerüchte von einem Aufruhr in Mexiko.

1797.

Portugal. Auslaufen der portugiesischen Flotte von Brasilien.

Ankunft des nordamerikanischen Residenten Smith und des preussischen Abgesandten Freilierrn von Schladen. 
Spanien. Gährungen in Mexiko; Ernennung des dortigen Erzbischofs zum Vizekönig an Stelle des Schwagers des Favoriten.

Ernennung des Humphreys zum dortigen bevollmächtigten Minister der nordamerikanischen vereinigten Staaten.

Besorgnis wegen eines Bruches der nordamerikanischen Staaten mit Frankreich und Spanien.

$$
\text { I } 798 .
$$

Spanien. Ankunft beladener Schiffe aus Mexiko.

Dortige grosse Besorgnis wegen der spanischen Besitzungen in Amerika bei Ausbruch des Krieges zwischen Frankreich und den nordamerikanischen Staaten.

Spanische eifrige Verwendung in Konstantinopel bei den nordamerikanischen Staaten und Barbaresquen zur Hintanhaltung eines Krieges gegen die Franzosen.

Französisches Anerbieten der Eroberung Portugals und der Einverleibung dieser Krone mit der spanischen gegen Abtretung von Brasilien und allen über den Ebro gegen die Pyrennäen gelegenen Provinzen.

Portugal. Auslauf der portugiesischen Flotte nach Brasilien.

Ankunft eines Teiles der Flotte aus Brasilien. Absendung eines englischen Konvois für den Rest.

Spuren heimlicher Anstalten zur Flucht des Hofes nach Brasilien auf den Fall der Annäherung französischer Truppen.

Ankunft der reichen Flotte aus Brasilien.

Entbindung der Prinzessin von Brasilien von einem Prinzen.

I799.

Portugal. Die Entbindung der Prinzessin von Brasilien von einem Infanten.

Entdeckung einer Revolutionsverschwörung in Brasilien.

Auslauf der grossen portugiesischen Konvoi nach Brasilien unter Bedeckung einiger Kriegsschiffe.

Amerika. Absendung zweier Gesandten der nordamerikanischen Staaten nach Paris zur Ausgleichung der Irrungen mit Frankreich.

Spanien. Nachrichten von bedenklichen Volksempörungen in den spanischamerikanischen Besitzungen.

Misshelligkeiten zwischen dem dortigen Hofe und den nordamerikanischen Staaten, wegen gekaperter amerikanischer Schiffe.

I 800 .

Portugal. Absegelung des grossen Konvoi nach Brasilien.

Entbindung der Prinzessin von Brasilien von einer Prinzessin.

Ankunft der portugiesischen Silberflotte aus Rio Janeiro und 7 spanischer reich beladener Gallionen; englische Beschwerde über die Freilassung der letzeren und Andringen auf den Beschlag; abschlägige Antwort des dortigen Hofés.

Spanien. Ernennung des Orosco zum spanischen Minister bei den nordamerikanischen Staaten und des D. Fruxo in gleicher Eigenschaft für die zisalpinische Republik.

Entbindung der Prinzessin von Brasilien. 
I80I.

Portugal. Zerstreuung der brasilianischen Flotte durch einen Sturm.

Spuren heimlicher Unterhandlungen des dortigen Hofes mit dem englischen für den Fall eines feindlichen französischen Angriffes und des Antrages des Hofes nach Brasilien zu flüchten.

Entbindung der Prinzessin von Brasilien von einer Infantin.

Jesuiten. Abschaffung der Jesuiten aus Spanien und Amerika und Relegierung nach Italien.

I802.

Amerika. Ansuchen um neue k. k. Seeurkunden für das Schiff Amerika.

Ernennung des Lamson zum Konsul der nordamerikanischen Freistaaten in Triest.

Ankunft nordamerikanischer Handelsschiffe in Triest.

Antrag auf Einleitung des diesseitigen Handels mit nordamerikanischen Freistaaten.

Kriegserklärung der nordamerikanischen Staaten gegen Tripolis.

Ernennung des Wilhelm Riggin zum Konsul dortiger nordamerikanischer Freistaaten in Triest und den benachbarten Seehäfen.

Frankreich. Auslaufen der französisch-spanischen Flotte aus Brest, vermutlich nach Brasilien.

Portugal. Ankunft portugiesischer Schiffe aus Brasilien mit Gold.

Rückkunft des Vizegonverneurs aus Brasilien.

Besorgnis wegen eines Aufstandes in den portugiesischen Kolonien.

Spanien. Abschiedsaudienzen des dortigen Gesandten der nordamerikanischen Staaten Humphreys und Antrittsaudienzen seines Nachfolgers Pinckney.

Ankunft reich beladener Schiffe aus Amerika.

Ankunft der Schätze aus Amerika.

Angebliche Grenzirrungen zwischen Frankreich und Spanien hinsichtlich Louisiana.

Louisiana. Die beabsichtigte französische Expedition nach Louisiana.

Tripolis. Der König von Schweden und die nordamerikanischen Staaten erklären die Blockade des dortigen Hafens.

$$
1803 \text {. }
$$

Amerika. Dic Gestattung der Visitierung aller nordamerikanischen Konsulate in Italien durch den Gesandten dieser Staaten bei der italienischen Republik.

Holland. Englische Eroberung der batavischen Kolonien.

Louisiana. Die beabsichtigte französische Militïrexpedition nach Louisiana ; Einstellung.

Die Franzosen verkanfen Lonisiana den nordamerikanischen Staaten.

Paolina. Reklamierung der von diesem österreichischen Schiffe durch einen Tunesischen Korsaren geraubten Effekten. Reklamierung des von einem amerikanischen Armateur unweit Malta weggenommenen österr. Schiffes, Kapitän Radich.

Portugal. Antwort des Kaisers und der Kaiserin an den dortigen Residenten wegen der Entbindung seiner Gemalılin, der Prinzessin von Brasilien, von einem Prinzen.

Gerücht von der Abtretung eines Teiles von Brasilien an Frankreich; England reklaniert das Kontingent von 6 Kriegsschifien. 
Riggin, William. Neuernannter amerikanischer Konsul in Triest, dessen Bitte um das Exequatur regium.

Spanien. Ankunft der Schätze aus Mexiko.

Irrungen des dortigen Hofes mit den amerikanischen Staaten wegen der Schiffahrt auf dem Mississippi.

Eine aus St. Domingue in Santander eingelaufene französische Kriegskorvette widersetzt sich der Quarantaine mit Gewalt.

$$
\text { I804. }
$$

Konsuln. Antrag, in Danzig und bei den nordamerikanischen Staaten einen k. k. österreichischen Konsul zu bestellen.

Frankreich. Eroberung von St. Domingo durch die Neger.

Batavische Republik. Wegnahme von Surinam durch die Engländer.

Louisiana. Eine von Frankreich an Nordamerika abgetretene Provinz. Verhandlungen zwischen Nordamerika und dem dagegen protestierenden Spanien.

Spanien. Irrungen zwischen dem dortigen Hofe und den nordamerikanischen Staaten. Abreise des amerikänischen Gesandten Pinkney.

Anfang der englischen Feindseligkeiten gegen Spanien wegen Wegnahme dreier reich beladener spanischer Schiffe aus Vera Cruz. Embargo auf die spanischen Schiffe in England.

Ankunft der Silberflotte aus Vera Cruz.

1805 .

Kolonisten. Aufstellung einer Kolonistenwerbung in Frankfurt für die nordamerikanischen Staaten. Abschaffung.

Spanien. Zerschlagen der Unterhandlungen mit den nordamerikanischen Staaten wegen der Grenzberichtigung von Louisiana.

Portugal. Der von der Prinzessin von Brasilien der Kaiserin Maria Theresia überschickte St. Elisabethorden.

Uebermachung eines Teiles der Schätze aus den spanischen Kolonien auf portugiesischen Schiffen.

\section{I806.}

Spanien. Die englische Eroberung von Buenos Ayres. Wiedereroberung.

Entdeckung einer Verschwörung in Buenos Ayres.

Spannung zwischen Spanien und den nordamerikanischen Staaten.

1807.

Spanien. Spanische Wiedereroberung von Buenos Ayres.

I 808 .

Amerika. Angebliches Dekret der französischen Regierung gegen die amerikanische Flagge. Die Sperrung aller französischen und Alliierten Häfen für sie.

Die Ausschliessung sämtlicher unter amerikanischer Flagge segelnder Schiffe aus den k. k. österreichischen Häfen.

England. Gerücht von dem Abschluss einer Alliance zwischen England und den amerikanischen Staaten. 
1809.

Amerika. Die Einnahme der nordamerikanischen Schiffe in den k. k. österreichischen Häfen nach Wiederherstellung der freundschaftlichen Verhältnisse mit England.

Spanien. Vorteile der Spanier in St. Domingo über die Franzosen.

Ankunft stärkerer Subsidiengelder aus England aus dem spanischen Amerika.

I8I I.

England. Gerüchte von dem Kriegsausbruche zwischen England und den amerikanischen Staaten.

I8I3.

Amerika. Absendung zweier Bevollmächtigter der nordamerikanischen Staaten, Gallatin und Bayard, ins preussische Hauptquartier wegen der von dem russischen Kaiser angebotenen Friedensvermittelung mit England.

\section{I8I 4 .}

Amerika. Englische Erklärung des Blockadezustandes der nordamerikanischen Küsten.

England. Englische Erklärung der Freiheit der Elbschiffahrt nach Abzug der Franzosen und der Blockade der Häfen, Flüsse, etc., an den Küsten der nordamerikanischen Staaten.

Spanien. Königliches Manifest für die amerikanischen Provinzen zur Rückkehr derselben in die spanische Oberherrschaft.

I 8 I 5 .

Amerika. Anzeige von den Feindseligkeiten amerikanischer Kriegsschiffe gegen die englischen Kauffahrteischiffe im Mittelländischen Meer.

Ansuchen dortiger Staaten um Gestattung der Aufnahme in den österreichischen Seehäfen der gegen die Barabaresquen-Korsaren kreuzenden amerikanischen Kriegsfahrzenge.

I $8 \mathrm{I} 6$.

Spanien. Ansuchen um ein Verbot der Waffenausfulhr aus den k. k. österr. Staaten für die spanischen Insurgenten in Amerika. Diesfällige Beschwerden.

$$
\text { I8I7. }
$$

Answanderung. Die Auswanderungen aus dem Badischen und dem k. $k$. Oberamt Silbach, Breisgau, Ortenau, etc., nach Nordamerika.

Spanien. Erklärung der Küsten von Peru und Chili mit Ausnalme einiger Häifen in Blockadestand.

Ausrïstung spanischer Insurgenten-Korsarenschiffe in Buenos Ayres.

Korsaren. Das Auslaufen zahlureicher Korsaren mit Kaperbriefen der spanischen Insurgentenregierung in Buenos Ayres in Amerika zur Krenzung in den europäischen Gewässern. 
I8I8.

Allen, John. Amerikanischer Grosshändler, Anerbieten desselben, seine auf hiesigem Hauptmarkt liegenden 79 Fässer mit amerikanischen Häringen zur Verteilung an die Armee zu überlassen.

Amerika. Notizen iiber die von den nordamerikanischen Freistaaten auf alle englischen und spanischen Schiffe gelegte Embargo-Konfiszierung der auf selben befindlichen Güter.

Spanien. Königliche Proklamation zur Vermehrung der Population der weissen Menschen in der Insel Cuba.

Ansuchen des dortigen Hofes um ein Ausfuhrsverbot aller Waffengattungen, des Pulvers aus den österreichischen Häfen nach Amerika, bis zur Dämpfung des Aufruhrs in den spanisch-amerikanischen Kolonien.

Edikt, die Bestrafung der mit Waffen in der Hand unter den Fahnen der Insurgenten in Amerika ergriffenen Fremden betreffend.

Anzeige des feindseligen Schrittes der Vereinigten Staaten von Nordamerika durch Verletzung des Gebietes von Florida gegen diesen Staat.

v. Stürmer, k. k. Generalkonsul bei den nordamerikanischen Staaten; die voreilige Kundmachung der Ernennung desselben zu diesem Posten in den Zeitungen betreffend.

Verleihung des preussischen roter Adlerordens an ihn.

Verständigung des englischen Hofes von seiner Ernennung zum k. k. österr. Generalkonsul in Philadelphia und Abberufung aus der Insel St. Helena. Antrag wegen seiner Reise nach Amerika.

I8I9.

Ansiedelung. Errichtung einer Gesellschaft in Stuttgart zur Erleichterung der Ansiedelung in Nordamerika. Statuten der Gesellschaft.

Amerika. Die Seeräubereien der südamerikanischen Freibeuter.

Nachrichten über den Handel in Nordamerika.

Die in England stattgehabte Subskription zu Gunsten der AmerikanerInsurgenten.

Spanien. Spanische Verordnung der Todesstrafe auf alle Ausländer, die bei den amerikanischen Insurgenten in Amerika bewaffnet ergriffen werden, oder die ihnen Kriegslieferungen zuführen.

Uebermachung der späteren Verordnungen unter der Regierung der Cortes.

Ob den k. k. Schiffspatronen zu gestatten sei, ihre Schiffe zum Transport der spanischen Truppen nach Amerika gegen die Insurgenten auszumieten.

Ansuchen um ein Ausfuhrsverbot wegen eines in Triest vorbereiteten für die Insel Thomas bestimmten Massentransports.

Schweiz. Die Auswanderungen aus der Schweiz nach Brasilien.

Antrag auf Errichtung schweizerischer Regimenter für den Hof von Brasilien.

Stürmer. Antrag auf ein Wartgeld von 2000 Fl. für ihn bis zum Antritt seiner neuen Anstellung. 
I820.

Amerika. Die Verfassungspolitik der nordamerikanischen Staaten.

Die Behandlung fremder Handelsschiffe in holländischen Quarantainesachen.

Dortiger Aufenthalt des exilierten Franzosen Joseph Bonaparte.

Exequatur für den k. k. Generalkonsul allda, Freiherrn von Lederer.

Die Revolution in Spanisch-Amerika.

Spanien. Ansuchen der spanischen Botschaft um ein Verbot wegen der vorbereiteten Massenausfuhr von Triest nach Amerika.

Beschwerden des amerikanischen Gesandten bei dem dortigen Ministerium wegen sciner Effekten in Cadiz.

Stürmer. Dessen Ernennung zum k. k. Gesandten in Brasilien.

K. k. Gesandter in Brasilien. Die Liquidierung mehrerer Dienst- und Kurierrechnungen. Vergütung der Auslagen wegen Verzögerung der Ankunft des Schiffes Carolina.

I $82 \mathrm{I}$.

Amerika. Antrag der nordamerikanischen Regierung wegen der Behandlung ihrer Nationalschiffe in den österreichischen Häfen.

Die Irrungen mit England wegen des Sklavenhandels und die spanische Abtretung von Florida an die dortige Regierung.

Die Gefechte mit den Insurgenten im spanischen und portugiesischen Amerika.

Spanien. Nachrichten von den Insurgenten in den spanischen Kolonien in Amerika.

Stürmer, k. k. Gesandter zu Rio Janeiro. Uebermachung eines Kreditbriefes für ihn, die Bezahlung eines neuen von 300 Pfund Sterling.

Nachrichten von der Reise desselben auf der Carolina nach Rio Janeiro.

Die Miete seines Gesandtschaftshauses.

Dessen Entfernung aus Brasilien.

Lederer, k. k. Generalkonsul in New-York. Anerkennung desselben von seite der nordamerikanischen Staaten.

Die Verfassung und Einrichtung seiner Berichte.

Dessen Bitte um Gestattung der Annahme des ihm verliehenen Toskanischen Generalkonsulates alldort.

\section{K. u. K. KRIEGSARCHIV.}

Location: Wien VII., Stiftgasse 2. The building was constructed in the eightecnth century, and was formerly the home of the "Technische Militärakademie". The archive is divided into: I. Die Direktion; II. Die Abteilung für Kriegsgeschichte; lII. Das Schriftenarchiv (containing over 5,000,000 "Schriftstïcke" since 1556 , and 15,000 folio volumes of "Protokolle") ; IV. Das Kartenarchiv; V. Die Kriegsbibliothek.

Hours: 10 a. 111. to 2 p. m. daily, except Sundays and holidays.

Bibliography: Das K. K. Kric ss-Archiv: Geschichte und Monographie (Vienna, Verlag des K. K. Generalstabs, 1878).

J. Langer, Das K. u. K. Kriegsarchiv von sciner Grïndung bis zum Jahre 1900 (Vienna, second ed., I900). 


\section{SCHRIFTENARCHIV.}

The Schriftenarchiv contains no materials relating to American history prior to I780. Indices to the "Protokolle" are very accessible for the period I 740-I 848 . The following entries appear, from I 780 on; some of the acta have been destroyed (cassiert), others preserved (asserviert).

\section{780 .}

G. 756. Nr. I433. Rekruten werden von Reichs-Ständen an Engelland überlassen, u. nach Amerika abgeschickt. "Feldmarschall Lt. Prinz von Nassau-Usingen (Frankfurt den 23. Februar 1780) zeiget an, dass vermög. eingegangener Meldung des Obristlieutenants Otto auf der Margräflich Bayreutischen Berg-Vestung Blasenburg gegen I6o Rekruten meistens Ausländer und Deserteurs, worunter sich etliche 20 Kayserliche befinden sollen, verwahret, und zu Completirung deren vom Herrn Margrafen von Anspach an England nach Amerika abgegebenen Truppen bestimmt wären, und sollten selbe, der Sage nach, mit Anfang Märzens durch die Reichs Lande, und sodann weiters zu Wasser dahin transportiret werden." Frankfurt, Feb. 23, I780.

Nr. I434. "Major Grün und Hauptmann La Sollaye und den aus dem Reich gebürtigen Kaiserl. Soldaten Urlaub erteilt." (Inquiry added, whether it might be possible to get the deserters back.)

G. 1724. Nr. 3355. "Feldmarschall Lt. Prinz von Nassau-Usingen, den $3 \mathrm{I}$. May I780, zeigt an, dass bei Höxter auf der Weser Iooo Recrouten nach Amerika vorbei passiret synd."

G. 2677. Nr. 5II3. "Prinz zu Nassau-Usingen, Erfurt den 29. August i780, zeiget an auf die Verordnung von-Juni Hindernisse, welche der Beförderung der diesseitigen Werbung im Reich im Weeg stehen, worunter besonders auch der in Mittel- und Nieder-Teutschland anhaltende Zulauf zu denen Werbungen der verschiedenen Reichsfürsten, so ihre Regimenter in Amerika zu ergänzen haben, vorzüglich aber die im ganzen Reich zerstreute Preussisch- und Dänische Werbungen begriffen sind, weil diese, und besonders die Preussische nun wiederum die vor dem letzten Krieg gehabten Hang und Zugang völlig, ja noch mehr hergestellet hat. [pag. 2678] Ohngeachtet dessen aber sey der Recruten Zuwachs in denen verflossenen Monaten dieses Jahres in seinem Verhältnis gegen die letzteren zwei Jahre nicht geringer. Indessen werde Berichtleger die untergebenen Werb Officiers die bessere Betreibung der Werbung einzubinden, auch wenn es diese Officiers besser kennen lernen, und darunter einige minder taugliche, oder unfleissige antreffen wird, deren Ablösung zu veranlassen nicht ermangeln."

Erledigung des Exhibiti, pag. 2677. "Soweit die Kayserl. Werbung in den Reichs Landen dadurch einen Abbruch zu erleiden hat, dass Reichs Unterthanen nacher America geschickt werden, muss der Reichswerbungs Directeur sich mit den betreffenden Ministres im Reich darïber einvernehmen, ob nicht etwa aus dem Grunde des Auswanderungs Edicts diesem Uebel Einhalt zu verschaffen thunlich seyn könnte, wohingegen, so viel die Anstalten betrifft, wodurch die Kayserlichen vor der Preussischen Werbung auf dem 
Reichs Boden der Vorzug zuwege zu bringen seyn mag, in den pag. 2678 Reichswerbungs Directeur das Vertrauen gesetzet wird, es werde derselbe, je nachdem es hierzu schickliche Mittel und Wege vorkommen, sich solche zu Nutzen zu machen und derowegen ins besondere auch denen zur Werbung bestellten Offiziers die diensame Belehrung zu erteilen besorgt seyn."

B. 880. "Dass die Kayserl. Unterthanen mit ihren Schiffen von dem Französischen Droit de Frèt befreyet seyen." (An das Carlstädter General Commando.)

B. 944. Questions and inquiries.

“Einen proviantischen Handel aus diesseitigen Landen nach den französischen Besitzungen allda einzuleiten ist der Antrag, und wird dieserwegen das Nöthige veranlasset."

W. 1110. "Nur bis Toulon, Marseille u. dgl. wollen diesseitige Seefahrer die Körner liefern. Gefahr wegen der Barbaresquen. ZenggerSchiffe zur Fahrt nach America nicht erbaut."

B. 1187. Weitere Mitteilungen an das Carlstädter General Commando.

$$
\text { I } 78 \mathrm{I} \text {. }
$$

B. 247. "Mit Salz dahin handeln zu dürfen haben diesseitige Seefahrer gebethen, und ist das Nöthige darüber veranlasset worden."

"Susanni Marcus, Handelsmann von Zengg, bittet, eine Ladung Salzes von Trappani, welches das beste zu Einsalzung des Fleisches ist, mittelst seines Schiffes La Madona del Carmine genannt, nacher Zengg verführen lassen zu können, und sodann mit solchem weiter nacher Frankreich und America zu handeln." (Referred to Carlstädter General Comnando, and granted.)

G. 1543. "Reichswerbungs Directeur Prinz Nassau zeiget an, dass den $5^{\text {ten }}$ April 1500 Hessisch-Waldekische und Anspachische, dann den 18. dieti 800 Hannauische Recruten auf der Weser bei Höxter vorbeigeschifft seyen, unı nach Engelland zu Verstärkung deren in America in englischem Sold dienenden Truppen abzufahren." May $10, \mathrm{I} 78 \mathrm{r}$.

G. 1767. Acknowledgment of the above: "An verschiedenen Reichs Landen nach America abgegangene Truppen."

G. 2137. "Nassau-Usingen, Reichs Werbungs-Directeur zeiget an, dass nicht nur in der Reichsstadt Müllhausen und Nordhausen Chur-Hannöversche Werbungen eingenommen worden seyen, sondern auch dem Vernehmen nach diese Werbung sich in mehrere Reichsstädte vorbereiten solle, die ihre aufgebrachte Recruten zum Dienst der Crone Engellands nacher America fortschleppet, mit dem Beysatz, dass auch in Frank furth einige Werbcommandirte eingerücket, und von diesen ein Officier mit einigen Commandirten nacher Wissbaden in Nassau-Usingschen aufgenommen worden seyn." July i4, I78I.

G. 2197. Erledigung des Exhibiti: "Das mit der Reichs Canzlei do. I777 verabredete Hilfsmittel bestche darin, dass bey den Chur- und Oberrheinischen Creisen, hauptsächlich bey Chur Pfalz, auch andern am Rheine liegenden Ständen erwürket werde, dass sie dem Volksauszuge Schranken setzen, den durchziehenden Trans- 
porten Unterthanen und Deserteurs abnehmen, allenfalls hierzu den Kayserl. Beystand aufrufen, zu welchem Ende diesseitige Werb Officiers ohne Aufsehen zu machen, auf alle Fälle, wo Reichs Unterthanen auswandern mögen, aufmerksam zu seyn, und davon im vertraulichen Wege, jene Stände, in deren Bezirke sie sich befinden, noch in Zeiten zu verständigen haben." Kriegshof Kanzlei, Aug. 2, r $78 \mathrm{I}$.

G. 2319. Acknowledgment of the above.

G. 2368. "Werbungen für die englischen Truppen in America werden im Reich aufgestellt, und wird wegen deren Abschaffung das Nöthige veranlasst."

“Werb Depot will in einigen Reichsstädten v. allda für die zum Dienst der englisch-ostindischen Compagnie allda v. in der Schweiz aufgebrachte Recruten errichtet werden, und wie diesfalls Abhülf zu treffen wird die Weisung gegeben."

G. 2664. "Englische Recruten Transports (aus dem oberen Theil Schwabens) sind von diesseitigen Militari angehalten worden." Erledigung: "Dürfen nur in so weit und so lange angehalten werden können, als nothwendig ist, die darunter befindliche diesseitige Landeskinder und Deserteure zu untersuchen und abzunehmen."

$$
\text { I782. }
$$

G. 974. "Recruten sind in Reichs Landen für fremde Mächte angeworben, und dahin transportirt worden, welches angezeigt, und das weitere darüber veranlasst worden."

Nr. 238: " $\mathrm{Zu}$ Anspach aufgebrachte Jäger über Hanau und Bremerleh für Cron Engelland nach America abgegangen."

$$
1783 .
$$

G. 4, 164. "Werbungen sind für dortige Engelländische Truppen in Reichs Landen aufgestellet worden, und wird wegen deren Abschaffung, dann Verhinderung der Auswanderung der Reichs Unterthanen dahin die Vorsicht getroffen."

G. 1608. "Handlungsschiffe diesseitige sind auf der Rückreise von America zu Grund gegangen."

G. 2181, 2278. "Hessische Truppen in englischem Sold gestandene (und zurück erwartete) werden zu diesseitigen Diensten angebothen, und hierauf der Entschluss ertheilt."

B. 892. "Commerzienrath Kayserl. (Freyherr von Beelen) ist zur Beförderung der wechselseitigen Handlung zwischen dies- und jenseitigen Unterthanen dahin abgesendet und solches kundgemacht worden."

$$
1784 \text {. }
$$

J. 1017, 1060. "Officiers dasige, bitten in K. K. Dienste angenommen zu werden, und folgt der Entschluss."

"Der Sohn des dortigen Hauptmanns von Brahm [i. e., of Lieut.-Col. Ferdinand de Brahm, U. S. A.], welcher io Jahre als Ingenieurs Officier in Diensten des americanischen Congress gestanden auch wegen Wohlverhalten und ganz besonderen Kenntnissen zum 
Obristlieut. ernannt, und mit dem Cincinnatus Orden beehrt worden ist, Gesundheits halber nach America zurückzukehren nicht mehr gesinnt, und da demselben andere Dienste in Europa angebothen worden, so wünschte gedachter K. Ninister (Baron Duminique, Chur-Trier. Staatsminister), dass selber wegen seiner besonderen Fähigkeit vorzüglich in K. K. Dienste genommen werden möchte." Petition not granted, apparently in deference to monarchical principles.

$$
1787 .
$$

A. 633. "Auswanderung nach America wird angesucht bewilliget oder abgeschlagen." (Passes granted to two women for Mexico.)

$$
\text { I } 789 \text {. }
$$

G. 221, 324, 472, 547, 1070, 1947, 2039. "Körner Lieferungen von America sind von Particularen (Beneke u. Pfister) angebothen, und das Nöthige veranlasset worden."

I79I.

G. 8479. "Verordnungen den Zoll für Otterbälge betreffende, werden publicirt."

$$
\text { I } 594 .
$$

B. 80. "Pest Ucbel soll alldort [Philadelphia] ausgebrochen seyn, und werden dagegen die nöthigen Vorkehrungen getroffen." (Quarantine of 14 days on ships from Philadelphia.)

G. 2692. "Ein Corps zu einer in Frankreichs Staaten auszuführenden Revolution aus französischen Deserteurs, Vertriebener, Emigrirten, und Kriegsgefangenen zusammenzusetzen wird vorgeschlagen, und das weitere verhandelt."

See also G. 2791, and acta fasc. 62, no. 574; also fase. 9, no. 620 .

I8I I.

G. 4-6/13, 25. "Kriegspässe dahin [America] Aufenthalt daselbst, ob solcher einigen Officiers ohne Compromittirung zu gestatten sey?"

G. 4-6/25. "Beurlaubung dahin, ob dagegen in politischer Hinsicht keine Unstände obwalten?"

$$
1815 .
$$

M.1-17/16. "Aufnahme, ol und welche den Nordamerikanischen Kriegsschiffen in diesseitigen Häfen zu gewälıren sey?"

M.1-1/9. "Fahrzeuge entbehrlicher, oder unbratuchbarer Verüusserung, oder Versteigerung, diesfällige Ausweise, Protokolle und Verhandlungen."

L. 4-13/211, 230. "Behandlung der unter der neapolitanischen Kriegsgefangenen befindlichen, jenseits der Meere grebürtigen Individuen, und ob entlassen werden dürfen." 


\section{I8I6.}

N. 2-7/1. "Erbteil Erfolgmachungs Gesuche daher, und diesfällige Verfügung."

K. 11-I, K.11-I/I. "Falschwerber ziehen herum-Massregeln gegen dieselben."

J. 1-I3/98, III, I32. "Massen Ausfuhr für die spanisch americanische Insurgenten zu verhindern."

M. 1-22/75. "Bestimmung einer Escadre zur Ueberschiffung der Gesandtschaft nach Brasilien."

I8I7.

M. 1-66/2-6. "Anschaffungen von Materialien für die nach Brasilien bestimmte Expedition sind nicht durch die bestimmte Gold Dotation, sondern durch den hierzu angewiesenen Vorschuss zu bewerkstelligen."

D. 9-3. "Einige allda sich aufhalten sollende Partheien."

N. 10-I. "Erbschaften auszufolgen wird angesucht und Entschluss."

"General Consuln werden für dortige Häfen angestellt."

I8I8.

1 “Erbschaften auszufolgen wird angesucht, und Entschluss."

18I9.

“Erbauung neuer Fregatten nach dem Modelle der Fregatten ersten Ranges in der dortigen [amerikanischer] Seemacht. Antrag und Entschluss."

"Unterstützungs Einwirkung in ministeriellem Weg von allda lebenden Verwandten, wird von Officiers Frauen angesucht, and Entschluss."

"Postportogebühren für Briefe nach America, oder den dortigen Colonien bestimmte."

I820.

"Anbau des californischen Waizens, Versuche und Resultate."

"Erbschaften auszufolgen."

I82I.

“ Nachrichten über die Fahrt, den Zustand und die sonstigen Ereignisse der Marine Expedition nach Brasilien und China."

1822 .

"Marine Expedition nach China. Nachrichten über die Fahrt usw."

"Ausfuhrs Pässe für nach America auszuführende englische Feuergewehre abverlangte."

"Erbschaften auszufolgen, angesuchte und Entschluss."

\footnotetext{
${ }^{1}$ The very numerous references to volume and pages, in this and following years,
} may be found in the indices. 


\section{I823.}

“Ausfuhrs Pässe für nach America auszuführende englische Feuergewehre. Waffen Ausfuhrs Verbothe, Aufhebungsgesuche von Feuerwehr Fabrikanten. Anbau ausländischer Getreide Arten, Versuche und Resultate. Fürnüsz, neu erfundenen, oder den nordamerikanischen Feuerversicherungs Anstrich bei aerarial Gebäuden "Erbschaften auszufolgen." anzuwenden, Antrag."

\section{I824.}

"Samengattungen ausländischer, Anbau, Versuch und Resultate."

" Confiscirtes Privat Eigentum während der Kriegs Ereignisse."

"Schiffbauhölzer, ob in Salzwasser zu legen, etc."

"Allerhöchste Zufriedenheit mit dem Kommandanten u. Equipagen der in Jahre I8I7 gemachten Fahrt nach Brasilien."

"Grenzer und sonstige Partheien."

"Freypass Erfolglassungs Gesuche zur Pulverausfuhr dahin."

"Beschlagung der Marine Fahrzeuge unter der Wasserlinic mit Leder statt Kupfer und Zink."

\section{5 .}

"Samen Gattungen."

"Land- oder Seekarten der Marine."

" Privateigentum, confiscirtes, während der Kriegsjahre."

"Fregatten ersten Ranges."

\section{I826.}

"Erbauung neuer Fregatten vom Grunde aus nach dem Bauplan der nordamericanischen Fregatten ersten Ranges."

"Nordamericanische Erfindung: Telescop zur Durchforschung des Grundes der Ströme und Flüsse, etc., ob anwendbar?"

"Erbschaften auszufolgen."

"Waffen Ausfuhr Verbot."

"Zusammenstossen K. K. Kriegsfahrzeuge mit frenden."

" Rückkehr K. öster. Unterthanen in die K. K. Staaten."

1827.

"Land- und Seckarten." “Telescop."

"Urlaubs Anträge." "Reisepässe öster. Militairs."

"Unter dortiger Flagge escortirte Handelsschiffe."

"Erbschaften."

I 828 .

"Urlaubsbewilligung."

"Erbschaften."

"Kupferbeschlag der Iahrzeuge nach Art der Americaner."

"Schädlichkeit des Peches für den Kupferbeschlag."

"Hilfeleistungen einigen k. k. Kriegsfalırzeugen (bei unglücklichen Ereignissen ) durch Mercantilfahrzeuge erwiesen."

" Differenzial Gebïhren eingestellt." 
"Erbschaften."

"Leopoldinenstiftung zur Unterstützung der americanischen katholischen Missionen."

"Einlaufen dortiger Fahrzeuge."

"Bericht des Secretairs für Kriegs- und Marine Angelegenheiten."

"Zerstörung der Schiffs Kupferbleche."

"Differenzial Gebühren eingestellt."

"Segel, baumwollene, statt der bisher üblichen hanfenen bei der nordamericanischen Marine."

$$
\text { I83o. }
$$

"Marine Eisenbahnen."

"Reise des Herzogs Bernhard von Sachsen Weimar nach Nordamerica. Anschaffung und Uebermachung dieses Werkes."

$$
\text { I83I. }
$$

"Verein zur Unterstützung der americanisch katholischen Mission, unter dem Namen Leopoldinen Errichtung, und Geldbeiträge Einsendung."

"Kupferbeschlag der Marinefahrzeuge nach americanischer Art."

"Handels- und Schiffahrts Traktat zwischen Oesterreich und den nordamericanischen Freistaaten."

"Merkantilfahrzeuge, dortige, in diesseitigen Häfen in Brand gerathene, ob und welche Hülfe denselben geleistet, dann deren Rettung oder Untergang."

$$
1832 \text {. }
$$

"Verein zur Unterstützung der americanisch katholischen Mission- dann Geldbeiträge Einsendung."

"Paquetboots Fahrt Etablirung, zur Erhaltung eines regelmässigen überseeischen Dienstes Verbindung, im Wege der Aerarial Regieoder einer zu patentierenden Privat-Entreprise, Anträge und Verfügungen."

$$
\text { I } 833 \text {. }
$$

"Dampfbootsmaschinen Verkaufs Offert an die k. k. Kriegsmarine und Entschluss."

"Dampfbootsmaschinen für die k. k. Kriegsmarine ob aus England oder aus Nordamerica vorzuziehen wäre?"

"Schiffszwieback nach America."

"Chronometer." "Blech Schüsseln für warme Getränke."

"Pharmaceutische Artikel." "Matrosen Mund-Razion."

$$
\text { I } 834 \text {. }
$$

"Sextanten englischer Construction von neuester Art."

"Sextanten alter Construction."

"New-Yorker Consulat."

"Zufriedenheit des Hofkriegsraths mit dem Stabe der Expedizion nach America." 
"Original Constitute der nach Nordamerica überschifften russisch-polenschen Flüchtlinge, Deckstellung, nach Zurücklassung von deren Abschriften bei dem k. k. General Consulate in New York."

1835 .

"Bücher, auf Dampfschiffbau und Dampfschiffahrt bezügliche, aus New York überbracht."

"Postporto für Amtspakete."

"Tabakpflanzen-Samen." "Thermometer Anschaffung."

"Dampfmaschinen Modelle. Anschaff und Bekostung."

" Fahrten der k. k. Kriegsfahrzeuge und Einlaufen derselben."

"Benehmen der russisch-polenschen Flüchtlinge bei ihrer Ueberschiffung auf k. k. Kriegsfahrzeugen nach Nordamerica."

"Kosten-Nachweisung. Vorbereitungen zur Expedizion einiger k. k. Kriegsfahrzeuge zur Reise nach Nordamerica."

"An Bordnahme italienischer Hochverrats Sträflinge und ihrer Familien auf k. k. Kriegsfahrzengen, deren Behandlung, Verpflegung, Uebergabe und Uebernahme."

"Verbannung nach America der Hochverräter der Giovani Italia allergnädigst bewilligte, anch auf die Milt Sträflinge dieser Secte auszudehnen Ansuchen."

I 836 .

"Eigenschaften der grösseren Inbarkazion der verschiedenen Schiffsgattungen."

"Expedizion nach Nordamerica."

"An Bordnahme italienischer Hochverrats Sträflinge. Auslagen."

"Seekarten."

"Auslagen der Entsendung russisch-polnischer Flüchtlinge nach Nordamerica."

"Panatica höhere (bessere Verköstigung)."

1837 .

“See Expedizion nach americanischen Häfen."

"Italienische Hochverraths Sträflinge."

"Medicamente etc." "Panatica höhere." "Speise- und Getränksartikel."

"Ucberführung russisch-polnischer Flüchtlinge."

1838 .

"Gesandten Stclle Verleihung an Generals, ohne militärische Gebülıren."

"Verpflegsauslagen."

I 839 .

“Mchrauslagen."

"Massregeln zum Verkehr fremder aus Gegenden, in welchen das gelbe

"Pontons."

Ficber herrscht, kommenden Schiffe."

"Eigentum eines abgrelebten Bürgers der Vereinigten Staten ist ohne Einvernchmen des Consuls nicht zu veräussern." 
I840.

“Mehrauslagen für Ueberschiffung russisch-polnischer Flüchtlinge.”

"Marine Angelegenheiten." "Pontons."

I $84 \mathrm{r}$.

Continuation of foregoing subjects.

1842.

Continuation as above.

"Einschiffungsbewilligung Ertheilung für Marine Officiers Söhne auf americanischen Schiffen."

1843.

"Umänderung im Leuchtfeuer System."

"Ankunft dortiger Kriegsfahrzeuge in österreichischen Häfen."

"Kriegsbrücken."

1844.

"Erbschaftsfälle, etc."

"Bekanntgebung der zwischen Oesterreich und den nordamericanischen Freystaaten Schiffahrts- und Handelstraktat."

$$
1845 \text {. }
$$

Naval affairs and events.

$$
1846 .
$$

"Mitgliedsdiploma des nordamericanischen National Instituts."

"Notizen über verstorbene ehemalige Officiers."

"Auswanderungsbewilligung."

$$
1847 .
$$

Routine matters.

$$
1848 .
$$

"Urlaubsbewilligung."

"Congressverhandlungen der Vereinigten Staaten."

"Russisch-polnische Flüchtlinge."

\section{Memoiren.}

\section{Akten, Amerika betreffend.}

Mem. 28/104. "Kapitulationen zwischen dem amerikanischen General Washington und dem französischen General Rochambeau, dann dem englischen General Lord Cornwallis [in York] und Gloucester." Two documents. I78I.

Mem. 28/606. "Ueber Amerika, dessen Unabhängigkeitskrieg, Sitten und Einrichtungen." Three note-books. I824.

Mem. 22/55. "Statistik von Nordamerika, Columbia und Mexico." Quarto note-book. 1836. 
Mem. 18/163. "Stand und Organisation der Armee und Seemacht Nordamerikas." Six documents. I840.

Mem. 18/169. "Notizen über die Land- und Seemacht der nordamerikanischen Freistaaten." Bundle. 844.

Mem. 18/234. "Die spanische Armee in Amerika." One document, no date.

\section{KARTENARCHIV.}

There is a card catalogue (Zettelkatalog) provided for this very large collection of maps. There are three divisions: (a) Politische, (b) Physikalische, (c) Fachwissenschaftliche Karten (including maps showing railroads, canals, postal-telegraph, military roads, ctc.).

The political maps include a section containing maps of Canada, the United States, Mexico, Central Anrerica, West Indies, etc. There are also maps of American cities. The war maps include the periods: "Engländer gegen die Spanier in Amerika"; "Nordamerikanischer Freiheitskrieg, I775-1 783 ": "Krieg von I86 I-I865."

A rare map is one in four volumes illustrating Santo Domingo. It is carefully executed by hand, and done in water-color. It is not complete, is without date, and bears the titles: "Plans des Lieux Principaux de St. Dominique.-Table des Plans relatifs au mémoire sur la defense Terrestre de St. Dominique." It was taken from Paris by the Allies in I8I 5.

\section{ALLGEMEINES ARCHIV DES K. K. MINISTERIUMS DES INNERN.}

Location: Wien I., Judemplatz I I. Building not modern.

Hours: Daily $9 \cdot 30$ a. ni. to 3.30 p. m.

Bibliography: Inventar des Allgemeinen Archio's des Ministerinms des Innern, bearbeitet von den Beamten dieses Archivs (Vienna, I909. Pp. 95).

Recent works based on researches in this archive covering periods for which the documents are usually not accessible:

August Fournier, Historische Studien und Skizzen, 3 Teile (Vicnna and Leipzig, I9I2).

Heinrich Friedjung, Oesterreich von IS $4 S-I S 60$, two vols. (Stuttgart and Berlin, igos).

L. Geiger, Das junge Deutschland (Berlin, I90\%).

K. Glossy, Literarische Geheimbericht aus dem Vormärz (Vienna, I9I3).

Herm. Giau, Die Zensur unter Joseph II. (Strassburg and Leipzig, I9I I ).

Augusto Sandonà, Contributo alla Storia dei Processi del Ventuno $e$ dello Spielberg, $1821-1838$ (Turin, I9I0).

The only section of this archive which contains any materials relating to American history is the division "Polizeiakten", which reveals the inner workings of the Metternich spying system. The period not accessible, after 1848 , probably contains more material on political refugees.

9. Neuere Polizeiakten 1793-1848, Fasz. I-1902.

I Sot.

98. Auswanderungsversuche.

Amerikanische IVerbkonmuissare. 
1805 .

317. Ansiedler, für Spanien und Nordamerika.

I 8I 2.

313I. “Vier Amerikaner, welche über Prag und Brünn in Presburg eingetroffen sind und ihre Reise über Pesth nach Constantinopel fortsetzen." Four names difficult to decipher: Miller, Rising, Wanhil[1] (?), Di[n]smore (?).

I8I3.

I3I I. Tyroler Ansiedlungsangelegenheiten.

$$
\text { I } 8 \text { I } 4 \text {. }
$$

4379. Auswanderung der Tyroler.

$$
\text { I8I } 5 \text {. }
$$

53. Auswanderung aus Südtyrol, etc., nach Spanien, etc. 486. Nordamerikaner wegen Tabakhandel.

I8I6.

I 19, 207, 2890. Auswanderung nach Nordamerika.

$$
\text { I8I7. }
$$

44. Auswanderung der Tyroler nach Spanien und Amerika.

283, 7072, 86i s. Amerikanische Emisseure in Livorno.

5034, 5535. Nordamerikanische Regierung, welche geneigt sein soll die Schiffe im venezianischen Arsenal anzukaufen. Neger-Regierung.

5510. Nordamerikan. General Konsulat. Auskünfte über dessen Competenten.

$$
\text { I818. }
$$

I $1977 / 9$. Americana, neue Sektenbenennung in Italien.

$$
\text { I8I9. }
$$

554I. Nordamerikanische Grundstücke. Verein in Deutschland zum Handel mit selben.

$$
1820 .
$$

I043. Auswanderer nach Amerika, angeblich debauchiert durch den Kaufmann v. Meredyth.

$$
1821 \text {. }
$$

2835. Amerikanische Gesellschaft in Bologna.

6317, 7786, 8797, 9667, etc. Americani Cacciatori. 
I 822.

3782. Auswanderung nach Brasilien.

$606,838,2104,2564,5337$, etc., etc. Americani Cacciatori, neue Sekte im Päpstlichen.

I817, I959, 3973, 4202, etc. Natter, Joh. Jos., Commandeur und Pfarrer der Karlskirche allhier. Entweichung.

$$
\text { I } 823 .
$$

4526. Karl Postl gew. Sekretär der Kreuzherm in Prag. Eleven acta concerning the fugitive monk Carl Postl, who fled from the Kreuzherrn monastery in Prague, travelled in the United States and Mexico, and wrote very popular novels descriptive of American life, under the pen-name Charles Sealsfield.

(a) Der Kreuzherr Commandeur Stöhr an den Bürger M. von Carlsbad. Eger, June I3, I823.

(b) Dekret von der K. K. Polizei Ober Direkzion. Vienna, June 27, 1823 .

(c) An den Hrn. Präs. der K. K. Polizeihofstelle. June I2, I823.

(d) Jos. Köhler, Gen. Grossmeister an Hochw. Fürst-Erzbisch. Konsistorium. June 9, I823.

(e) Zimmermann an d. Skriptor d. Universitätsbibliothek Hrn. Hanslik. Prag, May 29, 1823 .

(f) Inquiries about Postl; unfavorable. "Es ist für den Orden besser, wenn zur Schonung des Ganzen der Einzelne nicht geschont wird." Vienna, June 6, 1823 .

(g) Concerning Postl's movements. Karlsbad, June 2, I823.

(h) Der Elbogener Dechant Pecher an d. Pater Joh. Fischer, Amtmeister d. Kreuzhermordens in Prag. Elbogen, May 27, I823.

(i) Der Bürger M. an d. Krenzherrn Commandeur Stöhr in Eger. Karlsbad, June 2, I823.

(j) Schraml an d. vormal. Sekretär d. Krenzherrnordens Pater Karl Postl, nach Karlsbad. Wlaschin, May 24, I823.

(k) Including a personal description of Postl. June 7, I823.

$$
\text { I } 824 \text {. }
$$

7160. Auswanderung nach Brasilien.

1825.

3891. Auswanderung nach Brasilien.

I 826.

I 383 , 2064. Fliichtlinge in der Schweiz.

1827.

1054, 1683. 3484. Nenes Answanderungs-patent.

$$
1829 \text {. }
$$

828. Auswanderung nach Brasilien. 
I830.

7080. Auswanderung nach Nordamerika.

3726, 7080. Religionsschwärmersekte des Bernluard Müller zu Offenbach (bundle of papers).

Religionsschwärmerische Gesellschaft, zı Frankfurt.

Maximilian Bernard Proli, zu Offenbach, angeblich Stifter einer politisch-religiösen Gesellschaft. ${ }^{2}$

6041. Nordamerikanische Gelehrte Gesellschaft u. Freymaurer.

$$
\mathrm{r} 83 \mathrm{r} \text {. }
$$

737. Nordamerikan. Schiffahrts- u. Handelsvertrag.

I0838. Nordamerikanischer Freistaat, Bericht über den moralisch-politischen Zustand, durch die V. Magdalenengesellschaft.

\section{I835.}

6265, 6731. Amerikanische Auswanderung. Paul Szirmay (enthusiast for a plan of emigration) zu Giralth bei Eperjes.

5523. Paul Szirmay (Hermann), dessen Auswanderungsprojekt nach Amerika.

Reise nach Hüben, nach Amerika.

5523. Gottfried Duden in Bonn. Schreiben an ihn, des P. Szirmay.

Soo9, I I065. Deportation italienischer Hochverräter, Sträflinge.

8I 87. Flugschrift alldort gegen die katholische Religion und Oesterreich: Foreign Conspiracy.

I 560. Amerikanische Gesellschaft zur Verbesserung des Zustandes und zur Bekehrung der Juden.

Colonien am Hudson, gegründet zur Besserung ihres (der Juden) Zustandes, von einer amerikanischen Gesellschaft.

$$
\text { I836. }
$$

5437. Auswanderungs-Patent v. 24. März, I832. Bemerkungen hierüber des Mailänder Gen. Direktors.

3I, 44I3. Auswanderungsverfahren gegen lombardisch-venez. polit. Flüchtlinge.

7536, 8298. Auswanderungen aus Böhmen nach Amerika (Brasilien).

I6ı. Deportirte nach Amerika, in dem galizischen Hochverratsprozess verflochtene Individuen.

3o. Deportirte, italienische, Hochverräter. Sträflinge nach Amerika. (Two pages of names.)

$$
\text { I } 837 \text {. }
$$

790, 4375. Auswanderungen, nach Amerika (Brasilien).

7087, I 470, 4472, 472. Schwierigkeiten bei Aufnahme der Emigranten in New York. (Lederer's report.)

455 (and numerous other references, see manuscript index). Deportirte, italienische Hochverräter in Amerika.

${ }^{1}$ Cf. J. Hanno Deiler, Eine Vergessene Deutsche Colonie: eine Stimme zur Verteidigung des Grafen de Leon, alias Proli, alias Bernhard Mïller (New Orleans, 1900). 
I 838 .

9289. Nordamerika, Auswanderungen dahin.

1490. Nordamerikanischer Konsul in Algier.

I444, etc., etc. Italienische Deportirte in Nordamerika. Hochverrats Sträflinge.

$$
\text { I } 840 .
$$

4490. Amerika, Passausstellungen dahin.

7352, 7963. Die katholisch-bischöfliche Administration in Nordamerika. Broschüre.

2622, 2668. Deportirte italienische Hochverräter. Behandlung.

I 841 .

10525. Friedrich Baraga, Priester aus Laibach, Missionär in Nordamerika.

Manuskript: "Christliches Erbaumgsbuch in der Sprache der amerikanischen Otawas-Indianer."

1993. Deportirte italienische Hochverräter.

$$
1842 .
$$

2934, etc. Deportirte, italienische, nach Nordamerika.

$$
\text { I } 843 \text {. }
$$

7766, etc. Deportirte, italienische, nach Nordamerika.

$$
\text { I } 844 \text {. }
$$

4658, 7188 . Amerikaner, reisende.

$$
\text { I } 846 .
$$

2098. Nordamerikanische Pässe, falsche.

2007, 21 26, 6r 3, 3358, etc., etc. Amerika, Auswanderungen dahin.

2997. Auswanderungen nach Texas.

3504. Kaufmann Leopold Förstl (Ferstl).

$$
\text { I } 847 \text {. }
$$

10I39. Nordamerika, Auswanderung dahin. Friedrich Wilhelm Bornemann, Inhaber einer Agentur für Auswanderer nach Nordamerika zu Hannoverisch Münden.

8152. Nordamerika, Revolutionäre Tcutschen-Vereine daselbst. Verein zur Beförderung revol. Umtricbe in Deutschland.

12606. Brünn, Press Confiszierung.

328, I 108, 1905, 2595, 5796, 6367, 6986, etc. Karl Heinzen. Dessen Pamphlet: Der Teutsche Tribun. Neue revol. Schrift v. K. Heinzen: Die Teutsche Revolution.

$$
1848 \text {. }
$$

209, 210, 438, 1530. Karl Heinzen, Gewes, preuss. Landwehroffizier. Aus der Schweiz gewiesen; nach New York. 


\section{K. u. K. GEMEINSAMES FINANZ-ARCHIV (HOFKAMMER-ARCHIV).}

Location: Wien I., Johannesgasse 6. Five-story building specially constructed for the purpose, in 1833 .

Hours: 9 a. m. to 2 p. m., except Sundays and holidays.

Bibliography: Inventar des Archivs des $K$. K. Finanz-Ministeriums, hrg. v. d. Direktion dieses Archivs (Vienna, I9I I, pp. 77).

Fellner-Kretschmayr, Geschichte der Oesterreichischen Zentralverwaltung, three vols. (Vienna, I907).

Three divisions of the Hofkammerarchiv contain materials relating to American history, viz.: Commerz Litorale, containing material of the eighteenth century mainly ; Commerz Kammer, from I807 to 1830 ; Commerz Commission, from 1807 to 1830 .

\section{COMMERZ LITORALE.}

\section{Litorale 540r. Commerz. I 755-r 798.}

No. I22. Austria's declaration of neutrality, June I4, I756, in war between France and England in America.

"Mémoire sur le commerce avec les Isles Françoises en Amérique." Fait en 1756.

Treaty of commerce with France, I798 (use of French ships in American trade).

Litorale 5356. Commerz. 1763-1809.

No. I04. A bundle of reports on the East and West Indies. Mostly concerned with the beginnings of shipping and trade with the East Indies. A report on the ship Città di Trieste, designed in $178 \mathrm{I}$ for the trade in both Indies, is followed by several others, mentioning trading vessels between i $783-1787$.

No. 280. "Vorschläge des Filippo Fabrini, Chur-Pfälzischen Hofrathes, und Präsidenten zu Pisa, enthalten ein Verzeichnis aller Erzeugnisse der Natur und Kunst, so in dem Kayserl. Königl. Erblanden vorhanden, oder nicht vorhanden seyn mögen, mit welchen der Verschleusz [Verkauf] in alle Welt-Theile vormehmlich nach America getrieben werden sollte, und sehen einem Glücks-Haven ganz ähnlich, wo die fehlende, und treffende Numeri untereinander vermischet sind, jene aber diese unendlich übersteigen. Präsident des Hofkommerzienraths : Graf Andler-Witten." Nov. 6, I763. (This is an elaborate report written in Italian.)

"Die Vorschläge des Filippo Fabrini, und sein Gesuch $u m$ das $k$. $k$. Consulat in Toscana betreffend." Nov. 6 , I763.

"Die Aeusserungen des hiesigen Handelsstandes über die Commercialvorschläge des Filippo Fabrini betreffend." Jan. 30, I764.

Votum: "Da also die Sache nur auf Speculationen berulhet, und niemand sich darstellet, Hand an das Werk zu legen, um einige Waaren in die Canarischen Insulen, oder directa nach America zu versenden; so sieht man hier Orten auch noch nicht, was für ein Gebrauch von den Vorschlägen des Filippo Fabrini gemacht werden könne, und man muss sich lediglich auf den vorhinigen allerunterthänigsten Vortrag beziehen. Dass übrigens E. k. k. A. Maj. allerseits erkennet haben, dass einen Consul in Toscana anzustellen, der Zeit nicht diensam, noch anständig sey." 


\section{I776- 7777 .}

Aug. 17, 1776. " America, Project ein Commerce dahin einzuleiten. Christoph Beller, Hauptmann des Fabrischen Regiments, machet den Vorschlag, ihn nach America zu schicken, um alldort bei denen zwischen den Engländern und Colonisten obwaltenden Zwistigkeiten das Commerce zum Vortheil der k. k. Erblande einzuleiten."

$$
\text { i 780-i } 78 \mathrm{I} \text {. }
$$

July 29, 1780 . "America, wegen Verproviantirung der dortigen französischen Besitzungen von Seite der diesseitigen Handelsleuten."

$$
\text { I } 782-1783 \text {. }
$$

Aug. 7, 1783. "Die Dahinsendung des Freiherrn von Beelen zur Beförderung des diesseitigen Handels."

\section{I792-I793.}

Oct. II, I792. "Auswanderung, eigenmächtige, wie sich hiebey zu benehmen."

Oct. 25, I792. "Amerikanische Staaten, Gesuch des Joseph Mussi um das General Consulat in selben."

$$
\text { I } 796 .
$$

Mar. 4, I796. "Die Einleitung eines Consulats allda." Franz von Silbernagel offers plan of consulate. Refused June 30, I796.

$$
\text { I } 80 \mathrm{I}-\mathrm{I} 8 \mathrm{0} 3 \text {. }
$$

Jan., I802. John Lamson appointed American consul, asks for exequatur regium.

Feb., I802. His Majesty grants exequatur.

Oct., I802. William Riggin appears, stating that he was appointed U. S. consul in Triest; request for exequatur.

Nov., i802. Exequatur of John Lamson suspended until explanation can be obtained.

Same date. Reply to Riggin that the matter will have to be cleared up before exequatur can be given.

Jan., I803. Same reply to Riggin's repeated request.

Mar., I803. Action taken to request His Majesty to grant exequatur to William Riggin as successor to Lamson, consul at Triest.

COMMERZ KAMMER. I807-1830.

$$
\text { I8I } 4 \text {. }
$$

Lit. 38. Amerika, dort entdeckte Quecksilber Minen.

$$
\text { I } 8 \text { I } 5 \text {. }
$$

f. I7. "Amerika, dortiges Consulat."

f. 9. "Amerikanische Handelslente un Bewilligung ihrer Handelsbïcher in englischer Sprache führen zur dürfen." 
f. I6. "Steamböthe, deren Einführung vom Grosshändler Perry vorgeschlagen."

f. 5. "Amerika, dass die englische Regierung die Einfuhr der österreichischen Manufakte dorthin untersagt habe."

I8I6.

f. I7. "Amerika, dort zu besetzendes Consulat."

f. 5. "Amerika, Britisches Einfuhrsverboth der Oester. Fabrikate und Manufakte dorthin."

1824 .

f. 22. "Amerikanische Provenienzen, ob die Contumatz Periode nicht abzukürzen wäre?"

I 825 .

f. I6. "Amerika, dortiger Leinwandhandel."

I826.

f. I6. "Abzuschliessender Handelstraktat."

I829.

f. 5. "Amerika. Abgeschlossener Handels- und Schiffahrtstraktat zwischen Preussen und den Hansa-Städten."

f. 5. "Id. Dortiger Handel mit Triest."

f. 5. "Id. Zolltarif und Handel mit England."

f. 5. "Id. Handel mit Oesterreich und Wirkung des dortigen Zolltarifs auf den Handel."

f. I7. "Id. Schwendler zum Consul in Frankfurt ernannt."

f. 22. "Amerikanische Provenienzen, Contumaz gegen dieselben, und Handelstraktat mit."

f. 5. "Amerikanische Congressakte, von dem österreichischen Consulate in N. Y. eingesendete."

f. I6. "Abzuschliessender Handelstraktat mit Amerika."

f. 5. "Ausfall der heuerlichen Getreideernte in Amerika."

f. I6. "Nordamerika. Versuch statt hanfenen Schiffssegeln baumwollene anzuwenden."

f. I7. "J. G. Schwarz, amerikanischer Consul in Wien bittet um das Exequatur regium."

f. 5. "Amerika, dortiger Handelszustand und Bericht des General Consuls in N. Y."

1830.

f. I6. "Amerika, dortige Versuche mit baumwollenen Schiffssegeln."

f. 5. "Amerika, Handelstraktat."

f. I7. "Amerikanischer Consul in Wien, J. G. Schwarz." Exequatur.

f. I6. "Amerikanische Staaten, deren Zustand."

f. I6. "Leuchtthurm bei der Mündung des Delaware aufzustellen." 
f. 5. "Amerika, dortiger Beschluss allen Nationen gegen Reciprocität Schiffahrts- und Handelsbegünstigungen anzutragen."

f. 5. "Id. Bill wegen Handel mit den britischen Kolonien."

f. 5. "Id. Handelstraktat mit England und Dänemark."

f. 5. "Id. Dortige Handelsverordnungen."

f. 31. "Amerikanische Spinnmaschine zu verbessern. Privilegium des Franz Schulters."

f. 5. "Amerika, dortige Getreidepreise."

f. 16. "Schiffahrts- und Handelsreciprocität zwischen Amerika und England."

COMMERZ COMMISSION.

1816.

f. 22. "Amerikanische Provenienzen. Contumaz-Zeit für dieselben."

1821 .

f. 5. "Amerika. Quecksilberverkehr dahin und Stand der dortigen Glasund Wollwarenfabriken."

1824 .

f. 22. "Amerika. Von da kommende Waren sind den Sanitätsanstalten zu unterziehen."

Commerzial Notizen aus New York. Feb. I8, 1824.

1827 .

f. 16. "Nordamerika und Brasilien, abzuschliessender Handelstraktat und Handelsbeförderung dahin."

f. I6. "Amerika, dïrfen spanische Schiffe unter fremder Flagge einstweilen Handel treiben?"

1828 .

f. 22. "Amerikanische Provenienzen, Contumaz gegen dieselben und Handelstraktat mit."

f. i6. "Nordamerikanische und Preussische Flagge, deren Gleichstellung."

f. 33. "Amerikanisch-Swiftsche Tuchscheermaschine zu verbessern; diesfäll. Privilegium des Franz Ludwig.”

\section{IMPERIAL LIBRARY.}

(HOFbirLIOTHEK.)

Location: K. K. Hofburs, Wien I., Josefsplatz I.

Hours: g a. m. to 4 p. m., except on Sundays and holidays.

The Imperial Lilorary contains a good collection of printed books on America srouped as follows: A. Allgemeiner Teil; B. Nordamerika: 1. Literatur; 2. Geographie, Reisen, Einwanderung: 3. Religion, Politik, Geschichte; 4. Verwaltung, Justiz, Indianer: 5. Agrikultur. Handel, Gewerbe. Verkehr; 6. Sanität, Wissenschaften, Statistik; C. Central- und Südamerika, Westindien. 


\section{Codex in Imperial Library.}

12613 (Suppl. 602) ch. XVIII. 77f. "Discours sur la grandeur et importance de la dernière révolution de l'Amérique septentrionale; sur les causes principales qui l'ont déterminée et sur son influence vraisemblable sur l'état politique et sur le commerce des puissances européennes. Codex archetypus ab auctore exaratus multisque lituris, additamentis, etc., exornatus operis pro solvenda quaestione academiae condonati."

\section{ARCHIV DER STADT WIEN.}

Location: In the New Rathaus, fronting on the Franzensring. An imposing Gothic building, completed in 1882 . The archive contains materials from the thirteenth century to the present time. Nothing relating to American history was found in the archive proper; the acta enumerated below are contained in the Stadt Haupt-Registratur, which is under the same directorship.

Hours: Daily except Sundays, 9 a. $\mathrm{m}$. to $2 \mathrm{p}$. $\mathrm{m}$. The privilege of working in the archive nust be secured in advance.

\section{AKTEN DER STADT HAUPT-REGISTRATUR.}

Ad Arch. Z 53es 1913. Betr. Vereinigte Staaten von Nordamerika:

I783. Die nach dem vereinigten Amerika handelnden Vasallen können sich an den k. k. Kommerzialrath Baron von Beelen nach Philadelphia wenden. Hofdekret vom 7. August I783 (Josephinische Gesetzsammlung, 3 Band, VI. Hauptabteilung, Kommerziensachen).

I850. Passwerber für Nordamerika sind auf die Schwierigkeiten der Reise, wenn selbe ohne hinlängliche Geldmittel und Vorbereitung unternommen wird, aufmerksam zu machen und dies sowie die Art, wie der Passwerber seine Subsistenz zu decken gedenkt, in der Passanweisung anzumerken. Normale 42 ex I850.

1852. Vorschrift über Passwerbungen für Amerika. Normale 92 ex I852.

I853. Wiedereinwanderung aus Amerika; solche Gesuche sind in der Regel zurückzuweisen und es ist den Auswanderungsbewerbern mitzuteilen, dass sie durch diesen Schritt jedes Recht auf Wiedereinwanderung und Wiederverlangung der österreichischen Staatsbürgerschaft verlieren. Normale $2 \mathrm{I}$ ex 1853 .

Reiseerlaubnis für Amerika ist nur ausnahmsweise zu erteilen. Normale 137 ex 1853 .

I854. Auswanderungswerber nach Amerika haben Geldmittel auszuweisen. Den Auswanderungsagenten ist eifrig nachzuspüren. Normale 42 ex 1854 .

1857. Das Normale 21 ex 1853 ist wieder aufgehoben und es sind die Gesuche um Wiederaufnahme in den österr. Staatsverband nach den allgemeinen gesetzlichen Bestimmungen zu behandeln. Normale 17 ex 1857 .

I874. Bestallungs-Diplom des General-konsuls der Vereinigten Staaten in Wien P. Sidney-Post. F4-200606, I874.

David M. M. Gregg wird Konsul-der Vereinigten Staaten in Prag. $\mathrm{F}_{4}-6_{41} 82$, I 874 . 
1875. Bekanntgabe jener Klassen von Fremden, welcher die Einwanderung nach den Vereinigten Staaten nicht gestattet ist. Normale 19 ex 1875 .

I881. Verbot der Einfuhr von Schweinen, Schweinefleisch, Speck, und Würsten aus den Vereinigten Staaten. G8-992 I I, I 88I.

1885. Otto Maas wird zum Vice-Generalkonsul ernannt. Normale 89 ex 1885 .

Die Kenntnis des dortigen Auswanderungsgesetzes vom 3/8 I882, nach welchem Verbrechern, blöden, wahnsinnigen, und subsistenzlosen Personen die Landung in Amerika nicht gestattet wird, ist möglichst zu verbreiten, auch ist bei Passbewerbung die Nachweisung der Subsistenznittel zu fordern. Normale 59 ex 1885 .

I886. Auswanderungslustige sind auf die Wertlosigkeit der Fahrkarten des "Stettiner Lloyd" aufmerksam zu machen. Normale 69 ex I 886. 


\section{SALZBURG.}

ARCHIV DER K. K. LANDESREGIERUNG.

Location: In the K. K. Landesregierungsgebäude. Entrance, Mozartplatz. Hours: Week-days, in summer, 9 a. m. to 2 p. m.; in winter, 9 a. m. to I p. m., and 4 to 6 p. m. Permission to use the archive is granted by the director.

Bibliography: Inventar des Landesregierungsarchivs in Salzburg, bearbeitet von den Beamten dieses Archivs im Auftrage des K. K. Ministeriums des Innern, in Inventare Oesterreichischer Landesarchive, III. (Vienna, I9I2, pp. 88).

A. Prinzinger (d. j.), "Die Ansiedlung der Salzburger im Staate Georgien in Nordamerika", in Mitteilungen der Gesellschaft für Salzburger Landeskunde, XXII. Vereinsjahr, pp. I-36 (Salzburg, I882).

A collection of printed materials, described by Prinzinger (pp. I-2), relating to the Salzburgers in America, is to be found in the Bibliothek des Städtischen Museums, and the Studienbibliothek zu Salzburg.

The archive at Salzburg consists of remnants left over after the larger part had been sent to Vienna, forming there the section of the K. u. K. Haus-, Hof- und Staatsarchiv called Das salzburgisch-erzbischöfliche und Domkapitelarchiv. The latter was searched for materials of American history, but nothing was found, nor does the archive in Salzburg contain anything, bearing directly upon American history. For the study of the causes that led up to the large forced emigration of the Protestant Salzburgers in 173I, the Salzburg archive is, however, of very great value. Since there was an important colony of Salzburg emigrants who came to Georgia in 1734 , the causes for their emigration also bear upon American colonial history. For this reason the principal sources in the archive have been enumerated below, and typical entries have been recorded.

AKTEN C. : UNTERBEHÖRDEN.

Fach XXX. Pfleg- und Landgerichte.

Pfleg Werfen. Fach I, resp. 31-63. I675-I775. (Cf. Ia., Repertorium über die Acten von 1675-I775; über alle Bücher, Acten, u. Schriften der Hochfürstlich. Salzburgischen Probstey, und Pfleg Werfen, und des Landgerichts Bischofshof v. J. 1675 in 1775. .)

Fach XXXIII. Domkapitelsches Archiv.

Religions-Sachen, Commissions- u. Straf-Acten, 1675-1775. A few typical headings from among a very large number of acta are cited below, from the years $1729-1731$. 
I729.

Nr. 122. "Des Philipp Gumbers et Consorten 25 Reichsthaler Straf wegen Lesung verbothener Bücher, und Verachtung der Brüderschaften."

I23. "Zur Aufsicht auf die hereinschleichend Lutherische Bücher werden zwei Personen bestimmt."

I 24. "Ein Act von Nr.- über jene Personen die mit Fleischkochen, und Bücherlesen u. d. g. verbrochen haben."

I25. " Ein Act von Nr._- dass die im Glauben verdächtige zur Einschreibung in eine Brüderschaft angehalten werden oder emigriren sollen, wobei die Erklärungen.”

I 26. "Hans Thaner wird wegen einem verdächtigen Buch constituirt."

I73I.

I3I. "Getraud Häuszlin, Baurin zu Hinterholz, ihre zwei Söhne, Georg und Hanns, auch Magdalena Gwehnbergerin werden wegen Litherischen Büchern constituirt."

I34. "Bei Ruppert Eder zu-werden Lutherische Bücher gefunden."

I35. "Hanns Hubers Lutherische Bücher."

140. "Ein Act den von Nürnberg anher gekommen und verdächtig gehaltenen Peter Schwer Bildschnitzers Lehrling betref."

I 47. "Georg Frommers emigrirter Bauers Sohn von Kraxenbiehl alda nunmehr Bürgers zu Regenspurg angehengte Klag wieder das tyrannische Verfahren des hiesigen Hr. Pflegers Roman von Motzl gegen die evangelische, und der hiesigen Emigranten angegebener Beschwerden, durch die Gesandtschaft in Regensburg."

\section{Facil XXXVII. Aufruir- und EMigrations Saciien.}

("Allda fangen die Acten erst vom Jahre iz3I an, weilen zu dieser Zeit sich eigentlich die wegen der Religion entstandene Salzburgische Emigration angesponnen hat, worauf eine sonderbare geheime Deputation gesetzt worden.")

Nr. I. "Ein Schreiben von St. Johans nebst einem Constitut, dass nämlich die Gemeinde ihre in Glaubenssachen erlittene Bedrückungen den Protestantischen Gesandtschaften in Regenspurg vorgetragen, und ihr von dort Schutz sey versprochen worden."

2. "Die Unterthanen sollen, laut Hofrathsbefehl, ihre Beschwerden der ankommenden Commission schriftlich ïbergeben."

3. "Von Hr. Dechant bey der Pfarr anher communicirte Berichts Abschrift, samt einer Copie der Glatubens Bekenntnis der Lutherischen Batuern von St. Veit."

6. "Peter Holnsteiners sive Bernhofers Entweichung."

8. "Verzeichnis der Batern, die vor der Commission sich für evangelisch angegeben haben."

9. "Schreibens Abschrift, dass Hr. Pfleger auch zur Verantwortung über die etwane Commissionaliter eingegebenen Beschwerden gelassen werde."

I . "Schreiben an die Commission wegen gehaltenen Zusammenkïnften." 
13. "Designation der sich in der Hofmarch Bischofshof für evangelisch erklärten Personen."

I4. "Die überschickte Specification der Evangelischen Unterthanen."

15. "Commissions Befehl dass den Unterthanen eine Remedur ihrer Beschwerden erfolgen, sie aber sich friedlich und ohne Rottierung verhalten sollen."

I6. "Bericht dass sich die Werfener Gemeinde friedlich aufzuführen erbiethe."

17. "Copie die Zusammenkünften in der Schwarzach, und dabei gemachten Schluss lutherische Brediger zu überkommen, und einig Deputirte nach Regenspurg zu schicken."

19. "Schreiben wegen verdächtig ins Land schleichenden Personen."

20. "Die von da abmarschierte Bauern Rothen [Rotten], und mitge"nommenes vieles Gold."

21. "Schreiben die von den Bauern ausgesprengte Verhack- und Verlegung der Weg- und Strassen."

22. "Hofraths Befehl die Rothierungen, und offentliche Bredigten der Unterthanen sind Verbothen."

25. "Mathiasen Elmenthallers wider Se. Hochfürstlichen Gnaden ausgestossen vermessene Reden, die Zusammenkünfte der Bauern und Bredigten betreffent."

26. "Einige Radlführer werden allda um Mitternacht gefänglich eingezogen."

27. "Das Pfleggericht St. Johanns beführchtet einen Angriff."

28. "Die Evangelisch sich erklärte Unterthanen sollen specificirter nebst der Beyrückung der Profession eingesandt werden."

29. "An Hochlobl. Hofkammer die Berechnung der mit angefangen. Rebellionstroubeln erloffene [aufgelaufene] Unkosten, dann ein Verzeichnis der evangelisch sich erklärten Unterthanen nebst ihr Steuer sollen eingesendet werden."

30. "Alle Feuerschützen sollen beschrieben, und ihre Gewehr zu Gericht geliefert werden."

31. "Die Einrückung der Kaiserlichen Hilfsvölker, und ihre Verpflegung."

33. "Das General Mandat, und Emigrations Patent ist zu publiciren, und anzuschlagen."

34. "Endliche Erfahrung wegen des Hauptaufwiegler Peter Holnsteiner Entweichung nach Regenspurg, und von dem in der Festung Werfen der Schmiedin zu Hüttau an ihren eingekerkerten Mann geschriebenen Brief."

37. "Was diejenige zu thun, die sich anfangs evangelisch angeben, und "wieder zum katholischen Glauben umschreiben lassen."

39. "Befehl, kraft dessen der Emigrations Termin der Unansessigen wird verlängert auf 8 Tage."

40. "Befehl, dass wegen den Emigranten solle vor ihrer Abfahrt Richtigkeit gepflogen werden."

4I. "Befehl, wie die Passport sollen für die Emigranten eingerichtet "werden."

42. "Der Emigrations Termin wird auf H1. Georgy festgesetzt, und dass die Emigranten bis I 734 ihre Güter von Katholischen nach Belieben können verwalten lassen.." 
44. "Erläuterung über vorhin angesetzten Emigrationstermin und ob die Unterthanen damit zuf rieden, sollen Erfahrungen eingesendet werden."

45. "Wegen den gefangenen Rädlführern sollen eidliche Erfahrungen eingesendet werden."

47. "Die aus Brandenburg angekommene und nun in Verhaft sitzende Elisabeth Kraftin betreffend."

5I. "Die verdächtige Zusammenkunft wird bey Leib- und Lebensstraf verbothen, doch wird jedem unkatholischen Hausvater bewilliget in seinem Haus der Andacht abzuwarten."

52. "Denen zu Salzburg inliegenden Unterthanen solle zur Medizin und andern Nothdurften Geld hinausgeschickt werden."

53. "Den emigrirenden Unterthanen solle in Verkaufung ihrer Habschaften nichts in Weg gelegt werden."

54. "Das Pfleggericht St. Johanns notifizirt dass aldort die Lutherischen Handwerker abgeschafft werden."

55. "Landschaftsbefehl, das Abzugsgeld solle von den Emigranten eingelangt werden."

57. "Die unkatholischen Unterthanen mit Uebung ihres Glaubens abge"wiesen, doch ihnen der freye Auszug gestattet werden."

62. "Jene, da sich zu keiner Religion erklären, sollen constituirt werden."

65. "Was bey den von den Emigranten verlangten Vermögens Beschreibungen zu beobachten."

I 732 .

68. "Des Mathias EImanthallers Bestrafung wegen wider Sr. Hochfürstl. Gnaden ausgestossenen Lästerungen."

7I. "Kammerbefehl. Von den zu Salsburg inhastirten Unterthanen werden Schuld Beschreibungen hieher gesendet, wovon den Weibern Abschrift solle hinaus gegeben werden."

72. "Kammerbefehl, dass den emigrirenden Unterthanen in Vieh- und Getreid Verkauf nichts in Weg zu legen sey."

73. "Ein Solcher, dass der Emigranten Güter mit Bestandlenten, und Käufern versehn und bebaut werden sollen."

78. "Den emigrirenden Unterthanen steht frey ihre Güter in Bestand zu lassen, wie sie wollen."

8I. "Deputationsbefehl, wegen von den Emigranten hinterlassenen Büchern sollen die Häuser visitirt, und die neuen Besitzer davor gewarnt werden."

83. "Deputations-Befehl, dass man den Enigranten den Titel: Evangelisch nicht greben solle."

94. "Verbothener Verkauf aller gedruckten Bücher."

96. “Die PP. [Patres] Capncini sollen die hiesigen Pfarrkinder in Glanbenssachen unterweisen."

99. "Wegen geführlicher Correspondenz sollen die Bothen alle Brief zu Gericht einliefern."

roo. "General Befehl das wiederholte Verboth der Rottirungen enthaltend.".

I02. "Bei den rïckgebliebenen Unterthanen sollen fremde Dienstboten angestellt werlen," 
I03. "Die von den PP. Capucinis als verdächtig angegebenen Personen sollen constituirt werden."

ro6. "Zur Patrol wegen verdächtigen Personen werden vom Schloss täglich 3 Mann ausgesendet."

I08. "Ein Band Correspondenzen den Abmarsch, sowohl der hiesigen als von andern Gerichten anher gebrachten Emigranten."

\section{I733.}

I 6. " Generale, wie in Klagsache wider die abwesende Enigranten zu verfahren sey."

I I7. " Revers der emigrirenden Unterthanen. Jährlicher Aufruhr Strafschilling."

I I8. "Verdächtigen Personen ist ohne Vorwissen der Deportation kein Heuraths Schein zu ertheilen."

I I9. " Das Einstandrecht bey den Emigrantengütern ist aufgehoben."

I734.

142. "Den Beamten ist bey Verlust des Dienstes verbothen die in Glaubenssachen verdächtige Personen zu verdeuthigen, Schenkungen anzunehmen, bei Verbstand [Verpacht] und Erkaufung der Emigrantengüter ungebührende Gelder einzutreiben."

I43. "Peter Strobls zu Stroblhof in der Abtenau Landsverweisung wegen Lutherischen Büchern."

I48. "General Patent vom 26. Aug. I734 die Verkaufung der Emigranten Güter, Eintreibung der Activ. Schulden, dann die Vollmacht v. König v. Preussen ertheilt dem Erich Christoph Edeln vom Ploto für die ins Preussen emigrirte Salzburger betref. Nebst 2 gedruckten Verzeichnissen der Emigranten Güter."

I 735 .

I85. "Bey Abhandlung der Emigranten Güter ist die Tax wie bey den Katholischen einzulegen."

I86. " Die unbewussten Emigrantengelder sollen zu Gericht genommen, und zugewartet werden, bis ein rechtmässiger Ansprecher vorkommt."

$$
1738 .
$$

227. "Mit Abfertigung des Preussischen Hr. Abgeordneten solle mit allem Ernst Richtigkeit gemacht werden."

\section{BAND ZUM XXXVII. FACH.}

Nachstehende Nummern sind in folio gebunden und bestehen von $\mathrm{Nr} .269$ in 292.

269-273. "Zwei Bücher Vermögensbeschreibungen der Emigranten, welche angesessen waren, und im Jahre I 732 ausgezogen sind."

274-277. "Beschreibung der An- und Unangesessenen Personen, die zu emigriren gesonnell, und an der Zahl 4006 sind, diese verlangten im Jahre I73 I auszuziehen." 
"Emigrations-Akten und Schriften" run on to Nr. 35 I, in the year 1764 , which shows that it took over thirty years to settle property and other matters concerned with the expulsion of the Salzburgers.

RAURIS REPERTORIUN DES HOCHFURSTL. LAND- U. BERG-GERICHTS.

1 Band: Religions- und Emigrations-Sachen, I04.

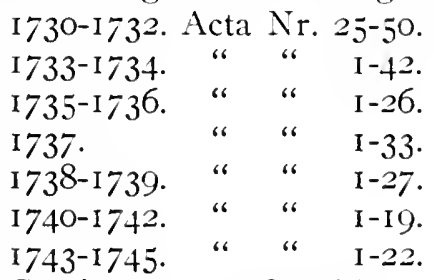

Continuous to 1785 with an occasional item on the Salzburgers.

K. K. HOFKOMMISSION.

I806-I807.

II. 259. Politicum. Regierung.

Auswanderung und Freyzügigkeit, sowohl überhaupt als in specie zwischen Oesterreich and Salzburg, dann Berchtesgaden. In specie :

Manumissionstaxe in Berchtesgaden.

Leibeigenschaftstaxe in Ytter.

Militärpflichtigkcits-Redimirungsgelder gegen Baiern.

Aus- und Einwanderer. Individuen.

II. 260. Politicum. Regierung. I806-I807.

Aus- und Einwandermingstabellen.

III. 139. Camerale. Aus- and Einwanderungen, Abfahrtsgelder. I806-I807. Printed copies of Verordunng ( I805), Circularbefehl ( 1796), Publikandum ( I804), Allsemeine Kundmachung ( I799), etc.

Auswanderungsverbot 30 . März, I774. No emigration permitted without consent, penalty loss of property left behind, punishment of those aiding emigrants.

\section{KATENICH.}

der Jahre 1729, I730, I731.

Contains among a large number of important printed documents, the famous edicts relating to the Salzburgers:

(1) Emigrations I:dikt vom 3I. Oktober, 173I. The edict of expulsion of the Protestant Salzburgers, with original signature of Archbishop Leopold, and H. Cristani ("Hof-Cantzler").

All Protestants that have reached the age of 12 of both sexes compelled to enigrate, those without property within 8 days, those with property of the value of less thin i $50 \mathrm{fl}$. within one month, of $150-500 \mathrm{fl}$. within two months, of over $500 \mathrm{fl}$. within three months, under threat of loss of property and life. 
ab anno I 734 et 1730 inclusive.

General-Patent, Saliburg den 26. August I734.

Vollmacht vor den Legationsrath Edlen von Plotho, umb der in Preussen angesessenen emigrirten Saltzburgern in ihrem vormahligen Vater-Lande linterlassene Vermögen einzufordern, und zu erheben. With :

Edikt des Königs von Preussen, Berlin den 22 Juni, I734. (Making a claim on land owned by emigrant Salzburgers.)

\section{FÜRST-ERZBISCHÖFLICHES CONSISTORIALARCHIV.}

Location: Kapitelgasse 2. Salzburg.

Hours: By arrangement. Permission to use the archive must be obtained from the Consistorialrat.

Documents relating to religious trials; only ecclesiastical affairs concerning the consistory. Secular matters, partly in Vienna, partly in the Landesregierungsarchiv of Salzburg. Every deanery represented; for ecclesiastical affairs much more complete than what is in the Landesregierungsarchiv. 


\section{INNSBRUCK.}

\section{K. K. STAATSARCHIV.}

Location: Central station, Statthalterei, Herrengasse.

Hours: Daily except Sundays and holidays, 8 a. m. to I p. m., and 3 to 5 p. $\mathrm{m}$.

This is the oldest and second largest archive in Austria. In the economic history of Tyrol, America has been an important factor in so far as the monopoly in silver-mining held for a long time by this province was destroyed by the discovery of silver in America, principally in Mexico. It is conjectured, that Tyrolese miners (Knappen) were sent to Mexico in the earliest period, to work the mines. The history of the control acquired by the Fuggers over the Tyrolese silver mines can be studied in this archive. The following works on the subject were prepared with the aid of materials found in this archive:

Max Jansen, Studien zur Fuggergeschichte.

I. Heft: Die Anfänge der Fugger, bis 1494, von Max Jansen (Leipzig, 1907).

II. Heft: Hans Fugger und die Kunst, I53I-I598, von Geo. Lill (Leipzig, 1908).

III. Heft: Jakob Fugger der Reiche: sein Eintritt in die Kaufmamnsschaft und scine ersten Unternehmungen, von Max Jansen (Leipzig. I9I0).

Cf. also, Konrad Hacbler, Die ïberseeischen Unternehmungen der Welser and ihrer Gesellschafter (Leipzig, 1903).

\section{BAIRISCHES ARCHIV.}

IV. Hauptarteilung, KL. II.

Sekt. A. Aus- und Einwanderungen und Vermögens-Ex- und Importatio11en. II. Acta Specialia, No. 2.

Auswanderungs- und Vermögens- Exportations-Bewilligungen.

Alphabetisches Verzeichnis über die Auswanderungs- und VermögensExportations-Bewilligungen.

\section{DIALERSCHE NORMALIEN-SAMMLUNG.}

Nos. 5233, 5332, 5416, 5436, 5656, 5775, 6445, 6446. (Answanderung nach Anerika.)

Scattered acta mostly on consular business. $1850-1857$.

Konsulats-Errichtung, i85I. Bundle of acta.

\section{K. K. STATTHALTEREI-ARCHIV.}

Aus- und Einwanderungstabellen in den Archiven der Tyrolischen Kreisämter, Inıst, Schwatz, Bruneck, Bozen, Trient (ital. Tyrol), Rovereto, Bregenz (für Vorarlberg). 
Annual statistics for I8I5-I849 in fascicle "Publica". (See Repertorium under the rubric "Auswanderung".) ${ }^{1}$

The lists from I850 on are contained in the "Registraturen der Bezirksämter", and from I868 (Sept. I) in the "Bezirkshauptmannschaften". There is a special rubric, "Auswanderung nach Amerika" (see Repertorien).

\section{FERDINANDEUM.}

Location: Museumstrasse.

Hours: Daily except Sunday, 9 a. m. to 5 p. m. Open also Sunday mornings.

The history of Tyrolese enigration to America since I850 can best be studied in the library of the Tiroler Landes-Museum Ferdinandeum. An excellent subject-catalogue gives precisely every item on America in the numerous local or provincial newspapers, some of which have long ago ceased publication. Some few examples of titles of articles will illustrate; they are not exhaustive :

In the Bothe fïr Tirol und Vorarlberg (then a daily, now a weekly paper), there are over 40 articles on America (North and South) between the years 1850 and I89I. E. g.:

I850, July 3I, Aug. 2. "Korrespondenz eines jungen Innsbruckers aus Amerika an seine Eltern."

I85 I, Dec. 24, 27, 29, 30, 3I. " Brief eines Vorarlberger Missions Priesters aus Nord-Amerika." St. Anton bei Milwaukee, Wis., Aug. I 5, I 85 I.

1854, Jan. 30. "Auswanderer aus dem Oberinnthal nach Amerika."

I866, Oct. 23. Monastery school founded by Tyrolese-American Franciscans, Louisville, $\mathrm{Ky}$.

I869, Jan. 21, 25, 28, Mar. I0, 24, Oct. I I. "Die neue Tyroler Ansiedelung in Virginien, Alpenburg, Henrico Co."

I874, Oct. I 4. "Tirolische Colonien in Amerika " (including one in Forestville, Mich., others in Brazil).

Nov. 26, Dec. 2. "Tirol in der Fremde."

I884, Dec. 23. "Südtirolische Auswanderer." An advertisement is mentioned of a Genoese immigration agency, exhibiting a woman with a barefooted child holding her hand. The woman's face beams at the sight of a beautiful transatlantic steamer. "Whither is the ship going, mother?" asks the poor little one. "To America, my child", is the answer. Warning against such methods of advertising.

I885, Feb. 9. "Die Odyssee einer Auswanderungs-Gesellschaft." Party of 29 from southern Tyrol embark for Buenos Aires. Cholera breaks out on board, what remained of the party is forced to return.

\footnotetext{
${ }^{1}$ Though the destination is given in the case of every emigrant, and the cause stated, there is a striking recurrence of the same destination and cause, viz.-Bavaria for the former, and "vortheilhafte Verehelichung" for the latter. The suspicion arises, that when young persons of either sex wished to emigrate, they found it most convenient and effective to give the neighboring country as their destination, and for the cause, bettering their condition by marriage. America very rarely appears as the destination named.
} 
I886, May i . "Florida, das amerikanische Eden." (Very unfavorable report.)

Dec. 2. Auswanderungsstatistik. Concerning emigration from Trent, 1870-1885. Out of population of 12,100 , it is reported, 716 persons emigrated: i 69 went to North, $5+7$ to South America.

Tiroler Schiïten-Zeitung: I85I, Dec. 26; I852, June I. (Increase of emigration.)

Volks- und Schiitzenzeitung: I853, Nov. 23. (Plea to assist emigrants.)

I 855 , June II, I3. (Texas.)

I862, Feb. 19, 21, 24. "Aus dem Tagebuch eines Tiroler-Frejwilligen bei der Armee von Nordamerika."

Oesterreichische Wochenschrift für Wissenschaft, Kunst u. öffentliches Leben (Vienna, I863), pp. 296-304, article by G. A. Schimmer, giving statistics of emigration from I820 to I86I. Government restrictions, and existence of fertile and minhabited areas in interior of Austria-Hungary, are causes of slight emigration. Overpopulation only in Bohemia. After Bohemia, Tyrol has furnished largest contingent of emigrants (1820-186I).

Rechenschafts-Bcricht des Tirolischen Landes-Ausschusses fïr das Jahr I889 (Innsbruck, 1890), pp. I72-173. "Errichtung eines Auswanderer-Auskunftsbureaus."

Innsbrucker Zcitung: I850, Oct. 8. Briefe. (Unfavorable.)

I 852 , Nov. 26. A group of gold-scekers, their misfortunes.

Tiroler Stimmen, fïr Gott, Kaiser, und Vaterland: 1866, Apr. 24. "Brief aus Nordamerika" (Cincinnati).

ı 868, Nov. 30. "Zum Aufruf d. Hrn. Ritters von Alpenburg (Virginien) betreff. Auswanderung."

I860, Feb. 3. "Aus u. über Amerika" (feuilleton), letter from Chicago.

Feb. 27. "Noch ein Wort über Auswanderung nach Virginien."

Mar. 9, Io. "Erlebnisse eines Auswanderers." Atchison, Kan.

Neuc Tiroler Stimmen: I897, Oct. I6. "Aus den Goldlande. Briefe aus Alaska."

I 898, May I 2, Oct. 7. More letters concerning Alaska. 


\section{INDEX.}

Aarau, aid to emigrants, ir6; Registratur in, Albinda, see Albinola I40; state archive in, iv, I 40

Aarburg, 45

Aargau, 2, 86, I40-I 43, I 53, I54; aid to emigrants, I4O-I 43 ; Berichtliche und Statistische Notizen ïber Auswanderung vom Kanton, I 43 ; bills, I 42 ; cantonal library, I 40 ; citizenship, I42; commercial laws, I4I; conference of I 846 , i 6 ; consul Wolff, complaint against, 69; death certificates, I4I ; emigration, 64. 75, I 40-I43, I53; emigration agents, I40; emigration bureau, I 42 ; emigration proposals, II7; emigration regulations, 48, 6I, I40, I4I ; emigration statistics, 64,75 , I42, 143; emigration tax, 140; emigration to Utah, I +3 ; emigration via France, $\mathrm{I} 4 \mathrm{I}$; insurance of wife's property, IfI ; loss of citizen and land rights, I40; Rechenschaftsberichte des Kleinen Raths, I43; Smaller Council, records of, I40-I43; state archive vi, I40; warrants for criminals, 142

Abschieds-Bücher, see Fribourg

Abschreckende Rilation von Philadelphia, Eine, see Rottenbiihler

Acapulco, destroyed by earthquake, 220, 22 I

Ackermann, Anna and Franz, emigration of, 89

Acta Conventus Ecclesiastici, see Akten des Kirchenkonvents

Act of Mediation, 2,9

Adams, Henry, Life of Gallatin, I80

Arlams, John, minister to England, 226, 227 ; minister to the Netherlands, 223-225; transfer of University of Geneva, proposed by, 184

Adams, John Quincy, andience with, I9o; enlogy of Iafayette, 198, 219; messages, I92, I94; pen-portrait of, 206; proposed for President, 190

Adet, Pierre Auguste, minister to U. S., I\&o

Adventure, frigate, 217

Aebnit, Peter Im, arrest, 47 ; attempt to escape, 5. 57 ; Bern refuses to surrender estate, $5 \mathrm{I}$; deportation, 47; emigrates to Carolina, 45. 56; emigration atgent. 47 ; cxamination of, 55, 56; extrallition of, 38,39 ; imprisoned, 57 ; killed, 57 ; persecution of, 47,56 ; return from Carolina, 47,56 ; trial, 4 ; visit to English minister, 56

Africa, Swiss emigration to, $1+2$

Agassiz, Louis, I 49

. Agricoltore Ticinese, $l$ ', article in, 148

.4kten des Kirchenkondents, Bern, 50-52, 58

Alabama. Swiss settlements in, 70

Alaska, letters from, 267

Albany, 196; deportation of lluber family, 22

Albinola, Giovanni, deportation of, 208, 212, 213 , 215

Alexander I., Russian emperor, ukase of, Igo

Alexandria, Egypt, emigration from Bern to, 69

Alexandria, Va., Cazenova, consul in, 24; Swiss consulate in, 7,64

Alfoltern, 23

Algeria, American consul in, 25I ; Swiss emigration to, $27,96,98$, I I 6, I 28

Algerian corsairs, Portuguese fleet against, 231

Allemann. 156

Allen, John, supply for U. S. army, 236

Allentown, Pa., 90

Allgemein Eidgenössische Bücher, 59

Almanaco del Popolo Ticinese, article in, I 47

Alpena, W. Va., Swiss settlement, 7I

Alpenburg, Va., Tyrolese settlement, 266, 267

Alpina, N.Y., colony of, 173; Notice sur Alpina. I73; Swiss settlers in, 161

Alpnacht, 86 ; letters from, 86 ; list of emigrants from, 87

Alsace, I3, 64

Alte und Neue IVelt, article in, 85

Alter u. verbesserter Schreib-Kalender, 29

Altmann, Professor, 58

Altorf (Uri), cantonal archive in, $8_{3}$

Altorf (Zurich), 20

America. discovery of, 221; enigration from Austria. 228, 235, 247; enrigration from Switzerland, 6, 7, 25, 26, 48, I41; Erdbeschreibung won ganz Amerika, i88; learned societies, I95; newspapers, I90; papers concerning, 4 I, 5 I $, 78,84,108$, I I 7, I 28, I 4 I, I 56 ; Russian colonies, 228; securities, 53: Sichere Nachricht aus America, 30; Sur la Population de l'Amériqui. 5I ; Swiss colonies, 4 ; ; trials relating to, 19; Tyrolese colonies, 266; Wunderbare Nachricht ans America, 72

Americana, new sect in Italy, 248

American Historical Revici', articles in, 7, 9. $55,175.186,187$

Americani Cacciatori, 248,249

American P'hilosophical Society, 195

American Revolutionary War, \&, 218-22.4. 238 . 2.10, 246, 256; Adams, minister to the Nethcrlands, 22.3. 224: alliance with Prussia. rumor of, 22I: American lrafts accepted in Spain and France, 223: American privateer Conyngham, 219; American ships with supplies leave french port, 218 : capture of New York, 218; commercial relations witl lirance, $220-222$; commercial relations witl the Netherlands, 222; commercial treaty with the Netherlands, 222. 
224; complaint of insurgents to Austrian minister in France, 219: correspondence of Howe with Secretary of State, 222 ; debates in Parliament, 219, 224; desertion, 223; Discours sur la grandeur et importance de la révolution, 256; England complains of supplies on Dutcl ships, 9, 2I7, 2IS, 220; England gives up hope of conquering the colonies, 222 ; England proposes to Austria to reject American emissaries, 2 I9; English peace plans, 22I, 222; English secret correspondence with colonies, 222 ; d'Estaing's arrival with French fleet, 22I ; evacuation of Boston, 2I8; evacuation of two Delaware forts, 22I; France favors American cause, 219; Franklin appointed minister to France, 222; Franklin in France, 220; French capture English possession on Hudson Bay, 224; French opinion, 218; French law against sale of American prizes, 219; French officers taken prisoners, 2I9; French secret commercial relations with English insurgents, 2r8; French ships with supplies land in Boston, 220; French subsidies, $22 \mathrm{I}$; Lord G. Germain's resignation, 224: grievances with England, 2I8; increase in population, 218; invasion of West Florida, 22I; Lafayette, 2I9; Laurens, deputy to France, 223 ; Lee arrives in Vienna, 22I ; Lisbon port closed to English-American ships, 219; loan in France, 22I, 223; loan in the Netherlands, 223, 224 ; mission of emissary to Berlin and Copenhagen, 223: mission of Gerard to America, 22 I ; peace debated in Parliament, 224; Pigott arrives with fleet in New York, 224; Portuguese prizes, 220; prizes of American privateers, 59, 219, 220, 224, 228, 232,235 ; proposals to send minister to Austria, 220; Russian-Prussian mediation, rumor of, 222; Scottish troops against English colonies, 2 I8; secret trading by way of St. Eustatius, 9, 2I7, 218, 220; seizure of American ship by English in Lisbon port, 220; Spain releases American privateers, 219; Spanish opinion, 219, 220; subsidies, $22 \mathrm{I}$; subsidy treaty between England, Prussia and Russia, 218; surrender of Cornwallis, 223, 246; treaty with France, 22 I, 222 Amerika, ship, 233

Amcrika, Die Bezichungen Oesterreichs zu, see Schlitter, Dr. Hanns

Amerikanische Gesellschaft zur Verbesserung des Zustandes und zur Bekehrung der Juden, $25^{\circ}$

Amerikanischer Wegweiser, see Ochs, Johann Rudolff

Amherst, Society of Natural History, I92

Amsterdam, 99; commerce with EnglishAmerican colonies, 222 ; complaint of Swiss council, I57; complaint respecting Anabaptists, 37 ; East India Co., 37 ; emigration measures, 79, I57, I7I intervention of, 37 ; Jean Noblet, I78; letters from, III, I79;
Swiss consul looks after emigrants, 6I, I4I ; synod, 58; transportation rates, $\mathbf{I} 28$

Antliche Sammlung der Bundesgesetze, 7, 69

Anabaptists, 3, I5, 23, 27, 36, 37, 38, 4I, 50, 63, 72

Andelfingen, 22

Andermatt, Joseph, emigration of, 87

Andler-Witten, Count, 252

Anekli, Ferdinando Antonio, 205

Angliombi [Aglionby], English envoy, 37

Anhalt-Zerbst, Prince von, recruiting for England, 224

Annalcn der Verbreitung des Glaubens, 84

Anne, Qucen. letters to, 72

Anspach contingent, see Army, British

Anthracite coal, I99

Antilles, I79; Spain fears English aggression against, 229; see also West Indies, and names of islands

Antrag zur Aufnahme schweizerischer Colonisten in Texas, 80

Antwerp, free transportation of baggage to, I53; Swiss consulate, 92 ; Swiss emigration via, 135

Anzeiger fïr Schweizerische Geschichte, articles in, I3, 27, 33, 83, 89

Appenzell, I, 2; emigration to Carolina, I8

Appenzell ausser Rhoden, I27; Amtsblätter des Kantons, I27; citizenship, I26; conference of 1846, I16; emigration, 62, I27 ; Rechenschaftsbcrichte des Regicrungsrats an den Kantonsrat, I27

Appenzell inner Rhoden, I26; cantonal archive, iv, I26; citizenship, I26; emigration, 126

Archivalische Zeitschrift, article in, IOI

Archivos de l'Histoire de France, see Langlois, Ch. V.

Archiv für Schweizerische Geschichte, article in, 100

Arenenberg, archive of the castle, I44

Argentina, I28; Swiss emigration to, 69, I48, I56; Swiss consulate, 26; see also Buenos Aires; La Plata states

Argentini, Felice, deportation of, 207, 208, 2I I, 215

Arkansas, Catholic missions in, 85 ; Swiss settlement in, 70

Arlesheim, 78

Army, British, Anspach contingent, 9, 238, 239, 240 ; Austrian troops, 9, 223, 224, 240; Danish troops, 238; German troops, 220, 238; Hanau troops, 239, 240; Hanover troops, 239 ; Hesse-Waldeck troops, 239, 240 ; Prussian troops, 238; Scottish troops, 2I8; recruiting for, $52,172,224,238,239,240$

Arnay, A. M. d', emigrates to Santo Domingo, 72

Asheville, N. C.. Swiss settlement, 7I

Asia Minor, Swiss emigration to, 69

Atchison, Kan., 267

Aubert, H. V., article by, I84

Audience du Comte, sce Neuchâtel

Audiences Générales, sce Neuchâtel

Augusta, Ga., 204

Australia, Swiss emigration to, 69 
Austria, American emissaries to, 219; American frigate used as model by, I1, 242, 243; American officers in Austrian service, 240; American vessels in port of, $24 I, 244$; archives of, see Innsbruck, Salzburg, Tyrol, Vienna; Austria as it Is, I I Berichte des ersten Agenten Oesterreichs in den Vereinigten Staaten von Amerika, 8, I86; Beziehungen Oesterreichs zu den Vereinigten Staaten, 8, I86, 221 ; Böcker, American consul general in, 25, 67, 84, 157; commercial relations with America, I88, I9I, 222. $224,233,236,254$; commercial relations with France, 252; commercial treaty with U. S., 9, I0, I86, I87, I89, I92, I93, 209. 225, 226, 244, 246, 250, 254 ; complaint to England over St. Eustatius affair, 226; convention between U. S. and, I96: deportation, 215; discrimination against American ships, 192, 194. 237; duty on Austrian wines, I95; emigration agents, $242,247,257$; emigration laws, 9, I I, 25, I88, 256 ; emigration licenses, 249,250 ; emigration to America, 8, I I, I88, 225, 228, 246-248. $250,25 \mathrm{I}, 263,265$; emigration to Brazil, 249, 250; emigration to Mexico, 24I : emigration to Spain, 248: emigration to Texas, 25I, 267; English ships in Austrian ports, 219: expeditions to America, 244, 245; extradition treaty with U. S., II, 2I4; Geschichte der Oesterrichischen Zentralverwaltwng, 252; military passes, 243; Mühlenberg. American minister to, Io, I99. 208. 209, 2 I0, 216; neutrality of, 252; Oesterreich von 18.48-1860, 247; Ocsterreichische $\mathrm{H}^{\circ} \mathrm{O}-$ chenschrift für IVissenschaft, cited, 267; ports closed to American flag. 234; ports reopened, 235; position on slavery, I95; prevents Austrians from joining English troops, 9, 223, 224, 238, 239, 240 ; readmission of emigrants, 243,256 ; recruiting for America, 227; steamship line to America, 244 ; stcamship line to the Orient, I89; supplies for French possessions, 223, 230, 253; trade in salt, 239; warships, 243, 245; s' ' also Bcelen-Bertholff: Hülsemann; Inmsbruck; Joseph II.; Lederer; Nareschal ; Metterniclı; Salzburg; Stürmer; Tyrol; Vienna

Auscianderungs Zeitung, 68

Aventure, frigate, 217

Avisblatt, 45,46

Bache, Alexander Dallas, 201

Bächthold, Martin (convict), and family, enigration of, 124

Baden (county), emigration laws, 58, I to

Baden (ducliy), cmigration decrees, I52; emigration from, 67, I I 6, 235

Baden (grandduchy), petition of Swiss in, 63

Baden (margraviate), list of Swiss emigrants to, 13

Bader, G., emigration of, 23

Paechli, Kaspar and family, petition of, I 42 Bättiger, Benedikt, emigration of. of

Bahama Islands, English occupation of, 225
Bahia, Swiss emigration to, I 8

Baltimore, I20, I92, 208, 209

Bancroft, George, History of the United States, 72

Bandtli, 8o

Bank, U. S., io6-108

Banking Act, N. Y., 202

Banking system and banks, 202, 203, 204, 206, 209, 2 II

Banks, Henry, letter from, I8I

Baptists, 27; see also Anabaptists

Bär, return from Pennsylvania of, 22

Baraga, Bishop Friedrich, Indian missionary, I I, $25 \mathrm{I}$; letter from. 84

Barbe, T., emigration agency, 32, I I 8 , I55

Bargnani, Alessandro, deportation of, 207,208 , $209,211,215,216$

Barlow, Joel, poem of, 227

Baron, Antoine, cantonal archivist, I 59

Barrozo vs. Torlade, I95

Bartlome, Johannes, emigration of, 43

Barzizza, Count Philippo Ignazio, land claim of, I92, I93, I94

Basel-Landschaft, information concerning cantomal archive, vi, I 2 I

Basel-Stadt, I, 2, 50, 5I, I7 I : aid to emigrants, IOI, I07, II3, II6, II7, II8; American consulate in, I I0, I53; Anabaptist New Testament printed at, 37; Armen-Seckel, I05; cantonal archive, vi, vii, I, 4, 5, IOI-I 20 ; circular letter, convicts to America. II8; conference of 1846 , I16; Department of Commerce and Agriculture on emigration. I I9; deportation of Hanhart, 23: Dreizehnerrat, IOI : emigration, $3,22,63,79$, IOI-I 20 : emigration agencies, 92, I02, I05, II7 IIS, II9, 120, I23, I42; emigration laws, IOI, I02, I04, 105, 106, 107, 108, 109, I I I, I I 3, I I 4. I 15, I 16, 117 , I18, I20; emigration of minors, 107. I I5; emigration statistics, I03, II2, II 4, I I5, I 19 ; emigration tax, 102, 103, 104, 105, 107, IO9. IIO, II2, II3. IIt; emigration to Bahia, I 18 ; emigration to Buenos Aires, I 15 ; emigration to Carolina, 39, IOI, 102, IO3, IO4, I06, I09, II0. II2; emigration to New Orleans, II6; emigration to Nova Scotia, I06: emigration to Pennsylvania, I03, I04, I06, I07, 1 IO, I I 2 ; emigration to Spain, I07; cmigration to Surinam, II ; emigration to Texas, II 6 ; emigration to Uruguav. I 18 ; emigration to Virginia, I07: emigration via France, II5: Geschichle der Stadt und Landschaft Basel, I I 3 : Handel und Industrie der Stadt Basel, I3 ; Huber arrested, 46. 5.5. 56: Kennan's advertising scheme, 1 I8; Kleiner Rat records concerning emigration, I01-108; land commission on emigration, I07; newspapers on emigration, 48 : police department on emigration, 47 , I Is, I 9 ; provisions for children of cmigrants, 102, I05-IOK; release of emigrants from serfolom, 112, I 13; Repertorium des Staatsarchiz's, IOI ; Schweizerisches Wirtschaftsarchiv, IOI

Basil. Ohio, Swiss settlement, 7 I

Pasler, N. J., Swiss consul in Madison, Ind., 67 
Batavian colonies, English occupation of, 233, 234

Baudin, Adm. Charles, negotiations with the Mexican government, 203; proclamation of, 202

Baumgardner, Pa., Swiss settlement at, 7 I

Baumgarten, emigration agency, 97, i 8

Baumgartner, Andreas, Ein Besuch in Neu Glarus, 94

Bavaria, emigration from, 67 ; emigration to, 266

Bayard, James A., 235

Beacons, 246

Beck and Herzog, emigration bureau, I I7, I I8

Beda, Abbot, letter to, I29

Beelen-Bertholff, Baron de, Belgian agent, 8, 9, $240,253,256$; reports of, 8 , I87

Beerli, Dr. H., article by, IzIn.

Belgiojoso, Count Barbiano de, plenipotentiary to Brussels, I87

Belgium, I96, 204; commerce with America, I87; emigration, 67; emigration law, 92 ; emigration via, 92, I54, I58; railroads, Io; Railroads in Belgium, 206; see also Netherlands

Bell County, Ky., Swiss emigration to, I29

Beller, Christoph, conimercial scheme of, 9, 253

Bellinzona, cantonal archive of Canton Ticino. I47

Belmont, August, letter of, 2 I 6

Benedictines, 5, 84, 85, 87

Bencke and Pfister, $24 \mathrm{I}$

Benton, Thomas H., 206

Benziger, J. C., article by, 8.4

Benzinger, $\mathrm{Pa}$., Swiss settlement at, $7 \mathrm{I}$

Benzoni, Cesare, deportation of, 215

Berchtesgaden, emigration from, 263; taxation in, 263

Bericht und Anleitung betr. die verschiedenen Reiscrouten, II 8

Berlin, I68; American commercial emissary to, 223

Bern, I, 2, 25, 86, 93, I7 1 ; aid to returning emigrants, 22, 45, 54; American legation, archives of, vi, $6,7,33,75-77$; Amsterdam intervention rejected, 37 ; approval of colonial scheme, 3,40; articles on Carolina forbidden, 45,48 ; bibliography, 33 ; cantonal archive, vi, vii, 33-63; cantonal library, $8 \mathrm{I}$; census, first, 5I; children not permitted to emigrate, 47 ; circular letter concerning Bolivar, 86; city library, 71-75; commission investigates emigration, 44, 5I; complaint against confiscation of goods, 59; conference of 1846 , i 6 ; co-operation of Ratsherren with Ritter, 3 ; correspondence of the Quatre Ministraux, 73; deportation of paupers and criminals, 43, 6I; Diplomatisches Departement, papers, 60-6I ; Direktion des Innern, papers, 6I; Ehemaliges Fürstbisch. Baselsches Archiv, 63; emigration, a cantonal question, 62,63 ; emigration agencies, 48, 68; emigration causes, 4, 60-62; emigration fever, $3,43,44,46,47,55$; emigration from, $3,4,5,33-76$; emigration laws, 33, 35-38, 4I, 44-50, 55, 57, 59, 6I, 62, $64-66,68$; emigration lists, 40,53 ; emigra- tion tax, 39, 40-48, 54, 61-63; emigration to California, 68; enigration to Carolina, 20, $34-36,3^{8}, 39,42-49,54-57$; emigration to Central America, 69; emigration to Danzig, $4 I$; emigration to East Indies, 69 ; emigration to France, 69; emigration to French colonies, 69; emigration to Georgia, 45, 46; emigration to Hungary, 69; Evangelische und Drey-Oerthische Abscheiden, 58-60; Geheimes Missivenbuch, 48; government assists emigration, 4I, 43; government declines Gasser's appeal, 50; government interested in lightning-rod, 52; Grosse Rat forbids cmigration, 47; Grosse Rat rejects England's deportation scheme, 43; Grütli Verein, colonization scheme, 76 ; inheritance dispute with France, 59; inheritance dispute with Holland, 38 ; jurisdiction dispute, 38 ; Justiz Rath, Akten des, 6I, 62 ; Kirchenkonvent, Akten des, 5 I, 52, 58; Kirchenkonvent favors aid to churches in Pennsylvania, 50; Klein Thurn-Buch der Stadt Bern, 56, 57; land rights imperilled by emigration, 33, 35, 40, 4I, 47, 50, 6I ; MandatenBuch, 33-36, 73; Manual der Recrouten Kammer der Stadt, 53; Manual der Täufer Kammer, 53, 54; Mississippi investments, failure of, 53 ; persecution of emigrants to Carolina, 39; persecution of recruiting agents, 52 ; plans to assist poor people, 55 ; police department on emigration, $23,24,46$, 47 ; printed circulars against emigration to Carolina, 47 ; proposals concerning colony of Red River, I72; purchase of American securities, 52 ; purchase of land in America, 4I ; Raths-Manuale der Stadt, 3, 4, 40-54, I3I ; redemptioner system, 6I, 62; religious books for emigrants, 40 ; religious permitted to emigrate, $4 \mathrm{I}$; reply to New York synod. 52 ; reports on Carolina, 43, 46; report on Prussian agents, 22 ; Responsa Prudentum, 55; Säckelschreiber Protocolle, 54, 55; sale of English securities, 53; synod in favor of Gasser's appeal, 50; Teutsche Missiven Buch der Stadt, 36-40; Thurn-Buch der Stadt, 4, 5, 55, 56, Vaud under authority of canton, I59; see also Vorort, Bern

Berne, Ind., Swiss settlement, 7o

Berne, Mich., Swiss settlement, 70

Berne, N. Y., Swiss settlement, 7 I

Berne, Ohio, Swiss settlement, 7I

Berne, Pa., Swiss settlement, 7 I

Berner Monatschrift, article in, 73

Bernese Oberland, see Oberland, Bernese

Bernhard, 2 I 2

Bernhard, Duke, of Saxe-Weimar, Reise nach Nordamerika, I I, 244

Bernhart, emigration of, 49

Bernhofer, 259

Bernstadt, colony in Kentucky, 69, 70

Berrien, John M., U. S. Senator, on abuse in naturalization, 2 I 3

Bersinger, of Weyach, complaint against, I9

Bersinger, Margaretta, death in Pennsylvania, 22 
Bertha, Quecn, of Burgundy, grant to the abbey of Payerne, I6I; will of, 150

Berthier, Marshal Alexandre, letter concerning Huguenin, I71; Prince of Neuclıâtel, 166

Bertoni, Brenno, article by, 148

Beza, Theodore, 184

Bezichungen Oesterrcichs zu den Vereinigten Staaten, see Schlitter, Dr. Hanns

Bible, Anabaptist New Testament, 37, 38; sent to Pennsylvania, 15

Bibliographie Nationale Suisse, 6

Biehl, Pa., Swiss settlement, $7 \mathbf{I}$

Bientz, Leonhard and Rudolf, examination of, 105

Bigamy, 77

Bilbao, 219

Billikon, emigration from, 20

Bills of lading, I 19

Bischofshof, 258,260

Bishops, Catholic, administration in America, 251

Biveleux, Antoine, president of the Central Committee, 179

Blasenberg, fortress, 238

Bleuler, Elisabeth, 22

Blockades, 200, 201, 202, 204, 216, 233, 235

Blonay, I6I

Blumer, W., letter from, 90

Board of health, 255; sce also Quarantine

Bodenstein, Dr. Gustav, vii

Böcker, J. G., American consul general, 25, 67, 84,157

Böhm, Constantin Edler von, Dic Handschriften des $K$. u. K. Hans-, Hof-, und Staatsarchivs, 186, 216

Boerlis, Barbara, III

Böttstein, deportation of undesirables from, i IS

Bohemia, II ; emigration, II, 250; over-population, 267

Bohni, Eva, I03; see also Joggi Bohni

Bolivar, S. A., circular letter of Bern concerning, 86

Bolivar, Gen. Simón, 190

Bolivia, 201

Bologna, Amerikanische Gesellschaft in, 248

Bonaparte, Jerome, 216

Bonaparte, Joseph, 23, 190, 195, 208, 237

Bonaparte, Napoleon, 2 ; at St. Helena, 208

Bonn, 250

Bontà, Emilio, article by, 147

Boppelsen, 20

Borck, commercial house in Amsterdam, 217

Borgeaud, Prof. Charles, Historie de l'Université de Gencive, 184

Bornenann, Friedrich Wilhelm, emigration agent, $I 1,25$ I

Borsieri, Pietro, deportation of, 215

Boston, 197, 208, 220; charitable institution in, 27, evacuation of, 218

Bote der Urschweiz, 87

Bathe fïr Tirol und Vorarlberg, articles in, 266 , 267

Boundary disputes, 190, 196, 201, 203, 224, 225. $226,230,233,234$

Bounties, 79

Bouquet, Col. Henry, I 49,162
Bourgognc, shipwreck of the, 8 I

Boutell, Han. Henry S., iii

Boxborough, 59

Boycotting, 254

Boyd, John J., consular agent, 200

Bozen, 265

Bozzachi, J. Karl, 21 I

Braditsch, 205

Brahm, Licut.-Col. Ferdinand de, in American army, 240

Brandenburg (Prussia), 216; Swiss emigration to, 40,72

Bratteler, agent, persecution of, 49, I I 3

Brazil, 79, 82, 84, I28, I 32, I56, 207 ; Austrian expedition, 242, 243; Conta-Gallo, I 47 ; cession of part to France, 233; conference concerning Swiss colonists in, 86; declaration of independence, 157 : emigration, Austrian, 249, 250; emigration, Swiss, 24, 27, 60, 69, 80, $86,96124,129,132,138,144,146,152,155$, 157, I 58, 236; fleet, Franco-Spanish, 233; fleet, Portuguese, 231, 232 ; fleet destroyed, 233 ; manuscript concerning, 82 ; NouvelleFribourg, colony, I 47 ; prince of, 227-229. $23 \mathrm{I}, 232$; princess of, $220,228,230-234$; resolution, 189, 232; seizure of French frigate, 230 ; Stürmer, minister, 237 ; Swiss consulate, 26; Swiss troops for the court of, 236; treaty with Portugal, I57; treaty with U. S., 255; Tyrolese colonies, 266; vice-governor, return of, 233

Brechbïhl, teacher, persecution of, 38

Bregenz, 265

Brei, Christ., and family, emigration to Tennessee, I34. I35

Breisgau, emigration from, 235

Breitenbach, 98

Breitenstein, Hans Heinrich, petition of, Ior

Bremen, emigration bureat at, 96 , I54; trip to N. Y. in nine days, 119

Bremen, Ind., Swiss settlement, zo

Bremerleh, 240

Brest, Franco-Spanish fleet leaves, 233

Bridel, Dean, Le Conscriatcur Suisse, 161

Britschgi, Alois, letter to, 86

Brodbecks, Pa., Swiss settlement, 7I

Broglio, depopulated by emigration, $1+8$

Brontallo, inseription in church in, 148

Brooklyn Naval Lyceum, 200

Brown and Co., emigration agency, I 18, 123.124

Brünigpass, emigration via, 46

Brünn, 248, 25I ; provincial arehive, 8

Brugg, enigration from, Ito

Brune, sce Von Kapff and Brune

Bruneck, 265

Pirunner, Anna, 36

Brunner, Hans, 35

Brumner, Jolannes, petition of, 28

Brunnerville, Pa., Swiss settlement, $7 \mathrm{I}$

Brussels, Swiss consulate at, 92

Bruton Parish Cluturch, 72

Bubendorf, 102

Buch, sec Captalat de Buch

Buchanan, James, correspondence of, 214, 216; pen-portrait of, 206; reply to German Diet, $2 \mathrm{I} 3$ 
Buchberg, emigration from, 124

Bucheckberg. $37,3 \mathrm{~S}$

Buchmann, Jacob, inheritance of, 23

Budapest, state archive of, 8

Büchele, Andreas, petition of, I37

Bücher, emigration of, 45

Büchi, Anna, deportation of, 142

Bühler, essay on the emigration to Brazil, $I_{52}$

Bïndner Tageblatt, I39

Bïndner Zeitung, I 39

Buenos Aires, I 18, 217, 221 ; discovery of plot in, 234: emigration from Tyrol, 266; English occupation, 234; Spanish insurgents:in, 235; Spanish reoccupation of, 23t; Swiss emigration, II5; see also Argentina

Büren, emigration agents around, ts

Bürkli, Karl, Das Evangelium der Armen, 3I

Büsserach, 98

Bugnon, Rev. Joseph, I74

Bulkeley, Count, offer of his services against Americans, 219

Bulle, 172

Bulletin Officiel, of Valais, I6t

Bulletin Officiel des Lois, Fribourg, I5I

Bundesarchiv, see Switzerland

Bundesblatt der Schweizerischen Eidgenosscnschaft, $7,69,148$

Bundesblatt, Sachregister zum. see Widmer, F.

Bundesrat, see Federal Council

Buochs, 89

Burkhardt, Wis., Swiss settlement, 7I

Burnand, A., article by, I62

Burnett, Edmund C.. article by, I 86

Bustelli, Signor, vii

Cabinet, U. S., resignation of members, 196

Cadiz, 23I, 237; exportation of clothing. 227; fleet for New Spain at, 219; steamship line to Spanish-American colonies, I88

Calhoun, John C., 206

California, Auswanderungsagenten der Kalifornischen Gesellschaft. 8I ; Colonie Svizzere di, I48; discoveries in, 219: Hardmeyer on the Ticinesi in, I48; Novella Helvetia, newspaper, I. 8; Swiss emigration to, 6, 87, $108,138,148,154$

Callava, Col. José, with Jackson at Pensacola, 190

Calvin, Jolnn, I83, I84

Calvinists, in Virginia, I3

Camenisch, Verena, petition of, I 37

Canada, 201, 202, 204; Auskunft für beabsichtigende Auswanderer, I18; disturbances in, 200; Great WVestern, 200; Hülsemann's report on, 208; NcLeod affair, 209; maps ó, 247; pacification of, 200; Régiment de Meuron, I72; Swiss emigration, 97; taxation, 217

Canary Islands, trade relations, 252

Cantons, Swiss, 2

Cape Charles. Labrador, 2 I 8

Capital punishment, 23, 236

Captalat de Buch, Swiss emigration forbidden to, 36

Capuchins, 26I, 262

Caribbee Islands, I79
Carleton, Sir Guy, 224

Carlsbad, 249

Carlstadt, General Commando, 239

Carmichael, William, arrival in Spain, 225

Carolina, $\mathrm{v}, 3$; emigration literature on, 102 ; letters from, 4, 46, 50, 74, I I I ; Ludwig Michel's trip to, 72 ; printed articles and books concerning, 3, 4, 29. 30, 3I, 45, 48, I I8; "Rabies Carolina," 3, 55; Reformed Church in, II9; reports on, 44,46 , II I ; Rodt in, 56 ; Swiss emigration laws, 32, 36; Swiss emigration to, 3, I4, I5, I7-22, 29-32, 34-36, 38 , 39. 4I-50, 54-57, 72-74, IOI-IO4, IO6, IO9-I I Swiss Mennonites for, 3 ; travels in, 20 ; see also North Carolina; South Carolina

Caroline, ship, 203, 237

Carroll, Charles, ig 8

Carroll, Bishop John, 228

Casatilly, Spanish fleet under, 220

Castelli, Bernardino, petition of, 2 Io

Castiglia, Gaetano, deportation of, 2 I 5

Castle Garden, 75

Catherine II., I73

Catholic Church in the United States, $8_{5}$

Catholic Historical Review, article in, 208

Catholics, Roman, in Appenzell, I26; in U. S., Io, 85, 194, 208, 216, 244

Canses of the Present Crisis, 202

Cayenne, 230

Cazenova, Anthony Charles, Swiss consul in Alexandria, 24. 64

Cedar Mill, Ore., Swiss settlement, 7 I

Census, of Bern, 51 ; of U. S., I56, 190

Central America, 128, 206; consulate in, 26; maps of, 247 : Swiss emigration to, 69

Cesares, Pueblo de los, South America, 217, 21 8

Cevallos, Gen., Spanish fleet under, 219, 220

Ceylon, Régiment de Meuron at, I72

Chamberlain, Mellen, estate of, 216

Chambre des Bannerets, see Vaud.

Chambre Economique, see Neuchâtel; Vaud

Chambrier, Col. A. de, I70, I7 I

Chaney, complaint against Maison Barbe by, I55

Charity institutions, $27,64,65,84,86,90,91,92$, I 7 , I 18 , I4I, I42, I44, I45

Charleston, S. C., I20; Hülsemann's report on, IO, 204; immigration via, I35; letter from, 29; Swiss consulates in, 26, I I0, 163

Charton, H. S., letter from, I8I

Chateau d'Oex, 59

Châtelain, $D r$., article by, I72

Chatelanat, Henri, in charge of consulship at New Orleans, 65

Cheesland, Texas, Swiss settlement, 7I

Chesapeake Bay, French failure on, 223; map of, 72

Chetlain, Gen. A. L., The Red River Colony, I72

Chicago, charitable institution at, 27 ; Exposition, 26; letter from, 267; Swiss consulate in, 26, I Io: Swiss emigration to, 129

Chicago Tribune, cited, I72

Chile, 128 ; blockade of the coast, 235 ; emigrants shipwrecked on way to, 79; Swiss consulate, 26: Swiss emigration, 97, I46, I57; treaty with U. S., I98 
Chillon, notarial documents in the castle of, 160

China, Austrian expedition to, 242

Cholera, i I6, I i 8, 197, 266

Christen, a widow, petition of, 45

Christen, A. M.., emigration of, 89

Christen, Johannes, to collect inheritance, 51

Christen, Father Ulrich, journey to America. 85

Christholds Gedanken, 30

Christian Alliance, constitution of, 2 I I

Cristofari, Peter, I9I, 192

Chronometer, $2+4$

Chur, cantonal archive in, vi, I32; city archive, I32; emigration to America, I38; emigration to Brazil, I38; Rathsprotokolls-Sbozzo, $133-136$

Churer IVochenblatt, I 39

Churer Zeitung, I39

Cincinnati, O., 120; charitable institution in, 27 ; letter from, 267; Swiss consulate in, 26. IIO

Cincinnati Volksblatt, clippings from, 67

Citizenship, by marriage, 96 , I 12

Città di Trieste, ship, 252

Civil War, U. S., diary of Tyrolese volunteer. 267 ; military papers, 79 ; recruiting in Switzerland, 155

Claims, 8I

Clarendon, Earl of (Elward Ilyde), iso

Classis, see Neuchâtel

Clay, Henry, Austrian treaty, I0, 193; letter to Lederer, I92 ; limitation of power of. I9.4; pen-portrait of, 206; Scliurz's Henry Clay', 2 I 5

Clay, J. Randolph, American chargé d'affaires, 216

Cleve (duchy), emigration via, I69

Clinton, Sir Henry, succeeds Howe, 22 I

Cliovitsch, 205

Clothing trade, 227

Cloth shears, 255

Clubs Insurgés, I79. Iso

Cobenzl, Count Johann Philipp von, letter to. I87

Cochranc, Vice-Adm. Thomas, expedition against Peru, Igo

Coinage, Swiss, value of, IO4

Colladon and Hentsch, Gallatin gives power of attorney to, I8 I

Collection des Manuscrits Historiques, I 76

Colombia, statistics of, 2.46; Swiss recognition of the repulilic, 79: Swiss troops for, 25; treaty with U. S., I02, 103

Colonie, Eine l'ergessene Deutsche, see Deiler, J. Hanno

Columbia River, 203

Colville, letter to, i 7

Comités d'Emigrations des Sociétés d'Utilité Publique, 7,64

Commerce, se Trade

Commercial conveution, Hülsemann's report on, 204

Commission Révolutionmaire, 180

Compagnie des Pasteurs et Professeurs, sec Geneva

Company of Pastors, see Neuchâtel

Conception, abbey of, see New Engelberg
Conestoga, Pa., $5+$

Confaloniere, Federigo, deportation of, $2 \mathrm{I}_{5}$

Conference of 1818 , concerning Swiss colonists in Brazil, 86,155

Conference of 18.46 , concerning Swiss emigration, i 16, i 72

Confiscation, of Swiss goods, 59

Congress, U. S., Io, I I, I79, I80, I00, I97, I98, I99, 204, 206, 246; Canadian and Mexican affairs in, 202 ; reciprocity navigation bill, 192

Conner, Father Beda, see O'Connor

Conrad, Father Frowin, 87

Conseil Fédéral, sce Federal Council

Conservateur Suisse, Le, see Bridel, Dean

Consistoire, archives of, sce Geneva

Constantinople, 232,248

Constitution, Swiss federal, 2 I

Consuls and consulates, see names of particular countries and places

Conta-Gallo, Swiss colony in Brazil, I 47

Continental Congress, Franklin appointed minister to France, 222

Contraband, $9,217,218,220$

Convention, French, decree of, 78

Convention Internationale $(18 ; 5),{ }_{5} 6$

Convention of $\mathrm{I} 8 \mathrm{I} 8$, see Conference of ISIS

Convoys, 220, 221, 230, 232, 243

Conyngham, Capt. Gustavus, 2 I9

Cook, Capt. James, voyage of, 217

Copenhagen, American emissary in, 223

Copia eines von einem Sohne N. N. Bricfes, Philadelphia, Pastorius, 30

Coppeln, Mo., Swiss settlement, 70

Coppinger, Col. José, governor of East Florida, I 00

Cornbury, Lord (Henry Hyde), crowned King of the Archers, I8o; Swiss Council confers citizenship on, I8o

Cornwallis, Lord (Charles), surrender of, 223, 246

Corpataux, Georges, 152

Cortes, government of the, 236

Coruña, ship line between Falmouth and, 230

Costa Rica, plan for colony in, 68 , I 55

Cotton duck, used in American sails, II, I94, 244,254

Cotton Hill, IV. Va., Swiss settlement, 7 I

Cour d'Appellation Romande, sic Vaud

Court, Antoine, papers of, I84

Couvet, I 70

Covelle, Alfred L., Le Liurc des Bourgeois de Genize, 175, ISI, IS2, IS3

Cracow, provincial archive of, 8

Cramer, August, Notes e.traites des Registres du Consistoire de Genive. IS3-IBt

Críole, ship, 2 Io

Cresson, Ellion. emigration of, If 2

Crimea, emigration from Thurgau to the, I4t

Cristani, H., I Iof-Kanzler, 263

Crittenden, I. J., 206

Croft, Thomas, treatise on the potato disease, 6 -

Cross, Order of the, se' Kreuzherren

Crousaz, Aymon, cantonal archivist, 159

Cuba. Lederer's report on, 19I; white population in, 236 
Cuculli, Simon, 194, 195, 196

Cullman, Ala., Swiss settlement, yo

Cunningham, Capt. Gustavus, see Conyngham

Curaçao, Spanish complaints against hostilities in, 222

Curt, Hans, 48

Cushing, Caleb, 206; resolutions proposed in the House of Representatives, 202

Cuvelier, Joseph, article by, 186

Czech, Prof. Hermann, method of teaching deaf-mutes, 199

Dachelsen, 23

Dällikon, 22

Daily Advertiser, New York, 195

Dakota, Swiss settlement in, 70

Dampierre, I 7 I

Dana. Francis, U. S. minister to Russia, 225

Danzig, Austrian consul in, 234; emigration from Bern to, $4 \mathrm{I}$

Décrets Romands, I6I

Degerfelden, assembling of emigrants at, 142

De Grasse, François, Comte, see Grasse

Deiler, J. Hanno, Eine Vergessene Deutsche Colonie, 196, 250

Deisz, Johann M., 194

Delaware River, capture of forts on, 22I ; lighthouse at motith of, 254

Delmonico Brothers, restaurant founded by, 147

Delplancq, letters to, 187

Demerara, appeal for convoys against English, $22 \mathrm{I}$; conquest by the French of, 224

Democratic convention (Baltimore, 1840), Hülsemann's report on the, II, 209

Democratic Review, 213

Denmark, treaty between U. S. and, 193, 195, 255

Deschwanden, Theresia von, 86

Des Marez, G., article by, I 86

Dessenzano, 205

Dettwyler, Joh., emigration of, II 7

Deutsche Colonic, Eive Vergessene, see Deiler, Hanno

Deutsche Schnellpost, 212

Deutschland, Das junge, see Geiger, L.

Dialersche Normalien-Sammlung, see Innsbruck

Dielstorf, emigration list of, I3

Dierauer, Prof. Dr. Johannes, vii

Diet, German, 213; Swiss, see Swiss Confederation

Dietikon, emigration list of, I3

Dietsch, Andreas, emigration agency, I4I

Dingley Bill, I3I

Dinsmore, 248

Diplomatischen Departement, Bern, Manual des, 60

Domicile, see Freizügigkeitsvertrag

Dovere, $I l, 147$

Dreifuss, J., Emigration, 6

Duden, Gottfried, 250; travels in the Middle West, I I

Dür, Aloysia, birth certificate of, 203

Dürrenberger, Jacob, examination of, II I

Dürring, letters from, 108

Dürst, D., Die Gründung der Kolonic Neu Glarus, 94
Dufour, Jean-Jacques, founder of colony of Firstvineyard, 161

Dufour-Vernes, Louis, archivist, 175, I83; article by, 175, 177; Catalogue des Minutes de Notaires, 178; Index des Chambres, 177; Inventaire des Titres et Droits de la Seigneurie de Genève, 178, 183; Inventaire Général et Topographique des Archives de l'Etat, I78; Militaire, Justice et Police, I77

Duhamel, F., I78

Duminique, Baron de, minister of state in Trier, $24 \mathrm{I}$

Dunklen, Hans, emigration of, 123

Dunscomb, Andrew, letter from, I 8 I

Dupaquier, emigration agent for Nova Scotia, 49

Du Ponceau, see Ponceau

Durham, Earl of (John George Lambton), departure of, 20I ; pacification of Canada, 200; remarks on, 20I ; resignation of, 200

Durrer, Dr. Robert, vii

Dutch West India Company, I79, 223, 229

Dye-wood, 226

Earthquake, 22I

East India Company, recruiting Austrians for 240 ; Swiss for, 52, 172; transportation of emigrants by, 37

East Indies, Austrian trade relations with, 252; return of fleet from, 22I; Swiss emigration to, 69; travels in, 20; troops and munitions for, 227

Eben, C. T., translation by, $5 \mathrm{I}$

Eberle, Oberstleutnant Ludwig, vii

Eberle, Ill.. Swiss settlement, 70

Eberly's Mill, Pa., Swiss settlement, 7I

Écho des Alpes, I64

Ecuador, treaty with Switzerland, 96

Eder, Rupert, persecution of, 259

Educational Review, cited, I84

Eger, 249

Egger, Hans, emigration of, 45

Eglisau, emigrant from, I4, I9

Eichthal, Count, 212

Eidgenössische Abschiede, I7I2-I743, 57

Eidgenössische Kanzlei, reports on emigration, 23

Eidgenössische Organisation der Auswanderung, conference of, 96 ; see also Federal Emigration Bureau

Eidgenössische Stände, Konferenz der, 86

Eidgenössische Vorort, see Vorort

Eidgenössiches Archiv, see Switzerland, Bundesarchiv

Eidgenössisches Auswanderungsamt, see Federal Emigration Bureau

Eidgenossenschaft, sce Swiss Confederation

Einsiedeln, Benedictine monastery in, $5 ; \mathrm{Be}-$ zirksarchiv, 85; emigration from, 85; Stifts-Archiv, vi, 84,85

Einsiedler Anzeiger, 85

Elbe, steamer, I 9

Elbagen, 249

Elggau, 20

Ellikon, schoolmaster, 19

Elm, Gemeinderat, aid to emigrants, 92 
Elmenthaller, Mathias, persecution of, 260, 261 Elsau, letters of emigrants from, 19

Embrach, 25

Emigration, see names of countries and places

Emigration, see Dreifuss, $J$.

Emigration Suisse, see Karrer, L.

Engelberg, archive of, vi, 87, 88; Benedictine monastery in, 5, 87, 88

Engelberg, Ore., Swiss settlement, $7 \mathbf{I}$

Engclland Buch, 59

England, 205; ambassador received by Van Buren, I94; attitude towards U. S., I90; audience of the American minister, John Adams, 226; begins hostilities with Spain, 234; blockade of American coast, 235; boundary disputes with U. S., I90; commercial relations with America, 226, 228, 229, 236, 254; commercial treaties with America. 191, 193, 225; complaint of Dutch supply of arms, 9, 218, 220; convention with Spain, 226 ; Cusling's resolutions against, 202 ; deportation sclieme of, 43; diplomatic exchanges with colonics, 218 ; disputes with colonies, 218; distrust by America of, 225 ; embargo on Spanish ships, 234; emigration from, 67, 225; Florida boundary dispute, 225, 226; free grain importation, 210; Frencl emissaries in English colonies, 218 ; generals in America, 222; Graffenried's adventures in, 75 ; law against importation of Austrian goods, 25.; McLeod affair, 209; manufacturers emigrate to America and France, 225 ; Mosquito Coast negotiations, 226, 227; navigation of neutral powers to the American colonies, 222: Nootka Sound negotiations, 229, 230; Parliament votes indemnities, 226; Parliamentary debate on slavery, 229, 237; Parliamentary debate on disputes with American colonies, 217 ; peace negotiations, 221, 222, 224; plantations, 51 ; proposals for offensive and defensive alliance, 224; proposals to put French islands under English protection, 23o; recapture of lost fleet, 230; rumor of alliance with U. S., 234; Scottish regiments in American colonies, 218 ; sccret correspondence with colonies, 222 ; securities, 5.3 ; seizure of Spanish ships at Vera Cruz, 2.4t; subscription in favor of American insurgents, 236; subsidies to Spain, 235; subsidy treaty between Prussia, Russia, and, 218; Van Buren's proposed trip to, I06; war with France, 252 ; war rumored with U. S., 235

England, ship, cholera on, i18

Englisch in Tcutschland verschickte Erklährung, Königlich, 30

Engwiller, report on supervision of agencies, 127

Enterprise, Kan., Swiss settlement, to

Eperjes, 250

Erdbcschrcibung von ganz Amcrilia, I 89

Erguel, Anabaptists, 6.3; emigration to Penusylvania, 36,50

Erlach, 41, 42, 54

Ernst, emigration of, 20

Erschwil, o8
Escher, Dr. Hermann, vii

Escholzmatt, Gemeinderat, on emigration, so

Esperanza, Argentina, Swiss settlers in, I6 1

Essequibo, conquest by the French of, 224 ; debauchery of negroes of, 226

Estaing, Count Charles d', arrival in America of, 22 I

Estates, sec Inheritance

Etudes Economiques, article in, 104

Etzweiler-Mer\%, report on emigration agency of, 127

Evangclium der Armen, sec Bürkli, Karl

Evarts, $11 \mathrm{~m} .11 .77$

Everett, Alexander H., 2 I 3

Exchange of official publications, 96, I 55

Expositions, Chicago, 26 ; New York, 26; Philadelphia, $26, \mathbf{I}_{42}$

Fabri regiment, 253

Fabrini, Filippo, scheme for world-wide trade. 9, 252

Falmouth, ship line betwecn Coruña and, 230

Farnis, Hans, inheritance of, 38

Faust, A. B.. article by, I62

Favarger, Charles L.ouis, manager of Alpina Co., I73; Société en Commandite pour Alpina, 173

Favin, Medamc, 73

Fay, Theodore S., U. S. minister to Switzer-• land, 6,75

Fechter, D. A.. editor of Eidgenössische Abschicde. 57

Federal Chancery, on emigration via Havre. $\mathrm{I} 70$

Federal Conncil. 128; appropriation for aid to emigrants, II7; Berichte des Sihweizcrischen Bundesrats, 69; circular letters on emigration, I19, I27, 154, 155, 156; complaint against agencies, I 8 ; emigration, a question for the, 153; emigration laws, 68 , 76,79 ; emigration list of Fribourg for the, I56, 157; emigration to Algeria, 27; emigration to Brazil, 27; emigration to New Orleans, 27; licensed agents and agencies, I 19; Liucoln's assassination and, 78 ; proposals for emigration statistics, I I9; Scluweizerische Auswanderungsvercin, petition to the, 68 ; warning concerning paupers and criminals, 93 ; sce also Federal Emigration Burcau

Fecleral Directory, circular letters concerning cmigration, I70, I72

Federal Emigration Bureau, vi, 5, 6, 33. 68-7 I, 97,154

Fehre, Maria, petition of, I 37

Fehre, Susamna, petition of, 137

Fellner-Kretsclimayr, Geschichte der Oesterrcichischen Zcntralacrabaltung, 252

Ferdinand 1., arbitrator in indemnity dispute, 212

Ferdinandenm, sio Innsbruck

Ferstl, in; sic also loerstl

Fetsclierin. Wilhelm, Repertorium, 62

Feuille léderale de la Confédération Suisse, sec Buncleshlatt

Fouille Officiclli. I5,3 
Fiess, brothers, 59

Filzbach, aid to emigration, 92

Financial situation in America, I70, 202, 206, 207,216

Fire-engine, patent for, I4I

Fire Islands, Swiss emigration to, 69

Firstvineyard, Ky., colony of, $16 \mathrm{I}$

Fischenthal, 25

Fischer, $\mathrm{K}$., petition of, II 6

Fischer, Ciprian, and family, emigration of, I34, 135

Fischer, Father Joh., 249

Fish, Nicholas, minister to Switzerland, 76, 77

Fitzgerald, Bishop Edward, 85

Fiume, trade relations with the French colonies, 223

Flag, U. S., I79, I80, 255

Flores, Manuel Antonio, viceroy, 227

Florida, I90, I99; article concerning, 267; boundary disputes, 225, 226; cession to $\mathrm{U}$. S., I90, 237; free land in, 69; Swiss settlement in, 70; U. S. violation of, 236; see also West Florida

Fluebacher, Adam, estate of, i Io

Flühli, 79

Förstl, Leopold, merchant, I I, 25 I

Fontes Rerum Austriacarum, 9, 186

Foreign Conspiracy, 198, 250

Forestville, Mich., Tyrolese colony in, 266

Forresti, Felice, deportation of, 207, 215

Forsyth, John, secretary of state, concerning minister to Austria, I99; conversation with Mühlenberg, 208; letter to Lederer, I99

Fort Douglas, I72

Fort York, I7 I, I72

Foster, Herbert D., article by, I75

Fourneau, Capt., voyage of, 217

Fournier, August, Historische Studien und Skizzen, 247

Fox, Henry S., minister of Great Britain, 204

Fragmens Biographiques et Historiques de Genèze, see Grenus-Saladin

France, 64, I7 I, 199, 205; ambassador received by Van Buren, I94; American drafts, 223; American vessels with supplies in ports of, 218; annexation of Geneva, I75: Austria recognizes new government, I95; boundary dispute with Spain, 233; commercial relations with American colonies, 220, 222, 223 ; commercial relations with English insurgents. 2I8: commercial treaty with U. S., I9I, 193; complaint against Swiss paupers, 5: Conyngham affair, 219: correspondence of the Quatre Ministraux, 173; Cushing's resolutions against, 202 ; decrees regarding America, 78, 234; diplomatic negotiations with American colonies, 22I ; dispute with Switzerland, 60; distrust in America of, 225; droit de fret, 239: Elizabeth, princess, 227 ; emigration from, 67 ; émigrés in Spanish service. 23I; emissaries in America. $2 \mathrm{I} 8$; d'Estaing arrives with fleet in America, $22 \mathrm{I}$; expedition against Louisiana, 233; fleet in America, 192; Franklin in Paris, 220, 222; French and Spanish subsidies for American colonies, 22I; Gerard's mission to America, 22I, 222; Graffenried's adventures, 75; indemnity treaty with U. S., I98; insurrection in French colonies, 228, 229; intrigues, 226; Jefferson, American minister, 226; Lafayette sails to America, 219; law against sale of American prizes, 219 ; loan for American colonies, 221, 223, 228; offer to conquer Portugal for Spain, 232; officers imprisoned in England, 2I9; opinion as to grievances between England and colonies, 2I8; ports closed to American flag, 234; refusal to exchange Santo Domingo, 231; reply to Swiss deportation scheme, 20, II6; revolutionary corps, 24I ; sale of Louisiana, 233, 234; secretly favors American cause, 219 ; steamship line from Port Louis to America, 225 ; subjugation of English possessions on Hudson Bay, 224; Swiss emigration to, 69, I 16; Swiss emigration via, I4, 25, 62, 81, 95, I I5, I I6, I40, I4I, I 58, 170; Swiss troops for, 99; Ternant, minister to America, 228; treaty with English colonies, 22I, 222; treaty with Mexico, 204; troubles in French-American colonies, 228, 229: Supplies arrive in Boston, 220; war with England, 252; see also French

Franciscans, Tyrolese-American, 266

Franckendorf, IO3

Frankfort (am Main), 17x, 213; emigration from, 234; recruiting colonists for America in, 234; recruiting troops for England in, 239; religious fanaticism in, 250; Schwendler, American consul at, 254

Franklin, Benjamin, in France, 220; letter concerning Austrian treaty, 9, I87; letter to Count Mercy, I87; minister to France, 9. 187,222

Frankreich Buch, Bern, 59

Frauenfeld, 20; cantonal archive in, 6, I44

Fredericksburg Gasette, article on Gallatin in, I8I

Frederick William I., of Prussia, edict of 1734 , Io, 264

Freemasons, 195, 250

Freiburger Geschichtsblätter, article in, I5I

Freie Rätier, Der, I39

Freizügigkeitsvertrag, 7, 25, 68, 79, 81, 93, 95 I IO, I 32, I 52,2 I 4

French cantons, emigration from, I49; order of, I 49

French colonies, Swiss emigration to, 69

French convention, see Clubs Insurgés

Frey, Barbara, death of, 24 ; estate of, 25

Frey, Carl, death in Virginia, 24

Frey, Col. Emil, Swiss minister to U. S., 78

Frey, Friedrich, cantonal archivist, vii

Fribourg, 1, 2, 39, 149; archives of the bishopric, I52; archives of the commune, I5I, I52; archives of the convents, I52; bishop of, 152; Bulletin Officiel des Lois, I5r; Chancellerie, I50; circular letter on emigration, I54; Correspondance Extérieure, 150-15I; deportation of criminals, ${ }_{5} 6$; emigration agents, I57, I58; emigration from, 152-I 58 ; emigration laws, 154 , I56, I 57 ; emigration to Prazil, $152,155,157,1_{5} 8$; emigration to 
Chile, I57 ; emigration to Punta Arena, I56, 157 ; emigration under police supervision, I54; emigration via France, I58; emigration via the Netherlands, 157, 158; état civil, registers, I5I; Freiburger Geschichtsblätcr, 15I; Grenette, 150; Hồtel de Ville, I 50, I5I, 152 ; Inventaire des Archives, I50; letter to Federal Council, I56; Livres de Bourgeoisie, I50, I5I; Maison de Ville, I5I; Mandaten-Bücher, I50; Manuaux du Conseil, I50, 151; Missiven-Bücher, 150; Rapports $d u$ Conseil d'Etat, I50; recruiting measures, I55; sale of railroad tickets, 154 . I55; state archive, vi, I 50-158; treasury accounts, I5I ; Tableau des Notaires, I5I ; viséing of passports, 154, I55, 158

Frick, emigration of, $1_{4}$

Fridolin, Count, 205

Friedjung, Heinrich, Oesterreich von $1848-1860$, 247

Friedrichsthal, Rilter von, 200, 20I

Frigates, II, 196, 217, 231, 242, 243

Froehlianists, 27

Frommer, Georg, complaint of, 259

Froschauer, New Testament, 38

Frïh, CIricl, a thief, enigration of, 145

Fruxo, D., Spanish minister, 232

Fïrstenau, reformatory, 130

Fiir wnd Wider der Auswanderung nach Amerika. see Lanz, Johann

Fugger, Hans, und dic Kunst, see Lill, Geo.

Fugger, Jacob. der Reiche, see Jansen, Max

Furrer, Jakob, petition of, 25

Fur-trade, 228

\section{Gais, 127}

Galena, 111., Swiss colonists at, I72

Galicia, revolutionists deported to America, II, 250

Gallati, Rud., petition of, 92

Gallatin, Albert, I49; Adam's Life of, I80; letter from P. S. du Ponceau, I8I ; report on emigrant transportation, 62 ; rumor of death of, I80-I8I ; U. S. commissioner, 235

Gallatin family, nobility of, I80

Galveston, Tex., Swiss consulate at, 7, 65, 67

Galvez, Bernardo de, viceroy of Mexico, 227

Gambato, Alessandro, petition of, 2 Io

Ganalh, Louis, 206

Gasc, Esaje, syndic, 180

Gasser, minister, appeal of, 50 ; persecution of, 50

Gataimai, Paragnay, evacuation of, 221

Gautier, Jean-Antoine, Histoire de Geniz'e, it9 Gazelle d'Émigration, 156

Geering. T., Handel und Industric der Stadt Basel. 13I

Geheimbericht, Literarische, aus dem Vormärz, 247

Geiger, I.., Das junge Deutschland, 247

Généalogique Suisse, Recueil, 183

Geneva, N. Y., Swiss settlers in, 161

Geneva, Ohio, Swiss settlement, 7 I

Geneva, Pa., Swiss settlement, 71

Geneva, Switzerland, 2, 149, 172; Allgemeine Gesellschaft gegenseitiger Unterstïtzung,
92 ; annexation of, 175 ; arclives, inventories of, I77-I78; Archizes de, I75; Archives de l'Église de, I83; Archives d'Etat, 179-182; attempt to organize emigration, 8o; Bibliothèque Publique et Universitaire, 184: Bourse Française, archives of, I77, I83; Calvin, Maison de, I76; Catalogue des Minutes des Notaires, I78; Catholic parish registers, 182, I83; Chancellerie, I75, I82, 183; Church of, I83: Collection des Manusscrits Historiques, 176; Communauté, registers of, 176, I82; Compagnie des Pasteurs et Professeurs, archives of, 183 , I84; Conseil d'Etat, registers of, $175,176,179,180$, I83: Consistoire, archives of, 183 , I84: Courts of Justice, archives, 177 , I 82 ; documents relating to refugees at, 182 ; ecclesiastical archives, r83-I84; electors, registers of, I8I ; emigration, 64 ; emigration lists, 182 ; état civil, archives, $181-182,183$; Etat Général et Sommaire des Fonds, I77, I78; Fragmens Biographiques et Historiques de, I75; Histoire de. 179: Histoire de l'Université $d e$, I84; Hopital Général, archives of, 177 , I78; Hôtel de Ville, I75, 176. I82; Index des Chambres, I77: inventories of archives, I77-I78; Journal de, 77 ; letter of council to U. S. Congress, I8o; Livere des Bourgeois $d \mathcal{c}, 175,18 \mathrm{I}, \mathrm{I} 82, \mathrm{I} 83$; member of Swiss Confederation, I75; Notes crtraites des Registres du Consistoire, 184; Notices Généalogiques sur les Famillès Genevoises, 183 ; part of the Département du Léman, 175; Portefeuilles des Pièces Historiques. $175,176,177,178$ : records of baptisms and narriages, I81, I82, I83; records of parish churches, I81. I82, I83; Regeste Gencvois, 183; Registres des Habitants, 18,3; St. Peter, documents of chapter of, 177,178 ; St. Victor, priory of, I78; Société d'Histoire et d'Archéologie de, documents and publications of, 175 , I76, I77, I79, I82, I84; Société d'Utilité Publique, Comité d'Emigration, 7, 64, 65, 66: Société des Catéchumènes, 177, 182; Société Economique, archives of, 178,182 ; state archives, vi, $175-183$; Tour Baudet, 176: University of, is ; Venerable Conpany, archives, 184: see also Léman. Département du

Genevoises, Notices Ginćalogiques sur les Famillis, Is 3

George's Creck, Gallatin returns to, I8I

Georyia, difficulties between federal and state goverument, 192: Hiilsemann's report on, 204: preparing for secession, 192, 10.3: Swiss emigration to, $17,29,38,45,46.70$; Swiss settlements in, 7o; see also Sal7.burger Protestants

Gerard, Cheatier Conrad Alexandre, mission 10 America of, 221,222

Germain, Lord George, resignation of, 224

(jerman American Anuals, cited, 3, 73, 74, I62 Germanna, German colony in Virginia. 13

German Reformed Clumrel in Anterica, is

Ciermantown, l'a., Pastorins, founder of, I,3, 30 
Germany, I96: Das junge Deutschland, 247; Der Tentsche Tribun, 12, 25I; Die Tcutsche Revolution, 251 ; emigration, 62

Gerstenberg, secretary of legation at Vienna, secret recruiting for England, 9, 223, 224

Gerstner, Prof. François Antoine de, death of, 209: Railroads in Bclgium compared with those of the U.S., 206, 209

Gex, Pays de, civil registers of, I82, I83

Ghega, engineer, arrival in America of, $2 \mathrm{I} I$

Gibraltar, proposal for exchange of, 229

Giegelmann, Hans, petition of, IO2

Gilgen, emigration of, 45

Gilgiano, Christen, death of, 39

Gimpert, Rud., testimony of, 24

Gingins, 53

Giovane Italia, deportation of members of, $215,245,250,25$ I

Giralth, 250

Girard, Abbé François, Histoire Abrégée dcs Officiers Suisses, 100

Girard College, Philadelphia, 20 I

Glanzmann family, 79

Glarnischer Verein, see Glarus

Glarus, I, 86; aid to emigrants, 90-92; bibliography; 94 ; conference of 1846 , 116; deportation, 93; Dreifache Rath, 93; emigration agencies, 92, 93; emigration from, 62, 75, 90-93, I08, I 16; emigration statistics, 92; Glarnischer Auswanderungs-Verein, 26, 9093; Handcl und Industrie des Kantons Glarus, I30; Kantonale Arbeiterbund, 93; Newes Archiv des Kantons Glarus, 6; police-commission, 9I ; property transfer, 90, 93; readmission of emigrants, 22 ; state archive, vi, 90-94; sce also New Glarus

Glass factories in America, 255

Globe, Washington, 2OI

Glossy, K.. Litcrarische Gehcimbericht aus dem Vormärz, 247

Gliicks-Hafen, odcr Reicher Schatz-Kasten, I4, 59

Gloucester, Va.. 2.46

Gnau, Herm., Die Zensur unter Joseph 11., 247

Gorldard, F. W., accident of, 24

Göpfert, H., emigration of, I22, I23

Göttschi, Heinrich, 5 ; letter from, I8

Göttschi, Johann Moritz, 5, I\&, 30; examination of, I4, 21 ; letter from, I4; petition of, 19 . 20, 22

Goldbach, 24

Goldenberg, 24

Good, James I., History of the Reformed Church, 30

Good, Vinz., cmigration of, 83

Goos, Dr. Roderick, vice-archivist, vii

Goundie, consul in Basel, concerning emigration, 95

Grabs, emigration from, 129

Graf. J. H., article by, 72

Graffenried, Anton, 75

Graffenried, Christoph von, 3, 60, 72-75; treaty with Tuscarora Indians, 74

Graffenried, Karl Emanuel, 60

Graffenried, Reese Calhoun de, member of U.S. Congress, 60
Graffenried family, 74 ; history of, 60

Graffenried manuscripts, vii, 4, 60, 73, I62

Grafstal, I8

Grain, crop in America, 254; prices in America, 255 ; trade. 9, 239, 24I

Grant and Co. vs. Cornelius Specht, 205

Grasse, Comte François de, engagement with Hood, 224

Graubünden, 2, 86; aid to emigrants, I32-I39; cantonal archive of, vi, 132 ; conference of I846, I 6 ; emigration, I32-I39; emigration commission, I33-I36; emigration of Catholics, I33; emigration proposals, I08, I72; emigration to Brazil, I 32 ; Italian refugees. 132 ; Ratsprotokolle, Register of, 136; see also Tennessee Colonisationsgesellschaft

Graz, provincial archive of, 8

Great IVestern, ship, 204

Grebel, Landvogt, petition of, 20

Greece, commercial treaty with U. S., 202

Greenland, coast of, 2 I 8

Gregg, David M. M., American consul at Prague, 256

Grenaud, $A b b e ́$, manuscripts, I 5 I

Grenaud Collection, Catalogue des MSS. de la, see Martin, Paul E.

Grenus-Saladin, Fragmens Biographiques et Historiques de Genc̀ve, I75

Greyffen See, 20

Grimm, teacher, persecution of, 38

Grindelwald, 47, 5 I, 56

Grisons, see Graubünden

Grivel, Ad. C., archivist, inventories by, I77, I78

Grob, Christian, death in Carolina, 22

Grob, Heinrich, power of attorney to, 22

Groszweibel, 49

Grïn, $M a j ., 238$

Grünheim, Ky., Swiss settlement, 7o

Grïtli, Neb., Swiss settlement, 70

Grütli, Tenn., Swiss settlement, 7 I

Grütli Verein, colonization scheme of, 76

Gruner, Maria Rosalia, I 98

Gruyères, emigration from, I53

Guatemala, 206

Gubler, D. Ursula, petition of, I38

Güggisberg, emigration from, 45

Guiana, Dutch, sce Surinam

Guide to the Gorman State Archives, sce Learned, Marion Dexter

Guie, Friederich, I 7 I

Guie, Jean Friederich, I7 I

Guie, Jeanne Marie, I7 I

Guienne, emigration to, 36

Guillemann, Franciscus, 217

Guinea, English and Danes on the coast of, 226

Gumbers, Philipp. persecution of, 259

Gustav, ship, 205

Guyenet, Jean Antoine, death in Philadelphia, 170

Guyot, Arnold, I49

Guyot, F. L., Swiss troops for Colombia, 25

Gwehnbergerin, Magdalena, persecution of, 259

Haebler, Konrad, Die ïbersceischen Unternehmungen der Velser, 265

Häfelfinger, inheritance, I Io 
Hängi, Denkschrift über die nordamerikanischen Verhältnisse, 99

Hānszlin, Georg, Getraud, and Hanns, persecutions of, 259

Haga, Georg Friedrich, death in Philadelphia, 25

Hagemanns, of Pennsylvania, 21

Hague, American and Austrian ministers at the, 25

Haldimand, Gen. Frederick, 149, I62

Halifax, Nova Scotia, 203

Hallers Sammlung, 72

Hallwyl, Régiment de, 172

Hallwyl manuscripts, Ito

Halter, H., report concerning transportation to America, II 5

Hamburg, direct trade with America, 225, 226

Hammond, George, English minister to U. S., 228

Hanau, recruiting for England from, 239, 240

Handwörterbuch der Schweizerischen Volksairtschaft, Reichesberg, 6

Hango, Dr. Hermann, vii

Hanhart, Capt., deportation of, 23

Hannauer, article by, IO4

Hanover, emigration from, 67 ; privileges to the Kingdom of, I93; troops in British service, 239

Hanover, Pa., Swiss near, I20

Hanse towns, treaty with Prussia, 254; treaty with U. S., 193, 194

Hanslik, 249

Hantz, pastor, letter of, IIo

Harder, Ober Vogt, 122, 123

Harder Chronik, I24

Hardmeyer, Narie, 32

Hardmeyer, T., article by, 148

Harlan County, Ky., Swiss emigration to, 129

Harland, Richard, 198

Harmony, town in America, 23, 24

Harper, Mrs. Robert Goodloe, igs

Harring, Harro, 2I 3

Harrisburg, Pa, disorder at the opening of the legislature at, 202

Hatz, Jeremias, blacksmith, petition of, 138

Hausen, 21

Hauser, expedition from Rotterdam to Fort York under, I I I

Hauser, Kaspar, article by, 39

Havana, 206, 21 I

Havre, I17; cholera in, 116; complaint of Swiss consul, 153, 154; emigration port, 61, 75, 80, 81, 170; proposals of Swiss consul, ir6; Werdenberg emigrants stranded at, 129

Hayti, 128

Hebron Church. 13

Hecht, Joseph, Beschreilung der Meerfahrt . . nach Brasilien, 82

Heimliche Emigranten, 5

Heinz, Johann Martin, surgeon, petition of, 136,137

Heinzen, Karl, revolutionist, I I deportation of, 25I; Der teutsche Tribun, 12, 251: Die Teutsche Revolution, 25I

Heisch, 24

Helffenstein, Rev. A., 59
Helvetia, Minn., Swiss settlement, jo

Helvetia, W. Va.. Swiss settlement, 7 I

Helvetia, Wis., Swiss settlement, $7 \mathrm{I}$

Helvetia, ship, cholera on, i 18

Helvetic Confederation, see Swiss Confederation

Helvetic Republic, I, 159, I60, 163, I75

Helvetisches Archiv, Bern, 63

Hennin, successor to Gerard, 221

Herder, Ludwig, emigration agent, 21

Herisau, cantonal archive in, 127

Hermann, Pierre, 155

Hersche, Hans, 126

Hershey, Scott Funk, History of the Hershey Family, 126

Hershey family, in Lancaster Co., Pa., 126

Herziken, 2I

Hesse-Darmstadt (grand-duchy), emigration from, 67

Hesse-Kassel (electorate), emigration from, 67

\section{Hesserschweil, 23}

Hessian troops, in British service, 239, 240

Heuser, Dr., Die Schweizer in St. Paolo, 86; report on Brazil, 86

Heyer, Théophile, director of archives, 175

Highland, Ill., emigration from Luzern, 78; emigration from Sursee, 78 ; Geschichte der Ansiedlung von. $\mathrm{8}_{\mathrm{I}}$; Kurier Reisebericht von Havre bis, 8r ; Swiss consulate in, 26, 78 , I Io; Swiss settlers in, 70,161

Highland, Ky., Swiss settlement, 70

Himmelrid, 98

Hinke, Wm. J., article by, 50; translator of Michel's journal. 72

Hinkender Bote, confiscated letters, 1752, 49

Hinderling. U1r., emigration of, 23

Hinterholz, 2.59

Hirzel, 22

Hirzel, Johann Conrad, I4

Hirzcl, L.. article by, 3 I

Hisky. Joseph, IOI

Historische Studien und Skizzen, 247

History of the Reformed Church, see Good, James 1 .

Höffern, Fran Antonia von, pension of, 206

Höxter, British recruits pass, 9, 238, 239

Hofmann, letters from, 109

Hohenberger, Carl Clirist., consul in New Orleans, 200,204

Uolusteiner. Peter. persecution of, 259, 260

Holzhofer, Michacl, Iof

Homburg. concerning emigration, if

Hood, .4dm. Sir Samuel, 224

Hopital Général, Archives de l', izs

Horger, enigration of, 15

Horger, Barbara, petition of, 54

Hough, I. B., II istory of Lereis County, 173

Howard. Tilghman A., 206

llowe, Sir William, correspondence with Secretary of State, 222; return to England of, 221; superseded by Clinton, 22 I

Iluber, a thicf, receives aid to emigrate, 145

Huber, Dr. August, assistant archivist, vii

Huler, Hanus, 259

Huber, I teinrich, examination of, 22

Huher, Konrad, 146 
Huber, Peter, agent, 39, II I ; arrest of, 46, 47, 55, I I ; attempt to smuggle letter, 4 ; deportation of, 46 ; emigrates to Carolina, 35, 38 ; escape of , 5 ; examination of , 55, 56, 57 ; extradition of, 22, 28; persecution of, 39, 46 ; returil of, 16 ; trial of, 4

Huber, Ulrich, petition of, 2 I

Hudson Bay, I28

Hudson River, colony for Jews on. 250

Hudson's Bay Company, I7 I, 224

Hüber, emigration agent, 140

Hülsemann, Chevalier de, IO, II, 2 IO, 2 I6 ; comnlaint to $\mathrm{U}$. S. government, 2I5; departure of, 215; despatches to Metternich, II, 2 I I215; on Canada, 208; on Catholic church in U. S., 208; on Charleston, 10, 204; on commercial convention, 204 ; on Democratic convention, I I, 209: on factories at Lowell, 10, 205; on Georgia, 204; on market for Austrian products, 204; on Norfolk. 10, 204; on North Carolina, 204; on products and commerce in Virginia, 204; on railroads, I0, 205; on Savannah, Io, 204; on Soutl Carolina, 204; on trip to New England, I0, 205; on trip to Southern States, IO; on trip to the IVest, 208; on Whig convention, II, 209; on white and black labor, IO, 204; on written constitution and the rights of neutrals on the sea, 10, 200; other reports, 207; pen-portraits of members of U. S. Congress, I I, 206

Hünigen, 20

Hüttau, 260

Hug, Alois, emigration of, 89

Hughes, Bishop John, influence over Irish population, $2 \mathrm{I} 4$

Huguenin, civil lieutenant, I7 I

Huguenot refugees, I 77

Humphreys, Col. David, American minister to Portugal, 229, 231 ; minister to Spain, 232, 23.3

Hungary, miners to America from, 227 ; revolution in, 2I4, 2I5: Russian intervention, 2I5; Swiss emigration to, 69

Huser, Hieronymus, 54

Huttwyl, 80

Hyde, Edward, governor of North Carolina, 74

Illinois, 67; Jahrbuch der Deutsch-Amerikanischen Historischen Gesellschaft von, 74; Swiss settlements in, 6, 70

Imst, 265

Indemnities, 212, 226

India companies, deportation scheme of, 43 ; see also East India Company

Indiana, 67; Benedictine missions in, 84, 85; Swiss settlements in, 70

Indiana Magazine of History, I6I

Indians, I8I, 199, 208, 22I, 25I; hostilities with Spain, 226; treaty of Graffenried with Tuscarora Indians, 74; war with U. S., 229

India-rubber, 206

Ingersoll, Charles J., nomination of, 2 I 2

Inheritance cases, 22-25, 38, 39, 42, 50, 51, 54, 58$60,63,79,86,90,93,95,105-107,109$, I I ,
I I2-I I 4, I I6, I 20, I24, I 28, I 4I, I 57, I 88, I 93 , 194-197, 203, 206, 212, 242-246

Innsbruck, archives of, v, vi, 8, 185 ; Bairisches Archiv, 265; Dialersche Normalien-Sammlung, 265; emigration records, I I, 265-267 ; Ferdinandeum, 266, 267 ; state archive, 265266; Statthalterei-Archiv, 265, 266

Innsbrucker Zeitung, 267

Interlaken, Switzerland, emigrants from, 34, 39, $45,46,48,50$

Interlaken, Wis., Swiss settlement, 7 I

Inventare Schweizerischer Archive, I3, 27, 33, 89

Iowa, 67; Swiss settlements in, 70

Ireland, emigration from, 67

Iselin, Adrian Georg, founder of American brancli, I20

Iselin, Heinrich, und sein Geschlecht, see WeissFrey, Fried.

Iselin brothers, transportation from Havre, II7

Iselin family, branches of, I2O

Isenfluh, 50

Italia, Giovane, sec Giovane Italia

Italiani negli Stati Uniti del Nord, Gl', I48

Italian-Swiss emigration, I47

Italy, Americana, new sect, 248; emigration from, 67 : Italian refugees, I32; revolution, 214 ; Young, see Giovane Italia

Iten, Bländus, emigrates to Canada, 97

Iverten, 4I

Jackson, Andrew, 206; and Col. Callava, I90; and Col. Coppinger, I90; attempted assassination of, I9s; exequatur, I95; inaugural address, I94; messages, I94. I97, I98, I99; proclamation of, I94, I97; probable appointments of, 194; proposed for President, IOI

Jägerlen, I9

Jäggi, letter of, 97

Jäggi-Gyger, Auswanderungs-Zeituing, 68

Jäggy, Valentin, emigration of, I 40

Jahrbuch fiir Schweizcrische Geschichte, 39, 53

Jamaica, disturbances in, 229; Spanish and French attack on, 224

Jameson. Dr. J. F., vi, 73, I49

Jansen, Max, Jakob Fugger dcr Reiche, 265; Studien zur Fuggergeschichte, 265

Tay, John, letters of Gallatin to, I80, I8I

Jecklin, $D r$. F. von, archivist, vii

Jefferson, Thomas, American minister to France, 226; letter to Tronchin, 181; University of Geneva and, 184 ; Writings of, I 80

Jenifer, Daniel, envoy to Austria, 2Io; successor to Mühlenberg, 2I6

Jenny, Peter, plan for a charitable institution, 90, 91

Jenny-Trümpy, Handel und Industrie des Kantons Glarus, I30

Jesuits, 233

Jews, 95, I58, 250

Joggi Bohni, Eva, I03

Joggi Bohni, Hans, emigration and return of, 103

John, Archduke, 2 I I 
Johnson, Col. R. M., 206

Joinville, Prince de, journey to U. S. of, 210

Joner, Jacob, agent, 49, 105, 106; deportation of $49,105,106$; examination of, 112 ; order to arrest, 48 ; return of, 48 , 113 ; reward for arrest of, 106

Jones, John Paul, exploits of, 224

Joos, Dr. Wilhelm, colonial scheme of, 68 , I 55

Joseph II., emperor, 187, 228; Die Zcusur unier, 247

Josephinische Gesetzsammlung. 256

Journal of the Presbyterian Historical Socicty. 50

Jovovich, Georgio, I94

Junt, and family, emigration of, 107

Jurisdiction, dispute over, 38

Kälin, Meinrad, article by, 85

Kahn, Dan., inleritance of, 59

Kaiser, Dr. Jakob, archivist, vii

Kalchrain, I 17

Kallbruner, Dr. Josef, secretary, vii

Kambli, Heinrich, suspected as agent, 2I

Kansas, Swiss settlements in, 70

Károlyi, Hofrat Ârpad von, vi; Katalog der Archivalien-Ausstcllung, I86

Karrer, L., L'Émigration Suisse, 6: Das Schweizerische Auswandcrungswesen, 6

Karrer-Hallwyl regiment, see Merveilleux

Katholische Missionen im nordoestlichen Arkansas, 85

Katholische Studien, $8+$

Kauf männisches Direktorium, Archive of, I30; Berichte des. 25, $13 \mathrm{I}$

Kaufmann, Isaac, deportation of, 37

Kaunitz, Princc Anton Wenzel von, report on treaty, 187

Keller, Pastor. recommendation of, 127

Keller, Gottínied, 29

Kendalia, IV. Va., Swiss settlement, 7 I

Kennan, K. K., emigration agent, I I8, I 19

Kentucky, 67; Bernstadt colony in, 69, 70: Bureall of Geology and Immigration, $8_{\mathbf{I}}$ : Dic matericllen I'crhältnisse . . für Einwanderer im Staate, 8I ; Swiss settlements, 70,161

Kerenzen, 92

Kilchberger, Dean, 58

Kilchenmann, I. E., article by, 100

Kissling, Daniel, letter from Carolina to, 46

Klagenf urth, provincial archive of, 8

Klein, Lisette, emigration of, I45

Kleinlützel, $0^{8}$

Klenk, V., emigration agent, 117

Knonatu, emigration from, I4, 20, 2I, 22, 2.3

Knox, Julia L., article by, $16 \mathrm{I}$

Köhler, Jos., 249

Köpfli, Kaspar, Licht und Schattenseite von Neiv-Sicitzerland 81

Köpfli. Salomon. Geschichte der Ansiedlung von Highland. 81; Neu Schaeizerland, 81: Spiegel von .lmerika, 82

Köpfli family, 78; Reisebericht der, 81

Körner, J., petition of, 28

Kolbener, 126
Kossuth, Louis, vs. Hülsemann, 2 I 5

Koster, Gerard, defalcations of, 68 ; extradition of, I09, IfI

Kraft. Elisabeth, persecution of, $26 \mathrm{I}$

Kraxenbiehl, 259

Kretschmayr, Prof. Dr. Heinrich, vii

Kretschmayr, see also Fellner-Kretschmayr

Kreuzherren, and Postl, 249

Kribeck, Frciherr von, 216

Kriens, 79

Kron, Andreas, and family, emigration of, I34, I 35 ; petition for aid, I 32

Kudlich. Hans, liberator of the Austrian peasantry, 12

Küntzi, Christian, emigration of, 43

Küntzlin, sec Schmidt, Anna Barbara

Künzli, inheritance of, 59

Küssnacht, 24

Küttigen, I 12

Kuhn, schoolmaster, petition of, I 8

Kuhn, T. C., Swiss consul to Texas, 67

Kulm, 25

Kurile Islands, commercial relations with, 226

Kurz, G., assistant archivist, vii

Kyburg, I4, 20

Laborie, Rcv. Jacques, letter of, 73

Labrador, 2 I 8

Lace, trade in, 7, I.3

Lady, English ship, 59

Läufelfingen, Io3

Lafayette, Marquis de, eulogy of, IgS; goes to America, 219

Laibach, 25I; provincial archive, 8

Lammer, Ed.. 200

La Mothe Piquet, seizure of English ships by, 59

Lamson, John, American consul in Triest. 233, 253

Lancaster, Ohio, 120

Lancaster, Pa., 59

Lancaster Co., Pa., Hershey family in, I 26 ; Swiss settlement, 63

Landau, commission receives letters from Carolina, 44

Landmann, article by, 53

Landry, John, article by, 162; New Bernc, 73

Landsassen, an undesirable element of population, 3. 40

Lang, carpenter, emigration of, 124

Langer. J.. Das K. ". K. Kricgsarchiz', 2.37

Langlois, Ch., and H. Stein, L.es Archices de l'Histoire de France, 111., 8, I86

Langnat, 42

Lanz, Johann, Das Fiir und Wider der fuswonderung nach Ameriliu, 80

La Planclice, Jean-l azare de, 180

la Plata states, Swiss emigration to, 9,3, 128

La Sollaye, Capt., 238

Laurens, Henry, 223

Latsanne. 46 ; acallemy of, 160; Bisliop of, 159; cantomal archives in, 159; city archives of, I6I: Hotel de Ville, I6I; synod of the national clurcli, archives, I6I

Lawson, New Toyage to Carolina, 3 
Learned, M. D., iii ; Guide to the Gcrman Statc Archives, 149 ; Life of Francis Daniel Pastorius, 30

Lebanon, Pa., 113, 193, 216

Lechner, $D r$. A., Staatsschreiber, vii

Lederer, Baron Alois, Austrian consul general, IO, I89, 200, 2IO, 2II, 237; application for post in Mexico, 205; audience with John Quincy Adams, I90; audience with President Monroe, I90; consular agents appointed by, I98; death of, 212 ; despatches to Metternich, I89-200; goes to Washington, 194, 199; instructions to, 215, 216; report on landing of immigrants, 250; report on Count Leon, I96; Tuscany consulate, I 90,237

Lee, William, mission to Vienna, 9, 221

Legacy, sce Inheritance

Legaré, Hugh S., 206

Leghorn, American emissaries in, 248

Lehmann, Christoph, petition of, i I6

Léman, Canton du, I59, I60, I6I, I75

Léman, Département du, 159, I75, I77, I83

Lemberg, provincial archive of, 8

Leon, Cownt, see Müller, Bernhard

Lecpold, Archibishop, 263

Leopoldina, Brazil, Swiss settlers in, I6I

Leopoldine Institution, 208, 216, 244

Lerch, Dr. E., Die Bernische Auswanderung nach Amerika, 33, 50

Lerchenau, Rittmeister von, vii

Le Roy, Jean Jaques, commissary, I7 I

Leu, Landvogt, 20

Leutmerk, 146

Lewis County, N. Y., History of, I73

Leyder wahrhaffte Traurige Geschicht, Eine, 30

Liberale Alpenbote, der, I39

Liberté, La, article in, I5 I

Library of Congress, Washington, D. C., Igo

Liebenau, Dr. Theodor, Geschichte der Stadt IVillisau, so

Liechstal, I03, I I I

Liestal, archives, I2I ; emigration from, I I4

Lighthouse, 254

Lightning-rod, 52

Lignières, 169

Lill, Geo., Hans Fugger und die Kunst, 265

Lincoln, Abrabam, assassination of, 78 ; death of, 96 ; Lincoln album, 142

Lindau, I8

Linen, trade in, I3I, I88, 254

Linherr, I26

Linnaean Society, New York, 192

Lisbon, II, 2 IO, 218, 220

Lithuania, I9

Little York, see York, Pa.

Livre des Bourgeois... de Genève, sce Covelle, Alfred L.

Locarno, section near, depopulated by emigration, 148

Locle, I7 I

Lodge, H. C., Daniel Webster, 215

Lombard-Venetian conspirators of 1835 , deportation of, I I, 250

Lombardy, history of, I85; political refugees from, 207
London, I4, 45, 46, 103; Austrian embassy in, 203

Longueville, house of, 166

Louisiana, American invasion, 227 ; boundary disputes, 233, 234; French expedition, 233; sale to U. S., 233; Spain fears English aggression against, 229; Spain protests against cession of, 234; see also Merveilleux, Capt.

Louisville, Ky., Franciscan monastery in, 266; Swiss consulate. 7, 26, 65, 67

Lowell, Hülsemann's report on factories at, 10, 205

Loyalists, indemnities to, 226

Luchsinger, John, The Planting of the Swiss Colony at Ncw Glarus, 94; The Swiss Colony of New Glarus, 94

Ludwig, Franz, 255

Lusser, Dr. Karl, manuscript collection of, 83

Lutherans, in Virginia, I3

Luze, L. Ph. de, Swiss consul at New York, 64

Luzenberg, Baron Carl von, 206

Luzern, 1, 2, 25, I I ; Bürgerbibliothek, 81, 82; city archives, 81,82 ; emigrants in France, I 6 ; emigration agencies, 8I ; emigration from, 79, 80; emigration laws, $78,80,81$; emigration statistics, $8 \mathrm{I}$; emigration to A1geria, I16; emigration to Highland, Ill., 78 ; emigration via, I29; emigration via Prussian Rhine provinces, II5; emigration via the Netherlands, 62 ; in favor of Swiss consulates, 62 ; Jesuitenkollegium, 78 ; organized emigration, $8 \mathrm{I}$; state archive, vi, 78-8I ; see also Vorort, Luzern

Luzerne, Ia., Swiss settlement, 70

Luzerne, Mich., Swiss settlement, 70

Luzerne, Pa., Swiss settlement, 7I

Maag, Hans Heinrich, emigration of, i8

Maas, Otto, Austrian vice-consul general to U. S., 257

Mclaughlin, English territorial agent, 203

McLeod affair, 209, 210

Madison, Wis., letters from, 67; Swiss consulate in, 7, 65, 67, 110; Swiss emigration to, 67

Madonna del Carmine, La, ship, 239

Madrid, 220

Märk, emigration agent, I40

Märlis, Johann Jakob, I4 I

Märsteten, complaint against emigration from, Io

Mafra, Franciscan convent at, 228

Magdalenengesellschaft, 250

Magellan, Strait of, 69

Magny, Constantin de, dépositaire royal, I77

Mahler, Joseph, in U. S. army, 79

Maine, act on finance, 204 ; boundary dispute. 196,203

Mainz, 92

Malacrida und Co., banking house, 53

Malta, priorships, 229

Mandatenbücher, Bern, 4I, 73

Mangourit, M. A. B., consul at Charleston, I63

Manila, 220

Mann, A. Dudley, mission to Hungary, 2I 5 
Maps, 72, 74, 218, 219, 229, 243, 245, 247

Marbach, 79

Marcos de Nizza, Fray, 2 I6

Marcus, Susanni, trade in salt. 2.39

Mareschal, Wenzel Philipp Freiherr von, minister to U. S., IO, 200 ; despatches to Metternich, 10, 200-210; instructions to, 215, 2 I6; receives post at Lisbon, II, 2IO; trip to New England, 208; trip to the West and North, 205

Maria Stein, near Pocahontas, Ark., 85

Maria Theresia, empress, 185, 234

Marine railroads, 244

Maronielli, Pietro. I98, I99

Marret, Swiss consul in Mexico, assassinated, 95

Marriage, citizenship by, 96,142

Martignier and Crousaz, Dictionnaire Historique du Canton de Vaud, I6r

Marschner, Anton, inheritance of, 193, 195, 196, 197

Marseille, 239

Martin, Father, letter to, 84

Martin, Lands-Vcnner, letter to, 82

Martin, C., article by, I76

Martin, $D r$. Franz, vii

Martin, Paul E., archivist, Catalogue des MSS. de la Collection Grenaud, 151; Etat Général et Sommaire de Fonds, 177,178

Martinique, Dutch occupation of, 230

Maryland, 210

Maschwanden, 22

Masonic orders in U. S., movement against, 195

Massachusetts, railroad legislation in, 205

Mater, von, petition of, 24

Mather, Cotton, Diary, 184

Mathey, Capt., letter to, I7 I

Mathisen, Heinrich, return of, 20

Maurer, Franz, claim of, 200

Maurer, Jakob, petition of, 29

Mauth-Tariff, regulation of, 216

Maximilian 1., I85

May, Swiss commissioner to England, 45

May, Beath Ludwig, Säckelschreiber, 54

May, Emanuel, IIistoire Militaire de la Suisse, 99

May, Capt. Einannel, Red River colony, 6r, г7ı. 172 ; see also Red River

May, Capt. Rudolph, Red River colony, 53. $6 \mathrm{I}, 128,171,172 ; K$ urze und zahre Ucbersicht, I15: see also Red River

Mayence, see Matinz

Mayr, Dr. Michael, director, vii

Mead, Edwin D., article hy, I84

Mediation, Russian and Prussian (1779), 222; Russian (1813), 235

Meiden, emigration of, 45

Meientlial, 83

Meier, J. P., petition of, I 42

Memmingen, city council on emigration, 127

Mennonites, Dutch, 3 ; Swiss, 3

Menzingen, 97

Mediterrancan, American warships in the, 235

Menzel, Josepl A., 2 Io

Mercury, mines, 25.3 ; trade, 255
Mercy-Argenteau, Count Florimond von, criticism of treaty of commerce, 9. 187; letter of, 187

Meredyth, emigration agent, 248

Meriszhausen, emigration from, 122, 123, 124

Merle, John A., Swiss consul at New Orleans, 65

Merveilleux, Capt., recruiting by, 3, 33, 34, 4I, $42,53,54$

Methodists, 27

Metmenstätten, 22

Mett, meeting at, 38

Metternich, Prince Clement Wenceslaus, Io, II, 200; despatches to Hülsemann, 21 I215; despatches of Lederer to. I89-200; despatches of Mareschal to, 200-210; despatches of Stïrmer to, I89; instructions to Hülsemann, 216; instructions to Lederer, 215; instructions to Mareschal. 2 I5; instructions to Stürmer, 215 ; letter to U. S. Secretary of State, 215; letters to, I99, 216; spying system of, 247

Meuron, Charles Daniel de, I72

Meuron, Th., articles by, 172; Essai Historique sur le Régiment Suisse de Meuron, I72

Meuron, Régiment de, I7I, I72

Mexico, 10, 79, 84, I28, 202-205, 213, 216; amnesty for insurgents, 225; archbishop appointed viceroy, 232: Austrian emigration to, 2.1 ; blockade of coast, 200, 20I, 204, 2I6: condition in, I95; convention between U. S. and, 2 I2; diplomatic agent to Vienna. 212 ; emigration of Tyrolese miners to, 265 : insurrections, 225, 226, 231, 232 ; list of gold and silver coins of, 220 ; maps of, 247 ; navigation treaty with U. S., I93; negotiations with Arlm. Baudin, 203: occupation of city of Mexico, 2I4; Prince Paul von Württemberg in, I96; secret trading in, 220 ; statistics, 246; Swiss commercial treaty, 95; Swiss consul Marret assassinated, 95 ; Swiss consular reports on, 93; Swiss consulate in, 26; Swiss emigration to, 69: trade relations with, 25, 95; treaty with France, 204; treaty with Switzcrland, 95; viceroy Don Bernardo de Galvez, death of, 227 : war with Texas, 61 ; war with U. S., 214 ; see also New Spain

Mexico, Gulf of, Austrian supplies for French colonies on, 223

Meyer, Daniel, return of. i i

Meyer, Jacob, petition of, 24

Meyer, Joh., inheritance of, 23, 24

Meyer, Lucia, petition of, 137; petition refused, 1.38

Meyer von Knonat, G., Der Kanton Zïrich, 28

Micarelli, V., commerce with U. S., mémoire on, 216

Michel, Franz Ludwig, article on, 72 ; contract with Ritter and Co., 74; letter of, 73; Reisebeschreibung, 72

Michigan, 67; Swiss settlements in, 70

Milan, 207, 250

Military pensions, see Pensions

Miller, 248

Milwankee, consulate in, 26 
Minder, Johann Baptist. 79

Minnesota, Swiss settlements in, 70

Mischler, emigration of, 45

Mississippi, 208; securities, 53; Swiss emigration to, 42, 54, I69; see also Merveilleux

Mississippi Company, 4I

Mississippi River, free navigation of, 229, 230, 234

Missiven Buch, 54

Missouri, 87; Duden's book brings settlers to, II; outline of the constitution of, Igo; slave-trade, I90; Swiss settlements in, 6, 70

Mittelberger, Gottlieb, Reise nach Pennsylz'anien, 20, 5 I

Mobile, English failure against, 223

Möhr, J., chief of the federal Auswanderungsamt, Bern, vii

Mölzel, Johann, death of, 206

Moering, Ingenicur Captain Carl, in U. S., 2II, $2 \mathrm{I} 2$

Mohl, cmigration of, I 6

Mollis, 92

Monitz, colony in Brazil, 156

Monroe, James, messages, I90, I9I ; reception in Geneva of, 179, I80; IV ritings, 179, 180

Monticello, Fla., Swiss settlement, 70

Montjou, Lieut.-Col., letter of, I7 I

Montreux, I6I

Moore, J. B., Digest of International Law, 215n.

Morancour, articles on Carolina and Pennsylvania, 48

Morgenstern, I 39

Morillo, Gen. Pablo, I9o

Moritzi, F., petition for aid refused, 138

Mormons, Swiss, acta, 27; emigration, 7, 75, 77

Morris. Robert, letter from, i8I

Morse, S. F. B., telegraph of, 2I 2

Moser, Hans, return of, 50

Mosquito Coast, grievances between England and Spain concerning, 226, 227

Motta, E., archivist, I47, I 48

Mottaz, E., Dictionnaire Historique . . . du Canton de Vaud, I59, I60

Motzl, 2.59

Mount Angel College, Ore., architectural plans of, 88; Die Benediktiner Kolonie, 87; founding of, 87 ; newspaper articles on, 88

Moustier, Count de, French minister to Prussia. 228

Mudrich, Dr. Andreas, director, vii

Mühlenberg, Henry A., U. S. minister to Austria, 10, 208, 209, 210, 216

Mülinen, Prof. Dr. W. F. von, chief librarian, vii; Christoph von Graffenried, 74 ; library of, 74,75

Müller, Bernhard, religionist, I I, 196, 250

Müller, Daniel, kidnapping of, 53

Müller, Jacob, petition of, IoI

Müller, Maria, petition for aid refused, 145

Müller, Ulrich, 56

Müller und Co., banking house, 53

Müllhausen, recruiting for England in, 239

Münchenbuchsee, 43

Münden (Hanover), $25 \mathrm{I}$

Mumpf, 22

Murat, Prince Achille, 207, 208
Muri, Casimir, donation of Civil War papers, 79; pension for, 79

Musée Neuchâtelois, article in, 172

Mussi, Joseph, 253

Muttenz, emigration from, 48 , I I I

Myers, A. C., Narratives of Early Pennsylvania, 30

Nabholz, Prof. Dr. Hans, state archivist, vii

Nach dem fernen IVesten, 87

Nachrichtsblättlein of Zürich, 18

Näf, Heinrich, agent, 2I

Nägely, Jakob and Peter, petitions of, 35

Nantes, proposal for Austrian consul at, 222

Naples, treaty with U. S., I 98

Napoleon I., see Bonaparte, Napoleon

Nassau-Saarbrücken, Swiss emigration to, 42

Nassau-Usingen, Ficld Marshal Lieut. Prinz, 238

Nater, Jakob, article by, I46

National Council, Bern, emigration laws discussed in, 76

National Gazette of Philadelphia, I90, I9I, 195

National Institute, 246

National Intelligencer, 190, 191, 193, 208

Natter, Rev. John Jos., 249

Natural History, Society of, Amherst, 192

Naturalization, 21 3 ; see also Citizenship

Naval expeditions, 218, 219, 220, 221, 224, 228, $229,230,23 \mathrm{I}, 232,233,242,244,245$

Navy, U. S., Secretary of the, report of, 195

Nebraska, Swiss settlements in, 70

Netherlands, 67: Adams, American minister, 224,225 ; commercial relations with America, 222, 224, 225; commercial relations with West Indies, 220, 227; complaint against Swiss emigrants, 5, 84, I I5, I4I, I44, I70; complaint against war supplies for the American colonies, $217,218,220$; complaint of Dutch West India Co., 226; complaint over Anabaptists, 37; complaint to Denmark regarding whale fishery, 218 ; complaint to France and Spain regarding negroes, 2I8, 220, 226; convoys for ships to West Indies, 220, 22I ; debt of Dutch West India Co., 229; emigration from, 67; emigration laws, 23, 24, 25, 79, II 5, I40, I4I, I70, I7I ; emigration via, $25,62,84,9 I$, I 40 , 157, 158, 170, 17 I, 217; fear of war between England and U. S., 23I : food supplies to English colonies, 2I8; foreign vessels in quarantine, 237; inheritance dispute with Bern, 38; list of Swiss emigrants to, 13 ; loan for American colonies, 224, 225, 228; Mennonites in, 3; Scottish regiments, 218; seizure of Dutch ships by English, 221 ; South Holland Synod, petition of, ro6; Swiss emigrants, I3, I07, I 1 5, I22; synod of the Reformed Church, 58; treaty with U. S., 205; Van Berckel, minister to U. S., 225. 227 ; see also Batavian; Belgium

Netzthal, emigration statistics from, 92

Neuchâtel, 38,42,49,54,57, I28, I 49; Audience .du Comte, I66; Audiences Générales, I66, I68; Chambre Economique, I68; Chancellerie, I66; church archives, I74; city ar- 
chives, I73: Classis, archives of, I66. I73174; colonial scheme, 3; Commissaire Général, I66; communes, I68, I69; Company of Pastors, I66, I73-I74; conference of 1846 , I 16; Corps Législatif, 166, 168; emigration from, 64, I69, I7 I ; emigration laws, 38, I69, I70 ; emigration to Pennsylvania, I7 I ; emigration to Russia, 173 ; état civil, registers, I68; Grand Council, I66, I68; independent principality, 2; insurrections, I66; le Véritable Messager Bôtteur de, I73; library of the city, 173; Manuaux du Conseil d'Etat, I67, I69; Missives, I68: Musée Neuchâtelois, cited, I72; notarial registers, I68; passport list since I 796 , I7 I ; Pièces Annexes, I67, I7 I ; Prince of, I66; Procès-Verbaur des Audiences Générales $d c$, I68; Protestants, I66; Quatre Ministraux, 173; reports on Carolina and Pennsylvania, 46; state archive, vi, I66-I73; Tribunal des Trois Etats, I66; under King of Prussia, 2, I66, I68; uniform policy of emigration, I7o; see also Pury. Jean Pierre

Neue Nachricht alter und neucr Merkwïrdigkciten, $3 \mathbf{I}$

Neuenburg, sce Neuchâtel

Neu Engelberg, see New Engelberg

Neuengelberg, see Mount Angel

Neu-Gefundenes Eden, 20, 30

Neu Helvetia, Uruguay, Siviss at, 93, 146

Newjahrsblatt des IV aiscnhauses Zürich. I3

Neuländer, iog, I I 3

Neunkirch, I22, I23

Neutäufer, 27

Neutrality, 78,252 ; violations of, 203. 222, 236

New Baden, Texas, Swiss settlement, 7 I

New Basel, Kan., Swiss settlement, 7o

Newbern, Ala.. Swiss settlement, 7o

Newbern, Ind. Swiss settlement, 7o

Newbern, Ia., Swiss settlement, 70

Newbern, Kan., Swiss settlement, zo

Newbern, Minn., Swiss settlement, jo

New Bern, N. C. article on, 73; description of 3. 60,73 ; map of, 74 ; Swiss settlement, 70

Newbern, Tenn., Swiss settlement, 7 I

Newbern, Va., Swiss settlement, 71

Newberne, III., Swiss settlement, 7o

New Brunswick, boundary dispute, 203, 204

Newburgh, N. Y.. Io7

New Engelberg. Mo., Abbey of Conception. 8s: petition to the Pope, 87 ; Swiss settlement, 70

New England, Hïlsemann's trip to, 10, 205 ; Mareschal's trip to, $20 \%$

Newfoundland, 2.30

New Glarıs, Wis., 6. 71, 92, 93 ; airl irom canton Glarus, 9, 92; bilulingrapliy, 9.4: congratulatory message to, 93; founding of, of: postoffice in, 92 ; report from, 9I ; report of the Glarner Verein on, 26

New lersey, Swiss inlabitants in, 6

New Orleans, 65, 193, 195, 200, 204. 206; climatic conditions, 66 ; i) ie l)entsche Gesell schaft and its agency, 66; English failure against, 223; immigration statistics, 66: Socićté de Bicufaisance do, Compto
Rendu, 65; Swiss charitable institution, 27. 65,84, II7, I4I ; Swiss consulate in, 7, 26, $65,66,80$, I 10, I70, 172: Swiss immigration via, 65, I 16, 135, I41 ; Swiss immigrants in, $27,66,141,170,172$

New Oxford, Mass., 73

New St. Gallen, W. Va., Swiss settlement, 7 I

New Spain, 219; see also Mexico

New Subiaco Abbey, Ark., 84

New Switzerland, Ga., Swiss settlement, 7o

New Switzerland, Ill., see Highland, Ill.

New York City, 52, 1.31, 1.54, I89, 192, 194. 195. I $98,109,205,207,210,250,251,255$; Agricultural Society, igr ; Austrian consulate in, 212. 245, 254; bureati of emigration, 96 ; capture of, 2IS; charitable institution in, 27 ; cholera, I97; commissioners of water works, report of, 201: Delmonico restaurant, 147: Exposition, 26; German Society offers aid to emigrants, II8: immigration statistics, 64; Italian newspaper in, I.48: Italian revolution, demonstration in favor of, 2It; Louis Kossuth in, 215: maps, 218, 2I0: Mareschal's arrival in. 200: Nen Yorker Staatsacitung, 7o; riots in, I9S; sequestration of silk in, 26; society for the benefit of Swiss immigrants, 64, I42: Swiss consulate, $7,24,26,63.64,9$ I, IIo, I70; synod. 52; trip from Bremen to, I 19; yellow fever in, igr

New York (state), I73; banking act, 202 ; immigration laws, 91 ; Swiss settlements in, 6 . 7 I, I3I :

Nicolaus, Simon, bishop of Pasel, 63

Nicolet, Theodore, first consul at New Orleans, 65

Nidwalden, emigration from, 87 ; emigration list, 89: state archive, vi, 89; sce also Unterwalden

Niederberg, Dr. Nikolaus, 103

Niles, Nathaniel, diplomatic mission to Austria, IO9

Noblet, Jean, colonimation scheme of, I-s: letter of, i78; petition of, 179

Nootka Sound, 229, 230

Nordhausen, recruiting for England in, 230

Norfolk. Va., Hülsemann's report on, 10, 201

North Carolina, Colonial Ricords of, 73, Ioz: Hiilsemann's report on, 204; letters from, 74; Swiss settlements in, 7I; si' also Carolina

Northeastern boundary question, I(\%, 1)6, 203. 204

North German I.luyel, ino

Northwest Comenan, 17

Nonvelle-libuturer. Swiss colomy in lirazil, it7 Nova seotia emieration to, 36, fie, fo. Ior

Nozella hilatetio, Italiall newspaper, Ifs

Nitscleler, Solomon, emigration of, 2 I

Vuozo Sicolo dell' Elácia, article in, IfS

Nurembers, 250

()beriigeri, 97

Ob dic Mirrsihaft Worb, 60

Obcrorf, os 
Oberhasli, 38, 46, 55, III ; emigration from, 34, $39,44,45,46$

Oberhofen, emigration from, 34

Oberinnthal, emigration from, 266

Oberland. Bernese, 55; emigration from, 5, 39, 44. 46,49

Oberried, 50

Ober-Simmenthal, Landschafts Commission, 60

Obwalden, emigration, 87 : agencies, 87 ; statistics, 86,87 ; state archive, vi, 86,87 ; see also Unterwalden

Ochs, Johann Rudolff, 4I ; Amerikanische Inseln, 4I ; Amerikanischer IVegweiser, 3, 3I; letter of, 73

Ochs, P., Geschichte der Stadt und Landschaft Basel, in 3

O'Connor, Father Beda, journey to America, 84, 85

Odermatt, Father Adelhelm, founder of Mount Angel, 87

Oehrli, Christ., 50

Öri, cooper, returns from Carolina, 22

Öri, Landiogt, estate of, 21

Oesterreichische Wochenschrift für Wissenschaft, Kunst, u. öffentliches Leben, article in, 267

Oesterreich von I848-1860, Friedjung, 247

Offenbach, religious fanaticism in, 250

Official publications, exchange of, 96, I 55

Ohio, 67; Swiss settlements in, 6, $7 \mathrm{I}$

Ohio River, free navigation, 229, 230

Opfershofen, I22

Opfikon, 22

Orange, Anna Pavlovna, Princess of, I97

Ordinari Sambstagsblätlin. 44

Oregon, monastery in, 87; Swiss settlements, 7I

Oregon question, $68,203,213,214,216$

Orosco, appointment as Spanish minister, 232

Ortenau, emigration from, 235

Othmarsingen, I to

Ott, Swiss consul at Madison, 67

Ottawa Indians, 25I

Otter-skins, tariff on, 24I

Otto, Col., 238

Ozark, Mo., Swiss settlement, 70

\section{Pacific Ocean, 222}

Pakenham, Richard, minister of England, 203

Palatinate, colonists from, 74 ; Swiss emigration to, 13

Palmerston, Viscount, correspondence over Caroline, 203

Panama, consulate in, 26

Paolina, ship, 233

Paquier, Joseph, letter of, I72

Paris, I7 I, 200, 221, 222

Parish, David, property of, 192, 193

Paraguay, I 28

Passett, A., petition to emigrate, I 38

Passports, American, 25I ; for Austrian officers during war, $24 \mathrm{I}$

Pastorius, Francis Daniel, founder of Germantown, 30; Copia cines von einem Sohne, N. N., 30; Life of, 30 ; Sichere Nachricht, 30
Patents, I 4 I, 255

Patria e Progresso, $\mathrm{I} 48$

Payerne, abbey of, I6I

Pecher, Dean, letter of, 249

Pecos River, I6r

Pedro, Dom: accession of, 157

Pelizcaro, Pietro, 2 I I

Pembina, 172

Pennsylvania, article on, 48; canal of, 206; Das verlangte, nicht erlangte Canaan, $3 \mathrm{I}$; description of, I4; German preachers for, 40; French colony in, 73; letters from, 4, 19, 49, 5o; Narratizes of Early Pennsylvania, 30; Nen-Gefundenes Eden, 29, 30; Reformed community of, I06, 130; Reise nach Pennsylvanien, 20, $5 \mathrm{I}$ :Ritter plans colony in, 40; Sichere Nachricht aus America, 30; Swiss emigration to, v, I4, I 5, I7-22, 29-31, 33, 36, $37,39-43,46,48-5$ I, $58,63,73$, IOI-I07, I I0I 12, I23, I25, I7I ; Swiss Mennonites to, 3; Swiss settlements in, 7I; travels in, 20; Wahrhafte Erzehlung, 19, $\mathbf{3} 30$

Pensacola, Jackson and Callava in, I90; rumor of English landing at, 228

Pensions, 7, 79, I24. I 42, I56, I 58, 206, 227

Percussion-locks, 195

Pernambuco. Brazil, 79; insurrection in, 228

Perry, merchant, recommends steamboats, 254

Peru, blockade of coast, 235 ; consulate in, 26 ; convention between U. S. and Peru-Bolivia confederation, 20I ; expedition of ViceAdmiral Cochrane, I90; silver-mines, 227 ; viceroy of, 226

Peter, estate of, I Io

Péter, Jean Friederich, I7 I

Péter, Samuel, I 7 I

Peterson, C. C., consular agent in New York, 192

Pewelef, Marguerite, I7 I

Pfäffikon, 23

Pfeiffer, Casper, agent, 129

Pfeiffer, Hans Jakob, I22, I23

Pfister, Balthazar, letter of, 19

Pfister, Joh. Jakob, power of attorney to, 59

Pfister (Beneke and Pfister), 24I

Pharmaceutical articles, 244

Philadelphia, Jakob, 52

Philadelphia, 25, 30, 43, 120, I28, 170, 198, 200, 206, 2II, 256; charitable institution in, 27 ; commissioners of water works, report, 201 ; Exposition, 26, I42; Handelskonsulat in, 66-67; letter from, Io3; newspaper advertisements concerning Gallatin, 180 ; relation of, 5 I : Schlatter, Michael, $40,49,58$; Stürmer, Austrian consul general in, 236 ; suspension of banks, 206; Swiss consul, complaint of, 97, 142; Swiss consulate in, 7, 26, 65,66 , I I0; Swiss consulate's reply to Société d'Utilité, 66; synod report to Swiss Reformed Church, 52 ; yellow fever in, 24I Piaget, Arthur, archivist, I68

Pictet, Marc Antoine, correspondence of, 184 Pietists, 38

Pigot, Adm. Hugh, arrival in New York, 224

Pilots, Austrian signal for, I92

Pine Hill-Salzburg, Ky., Swiss settlement, 70 
Pinckney, Charles, U. S. minister to Spain, 233, 234

Pirates, 34; Algerian, 23I ; of Barbary states. 235: of. Morocco, 225; of South America, 236; of Tunis, 233; West India, I9I

Pisa, 252

Pittsburgh, Pa., factories in, 206

Planta, consul general in Amsterdam, I15, I4I, 157

Plattner, Verena, letter of, i ro

Plitt, G., 205

Plöckli, Mathis and Peter, petitions for aid, I37

Plotho, Erich Christoph, Edler vom, property claims of the Salzburg Protestants, 262, 264

Plümacher, colonial scheme of, 69

Plïss, Jakob, estate of, 59

Pocahontas, Ark., Swiss settlement, 7o

Point Breeze. 195

Poland, 19; Russian-Polish refugees, 245, 246; Swiss emigration to, 79,96

Polignac, de, French ambassador, 59

Polk, James K., 206

Poll, arrested in Zürich, 36

Pomerania, Swiss emigration to, 3, 14, 18, 36

Ponceau, Peter S. du, letter of, I8I

Population increase in American colonies, 218

Port Bretton, emigration to, 69

Portalès-Gorgier, Count, proposals on emigration, I 68

Portefeuilles des Pièces Historiques, in Geneva archives, $175,176,177$, I 78

Porto Rico, 172, 194

Portugal, boundary disputes with Spain, 230; commercial relations with America, 227, 229; complaint against Dutch West India Co., 229; diplomatic agents of, 195; discord in ninistry, 227: England claims warships, 233; English convoy for fleet, 232 ; exportation of wines, 227 ; Aleet, 231, 232, 233, 234; fleet against Algiers, 228, 231 : France proposes to conquer, 232; hostilities on Rio Grande between Spain and, 217, 218, 219. 220 ; llumphreys, American minister, 229. 231 ; insurrection in colonies, 233 ; invasion by France, rumor of, 232.233; pensions, 227 ; ports closed to English-American vessels, 219 ; proposed commercial treaty with America, 232, 2.33; return of vice-governor to, 233; secret negotiations with England, 23.3; seizure of American ship at Lisbon, 220 ; seizure of French frigate, 230; silver fleet, 227, 231, 232; Spanish succession, 227; treaty of peace with Brazil, 157; Van Buren's proposed trip to, 196

Post. P. Sidney, American consul general in Vienna, 256

Postal relations, between Austria and America, 242,245 ; Swiss, 7, 96, 97, 120

Poster, 11ans, 56

Postl, Carl, II, 249; Alustria as it Is, II

Potato disease, treatise on, 67

Potownac, frigate, ing

Powder, exportation from Austria, 243

Powers, Swiss consul general to the U. S., 153. 158
Prague, 248, 249; archives, 8; Gregg, American consul at, 256

Prankl, Dr. Hans, vii, 217

Prattelen, 48

Presburg, 248

Presbyterian Historical Society, Journal of, 5on.

Preston, Wm. C., 206

Preziosi. G., Gl'Italiani negli Stati Uniti del Nord, I 48

Prinzinger, A., jr., article by, 258

Prisoners, French officers in England, 219; Neapolitan, release of, $24 \mathrm{I}$

Prizes, American, 59, 2 19, 220, 224, 228, 233. 235; English, 220, 221, 222, 226. 234; French, 59, 230; Portuguese, 231 ; Spanish, 224, 229, $230,232,235$

Proctor, John R., 81

Proli, see Müller, Bernhard

Proli, Count Balthasar de, diplomatic correspondence, 187

Property, private, confiscated, 243

Protestant cantons, emigration from, 5, 77

Protokollum Actorum Ecclesiasticorum, 18, 20

Providence Island, Spanish conquest of, 224

Prussia, 235: alliance with American colonies, 22 ; commercial treaty with Hanse towns, 254 ; commercial treaty with U. S., 226; complaint against Swiss paupers, 5 ; correspondence of the Quatre Ministraux with, 173; documents of the Neuchatel administration, 168; emigration from. 67: emigration from Bern to, 38, 41 ; emigration from Schaffhausen to, 125 ; flag, 225; mediation, 9, 222; navigation treaty with U. S., 193; Prince of Neuchàtel, I66, I68, I69: reciprocity, 193; refuge of Mennonites in, 3; regulations, emigrant transports, 23, 79 , I I5, I40; subsidy treaty with England and Russia, 2IS; Wicdertäufer, $38 ;$ see also Frederick William 1.; Neuchâtel; Salzburger Protestants

Prussia, East, Swiss emigration to, 42

Public Utility, Society of, see Société d' Utilité Publique

Punta Arena, emigration to, 156, 157

Purry, Jean Pierre, colonial scheme of, 3, 38, 42, $43,54,57,169,173$

P'urrysburgh, S. C., 3, 29, 174; article on, 169

Quarantine, 230, 234. 237, 241, 245

Quatre Ministraux, Neuchâtel, 173

Quebec, taxes, 217

Quinche. Capt., emigration agent, 45, 54: persecution of, 45

"Rabies Carolina," 3, 55

Radich, Capt., of the Paolina. 233

Raemy, Tobic de, state archivist, 15 m., 152

Railroads, 10, 200, 20.4. 205, 206, 209, 2 I I, 216,244 Randolph, Edmumd, mission to Vienna, 10, 195. 106

Ratgeber fïr die Schacizerischen iluswanderer, 6,81

Ratsmanuale, see Bern, Zürich

Rauch, Bernhard, merchant, 19r 
Rauris Repertorium des Hochfürstl. Land- und Berg-Gerichts, 263

Reading, Pa., 59

Reciprocity, I90, 192, I93, I94, I97, 255

Recruiting, see Army, British

Recueil Généalogique Suisse, I83

Red River, colony on, 53, 61, I15, 128, 170, 17I, 172

Reformed Church, History of, Good, 30

Regensberg, list of emigrants from, I3

Regensburg, Protestant Commission, 259

Regeste Genevois, I83

Register of German passengers, 62

Reiat, emigration from, 124

Reichenberg, English minister in, 56

Reichesberg, N., Handwörterbuch der Schweizerischen IVolkswirtschaft, 6

Reily, James R., appeal for a theological seminary in U. S., 24

Rekruten-Kammer, Manual der (Bern), 52, 5354

Repertorium der Abschicde der Eidgenössischen Tagsatzungen, 62

Repertorium des Staatsarchivs zu Basel, IоI

Resolution, frigate, 217

Responsa Prudentum, 4, 55

Reutingen, II I

Reutlinger, depcsition of, 24

Reuty, 91

Revolutionary Clubs, see Clubs Insurgés

Revolutionary War, see American Revolutionary War

Revue de l'Unizersité de Bru.relles, cited, I86

Revue des Bibliothèques et des Archives de Belgique, cited, 180 ó

Revue Historique Vaudoise, cited, 73, I5 I, 162

Reybaz, minister of Geneva, I79, I80

Reymond, Maxime, article by, 159

Rham, H. C. de, Swiss consul in New York, 63

Rheinquellen, I 39

Rheinthal, emigration law, I8

Rhodanique, République, 164

Richardton, N. D., abbey at, 84

Richmond, Va., I8I

Ridgeway, N. C.. Swiss settlement, 7I

Rieden, Georg, 38

Rieger, and family, emigrate to Virginia, 107

Riehen, II 7

Riemensperger, Hans, agent, 35, 38; persecution of, 46

Riggenbacher, H., letter from, I04

Riggenbagher, inheritance, I 2

Riggin, William, appointment of, 233, 234, 253

Rights of domicile, see Freizügigkeitsvertrag

Ringholz, Dr. P. Odilo, vii; Geschichte des Benediktinerstiftes Einsiedeln, 85

Rio de Janeiro, 79, $218,220,232$; Stürmer, Austrian minister to, 2,37

Rio de la Plata, blockade of the coast of, 204 ; see also La Plata states

Rio Grande River, Brazil, 217, 219

Rising, 248

Ritschard, Heinrich, return of, 50

Ritschard, Jacob, 56

Ritter, appeal of, 267
Ritter, Eugène, Les Archives de l'Église de Genève, 183,184

Ritter, George, 72 ; colonial scheme of, 3, 37, 40, 4I ; contract of, 74; emigration of, 73

Ritter, Dr. Paul, iii

Rivaz. Charles Emmanuel de, journal of, I63; Mémoires, 163

Rivaz family, archives of, 163

Rives, W'm. C., 206

Roatan, see Ruatan

Roch, C., attaché of the Geneva archives of state, 183

Roch, Moise, death in San Domingo, 59

Rochambeau, Comte de, in conference with Washington, 246

Rodney, Adm. Lord (George Brydges), capture of Austrian vessels, 226

Rodt, E., Bern im XVIII. Jahrhundert, 33

Rodt, Hans, 56

Röllin, Johannes, petition of, 97

Roenne, Baron L. von, minister of Prussia, 209

Röthlisberger, Ernest, article by, 6

Rohner, Joh., convict, petition for aid, 138, I39

Roman, complaint against, 259

Rome, French commissary on Spanish frigate, $23 \mathrm{I}$

Rommel and Co., emigration agency, II8, I20, 124

Rosati, Joseph, bishop of New Orleans and St. Louis, letter of, 208

Rosenfeld, I20

Rosenthal, Theodor A. T. von, 185

Rothschild, banking house in London, 203

Rottenbiihler, Relation von Philadelphia, 5I ; Theil von einem Schrciben eines Landsmanns aus Pennsylvanien, 82

Rotterdam, I7I ; complaint over deportation of Anabaptists, 37

Rovereto, 265

Rovigo, 210

Royal Charter, ship, sinking of, 68

Ruatan, Spanish conquest of, 224

Rubi, Lieut., letter to, 46

Ruckstuhl, J., thief, aid to emigrate, 145

Rübi, emigration of, 45

Rüdler, emigration of, 45

Rüdlingen, emigration from, I24

Rüger, Thebis, emigration of, 122,123

Rüegger, Franz G., Kurser Reisebericht von Havre bis Highland, 8I

Ruitschi, Rudolf, appeal of, 22

Rufenach, I4I

Ruffener, Elise, pension for, 158

Rufli, Joseph, lawsuit against, I 29

Russia, 205; claim to Northwest coast, I90; colonies in America, 228; concessions to colonists, 79; circulars concerning, II3; mediation, 9, 222, 235; secret alliance, 224; subsidy treaty between England, Prussia, and, 2I 8; Russian-Polish refugees, 245, 246; Swiss emigrants to, $3,22,36,69,98$, I I 5 , I44 I73; treaty with U. S., 19I, I98

Ryhinner, Charles, vice-consul of U. S., I52, I57

Rykeri, 22 
Sachseln, 86

Sachsenspiegel, 127

Sackcalender, Zürich. I8

Säckelschreiber Protokolle, Bern, 54

Sails, see Cotton duck

St. Andreas, convent of, 87

St. Anton, Wis., letter from, 266

St. Christopher, captured by the French, 224; naval battle near, 22.4

St. Elizabeth, order of, 234

St. Eustatius, captured by the English, 223; captured by the French, 224; Dutch stop American vessel at, 221 ; Portuguese corsair in, 231; secret trading with Americans by way of, 9, 220; seizure of Austrian ships in, 226

St. Gallen, 2, 7, 29, 58, 106; archive of the township, 129, 130; cantonal library, 128; city archives, I30; emigration from, I28, I29: enigration statistics, 129, 130: emigration to Algeria, I28: emigration to Bell Co.. $\mathrm{Ky}$, 129; emigration to Brazil, I29; emigration to Chicago, I29; emigration to Harlan Co., Ky., 120: emigration to South America, 129; export to U. S., I31; Industrie und Handel des Kantons, 130; Kaufmännisches Dircktorium, archive, vi, 7. 130-131; lace industry, 7. 131; May's colonial scheme rejected, 128 ; registers of preachers since the Reformation, I30; Stadtarchiv, I30: Stadtgemeinde, archive, 129-130; state archive, vi, 128-129; Stiftsarchiv, 129: Tageblatt St. Gallen, I29

St. Helena, recall of Stürmer from, 215, 236

St. Helens, Lord (Alleyne Fitzherbert), English minister to Spain, 230

St. John, 250, 260, 261

St. Louis, $81,86,172$; charitable institution at, 27: letter from, I16: Swiss consulate, 26, I10

St. Martin, island. English conquest of, 223: neutrality, violation by the English of, 222 ; scizure of American ships by the English. 222

St. Mary's abley, N. D., 84

St. Meinrad. Ind., abbey, 84,85 : Swiss settlement, 70

St. Peter, Geneva, 1,8

St. Thomas, troop slips from Triest to, 236, 237

St. Victor, priory of, 178

St. Vincent, English failure against, 223

St. Vincent's monastery, Pa., 84

Salt, trade in, 230

Salvador, commercial treaty with Switzerland, 96; extradition treaty witl Switzerland, 83

Salzburg, 185; Allgemoine Kundmachung, 263; Bibliothek des Städtischen Museums, 258: Circularbefehl, 263; colony in Cicorgia, 258; Domkapitelsches Archiv, 258-259; cmigration and emigration lists, 250-26.4: Lmigrations lidikt, Ort. 3I, 173I, 10, 263; Frederick William I., crlict of, 10, $264 ;$ Fiirst-Erzbiscliöfliches Consistorialarchiv, 264; Gencral-l'atent, Aug. 26, 1734, 264; Hofkominission, archive, 263 ; Katenich, 263 264; Landesregierung, archive, 258-264;
Landesregiernugsarchivs, Inventar des, 258 ; military service against Bavaria, 263; Mittcilungen der Gesellschaft für Salzburger Landeskunde, 258; Pfleg Werfen, 258 ; provincial archives, v, vi, 8 , Io, 258 264: Publikandum, 263; Rauris Repertorium des Hochfürstl. Land- u. BergGerichts, 263; Studienbibliothek, 258; Verordnung, 263

Salzburger Protestants, Io, 258, 264

Sancta Maria von Obernsee, sec Sault St. Maric

Sandonà, Augusto, Storia dei Processi del l'entuno: dello Spielbers, 2.47

Sandwich, John, earl of, investigation of, 222

San Francisco, charitable institution, 27; Swiss consulate, 26, i 10

San Ildefons, abolishing of cemetery at, 226

S. Ildefors, battleship, 226

San Iuan, Nicaragua, Spanish reconquest of, 223

San Juan de Ulloa, French conquest of, 202

Santa Anna, Gen. Antonio López de, I99, 203

Santa Catharina, island, capitulation of, 220

Santander, French battleship at, 234

Santa Rosa, Llanos de, 206

Santee Forks. 50

Santiago de Cuba, 205

Santo Domingo, 228, 234: advantage of the Spaniards over French in, 235; cession to France, 231; complaint to France, 228 ; conquest by the neroes, 234; French troops in Spanish service for. 231; insurrections. 229 , 231: maps, 247: Roch. death in, 59: supplies on Austrian ships for, 222; Swiss cmigration to, 72

São Paulo. Die Schaceizer in, 86: Swiss emigrants in, 1,32

Sardinia, King of, I77; treaty with U. S., 201

Sargans, emigration law, is

Sarmen, convent of St. Andreas. 87 : letters from, 86: state archive in, 86,87

Sault St. Marie, Bishop of (Baraga), 84

Savannah, Ga., 203, 206. Hiilsemann's report on, 10. 20.4

Savary, Gen. René, duc de Rovigo, letter of, 17 I

Savary de Valcoulon, letter of, 181

Savoy, 17I

Savoyard communes, Gencra. civil registers of, 182

Schämblins, Martin, examination of, 100

Schafthausen, 1, 10. 80 ; aid to cmigrants, 122, 123, 124: Ikten der Gesetzgebungsund l'eraillungsbehörden, Register, 122; (hronik dir Stadt Schaffhausin, 124; circular letter on emigration, 153; conference of 1846. 116: deportation, 124; emigration agencies, 123. 124: cmigration from, 75, 12,3-125: culgration laws, I22-125: emigration literature, 122: cmigration to Brazil, 86, 12.1: cmigration to Prussia, 125; emigration to V'enezucla, 12f; Offziclli Sammlung dir ciesctze, I24; Raths Protokolle, 12212,3: refusal to readuit emigrants, 123; state archive, vi, 122-125; uniform emigration policy, I 6 
Schaffner, Martin, deportation of, II7

Schaub, Jacob, emigration of, 106

Schauenburg, Christ., petition to emigrate, I I6

Scheitlin, J. M., president of the Verwaltungsrat, 129

Schenkel, Jakob, emigration of, 20

Scherz, Peter, 56

Scheuchzer, Landvogt, report of, 2I

Schiess, Dr., town archivist, vii

Schilling, Reinhard, convict, receives aid to emigrate, I44, I 45 , I 46

Schimmer, G. A., article by, 267

Schinz, Rev., 25

Schladen, Baron von, Prussian envoy to Portugal, 231

Schlatter, Rev. Michael, 5, 58, 130; petitions of, 19, 22, 39, 40, 40, 58, 106; Wahrhafte Erzehlung, I9. Iso

Schlitter, Dr. Hanns, archivist, 5, 186; Berichte des ersten Agenten Oesterreichs, 8, I86; Die Bezichungen Oesterreichs zu den Vereinigten Staatcn, 8, I86, 221

Schlötz, 79

Schmid, emigration agency, I 18

Schmid, Franz Vincenz, article by, 83

Schmid, Simon and family, emigration of, I34, I35

Schmidt, Anna Barbara, inheritance of, 59

Schmidt, Michael, conveys power of attorney, 59

Schmidtmeyer, Peter, report of, I47

Schneebeli, emigration agency, i 8

Schneebeli, E., death in America, 23

Schneebeli, Heinr., inheritance of, 23

Schneuwly, Joseph, state archivist, I5I

Schnottwil, 98

Schöneck, Pa., letter from, I20

Schraml, letter of, 249

Schrantz, Hans, legacy of, 54

Schuler, Heinr., emigration of, 137

Schultz, Joh., petition for aid, 1 I6

Schurz, Carl, Henry Clay, 215

Schwab, Johannes, examination of, II2

Schwaller, Benedikt, emigration of, 98

Schwanden, 90

Schwarz, brothers, emigration of, 42

Schwarz, J. G., American consul in Vienna, 198, 254

Schwarzach, 260

Schwarzenburg, emigration from, 40, 45

Schwatz, 265

Schweitzer, Jakob, letter from, I I4

Schweizer, Heinrich, 22

Schweizer, Johannes, emigration of, 20, 21, 28

Schweizer, Paul, article by, I3

Schweizer Verein zum Wohlthun in New Orleans, letter from, 84

Schweizerische Auswanderer, Bern, Ratgeber für, 6

Schweizerische Auswanderungswesen, Das, Karrer, 6

Schweizerische Auswanderungs-Zeitung, 96, 97

Schweizerische Blätter für Handel und Industrie, I3 $\mathrm{I}$

Schweizerische Hilfsgesellschaft, New York, II7
Schweizerischen Handels und Industrie Verein, Berichte des, I 30

Schweizerischer Consular Agenten Berichte, 94

Schweizerisches Auswanderungsbureau, see Federal Emigration Bureau

Schweizerisches Wirtschaftsarchiv, Basel, IoI

Schweizerische Unterstützungs- und SchutzGesellschaft für Auswanderer, 90

Schweizerische Wohltatigkeitsgesellschaft, complaint of, 86

Schwendler, American consul in Frankfort a. M., 254

Schwer, Peter, persecution of, 259

Schwyz, I, 84,85 ; cantonal archive, vi, 84 ; emigration from, 64, 84; Mitteilungen des Historischen Vereins des Kantons, 84

Scientific societies, 250

Scotland, emigration from, 67 ; regiments, 218

Sealsfield, Charles, see Postl, Carl

Seed varieties, 243

Seelisberg, Dak., Swiss settlement, 7o

Seguin, Texas, Swiss settlement, 7I

Seippel, Paul, Die Schweiz im Neunzehnten Jahrhundert, 6; La Suisse au Dix-neuvième Siècle, 6

Selkirk, Lord (Thomas Douglas), colonial scheme of, 53, I7 I, I72

Senate, U. S., 68; see also Congress

Separatists, 27

Servand, Martin, I77

Sextants, 244

Shindle, estate of, 216

Ships, 59, 68, 81, 96, 1 18, I 19, 145, 196, 203, 205, 210, 212, 215, 21 7, 226, 233, 237, 239, 252; see also Frigates; Prizes; Steamships; names of particular ships

Shipwrecks, 30, 68, 79, 8I, 96, I 18, I45, 203, 204, 233

Short, William, American minister to the Netherlands, 229; mission to Spain, 230, 23I

Shrok, J. M., extradition of, Io9

Sieben, judgments of, II I, I12

Sierra Morena, Swiss emigration to, 36

Siggenthal, emigration from, I $4 \mathrm{I}$

Signer, 126

Silbach, emigration from, 235

Silbernagel, Franz von, 253

Silk, trade in, 26, I3I, I4I

Simmlersche Sammlung, 4, 29

Singeisen, Mattis, emigration of, I I I

Sion, bishopric archives destroyed by fire, 165; cantonal archive in, I63; Lycée-Collège, I63

Sissach, letter from, II4

Sizlen, I29, I40

Slavery, Austria's position on, I0, I05; question, 34. 190, 191, 195, 206, 218, 220, 226, 228, 229, 237

Smith, Judge H. A. M., article by, 169

Smith, Wm. L., arrival in Portugal of, 23I

Smolinkary, letter of, 203

Société de-Bienfaisance de la Nouvelle-Orléans, Compte Rendu, 65

Société d'Utilité Publique, Geneva and Vaud, 7. $64,65,66$ 
Société Economique, archives of, Geneva, 178, 182

Soleure, see Solothurn

Solothurn, 1, 149; archives entitled Frankreich, 99, 100; deportation of Anabaptists, 37; emigration from, 22, 75, 98, 99; emigration law, 98; emigration tax, 98, 99; French ambassadors resident in, $99 ;$ Neues Solothurner Wochenblatt, 100 ; state archive, vi, 98-100

Sonderbund, 2

Sonora, 228

Sonsonate, destroyed by earthquake, 221

Sordet, Louis, archivist, 175

South America, 79, 84. 188, 217, 218; articles on, 266, 267; corsairs, 236; cmigration from Trent to, 267; insurgents in, 23, I90; report of Swiss consul in New Orleans on, 80; Swiss emigration to, 61, 69, 75, 93, 129; Swiss recognition of independence of states of, I90; Swiss troops in, 82

South Carolina, 50, 169; convention. I97 ; Hülsemann's report on, 10, 204; Swiss emigration to, I7; U. S. government and, 197; see also Carolina

South Carolina Historical Magazine, cited, I69 Southern States, Hülsemann's report on a trip to, 10

South Pittsburg, Tenn., Swiss settlement, 7 I

Spänhauwer, M., emigration agent, 48

Spain, 205, 216; advantages in Santo Domingo, 235; advantage under Cevallos, 220: American agent rejected by, 220: American emissary to, 228; American minister, complaint of, 237: American ships quarantined, 230; amnesty to the insurgents in Mexico, 225; anxious to prevent war with France, 232; appointment of two viceroys to America. 2.30; Austrian emigration to, 248 ; beginning of hostilities with England, 234; blockade of the coast of Peru and Chile. 235 ; boundary dispute with America and Indians, 226; boundary dispute with England concerning Florida, 190, 225, 226; boundary dispute with U. S. over Louisiana, 233, 234; capital punishment for aliens in the service of insurgents, 23, 236; capture of Gataimai, 221: capture of ships by lingland, 234: Carmichael, American envoy to, 225: cession of Floridla to U. S., I9o, 237: commercial and boundary treaties, $224,226,23 \mathrm{I}$; commercial relations with America, 221, 222, 226-229, 231, 23.33 commercial relations with Mexico, 232, 23.4 : commercial relations with Spanish West Indies, 223; complaint against $A u s t r i a n$ supplies to the insurgents, $235,236,2.42$; complaint concerning lostilities at Curaçiı, 222 ; complaint concerning troop ships from Triest to St. Thomas, 236, 237; complaint regarding relations at Rio Janciro with Portugal, 218; complaint regarding relations of Mosquito Coast with England, 226 , 227: concerning grievances between lingland and colonies, 18, 219; difficulties on Rio Grande with Portugal, 217, 219; dis- cord between Spain and U. S., 234: embargo on ships, 234, 236: emigration from, 67; emigration from Swabia to Spanish colonies, I29; emigration from Tyrol to. 248; England objects to cession of Santo Domingo, 231 ; English conquest of Buenos Aires, 234; English designs upon Louisiana, 229; English landing at Pensacola, 228; English settlers in Spanish America, 226; escape of slaves from Dutch to Spanish colonies, 220; fear of English power at sea, 230 ; fear of rupture of America with lirance, 232 ; fleet for West Indies. 230 ; France proposes conquest of Portugal, 232 ; freedom for slaves, 228 ; free navigation of Ohio and Mississippi rivers, 229. 230. 234; French troops in Spanish service, 231: Gibraltar exchange proposition, 229: guns from America, 217; hostilities with Indians, 226; insurrections in Mexico, 225, 2.31, 232; insurrection in Santo Domingo, 229, 231 ; insurrections in Spanish America. $190,225,228,232,237$; Jesuits driven out of. 23.3; negotiations with U. S. over captured ships, 232; nomination of archbishop as viceroy, 232; Nootka Sound affair, 229. 230; Orosco, Spanish minister to U. S., 2.32; Portuguese boundary dispute with, 230; position towards American insurgents, 220 ; proposed marriage of Princess of Brazil, 228; reconquest of Bucnos Aires, 234 : royal decree against American provinces, 235: royal decree concerning aid to South American insurgents, 23 ; royal decree concerning white population in Cuba. 236; ship-huilding yard in America, 221: silver fleet, 22I, 229, 230, 234: Spanisli America, serious effect of treaty of 1790 with England, 220; Spanish army in America, 247; Spanish colonies, 113, 128, 218; Spanish insurgent privateers in Buenos Aires, 235: Spanish position as to the treaty hetween France and colonies, 221 ; Spanish succession in Portugal, 227; Spanish troops on Austrian vessels, 236; steamship line to the Spanish-American colonies, 188; subsidies for the colonies, 221; subsidies from Fngland and Spanish America to, 235; Swiss emigration to Spanish colonies, 3. 14. $22,36,58,59.98,113,120$; transfer from Spanisli to Portuguese ships, 22.4, 23.4: U. S. violation of Iilorida, 236 ; volunteer corps in, 230: War with France, English negotintions with Spain over, 230; yellow fever in Spanish colonies, 2.3

Specht, Coruclins, 205

Speiszegger, 11:uns Courad, 122

spiegel an Amerita, këptli,

Spiclerville, Ark., 8.

Spinning machinery. American, 255

Spotswood, Gon. Alexander, founder of Ger-

inanna, 13 : letter of, it

Spring, Franz, legacy of, 5\%

Spring, Haus, agent, ilt

Spurzheim, Dr., legacy of. 197 
Stadion, Count, governor of Illyria and Triest, 216

Stäbli, emigration of, 45

Stans, Stammbuchamt, 89 ; state archive in, 89

Stapfer, Professor, 51 ; on book Sur la Population de l'Amérique, 5I, 52

Starhemberg, Prince Ludwig von, letter to Delplancq. I87

State, Department of, U. S., archives, 75

States General, see Netherlands

Stauffer, Pa., Swiss settlement, 71

Steamships, 244; lines, I88, 225, 230, 244; literature, 245

Steckborn, 50

Steffisburg. 38, 43

Steiger, R. von, article by, 100

Steinach, Dr. Adelrich, Geschichte und Leben der Sihweizer Kolonien, 7

Steinauer, J. A., founder of Steinauer, Neb., 85

Steinauer, Neb., founding of, 85 ; Swiss settlement, 70

Steinimann, Andreas, petition to emigrate, 122

Stettiner Lloyd, 257

Stettler, 158

Stevenson, Andrew, American minister to England, 203

Stiger, writings of, 142,155

Stiles, Wm. H., U. S. chargé d'affaires to Austria, 216

Stocker, Landvogt, report of, 20

Stöhr, Krensherr Commandeurr, letter of, 249

Stössel and Co., emigration agency, complaint of, 69

Stoker. Peter, letters confiscated, 35

Stolz, Dr. Otto, vii

Stoll. C., convict, aid to emigrate, 32

Storker, Johannes, letter from, 49

Stovall, Hon. Pleasant A., iii

Straaszer, Peter, emigration of, 123

Streif, Landvogt, report of, 20

Striker, emigration agent, examination of, 43 ; expelled, 44 ; letter confiscated, 46

Strobl, Peter, persecution of, 262

Stroblhof, 262

Stuckey, Ga., Swiss settlement, 70

Studien, und Mitheilungen ans dem Benediktiner- und Cistercienserorden, cited, 87

Studien zur Fuggergeschichte, Jansen, 265

Stürmer, Freiherr Bartholomaeus von, Austrian consul general, 10, 215, 236; despatches to Netternich from, 189; diplomatic post in Constantinople, I89; instructions from Metternich to, 215; minister to Brazil, I89, 237 ; order of the Red Eagle, 236; recall from Brazil, 237; recall from St. Helena, $189,215,236$

Stuttgart, 5 I ; emigration society, organization of, 236

Suchard, Philippe, 173

Süniken, 21

Suisse, Généalogique, Recueil, $\mathrm{I} 83$

Sulzer, goldsmith, emigration agent, 31

Sumiswald, 36,98

Superior, Lake, 84

Suppiger, John [Joseph], emigration of, 78; justice of the peace, 78 ; Reisebericht der
Familie Köpfli und Suppiger, 81 ; vice-consul, 78

Surinam, Dutch colony, I04, III ; emigrants from, i 12 : English conquest of, 234

Sur la Population de l'Amérique, $5 \mathbf{I}$

Sursee, emigration from, 78

Suter, Andreas, convict, emigration of, 108

Svilovich, Joseph, inheritance of, 203

Svilovich, Peter, death in Savannah, 203

Svizzera Italiana, Bollettino Storico della, article in, I 47

Swabia, 9; emigration to Spanish colonies from, I29; Swiss emigration to, 13

Sweden, blockade of port of Tripoli, 233; treaty with U. S., 193

Swift, patent of, 255

Swiss, Mo., Swiss settlement, 70

Swiss Alp, Tex., Swiss settlement, $7 \mathbf{I}$

Swiss Confederation, 2, 86, 149, 163, 164, 166, 175; correspondence of the Quatre Ministraux with the, 173; deportation scheme, 20 ; neutrality of, 78 ; registers of the diet, 161 ; see also Switzerland

Swissvale, Pa., Swiss settlement, 7I

Switz City, Ind., Swiss settlement, 70

Switzer, Ohio, Swiss settlement, 7I

Switzerland, American embassy, warning to emigrants, II7; Anjerican minister to, 6; American settlers liable to military duty, 120; archives, history and statistics, $\mathrm{I}-7$; Austrian refugees, I0, 249; Bote der Urschweiz, 87; Bundesblatt, 7, 9, I 48; Bundesarchiv, iv, I, 7, 33, 63-69, 97; charitable institution, 27; colony, 74; commercial laws, 25; commercial relations with Mexico, 25; commercial relations with U. S., 7, 25, 26, $64,81,83,119,128,158$; commercial treaty with Ecuador, 96 ; commercial treaty with Mexico, 95 ; commercial treaty with Salvador, 96 ; commercial treaty with U. S., 26, 95, I10, I28; conference of I846, i16; Le Conservateur Suisse, 161; Department of Foreign Affairs, emigration, I19, I27; Eidgenössischen Abschicde, 57, 58; emigration agents, 4, 22, 24, 25; emigration in the 18th century, $3,7,227$; emigration laws, 76,157 ; emigration statistics, $3,6,68,75,93,96$; Emigration Suisse, 6 ; emigration tax, 5 ; emigration treaties, 81, 128; extradition treaty with Salvador, 83, 96; extradition treaty with U. S., 26, 68, 79, 95, 96, 109, I IO, I28, I4I, 153, I54; federal constitution, 2; Geschichte und Leben der Schweizer Kolonien, 7; Handwörterbuch der Schweizerischen Volkswirtschaft, 6; Helvetisches Archiv, 63; Histoire Abrégée des Officiers Suisses, 100; Histoire Militaire de la Suisse, 99; Jahrbuch für Schweizerische Geschichte, 39n., 53n.; military affairs, 120; ministers to U. S., 141 ; negotiations with Brazil, 152; Neues Bundesarchiv, 63 ; neutrality of. 78 ; population, 2 ; postal treaty with U. S., 96, 97 ; Recueil Généalogique Suisse, 183; reformers, letters of, I30; Schweizerische Auswanderungswesen, Das, 6; Schweizerische Auswanderungszeitung, 96, 
97 ; Schweizerische Blätter für Handel und Industrie, I3In.; Schweizerische Consular Agenten, Berichte, 94; Schueizerischer Handels- und Industrie Verein, Berichte, I30; Schweiz im Neunzehnten Jahrhundert, 6; Tagsazungsarchiv, 63; troops in South America, 82; Uebersecische. Auswanderung aus der Schwein, 7o; see also Federal Council; Federal Directory: Federal Emigration Bureau; Freizügigkeitsvertrag; Helvetic Republic; Swiss Confederation

Switzerland, Ohio, Swiss settlement, I6I

Synod. Dutch, appeal to Swiss Protestants, 50; of New York and Philadelphia, 52 ; see also Schlatter, Rev. Michael

Syz, Heinrich, inheritance of, 22

Syz, Jean, Swiss consul in Philadelphia, 66

Syz, Johann Gcorg, Swiss consul in Philadelphia, 66

Szirmay, P., emigration scleme of, II, 250

Tacoma, Wash., Swiss settlers in, 87

Täufer-Jäger, sce Anabaptists

Täufer-Kammer, Bern, Manual der, 53

Tagsatzungsarchiv, Bern, 63

Tallmadge, F. A., 206

Tampico, blockade of, 202

Tariff, 26, 81, 83, 131, I41, 19 I, 195. 197, 199, 216, 241,254

Taylor, Pres. Zachary, agent sent to Hungary by, 214

Telegraph, 212

Telescope, 243

Tell, Pa., Swiss settlement, 7 I

Tell City, Ind., Swiss settlement, 7o

Tell Cottage, Ohio. Swiss settlement, 7I

Temple, Sir John, English consul general to America, 226

Tennessee, Plümacher's colonial scheme, 69 ; Swiss settlements in, 7 I

Tennessee Colonisationsgesellschaft, 133-136

Ternant, Comte Chr., French minister to U. S., 228

Terrasson, French consul, letter from, 18I

Terzi, Franz Anton, legacy of, 19,3-197

Texas, 80, 109, 212, 213; admission of, 213; Antrag zur Aufnahme Schacizerischer Colonisten in TCxas, 8o; Austrian emigration to, 25J ; convention of 1838,201 ; emigration from Tyrol, 267: free land in, 60 ; Kuhn, Swiss consul in, 67 ; Swiss consulate, 110: Swiss emigration to. 61, 116; Swiss settlements, 71 ; war with Mexico, 61

Thaner, llans, persecution of, 259

Theological seminary, Gernan Reformed, in U. S., 24

Thierachern, 43

Thorberg, convict, 6I

Thun, 34

Thurgau, 2 ; aid to emigrants, 1.4-1.46; Amtsblatt des Kantons Thurgau, I.fo; cantonal archive, iv, $14-1.46$; circular letter, emigrattion, 145; conference of 1846,116 ; emigration from, 21; cmigration laws, 18, 58; emigration statistics, 146; emigration to Brazil, I44. 146; emigration to Chile, 146; emigration to Russia, I4t; emigration to the Crimea, IH: police department, I +4 ; Schutzvercin für entlassene Sträflinge, IfH, I 45 ; serfdom, I $+4 ; L^{*}$. S. complaint against deportation from, 145; Thurgauer Zeitung, Sonntagsblatt der. $1+6$

Thurn-Buch, Bern, t. $5,55,56$

Ticino, 2, 6; cantonal archive, vi, $147-148$; conference of $1846,116,147$; emigration from, 6, I 47 ; emigration to Argentina, 148; emigration to Califormia, I 48 ; printed material iil archive, I $47-1+8$; returning emigrants, 148

Tillier. Rudolph, petition of, 52

Timber, exportation of, 219

Tinelli, Anne, 208

Tinelli, Luigi, deportation of, 207, 208, 215 ; divorce case before Senate, 208 ; petition of, 207.208

Tobacco, planters, convention of, 208 ; seed, 245 ; trade, 248

Tobago, English occupation of, 230

Tobler, Johann, Alter u. verbessirter SchreibKalender, article in. 20: Einc ausfïhrliche Relation aus Carolina, 29

Todd. Vincent H., article by. 74

Toggenburg. 46 ; emigration from, 18,35

Tonnage, tariff charge on, 19I

Torlade, Barrozo z's., I95

Torrenté, archives of the family of, 163

Toulon, 239

Tour Baudet, i 76

Trachselwald. 36

'Trachsler. Hans W., Kurtz z'erfassie ReiszBeschroibung, 29

Trade, anthracite coal, I99: cannon, 217 ; clothing, 227: cotton, 131; dye-wood, 226; cmbroideries, 131 ; fur, 228; glassware, 25.; grain, 9, 239, 241, 254, 255; india rubber, 206: lace, 7,131 ; linen, 131, 188, 254; mercury, 255; milk, 7 ; otter skins, 24l; pharmaceutical articles, 2.4; salt, 239; seed. 243 : silk, 26, 131, 141; timber, 219; tobaceo, 24:; under neutral flag, 255; whale tishery, 218 ; wheat, 242 ; wine, 107, 205, 227; wool, 255; 7wiehack, 107; sie also names of countries and places

Pransportation, arrangements and terms, 61, 62, $68,84,115-118,128,132,135,153,154,155$ : reports oll. 62,115

Trappani, 2.39

Traumannstorf, Count Ferdinand von, correspondence of, 187

Travantet, 170

Pravels, in America, 11 ; in the Middle West, I

Treasury, L. S., Secretary of the, reports, 26 . 197, 202, 2061, 207

Trent, 265; Council of, 151; emigration to South America, 267

Tribumal des Trois Titats, Neuchitel, 166

Triest. American merchant ressels in, 2.33 ; commercial expedition to U. S., 225 ; commercial relations with French colonics, 223; commercial relations with $L^{\circ}$. S., 192, 205, 254; Lamson, American consul. 233, 25.3: Oesterreichische-Amerikanische lland- 
lungsgescllschaft, I86, I88, 226; regulating ships visiting port of, 195; Riggin, American consul, 233, 234, 253; troop transports to St. Thomas, 236, 237; U. S. Treasury Department to the governor of, 204

Trinidad, French emigrants in, 230

Tripoli, blockade of port of, 233 ; U. S. at war with, 233

Trogen, cantonal archive, 127

Tronchin, letter from Jefferson to, I8I

Troppau, provincial archive, 8

Tschan, Johann, emigration of, 98

Tschann, letter from. 62

Tschudi, mission of, 69

Tschudi, J. J., emigration agent, 49, I06, I I2, I 3

Tschudi, Martin and Nicolaus, II 3

Türler, Dr. Heinrich, archivist, vii ; Uebersicht über den Inhalt des Staatsarchives des Kantons Bern, 33

Tunis, corsair captures Paolina, 233

Turc, François, secretary, I79

Turin, treaty of I8I6, I77

Turkey, relations with U. S., 195, 197

Turreau, Gen. Louis Marie, French minister to U. S., I63

Turrettini, F., Les Archives de Genève, I75

Tuscany, Austrian consulate in, 252 ; commercial relations with America, 225

Tuscarora Indians, treaty between Graffenried and, 74

Two Sicilies, I97

Tyler, Pres. John, letter to Mareschal, 2 io

Tyrol, article concerning emigrants from, 266; Auswanderer-Auskunftsbureau, 267; bibliography of emigration from, 266-267; Bothe für Tirol und Vorarlberg, cited, 266267 : colonies in Brazil, 266 ; colony in Forestville, Mich., 266; diary of a volunteer in U. S. army, 267; emigration from, II, 248, 267 : emigration to Buenos Aires, 266; emigration to Spain, 248; emigration to $\mathrm{Vir}$ ginia, 266, 267; emigration statistics, 265, 267 ; settlement in Alpenburg, Va., 266, 267 ; Tyrolese-American Franciscans, 266

Ueberseeische Auswanderung aus der Schweiz, Die, 70

Üelin, Verena, return of, 22

Ulloa, Dr. Antonio de, Spanish fleet under, 218

United States, alliance with England proposed, 224; army and navy, 244, 247; Austrian consuls, IO, 2I 5, 234, 236; Austrian minister in, Io; Austro-Italian political refugees, Io; banking system, 203, 2 II ; bankruptcy law, 209 ; banks, suspension of, 204, 206; BeelenBertholff, first agent to, 8; Benedictine monasteries in, 5,84 ; blockade of port of Tripoli, 233; boundary dispute with Spain, 226 ; bounties, 79 ; census of, I56, I90; census of Swiss born in, 6, IIo; chargé to Spain, 225; citizenship, 96; commercial conditions, I99; commercial laws, 255; commercial relations with Austria, I88, I9 I, 222, 224, 233, 236, 254; commercial relations with England, 228, 229, 236, 254; com- mercial relations with Portugal, 229; commercial relations with Spain, 228, 229, 23I, 233; commercial relations with Switzerland, $7,25,26,64,81,83$, I I9, I28, I3I, I58; commercial relations with Triest, I92, 205, 225 ; commercial treaty with Brazil, 255; commercial treaty with Chile, Ig8; commercial treaty with Colombia, I92, I93; commercial treaty with Denmark, I93, I95, 255; commercial treaty with Greece, 202 ; commercial treaty with Hanse towns, I93, I94: commercial treaty with Mexico, I93; commercial treaty with Naples, I98; commercial treaty with Russia, I91, I98; commercial treaty with Sardinia, 204 ; commercial treaty with Sweden, I93; commercial treaty with Turkey, I95; consuls, 67, 233, 234, 237, 257 ; convention with Austria, 196; convention with Mexico, 2I2 ; deportation of undesirables, $6,75,76,96$, I 17, 145, I56, $2 \mathrm{I} 3$; diplomatic correspondence concerning deportation, 75 , I 55 ; discrimination against ships of, 192, I94, 237 ; distrust of England and France in, 225; Dutch minister, 225; emigration from Austria to, 227; emigration from England to, 225; emigration literature, 60; English and Irish manufacturers for, 225; English blockade of coast of, 235; English consul in, 226; English delay in evacuating forts, 226; English law against importation of Austrian goods to, 254; English minister to, 228; exchange of official publications, 96,156 ; feeling against France, 230: financial situation in, 170, 202. 206, 207, 216; flag, I79, I80, 255; freedom of religion in, 66; French intrigues in, 226; Gesellschaft in Stuttgart zur Erleichterung der Ansiedelung in, 236; govérnment, I92, 237 ; high cost of living in, 201 ; hostilities against Indians, 229; immigration laws, 64, $67,77,257$; inspection of consulates in Italy, 233 ; invasion of Louisiana, 227 ; loan negotiated in the Netherlands, 225, 228; McLeod affair, 209; maps, 247 ; marine inventions, I ; merchant vessels in Austrian ports, 244; mercury mines, 253: ministers to Spain, 232, 233, 234; minister to the Netherlands, 229; mission to France, 226, 232 ; navigation of rivers of, 206, 229, 230, 234; neutrality, 78 ; payments of arrears to soldiers, 79, 96, I55; peace envoys, 235 ; pensions, $7 \mathrm{I}, \mathrm{I} 24$, I42, I56, I 58 ; political conditions in, 190, I92, I96-200; ports closed to, 2.34 : ports reopened to, 235 ; postal relations with Switzerland, 7, 96, 97, 120; purchase of Louisiana, 233, 234; railroads, Io, 200, 205, 206, 21 I, 244; relations with Austria, I 58, I88, 196, 206, 233; relations with England, I95, 225, 226, 234, 235; relations with France, I99; relations with Hamburg, 225, 226; relations with Portugal, 227 ; relations with South America, I90; relations with Spain, 232; Russian mediation, 9, 222, 235; secession, I92; ships in Venice, 248; ships seized by pirates, 225 ; slavery differences with England, 237; Spanish ministers in, 
225, 232; statistics, 64, 96, 156, 199, 246; steamship line from Port Louis to, 225; Swiss consulates, $7,24,26,79$, I IO, I53; Swiss settlements in, 70-7I; Swiss soldiers in, 79, II0; treaty relations with Austria, 9, 10, I I, 186, 187, 189, 192, I93, 194. 209. 214. $216,225,226,244,246,250,254$; treaty relations with England, 191, 193, 225, 255; treaty relations with France, 191, 193, 198; treaty relations with the Netherlands, 205, 225; treaty relations with Portugal, 225; treaty relations with Prussia, I93, 226; treaty relations with Spain, 224, 23I ; treaty relations with Switzerland, $26,68,79,95,96$, 109. $110,128,141,153$, I54; value of Spanish money in, 25; war against Tripoli, 233; warships in Austrian ports, 237, 24I, 246; warships in Mediterranean, 235; war with England, 235; war with Mexico, 214; war with Spain rumored, 192

Unteregeri, emigration from, 96

Unterehrendingen, 142

Unterhallau, emigration from, 125

Unter-Mettmenstetten, Huber family at, 22

Unterscen, emigration from, 34, 43

Unterwalden. I, 2, 64, 86-89; see also $\mathrm{Nid}$ walden; Obwalden

Upshur, Abel P., secretary of state, 212

Urech, Joh. Jakob, emigration of, I40

Uri, I; circular letter, 83 ; emigration from, 64,83 ; laws, 83 ; state archive, vi, 83

Urica, island, 221

Ussaro, brig, 215

Usteri, Theodor, article by, 27

Utah, 143

Utzendorf, 53

Uruguay, 128; Swiss emigration to, $69,97,118$

Vadiana, 130

Valais, 2, $149,163-165$; administration of the archives of, 163, 164; Bulletin Officicl, 164; cantonal library, I63; Conseil d'Etat, Rapport du, 164; état civil, records of. I64; state archive, vi, 163

Valcoulon, sec Savary de Valcoulon

Valangin, 38; emigration from, 169, 170, 171

Val-de-Travers, I $(x)$

Val Maggia, depopulated by emigration, 148

Val Verzasca, depopulated by emigration, 148

Van Berckel, P. J., Dutch minister to U. S., criminal process against, 227 ; recall of, 227

Van liuren, Martill, 107, I00, 206; appointed minister to England, I97; elected President, I09: Iederer invited to Washington by, 194; messages, 190-202, 207 ; proclamation of, 201; proposed trip to I'ortugal, 106; treaty with Austria, 10, 194

Van Houtte, Hubert, article by, 186

Vanuaz, Fricdricl, kidnapping of, 53

Vannoni, Giuseppe, political refugee, 208

Vaud, New Mexico, colony of, I61

Vaud, Switzerland, 1, 2, I49, 172, 175; Bernese administration, I59, I60; cantonal archives, vi, 150-161; Chambre des Bannerets, I60: Chambre ficonomique, 160; Commissariat, 160 ; communal arclives of, 161 ; conference of 1846, I 6 ; Conseil d'Etat, archives of, I61 ; Cour d'Appellation Romande, I60; Dictionnaire Historique, $159,160,161$; emigration from, I61; état civil, registers of, 160 ; Journal de la Société l'audoise, 159 ; national church, archives of, I61; part of the Canton du Léman, 159; part of the Département du Léman, I59; part of the French empire, 159; Revue Historique Vaudoise, 75, 151, 162; Société d'Utilité Publique, Comité d'Emigration, 7, 64, 65, 66 Venerable Company, sec Geneva, Compagnie des Pasteurs

Venetia, documents relating to the history of, I 85

Venezuela, Swiss emigration to, 69, I24

Ventuno $c$ dello Spiclberg, Storia dei processi $d c l$, Sandonà, 247

Vera Cruz, capitulation of, 202 ; declared open port, 202; renewal of hostilities at, 202 ; seizure of Spanish ships by the English at, 234; silver fleet from, 221, 234; Spanish fleet leaves, 219

Vergessene Deutsche Colonie, Eine, Deiler, Ig6, 250

Vergueiro and Co., agency, 132 ; lawsuit, 69,158

Verlangte, nicht erlangte Canaan, Das, $3 \mathrm{I}$

Vermont, de, inquiry as to deportation, 20

Verric̀res, iz I

Verzeichnis der Bencdiktinerinnen zur $\mathrm{Hl}$. Gertrud., 87

Vespucci, Mllc. Ameriga dei, pretension of, 202,203

Vevay, Ind., Swiss settlement, 66, 67, 70, 161

Vevey, Switzerland, I61

Vienna, American consulate, 248; American plants for botanical garden, 229; arclives, distribution and survey of material, 7-12, I85; Belgische Archiv, I86; bibliograpliy, I86, 237, 247, 252; Fürst-Erzbischöflisches Konsistorium, 249; Gemeinsames Finanzarchiv, 8, 185, 252-255; Haus-, Hof- und Staatsarcliv, vi, 8-10, 185-237, 258; Hofbibliothek, 8, 185, 255, 256; Hofkammerarchiv, vi, 8, $185,252-255$; Kartenarchiv, 247 ; Kriegsarchiv, vi, 8, 9, 185, 237-247; Ministerinm des lunerm, archive of, vi, 8 , $11,185,247-251$; Polizei Ober-Direction, decree of, 249; Porzellanfabrik, 108: Post. American consul general, 256; Royal Academy for the Deaf and Dumb, Io); Scliwarz, American consul, 254; Scliriftenarchiv, 238-247; Staatskanilei, notes of, 186, 215, 216; Stadt Wien, archive of, 8, $185,256,257$; Wiener Jahrbiucher, 212

Virginia, 13, 24, 37, 60, 74, 181, 221 ; emigration from Tyrol, 266, 267; Hiilsemanu's report on, 10: Swiss emigration to. 13. 71, 107; Swiss settlements i1, 71 : travels i11, 72 : Tyrolese settlement in, $26 x$ : University of, 18. I'irginia Magazine of Mistory, 72

Virginia, slip, cholera on, 118

loce del Popolo di S. Francisco, article in, 147 Vogel, Father Adalbert, Die Benediktiner Kolonic in Newengelberg. 87 
Vogel, Heinrich, aid to emigrate, 122

Vogel, William, letter of, 66

Vogt, letter of, IoS

Vogt, Friedrich, aid for family to emigrate, II

Vokinger, Adalbert, article by, 89

Volksfreund aus Schwaben, I 18

Volks- und Schïtzenseitung, cited, 267

Vollenweider, Emilie, aid to emigrate, I45

Vollmer, Joseph and family, emigration of, I34, 135

Von Kapff and Brune, Barzizza land claim, I92

Vorarlberg, 266 ; emigration statistics, 265

Vorort, Ber11, circular letters, I09, I 16, I28, I29; emigration, 63,9 , I 6 ; seat of government, 2

Vorort, Luzern, circular letters, II5, I I6, I28, 129

Vorort, Zürich, circular letters, I28, I29; commercial relations, 25, 26; Dutch emigration decree, 23, 24, 25; emigration, 26, 9I, I I6; emigration via France, 25 ; exportation, 25 ; extradition treaty, 26; inquiry as to Joh. Meyer, 24; passports, 25, II6; Prussian emigration decree, 23; Swiss commercial laws, 25; Swiss consuls to New York and Alexandria, 24

Vuagneux, Charles, notary in Porto Rico, I72

Vuagneux, Jacques, letter of, I72

Wackernagel, Dr. Rudolf, state archivist, vii, Io8

Wäber, emigration of, 45

Wädenschweil, 22

Wänger, emigration of, 45

Wagner, Heini, estate of, I I2

Wahrhafte Erzchlung, Schlatter, 19, I30

Waldenburg, emigration from, III, II 4, II5

Walder, Jacob, agent, 22

Waldstätter-Bote, 8I

Waldvogel, Elisabeth, emigration of, I23

Wales, emigration from, 67

Wallbach, guarantee for emigrants, I40

Wallenstadt, I35

Wallimann, Franz, emigration of, 87

Walliszellen, 15

Waltenstein, 23

Walter, agent, 39

Walterswil, 99

Walzenhausen, 127

Wangen, 48

Wanhill, 248

Wanner, Swiss consul in Havre, complaint against, 69

War, Secretary of, U. S., report of, I95

Warburg, Tenn., Swiss settlement, 7I

Wartmann, Dr. Hermann, vii, 7; Industrie und Handel des Kantons St. Gallen, I30

Washington, George, meeting with Rochambeau, 245; proposals concerning University of Geneva, 184

Washington, D. C., I I, I90, I91, I93, 194, 199209; charitable institution, 27; Swiss consulate general, 26, I Io; Swiss representation in, 96

Wasmer, emigration agent, I40
Wattenwil, 46

Wassen, 83

Watteville, Régiment de, 172

Weber, Hans, I22

Weber, J., vii

Weber, Ludwig, Der Hinckende Bott von Carolina, 30

Webster, Daniel, 206; Lodge's biography, 215; reply to Hülsemann on Hungarian question, 215

Wehrli, Marie, deportation of, I42

Weiach, I9, 22

Weidmann, Heinrich, emigration of, 2 I

Weinfeld, I46

Weiss-Frey, Fried., Heinrich Iselin, und sein Geschlecht, 120

Weisslingen, 24

Weisz, Johann M., I94

IVelser, Die ïberseeischen Unternehmungen der, Haebler, 265

Werdenberg, emigration agent, I I 8

Werdenberg, emigration from, 129

Werdtman, Jacob, I94

Werfen, 258, 260

Werner, Dr. H., archivist, vii

West Florida, American invasion of, 221 ; see also Florida

West Indies, v, 30; appropriation to stop piracy in, I9I; Austrian trade relations, 252; Dutch commercial relations, 227; Dutch fleet to, 229; English troops and war supplies to, 227; exportation of timber to, 219; fleet, return of, 22I ; maps, 247 ; Spanish fleet to, 230; Swiss emigration to, 37, 38; travels in, 20; see also Antilles and names of particular islands

West Point Military Academy, 206, 214

West Virginia, Swiss settlements in, 69, 7J

Westphalia, treaty of, I

Wetzstein, I9

Weyser, Konrad and family, emigration of, 106

Weysz, inquiry concerning, 106

Whale-fishery, Greenland, 218

Wheat, 242

Whig convention of I839, II, 209

White Lily, Ky., Swiss settlement, 70

Widerhold, Jean Herman, I8o

Widmer, F., Sachregister zumn Bundesblatt, 69

Wiedertäufer, see Anabaptists

Wiedlisbach, 49

Wiesbaden, recruiting for England in, 239

Wild, Philipp Friedrich, letter from, 47

William, Prince, of England, journey to America, 227

William and Mary, College of, 72

William Nelson, shipwreck of, $68,81,96,118$, I 45

Williamsburg, Va., I92

Willisau, 80; Geschichte der Stadt, 80

Wimmis, 34

Winchester, Tenn., Swiss settlement, 7 I

Windisch, I42

Wine, trade in, $197,205,227$

Winkel, 23, 24 
Winter, Gustav, Die Grïndung des K. K.|Zimmermann, 249 Haus- Hof- und Staalsarchivs, 186: Das Zimmermann, petition of, 28 neue Gebäudc des K.K. Haus- Hof-und Staatsarchivs, 186; Katalog der Archivalien-Ausstellung, 186

Winterthur, city archive, 3I, 32: emigration from, 5, 14, 32; inquiry concerning New Glarus, 91

Wisconsin, 67; commission of emigration bureau, literature, II9; Swiss settlements in, $71,118,119$

Wlaschin, 249

Wolf, Landvogt, 20

Woif, Gerson, Geschichte der K. K. Archiz' in Wien, 186

Wolf, Salomon, register of, 20

Wolfenbüttel, i 6

Wolff, consul, complaint against, 69

Wool factories in America, 255

Worb, estate of the Graffenried family, 60 ; Ob dic Herrschaft, 60

Wren, Christopher, 72

Wright, Silas, 206

Würenlingen, I +2

Württemberg, emigration from. 67, I16; Prince Paul of, in Mexico, 196: Swiss emigration to, I3

Würths, Jacob, examination of, I 13

Wüsten, examination of, 2 I

Wunderbare Nachriclit aus America, 72

Wunderlich, H., see Merveilleux

Wysen, Peter, 30

Wyss, Hans, arrested, 50

Wysz, 60

Wysz, Rev., is

Wytenbach, theologian, 58

Yedy, brothers, emigration of, 25

Yellow fever, 23, 191, 230, 241, 24.5

York. Pa., death in, 2.4

Yorktown, Va., surrender of Cornwallis, 246

Ytter, taxation in, 263

Yverdon, 49; Graffenried's adventures in. 75: library of, 162

Zäuger, emigration of, 15

Zanini, Baranne, sec 'linelli, Anue

Zcitschrift fïr Sichweizerische Statistik, arZell, is ticle in, I 48

Zengg, 2.39

Zinsur unter Joseph II., Gnaw, 247

Zimmermann, Jakob, protest against agency, 124

Zoller, Landvogt, reports on emigration, 20

Zoller, Hans 1 iligert, It

Zolliken. 22

Zollikofer, Jacob Christ., petition of, 13

Zschokke, Heinrich. Ph. Suchard, Mein Besuch Amerikas, 173; Ph. Swchard, Un loyage aux Etats Unis, 173

Zuberbihhler, Selsastian, 29

Zürich, Kan., Swiss settlement. 7o

Zürich, Neb., Swiss settlement, 7o

Zürich, N. Y.. Swiss settlement, 71

Zürich, I, 2, 36, 43, +6. +8, 86, 129, 172: aid to emigrants, 25, 28, 29: American consulate. 110: cantonal archive, liranent .lunster, 20; charity institution, 27: conference of 1846, I 6 ; city archive, 2-29: city library, 29-3I: criminal cases, It: enigration agencies, 22, 27: emigration from. 3. 5 . I4-29, 45. 57, 61, 101, 102, I I3, I16, 1 37 : emigration laws, $14-21,23,25,27-29.32 .+4$. 45, 57, I09, 113; emigration lists, 3, 13, I4. 21, 29: examination of emigrants. It. 21, 22: Kunton Ziirich, 28: land riglits lost by emigration, 14-17: Nowe Ziricher \%itung. It8: Veujahrsblatt des IV uisenhauses, I3; Purry's books forbidden, 57; Rats Mlanwale, 15: seat of goverument, 2: Simmler'sclue Sammlung. + 20: state archive, vi, vii, 13-27; Statthalteramt, circular letter, 20): Ziiricher licrbot seach Emisration nach l'renssisch Pommirn, 1 3 : sei also Vorort. Züricls

Züricher, P. Franz, article by, st

Zng, 1, 2, 140) cantonal arcluve, iv, 05-07: emigration agencies, of): emigration from, 0.5. 00 : emigration laws, on: emigration statistics, 96 ; emigration via linance, 0.5: milk industry, 7

Zurrlibil. llans, arrest of 50

7ur-Lauben, Baroun. Mistoire Milifaire des Suisses an Sirrice di la France, 9 )

Zwalnlen, emigration of, 45

7weysimmen, $4 \mathrm{I}$

\%wielsach, American, 197

Zwilkclenhart. Andr., emigration agency, 27, IIX, 120, 124. 155

Zwingle, lat. Swiss settlement, zo

zwingli, 1,30 
1 

178 int (3)

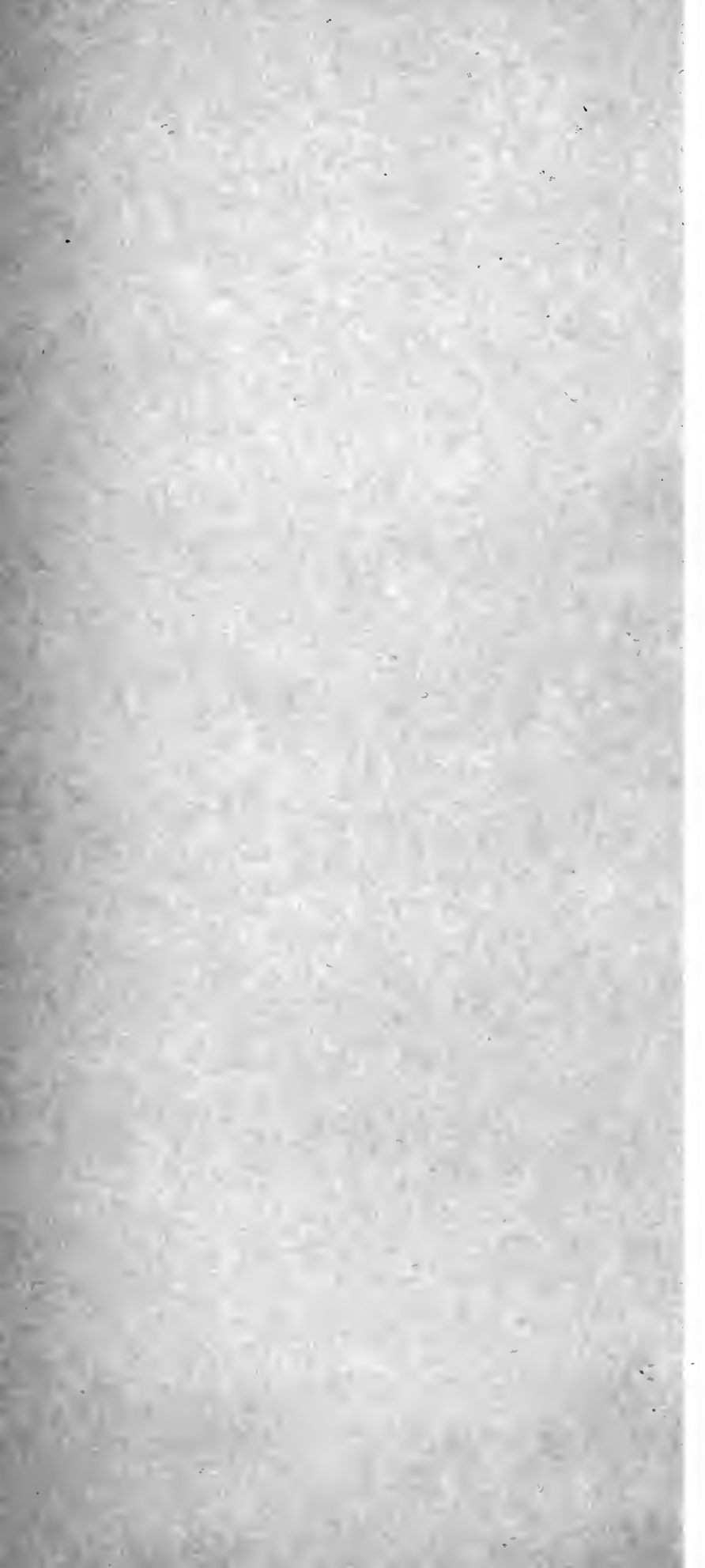

:

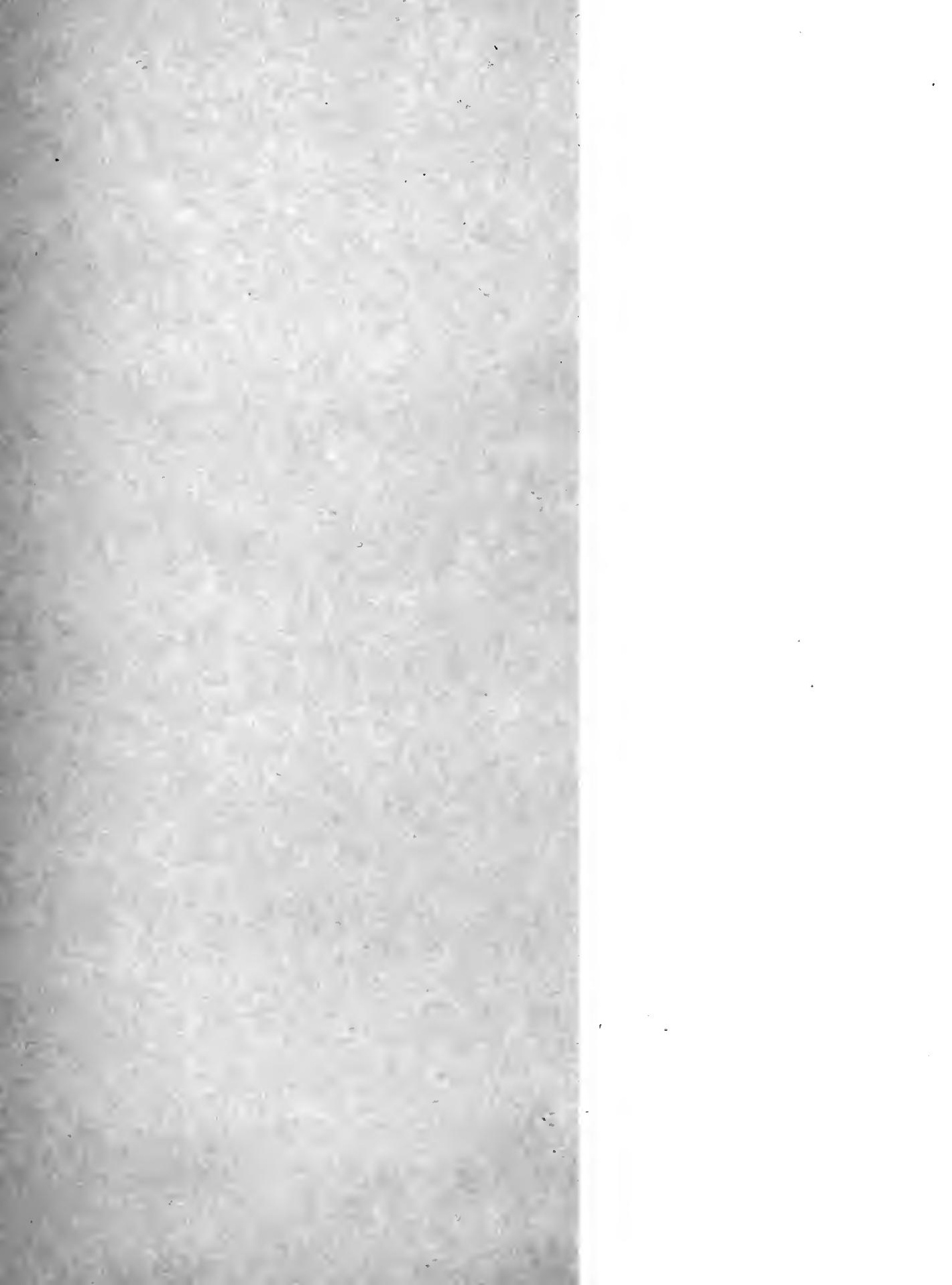


AA 0001353002

\section{For Reference}

Not to be taken from this roor 
